GABRIEL SAAD KIK BUSCHINELLI

\title{
COMPRA E VENDA DE PARTICIPAÇÕES SOCIETÁRIAS DE CONTROLE
}

\author{
Tese de Doutorado \\ Orientador: Professor Associado Dr. Eduardo Secchi Munhoz
}

UNIVERSIDADE DE SÃO PAULO

FACULDADE DE DIREITO

São Paulo-SP

2017 


\title{
GABRIEL SAAD KIK BUSCHINELLI
}

COMPRA E VENDA DE PARTICIPAÇÕES SOCIETÁRIAS DE CONTROLE

\author{
Tese apresentada a Banca \\ Examinadora do Programa de Pós- \\ Graduação em Direito, da Faculdade \\ de Direito da Universidade de São \\ Paulo, como exigência parcial para \\ obtenção do título de Doutor em \\ Direito, na área de concentração \\ Direito Comercial, sob a orientação \\ do Professor Associado Dr. Eduardo \\ Secchi Munhoz.
}

\section{UNIVERSIDADE DE SÃO PAULO}

FACULDADE DE DIREITO

São Paulo-SP 


\section{SUMÁRIO}

SUMÁRIO

$\begin{array}{lc}\text { ABREVIATURAS } & 8\end{array}$

INTRODUÇÃO

A. Atualidade e contribuição original para a ciência jurídica 13

B. Delimitação do objeto de estudo 15

$\begin{array}{ll}\text { C. Divisão do trabalho } & 17\end{array}$

I. OВJETO 19

A. Equiparação entre conteúdo econômico e jurídico: orientações generalizantes 26

1. Participações sociais como objeto meramente formal do negócio jurídico 26

2. Participações societárias como efetivo objeto do negócio jurídico 34

3. Posicionamento 39

B. Equiparação entre conteúdo econômico e jurídico: orientações casuísticas 49

1. Analogia 50

2. Sociedade simulada 51

3. Negócio jurídico indireto em fraude à lei 54

4. Desconsideração atributiva da personalidade jurídica 56

(1) Desconsideração fundada em abuso do direito 57

(2) Desconsideração fundada no âmbito de aplicação da norma jurídica 60

(3) Orientações ecléticas para a desconsideração atributiva 63

C. Conclusão parcial $\quad 64$

II. ELEMENTOS 
1. Natureza jurídica das participações societárias 68

2. Transferência da participação societária como cessão da posição contratual 72

3. Contrato de compra e venda como negócio jurídico causal 75

\section{B. Obrigação do vendedor: transferência da titularidade das participações} societárias

1. Transferência de ações $\quad 82$

a) Natureza jurídica das ações e tutela do adquirente de boa-fé

(1) Relevância da determinação da natureza jurídica das ações 82

(2) Ações como títulos de crédito $\quad 87$

(3) Proteção do adquirente de boa-fé contra a reivindicação 101

b) Transmissão de ações nominativas registrais e escriturais 103

(1) Requisitos e eficácia do termo de cessão 105

(2) Possibilidade de registro do contrato de compra e venda sem lavratura de termo de cessão

(3) Possibilidade de transferência de ações nominativas escriturais com base em contrato de compra e venda

$\begin{array}{ll}\text { c) Eficácia real do registro } & 117\end{array}$

d) Restrições à circulação $\quad 119$

(1) Requisitos de validade da cláusula de limitação à circulação 119

$\begin{array}{ll}\text { (2) Oponibilidade da cláusula de preferência } & 120\end{array}$

$\begin{array}{ll}\text { e) Requisitos para a negociação das ações } & 124\end{array}$

f) Responsabilidade do alienante 124

(1) Responsabilidade pela integralização das ações 125

(2) Responsabilidade por desconsideração da personalidade jurídica 125

2. Cessão de quotas de sociedade limitada $\quad 127$

$\begin{array}{ll}\text { a) Possibilidade de cessão da quota social } & 128\end{array}$

$\begin{array}{ll}\text { b) Regime legal dispositivo } & 128\end{array}$

c) Limitações convencionais à livre circulação das quotas previstas no contrato $\begin{array}{ll}\text { social ou acordo de quotistas } & 131\end{array}$

(1) Vedação à cessão 131

(2) Exigência de unanimidade 133

$\begin{array}{ll}\text { (3) Direito de preferência } & 135\end{array}$ 
d) Requisitos para a cessão da quota

(1) Certidões negativas de débitos fiscais e previdenciários

(2) Eficácia da cessão: entre as partes, perante a sociedade e terceiros

(3) Tutela do cessionário de boa-fé

e) Responsabilidade do cedente

(1) Necessidade de débito ser anterior à averbação do contrato social

(2) Fato gerador da desconsideração da personalidade jurídica anterior à averbação do contrato social

(3) Desconsideração da personalidade jurídica deve ser pleiteada ou deferida no prazo de dois anos

f) Repercussões sobre o nome empresarial: necessidade de alteração da firma ou da denominação social

1. Negociação e fixação do preço

2. Modalidades de preço

a) Preço determinado

b) Preço determinável

(1) Preço determinado por terceiro avaliador: arbitramento

(a) Diferença entre arbitramento e arbitragem 158

(b) Impossibilidade de indicação do avaliador $\quad 161$

(c) Possibilidade de impugnação do laudo $\quad 165$

(d) Consequência da impugnação de laudo 172

(2) Cláusula de ajuste de preço: diferenças em relação a cláusulas de garantia 173

(3) Determinação contingente do preço: cláusula de earn out 176

(a) Características: função econômica e modalidades $\quad 176$

(b) Elementos da regulação contratual 181

(i) Eventos condicionantes 181

(ii) Administração da sociedade 188

(iii) Prestação de contas e fiscalização 191

(c) Articulação com outras cláusulas contratuais 193

3. Garantias do pagamento do preço: o papel da conta garantia (escrow account) 193

D. Natureza jurídica: civil, empresarial, mercantil 195

1. Tratamento do tema no direito estrangeiro 195 
2. Situação anterior à vigência do Código Civil de 2002

3. Situação posterior à vigência do Código Civil de 2002

4. Projeto de Código Comercial

5. Posicionamento

a) Unificação do direito das obrigações

b) Contratos empresariais permanecem objeto de estudo doutrinário, mas não constituem categoria dogmática autônoma

(1) Dificuldades do conceito doutrinário e jurisprudencial de contratos empresariais

(2) Disciplina interpretativa ou de aplicação normativa diversa para contratos empresariais não encontra amparo legal

c) Inconveniência de nova distinção baseada na condição das partes

d) Compra e venda de participações societárias de controle não deve ser considerada compra e venda mercantil

1. Regramento vigente

2. Análise crítica dos requisitos de forma impostos para a transferência das participações societárias

a) Vantagens da liberdade de forma na compra e venda de participações societárias de controle

b) Desvantagens da liberdade de forma

(1) Incongruência valorativa

(2) Inconvenientes práticos

c) Tratamento do tema no direito estrangeiro

d) Posicionamento

a) Regras do Código Civil sobre trespasse de estabelecimento

(1) Publicidade do trespasse (CC, art. 1.144)

(2) Posição jurídica das contrapartes em contratos com a sociedade (CC, art.

(3) Proibição de concorrência (CC, art. 1.147) 
b) Lei de Recuperações e Falência

(1) Compra e venda de participações societárias como ato falimentar (LRE, art.

94, III, “c”) e sujeito à ineficácia (LRE, art. 129, caput, VI)

(2) Possibilidade de compra e venda de participações societárias viabilizar a alienação de unidade produtiva isolada (LRE, art. 60)

c) Direito tributário: sucessão no estabelecimento (CTN, art. 133)

B. Sociedade proprietária de bem imóvel

a) Direito de preferência do locatário de imóvel urbano e arrendatário de imóvel rural

(1) Direito de preferência do locatário de bem imóvel urbano

(2) Direito de preferência do arrendatário

b) Direito de família

C. Sociedade titular de posição contratual

a) Lei de locação: necessidade de consentimento do locador para transferência de controle

b) Direito de preferência e venda conjunta (tag along)

A. Dever de informar na compra e venda de participações societárias de controle 267

1. Delimitação positiva da abrangência do dever de informar 267

2. Delimitação negativa do dever de informar

a) Possibilidade de prestação de informação relativa à sociedade pelo vendedor 272

b) Preservação de informações estratégicas

B. Ônus de se informar do comprador

1. Auditoria como costume: efeitos da ausência ou incompletude da auditoria sobre a posição jurídica do comprador 285

2. Efeitos de auditoria defeituosa sobre declarações e garantias 290

3. Efeitos da auditoria sobre o dever de informar

C. Dever especial de informação do administrador na compra de participações societárias do sócio controlador 
A. Vícios redibitórios $\quad \mathbf{3 0 0}$

1. Direito estrangeiro 300

a) Alemanha 301

b) Itália $\quad 310$

c) França 313

d) Espanha 316

$\begin{array}{ll}\text { e) Portugal } & 317\end{array}$

2. Inaplicabilidade da disciplina dos vícios redibitórios em relação ao patrimônio societário

B. Evicção

C. Erro

D. Dolo

E. Responsabilidade civil por falha ao dever de informar

CONCLUSÃO

A. Recapitulação das teses formuladas

B. Considerações Finais

BIBLIOGRAFIA

RESUMO 


\section{ABREVIATURAS}

\begin{tabular}{|c|c|c|}
\hline $\mathbf{A c P}$ & - & Archiv für die civilistische Praxis (periódico alemão) \\
\hline Abs. & - & Absatz (alínea) \\
\hline ADC & - & Anuário de Derecho Civil (periódico espanhol) \\
\hline $\mathbf{A G}$ & - & Die Aktiengesellschaft (periódico alemão) \\
\hline AgInt no AREsp & - & Agravo Interno no Agravo em Recurso Especial \\
\hline AgRg & - & Agravo Regimental \\
\hline AI & - & Agravo de Instrumento \\
\hline AIRR & - & Agravo de Instrumento em Recurso de Revista \\
\hline AktG & - & Aktiengesetz (Lei de Sociedades por Ações alemã de 1965) \\
\hline a.F. & - & Alte Fassung (versão revogada) \\
\hline Am. J. Comp. L. & - & $\begin{array}{l}\text { American Journal of Comparative Law (periódico norte- } \\
\text { americano) }\end{array}$ \\
\hline Ap. & - & Apelação \\
\hline Ap. c/ rev. & - & Apelação com revisão \\
\hline Ap. Cív. & - & Apelação Cível \\
\hline Ap. Cív. c/ rev. & - & Apelação Cível com revisão \\
\hline Ap. Crim. & - & Apelação criminal \\
\hline $\mathbf{A R}$ & - & Ação Rescisória \\
\hline art. & - & Artigo \\
\hline Aufl. & - & Auflage (edição) \\
\hline BB & - & Betriebs-Berater (periódico alemão) \\
\hline BBTC & - & Banca, Borsa e Titoli di Credito (periódico italiano) \\
\hline BGB & - & Bürgerliches Gesetzbuch (Código Civil alemão) \\
\hline BGH & - & $\begin{array}{llll}\text { Bundesgerichtshof (Supremo Tribunal Federal da } \\
\text { Alemanha) }\end{array}$ \\
\hline BGHZ & - & $\begin{array}{l}\text { Decisões do Bundesgerichtshof em matéria civil (periódico } \\
\text { alemão) }\end{array}$ \\
\hline Bull. Joly & - & $\begin{array}{l}\text { Bulletin mensuel Joly d'information des sociétés } \\
\text { (periódico francês) }\end{array}$ \\
\hline $\mathbf{c} / \mathbf{c}$ & - & Combinado com \\
\hline Câm. Cív. & - & Câmara Cível \\
\hline Câm. Crim. & - & Câmara Criminal \\
\hline Câm. Dir. Com. & - & Câmara de Direito Comercial \\
\hline Câm. Dir. Priv. & - & Câmara de Direito Privado \\
\hline . Res. Dir. Empr. & - & Câmara Reservada de Direito Empresarial \\
\hline Cap. & - & Capítulo \\
\hline CARF & - & Conselho Administrativo de Recursos Fiscais \\
\hline Cass. Com. & - & $\begin{array}{l}\text { Cour de cassation - Chambre commerciale (Seção de } \\
\text { Direito Comercial da Corte de Cassação francesa) }\end{array}$ \\
\hline
\end{tabular}




\begin{tabular}{|c|c|c|}
\hline Cass. & - & Corte di cassazione (Corte de Cassação italiana) \\
\hline $\mathbf{C C}$ & - & Código Civil Brasileiro (Lei n. 10.406, de 10.01.2002) \\
\hline CCB & - & Cédula de Crédito Bancário \\
\hline CCJC & - & $\begin{array}{l}\text { Cuadernos Cívitas de jurisprudencia civil (periódico } \\
\text { espanhol) }\end{array}$ \\
\hline CCom & - & Código Comercial Brasileiro (Lei n. 556, de 25.06.1850) \\
\hline CDA & - & Certificado de Depósito de Ações \\
\hline CDC & - & $\begin{array}{l}\text { Código de Defesa do Consumidor (Lei n. 8.078, de } \\
11.09 .1990 \text { ) }\end{array}$ \\
\hline cf. & - & Conforme \\
\hline Cit. & - & Citado; Citação \\
\hline $\mathbf{C J F}$ & - & Conselho da Justiça Federal \\
\hline CJIL & - & Chicago Journal of International Law \\
\hline CLJ & - & Cambridge Law Journal (periódico inglês) \\
\hline CMN & - & Conselho Monetário Nacional \\
\hline CND & - & Certidão negativa de débito \\
\hline COJUR & - & Consultoria Jurídica \\
\hline Contr. impr. & - & Contratto e impresa (periódico italiano) \\
\hline $\operatorname{Coord}(s)$. & - & Coordenador; Coordenação; Coordenadores \\
\hline $\mathbf{C P}$ & - & Código Penal (Decreto-Lei n. 2.848, de 07.12.1940) \\
\hline СPC & - & $\begin{array}{l}\text { Código de Processo Civil (Lei n. 13.105, de } 16 \text { de março } \\
\text { de 2015) }\end{array}$ \\
\hline CSC & - & Código das Sociedades Comerciais (Portugal) \\
\hline CTN & - & Código Tributário Nacional (Lei n. 5.172, de 25.10.1966) \\
\hline CVM & - & Comissão de Valores Mobiliários \\
\hline DB & - & Der Betrieb (periódico alemão) \\
\hline DCFR & - & $\begin{array}{l}\text { Draft Common Frame of Reference (Quadro comum de } \\
\text { referência, lei modelo europeia) }\end{array}$ \\
\hline Des. & - & Desembargador \\
\hline Dir. & - & Diretor \\
\hline omm. Int. & - & Diritto del commercio internazionale (periódico italiano) \\
\hline Dir. Fall. & - & $\begin{array}{l}\text { Il diritto fallimentare e delle società commerciali } \\
\text { (periódico italiano) }\end{array}$ \\
\hline DNRC & - & Departamento Nacional de Registro do Comércio \\
\hline DREI & - & Departamento de Registro Empresarial e Integração \\
\hline DSR & - & Direito das Sociedades em Revista (periódico português) \\
\hline DstR & - & Deutsches Steuerrecht (periódico alemão) \\
\hline EBITDA & - & $\begin{array}{l}\text { Earnings Before Interest, Taxes, Depreciation and } \\
\text { Amortization (Lucros antes de juros, impostos, depreciação } \\
\text { e amortização) }\end{array}$ \\
\hline ECFR & - & $\begin{array}{l}\text { European Company and Financial Law Review (periódico } \\
\text { europeu) }\end{array}$ \\
\hline ECHR & - & European Convention on Human Rights (Convenção \\
\hline
\end{tabular}


Europeia de Direitos Humanos)

Ed. - Edição

ed. rev. e atual. - $\quad$ Edição revista e atualizada

EIRELI - $\quad$ Empresa Individual de Responsabilidade Limitada

EREsp - $\quad$ Embargos em Recurso Especial

FB - Finanz - Betrieb (periódico alemão)

FDUSP - $\quad$ Faculdade de Direito da Universidade de São Paulo

FGTS - $\quad$ Fundo de garantia por tempo de serviço

fls. - Folhas

Foro it. - Foro Italiano (periódico italiano)

GmbHG - Gesetz betreffend die Gesellschaften mit beschränkter Haftung (Lei alemã das Sociedades Limitadas)

HGB - Handelsgesetzbuch (Código Comercial alemão)

ITBI - Imposto sobre transmissão de bens imóveis

j. - Julgado

JCP E - L La semaine juridique - Entreprise et affaires (periódico francês)

JCP/ JCP G - La semaine juridique - Édition Générale (periódico francês)

JUCESP - Junta Comercial do Estado de São Paulo

JZ - Juristenzeitung (periódico alemão)

LINDB - Lei de Introdução às Normas do Direito Brasileiro

LRE - Lei de Recuperação de Empresas e Falência (Lei n. 11.101, de 09.02.2005)

LSA - Lei das Sociedades por Ações (Lei n. 6.404, de 15.12.1976)

LUG - Lei Uniforme de Genebra

Min. - Ministro

MS - Mandado de Segurança

n. - Número

NJW - Neue Juristische Wochenschrift (periódico alemão)

NZG - $\quad$ Neue Zeitschrift für Gesellschaftsrecht (periódico alemão)

Okla. L. Rev Oklahoma Law Review (periódico norte-americano)

Op. Cit. - Opus citate (Obra citada)

$\operatorname{Org(s).~-~} \quad$ Organizador; Organização; Organizadores

p. / pp. - Página; Páginas

p. ex. Por exemplo

RTDcom - Revue trimestrielle de droit commercial et de droit économique (periódico francês)

PECL - Principles of European Contract Law (Princípios do Direito Europeu dos Contratos)

RArb. - $\quad$ Revista de Arbitragem e Mediação (periódico brasileiro)

RCDI - Revista Critica de Derecho Imobiliario (periódico 


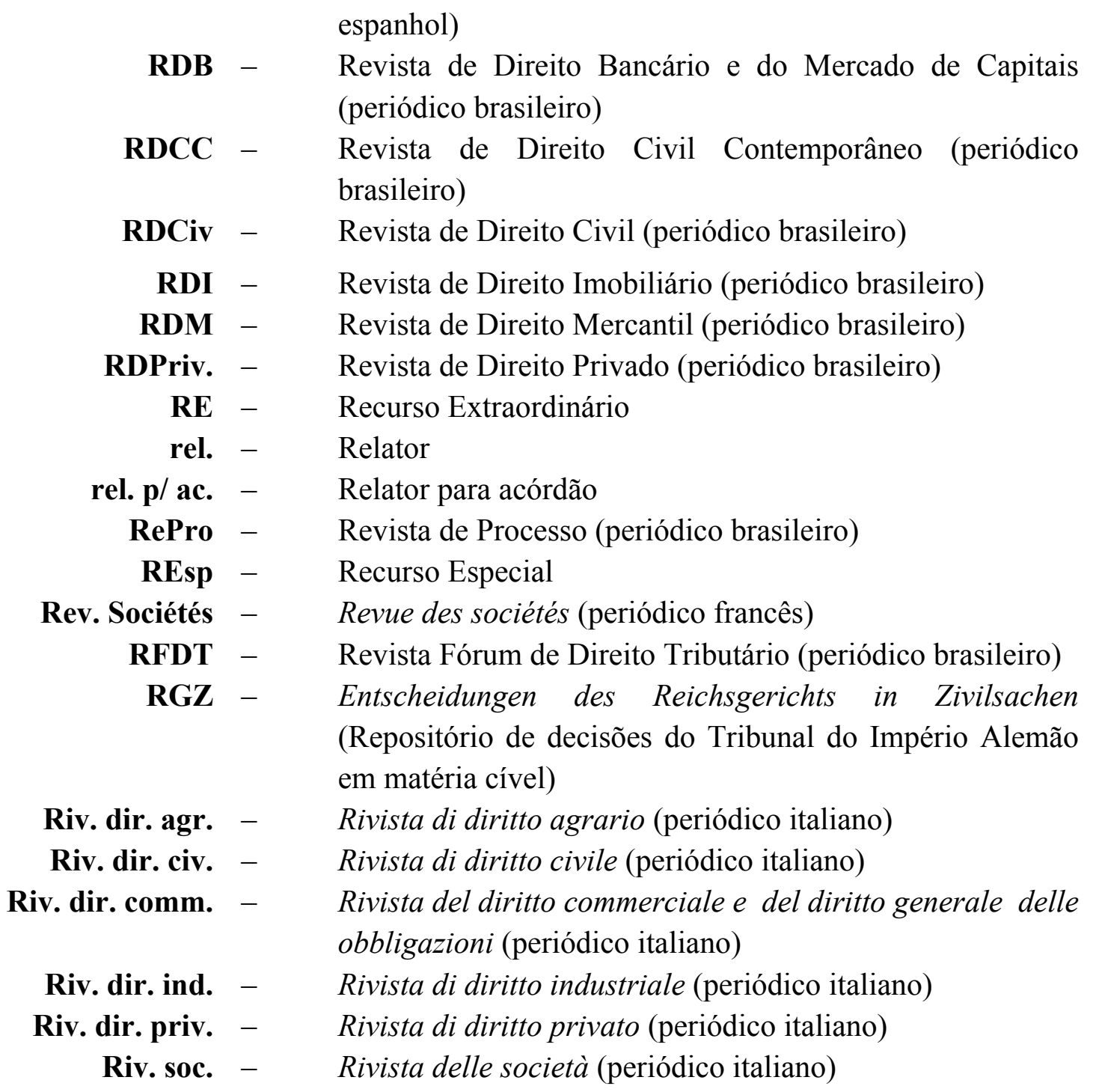

Riv. trim. dir. proc. civ. -

$$
\begin{aligned}
& \text { RJC - } \\
& \text { RJE - } \\
& \text { RLJ - }
\end{aligned}
$$

ROA -

RT -

RTDciv -

RTDPC -

RTRib. -

Rivista trimestrale di diritto e procedura civile (periódico italiano)

Revue de jurisprudence commerciale (periódico francês)

Revista Jurídica Empresarial (periódico brasileiro)

Revista de Legislação e Jurisprudência (periódico português)

Revista da Ordem dos Advogados (periódico português)

Revista dos Tribunais (periódico brasileiro)

Revue trimestrielle de droit civil (periódico francês)

Rivista trimestrale di diritto e procedura civile (periódico italiano)

Revista Tributária e de Finanças Públicas (periódico brasileiro)

$\mathbf{s} / \mathbf{p} \quad-\quad$ sem página

SARL - Société à responsabilité limitée (tipo societário francês)

SDM - Superintendência de Desenvolvimento de Mercado da 


\begin{tabular}{|c|c|c|}
\hline & & Comissão de Valores Mobiliários \\
\hline SJZ & - & Schweizerische Juristenzeitung (periódico suíço) \\
\hline STF & - & Supremo Tribunal Federal \\
\hline STJ & - & Superior Tribunal de Justiça \\
\hline STS & - & Sentencia de Tribunal Supremo (Espanha) \\
\hline T. & - & Turma \\
\hline t. & - & Tomo \\
\hline TCU & - & Tribunal de Contas da União \\
\hline TJDF & - & Tribunal de Justiça do Distrito Federal \\
\hline TJMG & - & Tribunal de Justiça do Estado de Minas Gerais \\
\hline TJPR & - & Tribunal de Justiça do Estado do Paraná \\
\hline TJRJ & - & Tribunal de Justiça do Estado do Rio de Janeiro \\
\hline TJRS & - & Tribunal de Justiça do Estado do Rio Grande do Sul \\
\hline TJSC & - & Tribunal de Justiça do Estado de Santa Catarina \\
\hline TJSP & - & Tribunal de Justiça do Estado de São Paulo \\
\hline trad. & - & Tradução \\
\hline TST & - & Tribunal Superior do Trabalho \\
\hline $\mathbf{v}$ & - & Volume \\
\hline WiB & - & Wirtschaftliche Betrachtung (periódico alemão) \\
\hline ZGR & - & $\begin{array}{l}\text { Zeitschrift für Unternehmens- und Gesellschaftsrecht } \\
\text { (periódico alemão) }\end{array}$ \\
\hline ZGS & - & Zeitschrift für das gesamte Schuldrecht (periódico alemão) \\
\hline ZHR & - & $\begin{array}{l}\text { Zeitschrift für das gesamte Handelsrecht und } \\
\text { Wirtschaftsrecht (periódico alemão) }\end{array}$ \\
\hline $\mathbf{Z I P}$ & - & Zeitschrift für Wirtschaftsrecht (periódico alemão) \\
\hline
\end{tabular}




\section{INTRODUÇÃO}

\section{A. Atualidade e contribuição original para a ciência jurídica}

A compra e venda de participações societárias de controle é regida pelo direito dos contratos. Tendo por objeto participações societárias, porém, constitui um contrato específico, que não pode ser compreendido adequadamente sem a perspectiva societária. ${ }^{1}$

Sob a perspectiva prática, a relevância dessa especial modalidade de compra e venda é indiscutível. Mantendo a sociedade como titular dos bens integrantes do seu patrimônio, a aquisição de participações societárias de controle permite que o poder de direção passe a ser exercido por novo sujeito que imprimirá rumo potencialmente diverso aos negócios sociais. Economicamente, o efeito obtido é semelhante ao da compra e venda dos ativos integrantes do patrimônio societário, com vantagens como a simplicidade para a celebração por um único contrato, além de possíveis benefícios fiscais e menor burocracia registral quando comparada à alienação isolada de bens do patrimônio.

A compra e venda de participações societárias, por dizer indiretamente respeito à empresa, constitui fenômeno complexo com caráter multidisciplinar. ${ }^{2}$ Somente mediante abordagem transversal ${ }^{3}$ seria possível compreender tal contrato que se situa "no ponto de intersecção entre o direito societário e o contratual", 4 e que repercute em diversas outras áreas do direito.

Justamente por se tratar de uma matéria abrangente, seria de se esperar que seu estudo pudesse se beneficiar de contribuições hauridas de diversas disciplinas. $\mathrm{O}$ fenômeno curioso constatado no direito francês, todavia, é que "a doutrina civilista e a

\footnotetext{
${ }^{1}$ CAFFIN-MOI, Marie. Cession de droits sociaux et droit des contrats. Paris: Economica, 2009, n. 4, p. 7.

${ }^{2}$ CORTEZ, Jorge S. "As formalidades da transmissão de quotas e acções no Direito Português: dos princípios à prática". In: COELHO, Fábio U.; RIBEIRO, Maria de Fátima (org.). Questões de direito societário em Portugal e no Brasil. Coimbra: Almedina, 2012, pp. 313-343, p. 319.

3 CÂMARA, Paulo; BASTOS, Miguel B. "O direito da aquisição de empresas: uma introdução". In: CÂMARA, Paulo; BASTOS, Miguel B. (org.). Aquisição de empresas. Coimbra: Almedina, 2011, pp. 1364, p. 16.

${ }^{4}$ CAFFIN-MOI, Marie. Cession de droits sociaux et droit des contrats. Op. cit., n. 87, p. 66 (" $A u$ carrefour du droit civil et du droit des sociétés, la cession de droits sociaux est soumise aux influences des deux branches").
} 
doutrina comercialista remetem a matéria uma à outra", 5 de tal forma que o comercialista, de quem se espera a capacidade de "ler e interpretar a normativa civil com olhos de comercialista", 6 tende a não aprofundar o estudo dos pressupostos aplicativos da disciplina do contrato, ao passo que o civilista normalmente considera a compra e venda de participações societárias como um exemplo de contrato que não se distinguiria fundamentalmente de outros, pertinentes a coisas diversas. ${ }^{7}$ Ora, o desafio do estudo da compra e venda de participações societárias reside justamente em buscar a análise conjunta de especialidades jurídicas, sem furtar-se à necessidade de "aventurar-se em muitos territórios". ${ }^{8} \mathrm{O}$ presente trabalho busca enfrentá-lo.

No direito brasileiro, as abordagens sobre o tema objeto da presente tese são pautadas por uma tendência à equiparação entre a compra e venda de participações societárias e a compra da empresa. É o caso do entendimento de FÁBIO KONDER COMPARATO, para quem a responsabilidade do vendedor abrangeria a inexistência de vícios nos bens e coisas constituintes do acervo empresarial, e não apenas nas ações, pois na cessão do controle "não é a apenas a propriedade sobre os títulos acionários, mas, precipuamente, o poder de fruição e disposição dos bens da empresa, explorada pela companhia emitente das ações". 9 É no mesmo sentido o posicionamento de GUILHERME DÖRING CUNHA PEREIRA, para quem "transferir o controle é transferir um poder sobre esses bens [do patrimônio societário]. Nesse sentido, é transferir esses mesmos bens". ${ }^{10} \mathrm{E}$ outros admitem a assimilação, considerando a compra de participações como modalidade de compra da própria empresa. É o caso de FÁBIO UlHOA COELHO, para quem “a compra de empresas tem, na verdade, por objeto participação societária, que pode consistir em quotas de sociedades limitadas ou ações de companhias. Para se configurar a compra da empresa, deve-se transferir a titularidade de participação societária em percentual

\footnotetext{
5 CAFFIN-MOI, Marie. Cession de droits sociaux et droit des contrats. Op. cit., n. 4, p. 7. ("il est intéressant de constater que la doctrine civiliste et la doctrine commercialiste se renvoient souvent dos à dos").

${ }^{6}$ IMBID IRUJO, José M. "Prefacio". In: GIMENO RIBES, Miguel. La protección del comprador en la adquisición de empresa. Granada: Comares, 2013, p. XVII-XX, p. XIX ("el jurista, cualquiera sea la función que desarrolle al contemplar la transmisión de empresa, haya de leer e interpretar la normativa civil con ojos de mercantilista").

${ }^{7}$ CAFFIN-MOI, Marie. Cession de droits sociaux et droit des contrats. Op. cit., n. 4 , p. 8.

${ }^{8}$ CAFFIN-MOI, Marie. Cession de droits sociaux et droit des contrats. Op. cit., n. 2 , p. 5.

${ }^{9}$ COMPARATO, Fábio K.; SAlOMÃO FILHO, Calixto. O Poder de Controle na Sociedade Anônima, $6{ }^{\text {a }}$ ed. rev. e atual. Rio de Janeiro: Forense, 2014, n. 89, p. 255.

${ }^{10}$ PEREIRA, Guilherme D. C. Alienação do poder de controle acionário. São Paulo: Saraiva, 1995, p. 53.
} 
suficiente para que o comprador se torne o novo detentor do poder de controle da sociedade empresária." 11

A tese possui o desiderato de analisar a compra e venda de participações societárias de controle como modalidade de contrato específico da prática civil e comercial, e não apenas sob a perspectiva da transmissão da empresa. Para além disso, pretende-se analisar criticamente se a compra e venda de participações societárias de controle representaria efetivamente um mero mecanismo para a transferência dos bens da sociedade, e se, em caso positivo, seria admissível a equiparação sob o ponto de vista jurídico entre o contrato pertinente aos ativos da empresa e o contrato sobre as participações societárias.

\section{B. Delimitação do objeto de estudo}

O objeto do presente estudo é o contrato relativo à "compra e venda de participações societárias de controle". Vale esclarecer o que se intende designar com a referência a (i) compra e venda; (ii) participações societárias; e (iii) controle.

A referência à compra e venda e não às expressões "alienação do poder"12 ou "cessão do controle",13, utilizadas com frequência na doutrina, busca, primeiramente, indicar que será analisado o contrato que é celebrado pelos contratantes e não a sua eventual consequência, pois não se vende poder, nem controle. Celebra-se contrato de compra e venda de participações societárias, o que conduz mediatamente a alteração subjetiva da posição de controlador da sociedade. Em segundo lugar, pretende indicar que não serão analisados os efeitos impostos pela legislação ou pela regulação em decorrência da alteração da posição jurídica do controlador, como ocorre, por exemplo, na obrigação de lançamento de oferta pública de aquisição de ações na companhia aberta (LSA, art. 254A), pois tal obrigação pode decorrer de uma variedade de negócios jurídicos onerosos relativos a ações, sendo muitas vezes indiferente o modo pelo qual a sucessão na posição

\footnotetext{
${ }^{11}$ COELHO, Fábio U. "Pequena reflexão sobre a boa-fé em arbitragens de direito societário". In: RArb, v. 38,2013 , pp. 21-23, p. 21.

12 PEREIRA, Guilherme D. C. Alienação do poder de controle acionário. Op. cit., p. 53.

${ }^{13}$ COMPARATO, Fábio K.; SALOMÃO FILHO, Calixto. O Poder de controle na sociedade anônima. Op. cit., n. 89, p. 254.
} 
de controlador ocorre. ${ }^{14} \mathrm{~A}$ menção à compra e venda, por fim, ainda que corrente em matéria de contratos sobre ações, é menos comum no âmbito das transferências de quotas de sociedades limitadas. Nesse caso, prefere-se em geral o termo cessão. ${ }^{15}$ A escolha do título, porém, ressalta a posição aqui adotada de que o contrato de compra e venda pode estar na base tanto da transferência da propriedade sobre ações quanto sobre quotas. ${ }^{16}$

A expressão "participações societárias" é consagrada na legislação para aludir, como gênero, tanto a ações quanto a quotas de outros tipos societários (Decreto-Lei n. 1.510/1976, art. $1^{\mathrm{o}}$, revogado; Lei n. 7.713/1988, art. 16, $\S 4^{\text {o }}$; Decreto-Lei 1.892/1981, art. $1^{\circ}$, caput; LSA, art. 184-A). É ainda utilizada pela doutrina para definir o "conjunto dos direitos e obrigações de uma posição jurídica de sócio, ou parte do contrato de sociedade". ${ }^{17}$ Para o escopo deste trabalho, porém, a despeito da previsão legislativa de outros tipos societários, optou-se pela restrição da análise aos mais comumente empregados, quais sejam, as sociedades anônimas e as sociedades limitadas.

A referência a "controle", apesar de plurívoca, deve ser aqui entendida como dizendo respeito apenas ao controle societário majoritário, garantido pela titularidade de maioria das ações com direito a voto nas sociedades anônimas ou a maioria suficiente para a alteração do contrato social no âmbito das limitadas. A delimitação não afasta a possibilidade de o controle se manifestar também sob a forma minoritária. A escolha se deve à deliberada decisão de enfrentar a situação que, em teoria, pode trazer as maiores dificuldades para determinação do regime jurídico incidente. É no âmbito do contrato que conduz à troca do controle majoritário que normalmente se pretende a desconsideração da personalidade jurídica para aplicação de regramento relativo à compra e venda dos bens integrantes do patrimônio societário. Com a investigação dos critérios adequados ao equacionamento das situações limite em que o controle é exercido da forma mais ostensiva, acredita-se que a solução para configurações intermediárias, como seria o caso de controle minoritário, ou de venda de blocos de participações societárias minoritárias, poderia ser extraída por derivação.

\footnotetext{
${ }^{14}$ Sobre o assunto, cf. item I.A.3, infra.

${ }^{15}$ CAMILO Jr., Ruy P. “Contrato de cessão de quotas sociais”. In: AZEVEDO, Luis A. N. de M.; CASTRO Rodrigo R. M. de (org.). Sociedade limitada contemporânea. São Paulo: Quartier Latin, 2013, pp. $217-259$.

${ }^{16}$ Sobre o assunto, cf. item II.A, infra.

17 PEDREIRA, José. L. Bulhões; LAMY FILHO, Alfredo. “Ação como participação societária”. In: PEDREIRA, José L. Bulhões; LAMY FILHO, Alfredo (org.). Direito das companhias, v. 1. Rio de Janeiro: Forense, 2009, pp. 215-274, p. 215.
} 


\section{Divisão do trabalho}

O trabalho está composto por cinco capítulos. No primeiro, questionam-se os pressupostos metodológicos para a definição do regime jurídico aplicável à compra e venda de participações societárias e sua eventual equiparação à transmissão dos bens integrantes do patrimônio social.

Assentadas as bases teóricas, passa-se à melhor compreensão dos traços específicos que caracterizam o contrato. No capítulo II são investigados seus aspectos fundamentais, quais sejam (i) a própria possibilidade de se denominar o contrato como compra e venda; (ii) a obrigação do vendedor de transmitir a titularidade das ações ou quotas, avaliando-se o regime de circulação de cada uma delas; (iii) as características específicas da negociação do preço em tais contratos; (iv) a natureza jurídica civil ou empresarial do contrato; e (v) sua forma.

Conhecendo método e estrutura, caminha-se no capítulo III à perspectiva funcional, sobre a possibilidade de regramentos relativos (i) ao trespasse do estabelecimento; (ii) à compra e venda de imóveis; e (iii) à cessão de posições contratuais serem aplicados à compra e venda de participações societárias de controle de sociedade que seja titular de um ou mais desses elementos patrimoniais.

$\mathrm{Na}$ fase pré-contratual, a boa-fé impõe às partes durante a negociação deveres laterais de informação. No capítulo IV, analisa-se qual o âmbito específico desses deveres na compra e venda de participações societárias, e qual a possibilidade de eles serem observados pelo vendedor caso, por exemplo, a própria sociedade entenda que não deve oferecer informações sigilosas ao comprador. Em segundo lugar, compete também ao comprador o ônus de se informar. $\mathrm{Na}$ prática contratual, é comum a realização de auditorias (due diligence), aqui analisadas sob a perspectiva dos efeitos que sua condução pode suscitar sobre a posição jurídica do vendedor e do comprador. Por fim, trata-se da hipótese específica da aquisição das participações societárias de controle pelos próprios administradores, situação peculiar em que os deveres de lealdade societários repercutem sobre a posição do administrador enquanto comprador, aludindo-se à possibilidade 
específica de o comprador (administrador), e não o vendedor (sócio), tornar-se destinatário de deveres informativos - em contraposição ao que normalmente ocorre nos contratos de compra e venda.

Apresentam-se, posteriormente, o regime de responsabilidade contratual do vendedor e os mecanismos de tutela de que o comprador pode-se valer em caso de deformidades dos próprios títulos ou do patrimônio societário, com referência à disciplina dos vícios redibitórios, da evicção, do erro, do dolo e da responsabilidade civil por falha ao dever de informar.

O trabalho se encerra com recapitulação das principais teses e considerações conclusivas. 


\section{OBJETO}

Ao celebrar contrato de compra e venda de ações ou quotas suficientes para o exercício do poder de controle majoritário, há normalmente um desencontro entre o significado econômico da operação e sua configuração formal. ${ }^{18}$ Juridicamente, o contrato versa sobre a transferência da titularidade de participações societárias necessárias para o exercício do controle societário. Economicamente, porém, o comprador não compra as ações ou quotas por suas características intrínsecas, pois não é comum se encontrar “colecionadores" de participações societárias. ${ }^{19} \mathrm{O}$ cálculo de conveniência do negócio jurídico pelo comprador normalmente é pautado pelos direitos políticos ou econômicos que a participação atribui na sociedade.

As participações societárias são bens peculiares, o que se reflete no contrato que visa à sua alienação. Nas ações ou quotas coexistem dois aspectos: externamente à organização societária, são tidas pelo ordenamento jurídico como objeto de circulação; internamente, fornecem o parâmetro para o exercício de direitos políticos e patrimoniais. ${ }^{20}$

Ao integralizar o capital social, os sócios sujeitam seus bens à gestão coletiva para a busca de um escopo comum, com vistas a perceber os resultados da atividade social. ${ }^{21}$ Com a atribuição da personalidade jurídica, a participação societária passa a ser considerada objeto autônomo de circulação e execução, sujeito à disciplina aplicável aos bens móveis. ${ }^{22}$ Trata-se de um processo de reificação (Verdinglichung) ${ }^{23}$ que permite transmitir um complexo de posições jurídicas ativas e passivas sem necessidade de múltiplos atos translativos. ${ }^{24}$ Nas participações societárias "são reunidos todos os direitos e

\footnotetext{
${ }^{18}$ SPERANZIN, Marco. Vendita delle partecipazione di 'controllo' e garanzie contrattuali. Milano: Giuffrè, 2006, p. 9.

${ }^{19}$ VIANDIER, Alain. "La protection du cessionnaire en cas de cession de contrôle". In: JCP G, v. II, 1997, n. 22875, pp. 323-325, p. 325.

${ }^{20}$ ANGELICI, Carlo. "La partecipazione azionaria come oggetto di circolazione". In: COLOMBO, Giovanni E.; PORTALE, Giuseppe B. (org.). Trattato delle società per azione, $2^{\circ}$ t. (Azioni e Gruppi). Torino: UTET, 1991, pp. 101-130, p. 102.

${ }^{21}$ ASCARELLI, Tullio. "Riflessioni in tema di titoli azionari e società tra società". In: Saggi di diritto commerciale. Milano: Giuffrè, 1955, pp. 219-271, p. 241.

${ }^{22}$ ASCARELLI, Tullio. "Riflessioni in tema di titoli azionari e società tra società". Op. cit., p. 242.

${ }^{23}$ LUTTER, Marcus. "Theorie der Mitgliedschaft". In: AcP, v. 180, 1980, pp. 84-159, p. 98.

${ }^{24}$ WIEDEMANN, Herbert. Gesellschaftsrecht, Bd. I: Grundlagen, München: C. H. Beck, 1980, p. 95.
} 
deveres atuais e futuros do membro da associação e transferidos a um eventual adquirente". 25

A autonomização das participações societárias sob essa perspectiva externa não deve induzir o intérprete a ignorar que o valor das participações societárias não é obtido exclusivamente em função das próprias ações ou quotas. Seu valor pressupõe e reflete, ainda que não exclusivamente, o dos bens que compõem o patrimônio social e dos direitos políticos conferidos pela participação nas instâncias decisórias da sociedade. Na clássica formulação de ASCARELLI, ações são bens de segundo grau, ${ }^{26}$ e o mesmo vale para quotas.

Sob a ótica interna da sociedade, com efeito, a participação societária cristaliza uma posição jurídica composta por direitos e deveres. ${ }^{27}$ Entre os direitos, incluem-se os patrimoniais, de participar dos resultados por meio da percepção de dividendos e da partilha do acervo societário em caso de liquidação (CC, art. 1.007, 1.108 e art. 1.103, IV; LSA, art. 109, I e II), e os políticos, de eleger e destituir membros da administração (CC, art. 1.071, II e III; LSA, art. 122, II) e de fiscalizar os negócios sociais (CC, art. 1. 021; CC, LSA, art. 109, III).

O embate entre realidade econômica e enquadramento jurídico, portanto, não é privativo de contratos de compra e venda de participações societárias de controle. Em menor ou maior medida, todas as vezes em que são negociadas ações ou quotas, tem-se um negócio jurídico que formalmente se relaciona com a faceta externa (participação enquanto bem passível de negociação), ao passo que a avaliação das partes sobre a conveniência do contrato pode ser, e normalmente é, realizada tendo em vista a faceta interna (enquanto título que legitima o exercício de direitos políticos ou econômicos).

Ao menos em potência, portanto, o contraste entre fundo e forma já se apresenta nas alienações de participações societárias isoladas, ou de blocos minoritários.

\footnotetext{
${ }^{25}$ LUTTER, Marcus. "Theorie der Mitgliedschaft". Op. cit., p. 99 ("In diesem Gegenstand sind alle aktuellen und potentiellen Rechte und Pflichten des Mitglieds im betreffenden Verband zu einer Einheit zusammengefaßt und gehen so auf einen etwaigen Erwerber über").

${ }^{26}$ ASCARELLI, Tullio. "Riflessioni in tema di titoli azionari e società tra società". Op. cit., p. 242.

${ }^{27}$ SCHMIDT, Karsten. Gesellschaftsrecht. Köln/Berlin/Bonn/München: Carl Haymann, 1986, p. 404; e BEUTHIEN, Volker. "Zur Mitgliedschaft als Grundbegriff des Gesellschaftsrechts - Subjektives Recht oder Stellung im pflichthaltigen Rechtsverhältnis?”. In: WANK, Rolf (et al., org.). Festschrift für Herbert Wiedemann zum 70. Geburtstag, München: C. H. Beck, 2002, pp. 755-768, p. 756.
} 
Nos contratos de compra e venda de participações societárias de controle, porém, a força mediadora da personalidade jurídica parece esvaecer-se. Na situação de unipessoalidade ou de controle societário majoritário, ${ }^{28}$ o controlador obtém um poder de "dispor praticamente dos bens alheios". ${ }^{29}$ Como definiu COMPARATO, "[c]ontrolar uma empresa significa poder dispor dos bens que lhe são destinados, de tal arte que o controlador se torna senhor de sua atividade econômica". 30

Na participação societária de controle, os direitos políticos e econômicos se apresentam de forma inequívoca. A tendência imediata, por conseguinte, é de associar a compra e venda de participação de controle à compra e venda dos próprios elementos que integram o patrimônio societário. Essa ultrapassagem do quadro jurídico formal, porém, é controversa na medida em que (i) há diferenças entre a posição jurídica material do comprador e do vendedor quando negociam ativos e quando alienam participação societária de controle; e (ii) a equiparação completa entre as modalidades de negociação traria diversas repercussões, que poderiam diminuir sensivelmente a atratividade do contrato de compra e venda de participações societárias enquanto mecanismo de mobilização de recursos.

Sem desconhecer o potencial didático e ilustrativo da contundente definição de COMPARATO referida, o fato é que, tecnicamente, o adquirente das ações ou quotas não adquire o poder jurídico de "dispor dos bens alheios". Em verdade, como reconhece o próprio autor em outra passagem da mesma obra, “[a] empresa não pertence ao controlador. Ela não é nem pode ser objeto de propriedade, no sentido técnico-legal". ${ }^{31}$

O controlador, com efeito, não pode praticar atos de disposição ou oneração do patrimônio da sociedade, que competem privativamente aos administradores da sociedade (CC, art. 1.015; LSA, art. 158). Embora o controlador possa eleger e destituir administradores, caso seja pessoa física, o controlador somente poderá administrar o

\footnotetext{
${ }^{28}$ Nesse sentido, afirma-se que o controle "est l'expression même du pouvoir majoritaire" (SCHMIDT, Dominique. "Les définitions du contrôle d'une société". In: RJC, n. 1, 1998, pp. 9-14, p. 10).

${ }^{29}$ GOMES, Orlando. "Em tema de sociedade anônima. In: RT, v. 429, 1971, pp. 13-20, p. 16.

${ }^{30}$ COMPARATO, Fábio K.; SALOMÃO FILHO, Calixto. O poder de controle na sociedade anônima. $O p$. cit., n. 27, p. 104.

${ }^{31}$ COMPARATO, Fábio K.; SALOMÃO FILHO, Calixto. O poder de controle na sociedade anônima. $O p$. cit., n. 97, p. 274.
} 
patrimônio social se atender aos requisitos de elegibilidade legalmente impostos $(\mathrm{CC}$, art. $\left.1.011, \S 1^{\mathrm{o}} ; \mathrm{LSA}, \operatorname{art} .147, \S 1^{\mathrm{o}}\right)$.

Mesmo de forma mediata, por meio da eleição de administradores que comande, o controlador não poderá se valer licitamente dos bens integrantes do patrimônio social de forma direta. Em primeiro lugar, porque, utilizando os bens sociais como se seus fossem, praticaria o ato de "confusão patrimonial" que autorizaria os credores sociais, ou o Ministério Público, a pretender que os efeitos de certas e determinadas obrigações fossem estendidos aos bens particulares dos administradores ou sócios da pessoa jurídica (CC, art. 50). Em segundo lugar, porque vige nas sociedades de responsabilidade limitada o princípio da vinculação patrimonial (Vermögensbindung), ${ }^{32}$ que se expressa no conjunto de normas que garantem que o patrimônio social seja mantido estritamente afetado à pessoa jurídica constituída para o exercício da atividade empresária. Trata-se de um regime de segregação entre os patrimônios do sócio e da pessoa jurídica, de tal forma que os credores do sócio não podem atacar o patrimônio social, da mesma forma que os credores sociais não podem exigir do sócio a satisfação de seu crédito. ${ }^{33}$ Para além dessa distinção patrimonial, são estabelecidas medidas de tutela para garantir a constituição do capital social (CC, art. 1.004, art. 1.052, art. 1.053, art. 1.103, V; LSA, art. 80, art. 81, arts. 106 a 108, art. 210, V; LRE, art. 82), ${ }^{34}$ bem como para assegurar sua intangibilidade, ou seja, a impossibilidade de as contribuições dos sócios serem a eles devolvidas, exceto após a liquidação da sociedade, ou nos casos expressamente previstos (CC, art. 1.009, art. 1.059, art. 1.082; LSA, art. 174). ${ }^{35}$ Nas sociedades anônimas, ademais, são estabelecidas regras que indiretamente protegem a vinculação patrimonial, como é o caso da proibição de prática de atos de liberalidade (LSA, art. $154, \S 2^{\circ}$ ), da exigência de que operações sejam equitativas entre as sociedades integrantes dos grupos societários de fato (LSA, art. 245), da obrigação de formação de reservas legais que limitam a livre distribuição dos resultados (LSA, art. 193) e da exigência de que dividendos sejam pagos somente à conta de origens

\footnotetext{
${ }^{32}$ ADAMEK, Marcelo V. von. "Da Invalidade do Mecanismo de Ajuste de Preço Inserido em Contrato de Investimento, por ofensa ao Regime Jurídico da Vinculação Patrimonial (Parecer)”. In: RDB, v. 66, 2014, pp. 245-269, p. 250.

${ }^{33}$ ADAMEK, Marcelo V. von. "Da Invalidade do Mecanismo de Ajuste de Preço Inserido em Contrato de Investimento, por ofensa ao Regime Jurídico da Vinculação Patrimonial (Parecer)”. Op. cit., p. 250.

${ }^{34}$ ADAMEK, Marcelo V. von. "Da Invalidade do Mecanismo de Ajuste de Preço Inserido em Contrato de Investimento, por ofensa ao Regime Jurídico da Vinculação Patrimonial (Parecer)”. Op. cit., p. 252.

${ }^{35}$ ADAMEK, Marcelo V. von. "Da Invalidade do Mecanismo de Ajuste de Preço Inserido em Contrato de Investimento, por ofensa ao Regime Jurídico da Vinculação Patrimonial (Parecer)”. Op. cit., p. 253.
} 
legalmente predispostas (LSA, art. 201), ${ }^{36}$ sob pena de responsabilidade solidária dos administradores e fiscais, sem prejuízo de ação penal cabível (LSA, art. 201, $\S 1^{\circ}$ ).

Mesmo que se admitisse, porém, que o adquirente de participações societárias de controle obtém posição jurídica material idêntica à do adquirente dos bens do patrimônio social, fato é que a posição jurídica material do alienante pode ser diversa da que teria o vendedor de bens do patrimônio. Nesse sentido, no âmbito da sociedade limitada, impõe-se ao cedente responsabilidade solidária com o cessionário perante a sociedade e terceiros pelas obrigações que tinha como sócio pelo prazo de dois anos a contados da averbação da modificação do contrato social $\left(\mathrm{CC}\right.$, art. 1.057, $\S 1^{\mathrm{o}} \mathrm{c} / \mathrm{c}$ art. 1.003, par. único). ${ }^{37}$ Igualmente, na sociedade anônima, os alienantes respondem solidariamente com os adquirentes pelo pagamento das prestações que faltarem para integralizar as ações transferidas pelo prazo de dois anos a contar da data da alienação (LSA, art. 108).

Para além dessas diferenças nas posições jurídicas de comprador e vendedor quando está em causa uma participação societária, e não ativos integrantes do patrimônio social, igualar a compra e venda de participação societária de controle e de elementos integrantes do patrimônio societário teria repercussões que se propagariam em diversos terrenos do ordenamento jurídico. Algumas são tratadas pela doutrina nacional. ${ }^{38}$ É o caso da possibilidade de considerar que o vendedor responderia por vícios redibitórios ou pela evicção em relação a bens integrantes do patrimônio social, e não às próprias ações ou quotas. ${ }^{39}$ Ou que a proibição de fazer concorrência ao adquirente do estabelecimento empresarial nos cinco anos subsequentes à transferência do estabelecimento se aplicaria ao vendedor de participação societária de controle $\left(\mathrm{CC}\right.$, art. 1.147). ${ }^{40}$

A equiparação teria, porém, outros efeitos, a depender da composição do patrimônio social. Uma sociedade pode ser titular de estabelecimento, de imóvel, ou de posição contratual cuja cessão a terceiros é restrita. Potencialmente, e por coerência, a defesa da aplicação do mesmo regime jurídico para as distintas modalidades negociais

\footnotetext{
${ }^{36}$ Sobre o tema, cf. MACHADO FILHO, Caio. O sistema de destinação de resultado e da distribuição de dividendos na Lei n. 6.404/76. Dissertação de mestrado (FDUSP), São Paulo, 2016.

${ }^{37}$ Sobre o assunto, cf. item II.B.2.f) infra.

${ }^{38}$ COMPARATO, Fábio K.; SALOMÃO FILHO, Calixto. O Poder de Controle na Sociedade Anônima. Op. cit., n. 82, pp. 237-246; n. 89, pp. 553-255; n. 90, pp. 255-261; PEREIRA, Guilherme D. C. Alienação do poder de controle acionário. Op. cit., pp. 90-103.

${ }^{39}$ Sobre o assunto, cf. item II.B.2.e) infra.

${ }^{40}$ Sobre o assunto, cf. item III.A.a) infra.
} 
conduziria à conclusão de que regras que seriam aplicáveis à alienação direta de um desses elementos (estabelecimento, imóveis, posições contratuais)) seriam igualmente aplicáveis às transferências indiretas, mediadas pela venda de participações societárias. Os efeitos desse nivelamento entre as hipóteses poderiam se espraiar pelo campo tributário, trabalhista, falimentar, civil, pela lei do inquilinato, estatuto da terra, entre outros. ${ }^{41}$ Acresce que, diferente do que ocorre na aplicação de regras de proteção ao adquirente como é o caso do regime dos vícios redibitórios, da evicção ou da proibição de concorrência -, está-se, neste caso, diante de regimes que, em geral, tutelam de forma cogente o interesse de terceiros que não figuram como vendedor ou comprador. Por maioria de razão, portanto, essas partes afetadas teriam motivos para buscar a prevalência da realidade econômica sobre a forma jurídica, pois não são capazes de conformar os efeitos do negócio jurídico para buscar a tutela de seus interesses próprios. Alguns exemplos podem ilustrar a problemática.

Suponha-se que uma sociedade seja unipessoal e possua em seu patrimônio apenas um imóvel locado a terceiro, com valor superior a trinta vezes o maior salário mínimo vigente no país. Seria necessária para a validade da transferência das participações relativas a essa sociedade a observância da forma de escritura pública (CC, art. 108)? Tratando-se de imóvel urbano, o locatário teria preferência na aquisição das ações ou quotas, considerando que a venda das quotas ou ações importa transferência mediata do imóvel (Lei 8.245/1991, art. 27)? Se o imóvel fosse rural e arrendado a terceiro, o arrendatário teria o mesmo direito de preferência (Estatuto da Terra, art. 92, $\S 3^{\circ}$ )? Considerando que a lei tributária não pode alterar a definição, o conteúdo e o alcance de institutos e forma de direito privado ( $\mathrm{CTN}$, art. 110) seria procedente a cobrança de imposto de transmissão sobre bens imóveis (ITBI)? O vendedor das quotas ou ações, não sendo casado no regime de separação absoluta, deveria obter consentimento conjugal necessário para a venda de bens imóveis, não para bens móveis, como ações ou quotas para alienar as participações societárias (CC, art. 1.647, I)?

Alterando o exemplo, admita-se que a sociedade unipessoal tivesse em seu ativo apenas uma posição contratual relativa a contrato de locação de imóvel, no qual constasse como locatária. Assumindo-se que a venda das participações societárias de controle importaria economicamente na transferência da posição contratual, seria exigível

\footnotetext{
${ }^{41}$ Para análise detalhada, cf. item III, infra.
} 
o consentimento prévio e escrito do locador para a cessão indireta da locação (Lei $8.245 / 1991$, art. 13)?

Considerando que o patrimônio fosse constituído apenas por um estabelecimento empresarial, seria reconhecido aos contratantes da sociedade o direito de rescindir os contratos em vigor no prazo de 90 (noventa) dias contados da transferência das participações, previsto para os contratantes após o trespasse de estabelecimento empresarial (CC, art. 1.148)? A transferência de ações ou quotas dessa sociedade com um único estabelecimento poderia ser considerada um ato falimentar (LRE, art. 94, III, "c")? Ou ineficaz em relação à massa falida, quando não houvesse consentimento expresso dos credores do vendedor (LRE, art. 129, VI)? O vendedor responderia pelos débitos tributários da sociedade caso prosseguisse na exploração ou iniciasse no prazo de seis meses a contar da alienação nova atividade no mesmo ou em outro ramo de comércio, indústria ou profissão (CTN, art. 133, II)?

Metodologicamente, há três possíveis posturas intelectuais para enfrentar essas questões. A primeira é considerar que no negócio de compra e venda de participação societária de controle há um objeto imediato ou formal, sob o qual se camufla um objeto mediato ou real, e que consiste na empresa, no poder de controle societário, ou em ambos. A segunda linha é absolutamente contrária à atribuição de especificidade ao fato de ser transferido o controle societário por meio das participações societárias, afirmando que o objeto do contrato de compra e venda seria constituído somente pelas próprias participações societárias. Avaliando que as duas primeiras linhas teóricas pecam pela generalização - a primeira torna o véu societário totalmente transparente; a segunda, completamente opaco -, apresentam-se perspectivas teóricas que buscam averiguar casuisticamente quais regras pertinentes a bens integrantes do patrimônio social seriam aplicáveis a compras e vendas de participações societárias de controle, baseando-se para tanto nos institutos da analogia, da simulação, do negócio indireto em fraude à lei e da desconsideração atributiva da personalidade jurídica. 


\section{A. Equiparação entre conteúdo econômico e jurídico: orientações generalizantes}

\section{Participações sociais como objeto meramente formal do negócio jurídico}

Na contraposição entre o enquadramento jurídico e a realidade econômica, parte da doutrina toma partido pela segunda e considera as participações societárias como mero instrumento para a obtenção do fim negocialmente pretendido e consistente na cessão da empresa, do controle, ou de ambos.

O título de uma obra clássica sobre o assunto bem expressa esse programa teórico. Em La cession de contrôle, mode de cession de l'entreprise, ${ }^{42}$ a suíça ANNE PETITPIERRE-SAUVAIN inicia sua exposição afirmando o caráter híbrido da cessão de controle. Nela, conviveriam, de um lado, a venda ordinária de ações, e de outro, a transferência de um poder sobre a empresa que, dado o funcionamento dos órgãos sociais, equivaleria ao de um proprietário. ${ }^{43} \mathrm{Na}$ compra e venda de ações de controle coexistiriam, assim, um objeto formal ${ }^{44}$ ou aparente, ${ }^{45}$ consistente na transferência da propriedade sobre as ações, e um objeto real que lhe seria subjacente. O objeto real, na obra da autora, não é completamente claro. Em certa passagem, afirma-se que o objeto real seria a empresa; ${ }^{46}$ em outra, que seria o poder de controle sobre a empresa. ${ }^{47} \mathrm{O}$ contrato, com isso, não teria natureza jurídica de verdadeira compra e venda. A cessão de controle constituiria acordo complexo no qual o vendedor se comprometeria a situar o comprador no controle da empresa transferindo de forma global a função de empresário, enquadrado como contrato

42 PETITPIERRE-SAUVAIN, Anne. La cession de contrôle, mode de cession de l'entreprise. Genève: Georg, 1977.

${ }^{43}$ PETITPIERRE-SAUVAIN, Anne. La cession de contrôle, mode de cession de l'entreprise. Op. cit., p. 1 .

${ }^{44}$ PETITPIERRE-SAUVAIN, Anne. La cession de contrôle, mode de cession de l'entreprise. Op. cit., p. 1.

${ }^{45}$ PETITPIERRE-SAUVAIN, Anne. La cession de contrôle, mode de cession de l'entreprise. Op. cit., p. 93.

${ }^{46}$ PETITPIERRE-SAUVAIN, Anne. La cession de contrôle, mode de cession de l'entreprise. Op. cit., p. 98 ("la cession de contrôle est une vente d'entreprise").

${ }^{47}$ PETITPIERRE-SAUVAIN, Anne. La cession de contrôle, mode de cession de l'entreprise. Op. cit., p. 93 (“dans ce cas, il n'y a aucun transfert de propriété sur l'entreprise elle-même ; seul est transféré, de façon définitive et sans restrictions, le pouvoir de diriger cette entreprise, pouvoir de fait que confère le mécanisme du droit des sociétés"). 
sui generis. ${ }^{48}$ As regras relativas à compra e venda somente lhe seriam aplicáveis por analogia. ${ }^{49}$

$\mathrm{Na}$ França, a atenção para a especificidade da operação de compra e venda de participações societárias de controle surge de forma contundente com o rumoroso affaire Saupiquet-Cassegrain, ${ }^{50}$ que incitou a discussão sobre a distinção entre venda de ações de controle e cessões ordinárias. ${ }^{51}$ No caso em questão, o controle da sociedade Cassegrain, tradicional produtora de conservas fundada em $1856 \mathrm{em}$ Nantes, fora cedido à Saupiquet, sua então concorrente, que estava interessada especialmente em obter acesso à rede de distribuição construída pela Cassegrain, mas não em gerir e manter os seus parques industriais. Pouco tempo após a aquisição do controle, determinou-se o fechamento de uma importante fábrica da Cassegrain, com demissão de todos os empregados. ${ }^{52} \mathrm{O}$ estatuto da Cassegrain previa que as ações somente poderiam ser transmitidas mediante prévia aprovação do conselho de administração, autorização essa que foi obtida pelos antigos controladores. Para os minoritários, contudo, a operação teria sido equivalente a uma incorporação (fusion-absorption), operação que deveria ser aprovada pela assembleia-geral de acionistas. A Cour de Rennes acatou o argumento e considerou que a operação teria ameaçado a própria existência da sociedade. ${ }^{53} \mathrm{~A}$ Cour de cassation, porém, anulou a decisão de segunda instância e, esposando orientação ortodoxa,${ }^{54}$ avaliou que a operação não alterou a existência da personalidade jurídica da Cassegrain.

A partir desse julgado, e discordando da posição da Cour de cassation, uma linha doutrinária passou a considerar que a compra e de venda de participações societárias de controle deveria ser submetida a um regime peculiar e diverso das transmissões de títulos isolados, por se tratar de operação com caráter específico, que toca diretamente a

\footnotetext{
${ }^{48}$ PETITPIERRE-SAUVAIN, Anne. La cession de contrôle, mode de cession de l'entreprise. Op. cit., p. 94.

${ }^{49}$ PETITPIERRE-SAUVAIN, Anne. La cession de contrôle, mode de cession de l'entreprise. Op. cit., p. 95.

${ }^{50}$ OPPETIT, Bruno. "Les cessions de droits sociaux emportant le transfert du contrôle d'une société: essai de synthèse". In: Rev. Sociétés, 1978, pp. 631-654, p. 631.

${ }^{51}$ Sobre o caso, cf. COMPARATO, Fábio K.; SALOMÃO FILHO, Calixto. O Poder de Controle na Sociedade Anônima. Op. cit., n. 47, p. 154.

${ }_{52}$ PAILLUSSEAU, Jean; CONTIN, Raphaël. "La cession de contrôle d'une société (à propos d'un important arrêt de la Cour d'appel de Rennes)". In: JCP G, II, 1969, n. 2287, s/p.

${ }^{53}$ OPPETIT, Bruno. "Les cessions de droits sociaux emportant le transfert du contrôle d'une société: essai de synthèse". Op. cit., p. 639.

${ }^{54}$ ROUX, Daniel. "La spécificité des cessions de contrôle". In: Rev. Sociétés, 1980, pp. 49-71, p. 55.
} 
organização e o funcionamento da sociedade. ${ }^{55}$ É nesse sentido o posicionamento de Claude Champaud, para quem quem "a cessão de ações utilizada para permitir a fusão econômica dos ativos afetados à empresas sociais é mais do que uma transferência de títulos". ${ }^{56}$ Igualmente, JEAN PAILLUSSEAU concebe a cessão do controle como "a cessão do poder (de direito) de administrar uma empresa e dispor de seus bens", ${ }^{57}$ ou como a venda de um bem incorpóreo, consistente no próprio poder societário. ${ }^{58}$ Como avaliou BRUNO OpPETIT, para além de uma discussão técnica, tem-se nessa controvérsia "um debate de fundo, que interessa os princípios maiores do direito societário e mesmo questões fundamentais do direito privado". 59

A tese da especificidade da compra venda de participações societárias de controle, entendida como negócio jurídico distinto da mera compra de ações isoladas, foi brandida como critério interpretativo em diversos contextos. Em primeiro lugar, na França, o alienante do fundo de comércio é obrigado, por conta de uma lei de 29 de junho de 1935 , transformada no art. L. 141-1 do Code de commerce, ${ }^{60}$ a prestar diversas informações ao adquirente, entre as quais se incluem dados contábeis e de rentabilidade. Trata-se de uma verdadeira obrigação de informação pré-contratual ${ }^{61}$ que, se inadimplida, autoriza o comprador a demandar a nulidade do contrato. Para a doutrina, a aplicação do dispositivo às cessões de controle seria uma consequência lógica da tese da especificidade da cessão

\footnotetext{
${ }^{55}$ ROUX, Daniel. "La spécificité des cessions de contrôle”. Op. cit., p. 50.

56 CHAMPAUD, Claude. "Présentation de la cession de contrôle". In: Nouvelles techniques de concentration. Paris: LITEC, 1972, pp. 137-158, p. 141 (“La cession d'actions qui intervient pour permettre la fusion économique des actifs affectés aux entreprises sociales est plus qu'un transfert de titres").

${ }^{57}$ PAILLUSSEAU, Jean; CONTIN, Raphaël. "La cession de contrôle d'une société (à propos d'un important arrêt de la Cour d'appel de Rennes)". Op. cit. ("La cession de contrôle est, fondamentalement, la cession du pouvoir (du droit) de gouverner une entreprise et de disposer de ses biens").

${ }^{58}$ PAILLUSSEAU, Jean. "La cession de contrôle et la situation financière de la société cédée (de la nature juridique du contrôle et de la cession de contrôle)". In: JCP G, I, 1992, n. 3587, pp. 185-199, p. 193.

${ }_{59}$ OPPETIT, Bruno. "Les cessions de droits sociaux emportant le transfert du contrôle d'une société: essai de synthèse". Op. cit., p. 631 ("un débat de fond, intéressant les principes majeurs du droit des sociétés et même certaines notions de base du droit privé").

${ }^{60}$ Code du commerce, art. L 141-1: I. - Dans tout acte constatant une cession amiable de fonds de commerce, consentie même sous condition et sous la forme d'un autre contrat ou l'apport en société d'un fonds de commerce, le vendeur est tenu d'énoncer $: 1^{\circ}$ Le nom du précédent vendeur, la date et la nature de son acte d'acquisition et le prix de cette acquisition pour les éléments incorporels, les marchandises et le matériel; $2^{\circ}$ L'état des privilèges et nantissements grevant le fonds ; $3^{\circ}$ Le chiffre d'affaires qu'il a réalisé durant les trois exercices comptables précédant celui de la vente, ce nombre étant réduit à la durée de la possession du fonds si elle a été inférieure à trois ans ; $4^{\circ}$ Les résultats d'exploitation réalisés pendant le même temps ; $5^{\circ}$ Le bail, sa date, sa durée, le nom et l'adresse du bailleur et du cédant, s'il a lieu. II. - L'omission des énonciations cidessus prescrites peut, sur la demande de l'acquéreur formée dans l'année, entraîner la nullité de l'acte de vente.

${ }^{61}$ CAFFIN-MOI, Marie. Cession de droits sociaux et droit des contrats. Op. cit., n. 17, p. 23.
} 
de controle. ${ }^{62}$ Em segundo lugar, no âmbito trabalhista, o art. L. 2323-33 ${ }^{63}$ exige a consulta ao comitê de trabalhadores (comité d'entreprise) na ocorrência de modificações na estrutura econômica ou jurídica da empresa, sob pena de responsabilidade criminal do representante legal da sociedade. Em um caso julgado em 1976, decidiu-se que uma cessão de controle não importaria alteração na sociedade ou em sua atividade e que, por conseguinte, não poderia ser imputada responsabilidade criminal ao representante que deixasse de consultar o comité. A Cour de cassation anulou essa decisão de segunda instância sob o fundamento de que, apesar de a venda de controle ser considerada uma operação patrimonial de ordem privada, à qual as disposições do código trabalhista não seriam aplicáveis, no caso de a transmissão de ações conduzir a uma subordinação de uma empresa a outra, sob o ponto de vista da ordem econômica, o dispositivo seria aplicável. ${ }^{64}$ A orientação jurisprudencial se consolidou posteriormente, ${ }^{65}$ a despeito da crítica formulada por BRUNO OPPETIT, para quem seria indevida a imposição de responsabilidade penal ao representante legal por um ato de disposição alheio, praticado pelos acionistas. ${ }^{66}$ Em terceiro lugar, em âmbito fiscal, alertou-se para o fato de que, a se equiparar a cessão de controle à transferência de ativos, caberia às autoridades fazendárias o poder de desconsiderar a escolha formal realizada pelo contribuinte para fazer incidir a exação correspondente à transferência de fundo de comércio. ${ }^{67}$ Por fim, a Cour de cassation equiparou a posição do cessionário de quotas de uma limitada ao adquirente de fundo de comércio. Tratava-se, no caso, de sociedade limitada que explorava hotel, cuja licença de operação foi cassada após a cessão do controle, como consequência da condenação do controlador anterior pela prática de lenocínio (proxénétisme). Considerou-se, no caso, que o cessionário, não podendo exercer a atividade empresária, teria sofrido evicção total. ${ }^{68}$

\footnotetext{
${ }^{62}$ ROUX, Daniel. "La spécificité des cessions de contrôle". Op. cit., p. 70.

63 Atualmente, Code du travail, art. L 2323-33: Le comité d'entreprise est informé et consulté sur les modifications de l'organisation économique ou juridique de l'entreprise, notamment en cas de fusion, de cession, de modification importante des structures de production de l'entreprise ainsi que lors de l'acquisition ou de la cession de filiales au sens de l'article L. 233-1 du code de commerce. L'employeur indique les motifs des modifications projetées et consulte le comité d'entreprise sur les mesures envisagées à l'égard des salariés lorsque ces modifications comportent des conséquences pour ceux-ci. Il consulte également le comité d'entreprise lorsqu'il prend une participation dans une société et l'informe d'une prise de participation dont son entreprise est l'objet lorsqu'il en a connaissance. Trata-se da atual numeração do antigo art. 432-1 do Code du travail.

${ }^{64}$ OPPETIT, Bruno. "Les cessions de droits sociaux emportant le transfert du contrôle d'une société: essai de synthèse". Op. cit., p. 643.

${ }^{65}$ CAFFIN-MOI, Marie. Cession de droits sociaux et droit des contrats. Op. cit., n. 23 , p. 27.

${ }^{66}$ OPPETIT, Bruno. "Les cessions de droits sociaux emportant le transfert du contrôle d'une société: essai de synthèse". Op. cit., p. 643.

${ }^{67}$ OPPETIT, Bruno. "Les cessions de droits sociaux emportant le transfert du contrôle d'une société: essai de synthèse". Op. cit., p. 636-638; ROUX, Daniel. "La spécificité des cessions de contrôle". Op. cit., p. 70.

${ }^{68}$ ROUX, Daniel. "La spécificité des cessions de contrôle". Op. cit., p. 58.
} 
Como se verá no item subsequente, essas orientações, de uma forma, geral, não prevaleceram. Mas são aqui mencionadas por serem representativas do entendimento de que a realidade econômica da operação de cessão de controle justificaria uma ultrapassagem plena do véu da personalidade jurídica, considerando que, sob o manto do objeto formal, estaria encoberto um negócio jurídico específico relativo ao próprio controle societário.

$\mathrm{Na}$ Itália, a teoria de que na compra e venda de participações societárias de controle conviveriam um objeto imediato e um objeto mediato é tida por claramente minoritária. ${ }^{69}$ Foi defendida, ainda assim, por autores de relevo, como é o caso de GAlgano. Para o autor, a constituição da pessoa jurídica não transferiria a propriedade sobre os bens aportados ao patrimônio societário. Os bens sociais, dessa forma, não seriam bens de terceiro sob a perspectiva do sócio controlador, mas bens que lhe pertencem. ${ }^{70}$ Com a constituição da sociedade, portanto, os bens não sofreriam uma alteração de titularidade, apenas passariam a ser utilizados de modo diverso, deixando o campo da ação individual para ingressar no da atuação coletiva. ${ }^{71}$ Em sentido similar, RoBERTO CALVO critica a interpretação formalista da pessoa jurídica, que reificaria conceitos carentes de significado ontológico. ${ }^{72}$ Considerando que a pessoa jurídica não passaria de critério normativo, mero centro de imputação de direitos e deveres, ${ }^{73}$ defende que "todas as vezes em que a propriedade dos bens não seja imputável às pessoas singulares, mas à pessoa coletiva, concretiza-se uma situação de titularidade comum de direitos reais" ${ }^{74}$ Negando a autonomia subjetiva das sociedades de capitais, dessa forma, considera que a compra e

\footnotetext{
69 Nesse sentido, SPERANZIN, Marco. Vendita delle partecipazione di 'controllo' e garanzie contrattuali. $O p$. cit., p. 15; TINA, Andrea. Il contratto di acquisizione di partecipazioni societarie. Milano: Giuffrè, 2007, p. 168.

${ }^{70}$ GALGANO, Francesco. "Cessione di partecipazione sociali e superamento della alterità soggettiva fra socio e società”. In: Contr. impr., 2004, pp. 537-544, p. 543.

${ }^{71}$ GALGANO, Francesco. "Cessione di partecipazione sociali e superamento della alterità soggettiva fra socio e società". Op. cit., p. 543.

72 CALVO, Roberto. "Il trasferimento della "proprietà' nella compravendita di titoli azionari". In: Contr. impr., 1993, pp. 1063-1123, p. 1107.

73 CALVO, Roberto. "Il trasferimento della 'proprietà' nella compravendita di titoli azionari". Op. cit., p. 1106.

${ }^{74}$ CALVO, Roberto. "Il trasferimento della 'proprietà' nella compravendita di titoli azionari”. Op. cit., p. 1109 ("Più in generale possiamo ritenere che ogniqualvolta la proprietà dei beni non sia imputabile alla singola persona fisica ma alla collettività, viene a concretizzarsi una situazione di contitolarità di diritti reali").
} 
venda de ações conduziria à aquisição de uma quota abstrata de propriedade sobre os bens do emissor das ações. ${ }^{75}$

No Brasil, COMPARATO foi o primeiro autor a tratar de maneira abrangente a problemática da compra e venda de participações acionárias de controle. Em sua obra seminal, faz-se sentir a influência do pensamento francês, seja por o capítulo dedicado ao tema iniciar-se com a citação de texto de CHAMPAUD referente à cessão de controle, seja pela designação do capítulo sob a epígrafe "A cessão do controle acionário", ${ }^{76}$ expressão que, em 1969, era considerada incomum no próprio espaço francófono, ${ }^{77}$ mas, sobretudo, pela estrutura argumentativa que se assemelha à tese da especificidade (spécificité) do contrato em relação à transferência ordinária de ações.

A similaridade com a doutrina francesa é evidenciada na consideração de que o contrato que importa a transferência do controle seria negócio jurídico distinto da compra e venda de ações ou quotas. Após reputar o contrato sinalagmático e comutativo, COMPARATO afirma que "[n]a cessão de controle, como na de ações, ou na compra e venda, há somente duas partes". ${ }^{78}$ Por oposição, é possível inferir dessa passagem que, para o autor, a cessão de controle não seria nem uma cessão de ações, nem uma compra e venda. Ao definir o objeto da cessão de controle, ademais, aponta haver em relação à cessão ordinária de ações uma "diversidade qualitativa do objeto", ${ }^{79}$ pois, com a maioria das ações votantes, seria transmitido o poder de decidir e comandar na sociedade, o que importaria "a alienação de outro bem econômico, diverso dos títulos acionários". ${ }^{80}$ Prosseguindo em sua análise, ressalta a impossibilidade de “confusão entre o negócio de cessão de controle e a

75 CALVO, Roberto. "Il trasferimento della 'proprietà' nella compravendita di titoli azionari”. Op. cit., p. 1110 .

${ }^{76}$ COMPARATO, Fábio Konder; SALOMÃO FILHO, Calixto. O poder de controle na sociedade anônima. Op. cit., p. 225.

${ }^{77}$ PAILLUSSEAU, Jean; CONTIN, Raphaël. "La cession de contrôle d'une société (à propos d'un important arrêt de la Cour d'appel de Rennes)". Op. cit., s/p (“Bien que l'expression 'cession de contrôle' soit rarement employée").

${ }^{78}$ COMPARATO, Fábio K.; SALOMÃO FILHO, Calixto. O poder de controle na sociedade anônima. $O p$. cit., n. 82, p. 230.

${ }^{79}$ COMPARATO, Fábio K.; SALOMÃO FILHO, Calixto. O poder de controle na sociedade anônima. $O p$. cit., n. 82, p. 231.

${ }^{80}$ COMPARATO, Fábio K.; SALOMÃO FILHO, Calixto. O poder de controle na sociedade anônima. $O p$. cit., n. 82, p. 231. É de se notar que, na mesma obra, o autor critica a posição de RUBENS REQUIÃO, para quem o controle deveria ser considerado um bem imaterial ou incorpóreo, análogo ao aviamento da empresa, assim como a posição de BERLE e MEANS, que viam no poder de controle um bem pertencente à própria companhia. Para COMPARATO, o controle não poderia ser reduzido "à categoria dos bens jurídicos, ou objetos de direito" (Id., n. 24, p. 100). 
cessão pura e simples de ações", ${ }^{81}$ critica a posição de ANTÔNIO CHAVES, para quem a cessão de controle seria uma cessão de posição contratual, ${ }^{82}$ e conclui que não seria possível “deixar de reconhecer a especificidade do negócio de cessão de controle, que não se reduz, em razão do seu objeto, à tipologia tradicional dos contratos, ou das categorias jurídicas comuns". 83

Considerando, portanto, que na cessão de controle se transfere "um poder sobre a empresa e, por conseguinte, também sobre os bens e as coisas constituintes do acervo empresarial", COMPARATO extrai a consequência de que o cedente responderia pela existência de vícios redibitórios ou pela evicção relativa a bens integrantes do patrimônio societário. ${ }^{84}$ Ressalva, contudo, sua discordância quanto à tese de PETITPIERRE-SAUVAIN de que a cessão de controle seria modo de cessão da empresa, pois a empresa não pertenceria ao controlador. ${ }^{85}$

A despeito da ressalva do autor, sua linha argumentativa guarda semelhanças com a de PetitPierre-Sauvain. Primeiramente, pelo fato de que, para ambos, o contrato teria natureza jurídica sui generis. Ademais, como acima se indicou, a autora suíça não é clara ao definir qual seria o objeto do negócio jurídico de cessão de controle, exceto para caracterizar as ações como objeto meramente formal. Quanto ao objeto real, a autora é dúbia: em certas passagens, refere a própria empresa; em outras, expressamente considera que o objeto real da cessão de controle seria o poder de dirigir a empresa, poder de fato conferido pelo mecanismo societário. ${ }^{86}$ As linhas doutrinárias assemelham-se, portanto, em virtude da circunstância de que comungam da rejeição à noção de que as participações societárias seriam o objeto do contrato, preferindo, em seu

\footnotetext{
${ }^{81}$ COMPARATO, Fábio K.; SALOMÃO FILHO, Calixto. O poder de controle na sociedade anônima. $O p$. cit., n. 82, p. 247.

${ }^{82}$ COMPARATO, Fábio K.; SALOMÃO FILHO, Calixto. O poder de controle na sociedade anônima. $O p$. cit., n. 83, p. 247. O trabalho referenciado por COMPARATO é parecer em que CHAVES considerou a cessão de controle como modalidade de cessão da posição contratual (CHAVES, Antônio. "Cessão de posição contratual e cessão de situação acionária. Apossamento posterior, pelo cedente, de bens do acervo transmitido. Frustração da finalidade contratual. Responsabilidade civil, criminal e administrativa”. In: RT, v. 427, 1971, pp. 35-56).

${ }^{83}$ COMPARATO, Fábio K.; SALOMÃO FILHO, Calixto. O poder de controle na sociedade anônima. $O p$. cit., n. 83, p. 248.

${ }^{84}$ COMPARATO, Fábio K.; SALOMÃO FILHO, Calixto. O poder de controle na sociedade anônima. $O p$. cit., n. 89, p. 255.

${ }^{85}$ COMPARATO, Fábio K.; SALOMÃO FILHO, Calixto. O poder de controle na sociedade anônima. $O p$. cit., n. 89 , p. 255, nota 45.

${ }^{86}$ PETITPIERRE-SAUVAIN, Anne. La cession de contrôle, mode de cession de l'entreprise. Op. cit., p. 93.
} 
lugar, a noção de que o objeto real (como expressamente o designa PETITPIERRE-SAUVAIN e, implicitamente, COMPARATO) seria o controle. Sendo o controle, porém, entendido como poder de disposição sobre os bens sociais, chega-se ao resultado de que, indiretamente, o próprio patrimônio societário também seria objeto da cessão de controle. É correta, nesse sentido, a observação de CALIXTO SALOMÃo FILHO de que seria "curioso notar que Comparato, rejeitando veementemente a equiparação do controlador ao 'proprietário' da empresa, chega, nesse tópico a resultados aplicativos que aproximam as figuras". 87

GUILHERME PEREIRA, em obra monográfica posterior, concordou com a avaliação de que a cessão não se subsumiria às categorias contratuais clássicas, julgando presente um profundo desajuste entre realidade negocial e disciplina jurídica. ${ }^{88} \mathrm{O}$ autor, contudo, discordou do enquadramento de COMPARATO, para quem a cessão de controle seria contrato sui generis. Para PEREIRA, o contrato seria efetiva compra e venda. ${ }^{89}$ Quanto ao objeto do contrato, contudo, há consenso entre ambos: “objeto do negócio é o poder de controle". ${ }^{90}$ Buscando mitigar a suposta divergência entre COMPARATO e PETITPIERRESAUVAIN sobre o objeto do negócio (suposta, porque, como se viu, a posição de ambos, em realidade, é similar), PEREIRA concilia ambas as visões defendendo que o poder de controle também englobaria a empresa, pois avalia que "transferir o controle é transferir um poder sobre esses bens. Nesse sentido, é transferir esses mesmos bens". 91 Compartilha, igualmente, da convicção de que as próprias ações não seriam objeto do contrato de compra e venda de controle, mas somente meio para a transferência desse poder. ${ }^{92}$ Como consequência, considera que na compra e venda de ações de controle o cedente responderia por vícios redibitórios ou pela evicção dos bens sociais, além de restar proibido de se estabelecer em concorrência ao cessionário. ${ }^{93}$

Mais recentemente, EVANDRO PONTES apresentou pensamento similar ao de Comparato e Pereira, mas dotado de autonomia teórica. Na visão do autor, o controle poderia ser entendido como "objeto de direito, como bem jurídico ou mesmo como objeto

\footnotetext{
${ }^{87}$ SALOMÃO FILHO, Calixto. A sociedade unipessoal. São Paulo: Malheiros, 1995, p. 82, nota 40.

${ }^{88}$ PEREIRA, Guilherme D. C. Alienação do poder de controle acionário. Op. cit., p. 50.

${ }^{89}$ PEREIRA, Guilherme D. C. Alienação do poder de controle acionário. Op. cit., p. 74.

${ }^{90}$ PEREIRA, Guilherme D. C. Alienação do poder de controle acionário. Op. cit., p. 65.

${ }^{91}$ PEREIRA, Guilherme D. C. Alienação do poder de controle acionário. Op. cit., p. 53.

${ }^{92}$ PEREIRA, Guilherme D. C. Alienação do poder de controle acionário. Op. cit., p. 73.

${ }^{93}$ PEREIRA, Guilherme D. C. Alienação do poder de controle acionário. Op. cit., pp. 95-73.
} 
de negócio jurídico", 94 por ser bem passível de quantificação econômica, titularidade e alienação. Valendo-se da categoria dos bens reciprocamente considerados e do conceito de objeto metafuncional de BAUDRILLARD, defende que o controle seria um bem principal (CC, art. 92), mas cuja existência dependeria de seus acessórios, que seriam "o direito de voto, a administração e disposição dos bens corporativos, a condução hierárquica e soberana da máquina empresarial" ${ }^{\text {" } 55}$, entre outros poderes inerentes ao controle societário. O controle, assim, seria um bem "complexo e reciprocamente considerado em relação a outros direito que lhe são acessórios" "96, mas com a peculiaridade de que somente poderia existir "quando uma boa parcela desses acessórios que o compõe se faz presente"97. Diferente de COMPARATo e PEREIRA, ademais, EVANDro PONTES avalia que o controle não poderia ser confundido com os bens pertencentes ao patrimônio, que guardariam com o controle uma relação de pertinência. ${ }^{98}$

Nos diversos posicionamentos mencionados, portanto, nota-se a presença de um denominador comum. A compra e venda de participações societárias de controle, por importar alteração do controle, seria um negócio específico, distinto da mera cessão de ações ou quotas. Na disciplina jurídica, o objeto mediato, consistente no controle, na empresa, ou em ambos, seria alçado ao posto de objeto real do contrato, prevalecendo sobre as participações societárias, que são rebaixadas ao papel de objeto imediato, ou formal.

\section{Participações societárias como efetivo objeto do negócio jurídico}

A tese da especificidade da cessão de controle foi criticada na França, com especial vigor, no já mencionado artigo de BRUNO OPPETIT. Pautado pela lição de RIPERT, para quem "a sociedade pessoa jurídica não é um aglomerado de acionistas que teria sobre os bens sociais uma forma de propriedade em mão comum", 99 OPPETIT argumenta que a tese da especificidade levaria seus defensores a cair em contradições inexplicáveis para

\footnotetext{
94 PONTES, Evandro F. Representations \& Warranties no Direito Brasileiro. São Paulo: Almedina, 2014, p. 20.

${ }_{95}$ PONTES, Evandro F. Representations \& Warranties no Direito Brasileiro. Op. cit., p. 24.

${ }^{96}$ PONTES, Evandro F. Representations \& Warranties no Direito Brasileiro. Op. cit., p. 25.

${ }^{97}$ PONTES, Evandro F. Representations \& Warranties no Direito Brasileiro. Op. cit., p. 25.

${ }^{98}$ PONTES, Evandro F. Representations \& Warranties no Direito Brasileiro. Op. cit., p. 22.

${ }^{99}$ RIPERT, Georges. Aspects juridiques du capitalisme moderne, $2^{\mathrm{a}}$ ed. Paris: LGDI, 1951, n. 44, p. 128 ("la société personne morale n'est pas un agglomérat d'actionnaires qui auraient sur les biens sociaux une sorte de propriété en main commune").
} 
justificar a requalificação jurídica de contratos de cessão de participações societárias. ${ }^{100} \mathrm{O}$ dado fundamental, em seu aviso, é o de que a cessão de participações sempre diz respeito a uma parcela do capital social, não dos ativos. Desconsiderar a natureza jurídica da operação representaria grave desconhecimento de uma das consequências fundamentais da personalidade jurídica. ${ }^{101}$

A Cour de cassation, após ter experimentado orientações tendentes a aceitar a tese de que a cessão de controle deveria ter um tratamento peculiar, aplicando-se a disciplina jurídica do contrato relativo ao objeto mediato (fundo de comércio) em lugar da aplicável ao objeto imediato (participações societárias), hoje condena firmemente a possibilidade de equiparação. Como aponta CAFFIN-MoI, a Cour "condenou solenemente" a possibilidade de requalificar uma cessão de participações societárias de controle para aplicar o regime pertinente ao trespasse de fundo de comércio, de tal forma que, atualmente, "a dúvida não é mais permitida". ${ }^{102}$ As únicas exceções em que os bens integrantes do patrimônio societário são tomados pela jurisprudência francesa como relevantes para a tutela do adquirente são as situações em que a sociedade vai à falência, ou deixa de exercer qualquer atividade, pois, nesse caso, as próprias participações societárias tornar-se-iam inúteis ao comprador. ${ }^{103}$ Mesmo essa possibilidade bastante restrita de atribuir relevância ao objeto "mediato" é considerada por CAFFIN-MOI como indevida. A autora pugna pela manutenção de adequada separação entre a personalidade dos sócios e da sociedade, pautada, sobretudo, pela incoerência que significaria desrespeitar a personalidade jurídica para proteger o adquirente, mas impor sua observância, por exemplo, às autoridades fazendárias. ${ }^{104}$

Na Itália, é antiga a discussão sobre a possibilidade de se considerar os passivos da sociedade como vícios redibitórios na alienação de controle societário. Ela se iniciou com uma decisão da Corte di Cassazione, proferida em julho de 1933, na qual os alienantes de participação societária foram condenados a responder pela evicção dos bens

\footnotetext{
${ }^{100}$ OPPETIT, Bruno. "Les cessions de droits sociaux emportant le transfert du contrôle d'une société: essai de synthèse". Op. cit., p. 652.

101 OPPETIT, Bruno. "Les cessions de droits sociaux emportant le transfert du contrôle d'une société: essai de synthèse". Op. cit., p. 653.

${ }^{102}$ CAFFIN-MOI, Marie. Cession de droits sociaux et droit des contrats. Op. cit., n. 29, p. 31 ("la Cour de cassation a solennellement condamné la possibilité d'une requalification de la cession massive de droits sociaux en cession de fonds de commerce. Le doute n'est plus permis").

${ }^{103}$ Sobre o assunto, cf. item V.A.1.c) infra.

${ }^{104}$ CAFFIN-MOI, Marie. Cession de droits sociaux et droit des contrats. Op. cit., n. 528, p. 338.
} 
sociais. ${ }^{105}$ A decisão foi objeto de crítica por PAOLO GRECO. ${ }^{106}$ Em seu entendimento, a afirmação da personalidade jurídica da sociedade exige o reconhecimento de que o patrimônio social é de titularidade de um outro ente que não os sócios. Ações, como títulos de participação, atribuem direitos diversos, entre os quais o de receber eventual patrimônio remanescente na hipótese de liquidação, mas não outorgam titularidade direta sobre os bens sociais. Por conseguinte, os vícios ou a evicção dos ativos dizem respeito ao patrimônio de um terceiro (sociedade), que não é transferido pelos sócios com as ações. ${ }^{107}$ Decerto o preço das ações poderá ser calculado com base no valor dos ativos da sociedade, mas, para GRECO, essa correlação econômica não somente seria inapta para que se desconsiderasse a independência jurídica decorrente da personalidade jurídica, como sequer se revelaria um fenômeno exclusivo da alienação de controle. Pode ocorrer, por exemplo, que o valor de direitos de crédito seja calculado com base no risco de solvência dos respectivos devedores. Não seria por isso, afirma o autor, que alguém em sã consciência poderia afirmar que o cedente seria um condômino pro parte indivisa do patrimônio do devedor e que, dispondo de seu crédito, estaria dispondo de sua parte do patrimônio do devedor, respondendo pela respectiva evicção. ${ }^{108}$

A dura crítica de GRECO teve uma "singolare fortuna". ${ }^{109}$ Ela foi aceita pela Corte di Cassazione que, no mesmo ano de 1935, alterou o seu entendimento para afirmar que "quando não há dúvidas sobre a real existência da sociedade anônima, a venda de suas ações não pode se identificar com a alienação do patrimônio social". ${ }^{110}$

ASCARELLI, na mesma linha, rejeitou o tratamento dos passivos da sociedade como vícios redibitórios da compra e venda de participações societárias. A despeito de caracterizar as ações como bens de segundo grau, ressalta claramente que "o objeto da venda de um bloco de ações é sempre constituído por ações e não por bens sociais e a invocação dos motivos econômicos perseguidos pelas partes com a transferência de um bloco de ações não pode ser suficiente para substituir o que foi objeto de compra e

${ }^{105}$ Cass., 27.07.1933. In: Riv. dir. comm., v. 33, II, 1935, pp. 121-139.

${ }^{106}$ GRECO, Paolo. "Le società di comodo e la vendita delle loro azioni". In: Riv. dir. comm., v. 33, II, 1935, pp. 123-141.

${ }^{107}$ GRECO, Paolo. "Le società di comodo e la vendita delle loro azioni”. Op. cit., pp. 132-133.

${ }^{108}$ GRECO, Paolo. "Le società di comodo e la vendita delle loro azioni". Op. cit., p. 134.

109 BONELLI, Franco. "Giurisprudenza e dottrina su acquisizioni di società e di pacchetti azionari di riferimento". In: BONELLI, Franco; DE ANDRÉ, Mauro (org.). Acquisizioni di società e di pacchetti azionari di riferimento. Milano: Giuffrè, 1990, pp. 4-48, p. 9.

${ }^{110}$ Cass., 29.03.1935 apud BONELLI, Franco. "Giurisprudenza e dottrina su acquisizioni di società e di pacchetti azionari di riferimento". Op. cit., p. 9. 
venda por um outro objeto" ${ }^{\text {111 }}$. FERRI, igualmente, sublinhou que o patrimônio societário não pode ser objeto de disposição por parte dos sócios. ${ }^{112}$ A doutrina e a jurisprudência que sustentam a plena distinção entre a compra e venda de participações societárias de controle e a alienação dos bens sociais ou do controle é francamente majoritária. ${ }^{113}$

Apesar de o posicionamento doutrinário mencionado fundar-se em considerações pertinentes à responsabilidade do vendedor de participações societárias, ${ }^{114}$ ele é aplicado de forma uniforme nas diversas situações em que se pretende atribuir relevância aos motivos econômicos do contrato para equiparar, por exemplo, a transferência de controle com o trespasse de estabelecimento comercial. A jurisprudência, dessa forma, nega, por exemplo, (i) o direito de preferência do locatário de bens imóveis se estes bens integram o patrimônio social da sociedade cujo controle foi alienado; (ii) a equiparação fiscal entre os dois tipos de alienação; ${ }^{115}$ e (iii) o direito de prelação do

${ }^{111}$ ASCARELLI, Tullio. "In tema di vendita di pacchetti di azioni". In: Studi in tema di società. Milano: Giuffrè, 1952, pp. 63-67, pp. 64-65 ("L'oggetto della vendita di un pacchetto azionario è pur sempre costituito dalle azioni, non dai beni sociali e l'invocazione dei motivi economici perseguiti dalle parti con il trapasso di un pacchetto azionario non può essere sufficiente per sostituire, a quanto è stato oggetto della vendita, un altro e diverso oggetto").

112 FERRI, Giuseppe. "Incidenza delle obbligazioni sociali nei rapporti fra cedente e cessionario di quote sociali”. In: Foro it., I, 1936, 712-720, p. 716.

${ }^{113}$ Nesse sentido, PUGLIATTI, Salvatore. "Vendita di azioni e garanzia per evizione". In: BBTC, II, 1937, pp. 86-100, p. 90-92; PANZARINI, Elisabetta. "Cessione di pacchetti azionari: il contenuto delle clausole di garanzia”. In: GALGANO, Francesco (org.). I contratti del commercio, dell'industria e del mercato finanziario, t. I. Torino: UTET, 1995, pp. 247-347, p. 257-261; ROVELLI, Luigi. "Natura della vendita del pacchetto azionario". In: Società, n. 11, 1988, pp. 1164-1167; CARNEVALI, Ugo. "Garanzie per vizi dei beni sociali nella cessione di azioni”. In: Società, n. 6, 1992, pp. 822-824; BONELLI, Franco. "Giurisprudenza e dottrina su acquisizioni di società e di pacchetti azionari di riferimento". Op. cit., pp. 1819; PETRUCCI, Anna Maria. "Cessione di pacchetti azionari e dolo del venditori”. In: Riv. dir. comm., II, 1994, pp. 384-393, p. 386-387; CAMPOBASSO, Mario. "Vendita del pacchetto azionario di società in liquidazione per perdite”. In: Riv. dir. priv., n. 21, 1996, pp. 362-392, pp. 378-380; ANGELICI, Carlo. "La partecipazione azionaria come oggetto di circolazione". Op. cit., pp. 108 e 116; SCARSO, Alessandro. "La responsabilità del venditore di partecipazioni sociali nel diritto italiano e tedesco". In: Riv. soc., 1999, pp. 455-486, p. 459-466; MONTALENTI, Paolo. "Le acquisizioni societarie - profili contrattuali". In: Persona giuridica, gruppi di società, corporate governance. Torino: CEDAM, 1999, pp. 147-163, p. 153; IUDICA, Giovanni. "Il prezzo nella compravendita di partecipazioni azionarie". In: Riv. soc., 1991, pp. 750-771, p. 767; PINTO, Maurizio. "Le garanzie 'patrimoniali' nella vendita di partecipazioni azionarie di controllo: qualificazione giuridica e termini di prescrizione”. In: Riv. soc., 2004, pp. 411-468, pp. 412-415; RUBINOSAMMARTANO, Mauro. Garanzie nella compravendita di pacchetti azionari e di imprese. Milano: Giuffrè, 2006, p. 45; SPERANZIN, Marco. Vendita delle partecipazione di 'controllo' e garanzie contrattuali. $O p$. cit., p. 13; TINA, Andrea. Il contratto di acquisizione di partecipazioni societarie. $O p$. cit., pp. 172-177.

${ }^{114}$ A tutela do comprador de participações societárias de controle no direito italiano será melhor avaliada no item V.A.1.b) infra.

115 BONELLI, Franco. "Giurisprudenza e dottrina su acquisizioni di società e di pacchetti azionari di riferimento". Op. cit., pp. 11-13. 
proprietário de confinante ou do arrendatário na hipótese de alteração do controle da sociedade proprietária de imóvel rural. ${ }^{116}$

$\mathrm{Na}$ Espanha, apesar de a produção doutrinária sobre o assunto ser comparativamente menos expressiva que a francesa e a italiana, prevalece o entendimento jurisprudencial contrário a qualquer possibilidade de reconhecer relevância jurídica a ponto de considerar que, na venda de participação societária de controle, o regime aplicável fosse o correspondente à cessão de bens do ativo. Rechaça-se, com isso, a pretensão do locatário de imóvel pertencente à sociedade de exercer direito de preferência em virtude da alteração do controle societário. ${ }^{117} \mathrm{Ou}$ a pretensão do adquirente da integridade das ações de obter tutela por meio de ação edilícia quando verificasse que um imóvel integrante do ativo social estaria afetado por vício oculto. ${ }^{118}$

No Brasil, Pontes DE MiRAnda diferencia a compra e venda de participações societárias da compra e venda de empresa, admitindo, porém, a equiparação entre as espécies no caso de compra de todas as ações. No caso de aquisição de posição de controle, porém, sua posição é dúbia. Em parecer, defendeu que a venda de ações pode outorgar o controle da empresa, mas isso não bastaria para considerá-la como venda do estabelecimento, mesmo no caso de serem vendidas quase todas as ações, ressaltando a exigência legal vigente de número mínimo de acionistas. De tal forma, em sua visão, "reputar venda de fundo de empresa a venda de quase todas as ações seria erro. Exercer controle não é ser dono. Adquirir ações que permitam o controle não é adquirir a sociedade". ${ }^{119}$ Em outro local de sua obra, porém, afirma que "se o contrato é sôbre todos os direitos sociais, ou da maioria das quotas de uma sociedade, há compra-e-venda de emprêsa, ou do contrôle de emprêsa". ${ }^{120}$ Mais recentemente, CALIXTO SALOMÃo FILHO, em um primeiro momento, defendeu o entendimento de que o comprador não adquiriria o domínio sobre os bens da empresa. Avaliou, com isso, que "[d]esconsiderar a pessoa

\footnotetext{
${ }^{116}$ TINA, Andrea. Il contratto di acquisizione di partecipazioni societarie. Op. cit., pp. 198-204. ${ }^{117}$ OLIVEIRA, J. L. Corrêa de. A Dupla Crise da Pessoa Jurídica. São Paulo: Saraiva, 1979, pp. 493-494.

118 Faz-se referência ao julgado do Tribunal Supremo de 21.12.2009 (RJ 2010/299), reproduzido em GARCÍA VICENTE, José-Ramón. "Compraventa de acciones compraventa de empresa: defectos ocultos en el activo principal de la sociedad. Calificación e interpretación de los contratos. Causa de los contratos móvil casualizado". In: CCJC, v. 84, 2010, pp. 1729-1746. Sobre o posicionamento doutrinário na Espanha a respeito do assunto, cf. item V.A.1.d), infra.

119 PONTES DE MIRANDA, Francisco C. "Parecer n. 201. Sobre compra-e-venda de ações de banco e responsabilidade contratualmente assumida, em termos explícitos e restritos, pelo vendedor e atos ilícitos de outrem". In: Dez anos de pareceres, v. 8, Rio de Janeiro: Francisco Alves, 1976, pp. 34-47, p. 41.

${ }^{120}$ PONTES DE MIRANDA, Francisco C. Tratado de direito privado, t. 39. Rio de Janeiro: Borsoi, 1962, $\S 4.289$, p. 154 .
} 
jurídica, permitindo a aplicação das regras da compra-e-venda diretamente aos bens e direitos componentes do ativo da empresa, implicaria admitir a consideração dos bens como coisa própria do controlador, ou seja, identificar controle a direito de propriedade, o que não é admissível". ${ }^{121}$ Para o autor, no negócio de compra e venda de participações societárias de controle, o vendedor responderia somente por vícios essenciais que impedissem o funcionamento da organização, o que incluiria, no máximo, componentes imateriais do fundo de comércio. Não seria possível, entretanto, "passar do direito sobre a organização ao direito sobre os bens da empresa". ${ }^{122}$ Posteriormente, contudo, o autor reviu parcialmente sua posição e passou a postular que, no âmbito da interpretação do contrato, seria possível que os ativos fossem tomados pelas partes como objeto do negócio jurídico, justificando a aplicação do regramento relativo aos vícios redibitórios. ${ }^{123}$

\section{Posicionamento}

As duas teses possuem méritos, mas pecam. A primeira pelo excesso; a segunda, pela falta.

O valor inegável da tese da especificidade da cessão de controle enquanto negócio jurídico distinto da compra e venda ordinária de ações ou quotas foi o de chamar a atenção para os diversos interesses envolvidos na operação. COMPARATO, de forma inovadora, analisa o contrato a partir da perspectiva dos trabalhadores, ${ }^{124}$ do Estado ${ }^{125} \mathrm{e}$ dos acionistas não-controladores, ${ }^{126}$ da mesma forma que, na França, analisava-se a relevância da transferência de controle para fins trabalhistas, ou mesmo para a obrigação de formulação de ofertas públicas de aquisição. ${ }^{127}$ Não é coincidência que, em seu capítulo denominado "A Cessão do Controle Acionário", COMPARATO aborde desde a proteção do adquirente pela disciplina dos vícios redibitórios ${ }^{128}$ até a necessidade de autorização do

\footnotetext{
${ }^{121}$ SALOMÃO FILHO, Calixto. A sociedade unipessoal. $O$ p. cit., p. 82.

122 SALOMÃO FILHO, Calixto. A sociedade unipessoal. Op. cit., p. 81.

${ }^{123}$ Sobre o assunto, cf. item V.A infra.

${ }^{124}$ COMPARATO, Fábio K.; SALOMÃO FILHO, Calixto. O poder de controle na sociedade anônima. Op. cit., n. 85 , p. $248-250$.

${ }^{125}$ COMPARATO, Fábio K.; SALOMÃO FILHO, Calixto. O poder de controle na sociedade anônima. Op. cit., n. 85 , p. 248-250.

${ }^{126}$ COMPARATO, Fábio K.; SALOMÃO FILHO, Calixto. O poder de controle na sociedade anônima. Op. cit., n. 91-96, pp. 261-274.

${ }^{127}$ OPPETIT, Bruno. "Les cessions de droits sociaux emportant le transfert du contrôle d'une société: essai de synthèse". Op. cit., pp. 631-654.

${ }^{128}$ COMPARATO, Fábio K.; SALOMÃO FILHO, Calixto. O poder de controle na sociedade anônima. Op. cit., n. 89, p. 255.
} 
ente público contratante para a cessão de controle societário. ${ }^{129}$ Essa estrutura que enfrenta de forma unitária problemas contratuais, como a tutela do adquirente, e problemas regulatórios, como o regramento da oferta pública de aquisição de controle, é seguida também nos trabalhos de PetitPierre-SAuvain ${ }^{130}$ e de Guilherme PereirA ${ }^{131}$.

Chegando, porém, ao extremo de considerar que a cessão de controle seria uma nova categoria de negócio jurídico sui generis, tendo por objeto o próprio controle, a orientação termina por negligenciar o fato de que soluções próprias para fins regulatórios podem ser insuficientes ou inadequadas para a disciplina contratual.

É pertinente, nessa medida, a distinção promovida por ANGELICI entre o que denomina problemas "externos" e problemas "internos" envolvidos na transferência do controle societário. ${ }^{132}$ Entre os problemas externos situam-se, por exemplo, aqueles relativos (i) à disciplina concorrencial, que, atualmente, abstrai das categorias formais, preferindo a noção de concentração econômica (Lei 12.529/2011, art. 88) ; (ii) às obrigações do controlador vis-à-vis os sócios minoritários no momento da transferência da participação de controle, como o dever de maximizar o valor obtido pelos minoritários ${ }^{133}$ ou de se abster de alienar o controle a adquirente interessado em destruir a organização empresarial (looter); ${ }^{134}$ (iii) às obrigações no mercado de capitais, como a proibição de negociar com informações confidenciais relativas à alienação de controle (Instrução CVM n. 358/2002, art. 13) e a obrigação divulgar fato relevante (Instrução CVM n. 358/2002, art. 10); (iv) à obrigação de lançamento de oferta pública de aquisição de controle (LSA, art. 254-A); (v) à exigência de autorização regulatória para alteração do controle societário (e.g.: para instituições financeiras, Lei 4.595/1964, art. 10, X, “g”; para concessionárias, Lei 8.987/1995, art. 27); e (vi) ao tratamento oferecido à aquisição, por companhia aberta, do controle de qualquer sociedade mercantil (LSA, art. 256).

\footnotetext{
${ }^{129}$ COMPARATO, Fábio K.; SALOMÃO FILHO, Calixto. O poder de controle na sociedade anônima. Op. cit., n. 86, p. 250.

${ }^{130}$ PETITPIERRE-SAUVAIN, Anne. La cession de contrôle, mode de cession de l'entreprise. Op. cit.

${ }^{131}$ PEREIRA, Guilherme D. C. Alienação do poder de controle acionário. Op. cit.

${ }^{132}$ ANGELICI, Carlo. "La partecipazione azionaria come oggetto di circolazione". Op. cit., p. 109.

133 BUXBAUM, Richard. "What happened to Perlman v. Feldman?". In: WANK, Rolf (et al., org.). Festschrift für Herbert Wiedemann zum 70. Geburtstag, München: C. H. Beck, 2002, pp. 769-785; FRANÇA, Erasmo V. A. e N. "Dever de lealdade do acionista controlador por ocasião da alienação do controle - dever de maximização do valor das ações dos acionistas não controladores - interpretação de estatuto de companhia aberta - possibilidade de cumulação de OPAs”. In: RDM, v. 158, 2011, pp. 251-266.

134 Sobre o assunto, cf. WIEDEMANN, Herbert. Minderheitenschutz und Aktienhandel. Stuttgart: Ferdinand Enke, 1968; CASQUET, Andréia C. B. Alienação de Controle de Companhias Fechadas. São Paulo: Quartier Latin, 2015, pp. 160-176.
} 
O denominador comum desses problemas "externos", que os diferencia dos problemas "internos", é o fato de que, para as finalidades normativas em questão, o que releva é a circunstância de que o controle exercido por uma pessoa passe a ser exercido por outra, e que essa sucessão sem solução de continuidade ocorra em seguida à transferência de ações ou quotas. ${ }^{135}$ Designar a operação como cessão, transferência, alienação ou aquisição do próprio controle, nesses contextos, parece adequado, ainda que se parta de evidente hipóstase. Para essas finalidades regulatórias, importa pouco o mecanismo pelo qual a alteração do quadro societário é promovida. A transferência de uma única ação ou quota, em uma sociedade igualitária, pode ser suficiente para desencadear todos os efeitos mencionados.

O regramento concernente a esses problemas externos, contudo, não deve ser idêntico ao pertinente aos problemas internos que se colocam, seja na relação entre vendedor e comprador, seja na diferenciação do contrato de compra e venda de participações societárias de outras modalidades de disposição patrimonial. A tese de que o contrato de cessão de controle seria um negócio sui generis peca por esse excesso.

Afirmar que o contrato de cessão de controle não tem como objeto as ações ou quotas, mas sim o próprio poder de controle, ou a empresa, ou ambos, significa ignorar as especificidades que cercam cada negócio translativo e, no limite, desconsiderar a autonomia patrimonial e pessoal conferida pela personalidade jurídica. O resultado é um enredar-se em entorses dogmáticos e contradições teóricas. ${ }^{136}$

O primeiro exemplo desses entorses que culminam em contradição está presente na obra de Guilherme Pereira. Tendo defendido que a compra e venda de participações societárias de controle seria, em verdade, uma compra e venda do próprio controle, o autor sustenta a aplicabilidade da disciplina dos vícios redibitórios, com responsabilidade do vendedor, por exemplo, por passivo não contabilizado, ou por ação trabalhista que viesse a ser julgada procedente, ou seja, responsabilidade do vendedor pela integridade do acervo societário, e não das ações transferidas. ${ }^{137}$ Passo subsequente, tendo em vista a especificidade do objeto do contrato (o próprio poder de controle), o autor

\footnotetext{
${ }^{135}$ Nesse sentido, parece adequada para as finalidades regulatórias a proposta interpretativa de MUNHOZ, Eduardo Secchi. Aquisição de controle na sociedade anônima. São Paulo: Saraiva, 2013, p. 350.

${ }^{136}$ OPPETIT, Bruno. "Les cessions de droits sociaux emportant le transfert du contrôle d'une société: essai de synthèse". Op. cit., p. 652.

${ }^{137}$ PEREIRA, Guilherme D. C. Alienação do poder de controle acionário. Op. cit., p. 99.
} 
propõe-se a definir se o prazo decadencial aplicável para exercício das ações edilícias seria o de 15 (quinze) dias então previsto para coisas móveis ou de 6 (seis) meses previsto para coisas imóveis $\left(\mathrm{CC} / 1916\right.$, art. $178, \S 2^{\circ}$ e $\left.\S 5^{\circ}, \mathrm{IV}\right)$. Em seu entendimento, não seria "muito audacioso sustentar que o prazo, nas alienações de controle, deva ser o de seis meses, previsto para imóveis". ${ }^{138}$ Para o autor, em que pese o controle não ser propriamente um direito, quando se faz necessário enquadrá-lo em uma das categorias da summa divisio, o correto seria, por analogia, aplicar o regime dos imóveis. A razão seria que, em complexos empresariais, um imóvel seria "praticamente sempre necessário", ${ }^{139}$ ainda que alugado de terceiro, de tal forma que, por acessão intelectual, o controle exercido sobre o imóvel seria uma coisa imóvel. ${ }^{140}$

As dificuldades teóricas são evidentes. Alça-se à posição de objeto do negócio jurídico um poder, que não é um bem. Posteriormente, quando se busca, por aproximação, enquadrar o mesmo objeto em uma das categorias dogmáticas que pautam a aplicação de remédios contratuais previstos no regramento do contrato de compra e venda, o resultado obtido é difícil de ser sustentado. Ele se assemelha, com efeito, ao posicionamento dos teóricos que viam no estabelecimento comercial um objeto de direito, distinto das coisas que o compõem, e que, como afirma ASCARELLI, "acham-se naturalmente bastante embaraçados ao decidir se se trata de coisa móvel ou imóvel; não são poucos os que, não sei com que fundamento, recorrem, para solucionar esta questão, ao fato de predominarem os móveis ou os imóveis, entre as coisas que compõem, no caso concreto, o estabelecimento comercial". ${ }^{141}$

Ainda que se admita que o controle sobre a empresa proprietária de um imóvel poderia ser considerado um bem imóvel, de toda forma, não parece que a mesma resposta seria adequada quando um imóvel estivesse meramente locado pela sociedade. A companhia teria em seu patrimônio, nesse caso, apenas um "direito de obrigação", claramente definido no Código Civil de 1916 como móvel para os fins legais (CC/1916, art. 48, II). Mesmo que se admitisse a validade da proposta de enquadramento do poder de controle como bem imóvel ainda na hipótese de ser a sociedade apenas locatária de um

\footnotetext{
${ }^{138}$ PEREIRA, Guilherme D. C. Alienação do poder de controle acionário. Op. cit., p. 101.

${ }^{139}$ PEREIRA, Guilherme D. C. Alienação do poder de controle acionário. Op. cit., p. 79.

${ }^{140}$ PEREIRA, Guilherme D. C. Alienação do poder de controle acionário. Op. cit., p. 79.

141 ASCARELLI, Tullio. "O Negócio Indireto". In: Problemas das Sociedades Anônimas e Direito Comparado, $2^{\text {a }}$ ed. São Paulo: Saraiva, 1969, pp. 91-163, p. 101, nota 34.
} 
imóvel, ter-se-ia, no limite, uma incoerente diversidade de tratamento, conforme estivesse em questão o controle sobre sociedade titular de um estabelecimento físico, ou apenas virtual. $^{142}$

As contradições também se fazem presentes. Aplicando uma regra pertinente à tutela do comprador, sobre a qual, em tese, é possível às partes negociar, PEREIRA afirma que o controle seria bem imóvel por analogia. Quando trata da forma desse mesmo negócio jurídico, por outro lado, o autor afirma não ser necessária nenhuma "formalidade especial", ${ }^{143}$ pois, ainda que os bens empresariais sejam compostos por móveis ou imóveis, continuam pertencendo a um titular formal que não é sucedido por outro, de tal forma que para a execução do contrato bastaria a transferência das ações. ${ }^{144}$ Por mais que se concorde com o resultado, ${ }^{145}$ não se pode deixar de notar a contradição teórica em que incorre a obra ao não exigir, coerentemente, a observância da forma solene prevista legalmente para os contratos constitutivos ou translativos de direitos reais sobre imóveis (CC/1916, art. 134; CC/2002, art. 108). Quanto mais pelo fato de que a solenidade, antes de tutelar o comprador, visa a induzir a ponderada reflexão das partes sobre a decisão negocial por meio da exigência de procedimento formal. É pautada, portanto, por um interesse público inderrogável em evitar que negócios jurídicos com relevante impacto patrimonial sejam decididos de forma precipitada.

$\mathrm{O}$ raciocínio poderia ser aplicado ainda às demais regras específicas relativas à negociação de bens imóveis ou do estabelecimento empresarial. Quando se considera que o objeto real do negócio jurídico é o poder de controle sobre a empresa e, com isso, a própria empresa - fulcro da tese da especificidade da cessão de controle -, torna-se incoerente a não aplicação dos regimes jurídicos pertinentes à negociação dos bens integrantes do patrimônio societário.

Um segundo entorse dogmático da tese da especificidade é a falta de clareza sobre a função das participações societárias no negócio jurídico. Vistas como um meio, mero expediente formal de que as partes se valem, não é evidente qual seria seu papel no contrato de cessão de controle. Em especial, não se sabe ao certo se o objeto do contrato

\footnotetext{
${ }^{142}$ Sobre o assunto, cf. TEIXEIRA, Tarcísio. "Estabelecimento empresarial virtual: regime jurídico". In: RDM, v. 157, 2011, pp. 201-217.

${ }^{143}$ PEREIRA, Guilherme D. C. Alienação do poder de controle acionário. Op. cit., p. 84.

${ }^{144}$ PEREIRA, Guilherme D. C. Alienação do poder de controle acionário. Op. cit., p. 85.

${ }^{145}$ Sobre o assunto, cf. item II.E, infra.
} 
seria somente o poder de controle como bem econômico diverso dos títulos acionários (relação de substituição do objeto mediato pelo imediato) ou se a prestação devida pelo vendedor seria integrada pelos dois objetos, ou seja, ações ou quotas e o próprio poder de controle (relação de complementaridade).

Para Guilherme PereirA, o caminho parece ser o da relação de substituição, tanto que afirma que o objeto do contrato seria o "poder de controle de uma sociedade determinada". ${ }^{146}$ Tal orientação redunda, porém, na ausência de uma disciplina jurídica aplicável a vícios relativos às próprias ações ou quotas, fazendo com que se tenha de recorrer a figuras gerais. Tome-se como exemplo a hipótese aventada por PEREIRA de ser celebrado contrato de compra e venda de controle, mas a transferência das ações não se realizar em virtude do exercício por outro sócio de direito de preferência previsto em acordo de acionistas arquivado na sede da companhia. Para o autor, estaria configurado na hipótese um inadimplemento contratual. ${ }^{147}$ Sem questionar neste momento o mérito da solução proposta, ${ }^{148}$ não deixa de causar espécie o fato de não se aventar para a hipótese de ocorrência de evicção (CC/1916, art. 1.107; CC/2002, art. 447), preferindo-se o recurso direto à figura mais geral, e consequentemente periférica, do inadimplemento. E a razão para esse procedimento é o fato de que o autor entende que o objeto devido seria apenas o controle, sendo a ele aplicável a disciplina da evicção, e não às próprias ações. Ao se abdicar do regime específico da evicção, porém, deixa-se de ter em vista os contornos jurídicos melhor talhados para enfrentar a situação concreta. No exemplo, considerando que o acordo de acionistas estivesse arquivado na sede da companhia, o recurso ao regime da evicção suscitaria o questionamento quanto à possibilidade de se considerar que o adquirente não teria direito a ser indenizado por ter celebrado o negócio jurídico sabendo que a coisa vendida seria "alheia, ou litigiosa" (CC/1916, art. 1.117, II; CC/2002, art. 457), como já se julgou em caso análogo relativo a bem imóvel, no qual se afastou a alegação de evicção em virtude do fato de que um dos condôminos exerceu seu direito de preferência. ${ }^{149}$

\footnotetext{
${ }^{146}$ PEREIRA, Guilherme D. C. Alienação do poder de controle acionário. Op. cit., p. 83.

${ }^{147}$ PEREIRA, Guilherme D. C. Alienação do poder de controle acionário.. Op. cit., p. 83.

${ }^{148}$ Sobre o assunto, cf. item V.B, infra.

149 TJMG, Ap. 1.0183.10.006541-0/001, 15ª Câm. Civ., rel. Des. Tiago Pinto, j. 13.06.2013 (afirmando que, se adquirente tem ciência de que bem encontra-se em condomínio, não ocorreria evicção em virtude do exercício de direito de preferência por um dos condôminos).
} 
Quando se adota a linha da complementaridade, contudo, o caminho tampouco parece ser frutífero. Afirmar que o objeto da cessão de controle seria a alienação de participações societárias somada à transferência do poder de controle, entendido enquanto bem jurídico, não parece a leitura mais adequada da estrutura negocial. As principais propostas tendentes a compreender o poder de controle enquanto um bem jurídico, formuladas por RuBEns REQuião, JoÃo BAPTISTA VILlELA e EVANDRO PONTES, não parecem convincentes.

RUBENS REQUIÃO defendeu que o controle seria bem imaterial, comparável ao aviamento e "apropriável, por ocupação, pelo acionista ou pelo grupo que conseguir reunir a disposição de maior número de títulos". ${ }^{150}$ Concorda-se, contudo, com a crítica que lhe formulou COMPARATO. Considerando que a opinião de REQUIÃo seria expressão da tendência à reificação dos direitos subjetivos, COMPARATO avalia que o controle não é um bem da empresa, senão um poder sobre ela, de tal forma que, do seu exercício, pode decorrer que a empresa tenha um bom ou mau aviamento, não se confundindo o controle com esse efeito. ${ }^{151}$

JoÃo BAPTISTA VILLELA, por sua vez, sustentou que o poder de controle teria dúplice natureza. Normalmente, não seria um bem, somente um valor, vantagem inerente ao bloco de ações que formam a maioria (anima). ${ }^{152}$ No momento em que se considerada a hipótese de sua transferência, porém, o poder assumiria existência fugaz e transitória, manifestando-se como coisa incorpórea ou imaterial, constituindo bem de troca passível de negócios jurídicos (corpus). ${ }^{153}$

O posicionamento de VILLELA, contudo, não parece o mais adequado, em primeiro lugar, porque nem sempre as ações do bloco de controle são caracterizadas por um sobrevalor. A existência de um prêmio de controle é circunstância contingente e dependente da possibilidade de o acionista controlador obter vantagens do exercício de seu poder. Tal prêmio de controle pode existir ou não, ${ }^{154}$ ser expressivo, como normalmente

${ }^{150}$ REQUIÃO, Rubens. "O Controle e a Proteção dos Acionistas”. In: RDM, v. 15/16, 1974, pp. 23-36, p. 31.

${ }^{151}$ COMPARATO, Fábio K.; SALOMÃO FILHO, Calixto. O poder de controle na sociedade anônima. Op. cit., n. 24, p. 101.

${ }^{152}$ VILLELA, João Baptista. Controle Acionário: corpus et anima. São Paulo: Malheiros, 2011, p. 28.

${ }^{153}$ VILLELA, João Baptista. Controle Acionário: corpus et anima. Op. cit., p. 28.

${ }^{154}$ IUDICA, Giovanni. "Il prezzo nella compravendita di partecipazioni azionarie". Op. cit., p. 761 (“il c.d. 'premio di maggioranza' o il c.d. 'sconto di minoranza' sono componenti economiche del valore di scambio; 
ocorre no Brasil, ou mesmo negativo, como já foi constatado em outros países. ${ }^{155}$ Mesmo que sempre se verificasse a obtenção de um valor superior na negociação das ações do bloco de controle, todavia, não parece que o próprio poder de controle poderia ser considerado um bem. Em universalidades de fato, é realidade conhecida e recorrente que o conjunto possa valer mais que a adição das partes. É o que ocorre na venda de uma coleção de livros, em que se pode obter valor superior pela negociação da obra completa do que pela soma dos tomos singulares. Nem por isso se afirma que a compra e venda dos livros tem por objeto os livros e a própria coleção. É certo que a circunstância qualifica o objeto da compra e venda (não são quaisquer livros, são livros que compõem uma coleção); mas não o altera. Igualmente, na venda de ações do bloco de controle, ou de expressivos blocos minoritários, ${ }^{156}$ normalmente se atribui às ações ou quotas um valor superior ao de participações isoladas, mas, nem por isso, será possível afirmar a duplicidade de objetos do negócio jurídico.

Evandro Pontes, por fim, sustenta que o Código Civil comportaria "duas categorias jurídicas de bens, a saber, os bens considerados em si mesmos e os bens reciprocamente considerados", de forma que seria necessário determinar qual o estatuto jurídico adequado para enquadrar o controle, entendido enquanto bem. ${ }^{157}$ Para o autor, o poder de controle seria um "bem reciprocamente considerado com seus acessórios", ${ }^{158}$ cuja existência dependeria da presença de "boa parcela desses acessórios que o compõem", como o direito de voto, poder de disposição dos bens corporativos, entre outros. A posição sofre, primeiramente, pela carência de clareza quanto à parcela de poderes que seriam necessários para perfazer o controle enquanto bem. Acredita-se, ademais, que a disciplina dos "bens reciprocamente considerados" (Capítulo II do título único denominado "Das diferentes classes de bens", que se inicia no art. 79 do CC) não se coloca como alternativa à disciplina dos "bens considerados em si mesmos" (Capítulo I do mesmo título único),

sono realtà economiche che in sé non hanno alcuna consistenza giuridica e formale; possono esserci come non esserci, non hanno un ammontare definito, variano da caso a caso").

${ }^{155}$ Em pesquisa publicada em 2004, constatou-se que o prêmio de controle médio no Brasil correspondia a um valor superior correspondente a $65 \%$ do valor da própria sociedade, ao passo que, no Japão, em média, atribuía-se valor inferior às ações do bloco de controle do que às ações negociadas em bolsa de valores (DYCK, Alexander; ZINGALES, Luigi. "Private benefits of control: an international comparison". In: Journal of Finance, v. 59, 2004, pp. 537-600, p. 551).

${ }^{156}$ COMPARATO, Fábio K.; SALOMÃO FILHO, Calixto. O poder de controle na sociedade anônima. Op. cit., nota de texto n. 45, p. 206 ("Blocos minoritários são também passíveis de valoração econômica, ainda mais quando garantem participação societária estratégica”).

${ }^{157}$ PONTES, Evandro F. Representations \& Warranties no Direito Brasileiro. Op. cit., p. 21.

${ }^{158}$ PONTES, Evandro F. Representations \& Warranties no Direito Brasileiro. Op. cit., p. 24. 
senão, antes, a pressupõe. Somente se estabelecem relações de acessoriedade ou pertinência entre bens singulares, ou seja, "bens que, embora reunidos, se consideram de per si, independentemente dos demais" (CC, art. 89). Se o controle dependesse para sua existência da reunião de diversos bens acessórios, faltar-lhe-ia a a característica de ser um bem singular, ou seja, com existência autônoma. Não pode, por conseguinte, ser um bem principal.

Em voto dissidente referindo-se ao estabelecimento empresarial, mas que parece igualmente aplicável ao poder de controle, Oliver Holmes observou que a "exatidão aparente é uma fonte de falácias em todo o direito. Ao denominar um estabelecimento como "propriedade" gera-se a impressão de que se trataria de algo como um terreno [...]. Um estabelecimento certamente pode ter valor pecuniário e ser normalmente protegido pela lei contra agressões ilícitas. Mas não se lhe pode atribuir um contorno definitivo chamando-o de coisa". ${ }^{159}$ MARIO STELla RICHTER JR., igualmente, recusa a representação do poder de controle enquanto bem, afirmando que o "controle não é situação ínsita às ações, que de nenhuma forma o representam ou incorporam, nem mesmo 'proporcionalmente'; dessa forma, a transferência (ou aquisição) destas não se resolve em uma transferência (ou em aquisição) em senso próprio daquele". ${ }^{160}$ Não é por acaso, portanto, que a expressão "transferência de controle" constante do título de sua obra esteja entre aspas.

A consideração de que o poder de controle seria um poder de fato, e não um bem, parece a mais acertada, pois, em linha com o que afirma BULHõES PEDREIRA, (i) não há norma legal que assegure o poder de controle: ele nasce com a formação do bloco de ações de controle e desaparece com sua dissolução, que pode ocorrer inclusive mortis causa; (ii) o poder de controle não é um direito subjetivo, pois não é possível ao acionista controlador pleitear tutela estatal autônoma para exigir o respeito desse poder; e (iii) o poder de controle não é objeto de direito, na medida em que não pode ser adquirido nem

\footnotetext{
${ }^{159}$ Truax v. Corrigan, 257 U.S. 312 (1921), p. 342 ("Delusive exactness is a source of fallacy throughout the law. By calling a business 'property', you make it seem like land, and lead up to the conclusion that a statute cannot substantially cut down the advantages of ownership existing before the statute was passed. An established business no doubt may have pecuniary value and commonly is protected by law against various unjustified injuries. But you cannot give it definiteness of contour by calling it a thing.").

${ }^{160}$ RICHTER JR., Mario S. "Trasferimento del controllo" e rapporti tra soci. Milano: Giuffrè, 1996, p. 100 ("controllo non è situazione insita nelle azioni, che in nessun modo lo rappresentano o incorporano, neanche 'frazionatamente'; cosicché il trasferimento (o l'acquisto) di queste non si risolverà mai in un trasferimento (o in un acquisto), in senso proprio, di quello").
} 
transferido independentemente das ações do bloco de controle, que constituem sua fonte. ${ }^{161}$ Quem adquire ações vale-se de um dos possíveis instrumentos - não é sequer o único, como demonstra a possibilidade de controle externo ${ }^{162}$ - que o ordenamento societário propicia para que alguém possa assumir o poder de fato consistente no controle societário.

Seja na vertente da relação de substituição (objeto mediato no lugar do imediato), seja na de complementaridade (objeto mediato ao lado do imediato), ademais, o fato é que a posição doutrinária da especificidade considera as participações societárias como um mero expediente formal, "un simple media"163, promovendo um "amálgama" entre as noções de cessão de controle, de trespasse de estabelecimento e de venda de ativos sociais. ${ }^{164}$ Não se atenta, assim, ao fato de que o objeto reputado meramente formal do negócio jurídico sujeita-se a vicissitudes próprias e tem sua transferência regida por princípios diversos dos aplicáveis ao trespasse do estabelecimento empresarial ou à alienação de bens integrantes do ativo.

A tese contrária possui a vantagem inegável de ressaltar que o contrato de compra e venda de participações societárias de controle tem por objeto justamente as participações societárias, e não o próprio controle. Não é necessário considerar que o patrimônio societário ou o poder de controle sejam os objetos do negócio jurídico para lhes reconhecer relevância. É evidente que tanto os direitos patrimoniais quanto os direitos políticos conferidos pelas participações societárias serão os fatores de maior importância para a atribuição de seu valor. Nem por isso é necessário desprezar a separação pessoal e patrimonial promovida pela personalidade jurídica.

O respeito absoluto pela interposição da personalidade jurídica, porém, pode igualmente conduzir a resultados inadequados. Peca-se pela falta, pois o diafragma é

${ }^{161}$ PEDREIRA, J. L. Bulhões. “Alienação de Controle de Companhia Aberta (Parecer)”. In: PEDREIRA, J. L. Bulhões; LAMY FILHO, Alfredo. A Lei das S.A. Rio de Janeiro: Renovar, 1992, pp. 691-717, p. 702. No mesmo sentido, COMPARATO, Fábio K.; SALOMÃO FILHO, Calixto. O poder de controle na sociedade anônima. Op. cit., n. 24, p. 100.

${ }^{162}$ OLIVEIRA, Ana Perestrelo de. Grupos de sociedades e deveres de lealdade. Coimbra: Almedina, 2012, pp. 276-291; COMPARATO, Fábio K. "Poder de controle na sociedade anônima". In: RDM, n. 9, 1973, pp. 67-75, p. 71. MACEDO, Ricardo F. de. Controle não societário. São Paulo/Rio de Janeiro/Recife: Renovar, 2004.

${ }^{163}$ CAFFIN-MOI, Marie. Cession de droits sociaux et droit des contrats. Op. cit., n. 487, p. 312 ("on en viendrait à considérer les droits sociaux comme un simple media et à faire de l'entreprise le véritable objet de la cession").

${ }^{164}$ CAFFIN-MOI, Marie. Cession de droits sociaux et droit des contrats. Op. cit., n. 487, p. 312. 
fechado demasiadamente, afastando qualquer possibilidade de se conferir relevância à realidade econômica subjacente à operação.

\section{B. Equiparação entre conteúdo econômico e jurídico: orientações casuísticas}

Partindo do entendimento de que o objeto do negócio jurídico efetivamente são as participações societárias, a doutrina formula propostas diversas tendentes a afastar, para certos e determinados efeitos, a distinção entre a esfera patrimonial da pessoa jurídica e a dos sócios. Essas orientações casuísticas defendem que (i) haveria lacuna a ser colmatada com recurso à analogia; (ii) a constituição da sociedade, em certas circunstâncias, poderia ser anulada por simulação; (iii) a compra e venda de participações societárias poderia ser considerada negócio jurídico indireto em fraude à lei; ou (iv) se deveria promover a desconsideração atributiva da personalidade jurídica.

Para além desses argumentos aptos a equiparar a transferência de participações societárias e de ativos integrantes do patrimônio social em contextos diversos, apresentam-se, por vezes, posicionamentos específicos, no âmbito da aplicação de determinada disciplina legislativa. É o que ocorre quando se discute a responsabilidade do vendedor por vícios redibitórios dos ativos sociais, em que, por vezes, se defende a responsabilidade do vendedor com fundamento na interpretação da vontade das partes ao celebrarem o contrato. ${ }^{165}$ Por se referir a temática específica, será analisado no tópico pertinente do presente trabalho. ${ }^{166}$

\footnotetext{
${ }^{165}$ Na Alemanha: WESTERMANN, Harm P. "Neuere Entwicklungen der Verkäuferhaftung beim Kauf von Unternehmensbeteiligungen". In: ZGR, 1982, pp. 45-62, p. 56; HUBER, Ulrich. "Mängelhaftung beim Kauf von Gesellschaftsanteilen". In: ZGR, 1972, pp. 395-420, p. 401. Em Portugal: FERRER CORREIA, A.; SÁ, Almeno de. "Parecer". In: NUNES, A. M. (org.). A privatização da sociedade financeira portuguesa. Lisboa: Lex, 1995, pp. 257-302, p. 272; MONTEIRO, António Pinto; MOTA PINTO, Paulo. "Compra e venda de empresa: a venda de participações sociais como venda de empresa (share deal)". In: RLJ, n. 3947, 2007, pp. 76-102, p. 88; ANTUNES, José Engrácia. "A empresa como objecto de negócios ("asset deal" vs. "share deal')". Op. cit., pp. 731-734; GALVÃO, Clemente. "Conteúdo e incumprimento do contrato de compra e venda de participações sociais". In: ROA, v. 70, n. 3-4, 2009, pp. 533-573.]

${ }^{166}$ Sobre o assunto, cf. item V.A, infra.
} 


\section{Analogia}

O contraste entre regulação jurídica e significado econômico que pode-se estabelecer na compra e venda de participações societárias incita o raciocínio jurídico a reconhecer lacunas. Tome-se o exemplo da regra que impõe a observância de escritura pública para a constituição, transferência, modificação ou renúncia de direitos reais sobre imóveis de valor superior a 30 (trinta) salários mínimos (CC, art. 108). A norma não abrange a transferência da integralidade das participações relativas a sociedade proprietária de um único imóvel. Para quem identificasse uma omissão nessa ausência de regulação da situação de fato, a analogia seria o primeiro recurso a ser empregado (LINDB, art. $4^{\circ}$ ). O recurso à analogia, contudo, parece metodologicamente inadequado para lidar com a situação mencionada, seja pela ausência de pressupostos, seja pela inadequação dos resultados a que conduziria.

A analogia pressupõe a constatação de que existe uma lacuna no ordenamento jurídico. A lacuna, por sua vez, somente se apresenta de forma relacional: da mesma forma que um buraco em um muro apenas pode ser apontado quando há um muro, ou seja, uma unidade maior que se dirige à completude, ${ }^{167}$ a ideia de lacuna em direito exige a ausência de uma regra que, para o ordenamento jurídico, seria absolutamente necessária. ${ }^{168}$ A lacuna, porém, não existe quando se pode afirmar que o silêncio do legislador é expressivo e indica uma decisão dirigida, justamente, a não oferecer o mesmo tratamento à situação distinta. ${ }^{169}$

Na compra e venda de participações societárias, o ordenamento jurídico não exige a observância da mesma forma pertinente à transferência de direitos reais, ${ }^{170}$ nem de outros deveres inerentes à compra e venda de cada um dos ativos, e há bons motivos para tanto. Uma das principais vantagens da autonomia patrimonial societária em relação à limitação da responsabilidade do empresário individual consiste, efetivamente, no aumento

167 CANARIS, Claus-Wilhelm. Die Feststellung von Lücken im Gesetz, 2. Aufl. Berlin: Duncker \& Humblot, 1983, p. 16.

${ }^{168}$ CANARIS, Claus-Wilhelm. Die Feststellung von Lücken im Gesetz, 2. Op. cit., p. 39.

${ }^{169}$ CANARIS, Claus-Wilhelm. Die Feststellung von Lücken im Gesetz, 2. Op. cit., p. 44.

${ }^{170}$ Sobre o assunto, cf. item II.E, infra. 
de liquidez decorrente da possibilidade de circulação e continuidade da empresa, facilitada pela transmissão de participações societárias. ${ }^{171}$

Sob a perspectiva das consequências, deve-se ter em vista que, entre o imóvel e o sócio, interpõe-se a personalidade autônoma da sociedade. O recurso à analogia, nessa circunstância, pode conduzir a um inconsequente afastamento da personalidade jurídica, pela simples razão de que uma regra aplicável à transferência de imóveis poderia ser "adaptada" à venda de participações societárias. ${ }^{172} \mathrm{O}$ afastamento da personalidade jurídica, contudo, ainda que possível, ${ }^{173}$ exige apreciação valorativa na qual sejam ponderadas e comparadas as vantagens e desvantagens da manutenção do princípio da autonomia da pessoa jurídica e do resultado eventualmente iníquo que poderia derivar de seu absoluto prestígio. ${ }^{174}$ A mera indicação de similaridade na razão de direito não basta para fundamentar adequadamente tal resultado.

2. Sociedade simulada

A alegação de simulação do ato de constituição da sociedade é um dos argumentos que poderiam ser utilizados para equiparar, in concreto, a compra e venda de participações societárias de controle à alienação dos bens integrantes do ativo. Suponha-se, por exemplo, que o proprietário de imóvel locado a terceiro, desejando vender o bem sem conceder o direito de preferência legalmente garantido ao locatário (Lei 8.245/1991, art. 27), constituísse empresa individual de responsabilidade limitada - EIRELI, integralizando o imóvel ao capital social - operação em relação à qual o locatário não é titular de direito de preferência ${ }^{175}-\mathrm{e}$, passo subsequente, transferisse a integralidade das quotas àquele que

\footnotetext{
${ }^{171}$ SALOMÃO FILHO, Calixto. A sociedade unipessoal. Op. cit., p. 39.

172 WIEDEMANN, Herbert. "Die Haftung des Verkäufers von Gesellschaftsanteilen für Mängel des Unternehmens". In: DIETZ, Rolf (et. al., org.). Festschrift für Hans Carl Nipperdey zum 70. Geburtstag, Bd. 1. München/Berlin, Beck, 1965, pp. 815-836, p. 822;

${ }^{173}$ Sobre o assunto, cf. item I.B.4, infra.

174 WIEDEMANN, Herbert. "Die Haftung des Verkäufers von Gesellschaftsanteilen für Mängel des Unternehmens". Op. cit., p. 822.

${ }^{175}$ STJ, REsp n. 3273-RS, 4a T., rel. Min. Athos Carneiro, j. 18.12.1990; STJ, REsp n. 14.924-0-SP, 4ª T., rel. Min. Athos Carneiro, j. 30.11.1992 ("não equivale à venda a transferência de bem imóvel com o fito de integralizar cotas em capital social").
} 
intentava adquirir o imóvel. Seria possível, nesse cenário, questionar se a própria EIRELI seria sociedade ${ }^{176}$ simulada.

Esse caminho argumentativo foi adotado em alguns precedentes italianos. Em decisão da década de 1930, discutia-se a possibilidade de os vendedores de ações responderem por vícios dos ativos integrantes do patrimônio social tendo em vista que a sociedade anônima seria constituída apenas por familiares para a administração em comum de bens imóveis. Avaliando que o valor das ações não decorria da cotação em bolsa, mas exclusivamente do patrimônio societário, considerou-se que a alienação da totalidade das participações societárias teria sido mero instrumento de mobilização dos bens sociais, de tal forma que se deveria considerar que o contrato teria por objeto os próprios bens. ${ }^{177}$

Posteriormente, em situação na qual se discutia o direito de preferência do arrendatário de imóvel rural (fondo rustico) de titularidade de sociedade anônima na hipótese de transferência de todas as ações de sua emissão, a Corte di Cassazione decidiu que, se a sociedade por ações é constituída com escopo empresarial, mas se limita a alugar os imóveis rurais integralizados pelos sócios a terceiros, estar-se-ia perante “um negócio jurídico constitutivo simulado, que apenas dissimularia entre os sócios aparentes uma situação real de condomínio sobre o imóvel". ${ }^{178}$ Constatada a simulação do contrato de sociedade, a consequência jurídica para as decisões mencionadas seria a equiparação da compra e venda de participações societárias à transferência dos próprios bens.

A doutrina majoritária, porém, censura as decisões. ${ }^{179}$ Nas hipóteses tratadas, não estariam presentes os pressupostos da simulação e, ainda que essa fosse

\footnotetext{
${ }^{176}$ Sobre o caráter de sociedade unipessoal da EIRELI, cf. FRANÇA, Erasmo V. A. e N.; ADAMEK, Marcelo V. von. "Empresa individual de responsabilidade limitada (Lei no 12.441/2011): anotações". In: AZEVEDO, Luis André N. de M.; CASTRO, Rodrigo R. M. de (org.). Sociedade limitada contemporânea. São Paulo: Quartier Latin, 2013, pp. 39-77, p. 46. Contra: JUSTIÇA FEDERAL, Enunciados da $1^{\text {a Jornada }}$ de Direito Comercial, Enunciado 3. A Empresa Individual de Responsabilidade Limitada - EIRELI não é sociedade unipessoal, mas um novo ente, distinto da pessoa do empresário e da sociedade empresária.

${ }^{177}$ Refere-se especialmente a decisão da Corte d'appello di Milano, de 14.10.1933. In: Riv. dir. comm., v. 33, II, 1935, pp. 121-187.

${ }^{178}$ Cass. 01.12.1987, n. 8939. ("In ipotesi di società per azioni che, contrariamente al dichiarato scopo sociale di natura imprenditoriale (nella specie acquisto, vendita, gestione, costruzione e miglioramento di beni immobili), dopo la sua costituzione e la registrazione, non abbia in concreto esercitato un'attività imprenditoriale bensì limitato l'attività all'acquisto di un fondo rustico ed alla concessione di esso in affitto a coltivatore diretto, deve ritenersi che il negozio costitutivo della società sia simulato, e dissimuli, fra gli apparenti soci, una reale situazione di comproprietà del fondo, di cui i titoli azionari rappresentano solo le quote di appartenenza.").

${ }_{179}^{17}$ TINA, Andrea. Il contratto di acquisizione di partecipazioni societarie. Op. cit., pp. 200-204.
} 
reconhecida, não se poderia impor como consequência o imediato afastamento da forma societária.

Os pressupostos para se afirmar a existência de simulação não se verificam, pois a simulação exige que se declare aquilo que não se deseja, por efeito de uma combinação entre as partes. ${ }^{180}$ Não é o que ocorre nas sociedade entre familiares ou poucos sócios criada para gerir o patrimônio comum, também denominadas "sociedades de conveniência" (società di comodo), ${ }^{181}$ ou sociedades anômalas. ${ }^{182}$ Em primeiro lugar porque, como aponta GRECO, nada há de ilegal ou de atípico em constituir-se uma sociedade entre sócios ligados por laços familiares, sendo de se recordar, aliás, que o conceito de affectio societatis do direito moderno deita raízes nas consortia ad exemplum fratrum, instituídas no direito romano entre herdeiros parentes entre si. ${ }^{183} \mathrm{Em}$ segundo, porque a sociedade com poucos sócios, ou ainda unipessoal, não é indício de que as partes (ou a parte) não desejam se submeter à disciplina societária, tendo em vista que a existência de efetiva pluralidade de centros de interesse não é elemento essencial do contrato de sociedade. ${ }^{184}$ Em terceiro, porque nada impede que o objeto social da sociedade envolva exatamente a administração de bens próprios, tendo em vista que a atividade empresarial pode englobar a geração de proveitos econômicos mediante a fruição. ${ }^{185}$ Em quarto, porque, ao constituir sociedade, os sócios efetivamente transferem seus bens ao novo ente jurídico criado, razão pela qual seria possível no máximo discutir a existência de negócio jurídico indireto, em que se celebra um negócio jurídico com vistas a obter resultado diverso daquele que lhe é típico, mas não simulação. ${ }^{186}$ Em quinto, porque, para parcela da doutrina, a disciplina da simulação somente seria aplicável a atos, não a atividades, ${ }^{187}$ com o resultado de que "sociedade simulada não há. O que pode haver é a

\footnotetext{
${ }^{180}$ AURICCHIO, Alberto. La simulazione nel negozio giuridico. Napoli: Jovena, 1957, p. 25.

${ }^{181}$ GRECO, Paolo. "Le società di comodo e la vendita delle loro azioni". Op. cit.

${ }^{182}$ ASCARELLI, Tullio. "O Negócio Indireto". Op. cit., p. 154.

${ }^{183}$ GRECO, Paolo. "Le società di comodo e la vendita delle loro azioni". Op. cit., p. 130. Sobre a sociedade no direito romano, cf. CANCELLI, Filippo. "voce Società (diritto romano)". In: AZARA, Antonio; EULA, Ernesto (org.). Novissimo digesto italiano, v. XVII, Torino: UTET, 1970, 495-516, p. 496; ZIMMERMANN, Reinhard. The law of obligations: roman foundations of the civilian tradition. Oxford: Oxford, 1996, p. 466.

${ }^{184}$ ASCARELLI, Tullio. "O Negócio Indireto". Op. cit., p. 142; SALOMÃO FILHO, Calixto. A sociedade unipessoal. Op. cit., p. 113.

185 ASCARELLI, Tullio. "O empresário (l'imprenditore)", trad. de F. K. Comparato. In: Revista da Faculdade de Direito da Universidade de São Paulo, v. 92, 1997, pp. 269-278, p. 276.

${ }^{186}$ Sobre o assunto, cf. item I.B.3, infra.

${ }^{187}$ É nesse sentido o posicionamento majoritário da doutrina italiana: ANGELICI, Carlo. La società nulla. Milano: Giuffrè, 1975, p. 191; MARASÀ, Giorgio. "Comunione di mero godimento in forma di società per azioni, simulazione e nullità". In: Riv. dir. comm., II, 1989, pp. 166-174; STOLFI, Giuseppe. "Rilievi in
} 
caracterização da simulação em um determinado ato especifico. A resposta a isso deve ser dada necessariamente em termos societários, ou identificando uma irregularidade na atividade social e aplicando as consequências respectivas, ou aplicando seletivamente a teoria da desconsideração da personalidade jurídica". ${ }^{188}$

Sob a perspectiva das consequências jurídicas, deve-se considerar que a simulação é causa de nulidade do negócio jurídico (CC, art. 167). Diversamente, porém, do que ocorre na declaração de nulidade dos negócios jurídicos em geral, à qual se segue a perda de eficácia ex tunc (CC, art. 182), a anulação da constituição da sociedade ocasiona a sua dissolução judicial (CC, 1.034, I; LSA, art. 206, II, “a”). Ainda que se considerasse admissível, portanto, a anulação da constituição da sociedade por simulação, a ela seguirse-ia a liquidação do patrimônio, ${ }^{189}$ sob a forma judicial (CC, art. 1.036, par. único; LSA, art. 209), com pagamento dos passivos sociais e partilha do remanescente entre os sócios. Como consequência, ainda que se reconhecesse a simulação da sociedade, a eficácia seria apenas ex nunc, de tal modo que a precedente alienação de participações societárias não poderia ser entendida como transferência direta dos bens integrantes do acervo patrimonial. $^{190}$

No exemplo, portanto, não seria possível reputar a EIRELI constituída como sociedade simulada e, ainda que o fosse, não teria o locatário direito a exercer preferência na aquisição do imóvel ou das quotas.

3. Negócio jurídico indireto em fraude à lei

O negócio indireto é caracterizado pelo emprego de negócio típico determinado e pela concomitante presença de um fim indireto subjacente. ${ }^{191} \mathrm{O}$ negócio

tema di società fittizie". In: Riv. dir. comm., I, 1976, pp. 315-330; SANTA MARIA, Luigi. "Società e simulazione, società e comunione di godimento". In: Riv. trim. dir. proc. civ., 1995, pp. 205-241, p. 218. Em sentido contrário, FERRER CORREIA, António de A. Sociedades fictícias e unipessoais. Coimbra: Atlântica, 1948, pp. 188-191 (indicando a possibilidade de o contrato de sociedade ser nulo na hipótese de ter sido celebrado com a intenção de fraude à lei imperativa).

${ }^{188}$ SALOMÃO FILHO, Calixto. O novo direito societário. Malheiros: São Paulo, 1998, p. 126.

189 PEREIRA, Lafayette Rodrigues. "Sociedade de facto: sua natureza; liquidação; direitos dos credores (Parecer n. 69)". In: Pareceres, v. 2. Rio de Janeiro: Candido de Oliveira, 1921, pp. 150-152.

${ }_{190}$ TINA, Andrea. Il contratto di acquisizione di partecipazioni societarie. Op. cit., pp. 200-203.

191 CARVALHO, Orlando de. "Negócio jurídico indirecto (teoria geral)". In: Boletim da Faculdade de Direito da Universidade de Coimbra, supl. 10, 1952, pp. 1-149, p. 5. 
indireto diferencia-se do negócio simulado, pois, na simulação, a vontade real das partes contrasta com a declaração negocial que proferem, ao passo que, no negócio indireto, as partes buscam efetivamente submeter-se à disciplina jurídica do contrato que celebram, ou seja, desejam a obtenção dos efeitos típicos da categoria contratual escolhida, mas visam, por meio desses efeitos, alcançar finalidade ulterior. Exemplo clássico de negócio indireto é a compra e venda com pacto de retrovenda, utilizada para escopo de garantia. ${ }^{192}$ A venda é efetivamente pretendida pelas partes, apenas não desejam elas, como de regra, a definitiva transmissão da propriedade, senão assegurar a posição jurídica do financiador.

A distinção entre negócio indireto e simulado não deve induzir à falsa impressão de que, seguindo a contraposição, estar-se-ia, de um lado, no âmbito dos comportamentos lícitos (negócio indireto) e, de outro, no campo da ilicitude (simulação). O negócio indireto pode ser nulo, sempre que o fim visado pelas partes seja ilícito.

O negócio fraudulento, com efeito, constitui uma modalidade de negócio indireto. ${ }^{193}$ O Código Civil de 1916 não previa a fraude à lei como categoria jurídica autônoma, mas a doutrina, ainda sob a vigência do diploma, considerava nulo o negócio indireto utilizado como meio para fraudar lei. O emprego de meios lícitos visando a objetivos ilícitos, com efeito, representaria violação objetiva da norma, e, portanto, ato contra legem. ${ }^{194}$ Havia discussão, porém, se a consequência do ato jurídico em fraude à lei seria (i) a ineficácia; (ii) a nulidade; ou (iii) a mesma sanção que a lei burlada imporia ao ato que a violasse frontalmente. ${ }^{195} \mathrm{O}$ Código Civil de 2002 seguiu a orientação então considerada dominante ${ }^{196}$ e passou a cominar a nulidade do negócio que "tiver por objetivo fraudar lei imperativa" (CC, art. 166, VI).

O direito societário constitui campo fértil para o contemporâneo emprego dos negócios indiretos, ${ }^{197}$ sejam eles lícitos ou ilícitos, e a razão para tanto liga-se com o caráter de "bens de segundo grau" das participações societárias. Por meio da compra e venda de ações ou quotas, é possível a obtenção de efeitos econômicos similares à

\footnotetext{
${ }^{192}$ CARVALHO, Orlando de. "Negócio jurídico indirecto (teoria geral)”. Op. cit., p. 20.

193 ASCARELLI, Tullio. “O Negócio Indireto". Op. cit., p. 112.

${ }^{194}$ MIRANDA, Custódio da P. U. "Negócio jurídico indireto e negócios fiduciários”. In: RDCiv, v. 29, n. 81, 1984, pp. 81-94, p.90.

${ }^{195}$ LIMA, Alvino. A fraude no direito civil. Saraiva: São Paulo, 1965, p. 314.

${ }^{196}$ MOREIRA ALVES, J. C. A parte geral do projeto de Código Civil brasileiro, $2^{\text {a }}$ ed. São Paulo: Saraiva, 2003, p. 125.

${ }^{197}$ ASCARELLI, Tullio. “O Negócio Indireto”. Op. cit., p. 120.
} 
transferência direta de ativos (imóvel, posição contratual, estabelecimento) da sociedade, sem que as partes se submetam ao regime correspondente à alienação desses bens.

Entre as modalidades de negócio indireto, AsCARELli inclui a venda de ações para transferir a mediata propriedade sobre os imóveis de propriedade da sociedade, evitando-se a incidência do imposto de transmissão respectivo. ${ }^{198}$ A despeito da obtenção de finalidade econômica similar pelas duas vias negociais, o autor ressalta que "a diferença entre uma transferência de ações e uma transferência dos bens da sociedade é nítida e decorre, não apenas da personalidade jurídica social, mas do fato de respeitar, a ação, à participação no conjunto do patrimônio social e não a um bem determinado". ${ }^{199}$ Na falta de disposição de lei, a venda de ações não poderia ser equiparada a uma venda dos próprios bens, seja sob o aspecto contratual (relação entre vendedor e comprador), seja em sua acepção tributária, ainda que a sociedade seja exclusivamente proprietária de imóveis e todas as suas ações sejam transferidas. ${ }^{200}$ Tratar-se-ia, portanto, de um "negócio indireto (pois o fim último visado é a transferência dos bens sociais), lícito e que não está, em princípio, sujeito às normas que, no direito privado e no fiscal, versariam uma transferência dos bens". 201

Não parece, contudo, que seja impossível a utilização da compra e venda de participações societárias como expediente para a prática de negócio indireto em fraude à lei. Com a natural necessidade de análise das peculiaridades do caso concreto, típica da avaliação da fraude à lei, parece possível que a compra e venda de participações societárias seja nula por fraudar lei imperativa. O exemplo apresentado no item anterior, relativo à constituição de sociedade para integralizar imóveis alugados e posteriormente alienar as quotas da sociedade como forma de burlar o direito de preferência poderia ser enquadrada nessa categoria.

4. Desconsideração atributiva da personalidade jurídica

\footnotetext{
198 ASCARELLI, Tullio. “O Negócio Indireto". Op. cit., p. 147.

${ }^{199}$ ASCARELLI, Tullio. "O Negócio Indireto". Op. cit., p. 147, nota 152.

${ }^{200}$ ASCARELLI, Tullio. "O Negócio Indireto". Op. cit., p. 147, nota 152.

${ }^{201}$ ASCARELLI, Tullio. "O Negócio Indireto". Op. cit., p. 148, nota 152. Sobre a validade do emprego do negócio indireto para fins tributários, cf. FERRAZ Jr., Tércio S. "Simulação e negócio jurídico indireto. No Direito Tributário e à luz do novo Código Civil”. In: RFDT, n. 48, 2010, pp. 9-25.
} 
A teoria da desconsideração da personalidade jurídica propugna o afastamento da distinção entre a pessoa jurídica e seus sócios para finalidades determinadas. Um caso típico em que tal afastamento pode ser necessário é a compra e venda de participação societária de controle. Os fundamentos teóricos para a desconsideração, contudo, variam: para alguns, a personalidade jurídica somente poderia ser afastada em caso de abuso caracterizado em termos subjetivos; para outros, seria necessária análise objetiva partindo-se da finalidade normativa da regra a ser aplicada.

(1) Desconsideração fundada em abuso do direito

Em sua conhecida obra sobre a forma jurídica e a realidade das pessoas jurídicas, SERICK inicia sua explanação avaliando a presença de decisões variadas na jurisprudência que se pautam pela necessidade de reconhecimento da "força dos fatos" ou pela aplicação de cláusulas gerais como a boa-fé para afastar os efeitos derivados da personalidade jurídica. ${ }^{202}$ Seriam, em seu entendimento, “fórmulas com as quais tudo pode ser fundamentado, mas que não convencem ninguém". ${ }^{203}$ Considerava que, naquela época, já se enfrentava uma "crise do conceito normativo da pessoa jurídica", ${ }^{204}$ razão pela qual buscou desenvolver critérios adequados e específicos que justificassem o afastamento da personalidade jurídica.

Para SERICK, primeiramente, não deveriam ser aceitas as linhas argumentativas que julgavam as sociedades unipessoais ou quase unipessoais como meros expedientes organizativos sem valor autônomo. A ausência de pluralidade de sócios não seria, para o autor, fundamento válido para menosprezar a personalidade jurídica. ${ }^{205}$ Tratase do primeiro traço do chamado unitarismo de SERICK: no âmbito interno da pessoa jurídica, não deveria importar a presença de mais ou menos sócios. ${ }^{206}$

\footnotetext{
${ }^{202}$ SERICK, Rolf. Rechtsform und Realität juristischer Personen. Berlin/Tübingen: De Gruyter/Mohr, 1955 , p. 1.

${ }^{203}$ SERICK, Rolf. Rechtsform und Realität juristischer Personen. Op. cit., p. 14 ("Formeln, mit denen man alles begründen kann und doch letztlich niemanden zu überzeugen vermag").

${ }^{204}$ SERICK, Rolf. Rechtsform und Realität juristischer Personen. Op. cit., p. 4.

${ }^{205}$ SERICK, Rolf. Rechtsform und Realität juristischer Personen. Op. cit., p. 15.

${ }^{206}$ OLIVEIRA, J. Lamartine Corrêa de. A Dupla Crise da Pessoa Jurídica. Op. cit., p. 299.
} 
A pessoa jurídica seria criação normativa dotada de valor próprio. Ao fixar seus contornos jurídicos, o legislador alçaria a pessoa jurídica ao papel de sujeito de direito pleno. Não seria justificável, dessa forma, a desconsideração pautada pelo argumento, sempre repetido, de que o respeito à personalidade jurídica prejudicaria a realização do escopo de uma disposição normativa específica, nem de que seria necessário proteger aqueles que contratam com a pessoa jurídica. A ninguém seria dado desconhecer as consequências derivadas da decisão do legislador de autorizar a criação de sujeitos de direito. O argumento que efetivamente justificaria a "penetração" (Durchgriff) do véu da personalidade moral seria o seu emprego pelos sócios para fins abusivos. ${ }^{207}$ Tem-se, com isso, o segundo traço distintivo da teoria: pautado por concepção baseada no sistema regraexceção, SERICK avalia que, como regra geral $^{208}$ a desconsideração seria devida somente quando houvesse intencional abuso do direito, consistente na fraude à lei, na fraude à responsabilidade contratual ou na intenção de impor danos a terceiros. ${ }^{209}$

Em sua obra, SERICK analisa quatro grupos de casos julgados pela jurisprudência alemã em que foi discutida a possibilidade de se equiparar a venda de participações societárias de controle a vendas de bens integrantes do patrimônio social. Questionava-se, na primeira, a possibilidade de a venda de ações de uma sociedade anônima titular de um imóvel ser realizada por instrumento particular, e não por escritura pública como se exige para os negócios modificativos de direitos reais. O Tribunal do Império (Reichsgericht) avaliou que os dispositivos concernentes à solenidade contratual regem-se exclusivamente pela conformação jurídica, não pelo interesse econômico das partes. ${ }^{210} \mathrm{Na}$ segunda, se uma companhia estatal com direito público de preferência para aquisição de imóveis poderia exercer tal direito no caso de compra e venda da integralidade das quotas de sociedade limitada titular de imóvel situado em sua circunscrição. Nesse caso, negando a pretensão do Poder Público, o Tribunal considerou que não ocorreria fraude à lei, pois, ao configurar as hipóteses de incidência do direito de preferência, o legislador teria sido específico. ${ }^{211} \mathrm{Na}$ terceira, se determinada regra que impõe ao tutor a obrigação de obter autorização judicial para alienar o estabelecimento

\footnotetext{
${ }^{207}$ SERICK, Rolf. Rechtsform und Realität juristischer Personen. Op. cit., p. 24.

${ }^{208}$ Um exemplo de exceção na doutrina de SERICK é o caso da aplicação de normas societárias que impõem impedimento de voto ao sócios, consideradas extensíveis à pessoa jurídica controlada pelo sócio independentemente da comprovação de abuso (SERICK, Rolf. Rechtsform und Realität juristischer Personen. Op. cit., p. 117).

${ }^{209}$ SERICK, Rolf. Rechtsform und Realität juristischer Personen. Op. cit., p. 203.

${ }^{210}$ SERICK, Rolf. Rechtsform und Realität juristischer Personen. Op. cit., p. 24.

${ }^{211}$ SERICK, Rolf. Rechtsform und Realität juristischer Personen. Op. cit., p. 25.
} 
comercial de propriedade do pupilo teria aplicação também na hipótese de o estabelecimento ter por titular uma sociedade limitada da qual o pupilo é quotista majoritário e se proceder à venda das quotas. Decidiu-se que, economicamente, as modalidades de alienação seriam equivalentes, sendo exigível a obtenção de autorização judicial. ${ }^{212} \mathrm{Na}$ quarta, avaliava-se a possibilidade de o vendedor que aliena a totalidade das quotas de uma sociedade limitada responder por vícios dos ativos sociais. O Tribunal, alterando sua prévia orientação, decidiu que, para o tráfego negocial, a cessão da totalidade das quotas seria semelhante à venda da própria empresa, sendo, assim, imputável ao vendedor a responsabilidade por vícios redibitórios dos ativos. ${ }^{213}$

Como se percebe, nas duas primeiras decisões prevaleceu estritamente a configuração formal, ao passo que, nas duas últimas, deu-se relevância ao substrato econômico da operação. Para SERICK, as duas primeiras decisões foram corretas, pois a desconsideração atributiva não seria justificável pelo mero argumento de que, sem ela, não seria possível o atingimento do escopo de determinada norma jurídica. Ainda que se alegue que os requisitos de forma aplicáveis à compra e venda de imóveis protegeriam o proprietário de decisões precipitadas, não se pode buscar o atingimento desse objetivo normativo à custa da personalidade jurídica. ${ }^{214}$ Igual raciocínio valeria para a questão pertinente ao direito de preferência do Poder Público sobre o imóvel. Entendimento diverso defraudaria a legítima confiança depositada pelas partes ao se valer de tipos contratuais lícitos, além de atentar contra a segurança jurídica. ${ }^{215}$

Em relação às duas últimas decisões, o autor expressa reserva. Julga que, em ambos os casos, a desconsideração somente seria devida se houvesse sido comprovada a intenção de abusar da personalidade jurídica. Seria necessário, portanto, no terceiro caso, indagar se tutor e adquirente se valeram da compra e venda de quotas para se esquivar da necessidade de obtenção de autorização judicial. E, no quarto, se as partes que negociaram a compra e venda de quotas concebiam as participações societárias como mero instrumento de mobilização dos bens integrantes do patrimônio societário. O abuso da personalidade jurídica restaria caracterizado se o vendedor, após a compra, se baseasse na separação entre

\footnotetext{
${ }^{212}$ SERICK, Rolf. Rechtsform und Realität juristischer Personen. Op. cit., p. 25.

${ }^{213}$ SERICK, Rolf. Rechtsform und Realität juristischer Personen. Op. cit., p. 35.

${ }^{214}$ SERICK, Rolf. Rechtsform und Realität juristischer Personen. Op. cit., p. 208.

${ }^{215}$ SERICK, Rolf. Rechtsform und Realität juristischer Personen. Op. cit., p. 209.
} 
a pessoa jurídica e os ativos para alegar que só seria responsável pelos vícios das próprias quotas. $^{216}$

Os problemas analisados, portanto, bem indicam a orientação metodológica de SERICK para a equiparação entre a compra e venda de participações societárias de controle e a venda dos próprios ativos. Segundo essa concepção, somente o abuso intencional da personalidade poderia justificar a desconsideração atributiva.

(2) Desconsideração fundada no âmbito de aplicação da norma jurídica

O trabalho de SERICK foi bem recebido pela crítica alemã, traduzido para o espanhol e o italiano, e comparado a grandes invenções, que, após descobertas, tornam difícil imaginar como se vivia antes delas. ${ }^{217}$ Sem deixar de subscrever os elogios de seus pares à contribuição acadêmica prestada, MüLLER-FREIENFELS, em curta, mas profunda recensão à obra de SERICK, divergiu em pontos relevantes, demonstrando novas perspectivas teóricas e metodológicas, inclusive para a correta compreensão da temática da desconsideração atributiva da personalidade jurídica no âmbito das compras e vendas de participações societárias de controle. $^{218}$

A primeira crítica de MÜLLER-FREIENFELS é dirigida à equiparação implícita de SERICK entre a pessoa física e a pessoa jurídica, que trataria ambos como sujeitos de direito com mesmo valor e mesma capacidade. ${ }^{219}$ Para Müller-FreIENFELs, tal paridade seria indevida. A personalidade jurídica seria apenas uma expressão cômoda e resumidora, um "símbolo adequado" de caráter técnico, ${ }^{220}$ que não passaria de uma veste giuridica (FERRARA), ${ }^{221}$ cujo lugar próprio seria o "céu dos conceitos" de JHERING. ${ }^{222}$

\footnotetext{
${ }^{216}$ SERICK, Rolf. Rechtsform und Realität juristischer Personen. Op. cit., p. 206.

${ }^{217}$ MÜLLER-FREIENFELS, Wolfram. “Zur Lehre vom sogenannten ,Durchgriff' bei juristischen Personen im Privatrecht”. In: AcP, 1957, pp. 522-543, pp. 522-524.

${ }^{218}$ MÜLLER-FREIENFELS, Wolfram. "Zur Lehre vom sogenannten ,Durchgriff' bei juristischen Personen im Privatrecht". Op. cit.

${ }^{219}$ MÜLLER-FREIENFELS, Wolfram. “Zur Lehre vom sogenannten ,Durchgriff' bei juristischen Personen im Privatrecht". Op. cit., p. 525.

${ }^{220}$ MÜLLER-FREIENFELS, Wolfram. "Zur Lehre vom sogenannten ,Durchgriff' bei juristischen Personen im Privatrecht". Op. cit., p. 529.

${ }^{221}$ MÜLLER-FREIENFELS, Wolfram. "Zur Lehre vom sogenannten ,Durchgriff' bei juristischen Personen im Privatrecht”. Op. cit., p. 529.
} 
A contraposição entre o realismo de MüLLER-FrEIENFELS e a postura metodológica típica da jurisprudência dos conceitos de SERICK reflete-se na avaliação diversa de cada um deles a respeito do papel da personalidade jurídica. ${ }^{223}$ Diferente do raciocínio unitarista baseado na ideia de penetração de SERICK, que redunda em um mecanismo de regra-exceção, MÜLLER-FrEIENFELS pugna por uma visão pluralista da pessoa jurídica sob a perspectiva interna e externa. ${ }^{224}$

Apesar de a obra de SERICK ser intitulada "Forma jurídica e realidade das pessoas jurídicas", sua atenção dirige-se unicamente ao problema da pessoa jurídica. ${ }^{225}$ MÜLlER-FreIENFELS, por outro lado, defende um pluralismo interno, propondo diferenciação, em primeiro lugar, entre os tipos associativos dotados de personalidade jurídica, pois não seria possível tratar da mesma maneira um clube de xadrez organizado sob a forma de associação, uma fundação e uma sociedade anônima. ${ }^{226}$ Dentro de um tipo societário, ademais, também seriam necessárias individualizações. As sociedades de capital, concebidas para promover a reunião material de pessoas e esforços, são cada vez mais empregadas como unidades administrativas similares ao patrimônio especial, o que fica evidente nas sociedades unipessoais. Essas sociedades teriam como "propósito de vida" (Lebenszweck) transferir riscos do empreendedor para os credores e nada teriam em comum com a finalidade típica das sociedades anônimas e limitadas. Por essa razão, exigiriam também uma postura particular por parte do Direito, para que não se permita que o sócio desapareça por trás da pessoa jurídica. ${ }^{227}$

O pluralismo externo, por sua vez, fica evidente na crítica de MÜlLERFREIENFELS à noção de que o afastamento da personalidade jurídica somente seria possível diante da comprovação do intento subjetivo de fraudar a lei. ${ }^{228} \mathrm{O}$ problema da desconsideração deveria ser entendido, para MülLER-FreIENFELs, de forma objetiva,

\footnotetext{
${ }^{222}$ MÜLLER-FREIENFELS, Wolfram. “Zur Lehre vom sogenannten ,Durchgriff' bei juristischen Personen im Privatrecht". Op. cit., p. 526.

${ }^{223}$ OLIVEIRA, J. Lamartine Corrêa de. A Dupla Crise da Pessoa Jurídica. Op. cit., pp. 358-359.

${ }^{224}$ SALOMÃO FILHO, Calixto. A sociedade unipessoal. Op. cit., p. 128.

${ }^{225}$ MÜLLER-FREIENFELS, Wolfram. "Zur Lehre vom sogenannten ,Durchgriff' bei juristischen Personen im Privatrecht". Op. cit., p. 531.

${ }^{226}$ MÜLLER-FREIENFELS, Wolfram. "Zur Lehre vom sogenannten ,Durchgriff' bei juristischen Personen im Privatrecht”. Op. cit., p. 531.

${ }^{227}$ MÜLLER-FREIENFELS, Wolfram. “Zur Lehre vom sogenannten ,Durchgriff” bei juristischen Personen im Privatrecht". Op. cit., p. 531.

${ }^{228}$ MÜLLER-FREIENFELS, Wolfram. “Zur Lehre vom sogenannten ,Durchgriff' bei juristischen Personen im Privatrecht". Op. cit., p. 536.
} 
considerando o escopo normativo, o sentido de eventual proibição legal e seu âmbito de aplicação. $^{229}$

A diversa postura metodológica de MüLLER-FreIENFELS é exemplificada por sua divergência em relação ao juízo de SERICK sobre a possibilidade de equiparação entre compra e venda de quotas e trespasse de estabelecimento. Retomando a análise da decisão do Tribunal do Império que considerou necessária a autorização judicial para que o tutor vendesse quotas de controle detidas pelo pupilo em sociedade titular de estabelecimento comercial, MÜLLER-FREIENFELS afirma que não se deve perquirir a intenção subjetiva de fraudar a lei por parte do tutor e do adquirente. Em lugar de sindicar o objetivo concreto das partes, deve-se determinar, primeiramente, se, sob a perspectiva do escopo normativo da regra de tutela do pupilo, a venda do estabelecimento e das quotas da sociedade limitada imporiam riscos similares. E, adicionalmente, definir se, no caso concreto, as duas modalidades de alienação seriam equivalentes. Em caso positivo, a obtenção da autorização legal seria exigível. ${ }^{230}$

Para MÜLLER-FrEIENFELS, por fim, sequer existiria uma unidade categorial apta a justificar a reunião dos diversos casos de desconsideração atributiva a partir do conceito de pessoa jurídica. Os problemas relativos à desconsideração da pessoa jurídica, seriam, em verdade, relacionados à adequada aplicação de regras cujo valor somente pode ser apreendido em sua ordenação hierárquica no conjunto normativo. Tratar-se-ia, portanto, de quesitos a serem resolvidos no âmbito de aplicação de cada norma, cabendo à doutrina e à jurisprudência estabelecer grupos de casos segundo situações de interesse. ${ }^{231}$

\footnotetext{
${ }^{229}$ MÜLLER-FREIENFELS, Wolfram. “Zur Lehre vom sogenannten ,Durchgriff' bei juristischen Personen im Privatrecht”. Op. cit., p. 537

${ }^{230}$ MÜLLER-FREIENFELS, Wolfram. "Zur Lehre vom sogenannten ,Durchgriff' bei juristischen Personen im Privatrecht". Op. cit., p. 538.

${ }^{231}$ MÜLLER-FREIENFELS, Wolfram. "Zur Lehre vom sogenannten ,Durchgriff' bei juristischen Personen im Privatrecht". Op. cit., p. 543.
} 
(3) Orientações ecléticas para a desconsideração atributiva

Posteriormente aos trabalhos seminais de SERICK e MÜLLER-FrEIENFELLS, a doutrina tem distinguido os casos de desconsideração conforme a finalidade. Assim, HERBERT WiEDEMANN, por exemplo, distingue hipóteses em que se pretende a desconsideração para fins de responsabilidade patrimonial, me que o mecanismo de regra e exceção se mostraria adequado, ${ }^{232}$ ao passo que, para a desconsideração atributiva, seria necessária uma tomada de posição valorativa sobre o cabimento do afastamento da autonomia pautada pro avaliação de equidade em vista dos interesses consagrados pela autonomia pessoal. $^{233}$

KARSTEN SCHMIDT, por sua vez, ressalta que atualmente existem problemas que envolvem a desconsideração atributiva, embora o caminho atual pareça ser o reconhecimento de que não haveria um método ou critério claro para determinar quando ela deveria ser promovida. ${ }^{234}$ Fala, nesse sentido, no reconhecimento de que há "problemas desconsiderativos" (Durchgriffsprobleme), sem que haja um respectivo método (Durchgriffsmethode). ${ }^{235}$ Diferencia, com isso, hipóteses em que a desconsideração atributiva seria necessária, quais sejam aquelas relacionadas (i) à interpretação contratual; (ii) à determinação do escopo de aplicação de normas objetivas; e (iii) ao exercício abusivo do direito. $^{236}$

No Brasil, o posicionamento de CALIXTO SAlOMÃo Filho é pautado pela constatação da impossibilidade de obtenção de resultados aplicativos juízos de essência. ${ }^{237}$ Quanto ao método para a desconsideração, ressalta a necessidade de separar desconsideração fins de responsabilidade patrimonial da desconsideração patrimonial, ${ }^{238}$ julgando que, no âmbito desta última, "não há possibilidade de ser definido um método. Para ela, muito mais relevante é a importância relativa de cada norma e a razoabilidade ou não da preservação das formalidades".

\footnotetext{
${ }^{232}$ WIEDEMANN, Herbert. Gesellschaftsrecht, Bd. I. Op. cit., §4 III, p. 220.

233 WIEDEMANN, Herbert. "Die Haftung des Verkäufers von Gesellschaftsanteilen für Mängel des Unternehmens". Op. cit., p. 821.

${ }^{234}$ SCHMIDT, Karsten. Gesellschaftsrecht. Op. cit., §9 II, p. 177

${ }^{235}$ SCHMIDT, Karsten. Gesellschaftsrecht. Op. cit., \$9 II, p. 178.

${ }^{236}$ SCHMIDT, Karsten. Gesellschaftsrecht. Op. cit., \$9 III, p. 178-182.

${ }^{237}$ SALOMÃO FILHO, Calixto. O novo direito societário. Op. cit., p. 234.

${ }^{238}$ SALOMÃO FILHO, Calixto. O novo direito societário. Op. cit., p. 235.
} 
Considera-se que, para definir a possibilidade de se equiparar a compra e venda de participações societárias de controle à venda dos ativos que integram seu patrimônio, é necessária essa análise pontual e valorativa do âmbito de aplicação e do escopo de cada norma incidente.

\section{Conclusão parcial}

Para solucionar o problema da possibilidade de equiparação da compra e venda de participações societárias de controle à alienação dos bens integrantes do seu ativo, as orientações generalizantes mostram-se inadequada, seja ao igualar o tratamento jurídico dispensado a hipóteses normativas diversas, seja ao se apegar excessivamente ao formalismo da separação da personalidade coletiva. O correto equacionamento da questão envolve o emprego de raciocínio jurídico tópico, pautado pela avaliação valorativa do escopo normativo e buscando coibir, igualmente, o emprego da personalidade jurídica como mecanismo para a prática de ilícitos absolutos ou relativos.

Depreende-se dessas afirmações que o contrato de compra e venda de participações societárias, a princípio, devem sempre ser analisados enquanto tais. A aplicação de regimes pertinentes à transmissão de bens integrantes do patrimônio societário é admitida. Por importa desconsideração da personalidade jurídica, porém, sujeita aquele que a propugna a se desincumbir de ônus argumentativo e a demonstrar a razão que justificaria o afastamento. 


\section{ELEMENTOS}

\section{A. Compra e venda de participações societárias}

A compra e venda é o contrato por meio do qual "um dos contratantes se obriga a transferir o domínio de certa coisa, e o outro, a pagar-lhe certo preço em dinheiro" (CC, art. 481). A redação do dispositivo difere, por exemplo, do seu congênere italiano, que define a venda como "o contrato que tem por objeto a transferência da propriedade de uma coisa ou outro direito contra o pagamento do preço" (Codice civile, art. 1740). A possibilidade de se considerar que as participações societárias seriam "coisas" parece, portanto, fundamental para que o contrato de compra e venda possa versar sobre quotas ou de ações. No direito brasileiro, porém, numerosas reservas são opostas à possibilidade quotas ou certos tipos de ações serem caracterizados como coisas, fato que repercute na possibilidade de aplicação do regime da compra e venda aos contratos que as tenham por objeto.

Referindo-se às quotas de sociedades limitadas, WALDEMAR FERREIRA foi enfático ao afirmar que "[n]ão se vendem quotas. Não se compram quotas. Quando a operação de que se trata se realiza, adquirem-se os direitos e, com eles, as obrigações dos sócios". ${ }^{239}$ O STJ, no mesmo sentido, considerou que "não há como equiparar a quota social à ação", 240 pois a quota não seria objeto de propriedade, não seria materializada em documento com vistas a circular no mercado, e não se desligaria da pessoa do sócio. Representaria, com isso, um conjunto de direitos e obrigações, poderes e deveres, que não poderia ser objeto de livre de compra, de tal forma que "nunca se diz que o quotista é proprietário da quota, mas titular dela, da mesma forma que não há compra e venda de quota, mas de (sic) cessão de direito de quota". ${ }^{241}$

Mesmo em relação às ações, ademais, afirma-se ser difícil a assimilação ao conceito de "coisas". Ressaltando o aspecto incorpóreo das ações, Geraldo VIDIGAL considerou, por exemplo que a lei incorreria em erro ao conceituar o agente escriturador

${ }^{239}$ FERREIRA, Waldemar. Tratado de sociedades mercantis, v. 3, $5^{\text {a }}$ ed. Rio de Janeiro: Editora Nacional, 1958, pp. 761-762.

${ }^{240}$ STJ, REsp n. 32.246-SP, $3^{\text {a }}$ T., rel. Min. Waldemar Zveiter, j. 11.05.1993.

${ }^{241}$ STJ, REsp n. 32.246-SP, $3^{\text {a }}$ T., rel. Min. Waldemar Zveiter, j. 11.05.1993. 
como depositário das ações, pois só há depósito de bens tangíveis, ou seja, de coisas. ${ }^{242}$ Modesto Carvalhosa, ademais, defendeu que as ações emitidas sob a forma escritural seriam bens sem existência material. ${ }^{243}$ Segundo o autor, "[p]ela sua natureza de bens incorpóreos, as escriturais não são objeto de compra e venda, mas de cessão, e por isso não se prestam à tradição". ${ }^{244}$

As consequências dessas considerações não são apenas teóricas, como se poderia imaginar. Na jurisprudência, sobretudo no âmbito da cessão de quotas de sociedade limitada, a possibilidade de aplicar o regramento pertinente à compra e venda é discutida para a definição da sujeição do negócio à regra da anulabilidade prevista no capítulo "Da compra e venda" para o contrato entre ascendente e descendente, celebrado sem consentimento dos demais descendentes e do cônjuge (CC/1916, art. 1.132; CC/2002, art. 496).

Em julgado sobre o tema, o Min. Aliomar BALEeIro decidiu que "o art. 1132 do C. Civ., velha regra que herdamos das Ordenações (nas Filipinas, L. IV, T. 12), abrange também a cessão de quotas sociais do pai ao filho, ainda que este já integre a sociedade. A velha experiência, que inspirou o legislador há séculos, mostra a fertilidade de imaginação da fraude à legítima, seja pela preferência paterna por motivos afetivos, seja pela captação de que já há traços na Bíblia. Não se poderá contestar que a cessão de quota do capital da sociedade entre pais e filhos pode ser meio adequado a essas manobras ilegais". ${ }^{245}$ Percebe-se, portanto, que não se considerou que o contrato de cessão de quotas representaria efetiva compra e venda. A incidência da regra foi fundamentada por seu escopo protetivo da igualdade entre os herdeiros, não na qualificação do contrato. Em outras palavras, promoveu-se interpretação extensiva fundada na teleologia da norma, não sua direta aplicação.

Em um segundo momento, o STJ igualmente considerou que a cessão de quotas não constituiria modalidade de contrato de compra e venda e que " "não se aplica a ratio legis do art. 1.132 do estatuto civil às transferências de quotas de capital de sociedade

\footnotetext{
${ }^{242}$ VIDIGAL, Geraldo apud PEDREIRA, José L. B. "Natureza de título de crédito da ação escritural". In: A lei das S.A., v. II: Pareceres, $2^{a}$ ed. Rio de Janeiro: Renovar, 1997, pp. 45-71, p. 48.

${ }^{243}$ CARVALHOSA, Modesto. Comentários à lei de sociedades anônimas, v. 1, $2^{\mathrm{a}}$ ed. rev. e atual. São Paulo: Saraiva, 1997, p. 247.

${ }^{244}$ CARVALHOSA, Modesto. Comentários à lei de sociedades anônimas. Op. cit., p. 247.

${ }^{245}$ STF, RE n. 76.054-MG, $1^{\mathrm{a}}$ T., rel. Min. Aliomar Baleeiro, j. 27.04.1973.
} 
limitada, quando esta constituída por pai e filhos". Considerou-se que se tratava, na hipótese, de sociedade de pessoas em que "o valor da affectio societatis tem preponderância, uma vez que intuitu personae". Por conseguinte, a operação pela qual o pai cedeu a quota ao filho representaria "hipótese de natureza comercial, por isso que escapa ao exame da teleologia do dispositivo civil referido". ${ }^{246} \mathrm{Na}$ fundamentação do seu voto, o Min. WALDEMAR ZVEITER consignou que "a quota é a representação da titularidade do sócio na sociedade, nas relações com ela mesma e com os demais sócios. É um conjunto de direitos e obrigações ou um conjunto de poderes e deveres personalíssimos que não pode ser objeto livre de compra e venda". ${ }^{247}$ Afirmou ainda que "o negócio de cessão de quotas perante a norma do artigo 1.132 do Código Civil não tem a mesma força de um ato negocial de natureza civil, por exemplo, venda de propriedade". ${ }^{248}$

A distinção que afasta o escopo da norma de anulabilidade da compra e venda em matéria comercial não convence. Ainda que a sociedade previsse restrições à alienação das quotas a terceiros, como apontou o MIN. EDUARDo RiBEIRO em voto divergente, não seria razoável que "alguém, para alienar qualquer bem a descendente seu, carecesse de consentimento dos demais mas pudesse, sem essa anuência, transferir o patrimônio, por mais vasto que fosse, apenas porque representado por cotas de sociedade". ${ }^{249}$ A despeito da divergência quanto à teleologia da norma, porém, também o MiN. EDUARDO RIBEIRO ponderou que seria "menos adequado falar-se em compra e venda, cuidando-se de transferência de cotas", de tal forma que, citando AGOSTINHO ALVIM, sua fundamentação pauta-se pela consideração de que a norma deveria ser aplicada a "todas as situações jurídicas que à compra e venda possam ser equiparadas, salientando, entre elas, a cessão onerosa". ${ }^{250}$ Em julgados posteriores, manteve-se tal aplicação da regra do atual art. 496 do Código Civil pautada por similitude, mas sem considerar o contrato como efetivamente de compra e venda. ${ }^{251}$ Nas instâncias inferiores, o mesmo posicionamento

\footnotetext{
${ }^{246}$ STJ, REsp n. 32.246-SP, $3^{\mathrm{a}}$ T., rel. Min. Waldemar Zveiter, j. 11.05.1993.

${ }^{247}$ STJ, REsp n. 32.246-SP, $3^{\text {a }}$ T., rel. Min. Waldemar Zveiter, j. 11.05.1993.

${ }^{248}$ STJ, REsp n. 32.246-SP, $3^{\text {a }}$ T., rel. Min. Waldemar Zweiter, j. 11.05.1993.

${ }^{249}$ Voto-divergente do Min. Eduardo Ribeiro, in STJ, REsp n. 32.246-SP, $3^{\mathrm{a}}$ T., rel. Min. Waldemar Zveiter, j. 11.05.1993.

${ }^{250}$ Voto-divergente do Min. Eduardo Ribeiro, in STJ, REsp n. 32.246-SP, $3^{\mathrm{a}}$ T., rel. Min. Waldemar Zveiter, j. 11.05.1993.

${ }^{251}$ STJ, REsp n. 38.813-9-MG, $3^{\mathrm{a}}$ T., rel. Min. Nilson Naves, j. 16.05.1995; STJ, REsp n. 208.521-RS, 4ª T., rel. Min. Ruy Rosado de Aguiar, j. 06.12 .1999 ("não há dúvida de a cessão de quotas, pelo titular aos seus filhos, caracteriza o ato proibido pelo art. 1.132”); STJ, REsp n. 886.133-MG, 4 ${ }^{\mathrm{a}}$ T., rel. Min. Fernando Gonçalves, j. 21.10.2008 ("Cumpre realçar - ainda - que, nada obstante referir-se a hipótese a transferência de quotas societárias, tem aplicabilidade a letra do art. 1132 do Código Civil de 1916").
} 
vem sendo seguido. ${ }^{252}$ Apenas em julgado mais recente afirmou-se que a regra do artigo 496 do Código Civil poderia ter aplicação imediata, e não por analogia, considerando-se que "a cessão de cotas sociais a título oneroso é uma espécie de venda, razão pela qual a regra do artigo 496 é plenamente aplicável". ${ }^{253}$ Não deixa de haver certa ironia na constatação de que, justamente nesse julgado em que se considerou que a cessão de quotas seria "espécie de venda", a conclusão quanto ao caso concreto tenha sido de que, ausente a contraprestação pecuniária pelo adquirente, o contrato constituiria doação. ${ }^{254}$ Em outras palavras, a cessão de quotas, "espécie de venda", não seria uma venda.

Como se nota, o próprio título do presente trabalho estaria sujeito a importantes reservas seguindo-se a perspectiva contrária à caracterização como compra e venda da cessão de quota ou de ações não corporificadas em títulos. A seguir-se essa orientação, a aplicação de regramentos relativos à compra e venda seria impossível, ou, ao menos, precisaria passar por uma prévia avaliação de similitude fática. Para avaliar a adequação desse posicionamento, é necessário analisar qual a natureza jurídica das participações societárias; no que consiste o ato pelo qual se dá a sua transferência; e, por fim, se o contrato de compra e venda poderia ter por objeto a obrigação de transferência da titularidade sobre participações societárias.

1. Natureza jurídica das participações societárias

A participação societária constitui um instituto jurídico que é comum às sociedades e que é passível de extensão a outras entidades de caráter associativo. É denominada em Portugal como "posição de membro", "participação social” ou “socialidade", ${ }^{255}$ em tradução literal do termo alemão Mitgliedschaft. ${ }^{256}$ Na França, utiliza-

${ }^{252}$ TJSP, Emb. Infr. 0006520-61.2008.260659/50001, $6^{\text {a }}$ Câm. Dir. Priv., rel. Des. Alexandre Lazzarini, j. 12.04.2012; TJMG, Ap. 1.0024.11.272663-3/001, 9 ${ }^{\mathrm{a}}$ Câm. Cív., rel. Des. Moacyr Lobato, j. 27.08.2014;

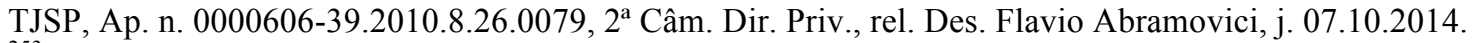

${ }^{253}$ TJSP, Ap. n. 0031686-31.2012.8.26.0344, $1^{\text {a }}$ Câm. Res. Dir. Empr., rel. Des. Francisco Loureiro, j. 03.02.2015.

${ }^{254}$ TJSP, Ap. n. 0031686-31.2012.8.26.0344, $1^{\text {a }}$ Câm. Res. Dir. Empr., rel. Des. Francisco Loureiro, j. 03.02.2015.

${ }^{255}$ ALMEIDA COSTA, Mário J.; MENDES, Evaristo. "Transmissão de acções tituladas nominativas". In: Estudos dedicados ao Prof. Dr. Luís Alberto Carvalho Fernandes, v. 3. Lisboa: Católica, 2011, pp. 1361, p. 17. 
se a expressão droit sociaux, a mesma utilizada para se referir aos direitos fundamentais do cidadão. ${ }^{257} \mathrm{Na}$ Itália, por fim, fala-se em partecipazione societaria, ${ }^{258}$ locução menos ampla que a congênere alemã, por não abarcar as formas associativas não societárias. É essa expressão, porém, a que foi transposta para o direito brasileiro como "participação societária" e consagrada pelo legislador (Decreto-Lei n. 1.510/1976, art. $2^{\circ}$ (revogado); Decreto-Lei n. 1.892/1981, art. 1º ; Decreto-Lei n. 17.713/1988, art. 16, $\S \S 3^{\circ}$ e $4^{\text {o}}$; LSA, art. 184-A) e pela doutrina para se referir ao "conjunto dos direitos e obrigações da posição jurídica de sócio", 259 razão pela qual é aqui adotada. Trata-se de uma categoria jurídica geral do direito associativo, que possui natureza jurídica comum, embora possam variar o seu conteúdo e significado concretos. ${ }^{260}$ As quotas e as ações, portanto, não se diferenciam por sua natureza jurídica. ${ }^{261}$

O regime de transferência pressupõe a compreensão da natureza jurídica da participação societária, matéria sobre a qual não há consenso doutrinário. ${ }^{262}$ Pelo contrário, as teorias sobre o assunto variam acentuadamente. Chega-se a afirmar que seu exame suscita vertigem, ${ }^{263}$ porque, a depender do ponto de vista pelo qual se análise a participação societária, aproxima-se ela de uma das categorias jurídicas conhecidas, sem que se amolde, perfeitamente, a nenhuma delas.

${ }^{256}$ HABERSACK, Mathias. Die Mitgliedschaft - subjektives und 'sonstiges' Recht. Tübingen: Paul Siebeck, 1996.

${ }^{257}$ CAFFIN-MOI, Marie. Cession de droits sociaux et droit des contrats. Op. cit., n. 7, p. 11.

${ }^{258}$ TINA, Andrea. Il contratto di acquisizione di partecipazioni societarie. Op. cit.; ANGELICI, Carlo. "La partecipazione azionaria come oggetto di circolazione". Op. cit., p. 107.

259 PEDREIRA, J. L. Bulhões; LAMY FILHO, Alfredo. "Ação como participação societária". In: PEDREIRA, J. L. Bulhões; LAMY FILHO, Alfredo. (org.). Direito das companhias, v. 1. Rio de Janeiro: Forense, 2009, pp. 215-274, p. 216.

${ }^{260}$ LUTTER, Marcus. "Theorie der Mitgliedschaft". Op. cit., p. 86.

${ }^{261}$ VENTURA, Raúl. Sociedade por quotas, v. I, 2a ed. Coimbra: Almedina, 1989, p. 377; LOBO, Jorge. Sociedades limitadas, v. I. Rio de Janeiro: Forense, 2004, p. 140; BIONE, Massimo. "Le azioni". In: COLOMBO, Giovanni E.; PORTALE, Giuseppe B. (org.). Trattato delle società per azioni, v. 2: Azioni, Gruppi. Torino: UTET, 1991, pp. 3-43, p. 5; NABASQUE, Hervé Le. "Les actions sont des droits de créance négociables". In: Aspects actuels du droit des affaires: Mélanges en l'honneur de Yves Guyon. Paris: Dalloz, 2003, pp. 671-694, p. 675; CORTEZ, Jorge Simões. "As formalidades da transmissão de quotas e acções no Direito Português: dos princípios à prática". Op. cit., p. 322.

${ }^{262}$ CAFFIN-MOI, Marie. Cession de droits sociaux et droit des contrats. Op. cit., n. 462, p. 298; COUTINHO DE ABREU, J. M. Da empresarialidade. Coimbra: Almedina, 1999, p. 343; PEDREIRA, J. L. Bulhões. "Natureza de título de crédito da ação escritural". In: A lei das S.A., v. II: Pareceres, $2^{\mathrm{a}}$ ed. Rio de Janeiro: Renovar, 1997, pp. 45-71, p. 51 ("Não há consenso na doutrina sobre a natureza jurídica da participação societária”).

${ }^{263}$ CAFFIN-MOI, Marie. Cession de droits sociaux et droit des contrats. Op. cit., n. 442, p. 290 (" $L a$ question de la nature des droits de l'associé donne inexorablement le vertige"). 
$\mathrm{Na}$ concepção clássica da doutrina francesa, considerava-se inconcebível que um direito não fosse nem um direito de propriedade, nem um direito de crédito. ${ }^{264} \mathrm{As}$ participações societárias, por conseguinte, deveriam se enquadrar em alguma das categorias. Por não estar na base da condição de sócio um direito sobre um bem, admitia-se que os sócios seriam credores. Na síntese de RIPERT e ROBLOT, os sócios, em virtude do aporte que realizam, tornar-se-iam titulares de crédito eventual, condicionado à verificação de dividendos e à permanência de saldo líquido positivo na hipótese de liquidação. ${ }^{265} \mathrm{~A}$ orientação, porém, nunca foi um consenso. Ainda no século XIX, TROPLONG, referindo-se à ação, acentuava a falta de precisão da consideração de que o acionista seria um credor, porque o direito de crédito não varia conforme o patrimônio do devedor aumente ou diminua, ao passo que o direito do acionista se altera na medida do enriquecimento ou empobrecimento do fundo social. ${ }^{266} \mathrm{~A}$ caracterização do sócio exclusivamente como um credor, ademais, é considerada uma "mutilação" teórica, ${ }^{267}$ porque a visão negligencia os aspectos políticos, relativos aos direitos de gestão e de fiscalização, que igualmente caracterizaram a participação societária.

Uma segunda possibilidade seria compreender a participação societária como direito subjetivo. ${ }^{268} \mathrm{~A}$ dificuldade desse enquadramento, porém, é que hoje se admite que parte relevante da posição de sócio é composta por deveres, e não somente por direitos. ${ }^{269}$ São exemplos a obrigação de integralização das entradas (CC, art. 1.004; LSA, 106); a obrigação eventual de reposição dos lucros ilícitos ou fictícios recebidos em conhecimento da ilegitimidade, solidária entre os sócios da limitada (CC, art. 1.009) e

\footnotetext{
${ }^{264}$ LYON-CAEN, Charles; RENAULT, Louis. Traité de droit commercial, t. II, première partie, $4^{\mathrm{a}}$ ed. Paris: LGDJ, 1908, n. 143, p. 141 ("Il n'est pas concevable qu'un droit de nature pécuniaire ne soit ni un droit réel ni un droit de créance").

${ }^{265}$ LYON-CAEN, Charles; RENAULT, Louis. Traité de droit commercial. Op. cit., n. 141, p. 140 ("Quand la société forme une personne morale, la part de chaque associé constitue un droit de créance contre la société").

${ }^{266}$ TROPLONG, Raymond-Théodore. Le droit civil expliqué - Du contrat de société civile et commerciale. Paris: Charles Hingray, 1843, n. 140, p. 154.

${ }^{267}$ LIBCHABER, Rémi. "Pour un renouvellement de l'analyse des droits sociaux". In: Aspects actuels du droit des affaires: Mélanges en l'honneur de Yves Guyon. Paris: Dalloz, 2003, pp. 717-736, p. 718.

268 WIEDEMANN, Herbert. Die Übertragung und Vererbung von Mitgliedschaftsrechten bei Handelsgesellschaften. München/Berlin: C. H. Beck, 1965, p. 39; LUTTER, Marcus. "Theorie der Mitgliedschaft". Op. cit., p. 102.

269 BEUTHIEN, Volker. "Zur Mitgliedschaft als Grundbegriff des Gesellschaftsrechts - Subjektives Recht oder Stellung im pflichthaltigen Rechtsverhältnis?". Op. cit., p. 756; CAFFIN-MOI, Marie. Cession de droits sociaux et droit des contrats. Op. cit., n. 399, p. 262.
} 
pessoal na sociedade anônima (LSA, art. 201, §2 $)$; e o dever de lealdade, admitido nas sociedades limitadas e anônimas. ${ }^{270}$

Em atenção à circunstância de que as participações societárias encerram também deveres, há quem proponha que ela constituiria uma relação jurídica. ${ }^{271}$ Fruto da autonomia das partes, a participação societária seria a representação do complexo de direitos e deveres do sócio na sociedade. ${ }^{272}$ A dificuldade desse enquadramento é o fato de que negligencia que nem toda a relação jurídica é resumida na participação societária. Ela reúne somente um conjunto de direitos e deveres que se contrapõem, respectivamente, a outros direitos e deveres dos demais sócios e da sociedade. Ignora-se nessa concepção, ademais, o específico poder de mobilização conferido pela ordem jurídica ao titular das participações societárias, aspecto que as diferencia de outras relações jurídicas. ${ }^{273}$

A quarta análise da participação societária deriva de seu caráter de objeto de direito. Todos os direitos e deveres inerentes à condição de sócio são resumidos em uma unidade passível de transmissão a terceiros ou de ser gravada por direitos reais como o usufruto ou o penhor. ${ }^{274}$ Como decidiu a Corte Europeia de Direitos Humanos no Caso Lithgow, relativo à nacionalização de ações emitidas por companhias aéreas, o conceito de propriedade abrange a titularidade sobre participações societárias. ${ }^{275}$ Percebe-se com isso, que a participação societária funciona como um mecanismo para mobilizar a posição de sócio. Afirmar que a participação societária seria apenas um bem, contudo, seria igualmente equivocado, pois não há outro bem na ordem jurídica que imponha os deveres e obrigações que podem advir da titularidade da participação societária e que ultrapassam outros exemplos de obrigações ad rem. ${ }^{276}$

\footnotetext{
${ }^{270}$ RAISER, Thomas.; VEIL, Rüdiger. Das Recht der Kapitalgesellschaften. München: Franz Vahlen, 2010, §11, Rn. 15, p. 61; NABASQUE, Hervé Le. "Le développement du devoir de loyauté en droit des sociétés". In: RTDCom, v. 52 (2), 1999, pp. 273-290; Para o tema no Brasil, cf. ADAMEK, Marcelo V. von. Abuso de minoria em direito societário. São Paulo: Malheiros, 2014, pp. 161-169; SPINELLI, L. F. Exclusão de sócio por falta grave na sociedade limitada. São Paulo: Quartier Latin, 2015, pp. 137-163. 271 WIEDEMANN, Herbert. Die Übertragung und Vererbung von Mitgliedschaftsrechten bei Handelsgesellschaften. Op. cit., p. 39 ("Die Mitgliedschaft ist ein Rechtsverhältnis").

${ }^{272}$ LUTTER, Marcus. "Theorie der Mitgliedschaft”. Op. cit., p. 97.

${ }^{273}$ LUTTER, Marcus. "Theorie der Mitgliedschaft". Op. cit., p. 99.

${ }^{274}$ LUTTER, Marcus. "Theorie der Mitgliedschaft". Op. cit., p. 99.

${ }^{275}$ ECHR, Lithgow and others v. The United Kingdom, j. 08.07.1986, p. 64.

${ }^{276}$ BEUTHIEN, Volker. "Zur Mitgliedschaft als Grundbegriff des Gesellschaftsrechts - Subjektives Recht oder Stellung im pflichthaltigen Rechtsverhältnis?”. Op. cit., p. 759.
} 
Diante da dificuldade de enquadrar a participação societária em uma das categorias jurídicas conhecidas, há quem entenda que a participação societária não seria um direito real, nem pessoal, constituindo um instituto jurídico próprio, de caráter sui generis. ${ }^{277}$ Mesmo essa classificação é criticada porque, fugindo de todas as categorias existentes, e sendo uma definição por negação, não refletiria aquilo que caracteriza a participação societária de forma positiva, isto é, o específico caráter compósito da participação societária e a circunstância de nela se enfeixarem direitos políticos e econômicos, poderes, deveres e sujeições. ${ }^{278} \mathrm{Na}$ doutrina italiana prefere-se, nesse sentido, a qualificação da participação societária como o veículo por meio do qual se transfere o status de sócio, ${ }^{279}$ ou a qualidade de sócio.

2. Transferência da participação societária como cessão da posição contratual

A falta de consenso sobre a natureza jurídica das participações societárias reflete-se na discussão sobre a forma de sua circulação. A transferência das quotas se dá por meio de alteração do contrato social. A alienação de ações, pela forma cambiária. ${ }^{280}$ Esses atos apresentam em comum o fato de que promovem uma alteração subjetiva da sociedade. Sendo tão diversos entre si, porém, questiona-se se seria possível reconduzi-los a um tipo contratual comum, ou se, necessariamente, seria preciso reconhecer uma clivagem no direito societário, com um contrato pertinente à transferência de quotas; outro às ações.

Um fundamento para negar a possibilidade de tratamento comum seria o fato de que a ação nominativa constitui título de crédito, ${ }^{281}$ ao passo que a quota somente representa uma posição no âmbito do contrato social. Não se pode, contudo, levar o

${ }^{277}$ SCHMIDT, Karsten. Gesellschaftsrecht. Op. cit., p. 405; HABERSACK, Mathias. Die Mitgliedschaft subjektives und 'sonstiges' Recht. Op. cit., pp. 99-101.

${ }^{278}$ CAFFIN-MOI, Marie. Cession de droits sociaux et droit des contrats. Op. cit., n. 410, p. 272.

${ }^{279}$ ASCARELLI, Tullio. Teoria geral dos títulos de crédito, trad. de Nicolau Nazo. São Paulo: Saraiva, 1943, p. 185; COTTINO, Gastone. Diritto societario, 2 ed. Padova: CEDAM, 2011, p. 249.

${ }^{280}$ Sobre o assunto, cf. item II.B, infra.

${ }^{281}$ PEDREIRA, J. L. Bulhões. "Natureza de título de crédito da ação escritural". Op. cit.; LA ROSA, A. Pavone. "Azioni 'dematerializzate' e legittimazione all'esercizio dei diritti sociali". In: Riv. soc., 2002, pp. 1209-1222, pp. 1209-1210. Sobre a caracterização das ações como títulos de crédito, cf. Item II.B.1.a)(2), infra. 
fenômeno da corporificação promovido pelo título de crédito ao limite de considerar que a cártula substituiria o direito em sua base, de maneira a afirmar que quotas e ações possuiriam naturezas jurídicas distintas. Tal tese não encontraria fundamento na lei societária vigente. A propriedade das ações nominativas é presumida pela inscrição do nome do acionista no livro de registro de ações nominativas (LSA, art. 31). Antes da abertura do livro de registro de ações nominativas, ou nas hipóteses em que o livro falte, porque foi destruído, o direito à participação societária não desaparece. ${ }^{282} \mathrm{~A}$ incorporação cartular, dessa forma, atende a um imperativo de simplicidade e segurança na circulação das ações, mas a participação societária preexiste à sua representação material, ${ }^{283}$ seja na antiga forma de ações ao portador ou endossáveis (extintas pela Lei n. 8.021/1990), seja na forma nominativa (esteja, ou não, sob a modalidade escritural). ${ }^{284}$ Em matéria societária, portanto, não há uma "obrigação societária cambial" diversa da "obrigação societária contratual”, como ocorre nos títulos de crédito strictu sensu. No título de legitimação, a posição jurídica preexiste ao título, que se apresenta como um mero veículo do direito (véhicule du droit). ${ }^{285} \mathrm{~A}$ ação, ainda que esteja incorporada em um documento, não tem sua existência a ele subordinada. ${ }^{286}$ Como se afirmou, portanto, as quotas e as ações não se diferenciam quanto à natureza jurídica. A distinção diz respeito somente à permissão legal de que as ações se autonomizem ou se objetivem, admitindo-se a circulação na forma cambial. ${ }^{287} \mathrm{~A}$ essa diferença se liga a exigência de padronização das ações (LSA, art. 109, $\left.\S 1^{\circ}\right)$, ao passo que se admite que as quotas sejam desiguais $(\mathrm{CC}$, art. 1.055$) .{ }^{288}$

Afastada a tese da diversidade da natureza jurídica das participações societárias, retorna-se à questão da forma pela qual se promove a sua alteração e à investigação da possibilidade de conceber a alteração subjetiva como um negócio jurídico típico. As tentativas nesse sentido variam conforme a concepção a respeito da natureza jurídica da participação societária. Para os defensores do enquadramento como direito de crédito, naturalmente, teria aplicação o regime da cessão de crédito. ${ }^{289}$ Apontou-se, porém,

\footnotetext{
${ }^{282}$ PEDREIRA, J. L. Bulhões. "Natureza de título de crédito da ação escritural". Op. cit., p. 56.

${ }^{283}$ CAFFIN-MOI, Marie. Cession de droits sociaux et droit des contrats. Op. cit., n. 433, p. 283.

284 WIEDEMANN, Herbert. Die Übertragung und Vererbung von Mitgliedschaftsrechten bei Handelsgesellschaften. Op. cit., p. 150 ("Die Namensaktie ist Wertpapier wie die Inhaberaktie").

${ }^{285}$ THALLER, Edmond- E. Traité élémentaire de droit commercial, $3^{\text {a }}$ ed. Paris: Rousseau, 1904, n. 892, p. 450.

${ }_{286}^{28}$ PEDREIRA, J. L. Bulhões. "Natureza de título de crédito da ação escritural”. Op. cit., p. 56.

287 ASCARELLI, Tullio. Teoria geral dos títulos de crédito, trad. de Nicolau Nazo. Op. cit., p. 457 ("É justamente no caráter de títulos de credito das ações, que se encontra o seu critério distintivo das quotas").

${ }_{288}$ FERRI, Giuseppe. Le società. Torino: UTET, 1971, pp. 333-338.

${ }^{289}$ NABASQUE, Hervé Le. "Les actions sont des droits de créance négociables". Op. cit..
} 
que as participações societárias não transmitem apenas direitos, razão pela qual a qualificação não convence. Para além disso, na cessão de crédito, o devedor deve apenas ser notificado, não consentir com a alteração subjetiva (CC, art. 286 c/c/ art. 290). Sobretudo nas sociedades limitadas, contudo, é possível que a própria sociedade, ou os demais sócios, tenham de consentir com a operação de cessão (CC, art. 1.057). ${ }^{290} \mathrm{~A}$ assimilação, dessa forma, não se justifica.

A figura que parece melhor explicar a natureza do ato de transferência da titularidade de participações societárias é a cessão de posição contratual. Por meio dela, são transferidas posições jurídicas ativas e passivas em sua totalidade. A explicação não é livre de críticas, porque a sociedade, a despeito de fundada em contrato (CC, art. 981), uma vez dotada de personalidade jurídica, autonomiza-se, passando a ser mais do que contrato. ${ }^{291}$ Não se tem em vista, ademais, a circunstância de que a participação societária, uma vez autonomizada, é passível circulação como um bem, e não como as demais posições contratuais. ${ }^{292}$ Como apontou LIBCHABER, porém, mesmo que a sociedade não se esgote no âmbito contratual e que haja especificidade na participação societária em comparação com outras posições contratuais, o fato é que, ainda que institucionalizada, a sociedade tem por base um contrato plurilateral, ${ }^{293}$ que não somente a institui como regula a vida entre os sócios. ${ }^{294}$ A teoria da cessão da posição contratual nessa medida, é aquela que melhor abarca o fenômeno da transferência da participação societária. A cessão de posição contratual não é disciplinada explicitamente no Código Civil, que se refere à cessão de crédito (CC, art. 286 ss.) e à assunção de dívida (CC, art. 299 ss.), mas não à operação na qual ambas as operações são realizadas concomitantemente. Admite-se, porém, sua possibilidade no direito brasileiro, ${ }^{295}$ como ocorre expressamente, por exemplo, na hipótese de previsão de cessão da locação, ou seja, dos direitos e deveres decorrentes do contrato de locação (Lei 8.245/1991, art. 13). Entende-se, dessa forma, que a transferência

\footnotetext{
${ }^{290}$ CAFFIN-MOI, Marie. Cession de droits sociaux et droit des contrats. Op. cit., n. 448, p. 293.

${ }^{291}$ LIBCHABER, Rémi. "Pour un renouvellement de l'analyse des droits sociaux". Op. cit., p. 723.

${ }^{292}$ LUTTER, Marcus. "Theorie der Mitgliedschaft". Op. cit., p. 101.

293 ASCARELLI, Tullio. "O contrato plurilateral". In: Problemas das sociedades anônimas e direito comparado, $2^{a}$ ed. São Paulo: Saraiva, 1969, pp. 255-312; COMPARATO, Fabio K. "Da imprescritibilidade da ação direta de nulidade estatutária". In: Novos ensaios e pareceres de direito empresarial. Rio de Janeiro: Forense, 1981, pp. 215-225, p. 221 (notando que, mesmo na sociedade anônima, por mais que o estatuto da sociedade anônima constitua sistema normativo, ou ato-regra, isso não implica denegar sua natureza de contrato plurilateral).

${ }^{294}$ LIBCHABER, Rémi. "Pour un renouvellement de l'analyse des droits sociaux". Op. cit., p. 723.

${ }^{295}$ MOTA PINTO, Carlos Alberto. Cessão de contrato. São Paulo: Saraiva, 1985, n. 76, p. 431.
} 
de participação societária constituiria modalidade de cessão de contrato, ${ }^{296}$ seja na hipótese de cessão de quotas, ${ }^{297}$ seja na de transferência de ações. ${ }^{298}$ Como uma das consequências dessa conceituação, tem-se que o consentimento dos demais sócios, quando exigido $(\mathrm{CC}$, art. 1.057), é equiparável ao consentimento da contraparte exigido para a cessão da posição contratual. Sua falta importa a inexistência da transferência. ${ }^{299}$

3. Contrato de compra e venda como negócio jurídico causal

A afirmação de que a transferência da participação societária representa uma cessão de posição contratual não significa, contudo, que se tenha de admitir, com WALDEMAR FERREIRA, que não se vendem e não se compram quotas. ${ }^{300}$ Tampouco que não se pode falar de um contrato de compra e venda de ações.

A análise da jurisprudência demonstra a falta de clareza quanto à separação do negócio jurídico jurídico obrigacional na base da transferência de participação societária, de um lado, e a própria cessão de quotas ou ações, de outro, que surge como momento de adimplemento do contrato. A cessão de quotas, por si, não é contrato de compra e venda. Ela pode estar integrada na fase de adimplemento de um contrato de compra e venda, de troca, de doação, ou mesmo de conferência ao capital social de outra sociedade.

\footnotetext{
${ }^{296}$ LIBCHABER, Rémi. "Pour un renouvellement de l'analyse des droits sociaux". Op. cit., p. 718; CAFFINMOI, Marie. Cession de droits sociaux et droit des contrats. Op. cit., n. 450-455, pp. 294-296; COUTINHO DE ABREU, Jorge M. Da empresarialidade. Op. cit., p. 344; CALVO, Roberto. "Il trasferimento della 'proprietà' nella compravendita di titoli azionari". Op. cit., p. 1095.

${ }^{297}$ VENTURA, Raúl. Sociedade por quotas. Op. cit., p. 578; MOTA PINTO, Carlos Alberto. Cessão de contrato. Op. cit., n. 10, p. 68; COSTA, Philomeno J. "Comentário ao acórdão n. 26.147, do TJSP". In: RDM, v. 50, 1983, pp. 106-109, p. 109; CAMILO Jr., Ruy Pereira. "Contrato de cessão de quotas sociais". In: AZEVEDO, Luis A. N. de M.; CASTRO Rodrigo. R. M. de (org.). Sociedade limitada contemporânea. São Paulo: Quartier Latin, 2013, pp. 217-259, p. 224-225.

${ }^{298}$ GATTI, Serafino. L'iscrizione nel libro dei soci. Milano: Giuffrè, 1969, p. 108; TINA, Andrea. II contratto di acquisizione di partecipazioni societarie. Op. cit., p. 6.

${ }^{299}$ MOTA PINTO, Carlos Alberto. Cessão de contrato. Op. cit., n. 10, p. 68, nota 17; CAMILO Jr., Ruy Pereira. "Contrato de cessão de quotas sociais". Op. cit., p. 230.

${ }^{300}$ FERREIRA, Waldemar. Tratado de sociedades mercantis, v. 3, $5^{\text {a }}$ ed. Rio de Janeiro: Editora Nacional, 1958, pp. 761-762.
} 
Reconhece-se no direito brasileiro a distinção entre negócios jurídicos de direito obrigacional e negócios jurídicos dispositivos, ou de direito real. Nos negócios jurídicos obrigacionais, há criação de direitos e obrigações de parte a parte. ${ }^{301} \mathrm{O}$ contrato de compra e venda gera ao vendedor a obrigação de transferir o domínio da coisa e ao comprador a obrigação de pagamento do preço. É completamente diversa a natureza do negócio jurídico dispositivo, ou de direito real, em que não há criação de deveres ou obrigações, mas criação, modificação ou extinção de direito real. ${ }^{302}$

A eficácia da compra e venda, no Brasil, é discutida. O Código Civil é claro ao afirmar que propriedade das coisas móveis somente é transferida pela tradição $(\mathrm{CC}$, art. 1.267), ao passo que a propriedade sobre coisas imóveis é transferida pelo registro do título translativo no registro de imóveis $(\mathrm{CC}$, art. 1.245). É certo, portanto, que não basta o consenso das partes quanto ao preço e a a coisa para que haja transferência de propriedade. Para DARCY RESSONE, porém, a compra e venda teria eficácia real entre as partes, sendo a tradição ou o registro ato necessário apenas para que tivesse efeitos perante terceiros. ${ }^{303}$ Seu principal fundamento é que os atos de tradição ou registro não constituiriam um novo negócio jurídico de direito real, pois não há neles uma adicional manifestação de vontade; tratar-se-ia, assim, somente de etapa do processo complexo de transferência da propriedade. Para a doutrina majoritária, porém, a eficácia da compra e venda seria estritamente obrigacional, ${ }^{304}$ orientação que se filia ao "princípio da tradição" de matriz romana e perpetuado nas Ordenações. ${ }^{305}$ Mesmo nas hipóteses em que compra e venda e a transferência de propriedade ocorram simultaneamente, o negócio jurídico obrigacional e o

\footnotetext{
${ }^{301}$ VANZELLA, Rafael D. F. Os contratos e os direitos reais. São Paulo: RT, 2012, p. 263.

${ }^{302}$ COUTO E SILVA, Clóvis V. do. "Negócios jurídicos e negócios jurídicos de disposição". In: FRADERA, Véra (org.). O direito privado brasileiro na visão de Clóvis do Couto e Silva. Porto Alegre: Livraria do Advogado, 1997, pp. 73-87, p. 85.

${ }^{303}$ BESSONE, Darcy. Da Compra e Venda. Belo Horizonte: Bernardo Álvares, 1960, pp. 74-81.

${ }^{304}$ BEVILÁQUA, Clóvis. Código Civil dos Estados Unidos do Brasil Comentado, vol. 4, São Paulo/Rio de Janeiro: Francisco Alves, 1917, p. 295; CARVALHO SANTOS, Jorge M. Código Civil Brasileiro Interpretado, vol. 16. Rio de Janeiro: Freitas Bastos, 1945, p. 10; GONÇALVES, Luiz da C. Da Compra e Venda no Direito Comercial Brasileiro. São Paulo: Max Limonad, 1950, pp. 67-77; GOMES, Orlando. Contratos, 22 a ed. atual. por Humberto Theodoro Jr., Rio de Janeiro: Forense, 2000, p. 221; COUTO E SILVA, Clóvis V. do. A Obrigação como Processo, reimpressão. Rio de Janeiro: Editora FGV, 2007, pp. 52-59. PONTES DE MIRANDA, FRANCISCO C. Tratado de direito privado, t. 39. Op. cit., $\$ 4.271$, p. 55; MARTINS-COSTA, Judith. Comentários ao novo Código Civil, v. 5, t. 1. Rio de Janeiro: Forense, 2003, pp. 125-126.

305 NACATA Jr., Edson K. "Tradição romanista e soluções de continuidade no direito obrigacional brasileiro: a eficácia translativa do contrato no projecto de Joaquim Felício dos Santos". In: RDCC, v. 5, 2015 , pp. 35-68, pp. 36-45.
} 
dispositivo situar-se-iam em planos lógicos distintos. ${ }^{306}$ Essa parece, com efeito, ser a melhor interpretação para o ordenamento vigente.

No direito brasileiro prevalece, ademais, o entendimento de que há separação relativa entre essas categorias de negócios jurídicos obrigacionais e dispositivos. Seguindo proposta de Clóvis do COUTO E SILVA, ${ }^{307}$ o direito brasileiro situar-se-ia entre a separação aceita no direito alemão e o mero consensualismo do direito italiano e francês. ${ }^{308}$

No direito alemão, com efeito, o negócio jurídico dispositivo é autônomo, abstrato e independente do negócio jurídico causal. Esse princípio da abstração desdobrase nos conceitos de abstração do conteúdo (inhaltliche Abstraktheit), entendida como a impossibilidade de a referência ao negócio jurídico causal torná-lo integrante do negócio jurídico dispositivo; e abstração externa (äußerliche Abstraktheit), compreendida como a desvinculação entre o negócio abstrato e a eficácia ou validade do negócio jurídico causal. $^{309}$ No direito francês, por outro lado, a doutrina majoritária admite que bastaria o consenso das partes para que houvesse a transferência de propriedade. A entrega da coisa representa, nesse sistema, transferência da posse, não da propriedade. É de notar, porém, que parte da doutrina ainda hoje considera que a transferência não ocorreria somente com o consenso, tratando-se, portanto, de uma questão ainda hoje controvertida. ${ }^{310}$

No direito brasileiro, o negócio jurídico dispositivo seria autônomo em relação ao negócio causal, mas permeável a suas vicissitudes. Anulado o contrato de compra e venda, por exemplo, o negócio dispositivo perde seu fundamento e pode ser igualmente anulado. ${ }^{311}$

\footnotetext{
${ }^{306}$ COUTO E SILVA, Clóvis V. do. A Obrigação como Processo, reimpressão. Op. cit., pp. 52-59.

${ }^{307}$ COUTO E SILVA, Clóvis V. do. A Obrigação como Processo, reimpressão. Op. cit., pp. $52-59$.

308 VIEIRA, Iacyr de A. "A compra e venda e a transferência de propriedade: modelos causais e abstratos". In: RT, v. 765, 1999, pp. 59-77.

309 GRIGOLEIT, Hans Christoph. "Abstraktion und Willensmängel - Die Anfechtbarkeit des Verfügungsgeschäfts". In: AcP, v. 199, 1999, pp. 379-420, pp. 380-381.

${ }^{310}$ CAFFIN-MOI, Marie. Cession de droits sociaux et droit des contrats. Op. cit., n. 265-267, pp. 185-188; CHAZAL, Jean-Pascal.; VICENTE, Serge. "Le transfert de propriété par l'effet des obligations dans le Code Civil”. In: RTDciv, n. 3, 2000, pp. 477-506, p. 505 (defendendo a interpretação de que se deveria considerar sempre subentendida a cláusula de que a transferência da propriedade pelo vendedor ficaria condicionada ao pagamento do preço pelo comprador).

${ }^{311}$ VANZELLA, Rafael D. F. Os contratos e os direitos reais. Op. cit., p. 261. LEONARDO, Rodrigo X. "A cessão de créditos à luz da tese da separação relativa". In: MARTINS-COSTA, Judith; FRADERA, Véra Jacob de. Estudos de direito privado e processual civil em homenagem a Clóvis do Couto e Silva. São Paulo: RT, 2014, pp. 255-277, p. 274.
} 
Considerando, portanto, as características dos negócios jurídicos obrigacionais e dispositivos, parece evidente que a transferência de quotas ou ações não é um ato criador de obrigações para as partes. Por meio delas, transferem-se direitos previamente existentes, o que é típico dos negócios de disposição. ${ }^{312} \mathrm{~A}$ transferência de participação societária, sejam quotas ou ações, rigorosamente, não não se pode afirmar que "a cessão de cotas sociais a título oneroso é uma espécie de venda". ${ }^{313}$ A cessão da quota ou da ação é o ato por meio do qual se transfere sua titularidade. Representa, assim, modalidade de exercício do poder de disposição sobre a propriedade da participação societária. ${ }^{314}$ Tal ato pode ser praticado como adimplemento de um contrato obrigacional preexistente, ou sem causa de atribuição patrimonial nenhuma. Nesta última hipótese, pela falta de um negócio jurídico obrigacional antecedente, teria lugar a ação de enriquecimento sem causa (CC, art. 884).

Tendo-se afirmado, portanto, que a cessão de quotas ou ações não é uma modalidade de compra e venda, porque não se trata de um negócio obrigacional, mas sim dispositivo, a questão que se coloca é de saber se o negócio de disposição sobre as participações societárias seria compatível com o modelo da compra e venda. Afinal, tratase de um contrato que impõe ao vendedor a obrigação de "transferir o domínio de coisa certa" contra o pagamento de preço em dinheiro (CC, art. 481). As participações societárias, por mais que sejam consideradas bens, não são coisas, ou seja, um objeto jurídico tangível, cuja acepção é mais restrita que a dos bens. ${ }^{315}$

A interpretação restritiva que negasse às participações societárias a aptidão para ser objeto da compra e venda não se justificaria no direito brasileiro. Em primeiro lugar porque, como aponta VILLELA, rigorosamente "não há consenso entre os autores quanto ao que seja bens e ao que seja coisas em direito privado", ${ }^{316}$ se os termos devem ser tomados por sinônimos, ou se há critérios que distingam as categorias. O Código Civil brasileiro emprega os termos com "incauta promiscuidade". ${ }^{317}$ De um lado, não define o

\footnotetext{
${ }^{312}$ COUTO E SILVA, Clóvis V. do. "Negócios jurídicos e negócios jurídicos de disposição”. Op. cit., p. 85.

313 TJSP, Ap. n. 0031686-31.2012.8.26.0344, $1^{\text {a }}$ Câm. Res. Dir. Empr., rel. Des. Francisco Loureiro, j. 03.02 .2015$.

${ }^{314}$ VANZELLA, Rafael D. F. Os contratos e os direitos reais. Op. cit., p. 261.

315 PENTEADO, Luciano de C. "Que coisa é uma coisa? Reflexões em torno a um pequeno ensaio de Carnelutti”. In: RDPriv, v. 39, 2009, pp. 249-258, p. 258 (apontando que as ações escriturais não constituiriam coisas).

${ }^{316}$ VILLELA, João Baptista. Controle Acionário: corpus et anima. Op. cit., p. 10.

${ }^{317}$ VILLELA, João Baptista. Controle Acionário: corpus et anima. Op. cit., p. 10.
} 
que sejam coisas, diferente do que faz seu congênere alemão, que expressamente determina que "coisas no sentido legal são apenas os objetos corpóreos" (BGB, §90). De outro, ao disciplinar a matéria, ora nomeia o Livro II da Parte Geral de "Dos bens", ora intitula o Livro III da Parte Especial como "Do Direito das Coisas". No âmbito dos direitos das coisas, porém, inclui a constituição de penhor sobre direitos sobre coisa móvel (CC, art. 1.451), objeto de direito real que, sendo direito, poderia ser entendido como bem, mas a princípio não seria coisa no sentido de objeto corpóreo tangível.

O segundo motivo para afastar um rigor interpretativo extremo a respeito do significado do termo "coisa" é o fato de que, mesmo nos países que efetivamente determinam normativamente o que sejam coisas, como é o caso da Alemanha, passou-se a admitir uma leitura jurídica (Sachbegriff als Rechtsbegriff), e não física do conceito de coisa (physikalischer Sachbegriff) para os fins do contrato de compra e venda, no âmbito da discussão havida na década de 1930 sobre o enquadramento jurídico do contrato de fornecimento de energia elétrica. ${ }^{318}$ Contrariando a posição tradicionalista que negava o caráter de coisa às energias e pretendia a qualificação do contrato no âmbito da prestação de serviço ou empreitada, entendeu o Tribunal do Império que a eletricidade de fato não é uma coisa, mas, conforme a visão do tráfego negocial, é tratada como coisa nos contrato de fornecimento de energia, sujeitando-se, com isso, à incidência das regras sobre a compra e venda. $^{319}$ O Código Civil brasileiro incluiu energias com valor econômico entre os bens móveis (CC, art. 83, I), não as definiu, porém, como coisa. Não parece, contudo que, por conta disso, seja de se afastar a disciplina legal da compra e venda para o contrato a respeito da energia. O direito privado, dessa forma, caminha para a superação da necessária verificação de um corpo tangível (corpus mechanicum) para que os bens recebam a tutela dispensada às coisas objeto do direito de propriedade, como ocorre na propriedade intelectual. $^{320}$

Considerando essa aptidão do contrato de compra e venda para ter por objeto a obrigação de entrega de outros bens que não sejam físicos, considera-se, com razão, que, no lugar da tradição do bem móvel, ou transmissão da propriedade do bem

\footnotetext{
318 RÜFNER, Thomas. $\S$ 90-103. In: SCHMOECKEL, Mathias; RÜCKERT, Joachin; ZIMMERMANN, Reinhard (org.). Historisch-kritischer Kommentar zum BGB, Bd. 1: Allg. Teil (§§ 1-230). Tübingen: Mohr Siebeck, 2003, pp. 326-327.

${ }^{319}$ RÜFNER, Thomas. $\S \S 90-103$. Op. cit., pp. 328.

${ }^{320}$ VANZELLA, Rafael D. F. Os contratos e os direitos reais. Op. cit., p. 63.
} 
imóvel mediante registro público, seria possível que a compra e venda conduzisse à disposição de outras posições patrimoniais. Aceita-se, com isso, que a compra e venda pode incluir como objeto a obrigação de transmissão de crédito, hipótese em que a cessão de crédito se apresenta como negócio dispositivo para adimplemento da compra e venda, que atua como negócio básico causal. ${ }^{321}$ Igualmente, aceita-se que o contrato de transferência de participações societárias, sejam ações ou quotas, pode-se inserir como medida para o adimplemento de contrato de compra e venda. ${ }^{322}$ Apesar de não ser a única designação possível - prefere-se, na França, a referência ao termo "cessão", por tratar-se de direito imaterial ${ }^{323}$ - não há ausência de técnica na referência ao contrato de compra e venda de participações societárias ${ }^{324}$ como contrato em que o vendedor se obriga a transferir a outrem a posição de sócio (promover a cessão de quotas de sociedade limitada; transferir a titularidade sobre ações) contra prestação pecuniária.

Não há, portanto, razão para afirmar que a regra do art. 496 do Código Civil deveria incidir por similitude à cessão de quotas, como fazem o STJ e as instâncias inferiores. O necessário é determinar se a cessão de quotas ou ações ocorre no âmbito de uma compra e venda, hipótese em que a regra do artigo 496 do Código Civil incide diretamente, e não por analogia. Ou se foi celebrada, por exemplo, no âmbito de doação,

\footnotetext{
${ }^{321}$ COUTO E SILVA, Clóvis V. do. "Cessão de crédito (parecer)". In: RT, v. 638, 1988, pp. 10-14, p. 11 (“a cessão de crédito manifesta esses dois momentos: o momento meramente obrigacional e causal, que é a venda do crédito ou a doação do crédito, e o momento absolutamente abstrato, que é a cessão do crédito em seu sentido próprio"); GOMES, Orlando. "Cessão de crédito; caracterização". In: Novíssimas questões de direito civil. São Paulo: Saraiva, 1984, pp. 79-94, p. 99; HAICAL, Gustavo. Cessão de crédito. São Paulo: Saraiva, 2013, p. 24; VANZELLA, Rafael D. F. Op. cit., p. 261; LEONARDO, Rodrigo X. "A cessão de créditos à luz da tese da separação relativa". Op. cit., p. 269.

${ }^{322}$ MENEZES CORDEIRO, António M. da R. Manual de direito das sociedades, II, $2^{\mathrm{a}}$ ed. Coimbra: Almedina, 2007, p. 368; VENTURA, Raúl. Sociedade por quotas, v. I, $2^{\mathrm{a}}$ ed. Op. cit., p. 582 (afirmando que a cessão de quotas pode integrar-se em uma compra e venda, mas ressaltando que ambos os contratos não se confundem); CAFFIN-MOI, Marie. Cession de droits sociaux et droit des contrats. Op. cit., n. 485, p. 297 (apontando que a jurisprudência francesa aplica as regras de garantia do vendedor, determinação do preço e transferência da propriedade pertinentes à venda para as operações relativas à transferência de participações societárias); MARTINS, Alexandre Soveral. Cessão de quotas. Coimbra: Almedina, 2007, p. 10; GONÇALVES NETO, Alfredo de A. In: CARVALHOSA, Modesto. (coord.). Tratado de direito empresarial, v. 2. São Paulo: RT, 2016, p. 453; TJSP, AP. n. 00100281-14.2007.8.26.0003, 9ª Câm. Dir. Priv., rel. Des. Piva Rodrigues, j. 14.04.2015 (afirmando que a validade do contrato de compra e venda de quotas depende apenas de acordo bilateral, sendo diversa a questão da efetiva eficácia da cessão das quotas).

${ }^{323}$ CAFFIN-MOI, Marie. Cession de droits sociaux et droit des contrats. Op. cit., n. 7, p. 12.

${ }^{324}$ A recondução da transferência de participação societária ao contrato de compra e venda é comum no direito continental, o que fica evidente inclusive pelo título adotado em certas produções doutrinárias. Exemplificativamente: (i) na Itália: D'ALESSANDRO, Carlo. "Vendita di partecipazioni sociali e promessa di qualità". In: Giustizia civile, 2005, pp. 1071-1078; (ii) em Portugal: MONTEIRO, António Pinto; MOTA PINTO, Paulo. "Compra e venda de empresa: a venda de participações sociais como venda de empresa (share deal)". Op. cit.; GALVÃO, Clemente. "Conteúdo e incumprimento do contrato de compra e venda de participações sociais". Op.cit; (iii) na Alemanha: JAGERSBERGER, Barbara. Die Haftung des Verkäufers beim Unternehmenskauf- und Anteilskauf. Baden-Baden: Nomos, 2006.
} 
situação em que o artigo 496 é inaplicável, ${ }^{325}$ e o negócio jurídico não é anulável, remanescendo apenas a obrigação de os descendentes conferirem o valor das doações recebidas em vida a título de colação (CC, art. 2.002).

A impossibilidade de a compra e venda versar sobre ações escriturais, ponderada por CARVALHOSA, ${ }^{326}$ por sua vez, não parece contar com fundamento jurídico. Critico a tal orientação, LAMY FILHO ressaltou que as ações nominativas e escriturais teriam caráter de títulos de crédito e sua circulação seria regida pelas regras cambiárias, sendo tratadas pelo ordenamento jurídico como bens móveis. ${ }^{327}$ Negou o autor, com isso a pertinência da proposta de tratar cada transferência de ação escritural como cessão de crédito. Após transcrever a a passagem em que CARVALHOSA afirma que "as escriturais não são objeto de compra e venda, mas de cessão" - mas, por um provável deslize, não nomear nem o autor criticado, nem a obra -, LAMY FILHO redarguiu que "aceita a singular opinião, cada negócio na Bolsa de Valores do Brasil, da França, de Portugal, deveria ser objeto de uma cessão de direito individuada! E teríamos, por certo, as três Bolsas encerrando seus trabalhos. ${ }^{328}$ Para além dessa consideração pertinente de que as ações nominativas ou escriturais constituem efetivamente títulos de crédito, contudo, deve-se ponderar que a incompatibilidade pretendida por CARVALHOSA entre a compra e venda e a transferência de ações escriturais não seria justificada mesmo que fossem aceitas suas premissas. Não há - segundo acima se defendeu - vedação jurídica ao emprego da compra e venda como negócio causal para a transferência de titularidade sobre bens incorpóreos.

\section{B. Obrigação do vendedor: transferência da titularidade das participações societárias}

\footnotetext{
325 TJSP, Ap. n. 0031686-31.2012.8.26.0344, $1^{\text {a }}$ Câm. Res. Dir. Empr., rel. Des. Francisco Loureiro, j. 03.02.2015.

${ }^{326}$ CARVALHOSA, Modesto. Comentários à lei de sociedades anônimas, v. $1,2^{\mathrm{a}}$ ed. rev. e atual. Op. cit., p. 247.

${ }^{327}$ LAMY FILHO, Alfredo. “Ações nominativas e ações escriturais - natureza - usucapião". Op. cit., p. 418.

${ }^{328}$ LAMY FILHO, Alfredo. "Ações nominativas e ações escriturais - natureza - usucapião". Op. cit., p. 425

(o autor transcreve a citação de CARVALHOSA referida previamente no texto, indicando somente a página 247, mas não a obra e o autor; como há plena coincidência textual, é possível inferir com segurança que se tratava de mençào à posição de CARVALHOSA, indevidamente não nomeado).
} 
O vendedor é obrigado a transferir o domínio de coisa certa (CC, art. 481). As participações societárias não são coisas móveis, passíveis de tradição; nem coisas imóveis, sujeitas a registro imobiliário. É necessário, portanto, compreender o regime de circulação das ações e das quotas, pois é por meio dos mecanismos societários de transferência de titularidade que o vendedor poderá cumprir seu dever. Para além disso, é relevante notar a diferença na posição jurídica de vendedor e de comprador no âmbito de cada uma das formas de transmissão.

1. Transferência de ações

Não há um regime específico na legislação acionária para a transmissão do conjunto de ações que outorgam o poder de controle ao acionista. Segue-se, com isso, o regime geral, que é aplicável de forma idêntica tanto à transferência de uma ação, quanto à transferência de um bloco, ou mesmo todas as ações.

a) Natureza jurídica das ações e tutela do adquirente de boa-fé

(1) Relevância da determinação da natureza jurídica das ações

Na primeira metade do século passado, TULLIO ASCARELLI constatou que “doutrina e jurisprudência são unânimes em reconhecer, nas ações, títulos de crédito". 329 Referia-se, então, ao panorama encontrado no direito italiano, francês e brasileiro e afirmava que, mesmo nos Estados Unidos, sob um ponto de vista funcional, era de se reconhecer no titular de ação uma posição análoga à do adquirente de título de crédito.

Na época, admitia-se no Brasil, para além da ação sob forma nominativa, a ação ao portador (Decreto-Lei 2.627/1940, art. 23). Para as ações ao portador, era possível a materialização da participação societária em uma cártula, cuja posse gerava ao possuidor

329 ASCARELLI, Tullio. Teoria geral dos títulos de crédito, trad. de Nicolau Nazo. Op. cit., p. 184 (“doutrina e jurisprudência são unânimes em reconhecer, nas ações, títulos de crédito").

ASCARELLI, Tullio. Teoria geral dos títulos de crédito, trad. de Nicolau Nazo. Op. cit., p. 184, nota 2. 
presunção de titularidade (Decreto-Lei 2.627/1940, art. 26). Por meio da transferência das ações ao portador era possível a transferência da titularidade da participação societária.

Desde então, a legislação se alterou. Em primeiro lugar, foi vedada a emissão de títulos ao portador (Lei 8.021/1990). A forma endossável, que era prevista pelo Decreto n. 434 de 1891 (art. 21), foi afastada pelo Decreto-Lei 2.627 de 1940 (art. 23); posteriormente, foi admitida pela Lei n. 4.728 de 1965 (art. 26) e pela Lei de Sociedades por Ações de 1976 (art. 20), ${ }^{330}$ para, depois, ser novamente vedada pela Lei n. 8.021/1990 (art. $4^{\circ}$ ). Atualmente, portanto, as ações devem ser nominativas (LSA, art. 20) ou escriturais (LSA, art. 34). Como as ações escriturais devem ser mantidas em nome dos seus titulares (LSA, art. 34), não há, em verdade, duas formas distintas. As ações escriturais, com razão, são consideradas "modalidade especial" de ação nominativa, ${ }^{331}$ ou um "subtipo", 332 razão pela qual CARVALHOSA propõe a divisão das ações nominativas nas subformas registral e escritural, ${ }^{333}$ denominação que aqui se adota. As ações nominativas registrais ou escriturais são materializadas em título de propriedade, mas não em documento ou papel circulante, isto é, documento volante e passível de transferência por meio de tradição ou endosso. ${ }^{334}$ A única modalidade de transferência por endosso que resta na lei não diz respeito diretamente a ações, mas a certificados de depósitos de ações CDA (LSA, art. 43, $\S 5^{\circ}$ ). Trata-se de título emitido pela instituição depositária de ações ${ }^{335}$ que circula por endosso em preto (Lei 8.088, art. 19), sem repercutir no livro de registro de ações nominativas e sem alterar a titularidade das ações, que permanece com a depositária. Ainda que conduza a efeitos econômicos semelhantes ao antigo endosso de ação, a transmissão do certificado de depósito de ações não constitui forma de transferência de titularidade. Adicionalmente, as ações passaram, em 1976, a ser incluídas no rol dos valores mobiliários (Lei 6.385/1976, art. 2º, I). O Código Civil de 2002, por fim, positivou o conceito de título de crédito como "documento necessário ao exercício do direito literal e

330 TEIXEIRA, Egberto L.; GUERREIRO, José Alexandre T. Das sociedades anônimas no direito brasileiro, v. I. São Paulo: Bushatsky, 1979, p. 204.

331 COMPARATO, Fábio K. "Responsabilidades na transferência de ações escriturais". In: Direito empresarial: estudos e pareceres. São Paulo: Saraiva, 1990, pp. 354-361, p. 355; LEÃES, Luiz G. P. de B. “Ações escriturais". In: Estudos e pareceres sobre sociedades anônimas. São Paulo: RT, 1989, pp. 53-70, p. 61; PEDREIRA, J. L. Bulhões; LAMY FILHO, Alfredo. "Valores mobiliários". In: PEDREIRA, J. L. Bulhões; LAMY FILHO, Alfredo. (org.). Direito das companhias, v. 1. Rio de Janeiro: Forense, 2009, pp. 503-542, p. 527.

${ }^{332}$ REQUIÃO, Rubens. Comentários à lei das sociedades anônimas. São Paulo: Saraiva, 1980, p. 218.

${ }^{333}$ CARVALHOSA, Modesto. Comentários à lei de sociedades anônimas, $1^{\circ}$ v., $7^{\mathrm{a}}$ ed. Op. cit., p. 412.

${ }^{334}$ COMPARATO, F. K. "Responsabilidades na transferência de ações escriturais". Op. cit., p. 355.

${ }^{335}$ EIZIRIK, Nelson. A Lei das S/A Comentada, v. 1, São Paulo: Quartier Latin, 2011, p. 264. 
autônomo nele contido" (CC, art. 887), disposição normativa que se inspira na conceituação doutrinária de VIVANTE, ${ }^{336} \mathrm{com}$ a diferença de que o texto legal define título de crédito como aquele em que o direito está "contido" (incorporado), ao passo que o autor reportava-se ao direito mencionado (menzionato) no título. ${ }^{337}$

Diante das alterações no cenário legislativo e, sobretudo, de novas orientações da doutrina, quem buscasse analisar a natureza jurídica das ações hoje provavelmente chegaria à conclusão de que, como se verá, a afirmação de ASCARELLI teria de ser atualizada para afirmar que doutrina e jurisprudência no Brasil são praticamente unânimes em não reconhecer, nas ações, títulos de crédito. Compreender e avaliar a correção dessa inflexão teórica em matéria que era tida por pacificada há não tanto tempo seria relevante ainda que o interesse sobre o assunto fosse puramente acadêmico. Mas não é esse o caso. Com o Código Civil 2002, saber se ações são modalidade de títulos de crédito é questão com consequências práticas.

O direito brasileiro, tradicionalmente, não acolhia o princípio de que a posse de boa-fé de móveis vale como título (en fait de meubles possession de bonne foi vaut titre). A regra geral relativa aos bens móveis era de que "feita por quem não seja proprietário, a tradição não alheia a propriedade" (CC/1916, art. 622). Eram exceções as hipóteses de pagamento por meio de coisa fungível consumida pelo credor de boa-fé, cenário em que o proprietário não poderia reivindicar a coisa do credor (CC/1916, art. 933, par. único) e a proteção do portador legítimo de títulos cambiários contra a reivindicação de terceiros (LUG, art. 16). ${ }^{338}$ Como nunca se considerou que as ações nominativas fossem títulos cambiais, para a tutela do adquirente, saber se as ações nominativas seriam ou não títulos de crédito era questão de menor importância. A proteção do adquirente de boa-fé de ações nominativas, por conseguinte, deveria pautar-se pelos princípios gerais aplicáveis à transferência de propriedade sobre coisas móveis.

\footnotetext{
${ }^{336}$ VIVANTE, C. Trattato di diritto commerciale, v. III, $4^{\text {a }}$ ed. Milano: Francesco Vallardi, 1914, n. 953, pp. 163-164

${ }^{337}$ LUCCA, Newton De. Comentários ao novo Código Civil, v. 12. Rio de Janeiro: Forense, 2003, p. 125.

${ }^{338}$ ASCARELLI, Tullio. Teoria geral dos títulos de crédito, trad. de Nicolau Nazo. Op. cit., p. 259, nota 1 (afirmando que o direito brasileiro admite a reivindicação contra o possuidor de boa-fé e que o princípio de que a posse de boa-fé de móveis seria equivalente a título não é consagrada quanto às coisas móveis ou títulos de crédito).
} 
Ao aplicar os princípios gerais à situação específica do adquirente de ações nominativas, a doutrina e a jurisprudência não eram pacíficas. CARVALHO DE MENDONÇA analisou a hipótese de ações nominativas serem transferidas fraudulentamente e, posteriormente, um terceiro adquiri-las confiando que o nome que constava do livro de registros era efetivamente o do titular. Sua opinião foi a de que seria necessário amparar a boa-fé do adquirente, ainda que tal orientação perturbasse a economia do direito civil. As ações nominativas, destinadas que são à intensa circulação em bolsa ou fora dela, não serviriam à finalidade de mobilização da riqueza se sua circulação não fosse dotada de certeza. Haveria, portanto, inegável interesse público de conferir segurança à circulação das ações nominativas, tutelando o possuidor de boa-fé contra uma reivindicação baseada em vícios na aquisição originária em que não figurou. ${ }^{339}$ No mesmo sentido, CuNHA PeIXoto considerava que "o terceiro que adquire, confiando no registro, deve ter, naturalmente, seu direito tutelado". 340 A posição, porém, não era unânime. MIRANDA VAlverde, igualmente, repeliu a posição de CARVALHO De MendonçA, segundo a qual o terceiro de boa-fé que adquire ações nominativas por transferência a non domino estaria abrigado contra ação do legítimo proprietário. Nem mesmo a alegada necessidade de segurança no tráfego mercantil dos títulos de crédito poderia justificar, em sua visão, a tutela do adquirente. ${ }^{341}$

O Código Civil de 2002 promoveu importantes alterações ao regime de proteção do adquirente de boa-fé. Mantendo as hipóteses previamente existentes (LUG, art. 16; CC, art. 307, par. único), agregou três novas. A primeira é de que a tradição de coisas móveis por quem não é proprietário confere propriedade ao adquirente "se a coisa, oferecida ao público, em leilão ou estabelecimento comercial, for transferida em circunstâncias tais que, ao adquirente de boa-fé, como a qualquer pessoa, o alienante se afigurar dono" (CC, art. 1.268). ${ }^{342}$ A segunda é a atribuição de eficácia às alienações feitas, a título oneroso, pelo herdeiro aparente a terceiro de boa-fé (CC, art. 1.827, par. único). E a terceira, que aqui mais de perto interessa, é a introdução de regra geral de tutela do adquirente de título de crédito, qual seja, a de que "o título de crédito não pode ser

${ }^{339}$ CARVALHO DE MENDONÇA, José X. Tratado de direito commercial brasileiro, v. 5, parte 2, $3^{\mathrm{a}}$ ed. atual. por Achilles Bevilaqua e Roberto Carvalho de Mendonça. Rio de Janeiro: Freitas Bastos, 1938, n. 488, p. 92.

${ }^{340}$ CUNHA PEIXOTO, Carlos F. Sociedades por ações, v. 1. São Paulo: Saraiva, 1972, p. 256.

${ }^{341}$ VALVERDE, Trajano de Miranda. Sociedades por ações, v. 1, 2 ${ }^{\mathrm{a}}$ ed. Rio de Janeiro: Forense, 1953, n. 143, p. 187.

${ }^{342}$ MARTINS-COSTA, Judith. Comentários ao novo Código Civil, v. 5, t. 1. Op. cit., pp. 127 (referindo o caráter inovador da regra). 
reivindicado do portador que o adquiriu de boa-fé e na conformidade das normas que disciplinam a sua circulação" (CC, art. 896). As hipóteses em que tais regras podem ser relevantes são múltiplas, e variam desde situações patológicas, de aquisição realizada de alguém que simplesmente não era titular e promoveu alteração fraudulenta no livro de registro de ações, até hipóteses de maior relevância na vida prática, como a do procurador sem poderes (falsus procurator), ou a hipótese em que o negócio jurídico intermediário inter vivos é inexistente, nulo, anulado, resolvido ou ineficaz, e o proprietário originário volta-se contra o segundo adquirente em ação reivindicatória. ${ }^{343}$ Quem considerar ações como coisas móveis, afirmará que o adquirente somente será tutelado se as adquirir em leilão ou estabelecimento comercial (CC, art. 1.268). Para quem considerar as ações como títulos de crédito, o relevante será verificar se a aquisição ocorreu "na conformidade das normas que disciplinam a sua circulação" (CC, art. 896), para saber se há proteção ao adquirente de boa-fé. E para quem considerar que a ação não seria nem coisa móvel, nem título de crédito, mas uma terceira categoria, como, por exemplo, valor mobiliário, provavelmente chegaria à conclusão de que nenhuma das regras seria aplicável.

A doutrina e a jurisprudência dominantes, como adiante se verá, negam a qualidade de título de crédito às ações. Em um julgado do STJ, ainda que em obiter dictum, afirmou-se que "as ações não constituem espécies de títulos de crédito, pois não apresentam os mesmos atributos destes último: autonomia, literalidade e cartularidade". 344 Nesse mesmo acórdão é transcrito trecho de autoria de FABIO UlhoA CoElHo, que bem exemplifica as consequências decorrentes do entendimento atualmente vigente. Após diferenciar os títulos de crédito e os valores mobiliários e considerar que as ações seriam espécies do segundo gênero, e não do primeiro, afirma COELHO que "[s]e, por ato viciado (falsidade da assinatura do acionista no termo lançado no livro de transferência de ações, p. ex.), é transmitida uma ação de Antonio para Benedito, e este a aliena a Carlos, o vício comprometedor da regularidade do primeiro ato estende-se também ao segundo. Mesmo que não se pudesse indicar, no isolado negócio de transferência do valor mobiliário de Benedito para Carlos, nenhuma invalidade ou irregularidade, este último não é acionista,

\footnotetext{
${ }^{343}$ MENGONI, Luigi. Gli acquisti 'a non domino', 2ª ed. Milano: Giuffrè, 1968, p. 334; LA SALA, Gian Paolo. "L'acquisto a non domino di strumenti finanziari dematerializzati”. In: BBTC, I, 2004, pp. 467-525, p. 479.

${ }^{344}$ STJ, REsp n. 759.391-PR, 1 ${ }^{\text {a }}$ T., rel. Min. José Delgado, 15.12.2005 (o caso tratava da possibilidade de ações serem consideradas títulos de crédito para fins de classificação entre os bens na ordem de penhora, mas a decisão foi pautada pela consideração de ordem geral de que ações não teriam natureza jurídica de títulos de crédito, mas de valores mobiliários).
} 
porque os direitos mencionados na ação não se transferem autonomamente, como nas cambiais". 345

(2) Ações como títulos de crédito

Como se afirmou anteriormente, ASCARELLI considerava que as ações constituiriam modalidade de título de crédito. ${ }^{346}$ Era no mesmo sentido o entendimento de parcela expressiva da doutrina nacional. MiRANDA VALVERDE considerava as ações títulos de crédito causais. ${ }^{347}$ CARVALHO DE MENDONÇA classificava os títulos de crédito em títulos propriamente ditos e os impropriamente ditos, ${ }^{348}$ incluindo as ações na última categoria. Reconhecendo que as ações representavam o complexo de direitos conexos à qualidade societária, o autor avaliava que as ações, "na circulação se comportam como titulos de credito". ${ }^{349}$ PONTES DE MIRANDA, em tradução praticamente literal do termo germânico, refere-se aos títulos nominativos como títulos-valor, afirmando haver erro em considerálos como documentos de crédito. ${ }^{350}$ As ações, em sua concepção, seriam espécie de títulos nominativos, ${ }^{351}$ sendo ainda consideradas como títulos corporativos. ${ }^{352}$

Progressivamente, porém, a doutrina passou a considerar que (i) as ações nominativas registrais e escriturais não seriam títulos de crédito; (ii) as ações, como gênero, não atenderiam aos requisitos para serem consideradas títulos de crédito; ou que (iii) as ações, sendo valores mobiliários, não seriam títulos de crédito. $\mathrm{O}$ estudo detalhado das diversas orientações sobre o assunto se faz necessário, porque, como se afirmou, não se trata de uma posição histórica consolidada e aceita, mas de uma ruptura, ocorrida em pouco mais de meio século, com um posicionamento que ASCARELLI defendia e tinha por

\footnotetext{
${ }^{345}$ COELHO, Fábio Ulhoa. Curso de direito comercial. São Paulo: Saraiva, 2013, p. 165.

${ }^{346}$ ASCARELLI, Tullio. Teoria geral dos títulos de crédito, trad. de Nicolau Nazo. Op. cit., pp. 184-186.

${ }^{347}$ VALVERDE, T. de Miranda. Sociedades por ações. Op. cit., n. 146, p. 190 ("As ações das sociedades anônimas, sendo, qualquer que seja a sua forma, títulos ou papéis de crédito causais").

${ }^{348}$ CARVALHO DE MENDONÇA, José X. Tratado de direito commercial brasileiro. Op. cit., n. 463, p. 55.

349 CARVALHO DE MENDONÇA, José X. Tratado de direito commercial brasileiro. Op. cit., n. 463, p. 56-57.

${ }^{350}$ PONTES DE MIRANDA, FRANCISCO C. Tratado de direito privado, t. 33. Op. cit., §3.788, p. 243.

${ }^{351}$ PONTES DE MIRANDA, FRANCISCO C. Tratado de direito privado, t. 33. Op. cit., §3.788, p. 244.

${ }^{352}$ PONTES DE MIRANDA, FRANCISCO C. Tratado de direito privado, t. 33. Op. cit., \$3.740, p. 39.
} 
pacífico. Cumpre reconstruir detalhadamente esse percurso intelectual antes de avaliar sua conveniência.

A vertente que nega o caráter de títulos de crédito às ações nominativas $\mathrm{e}$ escriturais, ou somente às escriturais, parece ter tido um marco com um trabalho publicado em 1956 por Theophilo de Azeredo Santos. Nele, defendeu-se que as ações nominativas não poderiam ser incluídas entre os títulos de crédito, postura que representaria verdadeiro "erro palmar". ${ }^{353}$ A lição teve repercussão. Mencionando o escrito de Theophilo Santos e com ele concordando, EgBerto Lacerda TeiXeira e Tavares GUERREIRO consideraram que as ações ao portador poderiam ser classificadas como títulos de crédito, mas imperfeitos, porque não outorgariam um crédito a seu titular, senão uma posição de sócio. $^{354}$ A caracterização como título de crédito, porém, somente teria cabimento nos casos de ações com certificados emitidos. Na visão dos autores, as ações escriturais, por não serem representadas por um documento corpóreo, "escapam completamente à condição de títulos de crédito". ${ }^{355}$ Em escrito posterior, TAVARES GUERREIRO afirmou que "no tocante às ações de sociedades anônimas, deve-se afirmar, em primeiro lugar, que comportam, inequivocamente, o vínculo usufrutuário, como títulos de crédito que são" 356 e que "não importa determinar, neste estudo, a natureza específica das ações de companhias no sentido de defini-las como títulos-valor, valores mobiliários ou títulos de legitimação. Basta que se tenha em mente o que o próprio Ascarelli afirmou com relação aos títulos de crédito em geral: são eles coisas". ${ }^{357}$ Não é claro, porém, se se referia às ações em geral, ou somente às ações ao portador, título e objeto do trabalho específico em que a afirmação em questão está contida.

Philomeno DA CostA, por sua vez, considerava que as ações seriam efetivamente títulos de crédito, porque representariam fração do capital da anônima "acompanhada de todos os atributos que o papel (a cártula) concentra". 358 Ponderava,

353 SANTOS, Teófilo de Azeredo Santos. "Natureza jurídicas das ações das sociedades". In: Revista Forense, v. 169, 1957, pp. 484-498, p. 497.

${ }^{354}$ TEIXEIRA, Egberto L.; GUERREIRO, José Alexandre T. Das sociedades anônimas no direito brasileiro, v. I. Op. cit., n. 66, p. 170.

355 TEIXEIRA, Egberto L.; GUERREIRO, José Alexandre T. Das sociedades anônimas no direito brasileiro, v. I. $O p$. cit., p. 171.

${ }^{356}$ GUERREIRO, José Alexandre T. "O usufruto de ações ao portador e a posição da companhia emissora". In: RDM, n. 39, 1980, pp. 84-90, p. 84

${ }^{357}$ GUERREIRO, José Alexandre T. "O usufruto de ações ao portador e a posição da companhia emissora". Op. cit., p. 85.

${ }^{358}$ COSTA, Philomeno J. da. Anotações às companhias. São Paulo: RT, 1980, p. 197. 
inclusive, que o conceito de título de crédito seria em geral mal compreendido devido à conotação restritiva sugerida pela expressão. Anotava que "em título de crédito, crédito não é apenas o direito de receber dinheiro; pode ser e é também o direito tranquilo a utilidades diferentes, incorporadas na cártula". ${ }^{359}$ Quando tratou das ações nominativas, porém, negou-lhes o caráter de títulos de crédito. Citando o trabalho de THEÓPHILO DE AZEREDO SANTOS, transcreveu a referência de que a classificação das ações nominativas entre os títulos de crédito representaria "erro palmar" e acrescentou: "Está certo". ${ }^{360}$ Para Philomeno DA CostA, o fato de a transferência das ações nominativas depender de registro nos livros sociais, "sem exibição do papel (ação)", 361 subtrairia das ações o caráter de "documento necessário para o exercício de um direito literal e autônomo, que nele se contém". ${ }^{362}$ Julgou, assim, que as ações nominativas não seriam sequer documentos de legitimação, mas meros comprovantes, porque a prova do direito exsurgiria dos registros sociais. ${ }^{363}$ Quanto às ações escriturais, afirmou peremptoriamente que "escapam à teórica geral dos títulos de crédito, porque lhes falta exatamente o pedaço de papel negociável". ${ }^{364}$

Igualmente considerando necessária a presença de cartularidade como requisito para a atribuição da condição de título de crédito, MODESTO CARVALHOSA afirma que as ações ao portador constituíam "documento literal e autônomo, necessário e autônomo para o exercício de direito que nele se contém", ${ }^{365}$ definição que atribui a VIVANTE. A atribuição é incorreta, porque, como se viu, o autor italiano utilizava a expressão "mencionado", distinção terminológica que não é insignificante. De toda forma, quanto às nominativas registrais e escriturais, o autor não é claro. Afirma que os certificados das ações nominativas seriam títulos sem serventia que não poderiam ser considerados títulos de crédito, ${ }^{366}$ com o que dá a entender que as ações nominativas registrais e escriturais por maioria de razão não poderiam ser consideradas títulos de crédito.

NEWTON DE LUCCA, em estudo monográfico, foi quem mais se aprofundou sobre o assunto. Julgou que, no direito brasileiro, as ações seriam carentes da qualidade de

\footnotetext{
${ }^{359}$ COSTA, Philomeno J. da. Anotações às companhias. Op. cit., p. 202.

${ }^{360}$ COSTA, Philomeno J. da. Anotações às companhias. Op. cit., p. 202.

${ }^{361}$ COSTA, Philomeno J. da. Anotações às companhias. Op. cit., p. 202.

${ }^{362}$ COSTA, Philomeno J. da. Anotações às companhias. Op. cit., p. 202.

${ }^{363}$ COSTA, Philomeno J. da. Anotações às companhias. Op. cit., p. 202.

${ }^{364}$ COSTA, Philomeno J. da. Anotações às companhias. Op. cit., p. 203.

${ }^{365}$ CARVALHOSA, Modesto. Comentários à Lei de Sociedades Anônimas. Op. cit., p. 172.

${ }^{366}$ CARVALHOSA, Modesto. Comentários à Lei de Sociedades Anônimas. Op. cit., p. 172.
} 
título de crédito porque, diferente do que ocorre em outros países, no Brasil a circulação se dá exclusivamente por meio de lançamento no livro de registro de ações, razão pela qual a ação perderia o atributo de portar consigo um direito literal e autônomo, porque depende do que está escrito nos livros da sociedade emissora. ${ }^{367}$

Posteriormente à proibição dos títulos ao portador e endossáveis, e restando apenas as ações nominativas registrais e escriturais, a doutrina deixa sequer de se preocupar em distinguir entre ações que seriam ou não títulos de crédito, e passa a negarlhes o caráter de título de crédito de uma forma geral. LuIZ EMYGDiO DA RosA JR. afirma que a ação não ostentaria os requisitos de (i) autonomia, porque o certificado de ações apenas comprovaria a qualidade de acionista, sem natureza constitutiva; (ii) cartularidade, porque a ação não dependeria de uma cártula; nem (iii) literalidade, porque os direitos do acionistas se fundam no estatuto e nas decisões assembleares. ${ }^{368}$

Outra corrente teórica aponta o fato de as ações estarem incluídas entre os valores mobiliários (Lei n. 6.385/1976, art. $2^{\circ}$, I) como fundamento para lhes negar a qualidade de títulos de crédito. FÁBIo UlhoA CoElho, nesse sentido, afirma que as ações seriam valores mobiliários, mas não títulos de crédito, por três razões. A primeira seria de que os títulos de crédito "sempre se referem a uma relação de crédito pecuniário, isto é, documentam o direito de um sujeito (credor) receber dinheiro de outro (devedor)". ${ }^{369}$ A segunda seria a executividade, conferida aos títulos de crédito pelo Código de Processo Civil, e não aos valores mobiliários. E a terceira seria o não atendimento aos princípios da cartularidade, porque seria admitida a ação escritural sem emissão de certificado; da literalidade, porque nos valores mobiliários não estão transcritos todos os direitos atribuídos ao titular; e da autonomia, porque, na hipótese já mencionada de aquisição a non domino, o adquirente final ficaria sujeito às exceções que pudessem ser opostas ao titular intermediário. ${ }^{370}$ Após diferenciar títulos de crédito de valores mobiliários, porém, CoELHO avalia que haveria relações complexas entre os institutos, com (i) valores mobiliários que não são títulos de crédito, o que seria o caso das ações; (ii) títulos de crédito que poderiam se tornar valores mobiliários, o que seria o caso das notas promissórias; e (iii) títulos de

\footnotetext{
367 LUCCA, Newton De. Aspectos da teoria geral dos títulos de crédito. Op. cit., p. 114

${ }^{368}$ ROSA Jr., Luiz Emygdio da. Títulos de crédito, $3^{\text {a }}$ ed. Rio de Janeiro/São Paulo/Recife: Renovar, 2004, p. 77.

${ }_{369}$ COELHO, Fábio Ulhoa. Curso de direito comercial. Op. cit., p. 163.

${ }^{370}$ COELHO, Fábio Ulhoa. Curso de direito comercial. Op. cit., p. 164-165.
} 
crédito que não poderiam se tornar valores mobiliários, como seria o caso do cheque e da duplicata. $^{371}$

Contrapondo de forma mais incisiva as categorias dos valores mobiliários e dos títulos de crédito, Ary Oswaldo Mattos Filho considera que os valores mobiliários, em especial no caso de títulos em massa, seriam marcados pela circunstância de que o regramento jurídico a que o titular está sujeito poderia ser alterado contra a sua vontade, por decisão majoritária, de tal forma que a relação cartular não seria literal, e nem mesmo relevante. ${ }^{372}$ Em seu ponto de vista, os títulos de crédito seriam caracterizados pela existência de cártula, ao passo que nos valores mobiliários a cártula não seria necessária; ${ }^{373}$ os valores mobiliários seriam por natureza contratos de investimento coletivo, ao passo que os títulos de crédito seriam "somente instrumentos representativo se dívida". ${ }^{374}$ As ações, com isso, seriam decisivamente sempre valores mobiliários. ${ }^{375}$ Outros títulos, porém, poderiam ser criados como título de crédito enquanto documentação de dívida; se a esse título "se agregar a expectativa de lucro, transformando-o por tal em um contrato de investimento", o título ingressa no domínio dos valores mobiliários. ${ }^{376}$

$\mathrm{Na}$ jurisprudência do STJ, considerou-se que "as ações, pelas suas peculiaridades intrínsecas, não compartilham de nenhum dos três elementos caracterizadores dos títulos de crédito, quais sejam, autonomia, literalidade e cartularidade", ${ }^{377}$ citando, para tanto, as posições de FÁBIO UlHOA COELHO e de LUIZ EMYGDIO DA ROSA JR., referidas anteriormente.

Conclui-se, em resumo, que a negativa do caráter de títulos de crédito devese, sobretudo, à compreensão de que as ações nominativas não seriam espécies de títulos de crédito, porque (i) não conferem direito de crédito, mas posição de sócio; (ii) não atendem ao requisito da cartularidade, porque o certificado não é documento necessário para o exercício do direito; (iii) não são literais, porque os direitos de sócio se fundam no

\footnotetext{
${ }^{371}$ COELHO, Fábio Ulhoa. Curso de direito comercial. Op. cit., p. 165.

${ }^{372}$ MATTOS FILHO, Ary Oswaldo. Direito dos valores mobiliários, v. 1, t. 1. FGV: Rio de Janeiro, 2015, p. 37.

${ }^{373}$ MATTOS FILHO, Ary Oswaldo. Direito dos valores mobiliários. Op. cit., p. 43.

${ }^{374}$ MATTOS FILHO, Ary Oswaldo. Direito dos valores mobiliários. Op. cit., p. 44.

${ }^{375}$ MATTOS FILHO, Ary Oswaldo. Direito dos valores mobiliários. Op.cit, p. 45.

${ }^{376}$ MATTOS FILHO, Ary Oswaldo. Direito dos valores mobiliários. Op.cit, p. 45.

${ }^{377}$ STJ, REsp n. 759.391-PR, $1^{\mathrm{a}}$ T., rel. Min. José Delgado, 15.12.2005.
} 
estatuto e nas deliberações assembleares; (iv) não seriam autônomas, pois sua circulação seguiria regras diversas das aplicáveis aos títulos de crédito.

Há poucas manifestações contrárias a esse entendimento, sendo de se ressaltar o posicionamento de BULHÕEs PEDREIRA e LAMY FILHO, que consideram que as ações nominativas e escriturais seriam sempre títulos de crédito; ${ }^{378}$ de FrAN MARTINS, que, sem nenhum aprofundamento, inclui as ações em categoria especial dos títulos de crédito que conferem direito de participação, mas não se prolonga em refutar as teses contrárias; ${ }^{379}$ e de WALDírio Bulgarelli, para quem o conceito de valor mobiliário não afastaria o caráter de título de crédito ínsito às ações devido à aptidão que apresentam para a circulação. $^{380}$

Para compreender o assunto, convém analisar de forma diversa se (i) as ações nominativas registrais poderiam ser consideradas títulos de crédito; (ii) o fato de serem mantidas sob a forma escritural delas retiraria tal predicado; e (ii) o fato de serem incluídas entre os valores mobiliários seria impeditivo da caracterização simultânea como títulos de crédito.

Definir se ações nominativas registrais seriam ou não títulos de crédito exige que se remonte ao conceito de VIVANTE, que está na base na definição de título de crédito atualmente positivada (CC, art. 887). Alterando a definição proposta por HEINRICH BRUNNER, VIVANTE caracterizou o título de crédito como "documento necessário para exercitar o direito literal e autônomo nele mencionado". ${ }^{381}$ Representaria flagrante erro imaginar que a definição de VIVANTE seria fruto de uma atividade puramente especulativa; os termos que utilizou são importantes exatamente porque significaram a tomada de posição do autor em relação a debates doutrinários que então se colocavam.

\footnotetext{
${ }^{378}$ PEDREIRA, J. L. Bulhões. "Natureza de título de crédito da ação escritural". Op. cit., pp. 45-71; LAMY FILHO, Alfredo. "Doação de ações nominativas sem a assinatura do termo no livro próprio". In: A lei das S.A., v. II: Pareceres, $2^{\mathrm{a}}$ ed. Rio de Janeiro: Renovar, 1997, pp. 37-45; LAMY FILHO, Alfredo. "Ações nominativas e ações escriturais - natureza - usucapião". Op. cit.; PEDREIRA, J. L. Bulhões; LAMY FILHO, Alfredo. "Valores mobiliários". Op. cit., §123, pp. 508-509.

${ }^{379}$ MARTINS, Fran. Títulos de crédito, $15^{\text {a }}$ ed. atual. por Joaquim Penalva Santos e Paulo Penalva Santos. Rio de Janeiro: Forense, 2010, p. 23.

${ }^{380}$ BULGARELLI, Waldirio. “Os valores mobiliários brasileiros como títulos de crédito". In: RDM, n. 37 , 1980, pp. 94-112, p. 111.

${ }^{381}$ VIVANTE, Cesare. Trattato di diritto commerciale, v. 3, $5^{\mathrm{a}}$ ed. Milano: Francesco Villardi, 1929, n. 953, p. 123 ("Il titolo di credito è un documento necessario per esercitare il diritto letterale ed autonomo che vi è menzionato" - itálico no original).
} 
O primeiro aspecto a ser ressaltado é o fato de que VIVANTE se refere ao documento que menciona um direito, não que o contém, e ressalta que tal seria o conceito jurídico, preciso e limitado, que deveria substituir a "frase vulgar" com que se ensinava que um título incorpora um direito. A relevância da distinção, para o autor, seria evidente na hipótese de perda ou de destruição do título, em que o direito não desaparece, apenas tem seu exercício como título de crédito suspenso. ${ }^{382}$ Um segundo aspecto da relevância do termo "mencionado" liga-se justamente aos títulos nominativos, que são emitidos em favor de determinadas pessoas inscritas no livro de registro do emissor e passíveis de transferência por termo de cessão seguido de registro, mas não apresentam uma cártula em que todas as condições do direito estão descritas. Os exemplos clássicos de títulos nominativos eram os títulos da dívida pública e as ações emitidas por sociedades anônimas. Antes do trabalho de VIVANTE, a doutrina contrapunha, de um lado, os títulos ao portador e os títulos endossáveis como categorias de títulos de crédito, porque a posse do próprio título outorgava o direito ao portador legitimado o direito; e, de outro lado, os títulos nominativos, que não eram considerados integrantes da categoria dos títulos de crédito, porque a transferência da titularidade decorreria do registro no livro mantido junto ao emissor. ${ }^{383}$ Não há nos títulos nominativos, ou pode não haver, uma cártula passível de negociação. O que justificaria sua inserção entre os títulos de crédito para VIVANTE, todavia, seria o fato de que o próprio registro do título nominativo atuaria como documento necessário para o exercício do direito nele mencionado. ${ }^{384}$

Tal proposta teórica de reconhecer nos títulos nominativos uma espécie passível de ser reconduzida ao gênero dos títulos de crédito não é uma questão de pormenor no pensamento de VIVANTE. Pelo contrário, representou uma contribuição doutrinária decisiva à época. Na quinta edição de seu Tratado, na qual teve a oportunidade de avaliar a repercussão de sua obra, o próprio VIVANTE ressalta a apreciação positiva oferecida na França por THALLER, para quem “[é] à generalização dos títulos fiduciários de todas as naturezas que o tratado de VIVANTE deve sua originalidade e seu mérito da primeira ordem", sublinhando a vantagem que poderia advir à doutrina francesa na constituição de uma doutrina de síntese que abarcasse os títulos nominativos sob o mesmo

\footnotetext{
${ }^{382}$ VIVANTE, Cesare. Trattato di diritto commerciale. Op. cit., n. 953, p. 123.

${ }^{383}$ VIVANTE, Cesare. Trattato di diritto commerciale. Op. cit., n. 992, p. 162.

${ }^{384}$ VIVANTE, Cesare. Trattato di diritto commerciale. Op. cit., n. 993, p. 165.
} 
raciocínio aplicável aos títulos à ordem e ao portador. ${ }^{385}$ Nessa mesma quinta edição, o próprio VIVANTE ressalta a relevância da inclusão dos títulos nominativos na categoria dos títulos de crédito em nota de caráter pessoal, na qual afirmou: "Eu considero a classificação realizada no texto, em especial no que toca aos títulos nominativos, que situei na teoria geral dos títulos de crédito com caracteres bem definidos, como a contribuição mais segura dada por este volume à sistematização do direito comercial". ${ }^{386}$ Tratava-se, afirma VIVANTE, de verdadeira inovação que não encontrava precedentes na doutrina de então. ${ }^{387} \mathrm{E}$ é justamente esse importante contributo que ASCARELLI destaca quando menciona que "o mestre" (il Maestro), forma pela qual se refere à VIVANTE, formulara indutivamente uma categoria geral por meio da identificação de um denominador comum a documentos sujeitos a disciplinas legislativas diversas e esparsas, classificando-os conforme as leis de circulação do título (nominativa, à ordem ou ao portador) e estendendo a definição para abarcar os títulos nominativos. ${ }^{388}$

Quando classifica os títulos de crédito por seu conteúdo, VIVANTE inclui entre eles, sem nenhuma hesitação, títulos que não materializam uma posição de crédito obrigacional, como, por exemplo, os títulos que atribuem direitos reais (como é o caso do depósito de mercadorias) e os títulos que "atribuem a qualidade de sócio, como as ações". ${ }^{389}$ Para o autor, não havia nenhuma incompatibilidade entre as ações e o conceito de título de crédito que propunha. A falta de literalidade - porque nem todo o direito vem descrito no título - que hoje se aponta como obstáculo à caracterização das ações como títulos de crédito não era para VIVANTE um traço que impedisse a classificação naquela categoria. Como afirma o autor, há títulos nos quais está presente a completude ou a independência, como ocorre na cambial, porque eles se destinam a circular por si; mas essa facilitação da circulação não seria inerente aos títulos de crédito, tendo em vista que há

\footnotetext{
${ }^{385}$ THALLER, E. apud VIVANTE, Cesare. Trattato di diritto commerciale. Op. cit., n. 993, p. 164, nota 4 ("C'est à la généralisation des titres fiduciaires de toute nature que le traité de VIVANTE doit son originalité et son mérite de tout premier ordre. On jugera par les citations suivantes de l'avantage que nous trouverions aussi en France à constituer une doctrine de synthèse").

${ }^{386}$ VIVANTE, Cesare. Trattato di diritto commerciale. Op. cit., n. 993, p. 165.

387 VIVANTE, Cesare. Trattato di diritto commerciale. Op. cit., n. 988, p. 156 ("Io considero la classificazione fatta nel testo, in ispecie per ciò che riguarda i titoli nominativi, che ho collocato nella teoria generale dei titoli di credito con caratteri ben definiti, come il più sicuro contributo dato da questo volume alla sistemazione del diritto commerciale").

${ }^{388}$ ASCARELLI, Tullio. "Sul concetto di titolo di credito e sulla disciplina del titolo V libro IV del nostro codice”. In: BBTC, I, 1954, pp. 367-388, pp. 367-368.

389 VIVANTE, Cesare. Trattato di diritto commerciale. Op. cit., n. 987, p. 155 ("I titoli di credito potrebbero anche distinguersi secondo il loro contenuto in quattro gruppi: [...] c) titoli che attribuiscono la qualità di socio, come le azioni”).
} 
"muitos títulos de crédito que se referem a outros contratos, e vale como exemplo a ação, que reclama necessariamente o ato constitutivo da sociedade". ${ }^{390}$ Igualmente, nem todo título de crédito deve ser abstrato e, entre os exemplos de títulos causais, o autor inclui, novamente, a ação de sociedade anônima, porque fica ela coligada à disciplina prevista no estatuto social. $^{391}$

A proposta de ViVAnTE de incluir os títulos nominativos entre os títulos de crédito foi efetivamente inovadora, porque somente com esforço intelectual é possível perceber traços comuns entre, por exemplo, uma cambial - paradigma dos títulos de crédito - e um livro de registro. Como apontou PelLizzI, “os títulos nominativos não fazem parte da natureza, são como, em botânica, os frutos de um enxerto; são títulos de crédito, como afirmei, não porque mas apesar de serem documentos ligados a um nome". ${ }^{392}$ É fato que a inclusão de títulos de participação como as ações na categoria dos títulos de crédito, promovida por VIVANTE, foi parcialmente infeliz, porque não está em questão uma posição de crédito. ASCARELLI, ciente de tal circunstância, afirmou que o termo "títulos-valores", em tradução do alemão (Wertpapier) seria mais adequado para incluir as ações que, não representando direitos de crédito, assim seriam melhor retratados dentro da categoria a que pertencem. ${ }^{393}$ A despeito dessa divergência, afirma que o termo "título de crédito" já entrara em uso corrente e que, com ciência de seu significado, não haveria risco em seu emprego. Como se percebe, portanto, as ações nominativas seriam títulos de crédito sem serem representadas por títulos, porque não há uma cártula que descreva todos os direitos conferidos ao acionista; e sem outorgarem a seu titular um crédito, porque se referem a uma posição de sócio. VIVANTE considerava as ações títulos de crédito ciente desses atributos.

É certo que, a despeito do que afirmasse VIVANTE, seria possível questionar se ainda hoje seria adequado inserir as ações na categoria dos títulos de crédito, tendo em vista que a ação não é materializada em um título e não veicula um crédito.

\footnotetext{
${ }^{390}$ VIVANTE, Cesare. Trattato di diritto commerciale. Op. cit., n. 954, p. 124.

${ }^{391}$ VIVANTE, Cesare. Trattato di diritto commerciale. Op. cit., n. 955, p. 125.

392 PELLIZZI, Giovanni. "Panorama dei titoli di credito". In: BBTC, I, 1984, pp. 1-13, p. 10 ("i titoli nominativi non fanno parte della natura, sono come, in botanica, il frutto di un innesto; sono titoli di credito, come ho detto, non perché ma nonostante che siano documenti intestati a un nome").

${ }^{393}$ ASCARELLI, Tullio. Teoria geral dos títulos de crédito. Op. cit., p. 26.
} 
A resposta parece ser positiva. A caracterização como título de crédito é relevante porque coloca luz sobre o aspecto de que, também nos títulos nominativos, a forma de circulação não é a comum pertinente ao direito dos bens móveis ou à cessão dos direitos de crédito. É justamente essa, por sinal, a grande contribuição que AsCARELLI, discípulo intelectual de VIVANTE, prestou à disciplina dos títulos de crédito. Escrevendo após o Codice civile de 1942, ASCARELLI nota que a orientação indutiva de VIVANTE havia se perdido e sido substituída por uma doutrina e jurisprudência conceituais que passaram a buscar exclusivamente no tipo legal do título de crédito a resposta para questões interpretativas. ${ }^{394}$ A situação assemelha-se, mutatis mutandis, à avaliação atualmente realizada para determinar no direito brasileiro se as ações seriam ou não títulos de crédito, buscando averiguar se os atributos da cartularidade, autonomia e literalidade estariam nela presentes. Crítico a tal orientação que buscava extrair a normatividade por operações de extração lógico-dedutivas, ${ }^{395}$ ASCARELLI ressaltou que o eixo da disciplina dos títulos de crédito e o norte para a sua correta interpretação é constituído pela compreensão da função que eles desempenham no tráfego jurídico e que vem a ser, justamente, a necessidade de conferir segurança e certeza à circulação. ${ }^{396}$ Nas páginas de "Advertencia" que iniciam sua Teoria geral dos títulos de crédito, ASCARELLI ressaltou que "os títulos de credito formam um instituto juridico destinado a facilitar a 'circulação' dos direitos". 397 Alguns anos depois de retornar à Itália, ASCARELLI transcreveria essas palavras - em português, a despeito de tratar-se de um artigo que publicava em italiano - para defender, novamente, que o cerne do direito dos títulos de crédito é a específica tutela da circulação. ${ }^{398}$ Definir que um título deve ser considerado título de crédito, nessa medida, significa admitir que ele se sujeita à especial forma de circulação na qual os imperativos da certeza e da segurança chegam a sobrepor-se aos igualmente tuteláveis princípios da equidade e da justiça do caso concreto. $^{399}$

\footnotetext{
${ }^{394}$ ASCARELLI, Tullio. "Sul concetto di titolo di credito e sulla disciplina del titolo V libro IV del nostro codice". Op. cit., pp. 374-375.

${ }^{395}$ ASCARELLI, Tullio. "Sul concetto di titolo di credito e sulla disciplina del titolo V libro IV del nostro codice". Op. cit., p. 375.

${ }^{396}$ BUTTARO, Luca. "Tullio Ascarelli e il titolo di credito". In: BBTC, I, 1981, pp. 414-432, p. 432.

${ }^{397}$ ASCARELLI, Tullio. Teoria geral dos títulos de crédito, trad. de Nicolau Nazo. Op. cit., p. VII.

${ }^{398}$ ASCARELLI, Tullio. "Ancora sul concetto di titolo di credito e sulla distinzione tra tipologia della realtà e normativa". In: BBTC, I, 1956, pp. 461-480, p. 462.

${ }^{999}$ ASCARELLI, Tullio. Teoria geral dos títulos de crédito, trad. de Nicolau Nazo. Op. cit., p. 5. No mesmo sentido, EIZAGUIRRE, José María. "Bases para una reelaboración de la teoría general de los títulosvalores". In: Revista de derecho mercantil, 1982, pp. 7-112, pp. 99-100; FERRI, Giuseppe. "Sul concetto di titolo di credito". In: BBTC, I, 1956, pp. 322-336, p. 327.
} 
No direito continental prevalece o entendimento que reconhece nas ações títulos de crédito. ${ }^{400} \mathrm{Na}$ Itália, especificamente, há divergências sobre o enquadramento, mas a posição dominante é de que, em relação à ação nominativa, a posse, caracterizada pela inscrição no livro de registro, é condição suficiente e necessária para o exercício dos direitos de sócio, ${ }^{401}$ cuidando-se de título eminentemente causal. ${ }^{402}$

No Brasil, um estudo de José Luiz Bulhões Pedreira constitui marco na doutrina favorável à classificação das ações nominativas entre os títulos de crédito. O autor reconhece que a denominação do instituto dos "títulos de crédito" não contribui para promover clareza ao enquadramento jurídico da ação, mas considera inquestionável que entre os títulos de crédito em sentido lato incluem-se os títulos de participação e os de mercadorias. Observa, ademais, que a referência a "títulos" acentua o aspecto da incorporação do direito, fato que pode suscitar certa confusão conceitual. Aproximando-se da teoria funcional de ASCARELLI, porém, sublinha que o aspecto distintivo dos títulos de crédito não se resume a características como a literalidade ou a cartularidade, mas, sobretudo, ao especial regime de circulação instituído pela lei para permitir que certos direitos sejam transmitidos como se fossem coisas móveis, o que é possibilitado pela objetivação dos direitos em documentos. O autor, dessa forma, discorda da posição de THEOPhILO DE AzEREDo SANTos que negava às ações nominativas o caráter de títulos de crédito. O equívoco doutrinário de tal posicionamento, em sua opinião, é o de confundir a ação com o certificado, que é documento emitido pela sociedade anônima como forma de comprovar a titularidade pelo acionista e que efetivamente não constitui título de crédito, tendo como serventia principal facilitar a prova da titularidade das ações na hipótese de perda ou destruição do livro de registro de ações (LSA, art. 24). Para BULHõES Pedreira,

\footnotetext{
${ }^{400}$ A título de exemplo, é o que se afirma: (i) na Alemanha: WIEDEMANN, Herbert. Die Übertragung und Vererbung von Mitgliedschaftsrechten bei Handelsgesellschaften. Op. cit., p. 150 ("Die Namensaktie ist Wertpapier wie die Inhaberaktie"); (ii) na Itália: ASCARELLI, Tullio. "Riflessioni in tema di titoli azionari e società tra società". Op. cit., p. 242; PANZARINI, Giovanni. "La tutela dell'acquirente nella vendita dei titoli di credito". In: Riv. dir. comm., I, 1959, pp. 252-294, p. 257, nota 10; LA LUMIA, Isidoro. "Appunti sulla natura giuridica dei titoli di credito". In: Riv. dir. comm., I, 1940, pp. 1-20, p. 3; CALVO, Roberto. "Il trasferimento della 'proprietà' nella compravendita di titoli azionari". Op. cit., p. 1085; ANGELICI, Carlo. "Le forme di circolazione". In: COLOMBO, Giovanni E.; PORTALE, Giuseppe B. (org.). Trattato delle società per azioni, v. 2: Azioni, Gruppi. Torino: UTET, 1991, pp. 254-297, p. 255; COTTINO, Gastone. Diritto societario. Op. cit., pp. 282-286; (iii) na Espanha: EIZAGUIRRE, José María. "Bases para una reelaboración de la teoría general de los títulos-valores". Op. cit., p. 101 ("la acción nominativa es funcional e conceptualmente un titulo-valor, máxime en los supuestos de nominatividad legal obligatoria"); (iv) em Portugal: ALMEIDA COSTA, M. J.; MENDES, Evaristo. "Transmissão de acções tituladas nominativas". Op. cit., p. 17.

${ }^{401}$ COTTINO, Gastone. Diritto societario. Op. cit., p. 283.

${ }^{402}$ FERRI, Giuseppe. "La teoria 'realista' dei titoli di credito". In: Estudios jurídicos en homenaje a Joaquín Garrigues, II. Madrid: Tecnos, 1971, pp. 313-324, pp. 321-322.
} 
porém, a atenção estaria voltada para o local errado, ao não se perceber que, nas ações nominativas, o documento suficiente e necessário não seria o certificado de ações, que pode existir como não existir, mas o próprio livro de registro no qual o direito é objetivado mediante inscrição do nome do titular. É o livro de registro somado à inscrição do nome do titular que configura, com efeito, o documento necessário e suficiente para o exercício dos direitos de sócio.

Os títulos ao portador e os títulos nominativos, nessa medida, seriam apenas formas diversas de representação material do direito e as opiniões que negam aos títulos nominativos o caráter de título de crédito resultariam do engano de considerar que a objetivação do direito necessariamente dependeria da sua corporificação em documento autônomo e volante. ${ }^{403}$ A assunção seria infundada para BULHÕES PEDREIRA porque não haveria diferença essencial quanto à natureza jurídica dos títulos ao portador e nominativos, pois ambos promovem a corporificação do direito mediante aposição de signos escritos em documentos. A única diferença relevante entre as espécies diria respeito às distintas leis de circulação às quais estão adstritos. Nos títulos ao portador, a circulação se dá pela tradição do título; nos títulos nominativos, mediante termo em registro mantido pelo emitente assinado pelo proprietário e pelo adquirente. ${ }^{404}$

A visão favorável à classificação das ações nominativas entre as espécies de títulos de crédito parece a mais adequada ao direito brasileiro. Considerar que essa classificação seria restrita às hipóteses em que são emitidos certificados seria elevar um traço característico de certas espécies de títulos de crédito (materialização em cártula volante) a elemento constitutivo do gênero. Seria, ainda, equivocado, pois os certificados não são aptos a transferir a titularidade sobre as ações, mas somente servir como elemento para sua prova. Afirmar, ademais, que as ações não seriam títulos de crédito porque não seriam literais, autônomas e abstratas parece uma leitura tipológica restritiva que não se justifica. Como apontou VIVANTE, é plenamente admissível que parcela da disciplina a que se sujeita o título esteja disposta em documento apartado e não seja transcrita na própria cártula.

\footnotetext{
${ }^{403}$ PEDREIRA, J. L. Bulhões. "Natureza de título de crédito da ação escritural”. Op. cit., p. 60.

${ }^{404}$ PEDREIRA, J. L. Bulhões. "Natureza de título de crédito da ação escritural". Op. cit., p. 60.
} 
Contra esse entendimento favorável ao enquadramento das ações nominativas entre os títulos de crédito, seria possível atualmente argumentar que o conceito de título de crédito positivado seria mais restritivo do que aquele utilizado por VIVANTE. ${ }^{405}$ O legislador, a despeito de diversas críticas, ${ }^{406}$ conscientemente definiu que título de crédito seria o "documento necessário ao exercício do direito literal e autônomo nele contido" (CC, art. 887); não "nele mencionado". Tal oposição teórica não teria fundamento. A disciplina dos títulos de crédito não se limita à enunciação de um conceito. Ela se desdobra no regramento das espécies de títulos de crédito, seguindo a diversa lei de circulação que os rege. Em linha com a lição de VIVANTE positivada pelo legislador italiano, são consideradas modalidades de títulos de crédito os títulos ao portador (CC, arts. 904 a 909), os endossáveis ( CC, arts. 910 a 920) e os nominativos (CC, arts. 921 a 926). O título nominativo, por sua vez, é o "emitido em favor da pessoa cujo nome conste no registro do emitente" (CC, art. 921). Ao incluir os títulos nominativos entre as categorias de títulos de crédito, o Código Civil incorreu em evidente contradição teórica, porque foi justamente para abranger os títulos nominativos na categoria dos títulos de crédito que VIVANTE preferiu o termo "mencionado" ao termo "contido". Seria um conceitualismo equivocado, portanto, considerar que os títulos nominativos não seriam títulos de crédito por lhes faltar uma cártula autônoma. Afinal, foi o próprio legislador que os inseriu sob a rubrica "Dos títulos de crédito". Pretender, nesse contexto, que as ações nominativas não seriam títulos de crédito por não se amoldarem perfeitamente à definição legal (CC, art. 887) seria negligenciar que a definição é conformada concretamente pela articulação das categorias de títulos de crédito, entre as quais se inclui a dos títulos nominativos. Em verdade, a aprovação do Código Civil milita justamente no sentido de corroborar o enquadramento das ações nominativas na categoria dos títulos de crédito nominativos.

Quanto à ponderação de que as ações não seriam títulos de crédito porque, no Brasil, diferentemente do que ocorre na Itália, não há emissão de um título que precise ser apresentado para que se promova a transferência da titularidade, deve-se ponderar que tal situação, efetivamente, era diversa no Brasil e na Itália e essa é, de longe, a mais importante crítica à posição aqui adotada de que as ações nominativas seriam espécies de títulos de crédito. Isso não obstante, percebe-se, em tais países, a crescente adaptação às formas escriturais, nas quais a lei de circulação do título passa ser uma única, caracterizada

${ }^{405}$ LUCCA, Newton de. Comentários ao Novo Código Civil, v. XII. Op. cit., p. 125.

${ }^{406}$ LUCCA, Newton De. Aspectos da teoria geral dos títulos de crédito. São Paulo: Pioneira, 1979, p. 125. 
pela transferência da titularidade. ${ }^{407}$ Apesar dessa migração para a forma escritural, não se nega a permanência do caráter de título de crédito. ${ }^{408}$

As mudanças no papel desempenhado pelo elemento corpóreo, com efeito não devem conduzir a uma negação do caráter de título de crédito às ações, mas a adaptações aos conceitos clássicos de cartularidade. ${ }^{409}$ A mudança da forma de representação com uma passagem do elemento corpóreo papel para a utilização de registros informáticos não promove uma modificação substancial sob o ponto de vista jurídico. $^{410}$ No Brasil, igualmente, ações nominativas registrais e escriturais não se distinguem pela natureza jurídica, mas somente por características técnicas ligadas à forma de sua representação objetiva. Nas nominativas registrais, há "corporificação do direito" por meio de anotação gráfica nas folhas do livro de "Registro de Ações Nominativas", com propriedade presumida pelo registro, do qual pode ser emitido certificado. Nas nominativas escriturais, há anotação eletrônica na memória do computador, com propriedade presumida pelo registro na conta de depósito de ações, e possibilidade de emissão de extrato da conta pela instituição depositária com os mesmos efeitos exclusivamente probatórios do certificado da ação nominativa. ${ }^{411}$ No Código Civil, ademais, reconhece-se que os títulos de crédito podem ser "emitidos a partir dos caracteres criados em computador ou meio técnico equivalente e que constem da escrituração do emitente" (CC, art. 889, §3º), corroborando a equiparação jurídica entre os títulos desmaterializados e aqueles que possuem suporte físico em papel.

Discorda-se, de resto, do argumento de que as ações não seriam títulos de crédito por serem valores mobiliários, conceitos que seriam tidos como potencialmente excludentes, porque um título de crédito não poderia ser, concomitantemente, um valor mobiliário.

\footnotetext{
${ }^{407}$ SPADA, Paolo. "La circolazione della 'ricchezza assente' alla fine del millennio". In: BBTC, I, 1999, pp. 407-425, p. 419.

408 LA SALA, Gian Paolo. "Disciplina del possesso e acquisto di buona fede in regime di dematerializzazione”. Op. cit., p. 1395

409 ZÖLLNER, Wolfgang. "Die Zurückdrängung des Verkörperungselements bei den Wertpapieren". In: BAUR, Fritz (et. al., org.). Funktionswandel der Rechtsinstitutionen - Festschrift für Ludwig Raiser zum 70. Geburtstag. Tübingen: Mohr Siebeck, 1974, pp. 249-285, p. 270.

${ }^{410}$ CORTEZ, Jorge Simões. "As formalidades da transmissão de quotas e acções no Direito Português: dos princípios à prática”. Op. cit., p. 333.

${ }^{411}$ PEDREIRA, J. L. Bulhões. "Natureza de título de crédito da ação escritural". Op. cit., p. 61.
} 
O conceito de valor mobiliário no direito brasileiro passou por importante alteração com a Lei 10.303/2001, por meio da qual se incluiu ao art. $2^{\circ}$ da Lei $n$. 6.385/1976 a previsão de que também são valores mobiliários “quando ofertados publicamente, quaisquer outros títulos ou contratos de investimento coletivo, que gerem direito de participação, de parceria ou de remuneração, inclusive resultante de prestação de serviços, cujos rendimentos advêm do esforço do empreendedor ou de terceiros". ${ }^{412}$ Tal alteração foi considerada "verdadeira revolução copérnica" por ter importado o abandono de uma concepção fechada de valor mobiliário e a adoção de uma "concepção funcionalinstrumental". ${ }^{413} \mathrm{O}$ conceito de valor mobiliário passa a ser pensado como delimitador do perímetro de intervenção regulatória e fiscalizatória da Comissão de Valores MobiliáriosCVM, de tal forma que passa a ser definido tendo por base o apelo à poupança popular, e não mais a natureza jurídica do instrumento utilizado para tal esforço de captação de recursos. Foi com base nessa nova orientação que a CVM julgou que as cédulas de crédito bancário - $\mathrm{CCB}$, que por força de lei são inegavelmente títulos de crédito (Lei n. 10.931/2004, art. 26), são consideradas valores mobiliários quando ofertadas publicamente sem a coobrigação da instituição financeira ofertante. ${ }^{414}$ Essa convivência da caracterização de um mesmo título como valor mobiliário e título de crédito mostra-se adequada, pois cada enquadramento jurídico é relevante para finalidades diversas. Afirmar que uma ação é, ou não é, um título de crédito representa afirmar sua sujeição à forma de circulação cambial; afirmar seu caráter de valor mobiliário, por sua vez, significa definir se sua oferta fica sujeita à fiscalização e regulação da $\mathrm{CVM}^{415} \mathrm{~A}$ ação, sendo título de crédito, poderá ou não ser valor mobiliário, conforme se trate de uma companhia fechada ou aberta.

Proteção do adquirente de boa-fé contra a reivindicação

Para além do quanto se afirmou, há uma razão prática relevante que milita a favor da consideração das ações nominativas como títulos de crédito. O titular com o nome inscrito no livro de registro de ações nominativas é considerado portador do título

412 BUSCHINELLI, Gabriel S. K. "Condo-hotéis' e o conceito de valor mobiliário". In: Revista comercialista, v. 10, 2013, pp. 26-28, p. 27.

${ }^{413}$ CVM, Proc. RJ 2003/0499, rel. Dir. Luiz Antonio de Sampaio Campos, j. 28.08.2003.

${ }^{414}$ CVM, Proc. 2007-11593, rel. Dir. Marcos Barbosa Pinto, j. 22.01.2008.

${ }^{415}$ BUSCHINELLI, Gabriel S. K. "Comentários aos arts. 19 e 20". In: CODORNIZ, G.; PATELLA, L. (coord.). Comentários à lei do mercado de capitais. São Paulo: Quartier Latin, 2015, pp. 379-425, p. 380. 
nominativo e é tutelado contra a reivindicação se adquiriu a ação de boa-fé na conformidade das normas que disciplinam a sua circulação (CC, art. 896 c/c art. 903). No caso das ações nominativas, isso significa afirmar que o titular que adquiriu ações por meio de termo lavrado no livro de transferência de ações nominativas (LSA, art. 31, $\S 1^{\circ}$ ) está protegido contra a eventual invalidação do negócio jurídico prévio. Diversamente do que defende FABIo UlhoA CoElho, ${ }^{416}$ portanto, considera-se que o adquirente não está obrigado a investigar a cadeia dominial e fica protegido contra a eventual invalidação do negócio jurídico prévio, desde que, como se afirmou, o cessionário efetivamente esteja de boa-fé. Se "A" adquire ações de "B", que por sua vez adquiriu as ações de "C", mas o contrato entre "B" e "C" é declarado inexistente, o adquirente " $\mathrm{A}$ " será tutelado contra a reivindicação do proprietário “C”", desde que a circulação das ações tenha obedecido à forma prevista para a circulação cartular das ações nominativas.

O posicionamento de tutela ao adquirente de boa-fé justifica-se não somente no contexto de aquisição de ações nominativas que outorgam o controle societário. Seguindo o entendimento diverso de que o adquirente estaria sujeito à reivindicação mesmo que adquirisse ações de boa-fé, chegar-se-ia à conclusão de que em todas as aquisições de ações seria prudente investigar o histórico da cadeia dominial. Tal procedimento aumentaria os custos relacionados às negociações, em pleno divórcio com o caráter de agilidade, certeza e segurança que deve ditar a circulação de ações de sociedades anônimas. Seria, para além disso, orientação que imporia um ônus do qual o adquirente sequer poderia se desincumbir. Na transferência de ações nominativas por termo de cessão, a companhia não pode exigir a informação da causa da transmissão, nem ter acesso ao contrato que a embasou. Como apontou COMPARATO, sublinha-se o "caráter abstrato da transferência de ações”, razão pela qual o emitente não tem legitimidade para questionar a causa alienationis, podendo as partes se recusar legitimamente a declarar qual o tipo de negócio que motivou a cessão de ações cuja inscrição nos livros sociais requerem. ${ }^{417}$ Como se verá, ${ }^{418}$ não compete à sociedade anônima no exercício da sua função registral perquirir a verdadeira titularidade para além da aparência documental. ${ }^{419}$ Ao impor ao adquirente o

\footnotetext{
${ }^{416}$ COELHO, Fábio Ulhoa. Curso de direito comercial. Op. cit., p. 165.

${ }^{417}$ COMPARATO, Fabio K. "As ações de sociedade anônima como valores mobiliários - natureza e efeitos do registro acionário". In: Novos ensaios e pareceres de direito empresarial. Rio de Janeiro: Forense, 1981, pp. 16-31, p. 24.

418 Sobre o assunto, cf. item II.B.1.b)(1), infra.

${ }^{419}$ COMPARATO, Fabio K. "As ações de sociedade anônima como valores mobiliários - natureza e efeitos do registro acionário". Op. cit., p. 21; GUERREIRO, José Alexandre T. "A função registrária das sociedades
} 
ônus de investigar a cadeia dominial para tutelar-se contra a reivindicação por proprietários anteriores, exige-se o impossível. É correta, nesse sentido, a afirmação de TAVARES GUERREIRO, para quem o adquirente que obtém atestado da companhia emissora de que o cedente era titular das ações nominativas pode opor "a terceiros eventualmente reivindicantes a exceção fundada em justo título e boa-fé", ${ }^{420}$ proteção à confiança depositada no registro que é prestigiada igualmente em outros países de direito continental. ${ }^{421}$ Em 1943, TUlLio AsCARELli escrevia que, na Itália, “o acionista de boa fé na aquisição do título é sócio, ainda que não o fosse o seu antecessor", ${ }^{422}$ ao passo que, no Brasil, anota o mesmo ASCARELLI, apenas excepcionalmente, no âmbito cambiário, aceitava-se que a posse de boa-fé de móveis equivalesse a título. ${ }^{423} \mathrm{~A}$ disciplina dos títulos de crédito do Código Civil de 2002, inspirada largamente no direito italiano, promoveu portanto relevante alteração ao regime jurídico de transferência das ações.

É de se acrescentar, porém, que desfruta da proteção contra reivindicação somente aquele que adquire, de boa-fé, ações nominativas em conformidade com a lei de circulação do título, isto é, no caso das ações nominativas, aquele que adquire ações por meio de termo lavrado no livro de transferência de ações nominativas $(\mathrm{CC}$, art. 896 e art. $903 \mathrm{c} / \mathrm{c} \mathrm{LSA}$, art. $31, \S 1^{\circ}$ ). No caso de transferência registrada mediante averbação no livro de registro de ações nominativas, como ocorre no caso de sucessão universal (LSA, art. 31, $\S 2^{\circ}$ ), não se confere a proteção cambiária ao novo titular. As ações nominativas, nessa hipótese, são transmitidas enquanto feixe de direitos e obrigações, e sem que tenham sido observadas as regras de circulação cambiária, o adquirente não desfruta da específica proteção conferida pelas regras cartulares. $^{424}$

b) Transmissão de ações nominativas registrais e escriturais

anônimas". In; WALD, Arnoldo. (coord.). O direito na década de 80: estudos jurídicos em homenagem a Hely Lopes Meirelles. São Paulo: RT, 1985, pp. 143-149, p. 145.

${ }^{420}$ GUERREIRO, José Alexandre T. “A função registrária das sociedades anônimas”. Op. cit., p. 145.

${ }^{421}$ CORTEZ, Jorge Simões. "As formalidades da transmissão de quotas e acções no Direito Português: dos princípios à prática”. Op. cit., p. 333-334.

${ }^{422}$ ASCARELLI, Tullio. Teoria geral dos títulos de crédito, trad. de Nicolau Nazo. Op. cit., p. 191.

${ }^{423}$ ASCARELLI, Tullio. Teoria geral dos títulos de crédito, trad. de Nicolau Nazo. Op. cit., p. 259.

${ }^{424}$ CORTEZ, Jorge Simões. "As formalidades da transmissão de quotas e acções no Direito Português: dos princípios à prática”. Op. cit., p. 337. 
A titularidade de ações nominativas registrais decorre de inscrições em livros que, não sendo propriamente comerciais, ${ }^{425}$ devem ser obrigatoriamente mantidos pela companhia no exercício de sua função registrária. ${ }^{426}$ Entre esses livros, são de especial relevância para a transferência de ações o livro de "Transferência de Ações Nominativas" (LSA, art. 100, II) e o livro de "Registro de Ações Nominativas" (LSA, art. 100, I), que ostentam a natureza de "livros públicos". ${ }^{427}$ Sua falsificação é equiparada expressamente pelo Código Penal à falsificação de documentos públicos $(\mathrm{CP}$, art. 297, §2º $)$ Em caso de dúvidas entre os acionistas, ou qualquer interessado e a companhia, o juiz competente é o mesmo responsável por solucionar as levantadas pelos oficiais dos registros públicos (LSA, art. 103, par. único). São, portanto, livros dotados de fé pública, a despeito de serem mantidos por entidade privada. ${ }^{428}$

As ações nominativas registrais são transferidas por meio de termo lavrado no livro de "Transferência de Ações Nominativas", datado e assinado por cedente e cessionário (LSA, art. $31, \S 1^{\circ}$ ). O termo, porém, não basta para que o cessionário possa exercer os direitos de acionista. É necessário que, com base no termo, seja efetuada averbação da transferência e o lançamento do nome do cessionário no livro de "Registro de Ações Nominativas". ${ }^{429}$ Há, ademais, uma segunda modalidade de transferência registrada diretamente no livro de Registro em virtude de transmissão por sucessão universal ou legado, de arrematação, adjudicação ou outro ato judicial, ou por qualquer outro título (LSA, art. $31, \S 2^{\circ}$ ). Não é necessária, nesse caso, a lavratura de termo de cessão e a averbação se dá à vista de documento hábil que permanece em poder da companhia.

Considerando as diversas possibilidades de transmissão da titularidade das ações para adimplemento do contrato de compra e venda de ações, vale analisar separadamente (i) os requisitos e a eficácia do termo de cessão; (ii) a possibilidade de registro do contrato de compra e venda de ações diretamente no Livro de Registro, sem a

\footnotetext{
${ }^{425}$ VALVERDE, Trajano de Miranda. Fôrça probante dos livros mercantis. Forense: Rio de Janeiro, 1960, p. 42.

${ }^{426}$ GUERREIRO, J.osé Alexandre T. "A função registrária das sociedades anônimas”. Op. cit., p. 143;

${ }^{427}$ VALVERDE, Trajano de Miranda. Fôrça probante dos livros mercantis. Op. cit., p. 42; TJSP, Ap. n. 0162142- 93.2010.8.26.0100, $1^{\text {a }}$ Câm. Res. Dir. Empr., rel. Des. Enio Zuliani, j. 28.08.2012.

${ }^{428}$ COMPARATO, Fabio K. "As ações de sociedade anônima como valores mobiliários - natureza e efeitos do registro acionário". In: Novos ensaios e pareceres de direito empresarial. Rio de Janeiro: Forense, 1981, pp. 16-31, p. 26.

${ }^{429}$ EIZIRIK, Nelson. A lei das S/A comentada, v. 1, 2a ed. São Paulo: Quartier Latin, 2015, p. 253.
} 
lavratura de termo de cessão; e (iii) se a mesma possibilidade de registro do contrato de compra e venda sem lavratura do termo de cessão no caso de ações escriturais.

(1) Requisitos e eficácia do termo de cessão

O termo de cessão deve ser assinado não somente pelo cedente, mas também pelo cessionário. Segundo MiRANDA VALVERDE, a aposição da firma representaria a "declaração formal de que o adquirente se responsabiliza pelo cumprimento das obrigações decorrentes de sua nova posição jurídica". ${ }^{430}$ A lição conta com apoio da doutrina. ${ }^{431} \mathrm{~A}$ intepretação, contudo, confere à assinatura do cessionário um caráter de adesão ao estatuto social que não é inerente ao ato.

Não é somente por termo de cessão assinado por cedente e cessionário que são transferidas ações nominativas. No caso de adoção da forma escritural, a transferência de ações se dá mediante "ordem escrita do alienante" em vista da qual a instituição depositária efetua lançamento em seus livros a debito da conta de ações do alienante e a crédito da conta de ações do adquirente (LSA, art. 35, $\S 1^{\circ}$ ). Não há necessidade de assinatura do cessionário nesse caso. Há, ainda, a possibilidade de aquisição com base em outros atos jurídicos com dispensa de lavratura do termo de cessão, tanto no caso das ações nominativas registrais (LSA, art. $31, \S 2^{\circ}$ ), quanto escriturais (LSA, art. $35, \S 1^{\circ}$ ). Seguindose a orientação doutrinária vigente que atribui à assinatura do cessionário o caráter de declaração formal de aceitação dos deveres sociais, a conclusão lógica parece ser de que, faltando tal assinatura nos casos legais em que ela não é prevista, o novo acionista não estaria tão obrigado perante a companhia quanto o cessionário signatário.

CARVALHOSA notou, depois de reproduzir a orientação doutrinária e com ela concordar, que há na lei outras modalidades de transferência de ações nas quais não há assinatura de termo pelo cessionário. Nesse caso, porém, considera que o ato formal não seria fonte da responsabilização do cessionário, "uma vez que a Lei adota outras formas

\footnotetext{
${ }^{430}$ VALVERDE, Trajano de Miranda. Sociedades por ações. Op. cit., n. 146, p. 192.

431 TEIXEIRA, Egberto. L.; GUERREIRO, José Alexandre T. Das sociedades anônimas no direito brasileiro, v. I. Op. cit., p. 232; EIZIRIK, Nelson. A lei das S/A comentada. Op. cit., p. 253; CARVALHOSA, Modesto. Comentários à lei de sociedades anônimas. Op. cit., p. 418.
} 
registrárias que fazem presumir essa responsabilidade". ${ }^{432}$ Em seu entender, portanto, ou haveria a aceitação expressa dos deveres pelo cessionário que assina o termo, ou, haveria presunção da responsabilidade, nos casos em que a assinatura é dispensada.

A orientação não parece ser a mais adequada, porque, segundo ela, toda a estrutura de deveres impostos ao acionista, incluindo o dever de integralizar as ações, ficaria dependente de um ato voluntário no caso das ações nominativas registrais, passível de ser desconstituído em caso de incapacidade do cessionário, por exemplo. No caso das demais modalidades de cessão, ficaria dependente de uma presunção, que não se sabe se seria absoluta ou relativa, nem qual fundamento teria. A ação, porém, enquanto unidade padronizada e destinada à circulação carrega consigo os direitos e deveres inerentes à posição de sócio, razão pela qual o cessionário de ações nominativas escriturais que não assina termo de cessão é tão obrigado quanto o cessionário de ações nominativas registrais. A companhia pode propor as medidas executivas previstas contra o acionista remisso (LSA, art. 107) tanto em um caso, quanto no outro.

A função da assinatura do cessionário no termo de cessão, em verdade, é diversa. Trata-se de medida prevista como regra para a transferência de todos os títulos de crédito nominativos (CC, art. 922), ou seja, corresponde à sua lei de circulação. Diferente do que ocorre nos títulos à ordem, nos quais se exigem a assinatura do endossante e a tradição do título para a transferência do título (CC, art. 910, $\S 1^{\circ}$ e $\left.\S 2^{\circ}\right)$, nos títulos nominativos em que não há cártula volante, requer-se a assinatura do cedente e do cessionário, para que o emissor, conhecendo a assinatura do novo titular, possa proceder a posteriores transferências por termo. É o que ocorre no caso das ações nominativas registrais. A assinatura do cessionário, portanto, não é essencial para a aceitação dos deveres inerentes à ação; ela é exigida apenas para que se aperfeiçoe a transferência sob a forma cambiária, conferindo ao novo titular de boa-fé a tutela contra eventuais reivindicações (CC, art. 896). No caso das ações escriturais, tendo em vista que o cessionário deve possuir conta junto à instituição depositária, a lei dispensa a assinatura específica do cessionário (LSA, art. $35, \S 1^{\circ}$ ), o que constitui uma forma diversa da lei de circulação do título, adaptada à forma escritural, mas que outorga ao cessionário a mesma proteção jurídica.

${ }^{432}$ CARVAlHOSA, Modesto. Comentários à lei de sociedades anônimas. Op. cit., p. 418. 
(2) Possibilidade de registro do contrato de compra e venda sem lavratura de termo de cessão

Se é certo que a transferência das ações nominativas "opera-se por termo lavrado" (LSA, art. $31, \S 1^{\circ}$ ), não é claro se, no âmbito da compra e venda, ela somente se opera por termo de cessão, ou se seria admissível a transferência voluntária de ações mediante outro ato jurídico. Se se considera que o contrato de compra e venda de ações insere-se na referência legal a "qualquer outro título" (LSA, art. 31, $2^{\circ}$ ) que justificaria a averbação no livro de Registro, dispensar-se-ia a lavratura de termo de cessão, caso o vendedor se recusasse a praticá-la. A questão é relevante para determinar a demanda que deve ser proposta em caso de inadimplemento. Tome-se o exemplo de um contrato de compra e venda sujeito a condições suspensivas que se implementam. Caso se considerasse que a lavratura do termo de cessão seria essencial para a transferência das ações, o comprador deveria propor demanda em face do acionista vendedor dirigida à emissão de declaração de vontade (CPC, art. 501). Caso se considerasse que o contrato de compra e venda poderia ser registrado diretamente, porém, a própria companhia teria de promover a inscrição registral, sendo parte legítima passiva caso se recusasse a fazê-lo quando instada pelo comprador.

Para além da previsão de transferência por termo de cessão, a lei admite uma segunda forma de transmissão, nos casos de "transmissão por sucessão universal ou legado, de arrematação, adjudicação ou outro ato judicial, ou por qualquer outro título" (LSA, art. $31, \S 2^{\circ}$ ). A diferença entre as hipóteses é que, na primeira, é lavrado termo de cessão no livro de "Transferência de Ações Nominativas" e, posteriormente, com base no termo, averba-se a transferência e lança-se o nome do cessionário no livro de "Registro de Ações Nominativas". ${ }^{433}$ Nas hipóteses de transferência sem lavratura de termo de cessão, a companhia deve promover averbação diretamente no livro de "Registro de Ações Nominativas" à vista de documento hábil que permanece em seu poder (LSA, art. $31, \S 2^{\circ}$ ).

${ }^{433}$ EIZIRIK, Nelson. A lei das S/A comentada. Op. cit., p. 253. 
As previsões de transferências de ações por forma diversa do termo de cessão (LSA, art. $31, \S 2^{\circ}$ ) reproduzem textualmente o dispositivo análogo da legislação anterior (Decreto-Lei 2.627/1940, art. 27, §1 $1^{\circ}$ ). A única diferença entre o teor dos artigos foi a adição da expressão "ou por qualquer outro título" em seguida à expressão genérica "ou outro ato judicial” que constava da legislação anterior. Na Exposição de Motivos da Lei das Sociedades por Ações destacou-se que "o $\S 2^{\circ}$ do artigo 31 admite a transferência de ações nominativas mediante averbação, no 'Livro de Registro de Ações Nominativas', de qualquer título, e não apenas de atos judiciais". Para justificar a inovação, afirmou-se que "a solução elimina, sem prejuízo da segurança da propriedade das ações (baseada, em qualquer caso, na inscrição no Livro de Registro) os inconvenientes do regime em vigor, em que há dúvidas sobre o assunto, sustentando muitos que somente permite a transferência por ato extrajudicial mediante termo lavrado no 'Livro de Transferência de Ações Nominativas', o que importa submeter essas ações a regime de registro de propriedade mais formal do que o próprio Registro de Imóveis”.

O texto da exposição de motivos não é totalmente claro, mas a comparação entre o formalismo exigido no registro de imóveis e o formalismo da transferência de ações bem indica qual era a intenção dos autores. No registro de imóveis, uma vez celebrada a escritura pública de compra e venda, não é necessário um novo contrato de direito real para que haja registro da transferência de propriedade do imóvel (Lei 6.015/1973, art. 167, I, 29). A exigência de que fosse lavrado termo de cessão no caso de ter sido celebrado contrato de compra e venda era justamente o aspecto que tornava o regime de registro de propriedade acionária mais formal do que o próprio registro de imóveis, pois era necessário um segundo ato voluntário, praticado por cedente e cessionário.

Interpretando o dispositivo, a doutrina divide-se em três orientações divergentes. A primeira orientação é a de que o contrato de compra e venda seria título hábil para a transferência das ações, dispensando-se a lavratura de termo de transferência. É o caso, sobretudo, das manifestações doutrinárias que se seguiram diretamente à lei e que não colocavam em dúvida a possibilidade de transferência de ações com base em títulos extrajudiciais. RUBENS REQUIÃo, nesse sentido, considerou que o termo de transferência seria dispensável se a parte conta com "instrumento público ou particular que fundamente 
a inscrição no Livro de Registro de transferência da sociedade". ${ }^{434}$ FrAN MARTINS, no mesmo diapasão, não somente reconheceu a possibilidade de transferência de ações fundada em contrato de compra e venda, como criticou a alteração legislativa promovida, por aumentar a suscetibilidade a fraudes, razão pela qual considerou que o melhor teria sido manter o sistema previamente vigente, de transferência entre vivos apenas por termo de cessão ou, alternativamente, por ato judicial. ${ }^{435}$ Em parecer, LAMY FILHO avaliou que um contrato de doação de ações seria título hábil a promover a transferência de ações, dispensando-se a lavratura de termo de cessão. ${ }^{436}$ Posteriormente, LAMY FILHO e BULHÕES PEDREIRA ressaltaram a inovação promovida pela lei e avaliaram que não haveria razão para afirmar que o contrato de compra e venda não seria título hábil para autorizar a transferência de ações. ${ }^{437}$ LACERDA TEIXEIRA e TAVARES GUERREIRO, ademais, ressaltaram que a lei passou a admitir que se averbasse "não somente atos judiciais (como acontecia no direito anterior), como também títulos extrajudiciais", 438 entre os quais destacam o instrumento de promessa de venda de ação, que pode inclusive ser averbado para eficácia perante terceiros (LSA, art. 40, par. único). No âmbito do STJ, decidiu-se que o dispositivo admite que a transferência das ações se faça por outros meios, e não somente por termo de cessão. ${ }^{439} \mathrm{Na}$ jurisprudência paulista, ademais, há precedentes nos quais se admite averbação de contrato de doação ${ }^{440}$ ou de instrumento de compra e venda ${ }^{441}$ diretamente no livro de "Registro de Ações Nominativas", a despeito de não ter sido lavrado termo de cessão.

A posição de que o contrato de compra e venda não autorizaria a transferência de ações, contrária à interpretação histórica fundada na exposição de motivos, foi defendida por Comparato. Ponderando que o acréscimo do legislador de 1976 não poderia ser interpretado fora do contexto normativo em que vem inserido, o autor ressalta que a lei destina parágrafos diversos às transferências de ações por ato de cessão entre

\footnotetext{
${ }^{434}$ REQUIÃO, Rubens. Comentários à lei das sociedades anônimas. São Paulo: Saraiva, 1980, p. 224.

${ }^{435}$ MARTINS, Fran. Comentários à lei das sociedades anônimas. Rio de Janeiro: Forense, 1982, p. 190.

${ }^{436}$ LAMY FILHO, Alfredo. "Doação de ações nominativas sem a assinatura do termo no livro próprio". $O p$. cit., pp. 44-45.

${ }^{437}$ PEDREIRA, J. L. Bulhões; LAMY FILHO, Alfredo. "Valores mobiliários". Op. cit., p. 524.

${ }^{438}$ TEIXEIRA, Egberto L.; GUERREIRO, José Alexandre T. Das sociedades anônimas no direito brasileiro. Op. cit., p. 233.

${ }^{439}$ STJ, REsp n. 40.276-0-RJ, $3^{\mathrm{a}}$ T, rel. Min. Eduardo Ribeiro, j. 07.12.1993.

${ }^{440}$ TJSP, AI n. 358.669-4/3-00, 8 a Câm. Dir. Priv., rel. Des. Luiz Ambra, j. 19.05.2005.

${ }^{441}$ TJSP, Ap. n. 0017552-38.2011.8.26.0019, 3 ${ }^{\text {a }}$ Câm. Dir. Priv., rel. Des. Viviani Nicolau, j. 15.03.2015 (“a transferência das ações nominativas pelo "Instrumento particular de transferência de ações bens e outros haveres" (fls. 32/35) deverá ser averbada pela ré no livro de "Registro das Ações Nominativas", consoante o previsto no art. 31 da Lei no 6.404/1976").
} 
vivos e às transferências por outras razões de direito. ${ }^{442}$ No parágrafo segundo, a lei enumera atos diversos do contrato de cessão, razão pela qual COMPARATO considera que a expressão introduzida deveria ser interpretada como "generalização dos atos que o dispositivo acaba de enumerar, isto é, como qualquer outro ato diverso do contrato de cessão". ${ }^{443}$ A rejeição à possibilidade de registro do contrato de compra e venda também é compartilhada por CARVALHOSA, ${ }^{444}$ EIZIRIK $^{445}$ e, em escrito posterior, também por TAVARES Guerreiro, que defendeu que o "negócio jurídico de cessão e transferência de ações nominativas somente se perfaz com a assinatura do termo respectivo no livro próprio, conforme o art. $31, \S 1^{\circ}$, da Lei 6.404", notando que essa seria "formalidade ad substantiam, que não encontra sucedâneo em qualquer outra forma de direito", 446 excluindo, portanto, a possibilidade de transferência das ações sem a lavratura de termo de cessão. Trata-se de posição que encontra ressonância na jurisprudência, que ressalta que a assinatura do termo seria imprescindível para a transferência da propriedade, podendo apenas ser substituída por ato judicial. ${ }^{447}$ Em julgados nos quais se discutia a eficácia de contratos de doação de ações, considerou-se que a eficácia da transferência dependeria da lavratura de termo de cessão. ${ }^{448}$

É de se mencionar, por fim, a orientação isolada de WALDECY LUCENA, para

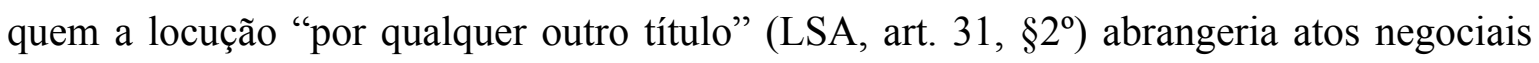
com ações inter vivos, como a doação, mas não a compra e venda, pois, em sua visão, a “compra e venda de ações, consoante visto, está disciplinada no parágrafo $1^{\circ}$ do artigo sob comento, o qual exige a lavratura e termo de transferência". ${ }^{449}$

A posição de WALDECY LUCENA não parece minimamente justificável, porque assume como premissa uma previsão legislativa que inexiste. Não há, no $\S 1^{\circ}$ do art. 31, nenhuma menção ao contrato de compra e venda. A lei refere-se ao "cedente" e ao "cessionário" das ações sem mencionar um ato de compra. Não faria sentido, ademais,

${ }^{442}$ COMPARATO, Fabio K. "As ações de sociedade anônima como valores mobiliários - natureza e efeitos do registro acionário". Op. cit., p. 24.

${ }^{443}$ COMPARATO, Fabio K. "As ações de sociedade anônima como valores mobiliários - natureza e efeitos do registro acionário". Op. cit., p. 25.

${ }_{444}^{44}$ CARVALHOSA, Modesto. Comentários à lei de sociedades anônimas. Op. cit., p. 414.

${ }^{445}$ EIZIRIK, Nelson. A lei das S/A comentada. Op. cit., p. 254.

${ }^{446}$ GUERREIRO, José Alexandre T. "A função registrária das sociedades anônimas". Op. cit., p. 146.

${ }^{447}$ Voto da Min. Nancy Andrighi. In: STJ, REsp n. 856.826-DF, $3^{\mathrm{a}}$ T., rel. p/ ac. Min. Ari Pargendler, j. 19.02.2008.

${ }^{448}$ STJ, REsp n. 1.196.634-RJ, $3^{\mathrm{a}}$ T., rel. Min. Paulo de Tarso Sanseverino, j. 05.11.2013; TJSP, Ap. n. 0193363-31.2009.8.26.0100, $7^{\mathrm{a}}$ Câm. Dir. Priv., rel. Des. Mary Grün, j. 16.03.2016.

${ }^{449}$ LUCENA, J. Waldecy. Das sociedades anônimas. Rio de Janeiro: Renovar, 2009, p. 353. 
afirmar que o contrato de doação poderia ser registrado diretamente pela companhia e o contrato de compra e venda não, pois ambos são contratos obrigacionais no direito brasileiro, não reais. ${ }^{450}$ Importa, portanto, considerar mais detidamente as duas outras posições doutrinárias.

O posicionamento de que o contrato de compra e venda não poderia ser registrado diretamente pela companhia funda-se, sobretudo, na má redação do dispositivo que, como apontou COMPARATO, enumera atos nos quais não há uma atuação voluntária das partes, senão uma transferência que ocorre em virtude de efeito da lei. A despeito disso, não parece que se deva conferir à expressão "por qualquer outro título" uma inteligência tão restritiva de forma a excluir contratos que visam à disposição das ações. Como apontou LAMY FILHO, é típico dos títulos de crédito, gênero que as ações integram, a possibilidade de serem transferidos sob a forma cambial, hipótese em que o adquirente conta com certeza e segurança beneficiando-se da inoponibilidade das exceções relacionadas ao portador anterior. O autor ressalta, porém, que ao submeter o título a meios próprios de circulação segundo a sua forma, não se veda ou impede que sejam adotadas as formas comuns de transferência de direitos. ${ }^{451}$ Esse posicionamento parece o mais adequado. Admite-se, com efeito, que a "aquisição de título à ordem, por meio diverso do endosso, tem efeito de cessão civil” (CC, art. 919). No caso das ações nominativas, igualmente, o fato de a lei determinar que a transferência das ações "opera-se por termo lavrado" (LSA, art. $31, \S 1^{\circ}$ ) não significa que essa seja a única forma de transferência da titularidade das ações. Há formas de transmissão diversas, como é o caso da sucessão universal ou legado, arrematação ou adjudicação, e também por meio da compra e venda ou da doação. O que se deve ter em vista claramente é que, quando as partes optam por uma ou outra modalidade de circulação, o adquirente situa-se em posições diferentes. $\mathrm{Na}$ transferência por meio de termo de cessão lavrado, há aquisição da ação "na conformidade das normas que disciplinam a sua circulação" (CC, art. 896), hipótese em que o adquirente de boa-fé fica tutelado contra a reivindicação. Trata-se de uma consequência lógica do fato de que a transferência das ações, nesse caso, terá ocorrido por meio de termo que não reproduz o conteúdo do contrato que o motivou e que está em sua base. No caso da aquisição por meio de averbação diretamente no livro de "Registro de Ações

\footnotetext{
${ }^{450}$ ALVIM, Agostinho. Da doação. São Paulo: Saraiva, 1980, n. 38, p. 78.

${ }^{451}$ LAMY FILHO, Alfredo. "Doação de ações nominativas sem a assinatura do termo no livro próprio". $O p$. cit., p. 38.
} 
Nominativas", seja do contrato de compra e venda, seja de outro título, o adquirente ingressa na mesma posição jurídica detida pelo antigo acionista.

Como consequência dessa constatação, pode-se afirmar que o comprador pode pleitear perante a própria companhia o registro do contrato de compra e venda. Em caso de divergência entre o interessado e a companhia, a competência para determinar a averbação deve ser dirimida pelo juiz competente para solucionar as dúvidas levantadas pelos oficiais do registros públicos (LSA, art. 103, par. único). ${ }^{452}$ Utiliza-se, ademais, também o procedimento aplicável à dúvida registral. ${ }^{453} \mathrm{~A}$ despeito de ter natureza administrativa (Lei 6.015/1973, art. 204), o procedimento de dúvida registral não é processo administrativo, e sim procedimento judicial de jurisdição voluntária regido pelo disposto nos artigos 719 e seguintes do do Código de Processo Civil. ${ }^{454} \mathrm{O}$ vendedor, sendo titular das ações, é parte legítima para intervir no processo de dúvida, apresentando impugnação. Nesse caso deverá ser garantida a ampla defesa e o contraditório entre o comprador que pleiteia a averbação e o vendedor, o que não se coaduna com o rito procedimental do processo de jurisdição voluntária. Em linha com o entendimento prevalecente no âmbito do registro imobiliário, deve-se, nesse caso, remeter as partes às vias ordinárias em caso de litígio, para que ali se desenvolva adequadamente o processo com adequado contraditório. ${ }^{455}$ Nesse processo contencioso de caráter constitutivo, são partes apenas o comprador e o vendedor. Não é necessário, nem possível, que a companhia integre o polo passivo, até porque, adotando-se entendimento diverso, a companhia poderia ser condenada a agir contra a lei, alterando a posição jurídica de um acionista que não fez parte do processo, ${ }^{456}$ ou ao pagamento de verbas sucumbenciais que seriam suportadas pela companhia e, economicamente, pelos demais acionistas que nada tem com o litígio entre alienante e adquirente. O litígio desenvolve-se, portanto, entre comprador que requer a inscrição e o vendedor que a ela resiste, sem que a companhia seja parte. Como aponta BotelHo DE MESQUiTA após ressaltar as atribuições de registro público conferidas às

\footnotetext{
${ }^{452}$ GUERREIRO, José Alexandre T. “A função registrária das sociedades anônimas”. Op. cit., p. 148.

${ }^{453}$ LUCENA, J. Waldecy. Das sociedades anônimas. Op. cit., p. 944.

${ }^{454}$ STJ, REsp n. 1.418.189-RJ, $3^{\text {a }}$ T., rel. Min. Sidnei Beneti, j. 10.06.2014 (“O processo de Dúvida Registral em causa possui natureza administrativa, instrumentalizado por jurisdição voluntária, não sendo, pois, de jurisdição contenciosa"); SARMENTO, Eduardo S. C. "A dúvida no registro de imóveis". In: RDI, v. 2, 1978, pp. 60-67; SALIM, P. de M. P. C. "A suscitação de dúvida no registro de imóveis". In: RDI, v. 76, 2014, pp. 117-189.

${ }^{455}$ STJ, REsp n. 678.371-MG, $3^{\mathrm{a}}$ T., rel. Min. Nancy Andrighi, j. 14.10.2008.

456 WIEDEMANN, Herbert. Die Übertragung und Vererbung von Mitgliedschaftsrechten bei Handelsgesellschaften. Op. cit., p. 142.
} 
companhias, ${ }^{457}$ os atos de registro são atos materiais que devem ser cumpridos por mandado judicial, em hipótese típica do que se denomina "ato de execução imprópria". ${ }^{458}$ A execução imprópria, ordenada pelo juiz estabelece uma relação processual "entre o órgão da jurisdição e o órgão do registro (no caso, a companhia)", ${ }^{459}$ cujo escopo é o exato cumprimento dos atos de registro necessários para efetivar a eficácia da sentença. Não há, assim, necessidade de nenhuma declaração de vontade pela própria companhia; apenas cumprimento da ordem judicial.

A possibilidade de pleitear a transferência da propriedade por meio de averbação do contrato de compra e venda não impede que o comprador, desejando, promova ação visando à emissão de declaração de vontade para que seja lavrado termo de cessão, ${ }^{460}$ hipótese em que o cessionário adquire as ações sob a forma de circulação cambial, beneficiando-se da tutela contra a reivindicação. $O$ ato judicial, nesse caso, não deve ser lavrado diretamente no livro de "Registro de Ações". A sentença judicial substitui a manifestação de vontade do cedente, fundamentando a lavratura de termo de cessão no livro de "Transferência de Ações Nominativas", sendo, subsequentemente, averbado no livro de "Registro de Ações Nominativas".

(3) Possibilidade de transferência de ações nominativas escriturais com base em contrato de compra e venda

Se o estatuto da companhia dispuser que todas as ações da companhia ou uma ou mais classes delas serão escriturais (LSA, art. 34), a transferência das ações se dá mediante "ordem escrita do alienante" (LSA, art. 35, $\S 1^{\circ}$ ), que corresponde, mutatis

\footnotetext{
${ }^{457}$ BOTELHO DE MESQUITA, José Ignácio. "Execução específica de direito de preferência originado de acordo de acionistas". In: ADAMEK, Marcelo V. von. Temas de direito societário e empresarial contemporâneos. São Paulo: Malheiros, 2011, pp. 836-848, p. 841.

${ }^{458}$ BOTELHO DE MESQUITA, José Ignácio. "Execução específica de direito de preferência originado de acordo de acionistas". Op. cit., p. 842.

${ }^{459}$ BOTELHO DE MESQUITA, José Ignácio. "Execução específica de direito de preferência originado de acordo de acionistas". Op. cit., p. 839.

${ }^{460}$ TJSP, Ap. n. 0193363-31.2009.8.26.0100, 7 $7^{\text {a }}$ Câm. Dir. Priv., rel. Des. Mary Grün, j. 16.03.2016 (afirmando que o contrato válido de doação autora o donatário a pleitear a execução específica para que seja lavrado termo de cessão).
} 
mutandis, ao termo de cessão. ${ }^{461}$ A segunda possibilidade de transferência se dá à vista de “autorização ou ordem judicial” (LSA, art. $35, \S 1^{\circ}$ ). Diversamente do que se prevê no âmbito das ações nominativas registrais, não há previsão ampla que possibilite o registro “em virtude de transmissão por sucessão universal ou legado, de arrematação, adjudicação ou outro ato judicial, ou por qualquer outro título" (LSA, art. $31, \S 2^{\circ}$ ). A regulamentação da Comissão de Valores Mobiliários sobre a prestação de serviços de escrituração de valores mobiliários amplia o rol dos atos passíveis de propiciar o lançamento pelo escriturador na conta de valores mobiliários, admitindo que ele decorra de (i) ordem do titular do valor mobiliário ou de pessoas legitimadas por contrato ou mandato; (ii) ordem judicial; (iii) ato ou evento societário com efeitos equivalentes promovidos pelo emissor ou responsável legal; ou (iv) instrução de depositário central (Instrução CVM n. 543/2013, art. 16, incisos I a IV). A dúvida que surge, nesse ponto, é de saber se o raciocínio apresentado acima acerca da possibilidade de registro do contrato de compra e venda de ações nominativas seria aplicável na hipótese de adoção da forma escritural.

Interpretando o dispositivo da lei, CARVALHOSA considera que, nos casos de transferência involuntária, como na sucessão, alienação judicial, ou na transferência causa mortis, o lançamento em conta corrente somente poderia ocorrer mediante exibição de título judicial que o autorize. ${ }^{462} \mathrm{O}$ contrato de compra e venda, seguindo-se tal raciocínio, não seria título hábil a lastrear a transferência da titularidade das ações nominativas escriturais.

O entendimento descrito coaduna-se com a interpretação literal, mas conduz a dificuldades práticas de relevo. Tome-se como exemplo a sucessão universal em razão de fusão, cisão ou incorporação, em que a sucessão em todas as posições jurídicas se faz a título universal, valendo a certidão da operação societária como documento hábil para a averbação nos registros públicos competentes da sucessão decorrente da operação (LSA, art. 234). Seguindo a orientação literal, seria necessária a obtenção de ato ou autorização judicial para que o agente escriturador promovesse a alteração na titularidade. Como segundo exemplo, considere-se a situação do inventariante. A jurisprudência reconhece que o "exercício dos direitos inerentes à condição de acionista condiciona-se à averbação",

\footnotetext{
${ }^{461}$ Sobre o assunto, cf. item II.B.1.b)(1), supra.

${ }^{462}$ CARVALHOSA, Modesto. Comentários à lei de sociedades anônimas. Op. cit., p. 443.
} 
promovida no livro de registro de ações nominativas. ${ }^{463} \mathrm{O}$ inventariante que não requer a averbação de sua condição, por conseguinte, não pode participar de deliberações societárias. ${ }^{464}$ Tratando-se de ações nominativas registrais, aberta a sucessão, o inventariante nomeado pode requerer de forma extrajudicial e diretamente à companhia a averbação no livro de registro, até que seja ultimada a partilha, exercendo os direitos de sócio que competem ao espólio. A seguir-se a interpretação literal, porém, seria necessária ordem judicial para que a transferência de titularidade ocorresse, de tal forma que, no interim, as ações permaneceriam sem nenhum titular que pudesse exercer os direitos de acionista enquanto não fosse proferida tal ordem. Outro exemplo, também no campo sucessório, poderia se dar com a lavratura de escritura pública de inventário extrajudicial $\left(\mathrm{CPC}\right.$, art. $\left.610, \S 1^{\circ}\right)$. Trata-se de documento que a lei expressamente determina ser hábil para a promoção de qualquer ato de registro $\left(\mathrm{CPC}\right.$, art. $\left.610, \S 1^{\circ}\right)$, mas que não configura “ato ou autorização judicial" (LSA, art. 35, $1^{\circ}$ ). Seria um evidente contrassenso, porém, que as partes pudessem ultimar a sucessão pela via extrajudicial, mas, visando a simplesmente obter a alteração da titularidade de ações nominativas, fossem obrigadas a buscar uma ordem judicial para efetivá-la. O resultado seria que a decisão de adotar a forma escritural pela companhia importaria alteração significativa na esfera jurídica dos acionistas.

Ultrapassando a literalidade do dispositivo e buscando compreender as eventuais razões de fundo para a regra, seria possível argumentar que o agente escriturador deveria promover transferências apenas quando amparado por documentos judiciais ou por ordem expressa do comprador, para diminuir o risco de litígios no exercício da atividade. A ordem do alienante e a ordem judicial seriam documentos dispositivos reputados indispensáveis pela razão de a atividade de escrituração constituir modalidade de prestação de serviços, ${ }^{465}$ visto que compete à instituição financeira depositária das ações escriturais verificar a regularidade das transferências e da constituição de direitos ou ônus sobre os valores mobiliários de emissão da companhia (LSA, art. 103, caput). ${ }^{466} \mathrm{O}$ acionista tem ação de responsabilidade em face da companhia por eventuais danos sofridos, respondendo

\footnotetext{
${ }^{463}$ STJ, REsp n. 40.276-0-RJ, 3ª T., rel. Min. Eduardo Ribeiro, j. 07.12 .1993 (referindo-se ao exercício do direito de recesso).

${ }^{464}$ TJSP, Ap. n. 994.08.126905-1, 8 a Câm. Dir. Priv., rel. Des. Salles Rossi, j. 24.11.2010 (“a condição de acionista ocorre apenas quando a sucessão universal for averbada no livro de registro de ações").

${ }^{465}$ COMPARATO, Fábio K. "Responsabilidades na transferência de ações escriturais”. Op. cit., p. 355.

${ }^{466}$ LEÃES, Luiz G. P. de B. “Ações escriturais". Op. cit., p. 63.
} 
a instituição financeira encarregada do registro pela via regressiva (LSA, art. $\left.34, \S 3^{\circ}\right) .{ }^{467}$ Considerando, assim, que a prestação de serviços deve remunerar os riscos envolvidos na atividade, seria possível sustentar que a lei limita os documentos capazes de gerar assento registral, de forma a não tornar a atividade extremamente custosa à companhia.

Tal interpretação teleológica, porém, tampouco prosperaria. A contratação do agente escriturador promove uma dissociação entre o emissor das ações e o órgão encarregado do registro. ${ }^{468}$ A atividade registral, no entanto, é a mesma, com a diferença de que passa a ser executada por um terceiro equidistante em relação aos acionistas que conta com capacitação técnica e atua para promover a higidez do mercado (gatekeeper). ${ }^{469} \mathrm{~A}$ adoção da modalidade escritural de ações não deveria, nesse limite, conduzir a restrições à esfera jurídica dos acionistas.

A interpretação que parece mais condizente com a sistemática legal, nesse sentido, é de que a ação nominativa escritural apresenta dispositivos específicos que complementam a disciplina geral das ações nominativas registrais, mas não os afastam, exceto na hipótese em que o regramento específico é incompatível com o geral. Na transferência de ações escriturais sem ordem expressa do alienante, a lei é clara ao estabelecer que a transferência opera-se à vista de "autorização ou ordem judicial" (LSA, art. $35, \S 1^{\circ}$ ), mas tal dispositivo não afasta a possibilidade de ser promovida a transferência “em virtude de transmissão por sucessão universal ou legado, de arrematação, adjudicação ou outro ato judicial, ou por qualquer outro título" (LSA, art. $31, \S 2^{\circ}$ ), como a regulação administrativa parece ter admitido ao autorizar a transferência de valores mobiliários em razão de ato ou evento societário (Instrução CVM n. 543/2013, art. 16, incisos III).

Considerando o quanto se afirmou sobre a possibilidade de transferência de ações nominativas registrais por meio de averbação do contrato de compra e venda no livro de "Registro de Ações Nominativas", ${ }^{470}$ conclui-se que comprador pode exigir do agente escriturador a transferência de ações apresentando o contrato de compra e venda celebrado com o titular da ação escritural.

\footnotetext{
${ }^{467}$ COMPARATO, Fábio K. "Responsabilidades na transferência de ações escriturais". Op. cit., p. 357

${ }^{468}$ COMPARATO, Fábio K. "Responsabilidades na transferência de ações escriturais". Op. cit., p. 355.

${ }^{469}$ CVM. Edital de audiência pública SDM n. 3/16, de 03.02.2016 (referindo-se à "importância das funções de escrituração como gatekeeper" no âmbito da escrituração de cotas de fundos de investimento).

${ }^{470}$ Sobre o assunto, cf. item II.B.1.b)(2), supra.
} 
c) Eficácia real do registro

No lapso temporal entre a celebração do contrato de compra e venda e a ultimação da transferência da propriedade por averbação no livro de "Registro", seja do termo de cessão, seja do próprio contrato de compra e venda, o vendedor remanesce como titular das ações. Nas compras e vendas de ações de controle, em geral, há previsão de que, em uma data definida, as partes se obrigam a promover a transferência das ações, dotando de eficácia real o contrato obrigacional de compra e venda. É possível, porém, que o contrato de compra e venda seja celebrado sob condição suspensiva e, uma vez implementada tal condição, a sociedade, controlada pelo vendedor, obste a promoção da averbação competente. A questão que se coloca é de saber se, entre as partes, deve-se reconhecer que se opera a transferência da propriedade, ou se a transmissão do direito real somente se aperfeiçoa mediante o registro.

A questão é especialmente relevante em países que admitem que as ações nominativas possam assumir também a forma "titulada", permitindo-se a emissão de cártula passível de circulação por endosso e que autoriza o endossatário a buscar o registro da transferência junto ao livro de registro mantido pelo emissor (transfert). É o que ocorre na Alemanha, na Itália, na França e em Portugal e, nesses países, aceita-se que a transferência da propriedade sobre as ações, ainda que inoponível à sociedade, já é eficaz entre as partes. ${ }^{471}$ Como consequência dessa admissão da transmissão da propriedade pelo consenso (solo consensu), os dividendos recebidos pelo alienante tornam-se imediatamente propriedade do adquirente, sendo assim tributados; ocorrendo a falência do alienante, as ações não integram a massa falida; se as ações são vendidas a duas pessoas, aquele que antes as adquiriu possui prioridade, ainda que a outra requeira previamente o registro.

No Brasil, como notou ASCARELLI, "não há a possibilidade de requerer-se o transfert de um título nominativo", ${ }^{472}$ razão pela qual a questão em geral não se coloca. Em

471 ALMEIDA COSTA, M. J.; MENDES, Evaristo. "Transmissão de acções tituladas nominativas". In: Estudos dedicados ao Prof. Dr. Luís Alberto Carvalho Fernandes, v. 3. Lisboa: Católica, 2011, pp. 1361, pp. 41-61.

${ }^{472}$ ASCARELLI, Tullio. Teoria geral dos títulos de crédito. Op. cit., p. 317. 
parecer, porém, LAMY FILHO defendeu a possibilidade de eficácia inter partes da alienação de ações. Analisando situação em que ocorreu doação de ações, mas não se lavrou termo de cessão nem se promoveu averbação no livro de "Registro", o autor defendeu, com base na doutrina francesa e italiana relativa à transferência consensual, que ainda que a doação ficasse oculta perante a sociedade, o doador "se teria demitido dos direitos dos títulos doados" e não poderia vender ou ceder a ações a terceiros. ${ }^{473}$

O entendimento não parece o mais adequado. Tendo-se em vista o quanto já se afirmou a respeito do caráter obrigacional do contrato de compra e venda, ${ }^{474}$ e mesmo do contrato de doação, ${ }^{475}$ não parece possível considerar que haveria uma eficácia real entre as partes, distinta da eficácia perante terceiros. Como apontou LEÃES, o direito brasileiro atribui à inscrição contábil eficácia constitutiva para a aquisição da condição de acionista. ${ }^{476}$ COMPARATO, igualmente, observa que não se institui relação de propriedade nem de direito real de gozo ou de garantia sobre ações nominativas sem a inscrição ou averbação no livro social de registro competente. ${ }^{477}$ Refutando a concepção de que o registro teria apenas eficácia em relação a terceiros, e não às próprias partes, afirma o autor que tal avaliação desconhece que "a verdadeira essência do direito real, seja ele pleno como no domínio, seja limitado, reside exatamente nessa eficácia erga omnes" ${ }^{478}$ razão pela qual constatar que o direito real não produz efeitos perante terceiros equivaleria a afirmar que ele não existe. ${ }^{479}$ Como afirmou AsCARELLI, ademais, diversamente do que ocorre no direito italiano ou francês, no direito brasileiro a transmissão da posse é indispensável à alteração da propriedade e, sendo a transferência no livro de registro a forma de imissão na posse das ações nominativas, conclui-se que a transferência da propriedade sobre essas ações "[n]ão pode verificar-se independentemente do registro nos livros da sociedade". 480

\footnotetext{
${ }^{473}$ LAMY FILHO, Alfredo. "Doação de ações nominativas sem a assinatura do termo no livro próprio". $O p$. cit., p. 44.

${ }^{474}$ Sobre o assunto, cf. item II.A, supra.

${ }^{475}$ ALVIM, Agostinho. Da doação. Op. cit., n. 38, p. 78.

${ }^{476}$ LEÃES, Luiz G. P. de B. "Ações escriturais". Op. cit., p. 61.

${ }^{477}$ COMPARATO, Fábio K. "As ações de sociedade anônima como valores mobiliários - natureza e efeitos do registro acionário”. Op. cit., p. 28.

${ }^{478}$ COMPARATO, Fábio K. "As ações de sociedade anônima como valores mobiliários - natureza e efeitos do registro acionário". Op. cit., p. 28.

${ }^{479}$ COMPARATO, Fábio K. "As ações de sociedade anônima como valores mobiliários - natureza e efeitos do registro acionário”. Op. cit., p. 28.

${ }^{480}$ ASCARELLI, Tullio. "Transferência de ações - participação na assembleia e propriedade das ações transferência das ações e livro de presença na assembleia". In: Ensaios e pareceres. São Paulo: Saraiva,
} 
Em vista dessa constatação, conclui-se que, na hipótese de alienações sucessivas a pessoas diversas, adquire a propriedade aquele que primeiro obtém o registro, ainda que tenha celebrado o contrato obrigacional de compra e venda posteriormente.

\section{d) Restrições à circulação}

A transferência de ações de controle pode ser limitada por cláusula de preferência prevista em acordo de acionistas (LSA, art. 118, caput) ou, no caso de companhia fechada, por cláusula estatutária que limite a circulação das ações nominativas (LSA, art. 36). No âmbito da compra e venda de ações de controle a presença de tais limitações gera questionamentos sobre (i) o limite da validade de tais cláusulas; e (ii) o papel da companhia em impedir a transação que descumpra a limitação, ficando eventualmente sujeita a ressarcir perdas e danos sofridos pelos demais acionistas em caso de desrespeito às restrições à circulação.

(1) Requisitos de validade da cláusula de limitação à circulação

A cláusula estatutária que limita a circulação das ações não pode desnaturar o requisito de inerente negociabilidade das ações. Tal limitação deve ser minuciosamente regulada e não pode sujeitar o acionista ao arbítrio dos órgão de administração da companhia ou da maioria dos acionistas (LSA, art. 36). Sendo a limitação instituída originariamente pelo estatuto social, sua oponibilidade a terceiros independe de averbação no livro de Registro de Ações Nominativas. Tratando-se de limitação criada por alteração estatutária, somente será aplicável a acionistas que com ela concordem expressamente mediante pedido de averbação no livro de Registro (LSA, art. $36, \S 1^{\circ}$ ).

1952, pp. 89-98, p. 90. No mesmo sentido: LEÃES, Luiz G. P. de B. "Doação e regime de transferência da propriedade acionária”. In: Pareceres, v. 1. São Paulo: Singular, 2004, pp. 221-231, p. 226. 
(2) Oponibilidade da cláusula de preferência

A cláusula de preferência constante de acordo de acionistas que vincule as ações de controle confere aos demais acionistas o direito de adquirir as ações nos termos ali previstos. A efetividade desse direito de preferência liga-se diretamente com sua eficácia perante terceiros, ou seja, com a possibilidade de ser oposta a terceiros adquirentes que não figuram como partes do acordo. A lei determina que a companhia deve observar o acordo de acionistas sobre a preferência para a aquisição de ações arquivado em sua sede (LSA, art. 118, caput), mas o ônus decorrente do acordo de acionistas apenas é oponível a terceiros depois de averbado nos livros de registro (LSA, art. 118, $\S 1^{\circ} \mathrm{c} / \mathrm{c}$ art. 40, par. único). Se o acordo de acionistas é eficaz perante terceiros, a companhia não pode registrar a transferência acionária em infração à preferência. Fazendo-o, sujeita-se a responsabilidade por perdas e danos sofridos pelos acionistas. O acionista lesado pelo desrespeito ao direito de preferência pode, ademais, adquirir as ações depositando em juízo o preço negociado entre o acionista e o adquirente. ${ }^{481}$ É necessário, portanto, determinar quando o direito de preferência é oponível a terceiros. Há, na doutrina, três principais posições sobre o assunto: (i) a de que seria exigível apenas a averbação do acordo de acionistas, sem necessidade de seu arquivamento na sede da companhia; (ii) a de que bastaria o arquivamento na sede, ainda que sem a averbação, para que o acordo pudesse ser oposto a terceiros; e (iii) a de que seriam indispensáveis o arquivamento e a averbação.

Para COMPARATO, a eficácia dos acordos de acionistas depende da natureza da disposição que veicula. Tratando-se de cláusula pertinente ao exercício do direito de voto, matéria que concerne diretamente o funcionamento dos órgão sociais, a única providência necessária seria o arquivamento na sede, dispensando-se a averbação no livro de registro (LSA, art. 118, caput). Tratando-se, por outro lado, de disposição relativa a direitos patrimoniais como é o caso de direito de preferência, o arquivamento do instrumento contratual na sede seria desnecessário, "bastando proceder ao registro do pactuado no livro social competente". ${ }^{482}$ Caberia à companhia, tão somente, promover a

\footnotetext{
${ }^{481}$ WAISBERG, Ivo. Direito de preferência para a aquisição de ações. São Paulo: Quartier Latin, 2016, p. 61.

${ }^{482}$ COMPARATO, Fábio K. "Eficácia dos acordos de acionistas". In: Novos ensaios e pareceres de direito empresarial. Rio de Janeiro: Forense, 1981, pp. 74-87, p. 85. No mesmo sentido, COMPARATO, Fábio K. "Validade e eficácia de acordo de acionistas. Execução específica de suas estipulações". In: Novos ensaios e pareceres de direito empresarial. Rio de Janeiro: Forense, 1981, pp. 52-73, p. 62. No mesmo sentido:
} 
averbação devida no livro de registro de ações nominativas, com o que a oponibilidade a terceiros seria garantida (LSA, art. $118, \S 1^{\circ}$ ). É dizer: o acordo de acionistas contendo direito de preferência arquivado na sede, mas não averbado a pedido do beneficiário não poderia ser oposto a terceiros.

A posição foi contrastada por TAVARES GuERreiro. Na hipótese de o acordo de acionistas ser arquivado na sede social, mas a cláusula específica não ser averbada, TAVARES GUERREIRO considera que o terceiro adquirente que agisse de boa-fé estaria tutelado caso a companhia procedesse à transferência das ações, não podendo ser oposta a ele a preempção pactuada que desconhecia. ${ }^{483} \mathrm{O}$ autor discorda, porém, da conclusão de COMPARATO de que a companhia estaria autorizada a promover a transferência das ações se o acordo de acionistas estivesse arquivado na sede da companhia, mas não averbado. Isso porque a companhia não poderia proceder a uma transferência que conflitasse com um direito de preferência que conhece. Em sua visão, a posição de COMPARATO que distingue os pactos de voto e os pactos patrimoniais não decorre do teor literal da lei, que, em um mesmo dispositivo legal, impõe à companhia o dever de observar tanto os acordo de acionistas com cláusula de preferência quanto aqueles relativos a direitos de voto desde que "arquivados na sua sede" (LSA, art. 118, caput). Como consequência, em caso de desrespeito do direito de preferência previsto no acordo de acionistas arquivado na sede, mas não averbado no livro de Registro, o prejudicado poderia ajuizar medida cautelar inominada - atual tutela de urgência (CPC, art. 300) para obstar a concretização de cessão e transferência de ações e pleitear, em face da companhia, indenização de perdas e danos que viesse a sofrer. ${ }^{484}$

As duas posições são meritórias por ressaltarem requisitos relevantes para a eficácia da preferência perante terceiros, mas nenhuma delas parece ser, por si, satisfatoriamente compatível com o texto legal. O entendimento de COMPARATO, como bem observou TAVARES GUERREIRO, não dá significado útil ao disposto expressamente na lei, que se refere ao arquivamento na sede da companhia para que o acordo de acionistas

LOBO, Carlos A. da S. "Acordo de acionista". In: PEDREIRA, José Luiz Bulhões; LAMY FILHO, Alfredo. (org.). Direito das companhias, v. 1. Rio de Janeiro: Forense, 2009, pp. 441-499, pp. 474-475.

483 GUERREIRO, José Alexandre T. "A função registrária das sociedades anônimas". Op. cit., p. 147. No mesmo sentido, CRAVEIRO, Mariana C. Contratos entre sócios. São Paulo: Quartier Latin, 2013, p. 121; FERREIRA, Mariana M.-C. "Reflexões sobre o regime jurídico do acordo de acionistas e seus mecanismos de cumprimento forçado". In: YARSHELL, Flávio L.; PEREIRA, Guilherme S. J. Processo societário II. São Paulo: Quartier Latin, 2015, pp. 509-551, p. 531.

${ }^{484}$ GUERREIRO, José Alexandre T. "A função registrária das sociedades anônimas". Op. cit., p. 148. 
seja por ela observado, sem distinguir o acordo de voto do acordo patrimonial (LSA, art. 118, caput). A posição de TAVARES GUERREIRO, por outro lado, indiretamente torna oponível um acordo de acionistas que não cumpriu as condições para projetar eficácia perante o terceiro. $\mathrm{O}$ adquirente que requeresse certidões dos assentamentos constantes do livro de Registro (LSA, art. $100, \S 1^{\circ}$ ) e verificasse a inexistência de averbação (LSA, art. 40, par. único c/c art. $118, \S 1^{\circ}$ ) não poderia ver concretizada a transferência da titularidade sobre as ações que adquiriu porque a companhia, para observar seu dever perante os acionistas, negar-se-ia a promover o registro pertinente. Essa impossibilidade de obter o registro imposta a alguém que não é parte do acordo constitui a projeção mais característica da oponibilidade perante terceiros. ${ }^{485}$ A solução, ademais, não considera que a solicitação da averbação da preferência constitui ônus, do qual o acionista beneficiado deve-se desincumbir para que seja tutelado. Ao outorgar ao acionista beneficiado pela preferência o direito de obter ressarcimento por perdas e danos em face da companhia mesmo sem ter requerido a averbação, a posição doutrinária impõe à companhia a obrigação de afastar-se do controle de estrita legalidade formal na atuação registral, sendo forçada a averiguar a compatibilidade das transferências com acordos de acionistas arquivados em sua sede, mas cuja averbação o acionista interessado não solicitou. Trata-se de atuação sem fundamento legal e que gera responsabilidade à própria companhia. É correta, nesse sentido, decisão que condenou ao pagamento de perdas e danos a sociedade anônima que se negou a promover a transferência de ações a terceiro sob a alegação de que teria sido desrespeitado direito de preferência não averbado no livro social. ${ }^{486}$

Uma leitura possível, diversa de ambas as posições apresentadas, seria a literal. Seria possível sustentar, com efeito, que o acordo de acionistas que versasse sobre direito de preferência deveria ser arquivado na sede na sede da companhia para que fosse a ela oponível (LSA, art. 118, caput) e averbado no livro de Registro, para que fosse oponível a terceiros (LSA, art. $118, \S 1^{\circ} \mathrm{c} / \mathrm{c}$ art. 40, par. único). Essa parece ser a posição de SALOMÃo FILHO, que critica a posição de COMPARATO por conduzir a uma "verdadeira divisão de registros por matérias". ${ }^{487}$ Considerando que a opinião não poderia ser compartilhada, defende que, para o pacto de preferência ou sobre a compra e venda de

\footnotetext{
${ }^{485}$ MARTINS, Alexandre S. Cláusulas do contrato de sociedade que limitam a transmissibilidade das acções. Coimbra: Almedina, 2006, p. 520.

486 TJSP, Ap. n. 0007020-63.2004.8.26.0564, $8^{\text {a }}$ Câm. Dir. Priv., rel. Des. Theodureto Camargo, j. 14.09.2016.

${ }^{487}$ SALOMÃO FILHO, Calixto. O novo direito societário. Op. cit., p. 115.
} 
ações, seria necessária não somente a averbação, mas também o registro junto à companhia que deverá cumpri-lo; e, para o acordo de voto, seria necessário não somente o arquivamento, mas também a averbação do instrumento, pois ele pode ser relevante também para os adquirentes que poderão por ele se obrigar. ${ }^{488}$ A menos que cumpridos os requisitos cumulativos do arquivamento e da averbação, portanto, a companhia, exercendo atuação registrária pautada pelo exame da estrita legalidade formal, não poderia recusar a transferência das ações.

Acredita-se, porém, que tal não seria a melhor interpretação do texto legal, porque geraria uma indevida diferenciação entre a preferência constante do acordo de acionistas e outras previsões de direito de preferência, previstos, por exemplo, em contratos celebrados pelos sócios com terceiros. Adicionalmente, negaria eficácia a uma cláusula de preferência averbada e executável pelo singular motivo de que o acordo de acionistas deixou de ser arquivado, razão pela qual o formalismo deve ceder espaço a uma análise da finalidade tutelada pelo registro.

O direito de preferência pode ser previsto em outros contratos, que não o acordo de acionistas. ${ }^{489}$ Tal direito de preferência previsto em pacto separado será oponível a terceiros se estiver averbado no livro de Registro (LSA, art. 40, par. único). Se a cláusula de preferência constante do acordo de acionistas é averbada no livro de Registro tal qual a cláusula de preferência que integra outro contrato celebrado pelo sócio e, da averbação, consta o inteiro teor da cláusula de preferência, não há motivo para sustentar que a preferência do acordo não seria oponível à companhia e a terceiros pela falta do arquivamento. O arquivamento na sede da companhia (LSA, art. 118, caput), porém, apresenta-se como uma alternativa para que, na averbação, não seja transcrito o inteiro teor da cláusula. Admite-se, na hipótese de arquivamento do acordo na sede da companhia, que a averbação apenas mencione a vinculação das ações ao acordo de acionistas. A eficácia da averbação, nesse caso, será integrada pelos termos do acordo (integração per relationem). O direito de preferência, com isso, será oponível à companhia e a terceiros se a averbação no livro de Registro regrar minuciosamente o direito de preferência, sendo possível, também, que a averbação apenas mencione a vinculação aos termos do acordo de

\footnotetext{
${ }^{488}$ SALOMÃO FILHO, Calixto. O novo direito societário. Op. cit., p. 116.

${ }^{489}$ WAISBERG, Ivo. Direito de preferência para a aquisição de ações. $O$ p. cit., p. 80.
} 
acionistas, hipótese em que a oponibilidade a terceiros condiciona-se adicionalmente ao arquivamento na sede social.

e) Requisitos para a negociação das ações

Na companhia fechada, as ações podem ser negociadas ainda que não estejam integralizadas, desde que tenha havido a realização do percentual mínimo de $10 \%$ (dez por cento) exigido para a constituição (LSA, art. 80, II) ou de superior, quando lei especial o exija (LSA, art. 80, par. único). Nas companhias abertas, a negociação das ações somente é permitida depois de realizados 30\% (trinta por cento) do preço de emissão (LSA, art. 29) das ações subscritas, sob pena de nulidade do ato (LSA, art. 29, par. único).

A nulidade prevista no dispositivo legal parece referir-se ao "ato" de negociação das ações. O contrato de compra e venda, segundo tal perspectiva, seria nulo quando versasse sobre ações não integralizadas. Não parece, porém, haver razão lógica para negar validade ao negócio jurídico obrigacional porque o vendedor, no momento da celebração do contrato, não integralizara o mínimo exigido em lei. Nada impede que o faça e transfira as ações, adimplindo o contrato. Considerar nulo o contrato de compra e venda, nessa medida, parece inadequado. A consequência efetiva do dispositivo parece ser outra. Seu escopo é vedar a negociação para evitar a especulação sobre ações não integralizadas, buscando-se a tutela do investidor. ${ }^{490}$ A companhia, por conseguinte, deve garantir a realização do capital social, razão pela qual deverá recusar o registro à transferência voluntária de ações. Não se trata, portanto, a princípio, de uma questão de nulidade, mas de ineficácia relativa. Se, porém, a companhia promover a transferência das ações, o termo de cessão lavrado pelo cedente e pelo cessionário e a decorrente averbação no livro de registro serão nulos por infração à norma cogente.

f) Responsabilidade do alienante

${ }^{490}$ MARTINS, Fran. Comentários à lei das sociedades anônimas. Op. cit., p 182. 
As ações conjugam os direitos e deveres sociais, razão pela qual, uma vez transferidas, a regra geral é a de que ao alienante não subsiste responsabilidade perante a companhia e terceiros. Há exceções a esse princípio no caso de (i) alienação de ações não completamente integralizadas, caso em que o cedente é solidariamente responsável pela integralização; (ii) desconsideração da personalidade jurídica fundada em fato anterior à transferência acionária; e (iii) responsabilidade por fato prévio à transferência acionária na hipótese de falência da sociedade.

(1) Responsabilidade pela integralização das ações

Em qualquer hipótese de alienação de ações não integralizadas, o alienante permanece responsável solidário com os adquirentes pelo pagamento das prestações faltantes para integralizar as ações transferidas (LSA, art. 108), responsabilidade que cessa ao fim de dois anos contados da data de transferência das ações (LSA, art. 108). Trata-se de disposição de ordem pública, destinada a assegurar a realização do capital, que não pode ser afastada pelas partes ou pelo estatuto social. ${ }^{491} \mathrm{O}$ prazo é contado da data do registro da transferência, e não da celebração do contrato de compra e venda. ${ }^{492}$ A responsabilidade pelo pagamento, a despeito da solidariedade, é do cessionário. O cedente que é demandado a integralizar o capital social pela companhia tem direito de regresso contra o cessionário; na hipótese reversa, não há direito de regresso do cessionário contra o cedente. ${ }^{493}$

(2) Responsabilidade por desconsideração da personalidade jurídica

A sociedade por ações é modalidade societária em que vige o princípio da responsabilidade limitada. O sócio, como regra, obriga-se apenas pela integralização das ações que subscreve. As exceções a tal princípio, porém, são tantas e de tal envergadura

\footnotetext{
${ }^{491}$ GUIMARÃES, Ruy C. Sociedades por ações. Rio de Janeiro: Forense, 1960, p. 75; PEIXOTO, Carlos F. da C. Sociedades por ações, v. 2. São Paulo: Saraiva, 1972, p. 300.

${ }^{492}$ GUIMARÃES, Ruy C. Sociedades por ações. Op. cit., p. 78; PEIXOTO, Carlos F. da C. Sociedades por ações, v. 2. Op. cit., p. 302.

${ }^{493}$ GUIMAR ÃES, Ruy C. Sociedades por ações. Op. cit., p. 77.
} 
que há quem considere que a responsabilidade limitada teria chegado ao fim no Brasil. ${ }^{494}$ Pode-se distinguir as hipóteses de desconsideração conforme sejam (i) condicionadas à verificação de certos pressupostos; e (ii) irrestritas, aplicáveis sempre que haja situação de controle societário.

A desconsideração da personalidade jurídica, a princípio, é condicionada à ocorrência de desvio de finalidade ou confusão patrimonial (CC, art. 50); ou, no caso de dívidas tributárias, à atuação com excesso de poderes ou infração da lei (CTN, art. 135, III). A desconsideração é irrestrita e incondicionada, porém, quando a personalidade jurídica pode ser afastada para alcançar o patrimônio do sócio independentemente da ocorrência de qualquer abuso, fraude ou confusão patrimonial. É o que se prevê no âmbito (i) trabalhista, seja para o controlador pessoa jurídica integrante de grupo econômico (CLT, art. $2^{\circ}, \S 2^{\circ}$ ), seja para pessoas físicas, por aplicação analógica do Código de Defesa do Consumidor $^{495}$; (ii) consumerista, em que a personalidade jurídica não pode ser obstáculo ao ressarcimento dos consumidores (CDC, art. 28, $\left.\S 5^{\circ}\right)^{496}$; (iii) ambiental, em que a personalidade jurídica igualmente não pode ser obstáculo ao ressarcimento (Lei n. 9.605/1998, art. $4^{\circ}$ ); (iv) concorrencial, em que há responsabilidade solidária de integrantes do mesmo grupo econômico (Lei n. 12.529/2011, art. 33 e 34); e da legislação anticorrupção, que impões à sociedade controladora responsabilidade solidária com a sociedade infratora controlada (Lei n. 12.846/2013, art. $4^{\circ}, \S 2^{\circ}$ ), cabendo ainda a desconsideração da personalidade jurídica sempre que esta for utilizada com abuso do direito ou para provocar confusão patrimonial (Lei n. 12.846/2013, art. 14).

$\mathrm{Na}$ aplicação do instituto da desconsideração da personalidade jurídica, a jurisprudência tem analisado a possibilidade de o acionista controlador ser alcançado pela desconsideração da personalidade jurídica mesmo que tenha alienado as ações de que era titular.

Se o acionista controlador deixa a sociedade, mas posteriormente se apura a ocorrência de abuso da personalidade jurídica ou confusão patrimonial (CC, art. 50) durante o período em que foi controlador, pode ser promovida a desconsideração da

\footnotetext{
${ }^{494}$ SALAMA, Bruno M. O fim da responsabilidade limitada no Brasil. São Paulo: Malheiros, 2014. ${ }^{495}$ SALAMA, Bruno M. O fim da responsabilidade limitada no Brasil. Op. cit., p. 208.

${ }^{496}$ STJ, REsp n. 279.273-SP, $3^{\text {a }}$ T., rel. p/ ac. Min. Nancy Andrighi, 04.12.2003 (sobre a desconsideração da personalidade jurídica por danos decorrentes no caso de explosão no Shopping Osasco).
} 
personalidade jurídica, permitindo que credores da sociedade alcancem o patrimônio do antigo controlador para satisfação de créditos. $^{497}$ A desconsideração da personalidade jurídica, no entendimento do STJ, implica exercício de direito potestativo pelo credor, não estando sujeita a prazos prescricionais ou decadenciais. ${ }^{498}$

Se se considera que o antigo controlador praticou atos fraudulentos que conduziram a sociedade à falência, ademais, é possível a desconsideração da personalidade jurídica para impor aos aos sócios responsabilidade não somente por dívidas contraídas pela sociedade no período em que foram sócios. Nessa hipótese, os sócios respondem por todos os créditos habilitados, ainda que o respectivo fato gerador tenha ocorrido após a saída da sociedade. ${ }^{499}$

Tendo em vista a amplitude das hipóteses de desconsideração da personalidade jurídica, o entendimento de que a desconsideração da personalidade jurídica não está sujeita a prazos decadenciais, e a possibilidade de que o antigo sócio responda por atos ocorridos posteriormente à alienação de suas ações em caso de falência posterior, percebe-se que o acionista que aliena o controle societário pode ficar sujeito a ser responsabilizado por terceiros no âmbito da desconsideração da personalidade jurídica.

2. Cessão de quotas de sociedade limitada

Tal qual ocorre em matéria acionária, não há um regime específico para a cessão de quotas de controle. Necessária, portanto, a investigação do regime de circulação das quotas, das limitações à circulação, dos requisitos para sua efetivação e da responsabilidade subsidiária do cedente.

${ }^{497}$ STJ, REsp n. 1.180.714-RJ, 4 $4^{\mathrm{a}}$ T., rel. Min. Luis Felipe Salomão, j. 05.04.2011.
${ }^{498}$ STJ, REsp n. 1.312.591-RS, 4 ${ }^{\mathrm{a}}$ T., rel. Min. Luis Felipe Salomão, j. 11.06.2013.
${ }^{499}$ STJ, REsp n. 1.180.714-RJ, 4 ${ }^{\mathrm{a}}$ T., rel. Min. Luis Felipe Salomão, j. 05.04.2011. 
a) Possibilidade de cessão da quota social

Antes da entrada em vigor do Código Civil de 2002, o tema da possibilidade de cessão de quotas de sociedade limitada sob o Decreto n. 3.708/1919 gerou dissensões doutrinárias. Em um primeiro momento, a doutrina negava a possibilidade de cessão a estranhos ao contrato social, com base na então vigente regra geral de que "a nenhum sócio é lícito ceder a um terceiro, que não seja sócio, a parte que tiver na sociedade" (CCom/1850, art. 334). As orientações sobre a possibilidade de cessão variavam acentuadamente, havendo quem defendesse que a transferência voluntária das quotas a terceiros não sócios, havendo quem afirmasse que pressuporia a concordância por todos os demais sócios; ${ }^{500}$ que poderia ser realizada por deliberação majoritária, cabendo direito de recesso aos dissidentes demais; ${ }^{501}$ e quem admitisse a livre possibilidade de cessão. ${ }^{502}$

Sob o novo Código Civil, não mais se dúvida que a quota da sociedade limitada pode ser cedida a terceiros, nos termos da regra constante do art. 1.057 do Código Civil. Para além da regra geral, porém, há a possibilidade de ser imposto regime convencional diverso.

b) Regime legal dispositivo

É difundida a concepção de que a limitada constituiria tipo societário com vínculo personalista, no qual os sócios seriam, como regra, infungíveis. É nesse sentido, por exemplo, a afirmação do STJ de que "[a] solução engendrada pelo art. 1.057 do Código Civil consiste exatamente na prevalência do caráter intuitu personae da sociedade limitada, uma vez que atribui ao silêncio do contrato a opção do quadro social pela restrição da

\footnotetext{
${ }^{500}$ MARTINS, Fran. Sociedade por quotas no direito estrangeiro e brasileiro. Rio de Janeiro: Forense, 1960, n. 290, p. 659.

501 CUNHA PEIXOTO, C. F. A sociedade por cotas de responsabilidade limitada. Rio de Janeiro: Forense, 1958, n. 239, p. 214.

502 BULGARELLI, Waldírio. "Alguns estranhos casos de sociedades por cotas de responsabilidade limitada no direito brasileiro". In: Estudos e pareceres de direito empresarial (o direito das empresas). São Paulo: RT, 1980, pp. 185-194, p. 193 (considerando que a liberdade de cessão somente seria admissível na hipótese de sociedade por prazo indeterminado).
} 
transmissão de quotas ao não sócio". ${ }^{503}$ Ou pela doutrina, quando defende que "a limitada apresenta-se, também, como sociedade intuitu personae". ${ }^{504}$ Se um sócio é titular de mais de três quartos das quotas, sendo capaz de alterar o contrato social (CC, art. 1.076, I), porém, a sociedade limitada, ao menos para esse sócio, não apresenta caráter personalista, a menos que haja dispositivo expresso no contrato social.

Durante a tramitação do Código Civil de 2002, buscou-se inovar o regime anterior de pouca clareza legislativa por meio da introdução do regramento dispositivo para o caso de silêncio do contrato. A cessão da quota a outro sócio seria livre, mas a cessão a terceiro estranho à sociedade não poderia ocorrer se houvesse oposição por mais de um quarto do capital social.

A proposta foi criticada durante a tramitação do projeto. Afirmava-se que a possibilidade de oposição por mais de um quarto do capital social não seria a corrente nos contratos de sociedades limitadas existentes à época. ${ }^{505}$ Argumentava-se que então prevalecia orientação inversa à enunciada no dispositivo, ou seja, "não permitir que o controle da empresa passe a terceiro, sem mais nem menos, sem que se ofereça oportunidade àqueles que vêm contribuindo para o seu engrandecimento desde o começo". ${ }^{506}$ A resposta à crítica foi de que a regra seria dispositiva e concederia liberdade aos sócios para regrar a matéria como desejassem. ${ }^{507}$ A orientação inicialmente proposta prevaleceu a despeito das críticas e foi cristalizada no atual art. 1.057 do Código Civil.

Apesar de a norma não ser cogente, constata-se que há forte tendência em matéria societária a que as partes não negociem cláusulas específicas no contrato social

\footnotetext{
${ }^{503}$ STJ, REsp n. 1.309.188 - SP, 4 4 T., rel. Min. Luis Felipe Salomão, j. 24.04.2014.

${ }^{504}$ CAMPINHO, Sérgio. O Direito de Empresa à Luz do Novo Código Civil. $3^{\text {a }}$ ed. rev. e atual. Rio de Janeiro: Renovar, 2003, p. 156. No mesmo sentido, COELHO, Fábio Ulhoa. Curso de direito comercial. Op. cit., p. 405 (afirmando que as sociedades limitadas "devem ser reputadas de pessoas" se não há cláusula contratual disciplinando a cessão das quotas a terceiros estranhos à sociedade).

${ }^{505}$ CONGRESSO NACIONAL. Emenda n. 587 da Câmara dos Deputados ao Projeto de Lei n. 634/75, proposta pelo Dep. Gomes da Silva. Publicada no Diário do Congresso Nacional (Seção I) - Suplemento, em 14. 09.1983 .

${ }^{506}$ CONGRESSO NACIONAL. Emenda n. 587 da Câmara dos Deputados ao Projeto de Lei n. 634/75, proposta pelo Dep. Gomes da Silva. Publicada no Diário do Congresso Nacional (Seção I) - Suplemento, em 14. 09.1983. Também em sentido crítico à proposta, cf. CARVALHO, Dora Martins de. "As Sociedades Limitadas no Projeto do Código Civil". In: RDM, v. 60, 1985, pp. 90-92, p. 92.

${ }^{507}$ CONGRESSO NACIONAL. Parecer do Relator, publicado no Diário do Congresso Nacional (Seção I) Suplemento, em 14.09.1983.
} 
quando há regramento dispositivo aplicável. ${ }^{508}$ Segundo pesquisa realizada pela Fundação Getúlio Vargas, ${ }^{509}$ ademais, em 46,8\% das sociedades limitadas registradas no Estado de São Paulo há um sócio titular de mais de três quartos do capital social, o que importa afirmar, por decorrência, que nessas sociedades limitadas não há nenhum outro sócio titular de mais de um quarto do capital social. Com essa distribuição das quotas, regimes diferentes para a cessão a terceiros coexistirão em uma mesma sociedade caso a regra do art. 1.057 não tenha sido expressamente afastada pelos contratantes. O titular de mais de três quartos do capital social pode ceder a quota livremente para terceiros; os titulares de menos de um quarto do capital social, por outro lado, não poderão se opor ao ingresso de terceiro, não terão direito de venda conjunta, e não terão preferência na aquisição em concorrência com o terceiro estranho ao capital social. ${ }^{510} \mathrm{Se}$ o sócio titular de menos de um quarto do capital social desejar ceder sua quota a terceiro, contudo, a situação se inverte: a operação poderá ser vetada de modo injustificado e imotivado pelo sócio controlador.

A conjugação desses dados permite que se afirme que, em grande parcela das sociedades, o sócio controlador desfruta da mesma liberdade que teria em uma sociedade por ações. O titular de menos de um quarto do capital social, na ausência de disciplina contratual expressa, fica sujeito ao ingresso de um novo controlador na sociedade. A sociedade, para o sócio controlador titular de mais de três quartos das quotas, pode ser vista como uma sociedade "de capital", ao passo que, para o sócio minoritário, será o perfeito exemplo das restrições vividas em uma sociedade “de pessoas".

O regime do art. 1.057 do Código Civil será aplicável, ademais, sempre que não houver disposição expressa no contrato social sobre o assunto. É equivocado, portanto, afirmar que a escolha da regência supletiva da lei das sociedades por ações no contrato social bastaria para que as quotas fossem livremente cedidas, como pretendeu WALDO

\footnotetext{
${ }^{508}$ PARGENDLER, Mariana. “O direito societário em ação: análise empírica e proposições de reforma”. In: RDB, v. 59, 2013, pp. 215-256, p. 239.

509 MATTOS FILHO, Ary O. (et.al.). "Radiografia das Sociedades Limitadas" (Relatório de pesquisa). Fundação Getúlio Vargas, 2014.

${ }^{510}$ Parece equivocado o posicionamento de Edmar Oliveira Andrade Filho, para quem, em virtude do disposto no art. 1.057, "os sócios gozam de um direito de preempção, vulgar e erroneamente denominado de 'preferência', para a aquisição das quotas daquele que pretende aliená-las" que deveria ser respeitado "em qualquer operação de mudança de titularidade da quota, exceto os casos de sucessão legal" (Sociedade de responsabilidade limitada. São Paulo: Quartier Latin, 2004, p. 111). O direito de preferência não decorre do teor do art. 1.057 do Código Civil, tendo aplicação somente na hipótese de ser previsto no contrato social ou em acordo de sócios. Sobre o assunto, cf. item II.B.2.c)(3), infra.
} 
FAZZIO JR., ${ }^{511}$ pois a regra dispositiva do art. 1.057 não deixa lacuna normativa para ser colmatada com o regime supletivo da legislação acionária. ${ }^{512}$

c) Limitações convencionais à livre circulação das quotas previstas no contrato social ou acordo de quotistas

O contrato social, ou o acordo de quotistas, ${ }^{513}$ podem prever regras diversas para a transferência de quotas a terceiros. Há diversas configurações admissíveis, desde as mais liberais, como a regra de livre transferência das quotas a terceiros, obrigatória para a limitada que resultar da transformação de sociedade anônima (LSA, art. 298), até as mais restritivas, entre as quais se incluem a regra de prévia aprovação do nome do cessionário pelos demais sócios (placet), de proibição da participação de certas pessoas na sociedade em razão da nacionalidade ou da profissão, por exemplo. ${ }^{514}$ Entre as modalidades com maior relevância para a cessão de quotas de controle encontram-se as previsões de (i) vedação à cessão a terceiros; (ii) exigência de concordância pela unanimidade dos quotistas para cessão a terceiros; (iii) e a previsão de direito de preferência.

Vedação à cessão

O contrato social ou acordo de quotistas pode vedar a cessão da quotas a terceiros. Na doutrina, parte dos autores considera tal cláusula inválida. Sob o direito anterior, já se apontava para a incompatibilidade da proibição de cessão com a natureza

${ }^{511}$ Como defende FAZZIO Jr., Waldo. Sociedades limitadas. São Paulo, Atlas, 2003, p. 139.

512 CAVALLI, Cássio. Sociedades limitadas: regime de circulação das quotas. São Paulo: Revista dos Tribunais, 2011, p. 75; TOKARS, Fábio. Sociedades limitadas. São Paulo: LTr, 2007, p. 234.

${ }^{513}$ CORVO, Erick. "Acordos de sócios de sociedades limitadas à luz do Código Civil de 2002". In: ADAMEK, M. V. von. Temas de direito societário e empresarial contemporâneos. São Paulo: Malheiros, 2011, pp. 84-114; KUGLER, H. Morgenstern. Os acordos de sócios nas sociedades limitadas. São Paulo: Quartier Latin, 2014, pp. 175-180; ZANETTI LEAL, Murilo. A transferência involuntária de quotas nas sociedades limitadas. São Paulo: Revista dos Tribunais, 2002, p. 35.

514 COMPARATO, Fábio K. "Exclusão de sócio, independentemente de específica previsão legal ou contratual". In: Ensaios e pareceres de direito empresarial. Rio de Janeiro: Forense, 1978, pp. 131-149, p. 147. 
jurídica das sociedades mercantis. ${ }^{515}$ Sob o direito atual, repete-se o argumento da incompatibilidade da cláusula com a natureza da sociedade limitada. ${ }^{516}$ Para VERÇOSA, a cláusula que impedisse completamente a cessão a terceiros tornaria o sócio "escravo das relações contratuais societárias", razão pela qual não poderia ser admitida. ${ }^{517}$ Para CARvalhosa, o princípio constitucional da liberdade de associação, em sua vertente negativa, implicaria a liberdade de desvincular-se da sociedade (ou seja, de não mais ser associado). ${ }^{518}$ Se o contrato social previsse a impossibilidade de cessão, tal cláusula deveria ser interpretada como instituindo um direito de preferência aos demais sócios. ${ }^{519}$ Para WALD, a impossibilidade completa de cessão da quota seria cláusula ilícita. ${ }^{520}$ Há, ainda, quem considere que a cláusula seria válida, mas não na hipótese de o contrato social ser regido supletivamente pela Lei das Sociedades por Ações. ${ }^{521}$

O entendimento não parece poder ser compartilhado. O sócio controlador, titular de mais de três quartos do capital social da limitada, caso celebre contrato social com cláusula prevendo a proibição absoluta de cessão da quota a terceiro, não poderá alegar, sem mais, que a cláusula seria inválida por torná-lo prisioneiro da sociedade, podendo transferir a quota a terceiros. Primeiramente, hoje prevalece o entendimento de que na sociedade limitada por prazo indeterminado o sócio pode, a qualquer momento, retirar-se da sociedade (CC, art. 1.029). ${ }^{522}$ Em segundo lugar, no caso de sócio titular de mais de três quartos do capital social, será possível, como regra, deliberar a liquidação da sociedade (CC, art. 1.071, VI c/c art. 1.076, I). O argumento de incompatibilidade da cláusula com a essência das limitadas, ademais, possui viés ontológico e conceitual, apresentando como conclusão um pressuposto que antes deveria comprovar, e não se

515 TEIXEIRA, Egberto L. Das sociedades por quotas de responsabilidade limitada, $2^{\mathrm{a}}$ ed. atual. por Syllas Tozzini e Renato Berger. São Paulo: Quartier Latin, 2007, n. 80, p. 145.

${ }^{516}$ ABRÃO, Nelson. Sociedades limitadas, $10^{\mathrm{a}}$ ed. rev. e atual. Por Carlos Henrique Abrão. São Paulo: Saraiva, 2012, n. 39, p. 118.

${ }^{517}$ VERÇOSA, Haroldo M. D. Direito Comercial, v. 2, $3^{\text {a }}$ ed. atual. São Paulo: Revista dos Tribunais, 2014, p. 577.

${ }_{518}$ CARVAlhOSA, Modesto. Comentários ao Código Civil, v. 13, 2ª ed. São Paulo: Saraiva, 2005, p. 82.

${ }^{519}$ CARVAlHOSA, Modesto. Comentários ao Código Civil. Op. cit., p. 84.

${ }^{520}$ WALD, Arnoldo. Comentários ao novo Código Civil. Rio de Janeiro: Forense, p. 346.

${ }^{521}$ CAMILO Jr., Ruy Pereira. "Contrato de cessão de quotas sociais". Op. cit., p. 242.

522 TJSP, AI n. 2167142-73.2015.8.26.0000, 1ª Câm. Res. Dir. Empr., rel. Des. Pereira Calças, 09.09.2015; TJSP, AI n. 2231196-82.2014.8.26.0000, 2a Câm. Res. Dir. Empr., rel. Des. Caio Marcelo Mendes de Oliveira, j. 15.06.2015; TJSP, AI n. 2042049-71.2013.8.26.0000, 1ª Câm. Res. Dir. Empr., rel. Des. Maia da Cunha, j. 05.12.2013. 
sustenta no plano internacional, tendo em vista que em Portugal, na Itália, na Alemanha, na Espanha e na Suíça tal cláusula é admitida. ${ }^{523}$

A cláusula de vedação à cessão pode ser efetivamente importante quando o contrato de sociedade é celebrado tendo em vista as condições pessoais do sócio, como sua expertise, o crédito de que desfruta junto a instituições bancárias, ou a ausência de restrições à contratação com o Poder Público.

A cláusula de vedação absoluta à cessão de quotas, nesse sentido, não é ilegal, sendo de se prestigiar a autonomia dos sócios ao decidirem regrar o contrato social dessa forma. ${ }^{524}$ Mesmo que o contrato social eleja o regramento das sociedades anônimas como aplicável supletivamente, a conclusão não se altera. As regras e os princípios das sociedades limitadas são conduzidos pela conjugação dos princípios aplicáveis às limitadas e às sociedades simples (CC, art. 1.053), razão pela qual a regência supletiva das normas das sociedades anônimas, quando eleita, apenas se presta a complementar aquilo que não está completamente disciplinado. ${ }^{525}$ As regras das sociedades anônimas, dessa forma, não podem ser aplicadas diretamente ao regramento específico das sociedades limitadas, razão pela qual, mesmo na presença da eleição da regência supletiva, é lícita que veda a cessão a terceiros estranhos ao contrato social. ${ }^{526} \mathrm{O}$ sócio controlador não poderá alegar a invalidade da cláusula para, desrespeitando o que aceitou no contrato social, ceder a quota a terceiro estranho ao contrato.

(2) Exigência de unanimidade

Modalidade diversa de restrição da livre transmissibilidade da quota social é a exigência de aprovação pela unanimidade dos sócios. A doutrina diverge acerca da validade de tal cláusula. Para CARvalhosA, tratar-se-ia de regra contratual ilícita, que

\footnotetext{
${ }^{523}$ CAMILO Jr., Ruy Pereira. "Contrato de cessão de quotas sociais”. Op. cit., p. 241.

${ }^{524}$ CAVALLI, Cássio. Sociedades limitadas: regime de circulação das quotas. Op. cit., p. 82.

${ }^{525}$ FORGIONI, Paula A. "A unicidade do regramento jurídico das sociedades limitadas e o art. 1.053 do Código Civil. Usos e costumes e regência supletiva". In: ADAMEK, Marcelo V. von. Temas de direito societário e empresarial contemporâneos. São Paulo: Malheiros, 2011, pp. 216-223, p. 222.

${ }^{526}$ FORGIONI, Paula A. "A unicidade do regramento jurídico das sociedades limitadas e o art. 1.053 do Código Civil. Usos e costumes e regência supletiva”. Op. cit., p. 222.
} 
geraria para as partes um direito de preferência para aquisição das quotas. ${ }^{527}$ Para WALD, a cláusula seria válida, mas a negação do consentimento não poderia ser desmotivada, pois nenhuma restrição à cessão da quota poderia importar sujeição do sócio ao capricho dos demais. A oposição sem razoável fundamento, nesse sentido, seria contrária ao princípio geral da boa-fé contratual e inválida, razão pela qual o consentimento faltante poderia ser suprido pela via judicial. ${ }^{528}$ Para JORGE LOBO, a recusa ou veto injustificado permitiria ao sócio e ao candidato a sócio pleitear "perdas e danos sob a alegação de tratar-se uma oposição gratuita e imotivada". 529

As posições doutrinárias pecam por partir do pressuposto de que a cessão da quota social deveria ser livre e por considerar que a cláusula restritiva seria exceção, que não poderia subverter a regra geral. O Código Civil, diferente da legislação acionária (LSA, art. 36), não estabelece uma regra geral da livre circulação da quota social, mas um regime dispositivo (CC, art. 1.057), que as partes podem livremente não adotar, preferindo em seu lugar outro regime, mais ou menos restritivo, que escolhem para aquela sociedade limitada. Entre as conformações contratuais possíveis, pode-se incluir a exigência de unanimidade. Uma vez instituído tal regime, não há porque desconsiderar a vontade das partes para ler "direito de preferência" onde as partes estabelecem exigência de unanimidade. O suprimento do consentimento faltante, ademais, não pode ser pleiteado sob a afirmativa vaga de que o sócio estaria abusando do seu direito de veto ao ingresso de novos sócios sempre que não contasse com justificativa válida, até porque a lei não exige que haja nenhuma justificativa na hipótese do art. 1.057 do Código Civil. ${ }^{530}$ Exigida a unanimidade no contrato social, não se faz necessária qualquer justificativa para a oposição ao ingresso de novo sócio. ${ }^{531}$ A cessão de quota social é espécie do gênero da cessão de posição contratual. ${ }^{532}$ Como apontou o STJ, a cessão de posição contratual é negócio válido a despeito da falta de previsão legislativa expressa, mas, por englobar simultânea cessão de créditos e assunção de dívida, exige o consentimento do cedido, manifestação que tem por finalidade garantir a "possibilidade de análise da capacidade econômicofinanceira do cessionário, de molde a não correr o risco de eventual inadimplemento; nesse

\footnotetext{
${ }^{527}$ CARVAlhOSA, Modesto. Comentários ao Código Civil. Op. cit., p. 84.

${ }^{528}$ WALD, Arnoldo. Comentários ao novo Código Civil. Op. cit., p. 347.

${ }^{529}$ LOBO, Jorge. Sociedades limitadas. Op. cit., p. 152.

${ }^{530}$ TOKARS, Fábio. Sociedades limitadas. Op. cit., p. 231.

531 TOMAZETTE, Marlon. Curso de direito empresarial. São Paulo: Atlas, 2012, p. 346.

${ }^{532}$ MOTA PINTO, Carlos Alberto. Cessão de contrato. Op. cit., n. 10, p. 68.
} 
ponto, assemelhando-se à figura do assentimento na assunção de dívida" ${ }^{533}$ A necessidade de consentimento é a regra inclusive nas previsões tópicas em que expressamente se reconhece a possibilidade de cessão de posição contratual, como é o caso em matéria locatícia (Lei n. 8.245/1991, art. 13), sendo perfeitamente admissível que alguém negue a outrem a possibilidade de cessão sem que para isso seja necessária motivação. ${ }^{534} \mathrm{~A}$ exigência de consentimento dos demais sócios, nessa medida, inscreve-se de forma harmoniosa no regime da cessão de posição contratual. Para além disso, no âmbito da sociedade limitada, em que as qualidades pessoais dos sócios são relevantes, é natural, e plenamente admissível, que as partes sujeitem a cessão a terceiros ao consentimento unânime dos sócios, e não há obrigação de os sócios remanescentes aceitarem o ingresso de estranho na sociedade. ${ }^{535} \mathrm{O}$ exercício do direito de oposição apenas pode ser considerado como disfuncional e abusivo em hipóteses extremas, nas quais o interesse social relacionado ao melhor desenvolvimento da atividade econômica da sociedade reclame a entrada do novo sócio, ${ }^{536}$ como poderia ser o caso no âmbito de uma recuperação judicial em que se discutisse a alternativa de ingresso dos credores na sociedade pela via da aquisição de direito de preferência para aumento de capital, seguida pela conversão de créditos como medida de saneamento.

Na hipótese, portanto, de estar prevista cláusula que exige o consentimento unânime dos sócios para a cessão da quota a terceiros, o sócio controlador não poderá ceder a quota sem que todos os sócios tenham concordado com a medida. Tal consentimento, caso negado, não poderá ser suprido pela via judicial

\footnotetext{
${ }^{533}$ Voto do Min. Luis Felipe Salomão. In: STJ, REsp n. 1.036.530-SC, $4^{\mathrm{a}}$ T., rel. p/ ac. Min. Luis Felipe Salomão, j. 25.03.2014.

${ }^{534}$ STJ, REsp n. 36.342-0, 5a T., rel. Min. Jesus Costa Lima, j. 17.11 .1993 (em que se considerou que a cessão da locação a parente depende de prévio consentimento por escrito do locador, sem que se mencione necessidade de motivação para a recusa).

${ }^{535}$ TJSP, Ap. n. 9058426-37.2009.8.26.0000, 6 ${ }^{\text {a }}$ Câm. Dir. Priv., rel. Des. Francisco Loureiro, j. 02.02.2012 (afirmando que "os sócios remanescentes não estão obrigados a aceitar o ingresso de estranho na sociedade, e muito menos de aquiescer à alteração do contrato social").

${ }^{536}$ CAVALLI, Cássio. Sociedades limitadas: regime de circulação das quotas. Op. cit., p. 78.
} 
Mediante a previsão de preferência convenciona-se o direito de se adquirir a quota pelo mesmo valor oferecido a terceiro. O contrato de compra e venda possui natureza obrigacional. Dessa forma, ainda que ele desrespeite a preferência dos demais sócios, produzirá efeitos entre comprador e vendedor. ${ }^{537}$ Não é possível, portanto, que o sócio prejudicado pelo desrespeito à preferência pleiteie a anulação do contrato de compra e venda. ${ }^{538}$ Trata-se de hipótese de ineficácia, não cabendo a propositura de ação constitutiva, "mas, se se quiser, tão-somente declaratória da ineficácia do ato, relativamente ao autor". 539

Sob a perspectiva societária, diversamente do que ocorre no caso da sociedade anônima, no âmbito da sociedade limitada compete ao Registro Mercantil o arquivamento dos atos que conduzem à alteração do contrato social (Lei 8.934/1994, art. 32, II, "a") . É possível, dessa forma, que as partes promovam a cessão da quota social vedada pela previsão no contrato social ou no acordo de quotistas registrado. As consequências daí decorrentes são de duas ordens. Primeiramente, o sócio prejudicado pode requerer a anulação da alteração do contrato social. ${ }^{540}$ Pode, ademais, buscar a adjudicação compulsória, depositando judicialmente o preço pago pelo adquirente. ${ }^{541}$

d) Requisitos para a cessão da quota

Desde a entrada em vigor do Código Civil, há dissenso se seria necessária deliberação social para efetivar a cessão da quota, ou se seria possível o arquivamento do instrumento particular junto ao registro de comércio.

${ }^{537}$ TJSP, Ap. n. 00100281-14.2007.8.26.0003, 9ª Câm. Dir. Priv., rel. Des. Piva Rodrigues, j. 14.04.2015 (apontando que, sendo o contrato de compra e venda bilateral e independe da aprovação dos demais sócios).

${ }^{538}$ TJSP, Ap. n. 0163143-79.2011.8.26.0100, $1^{\text {a }}$ Câm. Res. Dir. Empr., rel. Des. Francisco Loureiro, j. 12.09.2013 (considerando que o desrespeito à preferência gera ineficácia, e não nulidade do contrato); TJSP, Ap. n. 366.547-4/0-00, 6 Câm. Dir. Priv., rel. Des. Sebastião Carlos Garcia, j. 15.10.2009 (afirmando que, a despeito da preferência, entre o cessionário e o cedente "o negócio é em si mesmo válido").

539 COMPARATO, Fábio K. "Exclusão de sócio, independentemente de específica previsão legal ou contratual". Op. cit., p. 149.

${ }^{540}$ TJSP, Ap. n. 514.951-4/7-00, 6 Câm. Dir. Priv., rel. Des. Reis Kuntz, j. 19.07.2007 (anulando cessão de quota em desrespeito ao direito de preferência); DNRC, Parecer Jurídico DNRC/COJUR/n. 217/03, de 12.03.2004.

${ }^{541}$ TJSP, Ap. 0251780-11.2008.8.26.0100, $8^{\text {a }}$ Câm. Dir. Priv., rel. Des. Pedro de Alcântara da Silva Leme Filho, j. 18.12.2013 (admitindo a adjudicação compulsória por "violação do direito de preferência para compra e venda de quotas sociais"). 
O Código Civil determina que a cessão da quota social se opera por meio de averbação do instrumento de cessão subscrito pelos sócios anuentes $(\mathrm{CC}$, art. 1.057, par. único). Conduzindo, porém, à substituição de um dos sócios, e sendo obrigatório que constem do contrato social o nome e a qualificação do sócio e sua quota do capital social (CC, art. 1.054 c/c art. 997), é natural que a cessão da quota social gere também a necessidade de alteração do próprio contrato social. O parágrafo único do art. 1.057 do Código Civil, ademais, faz expressa referência ao art. 1.003, no qual se determina que a “cessão total ou parcial de quota, sem a correspondente modificação do contrato social com o consentimento dos demais sócios, não terá eficácia quanto a estes e à sociedade". $\mathrm{Na}$ interpretação conjunta desses dispositivos, há divergência quanto à necessidade de deliberação alterando o contrato social (CC, art. 1.071, V c/c art. 1.076, I) para a promoção da cessão da quota social. A questão possui relevo prático, pois o instrumento de cessão assinado pode ser levado a registro pelo adquirente sem o concurso do alienante; a alteração do contrato social, por outro lado, exige ato positivo dos sócios na representação da sociedade. Em caso de recalcitrância do alienante para cumprimento do contrato de compra e venda, a necessidade de realização de ato societário obstaria a imediata satisfação do interesse do adquirente.

O "Manual de Registro da Sociedade Limitada" (Anexo II à Instrução Normativa n. 10/2013, do Departamento de Registro Empresarial e Integração - DREI) considera que a cessão de quotas somente terá eficácia quanto à sociedade e a terceiros "a partir do arquivamento do respectivo instrumento pelos sócios anuentes”, mas estabelece que o "arquivamento não dispensa o da correspondente alteração contratual" (DREI, Manual de Registro da Sociedade Limitada, item 3.2.10.2). É no mesmo sentido o entendimento de JORGE LOBO, para quem a alteração do contrato social seria indispensável para fazer consignar a nova composição social. ${ }^{542} \mathrm{O}$ adquirente da quota social, por conseguinte, atualmente somente pode obter a plena eficácia da aquisição da quota social perante terceiros mediante alteração do contrato social deliberada em reunião de sócios ou assembleia. Em caso de não ser realizado o ato societário, o adquirente deve mover ação de obrigação de fazer em face dos demais sócios, para que seja alterado o contrato social, ${ }^{543} \mathrm{e}$

542 LOBO, Jorge. Sociedades limitadas. Op. cit., p. 154. No mesmo sentido, FAZZIO Jr., Waldo. Sociedades limitadas. $O p$. cit., p. 142; LEAL, Murilo Zanetti. "Transmissão de participações sociais". $O p$. cit., p. 284.

${ }^{543}$ TJSP, Ap. n. 9141038-37.2006.8.26.0000, $9^{\text {a }}$ Câm. Dir. Priv., rel. Des. Viviani Nicolau, j. 01.02.2011. 
em face da sociedade, para que promova a averbação do contrato social. ${ }^{544}$ Considera-se, ademais, que inclusão da pessoa jurídica como litisconsorte passivo seria obrigatória, sob pena de nulidade do processo. Isso porque os negócios jurídicos referentes à cessão de quotas de sociedade empresária relacionam-se com a alteração do quadro social e, consequentemente, afetam não apenas os sócios, como também a própria pessoa jurídica e terceiros que com ela celebram negócios jurídicos. ${ }^{545}$ A obrigação de assinar o termo de alteração contratual é considerada dever lateral, ou de conduta, passível de ser pleiteada pelo adquirente para a satisfação do seu interesse na formalização da alteração societária. $^{546}$

A maioria da doutrina, porém, considera equivocada a exigência de deliberação promovendo alteração do contrato social. Tendo em vista o disposto no parágrafo único do art. 1.057 do Código Civil, sustenta -se que o instrumento de cessão assinado pelas partes contratantes e por sócios que representem a maioria qualificada de três quartos seria documento hábil para ser averbado à margem da inscrição da sociedade, operando a transmissão de quotas com efeitos erga omnes. ${ }^{547} \mathrm{O}$ tema foi inclusive objeto do Enunciado n. 225 da III Jornada de Direito Civil do Conselho da Justiça Federal, no qual se aprovou a orientação de que "[n]a omissão do contrato social, a cessão de quotas sociais de uma sociedade limitada pode ser feita por instrumento próprio, averbado junto ao registro da sociedade, independentemente de alteração contratual, nos termos do art. 1.057 e parágrafo único do Código Civil”. O próprio adquirente, sem o concurso do alienante ou da sociedade, poderia levar o instrumento a registro. ${ }^{548}$ Para além da averbação do termo de transferência, porém, admite-se em doutrina que a cessão pudesse

\footnotetext{
544 TJRS, AI n. 70061594933, $18^{a}$ Câm. Cív., rel. Des. Pedro Celso Dal Prá, j. 20.11.2014; TJSP, Ap. n. 0007483- 40.2010.8.26.0161, Câm. Res. Dir. Empr., rel. Des. Ênio Zuliani, j. 08.11.2011 (ambos reconhecendo que não somente os sócios, mas também a sociedade possui legitimidade passiva no âmbito de pleito formulado pelo adquirente de quotas sociais para promoção de alteração societária).

545 TJRJ, Ap. n. 0031252-66.2012.8.19.0205, $21{ }^{\text {a }}$ Câm. Cív., rel. Des. Lucia Helena do Passo (decisão monocrática), j. 27.02.2015.

${ }^{546}$ TJSP, Ap. n. 595.583.4/0-00, 4a Câm. Dir. Priv., rel. Des. Francisco Loureiro, j. 21.05.2009.

${ }^{547}$ GONÇALVES NETO, Alfredo de A. Op. cit., p. 457; RIZZARDO, Arnaldo. Direito de empresa, $4^{\mathrm{a}}$ ed. atual. Rio de Janeiro: Forense, 2012, p. 211; LUCENA, J. Waldecy. Das sociedades limitadas. Op. cit., p. 353; CAVALLI, Cássio. Sociedades limitadas: regime de circulação das quotas. Op. cit., p. 78; TOKARS, Fábio. Sociedades limitadas. Op. cit., p. 233; CAMPINHO, Sérgio. Direito de empresa. Op. cit., p. 167; CAMILO, Jr., Ruy Pereira. "Contrato de cessão de quotas sociais". Op. cit., p. 245.

${ }^{548}$ CAVALLI, Cássio. Sociedades limitadas: regime de circulação das quotas. Op. cit., p. 89.
} 
ser promovida diretamente por meio da alteração do contrato social, caso as partes assim preferissem. $^{549}$

O entendimento que prevalece na doutrina parece o mais adequado, devendo ser revisto o posicionamento do Departamento de Registro Empresarial e Integração. O instrumento particular de cessão da quota social arquivado no registro de comércio é apto a promover a cessão e a decorrente alteração da posição contratual do sócio. Não há, portanto, necessidade de alteração do contrato social, pois não há alteração do regramento societário entre os sócios. A alteração formal do contrato social que decorre da averbação deve ser promovida na reunião ou assembleia de sócios subsequente, que deve consolidar o contrato social independentemente de deliberação nesse sentido; a eficácia da cessão perante terceiros, porém, deve ser contada do arquivamento do instrumento de cessão, desde que realizado o registro nos trinta dias subsequentes à lavratura do ato $(\mathrm{CC}$, art. $1.151, \S 1^{\mathrm{o}}$ e $\left.\S 2^{\circ}\right)$.

(1) Certidões negativas de débitos fiscais e previdenciários

Há dispositivos na legislação especial que exigem a apresentação de certidão negativa de débitos para transferência de quotas de sociedades de responsabilidade limitada. No âmbito da Seguridade Social, por exemplo, determina-se a obrigatoriedade de apresentação de Certidão Negativa de Débito (CND) perante o INSS para que seja arquivada, em registro próprio, a "transferência de controle de cotas de sociedades de responsabilidade limitada" (Lei n. 8.212/1991, art. 47, I, “d”). No âmbito da legislação do Fundo de Garantia por Tempo de Serviço (FGTS), igualmente, exige-se a apresentação do “Certificado de Regularidade do FGTS" emitido pela Caixa Econômica Federal para "registro ou arquivamento, nos órgãos competentes, de alteração ou distrato de contrato social, de estatuto, ou de qualquer documento que implique modificação na estrutura jurídica do empregador ou na sua extinção" (Lei n. 8.036/1990, art. 27, “e”).

${ }^{549}$ GONÇALVES NETO, Alfredo de A. Op. cit., p. 457. 
Assistiu-se, nos últimos anos, a uma alteração desse cenário que gerava importante disparidade entre o regime de circulação das quotas e das ações. Primeiro, a Lei Complementar n. 123/2006 dispensou as micro e pequeno empresas da necessidade de apresentação de certidões para o registro de alterações a seus atos constitutivos (Lei Complementar n. 123/2006, art. $9^{\circ}$ ). Posteriormente, a Lei Complementar n. 147, de 2014, introduziu o artigo $7^{\circ}$-A à Lei n. 11.598, de 2007, dispositivo dispositivo que estabelece que "O registro dos atos constitutivos, de suas alterações e extinções (baixas), referentes a empresários e pessoas jurídicas em qualquer órgão dos 3 (três) âmbitos de governo, ocorrerá independentemente da regularidade de obrigações tributárias, previdenciárias ou trabalhistas, principais ou acessórias, do empresário, da sociedade, dos sócios, dos administradores ou de empresas de que participem, sem prejuízo das responsabilidades do empresário, dos titulares, dos sócios ou dos administradores por tais obrigações, apuradas antes ou após o ato de extinção".

A Lei Complementar n. 147/2014 não revogou expressamente os dispositivos vigentes em matéria previdenciária, mas parece adequado o entendimento de que, pela incompatibilidade lógica, a norma posterior derrogou a legislação anterior. Foi esse o entendimento que prevaleceu no âmbito administrativo. Conforme a Instrução Normativa DREI n. 26/2014, o manual de registro das sociedades limitadas foi atualizado para que as juntas comerciais não mais exijam a apresentação de certidões negativas. A Junta Comercial do Estado de São Paulo, no entanto, ainda hoje apresenta em sua página na internet, ${ }^{550}$ entre seus enunciados, a exigência de apresentação de certidão para a cessão de quotas de limitadas (Enunciados JUCESP, n. 18).

(2) Eficácia da cessão: entre as partes, perante a sociedade e terceiros

Na eficácia da cessão da quota social, há três momentos diversos. O primeiro deles diz respeito à eficácia do negócio jurídico de compra e venda de quotas, que se estabelece entre o cedente e o cessionário. Ninguém questiona que tal negócio

550 Disponíveis sob o "link" denominado "Enunciados JUCESP" disponível na página http://www.institucional.jucesp.sp.gov.br/empresas_legislacao.php, acesso em 24.11.2016. 
obrigacional possa ser eficaz entre as partes, ainda que não o seja perante a sociedade ou terceiros. ${ }^{551}$ Diverso é o tema da eficácia perante a sociedade e perante terceiros, relevante, sobretudo, para a determinação do termo inicial do prazo de dois anos de responsabilidade solidária estabelecida entre cedente e cessionário pelas obrigações que o cedente tinha como sócio (CC, art. 1.057, par. único c/c art. 1.003, par. único).

O Código Civil determina que "a cessão total ou parcial da quota. sem a correspondente modificação do contrato social com o consentimento dos demais sócio, não terá eficácia quanto a estes e à sociedade" (CC, art. 1.003). Interpretando tal dispositivo, o STJ analisou a hipótese de instrumento de cessão celebrado por um sócio e terceiro, do qual constou a anuência da integralidade dos demais sócios. Nesse instrumento, previa-se que o cedente responderia pelas obrigações sociais pelo prazo de dois anos, em linha com o disposto na legislação de regência. ${ }^{552}$ Passados mais de dois anos da assinatura do instrumento de cessão, mas menos de dois anos da averbação da alteração do contrato social (que não foi protocolado no prazo de trinta dias da sua lavratura, não se beneficiando, por conseguinte, da eficácia retroativa prevista no art. 1.151, §1 do Código Civil), a sociedade ingressou em juízo em face do antigo sócio, postulando o recebimento de valores relativos a uma dívida trabalhista. Em segunda instância, julgou-se que, passados dois anos da assinatura do instrumento de cessão das quotas, não haveria mais responsabilidade do cedente perante a sociedade, pois o contrato produziria efeitos entre as partes, embora não os produzisse perante terceiros.

O STJ cassou a decisão da segunda instância sob o fundamento de que "a sociedade não é parte no negócio jurídico de cessão de cotas" e que, mesmo que todos os sócios tenham anuído à cessão, seria impossível afirmar que "a sociedade, (uma pessoa jurídica autônoma), tenha participado do negócio jurídico, de modo a estar subordinada (ou beneficiada) por seus efeitos". ${ }^{553}$ A cessão, nessa medida, apenas geraria efeitos em relação à sociedade a partir da efetiva averbação na Junta Comercial.

A decisão versa sobre temática relevante. Foi correta, sem dúvida, ao esclarecer que terceiros não são afetados enquanto não registrado o instrumento de cessão

\footnotetext{
${ }^{551}$ STJ, REsp n. 1.415.543-RJ, $3^{\text {a }}$ T., rel. Min. Paulo de Tarso Sanseverino, j. 07.06.2016 (afirmando que, na relação jurídica entre o cedente e o cessionário, o contrato é eficaz desde a data de sua assinatura).

${ }^{552}$ STJ, REsp n. 1.415.543-RJ, $3^{\text {a }}$ T., rel. Min. Paulo de Tarso Sanseverino, j. 07.06.2016.

${ }^{553}$ STJ, REsp n. 1.415.543-RJ, $3^{\text {a }}$ T., rel. Min. Paulo de Tarso Sanseverino, j. 07.06.2016.
} 
da quota social, pois o conhecimento efetivo ou pressuposto é condição essencial para a oponibilidade a terceiros. O aspecto mais difícil da decisão diz respeito à eficácia do negócio jurídico perante a sociedade. Em um caso como o ocorrido, em que a totalidade dos sócios anuiu com a cessão, seria possível sustentar que, ainda não averbada a alteração do contrato social, o cessionário deveria ser tratado nas relações internas como sócio, ou seja, ainda antes do registro, o cessionário deveria poder fiscalizar os negócios sociais $(\mathrm{CC}$, art. 1.021), ou receber distribuições de dividendos na qualidade de sócio, ou ser excluído ou retirar-se da sociedade. Diferente do que ocorre em Portugal, porém, em que se estabelece que a "transmissão de quota entre vivos torna-se eficaz para com a sociedade logo que lhe for comunicada por escrito ou por ela reconhecida, expressa ou tacitamente" $\left(\mathrm{CSC}\right.$, art. $\left.228^{\circ}, 3\right),{ }^{554}$ e no direito estrangeiro em geral, ${ }^{555}$ no Brasil é a própria eficácia da cessão perante a sociedade que fica dependente do registro ( $\mathrm{CC}$, art. 1.003, caput). O julgado, nessa medida, foi correto ao estabelecer que, a princípio, somente a averbação gera a eficácia perante a sociedade.

No caso concreto, porém, considerando a circunstância de que a totalidade dos sócios anuiu com a cessão, seria possível analisar o caso sob a perspectiva da desconsideração atributiva para imputar à própria sociedade a eficácia do instrumento de cessão, visto que ele foi assinado por todos os sócios. Não é claro no julgado se a sociedade se manteve com o mesmo quadro societário entre a assinatura do instrumento de cessão e a cobrança da dívida. Caso a resposta fosse positiva, considera-se que a própria sociedade não poderia legitimamente cobrar o sócio que cedeu sua participação uma vez transcorridos dois anos da cessão, ainda que não tivesse se completado o prazo de dois anos do registro.

(3) Tutela do cessionário de boa-fé

\footnotetext{
${ }^{554}$ CORTEZ, Jorge Simões. “As formalidades da transmissão de quotas e acções no Direito Português: dos princípios à prática”. Op. cit., p. 329.

${ }_{555}$ WALD, Arnoldo. Comentários ao novo Código Civil. Op. cit., p. 389.
} 
Diferente das ações, que são títulos de crédito, as quotas são posições contratuais. O princípio regente da matéria é o de que não se pode transferir mais direitos do que se possui (nemo plus iuris ad alium transferre potest quam ipse habet). ${ }^{556}$ No caso de cessão de quotas por alguém que as adquiriu sem título, por exemplo, em razão de o ato jurídico que embasou a transmissão da quotas ter sido anulado ou declarado inexistente, o cessionário não possui direito sobre a quota.

e) Responsabilidade do cedente

Após a averbação da cessão da quota, o cedente responde solidariamente com o cessionário, perante a sociedade e terceiros, pelas obrigações que tinha como sócio (CC, art. 1.057, par. único c/c art. 1.003, par. único). O regramento é similar ao previsto em matéria de resolução da sociedade em relação a um sócio (CC, art. 1.032), razão pela qual a interpretação dos normativos é comum.

A primeira leitura dos dispositivos mencionados poderia induzir à interpretação de que, cedendo a quota, o sócio passaria a responder não somente perante a sociedade, mas também perante terceiros pelas dívidas sociais, como expressamente determina o art. 1.003, par. único do Código Civil. Não é essa, porém, a correta inteligência dos dispositivos legais.

Nas sociedades limitadas, a responsabilidade de cada sócio é solidária pela integralização do capital social (CC, art. 1.052), passando a ser limitada à quota após a integralização. Seria contraditório, dessa forma, argumentar que o cedente de quota de limitada deveria responder perante terceiros pelas dívidas sociais solidariamente com o cessionário. Tal linha argumentativa imporia ao ex-integrante, que deixa de ser sócio, uma responsabilidade mais grave do que a imposta aos demais sócios, ${ }^{557}$ incoerência que não encontra fundamento jurídico. A interpretação literal dos dispositivos também não pode ser considerada decisiva, pois é necessário compreender os contextos em que cada um deles se

\footnotetext{
${ }^{556}$ CORTEZ, Jorge Simões. "As formalidades da transmissão de quotas e acções no Direito Português: dos princípios à prática”. Op. cit., p. 328.

${ }^{557}$ SPINELLI, Luis Felipe. Exclusão de sócio por falta grave na sociedade limitada. Op. cit., p. 467 (analisando o art. 1.032 do Código Civil, mas cuja interpretação é aplicável à hipótese de cessão da quota, como observa o autor à p. 466, na nota de rodapé 1083).
} 
inserem. O parágrafo único do art. 1.003 do Código Civil inscreve-se no capítulo destinado à sociedade simples, na qual vige o princípio da responsabilidade ilimitada, mas subsidiária, pelas obrigações sociais (CC, art. 997, VIII, art. 1.023 e art. 1.024). Nas sociedades limitadas, como se afirmou, o regime é diverso, de limitação de responsabilidade. É natural, portanto, que a cessão da quota da sociedade simples conduza à permanência da responsabilidade de que o sócio já era destinatário, perante a sociedade e perante terceiros. No caso da limitada, por simetria, o cedente permanece com a responsabilidade que possuía quando sócio, e que não abarca a responsabilidade perante terceiros pelas dívidas sociais. ${ }^{558}$

No âmbito da sociedade limitada, por conseguinte, o cedente permanece responsável solidariamente com os demais quotistas (i) pela integralização do capital social (CC, art. 1.052); (ii) pela exata estimação dos bens conferidos ao capital social até que corridos cinco anos da data de registro da sociedade ou do aumento de capital social (CC, art. 1.055, $\left.\S 1^{\circ}\right)$; (iii) pelos bens que aportou para a formação do capital social $(\mathrm{CC}$, art. 1.005). ${ }^{559} \mathrm{O}$ cessionário que tenha satisfeito a dívida, nesse caso, pode cobrar integralmente do cedente o valor pago, não se aplicando a presunção de responsabilidade proporcional entre os devedores solidários (CC, art. 283). ${ }^{560}$ Permanece, porém, exclusiva responsabilidade do cedente, sem solidariedade com o cessionário (i) o dever de reparar danos causados à sociedade na condição de administrador; (ii) a responsabilidade ilimitada decorrente da participação em deliberações ilegais (CC, art. 1.080); e (iii) o dever de repor lucros e quantias retiradas a qualquer título com prejuízo do capital social (CC, art. 1.059). O fundamento da responsabilidade, nessas hipóteses, é o ato ilícito praticado pelo sócio, não se incluindo como responsabilidade inerente à quota. ${ }^{561}$

O ponto mais polêmico na interpretação desses dispositivos, contudo, não diz com a responsabilidade do cedente perante a sociedade, mas perante terceiros, tendo em vista que há hipóteses reconhecidas pela legislação e pela jurisprudência nas quais se admite a desconsideração da personalidade jurídica. As dúvidas interpretativas que podem se colocar quando há um pleito de desconsideração da personalidade jurídica após a cessão

\footnotetext{
${ }^{558}$ SPINELLI, Luis Felipe. Exclusão de sócio por falta grave na sociedade limitada. $O$ p. cit., p. 468.

${ }^{559}$ SPINELLI, Luis Felipe. Exclusão de sócio por falta grave na sociedade limitada. Op. cit., p. 468-469; CAVALLI, Cássio. Sociedades limitadas: regime de circulação das quotas. Op. cit., p. 92.

${ }^{560}$ CAVALLI, Cássio. Sociedades limitadas: regime de circulação das quotas. Op. cit., p. 92.

${ }^{561}$ GONÇALVES NETO, A. de A. Direito de empresa, 4a ed. São Paulo: RT, 2013, p. 212; CAVALLI, Cássio. Sociedades limitadas: regime de circulação das quotas. Op. cit., p. 92.
} 
da quota buscando atingir o ex-sócio referem-se a saber se (i) se o débito deve ser anterior à averbação; (ii) se a desconsideração deve decorrer de fatos ocorridos enquanto o cedente era sócio; e (iii) se a desconsideração deve ser postulada, ou, no limite, deferida até o final do biênio.

(1) Necessidade de débito ser anterior à averbação do contrato social

O cedente responde solidariamente com o cessionário pelas responsabilidades que tinha como sócio pelo prazo de dois anos. Algumas decisões consideram que, no âmbito da desconsideração da personalidade jurídica por fraude ou abuso, o cedente responderia por fatos ocorridos no biênio posterior à alteração do contrato social, ainda que não fosse mais sócio. ${ }^{562}$ Em matéria trabalhista, ademais, admite-se amplamente a possibilidade de desconsideração da personalidade jurídica para atingir o patrimônio do sócio que indiretamente se beneficiou da relação de emprego e, na hipótese em que o contrato de trabalho inicia-se durante o período prévio à saída e permanece vigente após a averbação da cessão, prevalece a orientação de determinar o montante total das verbas trabalhistas, dividi-las pelo número de meses de duração do contrato, e multiplicar o resultado pela quantidade de meses decorridos antes da averbação do registro, imputando o valor obtido como responsabilidade ao cedente. ${ }^{563}$ Apesar da busca da proporcionalidade presente na fórmula, o fato é que o numerador passa a ser integrado por débitos decorrentes de fatos posteriores à cessão, o que importa também uma responsabilidade, ainda que mitigada, por obrigações de que o sócio não era destinatário.

Na desconsideração ocorrida no âmbito de processo falimentar, ademais, julgou-se que se beneficiariam da desconsideração da personalidade não somente os credores de obrigações contraídas pela sociedade antes da saída dos sócios, pois, afirmada a relação de causalidade entre os atos fraudulentos dos sócios e o estado de insolvência e esvaziamento patrimonial, no entendimento do STJ, a superação da pessoa jurídica

\footnotetext{
${ }^{562}$ TJSP, AI n. 0101904-49.2012.8.26.0000, 29a Câm. Dir. Priv., rel. Des. Ferraz Felisardo, j. 03.04.2013; TJSP, AI n. 056661-29.2010.8.26.0000, 20ª Câm. Dir. Priv., rel. Des. Rebello Pinho, j. 18.04.2011.

${ }^{563}$ SPINELLI, L. F. Exclusão de sócio por falta grave na sociedade limitada. São Paulo: Quartier Latin, 2015, p. 474-475 (com indicação de jurisprudência).
} 
estenderia aos antigos sócios a responsabilidade por todos os créditos habilitados, ainda que sua constituição tenha sido posterior à transferência da posição de sócio. ${ }^{564}$

As orientações mencionadas pecam por atentar contra a disposição literal da lei. A responsabilidade do cedente é "pelas obrigações que tinha como sócio" (CC, art. 1.003, par. único), não pelas que viria a ter. Não é possível, por conseguinte, haver responsabilização do sócio por fatos ocorridos ou por dívidas incorridas após a averbação da cessão, como reconhecem, com razão, doutrina e jurisprudência majoritárias. ${ }^{565}$

(2) Fato gerador da desconsideração da personalidade jurídica anterior à averbação do contrato social

O fato gerador da possibilidade de desconsideração da personalidade jurídica, como o abuso da personalidade jurídica ou confusão patrimonial, deve ter ocorrido previamente à cessão da quota social para que haja responsabilidade do cedente, sob pena de se considerar que a responsabilidade do cedente poderia ser agravada por atos de terceiros praticados sob a orientação do cessionário. ${ }^{566}$ Há, porém, situações nas quais se pretende atribuir ao sócio cedente responsabilidade no âmbito da desconsideração da personalidade jurídica a despeito de o fato gerador da desconsideração ter ocorrido após a cessão da quota. É o que ocorre, sobretudo, no âmbito da dissolução irregular que se segue à cessão da quota social.

\footnotetext{
${ }^{564}$ STJ, REsp n. 1.180.714-RJ, 4a T., rel. Min. Luis Felipe Salomão, j. 05.04.2011.

${ }^{565}$ GONÇALVES NETO, Alfredo de A. Direito de empresa, 4a ed. São Paulo: RT, 2013, p. 212; SPINELLI, Luis Felipe. Exclusão de sócio por falta grave na sociedade limitada. Op. cit., p. 471. Na jurisprudência: TJSP, Ap. n. 0034145- 33.2010.8.26.0002, $21^{\text {a }}$ Câm. Dir. Priv., rel. Des. Itamar Gaino, j. 17.09.2012; TJSP, Ap. n. 1009320-15.2014.8.26.0019, 14 Câm. Dir. Priv., rel. Des. Lígia Araújo Bisogni, j. 18.08.2015; TJSP, Ap. n. 0009023-25.2012.8.26.0268, $1^{\text {a }}$ Câm. Res. Dir. Empr., rel. Des. Claudio Godoy, j. 28.08.2014; TJSP, AI n. 0060667-35.2012.8.26.0000, $8^{\text {a }}$ Câm. Dir. Priv., rel. Des. Salles Rossi, j. 07.05.2014; TJSP, AI n. 2040520-17.2013.8.26.0000, 15a Câm. Dir. Priv., rel. Des. Castro Figliolia, j. 06.02.2014; TJSP, AI n. 0096439-59.2012.8.26.0000, rel. Des. Ana de Lourdes Coutinho Silva, $13^{\mathrm{a}}$ Câm. Dir. Priv., j. 06.06.2012; TJSP, Ap. n. 0003976-86.2011.8.26.0565, $16^{\text {a }}$ Câm. Dir. Priv., rel. Des. Luís Fernando Lodi, j. 03.04.2012; TJDF, AI n. 0032934-20.2015.8.07.0000, 4 T. Cív., rel. Des. James Eduardo Oliveira, j. 03.09.2016.

${ }^{566}$ SPINELLI, Luis Felipe. Exclusão de sócio por falta grave na sociedade limitada. Op. cit., p. 471.
} 
É assente na jurisprudência que a dissolução irregular representa violação à legislação que regula o fim da personalidade jurídica (CC, art. 51, §2 $2^{\circ}$, art. 1.102), razão pela qual os sócios que a promovem respondem ilimitadamente pelos débitos sociais (CC, art. 1.080). ${ }^{567}$ Após a cessão das quotas de controle, o cessionário, conhecendo a atividade, pode cessar irregularmente as atividades, sem que o cedente tenha participação em tal decisão. É comum, porém, que a dissolução irregular inscreva-se como elemento de fraude que se inicia com a cessão das quota de controle. Reconhecendo que a sociedade não terá condições de continuar suas atividades e adimplir seus débitos, é conhecido o expediente de se promover cessão da quota a homem de palha sem condições econômico-financeiras que não se imiscui minimamente na gestão social e abandona a sociedade, levando a um encerramento de fato das atividades sociais sem regular dissolução e liquidação. Supondo, portanto, que a cessão de quotas de controle ocorra e, posteriormente, a sociedade tenha suas atividades empresariais encerradas sem regular dissolução e liquidação, surge a questão de determinar se o cedente responderia pelas obrigações inadimplidas cujo fato gerador ocorreu durante sua participação na sociedade.

Em matéria tributária, a responsabilidade pessoal do "sócio-gerente" (denominação antiga, utilizada pelo Decreto Lei 3.708/1919, art. 10), atual sócio administrador $\left(\mathrm{CC}\right.$, art. $\left.1.063, \S 1^{\circ}\right)$, pressupõe a prática de ato com excesso de poderes ou infração de lei, contrato social ou estatutos (CTN, art. 135, III). No âmbito do STJ, firmouse o entendimento de que o mero inadimplemento de obrigação tributária não basta para a atração da responsabilidade pessoal. ${ }^{568} \mathrm{O}$ redirecionamento da execução fiscal para o sócio administrador, porém, é legitimado na hipótese de dissolução irregular da sociedade, a qual é presumida quando a empresa deixa de funcionar no seu domicílio fiscal sem comunicação aos órgãos competentes (STJ, Súmula 435). A responsabilidade do cedente e do cessionário por débitos tributários, nesses casos, devem ser analisadas autonomamente. Se o encerramento irregular da sociedade ocorre depois da alteração do contrato social e mesmo que durante o prazo de dois anos, reconhece-se pacificamente que o cedente não é responsável pelas dívidas físcais da pessoa jurídica, ainda que o respectivo fato gerador tenha ocorrido no período em que participava da administração da empresa. ${ }^{569}$ A regra conhece exceção no caso de a cessão da quota ser considerada fraudulenta, promovida para

\footnotetext{
${ }^{567}$ STJ, REsp n. 586.222-SP, $4^{\mathrm{a}}$ T., rel. Min. Luis Felipe Salomão, j. 23.11.2010.

${ }^{568}$ STJ, REsp n. 728.461-SP, $1^{\mathrm{a}}$ T., rel. Min. Teori Albino Zavascki, j. 06.12.2005.

${ }^{569}$ STJ, REsp n. 728.461-SP, $1^{\text {a }}$ T., rel. Min. Teori Albino Zavascki, j. 06.12.2005. No mesmo sentido: STJ, EREsp n. 100.739-SP, $1^{\text {a }}$ S., rel. Min. José Delgado, j. 06.12.1999
} 
transferir a quota a um homem de palha que não possui condição econômica de suportar a execução fiscal, com o escopo de afastar qualquer responsabilidade tributária do cedente. Nesse caso, a própria cessão da quota de controle será considerada como hipótese de ato em infração à lei, numa espécie de ato antecedente que atrai para o cedente o redirecionamento da execução físcal, mesmo que o cedente não conste do quadro societário quando da dissolução irregular. ${ }^{570} \mathrm{~A}$ responsabilidade do cessionário, por outro lado, sofreu alteração em 2015..$^{571}$ Historicamente, considerava-se que o sócio administrador cessionário que promovia a dissolução irregular somente responderia por débitos tributários que tivessem sido incorridos pela pessoa jurídica durante sua administração, ou seja, após a averbação da cessão. A orientação foi alterada sob o fundamento de que a dissolução irregular seria ato ilegal que atrai integralmente a responsabilidade tributária da pessoa jurídica para o sócio, independentemente do momento em que surgiu a dívida tributária, de tal forma que seriam "irrelevantes a data do surgimento da obrigação tributária (fato gerador) bem como o vencimento do respectivo débito fiscal". 572

Em matéria cível, há julgados que consideram a dissolução irregular posterior à cessão como causa para que se promova a desconsideração da personalidade jurídica, sem que se afirme que a própria cessão da quota seria fraudulenta. ${ }^{573} \mathrm{~A}$ despeito de o fundamento da desconsideração ser posterior à cessão da quota, considera-se que o cedente por elas responderia no prazo de dois anos.

O caminho trilhado em matéria tributária parece o mais adequado e deve ser aplicado, mutatis mutandis, para as demais disciplinas de responsabilidade. O sócio cedente não pode ser responsabilizado pela posterior dissolução irregular da sociedade, promovida pelo cessionário. A única exceção é a hipótese em que o próprio ato de cessão é promovido com conhecimento de que o cessionário não conduzirá as atividades sociais,

\footnotetext{
${ }^{570}$ STJ, REsp n. 1.520.257-SP, $2^{\mathrm{a}}$ T., rel. Min. Og Fernandes, j. 16.06.2015.

${ }^{571}$ STJ, REsp n. 1.520.257-SP, $2^{\mathrm{a}}$ T., rel. Min. Og Fernandes, j. 16.06.2015.

${ }^{572}$ STJ, REsp n. 1.520.257-SP, $2^{\mathrm{a}}$ T., rel. Min. Og Fernandes, j. 16.06.2015.

${ }^{573}$ SPINELLI, L. F. Exclusão de sócio por falta grave na sociedade limitada. Op. cit., p. 470-477 (com indicação de farta jurisprudência).
} 
razão pela qual a própria cessão poderia ser considerada como ato abrangido pela definição de ato em infração à legislação. ${ }^{574}$

(3) Desconsideração da personalidade jurídica deve ser pleiteada ou deferida no prazo de dois anos

A responsabilidade do cedente prolonga-se pelo prazo de dois anos e há decisões que consideram a medida desconsiderativa, em função disso, deveria ser pleiteada pela parte interessada dentro do biênio, ${ }^{575}$ ao passo que outras decisões consideram que também a medida de decretação da desconsideração da personalidade deveria ocorrer dentro do biênio. ${ }^{576}$

Seguindo a linha jurisprudencial que considera o prazo de dois anos como limite para que seja decretada a desconsideração, ter-se-ia uma distinção entre a possibilidade de responsabilização do acionista controlador que transfere suas ações e o quotista controlador que faz o mesmo em relação a suas quotas. No segundo caso, a desconsideração pleiteada pelo credor de fato ocorrido antes da alteração societária não atingiria o sócio cedente a menos que a desconsideração fosse decretada durante o biênio.

O Superior Tribunal de Justiça, porém, tem diferenciado a hipótese de permanência da responsabilidade do sócio pelo prazo de dois anos das situações de responsabilização pela via da desconsideração. Julgou-se que prazo de dois anos trata "da ultratividade da responsabilidade do sócio pelas obrigações da sociedade em situações

\footnotetext{
${ }^{574}$ Nesse sentido: STJ, REsp n. 1.312.591-RS, 4 ${ }^{\mathrm{a}}$ T., rel. Min. Luis Felipe Salomão, j. 11.06.2013; TJSP, AI n. 0111876-43.2012.8.26.0000, 24 ${ }^{\mathrm{a}}$ Câm. Dir. Priv., rel. Des. Cesar Mecchi Morales, j. 18.10.2012 (afirmando que a posterior inatividade da empresa não pode ser atribuída ao ex-sócio - que, no caso, havia se retirado - a menos que comprovada a má-fé).

${ }^{575}$ TJSP, AI n. 0070322-94.2013.8.26, $1^{\text {a }}$ Câm. Dir. Priv., rel. Des. Elliot Akel, j. 18.06.2013 (caso referente a pedido de desconsideração realizado sete anos após alteração do contrato social, mas julgado também com base no fato de que origem do título judicial foi posterior à alteração).

576 TJSP, AI n. 616.903-4/2-00, 1 a Câm. Dir. Priv., rel. Des. Luiz Antonio de Godoy, j. 17.03.2009; TJSP, AI n. 2033856-33.2014.8.26.0000, 26 a Câm. Dir. Priv., rel. Des. Bonilha Filho, j. 30.04.2014; TJSP, AI n. 0090810-70.2013.8.26.0000, 2a Câm. Res. Dir. Empr., rel. Des. Ricardo Negrão, j. 17.03.2014; TJSP, AI n. 2060398-25.2013.8.26.0000, 27 ${ }^{\mathrm{a}}$ Câm. Dir. Priv., rel. Des. Morais Pucci, j. 11.02.2014; TJSP, Ap. n. 0214139-18.2010.8.26.0100, 38 Câm. Dir. Priv., rel. Des. Mauro Conti Machado, j. 11.12.2013; TJSP, AI n. 0111876-43.2012.8.26.0000, 24ª Câm. Dir. Priv., rel. Des. Cesar Mecchi Morales, j. 18.10.2012; TJSP, AI n. 2033995-19.2013.8.26.0000, 2ª Câm. Dir. Priv. Rel. Neves Amorim, j. 05.11.2013.
} 
ordinárias", não sendo aplicável à hipótese de responsabilidade extraordinária, fundada na existência de abuso de direito, como ocorre no âmbito da desconsideração da personalidade jurídica. ${ }^{577}$ Considerou-se, ademais, que a desconsideração da personalidade jurídica seria medida diversa da responsabilidade societária, implicando exercício de direito potestativo pelo credor, buscando o reconhecimento da ineficácia relativa da pessoa jurídica. O autor do pedido de desconsideração, por conseguinte, exerceria direito potestativo, reclamando tutela constitutiva positiva, sujeita a decadência e não à prescrição. Como o Código Civil não prevê expressamente prazo decadencial para o exercício do direito de pleitear a desconsideração, conclui-se que "[à] míngua de previsão legal, o pedido de desconsideração da personalidade jurídica, quando preenchidos os requisitos da medida, poderá ser realizado a qualquer momento". 578

Aa duas linhas jurisprudenciais parecem parcialmente inadequadas. A jurisprudência paulista, ao impor o prazo de dois anos como termo final dentro do qual a desconsideração deveria ser decretada, ignorando a orientação do STJ, não distingue adequadamente entre a responsabilidade societária mencionada no art. 1.003 do Código Civil e a responsabilidade extraordinária imposta para o sócio com base na desconsideração da personalidade jurídica. É mérito das decisões do STJ tratar com clareza a diversidade da natureza jurídica dos fundamentos de responsabilidade. A linha argumentativa seguida pelo STJ, contudo, ao ver decretação da desconsideração da personalidade jurídica espécie de exercício de direito potestativo não sujeito a decadência impõe ao sócio uma exposição indefinida e perpétua à ação de terceiros, em desprestígio à segurança jurídica.

O mais adequado parece avaliar que, mesmo que a desconsideração não esteja sujeita a decadência, os fatos de abuso ou confusão patrimonial em que ela se funda são atos ilícitos, razão pela qual seria aplicável o prazo prescricional de três anos $(\mathrm{CC}$, art. 206, $\S 3^{\circ}, \mathrm{V}$ e VI). ${ }^{579}$ A responsabilidade daquele que transmite ações ou quotas, nesse sentido, seria a mesma.

\footnotetext{
${ }^{577}$ STJ, REsp n. 1.269.897-SP, $3^{\text {a }}$ T., rel. Min. Sidnei Beneti, j. 05.03.2013; STJ, AgRg na MC n. 20.472-DF, $4^{\mathrm{a}}$ T., rel. Min. Marco Buzzi, j. 03.09.2013.

${ }^{578}$ STJ, REsp n. 1.180.714-RJ, 4 ${ }^{\mathrm{a}}$ T., rel. Min. Luis Felipe Salomão, j. 05.04.2011; STJ, REsp n. 1.312.591RS, $4^{\mathrm{a}}$ T., rel. Min. Luis Felipe Salomão, j. 11.06.2013;

${ }^{579}$ SPINELLI, Luis Felipe. Exclusão de sócio por falta grave na sociedade limitada. Op. cit., p. 475.
} 
f) Repercussões sobre o nome empresarial: necessidade de alteração da firma ou da denominação social

O nome empresarial da sociedade limitada pode adotar firma ou razão social ou denominação, integradas pela palavra "limitada" ou pela abreviatura "Ltda." (CC, art. 1.158 , caput). A firma é composta pelo nome de um ou mais sócios pessoas físicas (CC, art. $\left.1.158, \S 1^{\circ}\right)$, sem necessidade de que tal sócio esteja autorizado a representar a sociedade limitada. ${ }^{580}$ Também não há responsabilidade ilimitada do sócio por seu nome constar da firma social da limitada. ${ }^{581}$ A denominação, por sua vez, deve designar o objeto da sociedade, sendo permitido que nela figure o nome de um dos sócios (CC, art. 1.158, $\S 2^{\circ}$ ). A cessão da quota social é relevante no caso de constar o nome do cedente da firma ou denominação, pois vige na formação do nome social o princípio da veracidade, implícito no Código Civil ${ }^{582}$ e positivado explicitamente na regulação do registro empresarial (Lei n. 8.934/1994, art. 34; Decreto 1.800/1996, art. 62, caput; Manual do Registro de Sociedade Limitada, item 1.2.15; Instrução Normativa DREI 15/2013, art. $4^{\circ}$ ).

Como expressão do princípio da veracidade, determina-se que o nome do sócio não pode ser conservado na firma social se este vier a falecer, for excluído ou se retirar (CC, art. 1.165). A cessão da quota social não está mencionada no dispositivo. Determina-se, por outro lado, que o nome empresarial não pode ser objeto de alienação (CC, art. 1.164), mas que o "adquirente de estabelecimento, por ato entre vivos, pode, se o contrato o permitir, usar o nome do alienante, precedido do seu próprio, com a qualificação de sucessor" (CC, art. 1.164, par. único). Seria possível, em leitura conjunta, pretender que o cessionário de quota de controle poderia ser equiparado ao "adquirente de estabelecimento" e continuar a firma do cedente na qualidade de sucessor. Trata-se, porém, de interpretação que conflitaria com o princípio expresso de que somente o nome dos sócios pode constar da firma (CC, art. 1.158, $\S 1^{\circ}$ ), e não de ex-sócios. $\mathrm{O}$ art. 1.164 do Código Civil, ademais, regula o nome empresarial do estabelecimento, seguindo a lista de

\footnotetext{
${ }^{580}$ SPINELLI, Luis Felipe. Exclusão de sócio por falta grave na sociedade limitada. Op. cit., p. 568. Em sentido contrário, mas sem fundamentação: WALD, Arnoldo. Comentários ao novo Código Civil. Op. cit., p. 790.

${ }_{581}^{5}$ WALD, Arnoldo. Comentários ao novo Código Civil. Op. cit., p. 789.

582 CARvalhosa, Modesto. Comentários ao Código Civil. Op. cit., p. 706; VIO, Daniel de A. A exclusão de sócios na sociedade limitada de acordo com o Código Civil de 2002. Dissertação de Mestrado- FDUSP, São Paulo, 2008, p. 213; SPINELLI, Luis Felipe. Exclusão de sócio por falta grave na sociedade limitada. Op. cit., p. 570.
} 
dispositivos pertinentes a cada uma das modalidades de exercício de empresa, aplicáveis (i) ao empresário individual (CC, art. 1.156); (ii) à sociedade com sócios de responsabilidade ilimitada (CC, art. 1.157); (iii) à sociedade limitada (CC, art. 1.158); (iv) à cooperativa (CC, art. 1.159); (v) à sociedade anônima (CC, art. 1.160); (vi) à comandita por ações (CC, art. 1.161); e (vii) à sociedade em conta de participação (CC, art. 1.162). O "adquirente de estabelecimento", nesse dispositivo legal, não pode ser equiparado ao cessionário da quota de controle, razão pela qual se deve considerar que a cessão da quota pelo quotista cujo nome integre a firma social deve conduzir à alteração da firma, a menos que o referido cedente permaneça sócio, sem possibilidade de aplicação analógica do disposto no parágrafo único do art. 1.164 do Código Civil.

No caso de falecimento, exclusão ou retirada do sócio cujo nome constava da denominação, há quem defenda que, na limitada, tal qual ocorre na sociedade anônima (CC, art. 1.160, par. único), o nome empresarial passaria a ser considerado com feição de homenagem a uma pessoa determinada, sem necessidade de alteração da denominação social formada com base no patronímico. ${ }^{583} \mathrm{O}$ raciocínio poderia ser estendido para a hipótese de cessão da quota. A leitura, contudo, parece equivocada porque, na denominação da sociedade limitada admite-se somente o nome de sócios (CC, art. 1.158, $\S 2^{\circ}$ ), razão pela qual, em caso de sua saída do quadro social por qualquer motivo, mostrase necessária a alteração da denominação. ${ }^{584}$

\section{Obrigação do comprador: pagamento do preço}

Na compra e venda, a principal obrigação do comprador é pagar o preço em dinheiro (CC, art. 481). Trata-se de elemento essencial que qualifica o contrato de compra e venda, ${ }^{585}$ diferenciando-o de outros tipos contratuais como a doação (em que não há contraprestação pecuniária: $\mathrm{CC}$, art. 538) ou a troca ou permuta (em que a contraprestação é a transferência de propriedade de outro bem: CC, art. 533).

\footnotetext{
${ }^{583}$ GONÇALVES NETO, A. de A. Direito de empresa. Op. cit., p. 692; CRISTIANO, Romano. Sociedades limitadas. São Paulo: Malheiros, 2008, pp. 185-186.

${ }^{584}$ TOKARS, Fábio. Sociedades limitadas. Op. cit., p. 110; SPINELLI, Luis Felipe. Exclusão de sócio por falta grave na sociedade limitada. Op. cit., p. 572.

${ }^{585}$ IUDICA, Giovanni. "Il prezzo nella compravendita di partecipazioni azionarie". Op. cit., p. 754.
} 


\section{Negociação e fixação do preço}

$\mathrm{Na}$ compra e venda de participações societárias de controle de sociedades empresárias, o patrimônio em geral é constituído por bens organizados para o exercício de empresa. O preço, por conseguinte, é calculado e negociado pelas partes tendo em vista avaliação que se faz da própria empresa.

A avaliação empresarial, porém, é tarefa especialmente complexa, marcada por grande subjetivismo. ${ }^{586} \mathrm{~A}$ avaliação dos bens não se esgota na determinação do valor dos próprios bens, pois a sua união faz surgir um novo valor, relativo à organização. As partes, em vista disso, em geral adotam critérios de mensuração como a análise da rentabilidade, de eventuais reservas ocultas, da estrutura tributária (para avaliar a possibilidade de aproveitamento de créditos existentes), do aviamento, da clientela, ou avaliação por múltiplos. ${ }^{587} \mathrm{O}$ método varia consideravelmente conforme o porte da companhia. Tratando-se de companhias abertas, pode-se utilizar como referência também o valor de negociação em bolsa, ainda que se ressalte que, em geral, esse é apenas um dos pontos de partida adotados pelas partes na negociação. ${ }^{588}$ No caso de sociedades fechadas, por outro lado, muitos métodos de avaliação adotados para grandes empresas, como é o caso do cálculo por fluxo de caixa descontado podem-se revelar inadequados para fins de avaliação, pois se ressalta que "a small business is not a little big business". ${ }^{589}$ No caso de sociedades de menor porte, com efeito, deve-se considerar o fato de que normalmente há uma base de clientes menos pulverizada, reduzida disponibilidade de capital próprio, possível falta de autonomização completa da esfera organizativa societária em relação à

\footnotetext{
${ }^{586}$ SCHREIER, Terrance; JOY, O. Maurice. "Judicial valuation of 'close' corporation stock: Alice in Wonderland revisited”. In: Okla. L. Rev., v. 31, 1978, pp. 853-885, p. 856.

${ }^{587}$ TINA, Andrea. Il contratto di acquisizione di partecipazioni societarie. Op. cit., p. 134; ANTUNES, José Engrácia. "A empresa como objecto de negócios ("asset deal" vs. "share deal')". Op. cit., p. 771; IUDICA, Giovanni. "Il prezzo nella compravendita di partecipazioni azionarie". Op. cit., p. 758.

${ }_{588}^{58}$ IUDICA, Giovanni. "Il prezzo nella compravendita di partecipazioni azionarie". Op. cit., p. 756.

${ }^{589}$ FLEISCHER, Holger. "Unternehmensbewertung und Bewertungsabschläge beim Ausscheiden aus einer geschlossenen Kapitalgesellschaft”. In: KALSS, S.; FLEISCHER, H.; VOGT, H.-U. (org.). Gesellschaftsund Kapitalmarktrecht in Deutschland, Österreich und der Schweiz 2013. Tübingen: Mohr Siebeck, 2014, pp. 137-161, p. 140.
} 
dos sócios. ${ }^{590}$ Se o patrimônio social for composto por bens imóveis, por sua vez, o cálculo normalmente levará em conta sobretudo o valor dos bens.

A referência aos critérios concretos utilizados pela prática adquire relevância tanto para a interpretação do negócio jurídico (CC, art. 113), quanto para a aplicação de remédios contratuais, como é o caso do dolo acidental, ${ }^{591}$ ou garantias contratualmente negociadas. ${ }^{592}$ Sendo expressa a forma de cálculo do preço utilizada pelas partes, defende-se, por exemplo, que eventual deformidade ocultada dolosamente pelo vendedor impõe dever de pagar indenização que tome como base o preço na forma como foi calculado. Se as partes utilizaram como critério um múltiplo da rentabilidade (EBITDA) e depois se descobre que a rentabilidade era menor que a afirmada, omitida pela atuação dolosa do vendedor, também a indenização deveria ser calculada tendo em vista o múltiplo adotado. ${ }^{593}$

Apesar de o raciocínio ser, a princípio, correto e adequado, deve-se ter em conta dois riscos inerentes à reconstrução da vontade das partes. O primeiro diz respeito ao fato de que a compra e venda de participações societárias não é um procedimento de avaliação empresarial, mas uma negociação que pode-se pautar pela atividade de avaliação, mas nela não se esgota. $\mathrm{O}$ preço, apesar de ser normalmente reputado como representação material do valor do bem vendido, em verdade não pode ser assim considerado. $^{594}$

O valor de um bem não existe de forma objetiva, cabendo ao direito contratual, como princípio, permitir que sua formação ocorra mediante a interação dos agentes do mercado. ${ }^{595}$ Juridicamente, esse reconhecimento da inexistência de um valor

\footnotetext{
${ }^{590}$ FLEISCHER, Holger. "Unternehmensbewertung und Bewertungsabschläge beim Ausscheiden aus einer geschlossenen Kapitalgesellschaft". Op. cit., p. 141.

${ }^{591}$ MARTINS-COSTA, Judith. "Os regimes do dolo civil no Direito Brasileiro: dolo antecedente, vício informativo por omissão e por comissão, dolo acidental e dever de indenizar”. In: RT, v. 923, 2012, pp. 115143, p. 137 (afirmando a necessidade de análise dos critérios usuais para a formação do preço para a possibilidade de cálculo das perdas e danos devidas em decorrência do dolo acidental).

${ }_{592}$ RUSSO, Fábio. "Das cláusulas de garantia nos contratos de compra e venda de participações sociais de controlo”. In: DSR, v. 4, 2010, pp. 115-136, p. 130.

${ }^{593}$ MARTINS-COSTA, Judith. "Os regimes do dolo civil no Direito Brasileiro: dolo antecedente, vício informativo por omissão e por comissão, dolo acidental e dever de indenizar”. Op. cit., p. 137.

${ }^{594}$ HÜBNER, Ulrich. "Der gerechte Preis". In: BAUR, Jürgen F. (org., et. al.). In: Festschrift für Ernst Steindorff zum 70. Geburtstag. Berlin/New York: De Gruyter, 1990, pp. 589-610, p. 590-591 (referindo que, na base da possibilidade de rescisão contratual por laesio enormis estava a pressuposição de um valor objetivo das prestações no direito canônico e comum).

${ }^{595}$ FLEISCHER, Holger. Informationsasymmetrie im Vertragsrecht. München: C. H. Beck, 2001, p. 66.
} 
justo e inerente fica evidente, por exemplo, na consideração de que o preço não constitui qualidade essencial da coisa, não fundamentando, por conseguinte, a anulação do negócio jurídico por erro substancial. ${ }^{596}$. O preço sempre representa, com isso, o resultado de uma avaliação subjetiva, realizada por alguém, sejam as partes, seja o mercado, seja um árbitro. ${ }^{597}$ Para além de a apuração ser subjetiva, o preço depende da negociação realizada pelas partes. ${ }^{598}$ Como apontou IUDICA, o preço é "filho do mercado, filho das circunstâncias, da força, da resistência, da habilidades das partes nas tratativas, o preço é filho da necessidade de vender ou da conveniência ou mesmo absoluta necessidade de comprar" ${ }^{599} \mathrm{O}$ preço, em vista disso, apenas corresponde à obrigação do vendedor, mas não expressa de forma objetiva o seu valor. ${ }^{600}$

O segundo risco a ser advertido diz respeito ao fato de que, em contratos de compra e venda de participações societárias de controle, é comum a hipótese de serem pactuadas cláusulas de declarações e garantias, por meio das quais o vendedor não se obriga somente a transferir ações ou quotas, mas também a garantir determinada situação patrimonial da sociedade. O comprador, com isso, não adquire somente ações ou quotas, mas, em certa medida, "adquire" as próprias garantias negociadas. ${ }^{601} \mathrm{O}$ preço, nessa medida, apresenta-se como contraprestação das participações societárias e, de forma incindível, também das obrigações assumidas pelo vendedor no contrato. ${ }^{602}$

\section{Modalidades de preço}

Para a existência da compra e venda, as partes devem alcançar consenso quanto ao preço. O valor exato do preço não precisa ser sempre previamente determinado (CC, art. 482). Ele pode ser determinável, desde que os critérios para fixação do preço estejam fixados ex ante, ${ }^{603}$ sendo possível a obtenção do preço sem que seja necessária nova manifestação de vontade pelas partes contratantes. O contrato de compra e venda,

\footnotetext{
${ }^{596}$ FLEISCHER, Holger. Informationsasymmetrie im Vertragsrecht. Op. cit., p. 104.

${ }^{597}$ IUDICA, Giovanni. "Il prezzo nella compravendita di partecipazioni azionarie". Op. cit., p. 751.

${ }^{598}$ QUACK, Karlheinz. “Der Unternehmenskauf und seine Probleme”. In: ZGR, 1982, pp. 350-365, p. 358.

599 IUDICA, Giovanni. "Il prezzo nella compravendita di partecipazioni azionarie". Op. cit., p. 751 ("il prezzo è figlio del mercato, figlio delle circostanze, della forza, della resistenza, della abilità delle parti nelle trattative, il prezzo è figlio del bisogno di vendere o della convenienza oppure della assoluta necessità di comprare").

${ }^{600}$ IUDICA, Giovanni. "Il prezzo nella compravendita di partecipazioni azionarie”. Op. cit., p. 752.

${ }^{601}$ CBS, Inc. v. Ziff Davis Publishing Co., 75 N.Y.2d 496 (1999), pp, 502-503. Essa decisão é discutida com maior detalhamento no item IV.B.2, infra.

${ }^{602}$ TINA, Andrea. Il contratto di acquisizione di partecipazioni societarie. Op. cit., p. 131.

${ }^{603}$ TINA, Andrea. Il contratto di acquisizione di partecipazioni societarie. Op. cit., p. 137.
} 
dessa forma, somente se aperfeiçoa quando eventual atividade posterior exigida das partes para determinação do preço tenha caráter de atuação e reconhecimento, mas não decisória. $^{604}$

Se o preço não é determinado ou determinável, a única alternativa prevista no Código Civil é o recurso ao preço corrente nas vendas habituais do vendedor (CC, art. 488). ${ }^{605}$ Participações de controle, porém, são infungíveis e não possuem um valor corrente de mercado. Como regra geral, ademais, o art. 488 somente pode ser aplicado quando se possa depreender da intenção comum das partes a consideração de que o contrato estaria concluído, não para surpreendê-las. ${ }^{606}$ Faltando consenso sobre o preço, dessa forma, o contrato não existe. ${ }^{607}$

a) Preço determinado

O preço determinado é aquele que encontra precisa expressão monetária ${ }^{608} \mathrm{e}$ é determinado pelas próprias partes. ${ }^{609}$ Ainda que derive de avaliação econômica realizada pelas partes ou por terceiros durante a negociação do contrato, o preço determinado autonomiza-se, de tal forma que, ainda que haja equívoco de uma parte sobre tais premissas, via de regra, tal erro sobre os motivos se mostra irrelevante. ${ }^{610}$

b) Preço determinável

O preço é determinável quando seu valor é parcial ou totalmente indefinido. Na compra e venda de participações societárias de controle, é comum que ao menos parte

\footnotetext{
${ }^{604}$ TINA, Andrea. Il contratto di acquisizione di partecipazioni societarie. Op. cit., p. 137, nota 228.

${ }^{605}$ TJSP, Ap. c/ rev. n. 1104540-0/9, $28^{\mathrm{a}}$ Câm. Dir. Priv., rel. Des. Celina Trigueiros Pinto, j. 06.11 .2007 (em caso de compra e venda de soja, determinou-se que a "falta de fixação do preço não equivale à sua inexistência").

${ }^{606}$ Nesse sentido, justificativa de autoria de Cristiano de Sousa Zanetti à proposta de Enunciado aprovada sob o n. 441 na V Jornada de Direito Civil do Conselho da Justiça Federal, realizada em 2011.

${ }^{607}$ AZEVEDO, Antônio Junqueira de. Negócio jurídico: existência, validade e eficácia, $4^{\mathrm{a}}$ ed. atual. São Paulo: Saraiva, 2002, p. 44. Em sentido diverso: ANDRADE, Ronaldo Alves de. In: ALVIM, Arruda; ALVIM, Thereza (coord.). Comentários ao Código Civil Brasileiro, v. 5. Rio de Janeiro: Forense, 2007, n. 238 , p. 752 (refere a nulidade).

${ }^{608}$ IUDICA, Giovanni. "Il prezzo nella compravendita di partecipazioni azionarie". Op. cit., p. 755.

${ }^{609}$ BERNINI, Giorgio. "Acquisizione di società e determinazione del prezzo". In: GALGANO, Francesco (org.). I contratti del commercio, dell'industria e del mercato finanziario, tomo primo. Torino: UTET, 1995, pp. 217-245, p. 232.

${ }^{610}$ LANCIANI, Andrea. "Il prezzo (modalità, aggiustamenti, garanzie del pagamento dilazionato)". In: IRRERA, Maurizio (org.). Le acquisizione societarie. Bologna: Zanichelli, 2011, pp. 319-335, p. 321. Sobre o assunto, cf. item V.C, infra.
} 
do preço tenha sua fixação confiada a terceiro (CC, art. 485); possa ser determinada em função de índices ou parâmetros suscetíveis de determinação objetiva (CC, art. 487); ou fique condicionada à verificação de eventos futuros e incertos (CC, art. 121).

$$
\text { Preço determinado por terceiro avaliador: arbitramento }
$$

Quando as partes conferem a terceiro o poder de determinar o preço, tem-se um contrato de compra e venda com preço determinável. ${ }^{611} \mathrm{O}$ Código Civil dedica um único dispositivo à hipótese, prevendo que "a fixação do preço pode ser deixada ao arbítrio de terceiro, que os contratantes logo designarem ou prometerem designar" e que, "se o terceiro não aceitar a incumbência, ficará sem efeito o contrato, salvo quando acordarem os contratantes designar outra pessoa" (CC, art. 485).

O dispositivo menciona apenas a possibilidade de a fixação do preço ser deixada ao arbítrio de terceiro, tal qual o fazia o art. 1.123 do Código Civil de 1916. Tratase de regra que se assemelha ao art. 1592 do Code Civil francês, herdeiro direto do direito romano. ${ }^{612} \mathrm{Na}$ prática, porém, o preceito não precisaria constar do âmbito do contrato de compra e venda, nem precisaria restringir as partes ao poder de outorgar a outrem a fixação do preço. Outros ordenamentos reconhecem que em qualquer contrato (e não somente na compra e venda) questões de fato (e não somente o preço) podem ser fixadas pelo terceiro. ${ }^{613}$ Mesmo na França, admite-se que outros aspectos do contrato podem ter sua fixação confiada a um terceiro, ${ }^{614}$ solução que no direito brasileiro também se sustenta, com base no princípio da autonomia privada.

\footnotetext{
${ }^{611}$ PONTES DE MIRANDA, FRANCISCO C. Tratado de direito privado, t. 39 . Op. cit., $\$ 4.268$, p. 36. Contra: CARVAlHO SANTOS, Jorge M. Código Civil Brasileiro interpretado. Op. cit., p. 24 (considerando que o preço seria "determinado" quando sua fixação fosse confiada a terceiro, sem justificativa para tal posicionamento).

${ }_{612}$ POTHIER, R. J. Traité du contrat de vente, 1 t. Paris/Orléans: s/e, 1772, n. 24, p. 21 (referindo expressamente Justiniano). KLEINSCHMIDT, Jens. Delegation von Privatautonomie auf Dritte. Tübingen: Mohr Siebeck, 2014, p. 38.

${ }^{613}$ KLEINSCHMIDT, Jens. "Die Bestimmung durch einen Dritten im Europäischen Vertragsrecht". In: RabelsZ, v. 76, 2012, pp. 785-818, p. 788 (é o caso da Alemanha, em que o $\$ 317$ do BGB se refere à determinação da prestação; e da Itália, em que o art. 1349 do codice civile menciona a prestação deduzida no contrato).

${ }^{614}$ KLEINSCHMIDT, Jens. "Die Bestimmung durch einen Dritten im Europäischen Vertragsrecht”. Op. cit., p. 788 .
} 
Contratos de compra e venda de participações societárias são o "domínio de predileção" da determinação de preço por terceiro. ${ }^{615}$ Não significa isso, contudo, que ocorra com frequência a situação prevista no art. 485 em sua forma pura. As partes geralmente não confiam "ao arbítrio de terceiro" o poder de determinar quanto um contratante pagará, quanto o outro receberá. ${ }^{616}$ A delegação de poderes a terceiro avaliador somente ocorre quando os contratantes não podem ainda determinar o preço por si próprios. No contrato de compra e venda de participações o que ocorre, em geral, é que se fixam critérios e parâmetros quando da assinatura do contrato definitivo ou preliminar de compra e venda (signing) e, posteriormente, é confiada a um terceiro a determinação do valor dos ativos que, uma vez obtido e integrado na fórmula contratualmente negociada, conduzirá à fixação do preço definitivo. ${ }^{617}$ Não se outorga ao terceiro, dessa forma, a estimação livre, nem a possibilidade de agir por equidade. Vinculam-se as partes somente a um exame técnico, ${ }^{618}$ de tal forma que, uma vez exarada a opinião, passa ela a integrar o contrato por expressa vontade das partes. Não procuram um arbitrador, senão um perito contratual. $^{619}$

(a) Diferença entre arbitramento e arbitragem

O terceiro que determina questões de fato realiza tarefa que é designada como "arbitramento", em oposição à arbitragem, pois não há exercício de jurisdição, nem se confia ao avaliador o poder de decidir questões de direito. ${ }^{620} \mathrm{O}$ árbitro (arbiter) resolve um litígio entre as partes; o arbitrador (arbitrator), apenas complementa o conteúdo contratual. ${ }^{621}$ Essas missões não podem ser confundidas. ${ }^{622}$ Se as partes contratam

${ }^{615}$ CAFFIN-MOI, Marie. Cession de droits sociaux et droit des contrats. Op. cit., n. 200, p. 136 (" $L a$ cession de droits sociaux est le domaine de prédilection de la détermination du prix par un tiers"); TINA, Andrea. Il contratto di acquisizione di partecipazioni societarie. Op. cit., p. 138, nota 231; REDONDO TRIGO, Francisco. "La impugnación de la determinación del precio por un tercero en los contratos de compraventa de acciones y la sentencia del tribunal supremo de 1 de septiembre de 2006". In: RCDI, n. 704, 2007, pp. 2766-2782, p. 2766.

${ }^{616}$ KLEINSCHMIDT, Jens. Delegation von Privatautonomie auf Dritte. Op. cit., p. 32.

${ }^{617}$ KLEINSCHMIDT, Jens. Delegation von Privatautonomie auf Dritte. Op. cit., p. 41.

${ }^{618}$ ARAGÃO, E. D. Moniz de. "Participação do Poder Judiciário no arbitramento de preço cuja fixação foi deixada a terceiro". In: RePro, v. 13, 1979, pp. 177-187, p. 181.

${ }^{619}$ MARANI, Giovanni. "In tema di arbitrato, arbitraggio, perizia contrattuale". In: RTDPC, 1983, pp. 610627, p. 613.

${ }^{620}$ CARMONA, Carlos A. Arbitragem e processo, $3^{\text {a }}$ ed. São Paulo: Atlas, 2009, p. 228.

${ }^{621}$ CAFFIN-MOI, Marie. Cession de droits sociaux et droit des contrats. Op. cit., n. 203, p. 138.

${ }^{622}$ No direito brasileiro, cf. CARMONA, Carlos Alberto. Arbitragem e processo, $3^{\text {a }}$ ed. São Paulo: Atlas, 2009, p. 228. BAPTISTA, Luiz Olavo. Arbitragem comercial e internacional. São Paulo: Lex Editora, 
procedimento para a nomeação de um ou mais avaliadores para definir o preço de ações ou quotas, há delegação da fixação do preço ao terceiro, e não cláusula compromissória arbitral.

O STJ, em decisão recente - e potencialmente paradigmática, pela falta de precedentes específicos sobre o assunto - relativa a contrato de compra e venda de ações, parece não ter atentado corretamente para a distinção supra mencionada. ${ }^{623}$ Pelo que se depreende do relatório, haviam as partes determinado que, caso não obtivessem acordo quanto ao valor das ações, nomeariam dois avaliadores (um avaliador por cada parte). Se necessário, os dois avaliadores apontariam, conjuntamente, um terceiro com vistas a apresentar o valor de mercado da empresa, o qual seria definitivo para as partes. ${ }^{624} \mathrm{~A}$ maioria seguiu o voto do relator, para quem o "avaliador" mencionado pelas partes deveria ser “compreendido como 'árbitro', na medida em que, no caso dos autos, a ele se atribuiu a função de dirimir específica controvérsia (decisão sobre o valor das ações a serem adquiridas), com força definitiva e em substituição às partes". Determinou-se, com isso, a celebração de compromisso arbitral perante o juízo (Lei de arbitragem, art. $7^{\circ}$ ).

O posicionamento é passível de críticas por adotar como critério distintivo da arbitragem e do arbitramento um aspecto que não as distingue. $\mathrm{O}$ caráter definitivo da decisão é característica comum da arbitragem do arbitramento. Em ambas as modalidades de submissão das partes à determinação de terceiros, há intenção de que a decisão seja vinculante. O que diferencia as modalidades, como se disse, é a escolha de confiar ao terceiro a solução de uma questão de fato, como é o caso da fixação do preço das ações, ou de direito. Os avaliadores, pelo que se depreende do caso, deveriam promover acertamento da situação patrimonial da sociedade para calcular o valor das ações; não deveriam exercer jurisdição. Por mais que a cláusula se revelasse lacunosa (não era clara a solução a ser tomada caso uma das partes não indicasse o seu avaliador), como bem observou o Min. Ricardo Villas BôAs Cueva em voto-vista vencido, "em verdade, a menção feita no

2011, p. 29; TEPEDINO, Gustavo; BARBOZA, Heloísa H.; MORAES, Maria Celina B. de. Código civil interpretado, v. 2, $2^{\mathrm{a}}$ ed. Rio de Janeiro: Renovar, 2012, p. 147; PONTES DE MIRANDA, FRANCISCO C. Tratado de direito privado, t. 39. Op. cit., $\$ 4.268$, p. 43.

${ }^{623}$ STJ, REsp n. 1.569.422-RJ, $3^{\mathrm{a}}$ T., rel. Min. Marco Aurélio Bellizze, j. 26.04.2016.

${ }^{624}$ A cláusula transcrita no acórdão tinha o seguinte teor: "Caso não seja acordado tal valor dentro de 30 (trinta) dias, as partes nomearão dois avaliadores (um indicado por cada parte), que apontarão um terceiro, se necessário for, e no prazo de no máximo 60 (sessenta) dias apresentarão o valor de mercado para a(s) Empresa(s). A decisão dos avaliadores será final, definitiva e acatada pelas partes" (STJ, REsp n. 1.569.422RJ, $3^{\mathrm{a}}$ T., rel. Min. Marco Aurélio Bellizze, j. 26.04.2016). 
instrumento à indicação de avaliadores não passou de uma cláusula de arbitramento ou de peritagem, que, como cediço, por não se confundir com a cláusula de arbitragem, não tem sua revisão excluída da esfera judicial". ${ }^{625}$ Diante da dificuldade de implementação do mecanismo, caberia ao juízo tomar uma decisão jurisdicional que as partes não confiaram aos árbitros: declarar o contrato definitivamente ineficaz, ou, dando-lhe cumprimento, indicar novo avaliador ou proceder diretamente à avaliação judicial. ${ }^{626}$

Apesar da clara divisão de competências entre o arbitrador, de um lado, e o juiz ou árbitro, de outro, na prática a distinção entre as esferas pode ser difícil. Em contratos relativos a participações societárias, é comum que as partes determinem que um auditor deve avaliar a sociedade pautado por cálculo de múltiplo de rentabilidade fixado em fórmula contratual. ${ }^{627}$ Toda aplicação de um contrato, porém, pressupõe sua interpretação. Se a cláusula contratual não for unívoca, o avaliador precisará tomar posição e adotar uma dentre eventuais possíveis interpretações para que possa bem cumprir o seu mister. A admissibilidade dessa apreciação pelo avaliador, contudo, é discutível. ${ }^{628}$ No direito alemão, admite-se que, ao confiar ao avaliador a fixação do preço, as partes delegam-lhe também o poder de determinar definitivamente questões jurídicas pressupostas (rechtliche Vorfragen) para a avaliação, não cabendo recurso ao Poder Judiciário ou à arbitragem. ${ }^{629}$ Não poderia o juiz ou árbitro, dessa forma, interpretar, no lugar do avaliador, o que as partes quiseram exprimir por meio da fórmula contratual cuja observância impuseram ao próprio avaliador. Na França, por outro lado, nega-se a possibilidade de qualquer interpretação contratual pelo avaliador, cabendo sempre ao juiz ou tribunal decidir as questões relativas ao direito. A jurisprudência, porém, não apresenta critérios claros para definir quando o avaliador apreciou apenas questões de fato e quando analisou o direito. As decisões a respeito do assunto são consideradas contraditórias, ora revendo as premissas adotadas pelo avaliador, ora não. ${ }^{630} \mathrm{~A}$ despeito das dificuldades

${ }^{625}$ STJ, REsp n. 1.569.422-RJ, 3 ${ }^{\mathrm{a}}$ T., rel. Min. Marco Aurélio Bellizze, j. 26.04.2016

${ }^{626}$ Sobre o assunto, cf. item II.C.2.b)(1)(b), infra.

${ }^{627}$ KLEINSCHMIDT, Jens. Delegation von Privatautonomie auf Dritte. Op. cit., p. 782.

${ }^{628}$ SACHS, Klaus. "Die rechtliche Abgrenzung des Schiedsgutachtens vom Schiedsverfahren am Beispiel des Unternehmenskaufvertrages". In: BACHMANN, Birgit (org., et. al.). Grenzüberschreitungen Festschrift für Peter Schlosser zum 70. Geburtstag. Tübingen: Mohr Siebeck, 2005, pp. 805-820 (comparando o direito francês e alemão com referência a cláusulas de determinação de preço em contratos de compra e venda de estabelecimentos ou de participações societárias).

${ }^{629}$ KLEINSCHMIDT, Jens. Delegation von Privatautonomie auf Dritte. Tübingen: Mohr Siebeck, 2014, p. 784.

${ }^{630}$ OPPETIT, Bruno. "Sur le concept d'arbitrage". In: FOUCHARD, P. (org., et. al.). Droit des relations économiques internationales - Études offertes a Berthold Goldman. Paris: Litec, 1982, pp. 229-239, p. 231. 
ínsitas à separação entre matéria de fato e de direito, ${ }^{631}$ não parece haver como negar às partes a possibilidade de valer-se da jurisdição quando considerem indevida a interpretação jurídica conferida à cláusula contratual.

(b) Impossibilidade de indicação do avaliador

Indicada uma ou mais pessoas - normalmente, pessoas jurídicas formadas por auditores - pode ocorrer de o indicado não aceitar o encargo. A consequência prevista em lei é de que "ficará sem efeito o contrato, salvo quando acordarem os contratantes designar outra pessoa" (CC, art. 485). A despeito da clareza do texto, algumas questões práticas podem se colocar. O julgado do STJ referido no item anterior exemplifica os problemas que podem advir e que se assemelham, mutatis mutandis, à temática das "cláusulas patológicas" no âmbito arbitral. A primeira diz com a pluralidade de avaliadores e a falta de acordo entre eles; a segunda, com a impossibilidade de o mecanismo de avaliação operar sem a concordância de uma das partes, o que sujeitaria o contrato a ficar sem efeito.

Se há mais de um avaliador, diferente do que ocorre no caso de uma arbitragem, não há obrigatoriedade, nem possibilidade, de os avaliadores adotarem uma solução por maioria. Cada avaliador responde por sua avaliação. Se as partes não atribuem "voto de qualidade" a um deles, considera-se que o contrato seria ineficaz. ${ }^{632}$ A solução, porém, parece inadequada. Se não há regra sobre qual preço deve prevalecer, há lacuna no contrato, que pode ser integrada por meio de interpretação integrativa. ${ }^{633}$ Não se pode, com efeito, presumir que as partes somente pretendiam se vincular reciprocamente se todos os avaliadores fossem absolutamente concordes em suas apreciações independentes; o

\footnotetext{
631 CASTANHEIRA NEVES, António. Questão-de-facto - questão-de-direito ou o problema metodológico da juridicidade. Coimbra: Almedina, 1967.

${ }^{632}$ CARVALHO SANTOS, Jorge M. Código Civil Brasileiro interpretado. Op. cit., p. 29.

${ }^{633}$ KLEINSCHMIDT, Jens. Delegation von Privatautonomie auf Dritte. Op. cit., p. 178. Sobre a interpretação integrativa, cf. LARENZ, Karl. Methodenlehre der Rechtswissenschaft, $6^{\mathrm{a}}$ ed. Berlin (et. al.): Springer, 1991, p. 300 (interpretação deve buscar completar as lacunas contratuais por meio do da "justiça do próprio contrato", fundada na boa-fé); HENCKEL, Wolfram. "Die ergänzende Vertragsauslegung". In: AcP, v. 160, 1960, pp. 107-126; FINKENAUER, Thomas. "Ergänzende Auslegung bei Individualabreden". In: AcP, v. 213, 2013, pp. 619-651, p. 630-642 (ressaltando que a interpretação integrativa deve buscar reconstruir normativamente a vontade hipotética das partes); ALMEIDA, Carlos Ferreira de. "Interpretação do Contrato". In: Revista de direito do consumidor, v. 17, 1996, pp. 5-19, p. 10 (preferindo a tradução “interpretação integradora"); MENEZES CORDEIRO, A. M. da R. Da boa-fé no direito civil. Coimbra: Almedina, 1983, p. 1066 (preferindo a expressão "interpretação contratual complementadora" para se referir à interpretação da regulação objetiva do contrato).
} 
objetivo das partes - ainda que não tenha sido expresso corretamente - é de se vincularem à opinião dos três, de tal forma que se poderia, na dúvida, aceitar o valor médio, excluída a maior e a menor avaliação, como expressamente se determina no direito alemão (BGB, $\S 317$, Abs. 2).

O precedente do STJ referido acima ${ }^{634}$ apresenta uma segunda possibilidade de cláusula "patológica". Exigia-se que cada uma das partes elegesse um avaliador e que ambos os avaliadores apontassem conjuntamente um terceiro. Não se previa, contudo, nenhuma consequência para a falta de indicação por uma delas. A decisão - jurídica - que precisava ser tomada e que o STJ remeteu - sem fundamento - à instância arbitral era a de afirmar se o contrato deveria remanescer sem efeito pela impossibilidade de colocar em prática o mecanismo contratual, ou se o juízo deveria intervir para suprir a lacuna no mecanismo, seja para fixar por meio de perícia o preço das ações, seja para nomear um novo avaliador. No direito estrangeiro, há exemplos das três orientações.

A jurisprudência francesa, ao aplicar o art. 1592 do Code Civil - cuja similaridade com o art. 485 do Código Civil já foi ressaltada -, considera que o contrato permanece ineficaz se as partes não conseguirem colocar em prática o mecanismo contratual que definiram para a fixação do preço. ${ }^{635} \mathrm{O}$ posicionamento funda-se na consideração de que (i) as partes confiam sua decisão a um terceiro escolhido por meio do mecanismo que definiram, não a qualquer terceiro; (ii) o conceito de autonomia contratual existe não somente para conferir às partes o poder de se vincular, mas também para impor, como contrapartida, o ônus de que as próprias partes consigam aperfeiçoar o contrato para, só então, exigir do Poder Judiciário sua observância obrigatória; e (iii) não seria papel do juiz ou do árbitro (office $d u$ juge) imiscuir-se em questões negociais. ${ }^{636}$ A posição jurisprudencial, contudo, vem sendo objeto de críticas da doutrina predominante, que adota posicionamento favorável à manutenção da força obrigatória do contrato (favor contractus) e avalia que a jurisprudência em certos casos chancela a má-fé, ${ }^{637}$ permitindo que uma parte se valha da própria torpeza para impedir a fixação do preço. ${ }^{638}$

\footnotetext{
${ }^{634}$ STJ, REsp n. 1.569.422-RJ, $3^{\text {a }}$ T., rel. Min. Marco Aurélio Bellizze, j. 26.04.2016.

${ }^{635}$ GHESTIN, Jacques. La formation du contrat, $3^{\text {a }}$ ed. Paris: LGDJ, 1993, n. 696, pp. 675-679.

${ }^{636}$ KLEINSCHMIDT, Jens. Delegation von Privatautonomie auf Dritte. Op. cit., pp. 239-244.

${ }^{637}$ GHESTIN, Jacques. La formation du contrat. Op. cit., n. 696, pp. 676.

${ }^{638}$ CAFFIN-MOI, Marie. Cession de droits sociaux et droit des contrats. Op. cit., n. 228, p. 158.
} 
Diversamente da orientação francesa, tanto na Alemanha quanto na Itália e na Inglaterra adota-se posição favorável à preservação do contrato por meio da intervenção judicial para fixar o preço. Na Alemanha, o assunto foi objeto de intensa discussão durante o processo de redação do BGB. Na versão final, diferenciaram-se as hipóteses em que as partes confiam a um terceiro o poder de escolher o preço conforme o caráter presumivelmente personalista da escolha. Se o terceiro pode decidir por equidade, presume-se que a escolha das partes é intuitu personae, de tal forma que, se as partes não o indicam, fica o contrato sem efeitos (BGB, §319, Abs. 2). Se os contratantes apenas delegam ao terceiro tarefa de acertamento da situação de fato (feststellendes Schiedsgutachten) e o terceiro atua como perito para colocar em prática o mecanismo de preço que as partes delimitaram, o juiz decide no caso de o terceiro não querer ou não poder decidir (BGB, §319, Abs. 1). ${ }^{639}$ Solução similar à alemã foi adotada pelo direito italiano, em que, como regra geral, o juiz decide se o avaliador não aceitar a incumbência (Codice civile, art. 1349), ou, no caso da compra e venda, nomeia outro avaliador (Codice civile, art. 1.473). No direito inglês, desde o início do século XIX consolidou-se o entendimento de que as partes não poderiam ser obrigadas a transferir a um terceiro a confiança que depositariam somente em avaliador escolhido na forma que contrataram. ${ }^{640}$ Se uma das partes se recusasse a indicar um avaliador e impedisse pela sua inércia a obtenção do preço, o contrato ficaria sem efeito. Em uma decisão de 1982 considerada "espetacular" ${ }^{641}$ e reputada como "triunfo do bom senso sobre precedentes", ${ }^{642}$ porém, a House of Lords afastou-se de sua consolidada linha de decisões. ${ }^{643}$ Tratava-se de contrato de locação de plantas industriais em que os locatários teriam a opção de compra dos imóveis por uma soma que deveria ser acordada por dois avaliadores, um indicado por cada parte, ou por um terceiro indicado pelos avaliadores, caso não fosse obtido acordo entre os avaliadores indicados pelas partes. Os locatários exerceram a opção, mas os locadores recusaram-se a indicar o avaliador que lhes cabia. Revertendo a decisão das instâncias originais que decretaram a ineficácia do contrato, a House of Lords considerou que os precedentes históricos não seriam “aptos a sobreviver em um sistema jurídico

\footnotetext{
${ }^{639}$ KLEINSCHMIDT, Jens. Delegation von Privatautonomie auf Dritte. Op. cit., pp. 245-247.

${ }^{640}$ KLEINSCHMIDT, Jens. Delegation von Privatautonomie auf Dritte. Op. cit., pp. 247-253.

${ }^{641}$ KLEINSCHMIDT, Jens. Delegation von Privatautonomie auf Dritte. Op. cit., pp. 253.

${ }^{642}$ HARPUM, Charles; JONES, David Lloyd. "Certainty at one fell swoop". In: CLJ, v. 41, 1982, pp. 233236, p. 233.

${ }^{643}$ Sudbrook Trading Estate Ltd. V. Eggleton [1983] 1 AC 444 apud HARPUM, Charles; JONES, David Lloyd. "Certainty at one fell swoop". Op. cit..
} 
civilizado" 644 e que, ao permitir que a parte arrependida se desvencilhasse de sua obrigação, estar-se-ia promovendo um desserviço público, ${ }^{645}$ estimulando-se comportamentos oportunistas. Avaliou-se, assim, que o mecanismo contratual seria um meio para um fim, qual seja, a obtenção de um preço razoável. Na hipótese de inércia das partes em colocar em marcha as previsões contratuais, o juízo, por meio de perícia, poderia determinar apropriadamente o preço de compra. ${ }^{646}$ Trata-se de orientação jurisprudencial que hoje é tida como consolidada no direito inglês. ${ }^{647}$

Uma terceira vertente é representada pelas legislações modelo europeias (PECL, art. 6:106(1); DCFR, art. II.-9:106(i)). Em proposta inovadora em relação à existente nos ordenamentos jurídicos nacionais, fixou-se como regra geral a possibilidade de o juiz indicar novo avaliador caso aquele indicado pelas partes não pudesse ou não quisesse realizar a avaliação, ou se as partes não conseguissem indicar um avaliador, desde que essa indicação judicial não fosse contraditória com os termos do contrato ou com a vontade presumida das partes. ${ }^{648}$

No direito brasileiro, em linha com a doutrina francesa, defende-se que “nunca será possível que o juiz se substitua às partes, e, na falta de entendimento entre elas, designe um perito que proceda à determinação do preço ou avaliação da coisa". ${ }^{649} \mathrm{~A}$ exceção é representada por PONTES DE MIRANDA, para quem, havendo divergência entre os contratantes após o contrato, "pode qualquer dêles pedir ao juiz que perante êle se faça o arbitramento", ${ }^{650}$ e por CUNHA GONÇALVES, no mesmo sentido. ${ }^{651}$ Se a ação de uma parte é pressuposta para o mecanismo de avaliação, porém, não se pode admitir que tal parte se beneficie de postura de inércia que venha a adotar. É pautado por esse princípio de vedação da extração de vantagens da própria torpeza que o Código Civil estatui que se reputa verificada quanto aos efeitos jurídicos "a condição cujo implemento for maliciosamente obstado pela parte a quem desfavorecer" (CC, art. 129). Não há, ademais, impossibilidade

\footnotetext{
${ }^{644}$ HARPUM, Charles; JONES, David Lloyd. "Certainty at one fell swoop". Op. cit., p. 234.

${ }^{645}$ KLEINSCHMIDT, Jens. Delegation von Privatautonomie auf Dritte. Op. cit., p. 254.

${ }^{646}$ KLEINSCHMIDT, Jens. Delegation von Privatautonomie auf Dritte. Op. cit., pp. 255.

${ }^{647}$ KLEINSCHMIDT, Jens. Delegation von Privatautonomie auf Dritte. Op. cit., pp. $258-259$.

${ }^{648}$ KLEINSCHMIDT, Jens. "Die Bestimmung durch einen Dritten im Europäischen Vertragsrecht". Op. cit., pp. 806-808.

${ }^{649}$ PEREIRA, Caio M. da S. Instituições de direito civil, v. 3, $19^{\text {a }}$ ed. rev. Rio de Janeiro: GEN/Forense, 2015, n. 219, p. 159. No mesmo sentido, MONIZ DE ARAGÃO, Egas D. "Participação do Poder Judiciário no arbitramento de preço cuja fixação foi deixada a terceiro". Op. cit., p. 183.

${ }^{650}$ PONTES DE MIRANDA, FRANCISCO C. Tratado de direito privado, t. 39. Op. cit., §4.268, p. 37.

${ }^{651}$ CUNHA GONÇALVES, Luiz da. Da compra e venda no direito comercial brasileiro. Op. cit., p. 155.
} 
de o juiz decidir no lugar das partes quando se nota que não há, no contrato, nenhuma estipulação que confira caráter personalíssimo à escolha do avaliador e a tarefa atribuída ao terceiro seja técnica, não de avaliação por equidade. A lei confia ao juiz decisões nas quais ele decide sem parâmetros objetivos, como ocorre, de forma geral, no caso das sentenças determinativas, de que é exemplo a fixação de alimentos. ${ }^{652}$ Nas obrigações alternativas com pluralidade de optantes, na falta de unanimidade, o juiz decide (CC, art. 252, $\left.\S 3^{\circ}\right)$; no impasse entre sócios de sociedade anônima, o juiz decide no interesse da companhia (LSA, art. $129, \S 2^{\circ}$ ) É também um princípio assente na ordem processual a possibilidade de execução específica das contratações (CPC, art. 501). É condizente com esses regramentos e com os princípios em sua base que o juiz priorize a manutenção do contrato quando as partes concordaram em se submeter à avaliação técnica realizada por terceiro e, nesse caso, possa tomar decisão em substituição às partes, auxiliado por perito, sob contraditório, buscando garantir a obtenção de preço tecnicamente fundamentado, que passa a integrar a eficácia do contrato. Essa decisão judicial, por sua vez, é necessária, porque, se se chegou a ela, é certo que as partes não se colocaram em acordo durante o processo, e não se valeram da autonomia contratual de que são titulares para indicar conjuntamente avaliador da confiança de ambas com vistas a dar efetividade ao contrato.

(c) Possibilidade de impugnação do laudo

O valor fixado pelo terceiro é vinculante, pois sua atuação se baseia na própria autonomia privada das partes. Não há, porém, nenhum fundamento para afirmar que as partes que delegam à livre apreciação de terceiro a fixação do preço "não se reservam o direito de a impugnar", sendo a decisão "obrigatoria, ainda que iníqua",653 como quis CUNHA GONÇALVES, em lição acriticamente reproduzida. ${ }^{654}$ A vinculação material não representa renúncia do direito de ação. As partes que cometem a terceiro a fixação do laudo podem impugnar o trabalho realizado conforme julguem pertinente; não poderá o juiz considerá-las carecedoras de ação. Diversa dessa questão processual, de

\footnotetext{
${ }^{652}$ ARAGÃO, Paulo Cézar. "Reflexões sobre as sentenças determinativas”. In: RePro, v. 2, 1976, pp. 159168, p. 161.

${ }^{653}$ CUNHA GONÇALVES, Luiz da. Da compra e venda no direito comercial brasileiro. Op. cit., p. 154.

${ }^{654}$ CARVAlHO SANTOS, Jorge M. Código Civil Brasileiro interpretado. Op. cit., p. 26; LÔBO, Paulo L.

N. Comentários ao Código Civil, v. 6. São Paulo: Saraiva, 2003, p. 42; PEREIRA, Caio M. da S. Instituições de direito civil. Op. cit., n. 219, p. 159.
} 
pouco relevo, é a questão material de saber em quais hipóteses podem as partes afastar a vinculação que decorreria da opinião do terceiro, seja por motivos objetivos, seja por motivos subjetivos.

Uma situação concreta relativa à compra e venda de ações foi objeto de pareceres no Brasil. Tratava-se, no caso, da compra e venda de ações equivalentes a $45 \%$ do capital social do Banco Metropolitano de Investimentos. Em contrato epistolar, as partes concordaram que o preço unitário corresponderia à divisão do valor do ativo líquido pelo número de ações adquiridas, somado a um valor fixo de Cr\$3.000.000,00, e juros contados da contratação, cabendo à sociedade de auditoria Deloitte a apuração do valor do ativo líquido, tomando como base o último balanço aprovado da sociedade. ${ }^{65} \mathrm{~A}$ firma incumbida de fixar o valor do ativo líquido, sem auditar o balanço, incluiu o valor da cartapatente no valor do ativo líquido, muito embora tal montante não estivesse lançado no último balanço aprovado. O comprador, discordando da avaliação, encomendou o parecer técnico de outro auditor, que, ao expurgar o valor da carta-patente, obteve preço por ações correspondente a um quinto daquele obtido pela Deloitte.

O caso concreto bem exemplifica a problemática da possibilidade de controle judicial do laudo produzido pelo avaliador, questão para a qual o Código Civil não oferece uma resposta explícita. Consultado pelo comprador, MONIZ DE ARAGÃO considerou em parecer que, a despeito de o termo "arbítrio" ser utilizado no dispositivo legal (CC/2002, art. 485; CC/1916, art. 1.123), não seria lícito ao terceiro agir arbitrariamente. Isso porque o texto do Digesto apontado por CLÓVIS BEVILÁQUA como fonte remota do antigo artigo 1.123 mencionava a possibilidade de a estimação do preço ser confiada ao arbítrio de um bom varão (arbitrium boni viri, por oposição ao arbitrium merum) ${ }^{656} \mathrm{Na}$ mesma linha do Digesto, TEIXEIRA DE FREITAS, em nota ao art. 546 da Consolidação das leis civis, ressalta que o arbítrio mencionado no artigo seria o "arbítrio de bom varão" e que "posto que de bom varão, é arbítrio indouto, sugerido somente pela

\footnotetext{
${ }^{655}$ LIMA, Alcides de Mendonça. "Contrato de compra e venda de ações de banco. Fixação do preço por terceiro em desacordo com o contrato". In: RePro, v. 14, 1979, pp. 271-294, p. 271.

${ }^{656}$ MONIZ DE ARAGÃO, Egas D. "Participação do Poder Judiciário no arbitramento de preço cuja fixação foi deixada a terceiro". Op. cit., p. 182. Sobre a determinação do preço por terceiro no direito romano, cf. ZIMMERMANN, Reinhard. The law of obligations: roman foundations of the civilian tradition. Op. cit., pp. 254-255; KLEINSCHMIDT, Jens. Delegation von Privatautonomie auf Dritte. Op. cit., pp. 196-203.
} 
luz da razão natural". ${ }^{657}$ Outros autores referem a possibilidade de as partes (i) buscarem a anulação do contrato por dolo; ${ }^{658}$ (ii) impugnarem o laudo por erro ou dolo, manifesta iniquidade, ${ }^{659}$ ou porque o terceiro teria agido com má-fé ${ }^{660}$ ou se afastado dos parâmetros contratualmente definidos. ${ }^{661}$ Há, ainda, os que meramente consignam que o terceiro teria um dever de estipular valor justo, ${ }^{662}$ sem especificar qual seria a medida cabível para a hipótese de tal preceito não ser observado, e os autores que não se pronunciam sobre a possibilidade de controle material da avaliação, ${ }^{663}$ ou afirmam que as partes teriam o dever de acatar a estimativa do terceiro. ${ }^{664}$ Mesmo entre os que defendem a possibilidade de impugnação, contudo, não se encontra esforço argumentativo para buscar reconduzir as vias impugnativas a um fundamento legal, transparecendo certa importação acrítica de soluções estrangeiras.

A especificação do que significa "arbítrio" no art. 485 do Código Civil possui valor histórico, mas, de um lado, é limitada; de outro, pouco útil. É limitada porque somente como regra se deve presumir que o arbítrio confiado ao terceiro seja um julgamento por equidade. Nada impede, porém, que a decisão confiada ao terceiro seja, efetivamente, de puro arbítrio, se as partes expressamente o desejarem, ${ }^{665}$ hipótese que é expressamente prevista e regulada no direito alemão (BGB, §319, Abs. 2) e italiano (Codice civile, art. 1349, 1), com a peculiaridade de que, ainda nesse caso, a avaliação pode ser questionada se o terceiro age de má-fé (Codice civile, art. 1349, 2). É também uma distinção pouco útil porque as partes dificilmente não cometem ao terceiro o poder de decidir livremente. Como ocorreu no caso concreto mencionado, as partes esperam "um exame técnico, como que uma radiografia, para calcular o valor de cada uma das ações

\footnotetext{
${ }^{657}$ TEIXEIRA DE FREITAS, Augusto. Consolidação das leis civis, ed. fac-símile. Brasília: Senado Federal, 2003, pp. 356-357.

${ }^{658}$ CARVALHO SANTOS, Jorge M. Código Civil Brasileiro interpretado. Op. cit., p. 26; LÔBO, Paulo L. N. Comentários ao Código Civil. Op. cit., p. 42;

${ }^{659}$ GOMES, Orlando. Contratos, $26^{\text {a }}$ ed. atual. por A. Junqueira de Azevedo e F. P. de C. Marino. Rio de Janeiro: Forense, 2007, n. 180, p. 276; TEPEDINO, G.; BARBOZA, H. H.; MORAES, M. C. B. Código civil interpretado. Op. cit., p. 146.

${ }^{660}$ PEREIRA, Guilherme D. C.. Alienação do poder de controle acionário. Op. cit., p. 84.

${ }^{661}$ GOMES, Orlando. Contratos. Op. cit., n. 180, p. 276; PEREIRA, Guilherme D. C. Alienação do poder de controle acionário. Op. cit., pp. 84.

${ }^{662}$ ROSENVALD, Nelson. "Comentário ao art. 485". In: PELUSO, C. (coord.). Código Civil comentado, $9^{\mathrm{a}}$ ed. atual. São Paulo: Manole, 2015, p. 520

${ }^{663}$ PONTES DE MIRANDA, FRANCISCO C. Tratado de direito privado, t. 39. Op. cit., §4.268, p. 37; RODRIGUES, Silvio. Direito civil, v. 3, 30 ed. atual. São Paulo: Saraiva, 2004, n. 74, p. 144.

${ }^{664}$ PEREIRA, Caio M. da S. Instituições de direito civil. Op. cit., n. 219, p. 159; SERPA LOPES, Miguel M. de. Curso de direito civil.. Op. cit., p. 291;

${ }^{665}$ KLEINSCHMIDT, Jens. "Die Bestimmung durch einen Dritten im Europäischen Vertragsrecht". Op. cit., pp. 806-808.
} 
adquiridas". ${ }^{666}$ Normalmente, portanto, não se coloca a questão de diferenciar o arbitrium boni viri do arbitrium merum, porque as partes não outorgam decisão discricionária ao terceiro.

A possibilidade de impugnação do laudo por erro, manifesta iniquidade ou afastamento dos parâmetros definidos, por sua vez, deveria ser fundamentada juridicamente. No Brasil, essa necessidade de fundamentação se mostra relevante, porque não há no Código Civil previsão da impugnação. A situação é diversa, portanto, da existente nos regramentos modelos europeus, que se referem à possibilidade de impugnação de laudos que sejam claramente irrazoáveis (grossly unreasonable) (PECL, art. 6:106; DCFR, II-9:106(2)); na Alemanha, em que podem as partes impugnar a avaliação por erro, coação ou dolo (BGB, §318, Abs. 2); ou na Itália, em que o laudo é impugnável se manifestamente iníquo ou errôneo (Codice civile, art. 1349), países de cuja doutrina alguns comentadores brasileiros parecem ter haurido inspiração. Em Portugal, país que não conta com regramento semelhante ao alemão ou italiano, considera-se que o artigo 400 do Código Comercial, análogo ao art. 485 do Código Civil Brasileiro, não oferece adequadas proteções às partes, razão pela qual se considera que a determinação por terceiro não seria adequada, ou recomendável, para as compras e vendas de participações societárias. ${ }^{667}$ No Brasil, a doutrina, com raras exceções, ${ }^{668}$ parece não apontar com clareza quais seriam os fundamentos jurídicos para a impugnação judicial do laudo, sob quais condições ela poderia ser promovida, e no que consistiria tal impugnação.

Particularmente importante para a delimitação da possibilidade de impugnação é o estudo do direito francês que, no artigo 1592 do Code Civil, conta com regra semelhante à brasileira $(\mathrm{CC}$, art. 485). A despeito da falta de dispositivo expresso autorizando o controle material do laudo pelo juiz, considera-se que o fundamento do poder de determinação do terceiro implica também, de forma negativa, o seu limite

\footnotetext{
${ }^{666}$ MONIZ DE ARAGÃO, Egas D. "Participação do Poder Judiciário no arbitramento de preço cuja fixação foi deixada a terceiro". Op. cit., p. 181.

${ }^{667}$ CÂMARA, Paulo; BASTOS, Miguel Brito. "O direito da aquisição de empresas: uma introdução". $O p$. cit., pp. 50-51.

${ }^{668}$ Pelo que se tenha conhecimento, o maior esforço de fundamentação para a impugnação do laudo foi promovido em parecer sobre a fixação do preço em compra e venda de ações proferido por ORLANDO GOMES, que, valendo-se de lições doutrinárias francesas e espanholas, apontou que o laudo inepto representaria o desatendimento, pelo avaliador, das instruções do mandante ("Arbitramento por terceiro de preço para venda de ações. Desatendimento pelo arbirator às instruções das partes. Ineficácia, nulidade ou inexistência do contrato de compra e venda por falta de preço". In: Pareceres inéditos. Belo Horizonte: Nova Alvorada, 1999, pp. 209-217, p. 215).
} 
imanente, e com isso se justifica a intervenção judicial para afastar os efeitos do laudo que não se funda na vontade (efetiva ou presumida) dos contratantes. O avaliador é considerado um mandatário comum das partes, que as vincula em virtude da manifestação de vontade que proferiram. ${ }^{669}$ É por conta disso que POTHIER, referindo-se à possibilidade de o preço indicado ser iníquo, fundamenta a ausência de vinculação dos contratantes à avaliação por meio da própria vontade dos contratantes, uma vez que a intenção implícita dos que celebram o contrato não seria de se submeter a uma apreciação iníqua pelo terceiro, mas somente a uma estimação justa. ${ }^{670}$

Desenvolvendo essa concepção baseada na vontade hipotética das partes, a jurisprudência passou a negar a vinculação das partes em caso de erro grosseiro (erreur grossière), ${ }^{671}$ reconhecido no caso da compra e venda de participações societárias como aquele que alguém com qualificação técnica apropriada não cometeria, ${ }^{672}$ como erros de cálculo, ou a avaliação de bens imóveis pelo seu custo de aquisição, ou a avaliação da empresa pressupondo sua liquidação e não a sua continuidade, ${ }^{673}$ ou a intenção dolosa de prejudicar uma das partes. ${ }^{674}$ A qualificação do erro como "grosseiro", nesse contexto, é utilizada propositadamente para esclarecer que não se trata, na hipótese, do erro como vício do conhecimento, até porque o erro de terceiro dificilmente pode ser subsumido nas hipóteses de erro, dolo ou coação como pressupostos para a anulação do negócio jurídico. ${ }^{675}$

A segunda possibilidade de impugnação do laudo se dá quando o avaliador não segue instruções precisas ministradas pelas partes. Por aplicação do princípio de que o mandatário não vincula o mandante quando desborda de seus poderes (dépassement de pouvoir), afirma-se que, imposta ao terceiro a observância de fórmula de cálculo, deve ele

\footnotetext{
${ }^{669}$ CAFFIN-MOI, Marie. Cession de droits sociaux et droit des contrats. Op. cit., n. 213, p. 145.

${ }^{670}$ POTHIER, R. J. Traité du contrat de vente. Op. cit., n. 24, p. 22.

${ }^{671}$ CAFFIN-MOI, Marie. Cession de droits sociaux et droit des contrats. Op. cit., n. 231, p. 162.

${ }^{672}$ GARÇON, J.-P. "Fixation d'un prix de cession de titres et référence aux éléments comptables". In: JCP E, 2000, pp. 496-498, p. 498.

${ }^{673}$ COZIAN, Maurice; VIANDIER, Alain; DEBOISSY, Florence. Droit des sociétés, 26 a ed. Paris: LexisNexis, 2012, n. 801, p. 425; FLEISCHER, Holger; JAEGER, Felix. "Gesellschaftsrechtliche Anteilsbewertung in Frankreich gemäß Art. 1843-4 Code civil - Eine Vorstudie zur Komparatistik im Recht der Unternehmensbewertung". In: RabelsZ, v. 77, 2013, pp. 693-722, p. 707.

${ }^{674}$ WERTENSCHLAG, Bruno. "Prix déterminable et cession de droits sociaux". In: JCP E, I, 1999, n. 99 , pp. 503-508, p. 508.

${ }^{675}$ KLEINSCHMIDT, Jens. Delegation von Privatautonomie auf Dritte. Op. cit., p. 702.
} 
se ater estritamente ao quanto previsto. ${ }^{676} \mathrm{O}$ direito inglês, que também não conta com regra expressa sobre o controle material do laudo, é reticente quanto à possibilidade de controle material do erro, mas, tal qual o francês, recusa força vinculante à avaliação que não observa os parâmetros contratualmente fixados (departure from instructions in a material respect). ${ }^{677} \mathrm{Em}$ expressão que resume o entendimento prevalecente nas cortes, afirma-se que "if [the expert] has answered the right question in the wrong way, his decision will be binding. If he has answered the wrong question, his decision will be a nullity". ${ }^{678}$ A jurisprudência espanhola em matéria de compra e venda de ações, no mesmo sentido, recusa a vinculação das partes à auditoria realizada sem atenção aos preceitos formulados contratualmente. ${ }^{679}$

O terceiro limite material imanente deriva, por sua vez, da própria necessidade de controle material do laudo: se o laudo pode ser considerado não vinculante para as partes quando o avaliador técnico comete erro grosseiro ou não observa as instruções contratualmente fixadas, é necessário que o laudo seja passível de sofrer apreciação crítica pelo juízo e pelas partes. Somente pode ser submetido a crítica, porém, o laudo que apresente justificativa, ou seja, fundamentação técnica. Na jurisprudência alemã, julga-se imprestável, por exemplo, o laudo de avaliação de terreno no qual o avaliador afirma ter realizado "amplas pesquisas", mas não indica o valor de outros imóveis com base nos quais promoveu a comparação com o terreno a ser avaliado. ${ }^{680}$ A necessidade de fundamentação técnica é, portanto, consectário lógico da possibilidade de controle judicial e sua ausência justifica a impugnação. ${ }^{681}$

Sob o ponto de vista subjetivo, outro limite imanente extraído pela doutrina francesa diz respeito à possibilidade de controle do laudo por condições pessoais do avaliador. No direito brasileiro, entre as poucas referências na doutrina às qualificações que seriam exigidas do avaliador, menciona-se somente que não se aplicam ao avaliador as

\footnotetext{
${ }^{676}$ CAFFIN-MOI, Marie. Cession de droits sociaux et droit des contrats. Op. cit., n. 230, p. 160; COZIAN, Maurice; VIANDIER, Alain; DEBOISSY, Florence. Droit des sociétés. Op. cit., n. 801, p. 426.

${ }^{677}$ KLEINSCHMIDT, Jens. Delegation von Privatautonomie auf Dritte. Op. cit., p. 709.

${ }^{678}$ Jones v. Sherwood Computer Services Plc. [1992] 1 WLR 227, p. 287 apud KLEINSCHMIDT, Jens. Delegation von Privatautonomie auf Dritte. Op. cit., pp. 711.

${ }^{679}$ REDONDO TRIGO, Francisco. "La impugnación de la determinación del precio por un tercero en los contratos de compraventa de acciones y la sentencia del tribunal supremo de 1 de septiembre de 2006". Op. cit.

${ }^{680}$ BGH 23.11.1984, V ZR 120/83, in JurionRS 1984, 14009.

${ }^{681}$ KLEINSCHMIDT, Jens. Delegation von Privatautonomie auf Dritte. Op. cit., p. 548-550.
} 
regras de suspeição ou impedimento da legislação processual, ${ }^{682}$ e que o avaliador não poderia ser uma das partes. ${ }^{683}$ Mas o que dizer de uma situação julgada pela Cour de cassation no âmbito de contrato de compra e venda de ações: as partes determinam que um terceiro avalie os ativos para fixar o preço das ações e o vendedor, posteriormente, descobre que o avaliador trabalhara por dois anos como assessor financeiro de sociedade integrante do grupo de fato da compradora, fato que lhe foi omitido. ${ }^{684}$ No direito brasileiro, deixando de lado a discussão sobre eventual falha ao dever de informar que decorreria da boa-fé, haveria fundamento para afastar a vinculação das partes? A solução da Cour de cassation foi buscar no conceito de "terceiro", constante também do art. 485 do Código Civil, o fundamento para afirmar que a parte vinculada a um dos contratantes - e que, por isso, não possui independência necessária para desempenhar sua função imparcialmente - não seria efetivamente um "terceiro". ${ }^{685}$ No direito alemão, defende-se que os casos de impedimento para atuar como juiz e árbitro correspondem a manifestações da proibição de julgamento em causa própria, aplicáveis também ao avaliador. ${ }^{686}$ No Brasil, as hipóteses de impedimento e suspeição (CPC, art. 144 e 145) impedem a atuação de alguém como árbitro (Lei 9.307/1996, art. 14). Aplicar tal regra por analogia ao arbitramento parece excessivo, pois a atividade do arbitrador é eminentemente técnica. Isso não obstante, parece plenamente aplicável, por analogia, a obrigação de revelar, antes da aceitação da função, qualquer fator que denote dúvida justificada quanto à imparcialidade $\mathrm{e}$ independência (Lei 9.307/1996, art. 14, § $1^{\circ}$ ), sob pena de não vinculação dos contratantes ao laudo assim produzido.

No direito brasileiro, dessa forma, em linha sobretudo com a fundamentação apresentada no direito francês, considera-se possível a impugnação objetiva do laudo em que o avaliador (i) comete erro grosseiro; (ii) não segue as instruções fixadas pelas partes; ou (iii) impossibilita a avaliação da ocorrência de algum desses vícios ao não fornecer fundamentação técnica adequada, pois, nesses casos, o ato do terceiro não se encontra abrangido pela delegação de poderes promovida pelas partes. Igualmente, a impugnação subjetiva é possível quando o terceiro, indicado pelas partes, não se revelar um efetivo

\footnotetext{
${ }^{682}$ ANDRADE, Ronaldo Alves de. In: ALVIM, Arruda; ALVIM, Thereza (coord.). Comentários ao Código Civil Brasileiro. Op. cit., n. 238, p. 753.

${ }^{683}$ PONTES DE MIRANDA, FRANCISCO C. Tratado de direito privado, t. 39. Rio de Janeiro: Borsoi, 1962, §4.268, p. 37.

${ }^{684}$ KLEINSCHMIDT, Jens. Delegation von Privatautonomie auf Dritte. Op. cit., pp. 460.

${ }^{685}$ CAFFIN-MOI, Marie. Cession de droits sociaux et droit des contrats. Op. cit., n. 230, p. 160.

${ }^{686}$ KLEINSCHMIDT, Jens. Delegation von Privatautonomie auf Dritte. Op. cit., pp. 474.
} 
“terceiro", como prevê o art. 485 do Código Civil, por não ser imparcial e independente em relação a elas.

A avaliação do terceiro não configura uma declaração negocial. É ato de participação (ou comunicação) de conhecimento, ${ }^{687}$ mero ato de ciência. ${ }^{688} \mathrm{~A}$ impugnação do laudo, por consequência, não tem por objetivo anulá-lo e não se pauta pelo regime dos vícios da vontade. Na impugnação, uma das partes pleiteia, em face da outra, provimento judicial declaratório afirmando que o laudo impugnado não integrou o contrato e não gerou eficácia vinculante para as partes. O avaliador, por conseguinte, não deve integrar o polo passivo da lide, em linha com o que expressamente se determina no direito alemão (BGB, $\S 318$, Abs. 2).

(d) Consequência da impugnação de laudo

No caso referido no item anterior relativo à venda de ações de banco, o laudo impugnado por erro decorrente da inclusão do valor da carta-patente foi declarado como insuscetível de vincular as partes. O juiz da causa, nomeando perito, obteve novo valor das ações e declarou-o aplicável à compra e venda. ${ }^{689}$ MONIZ DE ARAGÃo considerou que a decisão representou "solução sem precedentes, pois os repositórios de jurisprudência não contêm qualquer outro a esse propósito". ${ }^{690}$ Baseando-se no princípio de que ninguém pode ser obrigado a fazer ou não fazer algo senão em virtude de lei, o autor considerou que não poderiam os contraentes ficarem submetidos ao arbitramento feito em processo judicial. ${ }^{691}$ Também em parecer, ORLANDO GOMES analisou a situação de contrato de compra e venda de ações em que o laudo preparado por perito foi impugnado e, por consequência, entendeu o autor que "o contrato não se perfez por lhe ter faltado um elemento essencial, devendo as partes serem restituídas à situação anterior à sua

${ }^{687}$ PONTES DE MIRANDA, FRANCISCO C. Tratado de direito privado, t. 39. Op. cit., §4.268, p. 43; .

${ }^{688}$ ZACCARIA, Alessio. In: CIAN, Giorgio (coord). Commentario breve al codice civile, 11 ed. Padova: CEDAM, 2011, art. 1349, p. 1417.

${ }^{689}$ MONIZ DE ARAGÃO, Egas D. "Participação do Poder Judiciário no arbitramento de preço cuja fixação foi deixada a terceiro". Op. cit., p. 178.

${ }^{690}$ MONIZ DE ARAGÃO, Egas D. "Participação do Poder Judiciário no arbitramento de preço cuja fixação foi deixada a terceiro". Op. cit., p. 178.

${ }^{691}$ MONIZ DE ARAGÃO, Egas D. "Participação do Poder Judiciário no arbitramento de preço cuja fixação foi deixada a terceiro". Op. cit., p. 178. No mesmo sentido: PEREIRA, Caio M. da S. Instituições de direito civil. Op. cit., n. 219, p. 159; SERPA LOPES, Miguel M. de. Curso de direito civil. Op. cit., p. 291; CARVAlHO SANTOS, Jorge M. Código Civil Brasileiro interpretado. Op. cit., 1945, p. 27; ALVIM, Agostinho. Da compra e venda e da troca. Rio de Janeiro/São Paulo: Forense, 1961, p. 43. 
celebração" ${ }^{692}$ Em sentido contrário, há os que defendem que, na hipótese de impugnação, seria possível a fixação de novo preço pelo juízo ${ }^{693}$ ou a indicação de novo avaliador. ${ }^{694}$

Em linha com o que se afirmou para o caso de viabilidade da determinação judicial do preço no caso de impossibilidade de indicação do arbitrador, ${ }^{695}$ também no caso de o laudo ser impugnado e ter negada sua eficácia contratual, parece ainda mais inadequado relegar o contrato à total ineficácia. Os contratantes, nessa hipótese, efetivamente fazem atuar o mecanismo contratual de determinação do preço pelo terceiro a que se comprometem, mas o preço remanesce indeterminado por conta da atuação do terceiro, que prepara laudo imprestável ou não é independente e imparcial. Declarar o contrato ineficaz, nesse caso, poderia mesmo prestigiar o comportamento da parte que, para beneficiar-se ou furtar-se aos efeitos do contrato, atua para tornar o laudo imprestável. É o que parece ter ocorrido no caso já mencionado, em que a inclusão do valor da cartapatente na avaliação decorreu de solicitação dos vendedores, atendida pelos auditores. ${ }^{696}$ Por maioria de razão, nesse caso, aplica-se a mesma solução previamente indicada: ${ }^{697}$ cabe ao juiz nomear perito e promover a avaliação técnica pretendida pelas partes.

(2) Cláusula de ajuste de preço: diferenças em relação a cláusulas de garantia

Mais comum que a fixação do preço integralmente com base em avaliação por terceiro é a previsão de que sejam realizados ajustes a uma parcela do preço com base em auditoria realizada entre a assinatura (signing) do contrato e a sua execução (closing), ou posteriormente a este último ato. Em geral, a auditoria não é confiada a um terceiro, mas é promovida pelo próprio comprador que, constatando contingências, insuficiências ou superveniências passivas não divulgadas, fica autorizado pelo contrato a reter parcela do preço, reduzindo seu montante. ${ }^{698}$ É possível, porém, que a auditoria seja vinculante e confiada a um terceiro, ou que seja confiada a um terceiro somente a função de avaliar de

${ }^{692}$ GOMES, Orlando. "Arbitramento por terceiro de preço para venda de ações. Desatendimento pelo arbirator às instruções das partes. Ineficácia, nulidade ou inexistência do contrato de compra e venda por falta de preço". Op. cit., p. 217.

${ }_{693}$ PONTES DE MIRANDA, FRANCISCO C. Tratado de direito privado, t. 39. Op. cit., §4.268, p. 37.

${ }^{694}$ FERREIRA, Waldemar. Tratado de direito comercial, v. 10. São Paulo: Saraiva, 1963, n. 2.120, p. 41.

${ }^{695}$ Sobre o assunto, cf. item II.C.2.b)(1)(b), supra.

${ }^{696}$ MONIZ DE ARAGÃO, Egas D. "Participação do Poder Judiciário no arbitramento de preço cuja fixação foi deixada a terceiro". Op. cit., p. 178.

${ }^{697}$ Sobre o assunto, cf. item II.C.2.b)(1)(b), supra

698 Para exemplo do emprego desse mecanismo em caso concreto, cf. análise de acompanhamento da aquisição das ações do Banco Votorantim S.A. pelo Banco do Brasil S.A. TCU, Ac. n. 2570, rel. Min. Aroldo Cedraz, 04.11.2009. 
forma definitiva os aspectos negociais sobre os quais o comprador e o vendedor não se colocam em acordo. ${ }^{699}$

O emprego de mecanismo de ajuste de preço (price adjustment) se mostra especialmente relevante na praxis contratual por conta da necessidade de, por um lado, formalizar a operação de forma definitiva e irrevogável, mas, por outro, permitir que o comprador, de forma mais serena, complete o quadro de informações relativo à consistência patrimonial da sociedade. ${ }^{700}$

A definição do que seja uma hipótese de ajuste de preço no contrato pode não ficar clara nas circunstâncias em que, para além do ajuste do preço, são previstos deveres de indenização pelo vendedor em caso de não correspondência entre a situação patrimonial efetiva da sociedade e aquela declarada ou garantida no contrato. Economicamente, as duas previsões se assemelham, com a diferença de que, verificando-se a deformidade, na cláusula de ajuste de preço o comprador pagaria menos; na cláusula de garantia, receberia pagamento do vendedor a título de indenização. ${ }^{701}$ Juridicamente, porém, as cláusulas possuem naturezas distintas. A cláusula de ajuste de preço incide sobre a obrigação do comprador modificando-a; as cláusulas de garantia impõem dever de indenizar ao vendedor. ${ }^{702} \mathrm{~A}$ distinção pode ter efeitos relevantes. O vendedor é tributado com base no preço que obtém pela compra e venda, de forma que o ajuste de preço reduz a base de cálculo tributária; ${ }^{703}$ não há previsão semelhante para a cláusula de garantia. São normalmente fixados limites máximos e mínimos de indenização em cláusulas de garantia, que não se aplicariam às hipóteses já cobertas pelo ajuste de preço. ${ }^{704} \mathrm{Se}$ a cláusula for de revisão de preço, no máximo, o comprador não pagará nenhum valor; se for de garantia, o

\footnotetext{
${ }^{699}$ DE ANDRÉ, Mauro. "Le clausole relative al prezzo". In: BONELLI, Franco; DE ANDRÉ, Mauro. (org.). Acquisizioni di società e di pacchetti azionari di riferimento. Milano: Giuffrè, 1990, pp. 4-48, p. 9; BRAUNSCHWEIG, Philipp von. "Variable Kaufpreisklauseln in Unternehmenskaufverträgen". In: DB, 2002, pp. 1815-1818, p. 1816.

${ }^{700}$ TINA, Andrea. Il contratto di acquisizione di partecipazioni societarie. Op. cit., p. 507; PANZARINI, Elisabetta. "Cessione di pacchetti azionari: il contenuto delle clausole di garanzia". Op. cit., pp. 287-288; IUDICA, Giovanni. "Il prezzo nella compravendita di partecipazioni azionarie”. Op. cit., p. 763; DRAETTA, Ugo. "Alcune clausole di adeguamento del prezzo a seguito di verifica contabile nei contratti di acquisto di partecipazioni azionarie”. In: Dir. comm. int., 1991, pp. 143-150, p. 144.

${ }^{701}$ TINA, Andrea. Il contratto di acquisizione di partecipazioni societarie. Op. cit., p. 507.

702 SPERANZIN, Marco. Vendita delle partecipazione di 'controllo' e garanzie contrattuali. Op. cit., p. 300.

${ }^{703}$ PARO, Giácomo; DINIZ, Rodrigo de M. P. "As implicações das cláusulas de ajustes de preço e das contas escrow na tributação pelo imposto de renda". In: RTRib, v. 121, 2015, pp. 141-159.

${ }^{704}$ SPERANZIN, Marco. Vendita delle partecipazione di 'controllo' e garanzie contrattuali. $O p$. cit., p. 302.
} 
vendedor poderia ser obrigado a pagar a título de indenização valor superior ao que recebeu. ${ }^{705}$

A despeito da dificuldade prática que pode surgir para distinguir a cláusula de revisão de preço das cláusulas de garantia, ${ }^{706}$ o principal indicador para qualificar o contrato é a declaração de vontade das partes. Se as partes, por exemplo, determinam o valor das ações ou quotas com base em critérios de rentabilidade e consideram o preço determinado, pactuando cláusulas de garantia para hipóteses de não conformidade dos ativos, não há que se falar em redução do preço em caso de ser exigida a garantia. Ainda que, economicamente, para o vendedor, as situações sejam equivalentes, sob o ponto de vista jurídico são diversos. Se, por outro lado, a verificação de deformidades é vista como elemento que contribuirá para a fixação final do preço, a cláusula será de revisão do preço. São indicativos da vontade das partes (i) o estabelecimento de "franquias" (limites máximos e mínimos), hipótese em que normalmente se trata de cláusula de indenização; (ii) a atuação da cláusula ficar dependente de mera verificação da existência ou presença de fatos, operando de forma "automática" quando esses fatos se apresentam ${ }^{707}$ (ajuste de preço); ou (iii) ficar sujeita à ocorrência de eventos posteriores à transferência, como é o caso da propositura de demanda por terceiro (cláusula de indenização). O ajuste de preço, além disso, normalmente tem caráter de definição contábil, ao passo que, nas cláusulas de garantia, avulta o aspecto indenizatório, com o pressuposto de violação da declaração ou garantia. $^{708}$

É possível, ainda, que, para uma mesma hipótese de fato, as partes prevejam tanto a consequência de que o preço deve ser ajustado quanto a possibilidade de o comprador exigir a garantia contratualmente prestada. ${ }^{709}$ ANDREA TINA afirma que essa sobreposição seria inadmissível, mas não indica qual seria a solução para o caso concreto sob o direito italiano. ${ }^{710}$ No Brasil, em primeiro lugar, deve-se buscar por via da interpretação contratual estabelecer se há relação de especialidade de um dos remédios

\footnotetext{
705 CAFFIN-MOI, Marie. Cession de droits sociaux et droit des contrats. Op. cit., n. 544, p. 349-350; SPERANZIN, Marco. Vendita delle partecipazione di 'controllo' e garanzie contrattuali. Op. cit., p. 301. ${ }^{706}$ CAFFIN-MOI, Marie. Cession de droits sociaux et droit des contrats. Op. cit., n. 173, p. 120.

${ }^{707}$ IUDICA, Giovanni. "Il prezzo nella compravendita di partecipazioni azionarie". Op. cit., p. 764.

${ }^{708}$ DUBOUT, H. "La distinction des clauses d'ajustement de prix et des clauses de garantie dans les contrats d'acquisition d'entreprises". In: Bull Joly, 2004, pp. 891-899, p. 897.

${ }^{709}$ PANZARINI, Elisabetta. "Cessione di pacchetti azionari: il contenuto delle clausole di garanzia". Op. cit., p. 288.

${ }^{710}$ TINA, Andrea. Il contratto di acquisizione di partecipazioni societarie. $O p$. cit., p. 512.
} 
para a situação de fato; existindo, prevalece o remédio especial. Caso não seja possível apontar tal relação, seria admissível a aplicação, por analogia, do regime da obrigação alternativa a favor do credor (CC, art. 252). É certo, de qualquer forma, que não se admite a pretensão de, ao mesmo tempo, obter a redução do preço e a ativação da garantia, sob pena de se chancelar o enriquecimento sem causa.

A determinação do preço pode ser submetida à verificação de eventos futuros e incertos previstos pelas partes, articulação contratual que é comum no âmbito da compra e venda de participações societárias de controle. Depois de compreender a motivação e a função econômica desempenhada por esse tipo de cláusula, ${ }^{711}$ cabe apontar os problemas jurídicos que elas podem impor.

(a) Características: função econômica e modalidades

A determinação do preço pode ser submetida à verificação de eventos futuros e incertos delimitados pelas partes, articulação contratual que é comumente designada como cláusula de earn out. ${ }^{712}$ Apesar da origem anglo-saxônica denunciada pela denominação, a cláusula foi importada para a prática contratual dos países do direito continental. ${ }^{713} \mathrm{O}$ Brasil não é exceção. ${ }^{714}$ Passível de ser traduzida como cláusula de

\footnotetext{
${ }^{711}$ MARTINS-COSTA, Judith. "Contrato de cessão e transferência de quotas. Acordo de sócios. Pactuação de parcela variável do preço contratual denominada earn out. Caraterísticas e função ('causa objetiva') do earn out”. In: RArb, v. 42, 2014, pp. 153-188, p. 156 (apontando a relevância da correta compreensão da função econômica da cláusula para sua aplicação jurídica).

712 GILSON, Ronald; BLACK, Bernard. The law and finance of corporate acquisitions, $2^{\mathrm{a}}$ ed. Westbury: Foundation Press, 1995, p. 1572 (os autores, contudo, preferem a contração dos termos sob a forma "earnout").

${ }^{713}$ SCHWEITZER, Heike. "Private legal transplants in negotiated deals". In: ECFR, 2007, pp. 79-125, p. 82. Encontra-se na doutrina de países de direito continental a preocupação com o enquadramento jurídico da cláusula e dos possíveis problemas que suscita. Exemplificativamente: (i) POITRINAL, François D. “Cession d'entreprise: les conventions de earn out". In: JCP E, 1999, pp. 18-28, p. 19 (indicando o início do emprego da cláusula na França na década de 1980); (ii) SÁ, F. Oliveira e. "A determinação contingente do preço de aquisição de uma empresa através de cláusulas de earn-out". In: CÂMARA, Paulo; BASTOS, Miguel (org.). Aquisição de empresas. Coimbra: Almedina, 2011, pp. 401-415 (para o direito português); (iii) LANCIANI, Andrea. "Il prezzo (modalità, aggiustamenti, garanzie del pagamento dilazionato)". Op. cit., pp. 319-335, p. 325 (para o direito italiano); (iv) VISCHER, Markus. "Earn out-Klauseln in Unternehmenskaufverträgen”. In: SJZ, v. 98, 2002, pp. 509- 517 (para o direito suíço); (v) BAUMS,
} 
determinação contingente do preço, ${ }^{715}$ ou cláusula de complemento de preço, ${ }^{716}$ o que é característico dessa previsão é que o vendedor permaneça recebendo valores - earn mesmo depois de deixar formalmente o controle da sociedade - out. ${ }^{717}$

É comum que, nas negociações, as partes possuam visões diversas sobre o valor da sociedade-alvo. $O$ vendedor considera que as perspectivas negociais são excelentes, algo que, aos olhos do comprador, pode não parecer tão evidente. Uma solução "simples e de bom senso",718 é dividir o preço em uma parcela determinada e outra que fica condicionada ao atingimento de certos resultados, que são alçados no contrato ao posto de eventos condicionantes do pagamento da parcela adicional do preço.

A cláusula é atrativa por diversos motivos: (i) como o vendedor somente obterá o preço integral se a projeção de lucros que apresentar ao comprador efetivamente vier a se concretizar, promove-se o alinhamento de interesses entre as $\operatorname{partes}^{719}$ e se diminui a assimetria informacional e o risco de adoção de comportamentos oportunistas pelo vendedor no plano pré-contratual; ${ }^{720}$ (ii) sob o ponto de vista psicológico, normalmente é mais palatável ao comprador pagar uma parcela do preço após efetivamente perceber a realização da lucratividade projetada; ${ }^{721}$ (iii) parte do preço torna-se exigível somente depois de consumada a compra e venda, o que permite que o comprador se valha ao menos parcialmente do lucro que obtém por meio da sociedade para pagar a parcela contingente; ${ }^{722}$ e (iv) permite-se que a avaliação da sociedade seja fruto do efetivo

Theodor. "Ergebnisabhängige Preisvereinbarungen in Unternehmenskaufverträgen”. In: DB, 1993, pp. 12731276 (para o direito alemão).

${ }^{714}$ MARTINS-COSTA, Judith. "Contrato de cessão e transferência de quotas. Acordo de sócios. Pactuação de parcela variável do preço contratual denominada earn out. Caraterísticas e função ('causa objetiva') do earn out". Op. cit..

${ }^{715}$ Sá, F. Oliveira e. "A determinação contingente do preço de aquisição de uma empresa através de cláusulas de earn-out". In: CÂMARA, Paulo; BASTOS, Miguel (org.). Aquisição de empresas. Op. cit., pp. 401-415.

${ }^{716}$ CAFFIN-MOI, Marie. Cession de droits sociaux et droit des contrats. Op. cit., p. 120.

${ }^{717}$ CAFFIN-MOI, Marie. Cession de droits sociaux et droit des contrats. Op. cit., p. 120.

${ }^{718}$ POITRINAL, François D. “Cession d'entreprise: les conventions de earn out”. Op. cit., p. 18.

${ }^{719}$ POITRINAL, François D. “Cession d'entreprise: les conventions de earn out”. Op. cit., p. 18.

${ }^{720}$ MARTINS-COSTA, Judith. "Contrato de cessão e transferência de quotas. Acordo de sócios. Pactuação de parcela variável do preço contratual denominada earn out. Caraterísticas e função ('causa objetiva') do earn out". Op. cit., p. 157.

${ }^{721}$ BAUMS, Theodor. "Ergebnisabhängige Preisvereinbarungen in Unternehmenskaufverträgen". Op. cit., p. 1273.

${ }^{722}$ WERNER, Rüdiger. "Earn-Out-Klauseln - Kaufpreisanpassung beim Unternehmenskauf”. In: DStR, 2012, pp. 1662-1667, p. 1663; HILGARD, Mark. "Earn-out Klauseln beim Unternehmenskauf”. In: BB, 2010, pp. 2912-2919, p. 2913. 
faturamento obtido, e não somente do prognóstico esperado pelas partes, cuja precisão normalmente é inferior. ${ }^{723}$

A cláusula pode assumir diferentes configurações. Em primeiro lugar, pode ser positiva, de tal forma que, ocorrendo os eventos determinantes, fica devido o pagamento da parcela adicional do preço; ou pode ser negativa, caso em que o vendedor garante que, se não ocorrer determinado evento condicionante (como a obtenção da rentabilidade projetada), o comprador faz jus à devolução de parcela do preço já pago. ${ }^{724}$ Apesar de economicamente semelhantes, ${ }^{725}$ sobretudo quando parcela do preço fica retida em conta garantia (escrow), ${ }^{726}$ a primeira hipótese costuma ser preferida por motivos psicológicos, porque a divisão de lucros pelo comprador se apresenta como mais atraente do que a garantia de um resultado pelo vendedor. ${ }^{727}$ A segunda forma de configuração diz com a modalidade do evento condicionante, que pode ser um marco financeiro, como o lucro ou o faturamento (economic earn out); ou um evento gerencial ou indicador nãofinanceiro, ${ }^{728}$ como a manutenção da vinculação de determinados empregados, ${ }^{729}$ ou o alcance de determinadas metas (milestones) ${ }^{730}$ previstas no âmbito de contratos de investimento de risco (performance earn out). ${ }^{731}$ A terceira distinção respeita os valores a serem pagos, ou seja, a parcela adicional do preço, que pode consistir em um percentual de determinado indicativo financeiro (faturamento, lucro), ou em valores fixos a serem pagos conforme certos eventos condicionantes ocorram (lockstep) ${ }^{732}$

As cláusulas normalmente determinam um período de tempo dentro do qual os eventos condicionantes devem se verificar para que o vendedor faça jus à parcela de preço adicional. Como o objetivo da contratação é permitir que o vendedor participe daqueles resultados que derivam mediata ou imediatamente de sua gestão prévia e que se

\footnotetext{
${ }^{723}$ SÁ, F. Oliveira e. "A determinação contingente do preço de aquisição de uma empresa através de cláusulas de earn-out". Op. cit., p. 402.

${ }^{724}$ TINA, Andrea. Il contratto di acquisizione di partecipazioni societarie. Op. cit., pp. 411-413.

${ }^{725}$ VISCHER, Markus. "Earn out-Klauseln in Unternehmenskaufverträgen”. Op. cit., p. 510.

${ }^{726}$ Sobre o assunto, cf. item II.C.3, infra.

${ }^{727}$ BAUMS, Theodor. "Ergebnisabhängige Preisvereinbarungen in Unternehmenskaufverträgen". Op. cit., p. 1273.

${ }^{728}$ HILGARD, Mark. “Earn-out Klauseln beim Unternehmenskauf”. Op. cit., p. 2914.

${ }^{729}$ VISCHER, Markus. “Earn out-Klauseln in Unternehmenskaufverträgen”. Op. cit., p. 510.

${ }^{730}$ WERNER, Rüdiger. "Earn-Out-Klauseln - Kaufpreisanpassung beim Unternehmenskauf”. Op. cit., p. 1662.

${ }^{731}$ CROSIO, Stefano; GREGORI, Claudia. "Acquisizione di società ad elevato contenuto tecnologico: clausole di earn-out e dichiarazioni e garanzie del venditore”. In: Contr. impr., 2000, pp. 1109-1123.

${ }^{732}$ POITRINAL, François D. "Cession d'entreprise: les conventions de earn out". Op. cit., p. 24.
} 
encontram, de certa forma, já "em germe", ${ }^{733}$ normalmente o período fixado não é longo, limitando-se, em regra, a três anos. Durante esse período, a cláusula promove certa subversão ao princípio de que os riscos da coisa são integralmente transferidos ao comprador após a tradição (CC, art. 492), pois o vendedor continua sendo impactado financeiramente - ainda que de forma mediata - pelos destinos da sociedade. ${ }^{734}$

O emprego da cláusula pode se dar em diversos contextos, mas o que se ressalta é a maior incidência em contratos relativos a sociedades que produzem bens ou serviços inovadores; que estão no curso do desenvolvimento de tecnologia e ainda não obtiveram patente; e, sobretudo, prestadores de serviços cujo valor depende da relação com um círculo restrito de clientes ou fornecedores, em que a manutenção do antigo sócio controlador é relevante. ${ }^{735}$ O período de earn out representa uma "passagem de bastão", 736 em que a sociedade continua a se beneficiar das qualidades individuais do vendedor, como seus relacionamentos com clientes e fornecedores, e da transferência de conhecimentos específicos à nova equipe responsável pela gestão. ${ }^{737}$

A cláusula de earn out diferencia-se da cláusula de revisão de preço. $\mathrm{Na}$ primeira, há condição ligada à ocorrência de fatos futuros posteriores ao fechamento da operação (closing); na segunda, o ajuste de preço liga-se a fatos anteriores. ${ }^{738}$ Apesar de ambas serem cláusulas que sujeitam efeitos do contrato a condições suspensivas, a cláusula de earn out diferencia-se das chamadas condições de fechamento (closing conditions), cuja finalidade é sujeitar todo o negócio jurídico à verificação de efeitos que se consideram essenciais, como por exemplo, a obtenção de determinadas autorizações administrativas, ao passo que, na cláusula de earn out, condicionada é apenas a exigibilidade de parcela do preço, ou seja, uma prestação, não toda a eficácia do negócio jurídico. ${ }^{739}$

\footnotetext{
${ }^{733}$ POITRINAL, François D. “Cession d'entreprise: les conventions de earn out”. Op. cit., p. 19.

${ }^{734}$ HILGARD, Mark. “Earn-out Klauseln beim Unternehmenskauf”. Op. cit., p. 2912.

${ }^{735}$ BAUMS, Theodor. "Ergebnisabhängige Preisvereinbarungen in Unternehmenskaufverträgen”. Op. cit., p. 1273; SÁ, F. Oliveira e. "A determinação contingente do preço de aquisição de uma empresa através de cláusulas de earn-out". Op. cit., p. 403.

${ }^{736}$ POITRINAL, François D. “Cession d'entreprise: les conventions de earn out”. Op. cit., p. 18.

${ }^{737}$ HILGARD, Mark. “Earn-out Klauseln beim Unternehmenskauf”. Op. cit., p. 2913.

738 WERNER, Rüdiger. "Earn-Out-Klauseln - Kaufpreisanpassung beim Unternehmenskauf”. Op. cit., p. 1662.

${ }^{739}$ VISCHER, Markus. "Earn out-Klauseln in Unternehmenskaufverträgen”. Op. cit., p. 509; SÁ, F. Oliveira e. "A determinação contingente do preço de aquisição de uma empresa através de cláusulas de earn-out". Op. cit., p. 405.
} 
A cláusula de earn out pode ser empregada no caso de o vendedor deixar definitivamente o quadro societário. Como regra, porém, mantém-se o vendedor como sócio minoritário e titular de cargo administrativo, no conselho de administração ou diretoria, com escopo diverso conforme o interesse das partes. ${ }^{740}$ Há, com isso, uma utilização peculiar, e em certa medida atípica, de institutos societários para realizar o escopo contratual. Nos casos em que, no período de earn out, a gestão continua a ser realizada pelo vendedor (o que é comum, por exemplo, em sociedades de gestão de investimentos), este continua na condição de diretor, o que lhe permite imprimir sua orientação aos negócios sociais; mas, diferente, do que ocorre normalmente nas companhias com controlador majoritário, o que releva, nessa configuração é que o vendedor possa permanecer influenciando na orientação da sociedade, sendo conferidos ao comprador e novo controlador direitos de veto e de físcalização.

Quando o contrato prevê que a gestão passa imediatamente a se sujeitar à orientação do comprador (e novo controlador), por sua vez, é normal que, em vez de se preverem no contrato de compra e venda quais os poderes de veto e de fiscalização do vendedor, este se mantenha como sócio e celebre com o comprador um acordo de sócios, conferindo ao vendedor a condição de conselheiro de administração. Novamente, tem-se com isso uma peculiar utilização de institutos societários para o preenchimento de finalidade contratual. $\mathrm{O}$ vendedor vale-se dos poderes conferidos aos conselheiros para "fiscalizar a gestão dos diretores, examinar, a qualquer tempo, os livros e papéis da companhia, solicitar informações sobre contratos celebrados ou em via de celebração, e quaisquer outros atos" (LSA, art. 142, III), mas não tem em vista em primeira linha, os interesses da sociedade, senão os seus próprios, ligados ao atingimento dos eventos condicionantes.

A despeito das vantagens que pode proporcionar, o emprego da cláusula é limitado pela dificuldade ínsita em sua redação. A fórmula do earn out deve prevenir, adequadamente, a adoção dos chamados “comportamentos estratégicos” pelos contratantes, tendentes à obtenção de vantagens às custas da contraparte. ${ }^{741}$ No direito brasileiro, como

\footnotetext{
${ }^{740}$ POITRINAL, François D. “Cession d'entreprise: les conventions de earn out”. Op. cit., p. 19.

${ }^{741}$ GILSON, Ronald; BLACK, Bernard. The law and finance of corporate acquisitions. Op. cit., p. 1574; HILGARD, Mark. "Earn-out Klauseln beim Unternehmenskauf". Op. cit., p. 2914; BAUMS, Theodor. "Ergebnisabhängige Preisvereinbarungen in Unternehmenskaufverträgen". Op. cit., p. 1274; SÁ, F. Oliveira e. "A determinação contingente do preço de aquisição de uma empresa através de cláusulas de earn-out". Op. cit., p. 407.
} 
de resto no direito continental, contudo, é importante ressaltar que, para além dos mecanismos contratuais, a regra da boa fé censura comportamentos que não sejam expressamente acautelados pela disposição contratual. ${ }^{742}$

(b) Elementos da regulação contratual

Sob um ponto de vista analítico, há três principais preocupações presentes na negociação da cláusula de earn out, quais sejam, (i) definição dos eventos condicionantes; (ii) predeterminação dos poderes de gestão societária; e (iii) previsão de prestação de contas e fiscalização.

(i) Eventos condicionantes

Cabe às partes contratantes determinar autonomamente quais serão os eventos condicionantes, fixando claramente o período durante o qual os eventos devem ocorrer; se o vendedor precisa se manter no cargo até o final do período, e quais as consequências em caso de sua saída prévia. Em segundo lugar, deve haver clareza quanto ao parâmetro para aferição do evento condicionante, ou seja, se será apurado o atingimento de metas, por exemplo, tomando como base o faturamento, que pode ser bruto ou descontar certas despesas, ou o lucro e, nesse caso, definir qual a base para a apuração do lucro, e se o resultado positivo de um ano pode ser compensado com eventual prejuízo verificado em outro. Por fim, cabe fixar se haverá um terceiro avaliador responsável por atestar a verificação dos eventos condicionantes em caso de divergência entre as partes. ${ }^{743}$ Há uma panóplia de configurações possíveis, e a escolha das partes varia conforme o porte da sociedade. ${ }^{744}$

Sob o ponto de vista jurídico, o que importa é ter-se presente que, qualquer que seja o parâmetro, os eventos são pressupostos da produção de efeitos do negócio jurídico. Como já se apontou na jurisprudência, "a subordinação de composição de parte

\footnotetext{
${ }^{742}$ SÁ, F. Oliveira e. "A determinação contingente do preço de aquisição de uma empresa através de cláusulas de earn-out". Op. cit., p. 407.

${ }^{743}$ VISCHER, Markus. "Earn out-Klauseln in Unternehmenskaufverträgen”. Op. cit., p. 511; BAUMS, Theodor. "Ergebnisabhängige Preisvereinbarungen in Unternehmenskaufverträgen". Op. cit., p. 1275.

${ }^{744}$ GILSON, Ronald; BLACK, Bernard. The law and finance of corporate acquisitions. Op. cit., p. 1572; HILGARD, Mark. "Earn-out Klauseln beim Unternehmenskauf”. Op. cit..
} 
do preço a evento futuro e incerto, de atingimento de metas de faturamento, tem a natureza jurídica de condição suspensiva, na forma do art. 125 do Código Civil". ${ }^{745}$ Atrai-se, com isso, o regime legal pertinente às condições, o que traz consequências diretas para a validade e eficácia das cláusulas de earn out. Em primeiro lugar, a condição não pode sujeitar o negócio jurídico ao puro arbítrio de uma das partes (CC, art. 122).

É consagrada no direito brasileiro a distinção entre a condição simplesmente potestativa e a condição exclusivamente potestativa. Ressalta-se, claramente, que a condição ilícita é a de simples querer, cuja realização não somente dependa do devedor (pois senão a cláusula seria simplesmente potestativa), mas que se ligue exclusivamente com sua vontade, ou seja, no caso em que a não realização do evento não lhe impõe consequências. $^{746}$

A aplicação da distinção, contudo, nem sempre é precisa, nem mesmo no âmbito do STJ. Em decisão relativa a contrato que adotava, mutatis mutandis, a mesma lógica que inspira a cláusula de earn out, reconheceu-se o caráter puramente potestativo de condição a que estava vinculada a fixação do preço. ${ }^{747}$ No caso, o Ituano Futebol Clube transferira ao São Paulo Futebol Clube o "passe" do atleta profissional Oswaldo Giroldo Júnior, conhecido como “Juninho", pelo preço determinado de US\$ 350.000,00 (trezentos e cinquenta mil dólares), somado a parcela variável na hipótese de o "passe" ser novamente negociado pelo cessionário com um terceiro. A parcela adicional corresponderia a 50\% (se a nova transferência ocorresse até 31.12 .1994 ) ou a $25 \%$ (se a nova transferência ocorresse entre 01.01.1995 e 31.08.1995). Durante o período previsto, o cessionário (São Paulo Futebol Clube) recebeu e recusou duas propostas do clube inglês Middlesbrough, pelos valores de US\$ 4.800.000,00 (quatro milhões e oitocentos mil dólares) e US\$ 5.000.000,00 (cinco milhões de dólares). Cerca de 40 (quarenta) dias após o fim do período de participação do cedente, contudo, foi efetivada a transferência, ao mesmo clube inglês, pelo valor de US\$ 7.500.000,00 (sete milhões e meio de dólares), hipótese em que, pelo contrato, nenhum valor seria devido ao Ituano. A $3^{\text {a }}$ Turma do STJ,

${ }^{745}$ TJSP, Ap. n. 125493- 61.2012.8.26.0100, $1^{\text {a }}$ Câm. Res. Dir. Empr., rel. Des. Francisco Loureiro, j. 02.10 .2012$.

${ }^{746}$ STJ, REsp n. 20.982-5-MG, 3a T., rel. p/ ac. Min. Eduardo Ribeiro, j. 10.11 .1992 (“Condição potestativa. Não é vedada em lei a condição simplesmente potestativa. Inexiste, pois, proibição a que a eficácia do ato esteja condicionada a acontecimento futuro, cuja realização dependa do devedor ou possa ser por ele obstada. Defesa é a condição meramente potestativa, correspondente à fórmula 'si volam' (...)”).

${ }^{747}$ STJ, REsp n. 291.631-SP, $3^{\text {a }}$ T., rel. Min. Castro Filho, j. 04.10.2001. 
por unanimidade, considerou que "da simples narrativa dos fatos exsurge, cristalino, o conteúdo puramente potestativo do contrato, que impôs a uma das partes a condição, apenas e tão-somente, de mero espectador, em permanente expectativa, enquanto dava ao outro parceiro irrestritos poderes para decidir como bem lhe aprouvesse". E, mantendo o espírito "futebolístico", entendeu o Ministro CASTRO FILHO que "cometeu o contrato 'penalidade máxima', ao dispor, como fez, sobre a venda do aplaudido atleta, devendo ser considerada sem efeito a cláusula no que se refere o limite de tempo". 748

O acórdão pode ser criticado por dois eqívocos, um de compreensão da matéria de fato, outro de ordem jurídica. No âmbito fático, a decisão não atentou para a importância - típica também nas cláusulas de earn out relativas a ações ou quotas - de se determinar o período de tempo durante o qual o evento condicionante deve ocorrer, porque o objetivo da cláusula é permitir que o vendedor participe dos lucros que já estão, de certa forma, "em germe",749 quando da transferência. Consumada a compra e venda, quando há transferência da gestão ao comprador, a verificação dos eventos condicionantes deixa progressivamente de depender exclusivamente da atuação do vendedor. O período de tempo reflete essa progressiva dissipação da ligação causal entre a gestão previamente exercida pelo vendedor e a ocorrência do evento. No caso, igualmente, seria possível entrever uma razão lógica negocial para que, a cada temporada, diminuísse a participação do cedente na operação, pois o cessionário passava a investir no atleta e a projetar sua imagem no mercado. O erro de ordem jurídica, por sua vez, prende-se à incorreta qualificação da condição, que não poderia ser considerada puramente potestativa. A não realização de nova transferência repercutia economicamente para o cessionário, que deixava de obter os lucros da operação e continuava a correr os riscos de que, porventura, não se apresentassem no futuro novas perspectivas para a celebração de negócio semelhante (no caso, inclusive, esse risco era especialmente presente, pois o "ativo" eram os direitos desportivos de um atleta, que poderia se acidentar, por exemplo). O que poderia ser alegado é que o implemento da condição teria sido maliciosamente obstado pelo cessionário ao recusar propostas durante o período previsto (CC, art. 129), o que, diga-se de passagem, sequer poderia ser imediatamente admitido, já que as ofertas recusadas e que dariam direito de participação ao cedente foram posteriormente incrementadas pelo

\footnotetext{
${ }^{748}$ STJ, REsp n. 291.631-SP, $3^{\mathrm{a}}$ T., rel. Min. Castro Filho, j. 04.10.2001.

${ }^{749}$ POITRINAL, François D. "Cession d'entreprise: les conventions de earn out". Op. cit., p. 19.
} 
adquirente em quase $50 \%$, indício de que havia fundamento racional na postura de postergar a transação.

No âmbito específico da cláusula de earn out na compra e venda de participações societárias de controle, a alegação do caráter puramente potestativo da cláusula de complementação do preço pode-se colocar na hipótese de o comprador assumir a gestão e poder determinar, por meio de seu comportamento, se o objetivo previsto como evento condicionante será ou não alcançado. No caso da cláusula de earn out, porém, o caráter puramente potestativo requerido para a invalidade dificilmente se apresenta. Em julgado da Cour de cassation, o autor pleiteava a invalidade da cláusula pela qual o preço das ações ficava condicionado à rentabilidade obtida com o aluguel do patrimônio imobiliário da sociedade cujas ações foram vendidas, considerando que o adquirente poderia influenciar a obtenção do lucro. Decidiu-se, porém, que a condição não seria puramente potestativa, pois a sociedade teria atividade e interesses distintos daqueles dos adquirentes. $^{750}$ Somente no caso em que a cláusula se mostrasse absolutamente disfuncional e permitisse que o adquirente manipulasse os resultados da sociedade sem sofrer nenhuma repercussão em sua esfera patrimonial, ou na esfera patrimonial da sociedade, seria possível a consideração da condição como potestativa. ${ }^{751}$

No direito brasileiro, há precedente relativo à compra e venda de ações de controle, no qual se previu que parcela do preço ficaria condicionada ao lançamento pela sociedade de empreendimento imobiliário de alto luxo, denominado Villa Trump, idealizado pelo vendedor, que obtivera para a sociedade a exclusividade para utilizar a marca Trump no Brasil. ${ }^{752}$ O DES. ROBERTO MAC CRACKEN defendeu, com fundamento na decisão do STJ relativa ao passe do atleta referida anteriormente, ${ }^{753}$ que haveria, pelas mesmas razões, condição puramente potestativa se o comprador pudesse, simplesmente, recusar-se a realizar o empreendimento idealizado, não ficando, com isso, obrigado ao

\footnotetext{
${ }^{750}$ Cass. comm. 15.06.1982, Bulletin n. 229 (“N'est pas purement potestative la condition selon laquelle le prix d'actions sociales cédées devait être évalué en fonction du chiffre d'affaires et de certains loyers perçus par la société dès lors que l'activité et l'intérêt de celle-ci sont distincts de celle des cessionnaires débiteurs").

${ }^{751}$ POITRINAL, François D. “Cession d'entreprise: les conventions de earn out”. Op. cit., p. 22.

752 TJSP, Ap. n. 0219551-27.2010.8.26.0100, 2a Câm. Res. Dir. Emp., rel. Des. Ligia Araújo Bisogni, j. 20.05.2013 (a informação consta da declaração de voto do $3^{\circ}$ Juiz Alexandre Lazzarini).

${ }^{753}$ STJ, REsp n. 291.631-SP, $3^{\mathrm{a}}$ T., rel. Min. Castro Filho, j. 04.10.2001.
} 
pagamento de parcela adicional do preço. ${ }^{754}$ A maioria dos julgadores, contudo, entendeu que a cláusula não seria puramente potestativa, "porque o fator determinante, dada a magnitude do negócio envolvido, realmente era a sua viabilidade econômica e a realização das etapas do empreendimento, o que inclusive extravasa o mero arbítrio de uma das partes". ${ }^{755} \mathrm{O}$ julgado foi acertado, pois realizar ou não o empreendimento imobiliário era decisão com sérias repercussões para a sociedade, não se tratando de condição puramente potestativa. Se as partes não determinaram um valor fixo adicional para o caso de a sociedade não realizar o empreendimento imobiliário, nada efetivamente seria devido pelo comprador ao vendedor. Esse resultado é, ademais, condizente com a lógica negocial, pois na hipótese de não ser realizado o empreendimento, tampouco seria gerado lucro que justificasse o pagamento da parcela adicional do preço.

A segunda limitação implícita diz respeito ao regime de verificação e não verificação das condições e à consequente projeção de eficácia dela derivada. No caso da cláusula de earn out, se o vendedor comanda a gestão social, ele pode atuar para que a condição que o favorece se verifique; se a gestão passa ao comprador, este pode atuar para que, pelo contrário, a condição não se implemente. Seria aplicável, nesse caso, o regramento de que se reputa "verificada, quanto aos efeitos jurídicos, a condição cujo implemento for maliciosamente obstado pela parte a quem desfavorecer, considerando-se, ao contrário, não verificada a condição maliciosamente levada a efeito por aquele a quem aproveita o seu implemento" (CC, art. 129).

Reproduzindo o art. 120 do Código Civil de 1916, o dispositivo assemelhase ao $§ 162$ do BGB, com a diferença de que, na redação germânica, faz-se referência explícita à conduta contrária à boa-fé, ao passo que, no Código Civil Brasileiro, mencionase a atuação maliciosa. Seria possível ver nessa diferença redacional uma ideia de que o comportamento "malicioso" da parte deveria ser doloso, intencional, não passível de verificação objetiva. A leitura sistemática do artigo no Código Civil, contudo, indica para um resultado hermenêutico semelhante ao alemão. Indica-se, nesse sentido, que "a expressão maliciosamente, informada pelo princípio da boa-fé objetiva, adquire novo significado, não já associado ao elemento intencional, mas restrito à culpa (imputabilidade

\footnotetext{
${ }^{754}$ Voto-vista do Des. Roberto Mac Cracken. In: TJSP, AP. N. 0219551-27.2010.8.26.0100, 2ª Câm. Res. Dir. Emp., rel. Des. Ligia Araújo Bisogni, j. 20.05.2013.

755 TJSP, Ap. n. 0219551-27.2010.8.26.0100, 2 ${ }^{\text {a }}$ Câm. Res. Dir. Emp., rel. Des. Ligia Araújo Bisogni, j. 20.05.2013.
} 
da conduta do agente)", de tal forma que "o credor que não colabora com o devedor para o adimplemento da obrigação viola dever contratual, por afrontar a boa-fé objetiva". 756 Promove-se, com isso, a ficção da verificação ou não verificação da condição que emerge, não como uma sanção ao comportamento desleal das partes, mas como forma de concretizar a vontade expressa pelas próprias partes. ${ }^{757}$ Como se verá no item subsequente, no contexto da cláusula de earn out, a aferição do significado de comportamento malicioso liga-se, concretamente, com a verificação da observância dos critérios de administração diligente da sociedade (business judgment rule).

Um terceiro limite imposto pelo ordenamento jurídico diz com a consequência da não verificação das condições e o regime da cláusula penal. Um caso prático sobre o qual opinou JUDITH MARTINS-COSTA exemplifica a problemática. Tratavase de contrato de compra e venda de ações de controle em que as partes condicionaram o pagamento de parcela adicional do preço à continuidade do vendedor na gestão da sociedade pelo prazo de 36 (trinta e seis) meses e ao atingimento de metas gerenciais determinadas. Alcançada as metas antes do fim do período, no $35^{\circ}$ (trigésimo quinto) mês, o comprador, sob o pretexto da ocorrência de falta grave que justificaria a destituição do vendedor, alegou que o direito ao pagamento da parcela adicional não teria sido obtido pelo vendedor por não ter sido preenchido um dos pressupostos previstos na cláusula (manutenção do vendedor no cargo por todo o período). ${ }^{758} \mathrm{~A}$ opinião da professora desenvolveu-se no sentido de que, de um lado, não teria ocorrido a falta grave pressuposta e, de outro, a demissão faltando brevíssimo período de tempo representaria óbice malicioso à verificação da condição. ${ }^{759}$

Para além dessas adequadas interpretativas, seria possível analisar o caso sob a vertente da vedação à cláusula penal excessiva (CC, art. 413). A menção ao instituto da cláusula penal, nesse contexto, pode parecer à primeira vista incompreensível, porque somente incorre na cláusula penal o devedor que, culposamente, deixe de cumprir a

\footnotetext{
756 TEPEDINO, Gustavo; BARBOZA, Heloísa H.; MORAES, Maria Celina B. (coord.). Código civil interpretado. Op. cit., p. 262.

757 SÁ, F. Oliveira e. "A determinação contingente do preço de aquisição de uma empresa através de cláusulas de earn-out”. Op. cit., p. 412.

${ }^{758}$ MARTINS-COSTA, Judith. "Contrato de cessão e transferência de quotas. Acordo de sócios. Pactuação de parcela variável do preço contratual denominada earn out. Caraterísticas e função ('causa objetiva') do earn out". Op. cit., pp. 153-155.

${ }^{759}$ MARTINS-COSTA, Judith. "Contrato de cessão e transferência de quotas. Acordo de sócios. Pactuação de parcela variável do preço contratual denominada earn out. Caraterísticas e função ('causa objetiva') do earn out". Op. cit., pp. 180-184.
} 
obrigação (CC, art. 408). Na cláusula de earn out, não há obrigação de a sociedade obter algum resultado, menos ainda obrigação do comprador ou do vendedor adotar algum comportamento. Quando a cláusula de earn out, porém, prevê a não obtenção de um direito por não serem reunidos todos os eventos condicionantes, mas o vendedor - como no caso concreto - promove por meio de sua atuação o atingimento de metas e resultados que revertem em lucro para a sociedade e, mediatamente, também para o comprador sob a forma de percepção dividendos, percebe-se que a absoluta não obtenção de nenhuma parcela adicional do preço pode-se mostrar consequência excessiva. $\mathrm{O}$ vendedor, via de regra, atua como administrador da sociedade, mas não obtém a compensação completa de seu trabalho por meio da remuneração paga pela sociedade, senão também por meio do complemento de preço que será pago caso obtidos os resultados pretendidos. Afirmar que o vendedor, em um caso como esse, não faria jus a absolutamente nenhum pagamento representaria medida excessiva.

A cláusula penal deve ser "reduzida equitativamente pelo juiz se a obrigação principal tiver sido cumprida em parte, ou se o montante da penalidade for manifestamente excessivo, tendo-se em vista a natureza e a finalidade do negócio" (CC, art. 413). Já se decidiu, por sua vez, que "o art. 413, especialmente a sua segunda parte, pode servir como norma de aplicação analógica para fundamentar a atuação judicial de coibir excessos cometidos na previsão ou aplicação de tais penas, como nos casos de previsão de perda de direitos, vencimento antecipado, etc." ${ }^{760} \mathrm{Na}$ jurisprudência, encontram-se exemplos de decisões que consideram o regramento de limitação a penalidades moratórias aplicável, igualmente, a situações nas quais alguém não deixa de cumprir uma obrigação, senão de se beneficiar de uma vantagem estabelecida para aqueles que preenchem certos requisitos contratualmente previstos. O exemplo típico é a prática de condomínios de oferecerem "descontos premiais" (da ordem de 20\%) para aqueles que adimplissem sua cota condominial com antecedência. Sem o pagamento na data prevista, para além da não obtenção do desconto, incidiria multa fixada na forma legal (2\%). Reconhece-se, porém, que a não obtenção do benefício (perda do desconto) pode ser equiparada a uma sanção,

${ }^{760}$ SILVA, Jorge Cesa F. da. Inadimplemento das obrigações. São Paulo: RT, 2007, p. 282. 
sendo considerada verdadeira multa disfarçada, "cláusula penal ao inverso", ${ }^{761}$ à qual seriam aplicáveis os limites legais cogentes $\left(\mathrm{CC}\right.$, art. 1.336, $\left.\S 1^{\circ}\right){ }^{762}$

No caso da cláusula de earn out, a depender da configuração, e desde que se atente para a natureza e a finalidade do negócio, parece possível aplicar analogicamente o princípio da redução proporcional da cláusula penal manifestamente excessiva. ${ }^{763}$ No caso concreto, por conseguinte, ainda que houvesse falta grave cometida pelo vendedor no $35^{\circ}$ mês, após terem sido atingidos absolutamente todas as metas de faturamento ajustadas, parece excessivo que daí resultasse o não recebimento de nenhuma parcela adicional do preço estabelecida, devendo ser determinado judicialmente valor equitativo. Deixar-se-ia, com isso, da solução binária para a qual o mecanismo de verificação ou não verificação da condição normalmente conduz.

(ii) Administração da sociedade

A interação entre a dimensão contratual e a societária é evidente na clausula de earn out. Ao negociar a cláusula de earn out, portanto, é preciso que se tenha preocupação em alinhar os incentivos conferidos às partes com a persecução do interesse social, de tal forma que o comprador ou o vendedor (conforme um ou outro assuma a orientação última da gestão social) sejam incitados a maximizar o lucro de longo prazo, e não a privilegiar a obtenção das metas fixadas no contrato à custa dos desenvolvimentos futuros da sociedade. ${ }^{764}$ A cautela se justifica porque, funcionalmente, está-se diante de uma cláusula contratual fixada entre comprador e vendedor, mas que toma como pressuposto a gestão da sociedade, o que suscita indiretamente a problemática da adequação dos incentivos na remuneração dos administradores. ${ }^{765}$

\footnotetext{
${ }^{761}$ TJDF, Ap. n. 20140110685294, 33 T. Cív., rel. Des. Flavio Rostirola, j. 01.10.2014.

762 TJSP, Ap. n. 9243930-53.2008.8.26.0000, 27 Câm. Dir. Priv., rel. Des. Claudio Hamilton, j. 20.03.2012; TJSP, Ap. n. 0128707-02.2008.8.26.0100, 29a Câm. Dir. Priv., rel. Des. Francisco Thomas, j. 01.02.2012; TJSC, Ap. n. 2012.029174-9, 5 Câm. Dir. Civ., rel. Des. Henry Petry Junior, j. 13.09.2012; Contra: STJ, REsp n. 236.828-RJ, 3 ${ }^{\mathrm{a}}$ T., rel. Min. Carlos Alberto Menezes Direito, j. 31.08.2000 (fundamentando a admissão do desconto cumulado à multa tendo em vista a alta taxa inflacionária então vigente); TJSC, Ap. 2007.046001-8, $3^{\text {a }}$ Câm. Dir. Civ., rel. Des. Maria do Rocio Luz Santa Ritta, j. 04.03.2008.

${ }^{763}$ POITRINAL, François D. “Cession d'entreprise: les conventions de earn out”. Op. cit., p. 24.

${ }^{764}$ POITRINAL, François D. “Cession d'entreprise: les conventions de earn out”. Op. cit., p. 19.

${ }^{765}$ LUNARDI FILHO, Ferdinando César. A remuneração dos administradores das sociedades anônimas. Dissertação de mestrado, São Paulo: Faculdade de Direito - USP, 2013, pp. 38-44.
} 
A gestão da sociedade permitirá ou não a verificação dos eventos condicionantes. É essencial, portanto, que, na cláusula de earn out se delimite a quem cabe a orientação da administração da sociedade e quais os poderes de veto ou de deliberação atribuídos ao outro contratante, sobretudo no que diz respeito a medidas que podem impossibilitar o atingimento dos eventos condicionantes como seria o caso da fusão, incorporação ou liquidação da sociedade, ${ }^{766}$ ou que possam impactar o lucro, como seria o caso da integração gerencial com outras sociedades integrantes do grupo societário do comprador. $^{767}$

Os conflitos entre os contratantes surgem, normalmente, quando o contrato não é expresso a respeito de medidas societárias que tipicamente se colocam no centro da problemática de tutela das minorias societárias e que, igualmente, podem assumir relevância na verificação dos eventos condicionantes. É o caso das contratações entre partes relacionadas integrantes do grupo de fato do comprador ou do aproveitamento de oportunidades comerciais. ${ }^{768}$ Em caso de omissão contratual, o mero interesse econômico do vendedor na realização do evento condicionante não o autoriza a intervir na gestão da sociedade. Defende-se que a cláusula de earn out, a despeito de gerar uma comunhão de esforços entre as partes, não cria entre elas uma sociedade em comum ou sociedade em conta de participação; trata-se somente de negócio jurídico parciário (partiarisches Rechtsgeschäft), ${ }^{769}$ gênero integrado, por exemplo, pelo contrato de edição de obra intelectual (Lei 9.610/1998, art. 53); pela parceria agrícola, pecuária, agro-industrial ou extrativa (Estatuto da Terra, art. 96); pelo aluguel de espaço em shopping center no qual se ajusta que parcela do aluguel é fixada como porcentagem das vendas (Lei de Locação, art. 54); ou pelo mútuo parciário. Em todos esses casos, não se estabelece sociedade, mas um

\footnotetext{
${ }^{766}$ BAUMS, Theodor. "Ergebnisabhängige Preisvereinbarungen in Unternehmenskaufverträgen". Op. cit., p. 1274; HILGARD, Mark. “Earn-out Klauseln beim Unternehmenskauf”. Op. cit., p. 2916.

${ }^{767}$ BAUMS, Theodor. "Ergebnisabhängige Preisvereinbarungen in Unternehmenskaufverträgen". Op. cit., p. 1274; HILGARD, Mark. "Earn-out Klauseln beim Unternehmenskauf". Op. cit., p. 2913; WERNER, Rüdiger. "Earn-Out-Klauseln - Kaufpreisanpassung beim Unternehmenskauf". Op. cit., p. 1665; TINA, Andrea. Il contratto di acquisizione di partecipazioni societarie. Op. cit., p. 419; POITRINAL, François D. "Cession d'entreprise: les conventions de earn out". Op. cit., p. 24.

${ }^{768}$ Sobre o assunto, cf. FRANÇA, Erasmo V. A. e N.; ADAMEK, Marcelo V. von. "Aproveitamento de oportunidades comerciais da companhia pelo acionista controlador (corporate opportunity doctrine)". In: FRANÇA, Erasmo V. A. e N.; ADAMEK, Marcelo V. von (coord). Temas de direito empresarial e outros estudos em homenagem ao Prof. Luiz Gastão Paes de Barros Leães. São Paulo: Malheiros, 2014, pp. 88110 .

769 Sobre a diferença entre o contrato de sociedade e o negócio jurídico parciário, cf. WIEDEMANN, Herbert. Gesellschaftsrecht. Op. cit., p. 653; SCHÖN, Wolfgang. „Gibt es das partiarische Darlehen? ”. In: ZGR, 1993, pp. 210-244; SCALZILLI, João Pedro; SPINELLI, Luís Felipe. "Reflexões sobre a sociedade em conta de participação no direito brasileiro". In: RJE, v. 12, 2010, pp. 17-115, p. 95 (diferenciando a sociedade em conta de participação do mútuo parciário).
} 
contratante participa dos resultados da atividade exercida pelo outro contratante, sem determinar - como regra - a orientação dessa atividade. ${ }^{770}$ Tampouco se pode argumentar que, por ser titular ao direito eventual de receber a parcela do preço, teria o comprador o direito de praticar atos destinados a conservá-lo (CC, art. 130), o que fundamentaria o direito do vendedor de participar da gestão social ou limitá-la. Foi correta, nesse sentido, decisão em caso relativo a compra e venda de ações com cláusula de earn out em que o vendedor foi afastado da administração durante o período previsto para a verificação das condições e pleiteava que a realização de operações e contratos pela sociedade (então sob o controle do comprador) ficasse subordinada ao seu prévio consentimento. Decidiu-se em caráter liminar que o vendedor teria direito a fiscalizar a gestão social, mas não de nela intervir, senão por meio de sua eventual recondução ao cargo de que avaliava ter sido injustamente despedido. ${ }^{771}$

Em que pese não possuir o vendedor o poder de intervir diretamente na gestão, impõe-se como limite externo implícito à conduta das partes a proibição de adoção de comportamento malicioso tendente à verificação ou não verificação da condição, como já se mencionou. No âmbito da cláusula de earn out, a pauta concreta e específica para a avaliação do comportamento é o dever de diligência na administração dos negócios sociais (business judgment rule). ${ }^{772}$ Seria contrária ao dever de diligência a atuação do vendedor que permanecesse como administrador e atuasse, por exemplo, para adiantar receitas apenas para que a condição fosse alcançada, ainda que o comportamento fosse economicamente irracional e prejudicial ao interesse social; ou a atuação do comprador que, assumindo o comando da gestão social, passasse a promover investimentos de longo prazo que deprimissem o lucro e que não se apresentassem condizentes com padrões de boa técnica de gestão societária, ou que retardasse a cobrança de créditos, ou que se aproveitasse de oportunidades comerciais pertinentes à sociedade por meio de outras sociedades que controlasse e que integrassem o mesmo grupo societário de fato. Os efeitos

\footnotetext{
${ }^{770}$ VISCHER, Markus. “Earn out-Klauseln in Unternehmenskaufverträgen”. Op. cit., p. 513.

771 TJSP, Ap. n. 125493- 61.2012.8.26.0100, $1^{\mathrm{a}}$ Câm. Res. Dir. Empr., rel. Des. Francisco Loureiro, j. 02.10.2012.

772 SPERANZIN, Marco. Vendita delle partecipazione di 'controllo' e garanzie contrattuali. Op. cit., p. 290; VISCHER, Markus. "Earn out-Klauseln in Unternehmenskaufverträgen”. Op. cit., p. 513.
} 
das escolhas de gestão que conflitam com a administração diligente devem ser, com isso, expurgados para o efeito da verificação da condição. ${ }^{773}$

É comum, ainda, que, no lugar de os poderes de administração das partes serem previstos no contrato de compra e venda de participações societárias, sejam eles disciplinados em acordo de sócios ou quotistas celebrados entre as partes, sob o pressuposto de que o vendedor permaneça na condição de sócio minoritário. Apesar de formalmente autônomo, tal acordo de acionistas pode ser interpretado como funcionalmente coligado de forma necessária ao contrato de compra e venda, ${ }^{774}$ de tal forma que, advindo a invalidade ou a ineficácia do contrato de compra e venda, tem-se como consequência também a propagação da invalidade ou ineficácia do acordo de sócios. Há, ainda, a possibilidade de que ocorra a resilição ou resolução prévia do acordo de sócios, mas, a princípio, não seria cabível presumir a vontade de extinguir a compra e venda, cujos efeitos já se produziram. ${ }^{775}$

(iii) Prestação de contas e fiscalização

O contrato de compra e venda do qual conste cláusula de earn out deve assegurar a prestação de contas pelas partes, de tal forma que toda informação relevante para a verificação do implemento das condições seja passível de controle e verificação pelo contratante interessado. ${ }^{776} \mathrm{O}$ contrato, contudo, pode ser omisso quanto à questão e a situação, apesar de parecer teratológica, em verdade não é tão rara, pois os contratantes,

\footnotetext{
${ }^{773}$ TINA, Andrea. Il contratto di acquisizione di partecipazioni societarie. Op. cit., p. 419; LEVY, Daniel de A. "Acionista controlador - abuso do poder de controle - diminuição do valor das ações - exercício do call pelo controlador - alegação da própria torpeza - incorporação de contingências". In: YARSHELL, F. L.; PEREIRA, G. S. Processo societário II. São Paulo: Quartier Latin, 2015, pp. 117-136, p. 136 (referindo a hipótese assemelhada em que se adota gestão prejudicial à companhia com a intenção de diminuir o preço de exercício de opção de compra de ações e defendendo, para a hipótese, que sejam expurgados os efeitos derivados da atuação abusiva).

${ }_{774}$ Sobre a coligação funcional, cf. PÉLLE, Sebastien. La notion d'interdépendance contractuelle: contribution à l' étude des ensembles de contrats. Paris: Dalloz, 2007, p. 225; LÓPEZ FRIAS, Ana. Los contratos conexos. Barcelona: Bosch, 1994, pp. 276-284; FERRI, Giuseppe. Causa e tipo nella teoria del negozio giuridico. Milano, Giuffrè, 1966, p. 405.

775 MARINO, Francisco P. de Crescenzo. Contratos coligados no direito brasileiro. São Paulo: Saraiva, 2009, p. 141-144 (analisando a situação parcialmente semelhante de contrato de cessão de controle coligado à celebração de contrato de fornecimento entre o vendedor e a sociedade cujo controle foi cedido).

${ }^{776}$ SÁ, F. Oliveira e. "A determinação contingente do preço de aquisição de uma empresa através de cláusulas de earn-out”. Op. cit., p. 409.
} 
conjuntamente com a celebração da cláusula de earn out, geralmente preveem a manutenção do vendedor na gestão social, e é com base nessa condição de administrador que se promove a fiscalização. ${ }^{777} \mathrm{O}$ problema surge, porém, se por qualquer vicissitude, como a incapacidade, ou mesmo o falecimento, ou por divergência entre as partes, o contratante deixa de exercer o cargo de administrador. ${ }^{778}$

A questão que se coloca, nesses casos, é de saber se, mesmo na omissão do contrato de compra e venda, o contratante teria direito de fiscalizar a ocorrência da condição que lhe beneficia. Um possível fundamento seria argumentar que, ao celebrar o contrato de compra e venda com cláusula de earn out, as partes preveem partilha de resultados do exercício em comum de atividade econômica, o que caracterizaria o contrato como sociedade (CC, art. 981). Por consequência, o contratante possuiria o direito de examinar a qualquer tempo os livros e documentos, o estado de caixa e a carteira da sociedade (CC, art. 1.021). A qualificação da cláusula de earn out como contrato de sociedade, porém, parece inadequada. A despeito da semelhança econômica com o contrato de sociedade, não há, na cláusula de earn out, a intenção associativa que caracteriza o contrato de sociedade (CC, art. 981). ${ }^{779}$ Trata-se, como se viu, ${ }^{780}$ de contrato parciário, em que prevalece o princípio de que o participante possui direito de fiscalizar os documentos relevantes para aferir a observância de seus direitos, como se vê, por exemplo, na regra do contrato de edição de obra literária (exemplo de contrato parciário) segundo a qual o editor é obrigado a facultar ao autor "o exame da escrituração na parte que lhe corresponde, bem como a informá-lo sobre o estado da edição" (Lei 9.610/1998, art. 59). Prevista a cláusula de earn out, por conseguinte, a parte a quem beneficia a verificação da condição possui o direito de obter a documentação pertinente e necessária para a fiscalização, ${ }^{781}$ ou seja, que tenha acesso a todos os documentos "indispensáveis à aferição de eventual frustração da condição suspensiva a que está subordinada a fixação do preço das quotas sociais". ${ }^{782}$ Sendo previsto que a parcela adicional do preço deve ser paga caso

\footnotetext{
${ }^{777}$ VISCHER, Markus. “Earn out-Klauseln in Unternehmenskaufverträgen”. Op. cit., pp. 509- 517, p. 512.

778 TJSP, Ap. n. 125493-61.2012.8.26.0100, 1 ${ }^{\text {a }}$ Câm. Res. Dir. Empr., rel. Des. Francisco Loureiro, j. 02.10.2012 (em que se discutia o afastamento supostamente ilegal do vendedor da administração da sociedade, o que lhe impedia de fiscalizar a verificação das condições previstas em cláusula de earn out, pois o contrato de compra e venda não previa direitos de fiscalização).

${ }^{779}$ VISCHER, Markus. "Earn out-Klauseln in Unternehmenskaufverträgen”. Op. cit., p. 514.

${ }^{780}$ Sobre o assunto, cf. item II.C.2.b)(3)(b)(ii), supra.

${ }^{781}$ VISCHER, Markus. "Earn out-Klauseln in Unternehmenskaufverträgen”. Op. cit., p. 515; CAMILO Jr., Ruy Pereira. "Contrato de cessão de quotas sociais". Op. cit., p. 250.

782 TJSP, Ap. n. 125493- 61.2012.8.26.0100, 1a Câm. Res. Dir. Empr., rel. Des. Francisco Loureiro, j. 02.10 .2012
} 
atingido certo faturamento, por conseguinte, somente é pertinente a prestação de contas referente a dados do faturamento e, não às despesas.

(c) Articulação com outras cláusulas contratuais

O condicionamento do pagamento do preço à verificação de eventos futuros pode conduzir a dificuldades de convivência com outras cláusulas do contrato, como é o caso das cláusulas de ajuste de preço ou garantais contratuais. ${ }^{783} \mathrm{~A}$ depender da configuração do contrato, a concretização de um único risco poderia conduzir a dois efeitos, como seria o caso de demanda tributária que impusesse dever de indenizar ao vendedor, mas, ao mesmo tempo, impactasse o lucro da sociedade no período base. A certo prática contratual deve estar atenta para esse aspecto, cabendo demarcar fronteiras, seja para determinar uma aceitação desse duplo impacto, seja para afastá-lo. ${ }^{784}$ Se o contrato não regular a articulação entre as cláusulas, normalmente a interpretação pautada pelos usos e costumes e pela boa-fé caminha no sentido de fazer prevalecer o efeito específico (garantia contratual, por exemplo) com neutralização do impacto do fato garantido sobre a base de cálculo da parcela contingente do preço, evitando a duplicidade de efeitos para o mesmo fato.

3. Garantias do pagamento do preço: o papel da conta garantia (escrow account)

Para garantir o pagamento do preço são admissíveis as garantias reais e fidejussórias passíveis de constituição nos contratos em geral. Merece destaque, porém, o emprego dos chamados depósitos em conta garantia (escrow account), ${ }^{785}$ ou "depósitos bancários fiduciários caucionados”, na terminologia portuguesa, modalidade de depósito realizado pelo comprador em instituição financeira em que os recursos não fícam disponíveis nem ao comprador, nem ao vendedor. ${ }^{786}$ Utilizados sobretudo nas aquisições

\footnotetext{
${ }^{783}$ SÁ, F. Oliveira e. "A determinação contingente do preço de aquisição de uma empresa através de cláusulas de earn-out”. Op. cit., p. 414.

${ }^{784}$ WERNER, Rüdiger. "Earn-Out-Klauseln - Kaufpreisanpassung beim Unternehmenskauf”. Op. cit., p. 1665; VISCHER, Markus. "Earn out-Klauseln in Unternehmenskaufverträgen”. Op. cit., p. 516; SÁ, F. Oliveira e. "A determinação contingente do preço de aquisição de uma empresa através de cláusulas de earnout". Op. cit., p. 415; POITRINAL, François D. "Cession d'entreprise: les conventions de earn out". Op. cit., p. 26.

${ }_{785}$ SALOMÃO NETO, Eduardo. Direito bancário, $2^{\mathrm{a}}$ ed. São Paulo: Atlas, 2014, p. 271.

786 ANTUNES, João Tiago M. Do contrato de depósito escrow. Coimbra: Almedina, 2007, p. 192 (afirmando que há frequente aplicação do contrato de escrow na compra e venda de participações societárias).
} 
de participações societárias em que há grande quantidade de vendedores ou em que o risco de crédito é elevado, ${ }^{787}$ o depósito em garantia configura contrato trilateral, ${ }^{788}$ coligado por vínculo de subordinação ao contrato de compra e venda, ${ }^{789}$ em que a instituição financeira figura como mandatária das partes e age conforme a regulação contratual, liberando os recursos a uma ou a outra parte conforme as previsões estabelecidas contratualmente.

Sob o ponto de vista jurídico, a primeira dificuldade que se apresenta é a incompatibilidade entre a estrutura jurídica e a função. ${ }^{790}$ Como o direito brasileiro não conhece o desdobramento da propriedade típico do trust, é preciso que o comprador ou o vendedor conste como depositante e beneficiário da conta garantia. ${ }^{791} \mathrm{O}$ objetivo desse expediente é que nenhuma das partes permaneça correndo o risco de solvência da outra. ${ }^{792}$ $\mathrm{Na}$ realidade, porém, os valores depositados ficam sujeitos a penhoras (inclusive a "penhora online") promovidas contra o titular e, em caso de recuperação judicial ou falência, os recursos não poderiam ser objeto de pedido de restituição pela contraparte contratual, ficando, assim, passíveis de utilização para satisfação dos demais credores. A forma encontrada para superar essa dificuldade no Brasil é a abertura, em nome do comprador, de conta vinculada (CMN, Res. N. 2.525/1998), cuja movimentação pelo cliente é restrita e deve ter por finalidade exclusiva a garantia da operação de crédito específica. ${ }^{793}$ Para obviar os riscos de crédito do comprador, por outro lado, os recursos depositados são normalmente transferidos fiduciariamente em garantia ao vendedor, de tal forma que o vendedor poderia satisfazer seu crédito por meio dos recursos alienados fiduciariamente (LRE, art. $49, \S 3^{\circ}$ ).

A segunda dificuldade diz respeito à possibilidade de afirmar que, com o depósito dos recursos na conta garantia, o vendedor adquire disponibilidade sobre a parcela do preço depositada, restando obrigado ao recolhimento de imposto de renda. Essa

\footnotetext{
${ }^{787}$ REED, Stanley F.; LAJOUX, Alexandra R. The art of M\&A, 2a ed. New York: Irwin, 2011, p. 488.

${ }^{788}$ LANCIANI, Andrea. "Il prezzo (modalità, aggiustamenti, garanzie del pagamento dilazionato)". Op. cit., p. 331.

${ }^{789}$ ANTUNES, João Tiago M. Do contrato de depósito escrow. Op. cit., pp. 164-165.

790 COMPARATO, Fábio Konder; SALOMÃO FILHO, Calixto. O poder de controle na sociedade anônima Anônima. Op. cit., nota de texto n. 54, p. 246.

${ }^{791}$ SALOMÃO NETO, Eduardo. O trust e o direito brasileiro. São Paulo: Trevisan, 2016, pp. 93-99.

792 BOTREL, Sérgio. Fusões e aquisições. São Paulo: Saraiva, 2012, p. 270.

793 SALOMÃ̃ NETO, Eduardo. Direito bancário. Op. cit., p. 438.
} 
costumava ser a interpretação das autoridades fazendárias. ${ }^{794}$ Esse entendimento foi alterado e, atualmente, considera-se que o imposto de renda sobre o ganho de capital somente incide quando há efetiva disponibilidade econômica ou jurídica ao alienante. ${ }^{795}$

\section{Natureza jurídica: civil, empresarial, mercantil}

A natureza jurídica da compra e venda de participações societárias de controle e o seu enquadramento como compra e venda comercial ou mercantil nos países que diferenciam tais modalidades é matéria que tradicionalmente comporta divergências.

1. Tratamento do tema no direito estrangeiro

Em Portugal, o Código de Comércio expressamente determina que são comerciais as compras e vendas "de partes ou de acções de sociedades comerciais", 796 sendo assim consideradas também as operações relativas às participações societárias que conferem o controle societário. ${ }^{797}$ No direito francês, à míngua de disposição semelhante no Code de commerce, os contratos de compra e venda de ações ou quotas são considerados civis, mas, após vacilar e se orientar no sentido de que mesmo a transferência da maioria das participações societárias seria contrato civil, terminou-se por acolher um dos postulados da tese da especificidade da cessão de controle, ${ }^{798}$ de que a cessão que implicasse alteração do controle deveria ser considerada comercial. ${ }^{799}$

Na Alemanha, o contrato de compra e venda do estabelecimento ou de participações societárias de controle não é considerado comercial, sendo inaplicáveis, por exemplo, o ônus de examinar e imediatamente comunicar qualquer defeito encontrado nas

\footnotetext{
${ }^{794}$ HALEMBECK, Luiz F. A. "Compra e venda de sociedades fechadas". In: ROVAI, A. L.; MURRAY NETO, A. (coord.). As sociedades por ações na visão prática do advogado. Rio de Janeiro: Elsevier, 2010, pp. 147-168, p. 161.

SECRETARIA DA RECEITA FEDERAL DA 4 ${ }^{\mathrm{a}}$ REGIÃO, Solução de Consulta n. 58, 17.08.2013; CARF, Proc. n. 19515.720697/2011-28, 2 2âm. / 2 ${ }^{\mathrm{a}}$ T., j. 05.11.2014. Sobre o assunto, cf. PARO, Giácomo; DINIZ, Rodrigo de Madureira Pará. “As implicações das cláusulas de ajustes de preço e das contas escrow na tributação pelo imposto de renda". Op. cit.

${ }^{796}$ Código Comercial Português, art. $^{\circ} 463^{\circ}$ : São consideradas comerciais: [...] 5. ${ }^{\circ}$ As compras e vendas de partes ou de acções de sociedades comerciais.

797 GALVÃO, Clemente. "Conteúdo e incumprimento do contrato de compra e venda de participações sociais". Op. cit., p. 534.

798 OPPETIT, Bruno. "Les cessions de droits sociaux emportant le transfert du contrôle d'une société: essai de synthèse". Op. cit., p. 633-634; ROUX, Daniel. "La spécificité des cessions de contrôle”. Op. cit., pp. 6466.

${ }^{799}$ CAFFIN-MOI, Marie. Cession de droits sociaux et droit des contrats. Op. cit., n. 2, pp. 4-5.
} 
mercadorias recebidas. ${ }^{800} \mathrm{~A}$ empresa não é considerada mercadoria (Ware), razão pela qual o regime aplicável ao contrato é o da compra e venda civil. ${ }^{801}$ Entendimento semelhante prevalece na Espanha. ${ }^{802}$

2. Situação anterior à vigência do Código Civil de 2002

No Brasil, até a revogação da parte primeira do Código Comercial de 1850 pelo Código Civil de 2002 (CC, art. 2.045), vigiam regimes parcialmente diversos para a compra e venda civil e comercial. Era comum o regime de sua formação e execução, pois as regras do direito civil para os contratos em geral eram aplicáveis aos contratos comerciais $(\mathrm{CCom} / 1850$, art. 121). Diferenciavam-se os regimes, porém, quanto às normas específicas da compra e venda mercantil, como, por exemplo, a necessidade de interpelação para constituição em mora das partes (CCom/1850, art. 205) ou o prazo de 10 (dez) dias para reclamar a presença de vícios ocultos (CCom/1850, art. 211). Para além dessas diferenças pontuais, aplicavam-se aos contratos e obrigações mercantis regras gerais peculiares, entre as quais se incluíam a disciplina da prova da celebração do negócio (CCom/1850, art. 122) e de sua intepretação (CCom/1850, art. 131).

Analisando a qualificação jurídica do contrato de cessão de controle, COMPARATO considerou que as regras comerciais mostravam-se como "autênticas normas de exceção" ${ }^{\# 03}$, aplicáveis somente às compras e vendas de "efeitos móveis ou semoventes para os revender por grosso ou a retalho" (CCom/1850, art. 191, par. único). Para COMPARATO, a cessão de controle não poderia, de forma nenhuma, ser assimilada a uma compra de mercadoria, razão pela qual lhe seriam inaplicáveis as normas constantes do Código Comercial. ${ }^{804}$

\footnotetext{
${ }^{800}$ HOMMELHOFF, Peter. Die Sachmängelhaftung beim Unternehmenskauf. Op. cit., pp. 125-126.

${ }^{801} \mathrm{HGB}, \S 377$.

${ }^{802}$ GIMENO RIBES, Miguel. La protección del comprador en la adquisición de empresa. Op. cit., p. 29.

${ }^{803}$ COMPARATO, Fábio K. “A cessão de controle acionário é negócio mercantil?”. In: Novos ensaios e pareceres de direito empresarial. Rio de Janeiro: Forense, 1981, pp. 245-260, p. 251.

${ }^{804}$ COMPARATO, Fábio K. “A cessão de controle acionário é negócio mercantil?”. Op. cit., p. 256. No mesmo sentido, PEREIRA, Guilherme D. C. Alienação do poder de controle acionário. Op. cit., p. 78.
} 


\section{Situação posterior à vigência do Código Civil de 2002}

Com a vigência do Código Civil de 2002, a compra e venda mercantil deixa de ter regramento expresso. Em termos legislativos, portanto, não haveria propósito em buscar definir se o contrato de compra e venda de participações societárias de controle teria natureza civil, comercial ou empresarial, tendo em vista a unificação do direito das obrigações promovida pelo Código.

Não obstante a ausência de regramento legislativo expresso, após a entrada em vigor do Código Civil de 2002, doutrina e jurisprudência passaram a defender a necessidade de se reconhecer a peculiaridade dos contratos empresariais, que seriam regidos por uma lógica própria e diversa da aplicável aos contratos em geral. A interpretação de certos institutos do direito contratual e a sua aplicação aos contratos empresariais deveria ser matizada por princípios igualmente específicos.

Os contratos empresariais sofreriam o influxo de vértices próprios do sistema comercial, como os princípios da tutela do crédito, prestígio da segurança e previsibilidade, importância do erro (ou jogada equivocada) como permissivo para viabilizar o diferencial competitivo dos participantes do mercado, e respeito à autonomia privada e ao pacta sunt servanda. ${ }^{805}$ Pautado por particularismos ligados à sua origem histórica, o direito comercial seria calcado em fundamentos peculiares que se refletiriam na atividade de interpretação dos contratos e na aplicação de certos institutos jurídicos. $\mathrm{Na}$ interpretação, destaca-se o privilégio à boa-fé objetiva pelos usos e costumes de determinado mercado, interpretação objetiva das manifestações de vontade, e não subjetiva, como derivaria da aplicação literal do 112 do Código Civil, necessidade de interpretação a favor do devedor, respeito à função social e coerência na interpretação dos textos contratuais tendo em vista a função econômica do contrato. No que diz respeito à aplicação de regimes de "proteção à parte mais fraca", ${ }^{806}$ como seria o caso do instituto da lesão e da onerosidade excessiva, seria necessário cuidado na aplicação das regras

\footnotetext{
${ }^{805}$ FORGIONI, Paula A. “A interpretação dos negócios empresariais no novo Código Civil”. In: RDM, n. 130, 2003, pp. 7-38, p. 16.

${ }^{806}$ FORGIONI, Paula A. “A interpretação dos negócios empresariais no novo Código Civil”. Op. cit., p. 35.
} 
constantes do Código Civil para que as vantagens competitivas normais e desejáveis no mercado não fossem neutralizadas. ${ }^{807}$

Na mesma esteira, FÁBio Ulhoa Coelho defende que, a despeito da unificação do direito das obrigações, uma das "mais equivocadas interpretações a que se pode chegar" seria a de que os "contratos empresariais (anteriormente denominados 'mercantis') estariam sujeitos, no direito brasileiro, à mesma disciplina jurídica, princípios e regras aplicáveis aos contratos civis". ${ }^{808} \mathrm{O}$ autor defende que seria inconstitucional a aplicação do regime jurídico dos contratos civis aos contratos empresariais, pois "de um lado, uma realidade econômica (baliza material), e, de outro, uma conformação constitucional (baliza formal), que simplesmente impedem a lei ordinária de tentar suprimi-la, igualando os regimes jurídicos de todos os contratos cíveis (os civis e os empresariais)". 809

A autonomia categorial dos contratos empresariais foi reconhecida com especial relevo no âmbito da $1^{\mathrm{a}}$ Jornada de Direito Comercial do CJF, realizada em outubro de 2012, em que os estudiosos ali reunidos aprovaram enunciados afirmando que (i) "o dirigismo contratual deve ser mitigado, tendo em vista a simetria natural das relações interempresariais" (Enunciado 21); (ii) "é lícito às partes contratantes estabelecer parâmetros objetivos para a interpretação dos requisitos de revisão e/ou resolução do pacto contratual" (Enunciado 22); (iii) "a revisão do contrato por onerosidade excessiva fundada no Código Civil deve levar em conta a natureza do objeto do contrato. Nas relações empresariais, deve-se presumir a sofisticação dos contratantes e observar a alocação de riscos por eles acordada” (Enunciado 25); (iv) “em razão do profíssionalismo com que os empresários devem exercer sua atividade, os contratos empresariais não podem ser anulados pelo vício da lesão fundada na inexperiência" (Enunciado 28); e (v) "aplicam-se aos negócios jurídicos entre empresários a função social do contrato e a boa-fé objetiva (art. 421 e 422 do Código Civil), em conformidade com as especificidades dos contratos empresariais" (Enunciado 29).

\footnotetext{
${ }^{807}$ FORGIONI, Paula A. "A interpretação dos negócios empresariais no novo Código Civil”. Op. cit., p. 36; FORGIONI, Paula A. Teoria geral dos contratos empresariais, $2^{\mathrm{a}}$ ed. São Paulo: RT, 2010, pp. 215-250. ${ }^{808}$ COELHO, Fábio Ulhoa. "As obrigações empresariais". In: COELHO, Fábio Ulhoa (Coord.). Tratado de direito comercial, v. 5. São Paulo: Saraiva, 2015, 13-20, p. 14.

${ }^{809}$ COELHO, Fábio Ulhoa. "As obrigações empresariais". Op. cit., pp. 14-15.
} 
$\mathrm{Na}$ jurisprudência do STJ, igualmente, já se decidiu que (i) o profissionalismo seria ínsito ao conceito de empresário, de tal forma que o empresário não poderia justificar eventuais deslizes no trato comercial alegando amadorismo; ${ }^{810}$ (ii) nos contratos empresariais, haveria "simetria natural" entre as partes contratantes, sendo impossível "tratá-los da mesma forma que os demais contratos de direito privado, tais como os contratos de trabalho, os contratos de consumo ou mesmo os contratos entre particulares", de tal forma que o "fato de o Código Civil de 2002 ter submetido os contratos cíveis e empresariais às mesmas regras gerais não significa que estes contratos sejam essencialmente iguais"; 811 e (iii) nos contratos empresariais teria vigência "o princípio da plena 'vinculação dos contratantes ao contrato', ou seja uma especial força obrigatória dos efeitos do contrato (pacta sunt servanda), em grau superior ao do Direito Civil, cujo afastamento somente poderia ocorrer em hipóteses excepcionais", ${ }^{812}$ resultando na circunstância de que nesse campo o "princípio da autonomia privada é mais saliente do que em outros setores do Direito Privado". 813

No âmbito do contrato de compra e venda, defende-se que o tipo contratual, a despeito de ser formulado como estrutura única, comportaria diversas funcionalidades, entre as quais a compra e venda de consumo, civil e empresarial. ${ }^{814}$ A última modalidade seria caracterizada pela circunstância de ser celebrada pelo empresário no âmbito de suas atividades usuais. ${ }^{815}$ A compra e venda de participações societárias de controle, após a vigência do Código Civil de 2002, muito embora não fosse considerada modalidade de

\footnotetext{
${ }^{810}$ STJ, REsp n. 1.279.188-SP, 4 ${ }^{\mathrm{a}}$ T., rel. Min. Luis Felipe Salomão, j. 16.04.2015 (afirmando que, em contrato de fornecimento de matéria-prima não formalizado contratualmente, o adquirente de matéria-prima não poderia se voltar contra o fornecedor que decidisse diminuir a quantidade de produtos fornecidos).

${ }^{811}$ STJ, REsp n. 936.741-GO, 4 ${ }^{\mathrm{a}}$ T., rel. Min. Antonio Carlos Ferreira, j. 03.11 .2011 (negando a possibilidade de aplicação de teorias da imprevisão ou da onerosidade excessiva para afastar a obrigatoriedade de contrato de compra e venda futura de soja em função da variação cambial).

${ }^{812}$ STJ, REsp n. 1.158.815-RJ, 3ª T., rel. Min. Paulo de Tarso Sanseverino, j. 07.02.2012 (manutenção de prêmio de produtividade estipulado em contrato de gestão de empreendimento imobiliário); e STJ, REsp n. 1.409.849-PR, $3^{\mathrm{a}}$ T., rel. Min. Paulo de Tarso Sanseverino, j. 26.04.2016 (reformando decisão que considerou nula previsão de pagamento de aluguel em dobro no mês de dezembro constate de contrato de locação em shopping center).

${ }^{813}$ STJ, REsp n. 1.158.815-RJ, $3^{\mathrm{a}}$ T., rel. Min. Paulo de Tarso Sanseverino, j. 07.02.2012 (manutenção de prêmio de produtividade estipulado em contrato de gestão de empreendimento imobiliário); e STJ, REsp n. 1.409.849-PR, $3^{\mathrm{a}}$ T., rel. Min. Paulo de Tarso Sanseverino, j. 26.04.2016 (reformando decisão que considerou nula previsão de pagamento de aluguel em dobro no mês de dezembro constate de contrato de locação em shopping center).

${ }^{814}$ BRANCO, Luiz. C. G. "O regime obrigacional unificado do Código Civil Brasileiro e seus efeitos sobre a liberdade contratual. A compra e venda como modelo jurídico multifuncional”. In: RT, v. 872, 2008, pp. 1142 , p. 32.

${ }^{815}$ BRANCO, Luiz. C. G. "O regime obrigacional unificado do Código Civil Brasileiro e seus efeitos sobre a liberdade contratual. A compra e venda como modelo jurídico multifuncional”. Op. cit., p. 32.
} 
contrato comercial enquanto o Código Comercial de 1850 estava em plena vigência, passou a ser considerada exemplo típico de contrato empresarial. FÁBIO UlHOA COELHO defende que a compra e venda que denomina "compra e venda de empresas" teria "na verdade, por objeto participação societária, que pode consistir em quotas de sociedades limitadas ou ações de companhias" e se diferenciaria do trespasse, cujo objeto seria o estabelecimento. ${ }^{816}$ Para o autor, "a alienação de debêntures ou ações e a cessão de quotas sociais são espécies do gênero compra e venda mercantil". ${ }^{817}$ Também na jurisprudência encontra-se referência ao fato de que o contrato de compra e venda de quotas ou ações teria natureza empresarial. ${ }^{818}$

\section{Projeto de Código Comercial}

Em linha com o entendimento doutrinário referido, tramita no Congresso Nacional o Projeto de Código Comercial. ${ }^{819}$ Foi formada comissão de juristas para elaboração de anteprojeto de Código Comercial no âmbito do Senado Federal que, em 19 de novembro de 2013, apresentou relatório final de sua atividade, integrado por minuta do anteprojeto de Código Comercial, do qual consta o art. 429, de seguinte teor: "Aplicam-se as normas sobre a compra e venda mercantil à compra e venda de empresa, ações ou quotas representativas do capital de sociedade, estabelecimento empresarial ou moeda".

\section{Posicionamento}

Como se depreende do quanto foi acima exposto, prevalece hoje a visão na doutrina e na jurisprudência de que (i) os contratos empresariais constituiriam categoria jurídica autônoma; (ii) a compra e venda de participações societárias de controle seria compra e venda empresarial (ou mercantil); e (iii) no futuro, o mais adequado para a legislação nacional seria o tratamento do contrato como categoria de compra e venda mercantil.

\footnotetext{
${ }^{816}$ COELHO, Fábio Ulhoa. "Compra e venda mercantil". In: COELHO, Fábio Ulhoa (coord.). Tratado de direito comercial, v. 5. São Paulo: Saraiva, 2015, pp. 235-269, p. 262.

${ }_{817}^{817}$ COELHO, Fábio Ulhoa. "Compra e venda mercantil". Op. cit., p. 255.

${ }^{818}$ Declaração de voto do Des. Alexandre Lazzarini. In: TJSP, Ap. 0219551-27.2010.8.26.0100, $2^{\mathrm{a}}$ Câm. Res. Dir. Empr., rel. Des. Ligia Araújo Bisogni.

${ }^{819}$ Projeto de Lei do Senado n. 487, de 2013; Projeto de Lei n. 1572, de 2011 na Câmara dos Deputados.
} 
Acredita-se, contudo, que tal orientação (i) parte de uma compreensão inadequada do processo de unificação do direito das obrigações; (ii) é equivocada a concepção de que atualmente os contratos empresariais constituiriam categoria jurídica jurídica autônoma; (iii) ainda que se admitisse que os contratos empresariais constituíssem uma categoria autônoma, os pressupostos para a aplicação da sua disciplina não são claros, nem coerentes; (iv) as consequências extraídas da caracterização de certos contratos como empresariais não possuem fundamento legal autônomo; e (v) a posição doutrinária predominante encontra-se em direção oposta ao reconhecimento crescente de que a regulação contratual deve ser pautada pela análise de situações de interesses características, deixando de lado o raciocínio por meio de padronizações subjetivas ou objetivas.

a) Unificação do direito das obrigações

A unificação do direito das obrigações promovida pelo Código Civil de 2002 representou o ápice de um longo processo na história do direito privado brasileiro, iniciado por TEIXEIRA DE FREITAS, reconhecido como pioneiro na defesa do fim da distinção entre obrigações civis e comerciais. ${ }^{820}$ Ao promover a unificação, MigUEL REALE expressou seu intento de alinhar-se ao pensamento prevalecente não somente na obra de TEIXEIRA DE FreitAs, mas no projeto de INGLÊZ DE SOUZA e nos anteprojetos de Códigos das Obrigações de 1941 e $1964 .{ }^{821}$ A compreensão claramente subjacente a esse propósito é a de que o "direito das obrigações, compreendendo o direito contratual, constitui o núcleo do direito comercial". 822

\footnotetext{
${ }^{820}$ ROTONDI, Mario. "The proposed franco-italian code of obligations”. In: Am. J. Comp. L., v. 3, 1954, pp. 345-359, p. 350 (referindo-se à unificação do direito das obrigações promovida pelo codice civile de 1942 na Itália, afirmou que "this legislative reform which, suppressing the anachronistic survival of now obsolete considerations, involves unification of the law of obligations, not only has venerable support (for example, of the great jurist Teixeira de Freitas in Brazil, even before M. Vivante in Italy) but it also represents a natural and in- evitable trend toward "commercialization" of the civil law of obligations"); CARVALHO, Orlando de. "Teixeira de Freitas e a unificação do direito privado". In: SCHIPANI, Sandro (org.). Augusto Teixeira de Freitas e il diritto latinoamericano. Padova: Cedam, 1988, pp. 101-153, p. 104; MOREIRA ALVES, J. C. "Panorama do Direito Civil Brasileiro: das origens aos dias atuais". In: Revista da Faculdade de Direito da Universidade de São Paulo, v. 88, 1993, pp. 185-238, p. 196; COSTA, Philomeno J. da. Autonomia do direito comercial. São Paulo: RT, 1956, pp. 77-81.

${ }^{821}$ REALE, Miguel. História do novo Código Civil. São Paulo: RT, 2005, p. 77.

${ }^{822}$ COUTO E SILVA, Clóvis V. do. "Miguel Reale, civilista". In: LAFER, Celso; FERRAZ Jr., Tércio Sampaio (org.). Direito, política, filosofia, poesia: estudos em homenagem ao Professor Miguel Reale no seu octogésimo aniversário. São Paulo: Saraiva, 1992, pp. 413-425, p. 422.
} 
As propostas de unificação enfrentaram questionamentos por parte daqueles que defendiam a manutenção de regramento especial às obrigações comerciais. Os argumentos então utilizados para defender a autonomia legislativa são similares àqueles hoje empregados para defender a autonomia categorial dos mesmos contratos.

$\mathrm{O}$ argumento de que a realidade econômica nas obrigações empresariais seria diversa, utilizado por FÁBIO UlHOA COELHO para defender a inconstitucionalidade de um tratamento unitário das obrigações civis e comerciais, foi combatido por ASCARELLI, para quem "não é possível, porém, identificar um constante e necessário critério de distinção entre direito civil e comercial em correspondência com o constante particularismo de algumas relações econômicas que, por efeito da sua natureza, houvessem 'sempre' e 'necessariamente' de dar lugar a um direito particular" ${ }^{\text {}} 823$ e, especialmente por Philomeno J. DA COSTA, que ressaltava que "cada espécie de atividade tem normalmente exigências privativas e desnecessidade de outras que possam ser mesmo genéricas", mas "não há tantos direitos quantas forem as atividades ou profissões". 824

Os princípios peculiares do direito comercial, ademais, não justificariam a sobrevivência das obrigações comerciais como categoria autônoma. Como sustentou o mesmo PhILOMENo DA Costa, "nenhuma das peculiaridades de um direito comercial (simplicidade das formas, tutela maior do crédito, velocidade na prática dos atos, onerosidade das obrigações, solidariedade passiva, etc.) tem caráter exclusivo, ou privativo; nenhuma delas dá formas ou atributos especiais às normas jurídicas que seriam dêsse direito comercial; elas são iguais às demais normas jurídico privadas". 825

Apesar de não ser intuitiva, a afirmação de PHILOMENO DA CosTA justificase pelo fato de que grande parte da especificidade do regramento comercial liga-se a aspectos históricos. Foi a resistência e a inadaptabilidade do ius commune que fez florescer o direito comercial enquanto categoria autônoma. ${ }^{826}$ No direito romano clássico ${ }^{827}$ e na

\footnotetext{
${ }^{823}$ ASCARELLI, Tullio. "O conceito de direito especial e a autonomia do direito comercial”. In: Problemas das Sociedades Anônimas e Direito Comparado, $2^{a}$ ed. São Paulo: Saraiva, 1969, pp. 84-89, p. 85.

${ }^{824}$ COSTA, Philomeno J. da. Autonomia do direito comercial. Op. cit., pp. 289.

${ }^{825}$ COSTA, Philomeno J. da. Autonomia do direito comercial. Op. cit., pp. 343.

${ }^{826}$ ROTONDI, Mario. "Entstehung und Niedergang des autonomen Handelsrechts in Italien”. In: AcP, 1967, pp. 29-63, pp. 32-33.

${ }^{827}$ HECK, Phillip von. "Weshalb besteht ein von dem bürgerlichen Rechte gesondertes Handelsprivatrecht?". In: AcP, 1902, pp. 438-466, p. 447.
} 
common $\operatorname{law}^{828}$ não se conheciam contratos exclusivamente comerciais ao lado dos contratos civis, pois esses ordenamentos atendiam adequadamente as necessidades do comércio. O direito das obrigações comerciais, portanto, exerceu papel de pioneirismo, elaborando institutos que depois foram transpostos ao direito comum, ${ }^{829}$ de forma similar ao que se passou no direito romano entre o ius honorarium e o ius civile. Trata-se do conhecido fenômeno da "comercialização do direito civil". ${ }^{830}$ Constatada essa influência e reconhecida a possibilidade de se aplicar as regras comerciais a todos, deixa de haver motivos para criar um direito especial para uma classe de pessoas ou atos. Evita-se, com isso, a tormentosa tarefa de oferecer critérios adequados para discriminar atos civis dos comerciais ou empresariais. ${ }^{831}$

No Brasil, a unificação do direito das obrigações valeu-se de três estratégias principais. Em primeiro lugar, moldar o regramento contratual de forma adaptada ao direito comercial, consagrando a possibilidade de celebração de contratos atípicos e conferindo elevada relevância aos usos e costumes na aplicação normativa, recepcionando, portanto, a influência do direito comercial (a socialidade do Código Civil, como pretendia Miguel ReAle). Em segundo lugar, para contratos que apresentavam típicos aspectos comerciais, adotou-se a solução de os dotar de feições comerciais. Impôs-se, assim, a todos aqueles que se valessem de tais tipos contratuais a sujeição às regras materialmente comerciais, procedimento similar ao ocorrido no âmbito dos títulos de crédito, típicos instrumentos mercantis, mas que sujeitam qualquer um que deles se utiliza (empresário ou não) à mesma disciplina. Em terceiro lugar, nos casos em que fosse necessário diferenciar os contratos civis daqueles celebrados com escopo lucrativo, o Código Civil evitou a referência à condição de empresário. Quando estabelece regras específicas para certos contratos, faz-se referência à finalidade econômica, como ocorre no caso do mútuo que, destinado a fins econômicos, faz com que se presumam devidos juros (CC, art. 591). Outra alternativa utilizada foi estabelecer regras vazadas em termos gerais, sem referir especificamente a figura do empresário. É o que ocorre no caso da aquisição de propriedade de bens móveis de boa-fé, regra tipicamente talhada para a proteção do

\footnotetext{
${ }^{828}$ CAEMMERER, Ernst von. "The influence of the of international trade on the development and character of the commercial law in the civil law countries". In: ROTONDI, Mario. Inchieste di diritto comparato, v. 3: L'unità del diritto delle obbligazioni. Padova: CEDAM, 1974, pp. 12-29, p. 15.

${ }^{829}$ ASCARELLI, Tullio. Panorama do direito comercial. São Paulo: Saraiva, 1947, pp. 22-40.

${ }^{830}$ HECK, Phillip von. "Weshalb besteht ein von dem bürgerlichen Rechte gesondertes Handelsprivatrecht?". Op. cit., p. 446.

${ }^{831}$ SCHMIDT, Jan Peter. Zivilrechtskodifikation in Brasilien. Tübingen: Mohr Siebeck, 2009, p. 193.
} 
adquirente em negócios comerciais, mas que no Código Civil pressupõe que a coisa seja “oferecida ao público, em leilão ou estabelecimento comercial" e tenha sido "transferida em circunstâncias tais que, ao adquirente de boa-fé, como a qualquer pessoa, o alienante se afigurar dono" (CC, art. 1.268). Foi por essa decidida orientação de afastar a referência à categoria do empresário como critério para aplicação da disciplina dos contratos típicos que COMPARATO considerou a seção relativa à atividade negocial, posteriormente batizada como o Livro II "Do direito de empresa", como um "corpo estranho no Código, sem ligação interna e necessária com as demais partes da obra", ${ }^{832}$ e RUBENS REQUIÃO considerou que os termos comerciante e mercantil teriam sido proscritos, tratados como se fossem "expressões pornográficas", ${ }^{833}$ verdadeiro "tabu". ${ }^{834}$ A despeito das críticas, hoje se reconhece que há certa elegância na solução de REALE para oferecer um tratamento unitário tornando desnecessária a caracterização do contrato como empresarial. ${ }^{835}$

A iniciativa de unificação do direito das obrigações é considerada um erro por FÁBio UlhoA COElHo, ${ }^{836}$ sob o argumento de que a realidade econômica teria se alterado excessivamente nos anos seguintes à promulgação do Código Civil, de tal forma que, em seu aviso, "considerar a questão da unificação do direito privado a partir exclusivamente de intuições de juristas que viveram em contextos históricos radicalmente diferentes beira à irresponsabilidade". 837 Como exemplos de alterações nomeia a consolidação pelo Brasil do seu processo de inserção na economia global, além de outros três aspectos que afastariam a conveniência da solução unificadora: (i) a superação das fronteiras nacionais, com países competindo pela atração de investimentos; ${ }^{838}$ (ii) externalidades geradas pela transferência do custo da insegurança jurídica sofrida pelo empresário para seus consumidores; ${ }^{839}$ e (iii) o fato de que a Constituição Federal tutela o “interesse dos consumidores por produtos mais baratos e de maior qualidade" 840 e que, ao

\footnotetext{
${ }^{832}$ COMPARATO, F. K. "Parecer sobre o Projeto de Lei n. 634/75, do Executivo". In: RDM, n. 17, 1975, pp. 173-187, p. 177.

${ }^{833}$ REQUIÃO, Rubens. "Parecer sobre o Projeto de Lei n. 634/75, do Executivo". In: RDM, n. 17, 1975, pp. 133-173, p. 172.

${ }^{834}$ REQUIÃO, Rubens. "Parecer sobre o Projeto de Lei n. 634/75, do Executivo". Op. cit., p. 153.

${ }^{835}$ SCHMIDT, Jan Peter. Zivilrechtskodifikation in Brasilien. Op. cit., p. 199.

${ }^{836}$ COELHO, Fábio Ulhoa. "Os contratos empresariais no projeto de Código Comercial". In: Revista da Faculdade de Direito da Universidade do Porto, v. XI, 2014, pp. 387-395, p. 394.

${ }^{837}$ COELHO, Fábio Ulhoa. “Os contratos empresariais no projeto de Código Comercial”. Op. cit., p. 394.

${ }^{838}$ COELHO, Fábio Ulhoa. “Os contratos empresariais no projeto de Código Comercial”. Op. cit., pp. 390392

${ }^{839}$ COELHO, Fábio Ulhoa. “Os contratos empresariais no projeto de Código Comercial”. Op. cit., p. 393.

${ }^{840}$ COELHO, Fábio Ulhoa. “Os contratos empresariais no projeto de Código Comercial”. Op. cit., p. 394.
} 
poupar o empresário pelas consequências de seus erros em matéria contratual, estar-se-ia distorcendo a equação básica da competição, em prejuízo dos consumidores. ${ }^{841}$

Em perspectiva comparada, porém, o que se nota é que a unificação do direito das obrigações foi possível na Suíca e na Itália e conta com elevado apoio doutrinário na Alemanha. ${ }^{842} \mathrm{~A}$ decisão do legislador brasileira é avaliada como adequada tendo em vista as vantagens promovidas pela unificação. ${ }^{843}$

b) Contratos empresariais permanecem objeto de estudo doutrinário, mas não constituem categoria dogmática autônoma

Os contratos empresariais não deixaram de existir enquanto objeto de estudo doutrinário. Não há dúvidas de que os contratos entre empresários suscitam preocupações peculiares. Da mesma forma que o direito marítimo e o direito cambiário continuam sendo matérias adstritas ao direito comercial, alguns contratos tipicamente mercantis não deixam de interessar a disciplina comercial pelo fato de passarem ao Código Civil, como é o caso da comissão, agência ou distribuição.

Bastante diverso de afirmar que certos contratos se mantêm afeitos à disciplina empresarial (autonomia doutrinária) é selecionar, entre contratos efetivamente celebrados, alguns que podem ser denominados empresariais, a eles se aplicando regras específicas de interpretação e de aplicação (autonomia material). Ao tratar os contratos empresariais como categoria especial digna de disciplina jurídica autônoma, doutrina e jurisprudência promovem um regresso das históricas dificuldades ínsitas à qualificação dos contratos comerciais e atribuem, incoerentemente, caráter especial a alguns contratos, e não a outros. Afirmam presente, ainda, especificidades na interpretação e aplicação normativa dos contratos empresariais que não parecem ostentar fundamento jurídico.

\footnotetext{
${ }^{841}$ COELHO, Fábio Ulhoa. “Os contratos empresariais no projeto de Código Comercial”. Op. cit., p. 394.

${ }^{842}$ MÜLLER-FREIENFELS, Wolfram. "Zur 'Selbständigkeit' des Handelsrechts". In: FICKER, Hans Claudiu (org., et. al.). Festschrift für Ernst von Caemmerer zum 70. Geburtstag. Tübingen: Mohr Siebeck, 1978, pp. 583-622, pp. 615-616; GRUNDMANN, Stefan. "Verbraucherrecht, Unternehmensrecht, Privatrecht - warum sind sich UN-Kaufrecht und EU-Kaufrechtsrichtlinie so ähnlich?. In: AcP, v. 202, 2002, pp. 40-71, p. 69; CANARIS, Claus-Wilhelm. Handelsrecht. Op. cit., §1 III, Rn. 30 ff.

${ }^{843}$ SCHMIDT, Jan Peter. Zivilrechtskodifikation in Brasilien. Op. cit., p. 196.
} 
Antes da vigência do Código Civil, saber se um contrato era comercial ou civil era questão estritamente técnica, que COMPARATO definiu como típico de qualificação, ou seja, de identificação na realidade de situações da realidade que se amoldassem à configuração típica prevista no Código Comercial. ${ }^{844} \mathrm{Na}$ situação concreta em que analisou o caráter civil ou comercial da cessão de controle acionário, afirmou que a questão exigiria "raciocinar e decidir em face do sistema jurídico em vigor", sem cuidar de "questões meramente doutrinárias ou de suputações de iure condendo". ${ }^{845}$

Com a revogação da Parte Primeira do Código Comercial, porém, perdeu-se o referencial então existente para discriminar quais seriam os contratos comerciais submetidos à disciplina especial. Ao propor que haveria princípios interpretativos e aplicativos específicos para os contratos empresariais, volta a ser necessário um critério para determinar quais seriam esses contratos. A doutrina por vezes refere que contratos empresariais seriam os celebrados apenas entre empresários, ${ }^{846}$ ou somente entre empresários no exercício de suas atividades. ${ }^{847}$ No âmbito da compra e venda, porém, entende-se que "toda compra e venda em que comprador e vendedor são empresários chama-se mercantil e é estudada pelo direito comercial". 848

A jurisprudência, contudo, parece não se importar com o caráter subjetivo das partes para afirmar que certos contratos seriam empresariais. Em um caso de venda de soja futura, julgou-se que "o caso dos autos refere-se a contratos empresariais (sic) e não a contratos de consumo, nos quais se tem defendido, atualmente, um maior dirigismo contratual". ${ }^{849} \mathrm{O}$ referido contrato de venda futura de soja, porém, foi celebrado entre uma sociedade anônima (Cargill Agrícola S.A.) e uma pessoa física (Darci Luiz da Silva) que, ao que tudo indica, seria agricultor, desenvolvendo atividade rural, razão pela qual somente

\footnotetext{
${ }^{844}$ COMPARATO, Fábio Konder. “A cessão de controle acionário é negócio mercantil?”. Op. cit., p. 246. ${ }^{845}$ COMPARATO, Fábio Konder. "A cessão de controle acionário é negócio mercantil?". Op. cit., p. 245.

${ }^{846}$ FORGIONI, Paula A. "A interpretação dos negócios empresariais no novo Código Civil". Op. cit., p. 9 ("o foco deste trabalho são os negócios comerciais dos quais participam exclusivamente empresários ou sociedades empresárias").

${ }^{847}$ COELHO, Fábio Ulhoa. "As obrigações empresariais". Op. cit., p. 13 (defendendo que as duas partes devem empresárias e que a natureza da obrigação deve decorre do exercício da atividade empresarial das duas partes).

${ }^{848}$ COELHO, Fábio Ulhoa. "Compra e venda mercantil". Op. cit., p. 236.

${ }^{849}$ STJ, REsp n. 936.741-GO, 4ª T., rel. Min. Antonio Carlos Ferreira, j. 03.11.2011.
} 
seria considerado empresário se requeresses inscrição no Registro Público de Empresas Mercantis (CC, art. 971). No acórdão, não há menção nesse sentido, o que indica que a etapa de qualificação referida por COMPARATO, no mínimo, não exerce o mesmo papel de relevo na aplicação normativa.

Em outro julgado, relativo a contrato de prestação de serviços de gerenciamento e comercialização de empreendimento de shopping center, assevera-se que “no Direito Empresarial, regido por princípios peculiares, como a liberdade de iniciativa, a liberdade de concorrência e a função social da empresa, a presença do princípio da autonomia privada é mais saliente do que em outros setores do Direito Privado", 850 e, embora se reconheça a possibilidade de mitigação do princípio da autonomia privada quando houvesse desigualdade material entre as empresas contratantes, defende-se que tal desigualdade não se verificaria no caso concreto em que "os contratantes não [são] pequenas empresas, mas pessoas jurídicas de grande dimensão econômica, como a FUNCEF (Fundação do Economiários Federais) e a TELOS (Fundação Embratel de Seguridade Social)". Considerando, porém, que as fundações são constituídas para fins não econômicos ( $\mathrm{CC}$, art. 62, par. único), percebe-se que a jurisprudência não se mantém fiel à exigência de que ambas as partes sejam empresárias.

Os exemplos demonstram que a categoria doutrinária de contratos empresariais é utilizada sem grandes cuidados com a prévia qualificação do contrato. A classificação doutrinária que autonomizasse os contratos empresariais e fosse absolutamente fiel à exigência de que as partes fossem empresárias para que o contrato se sujeitasse a regras interpretativas e aplicativas diversas, por outro lado, poderia conduzir a resultados equivocados. Postulando uma disciplina especial para contratos empresariais, terminar-se-ia por privilegiar um critério formal (desenvolvimento de atividade empresarial ou constituição sob a forma de sociedade anônima), com o possível resultado de que um contrato entre um agricultor de grande porte e uma empresa ficasse sujeito a regras diversas e menos rigorosas do que as aplicáveis a contratos entre um microempresário e uma grande multinacional.

Uma das razões da oposição de TEIXEIRA DE FrEITAS a regras específicas para o direito obrigacional comercial foi a indevida discriminação que considerou existente

${ }^{850}$ STJ, REsp n. 1.158.815-RJ, $3^{\mathrm{a}}$ T., rel. Min. Paulo de Tarso Sanseverino, j. 07.02.2012. 
em relação à agricultura. Via no direito mercantil um direito de exceção em benefício do comércio e da indústria, mas com desprezo pelas atividades rurais que caracterizavam essencialmente a economia brasileira. ${ }^{851}$ A realidade no Brasil bem demonstra como os usos e costumes não são relevantes apenas entre comerciantes, mas também, talvez com igualmente acentuada expressão, entre produtores do campo. Em um acórdão sempre lembrado relativo à compra e venda de cacau, um fazendeiro alegou não estar obrigado a entregar o produto antes de receber o pagamento, com base na exceção do contrato não cumprido. O Ministro Aliomar BAleEIro, ao julgar o caso, apontou que "como é de uso muito antigo no comércio de cacau entre fazendeiros e produtores e firmas exportadoras da Bahia, as operações se realizam a termo, para entrega futura, fixados desde logo em singelo "pedido", - único documento - a quantidade, a data de entrega e o preço. Nada mais, do que é o exemplo o sucinto doc. de f. 30, impresso com os claros preenchidos a lápis comum. É o uso imemorial na Bahia. Milhões de quilogramas são vendidos, desse modo, cada ano, sem estrépito". 852

O caso exemplifica a contribuição que o Direito Comercial ofereceu ao Direito Civil por meio da unificação do direito das obrigações. Na ocasião, chegou-se à relevância dos usos e costumes por meio da caracterização do contrato como compra e venda comercial e aplicação do disposto no art. 131 do Código Comercial. Atualmente, contudo, tal caracterização do contrato como empresarial se mostra desnecessária, pois, a interpretação de todos os contratos deve ser realizada com base na boa-fé e nos usos e costumes (CC, art. 113), sem necessidade de diferenciação com base em critérios pessoais, como poderia ocorrer se o produtor rural alegasse não ser empresário para não se sujeitar à força dos usos e costumes que conhecia e praticava.

(2) Disciplina interpretativa ou de aplicação normativa diversa para contratos empresariais não encontra amparo legal

Para além de reintroduzir doutrinariamente clivagens que o direito positivo decididamente buscou afastar, a categoria dos contratos empresariais mostra-se prescindível. Sem pretensão de exaustividade, pode-se apontar alguns exemplos de como a

\footnotetext{
${ }^{851}$ CARVALHO, Orlando de. "Teixeira de Freitas e a unificação do direito privado". Op. cit., p. 108.

${ }^{852}$ STF, RE n. 79.545-BA, $1^{\text {a }}$ T., rel. Min. Aliomar Baleeiro, j. 22.11.1974.
} 
separação entre contratos empresariais e civis parece desnecessária. Os casos mencionados no item imediatamente anterior são ilustrativos. Não é preciso afirmar que um contrato é empresarial para se afastar a aplicação do CDC, como foi feito no caso da venda da soja futura. Basta demonstrar que o contrato não se destinava à aquisição de bens ou serviços como destinatário final (CDC, art. $2^{\circ}$ ). É igualmente desnecessário classificar o contrato empresarial para afastar a aplicação de onerosidade excessiva. Basta afirmar que a variação cambial não se apresenta como acontecimento extraordinário ou imprevisível, como, aliás, diversos precedentes do STJ reconheceram, sem que, em nenhum deles, se tenha afirmado o caráter empresarial do contrato. ${ }^{853}$ No caso da administração do shopping center, igualmente, não se exige a caracterização do contrato como empresarial para afirmar que o contrato deve ser cumprido. A obrigação de cumprir o contrato (pacta sunt servanda) é aplicável a todos os contratos entre partes civis. Quem vende um apartamento, deve transferir a propriedade sobre a coisa.. Não há maior vigência do princípio nos contratos empresariais, porque, para tanto, seria preciso afirmar que sua vigência seria menor nos demais contratos. Ignora-se qual seria o fundamento jurídico que autorizaria tal afirmação.

A especialidade interpretativa que deveria pautar os contratos empresariais, ademais, não se mostra peculiar, podendo ser extraída do Direito Civil e aplicada também a contratos entre partes que não são empresárias. A interpretação de boa-fé de acordo com os usos e costumes é uma regra geral do Código Civil ( $\mathrm{CC}$, art. 113), não constitui exclusividade dos contratos empresariais. Em segundo lugar, seria equivocado sustentar que a intepretação dos contratos civis seria sempre subjetiva enquanto a dos contratos empresariais deveria ser objetiva, ainda que o Código Civil tenha praticamente repetido a regra do art. 85 do Código Civil de 1916, segundo o qual a interpretação deve buscar atender à intenção das partes. Mesmo sob a vigência do antigo Código Civil prevalecia a corrente que defendia a interpretação objetiva das declarações de vontade, com base no princípio da interpretação de boa-fé, ${ }^{854}$ como ocorre também em países que contam com dispositivos legais semelhantes. ${ }^{855}$ Tal posicionamento persiste sob o atual Código Civil, ${ }^{856}$

${ }^{853}$ STJ, REsp n. 803.481-GO, $3^{\text {a }}$ T., rel. Min. Nancy Andrighi, j. 18.06.2007; STJ, REsp n. 849.228-GO, 4 T., rel. Min. Luis Felipe Salomão, j. 03.08.2010; STJ, AgRG no REsp n. 1.016.988-GO, 4a T., rel. Min. João Otávio de Noronha, j. 17.06.2010; STJ, REsp n. 809.464-GO, 4 ${ }^{\mathrm{a}}$ T., rel. Min. Fernando Gonçalves, j. 10.06.2008; STJ, REsp n. 866.414-GO, rel. Min. Humberto Gomes de Barros, j. 06.03.2008.

${ }^{854}$ AZEVEDO, Antônio Junqueira. Negócio Jurídico: Existência, Validade e Eficácia. Op. cit., p. 117. No mesmo sentido, cf. MARTINS-COSTA, Judith. A Boa-fé no Direito Privado. São Paulo: RT, 1999, pp. 428-437.

855 VOGENAUER, Stefan. "Interpretation of contracts: concluding comparative observations". In: BURROWS, Andrew; PEEL, Edwin. Contract terms. Oxford: Oxford, 2007, pp. 123-150, pp. 125-129; 
com legitimidade corroborada pelo fato de que, no vigente art. 112, faz-se referência à intenção consubstanciada na declaração (CC, art. 112) - inovação cuja importância MOREIRA ALVES, seu autor, fez questão de ressaltar. ${ }^{857}$ Em terceiro lugar, muito embora o artigo 131 do Código Comercial previsse diversas regras interpretativas relevantes, não há razão para que, hoje, se proponha sua reintrodução como norma especial relativa aos contratos empresariais (Projeto CCom, art. 415). Os mandamentos de interpretação ali contidos são passíveis de aplicação aos contratos em geral, tanto que o codice civile (nos arts. 1362 a 1371) prevê regras que a elas se assemelham. Tome-se como exemplo o cânone de que "cada cláusula deve ser interpretada como se compusesse com as demais um conjunto lógico e ordenado de disposições de vontade" (Projeto CCom, art. 415, III, que guarda semelhança com o art. 131, “2” do CCom/1850). Trata-se de regra que pode ser aplicada aos contratos civis em geral, tanto que está expressamente consagrada no codice civile italiano ${ }^{858}$ e foi incluída pela comunidade acadêmica entre os Princípios de Direito Contratual Europeu (PECL). ${ }^{859} \mathrm{O}$ mesmo se diga quanto à proposta de prever que "o comportamento comum dos contratantes após a assinatura do contrato, relativamente à sua execução, será a melhor explicação da vontade por eles expressa no ato da celebração" (Projeto de CCom, art. 415, IV, similar ao art. 131, “3” do CCom/1850). Como afirmava Junqueira De AzEvedo ainda sob a vigência do Código Civil de 1916, apesar de o art. 131 constar do Código Comercial, "o comportamento das partes é universalmente

CANARIS, Claus-Wilhelm; GRIGOLEIT, Hans Christoph. "Interpretation of contracts". In: HARTKAMP, Arthur (org., et.al.). Towards a European Civil Code, $4^{\mathrm{a}}$ ed. Alphen aan den Rijn: Kluwer/Ars Aequi, 2011 pp. 587-618, pp. 591-594; LORENZO, Sixto Sánchez. "La interpretación del contrato". In: LORENZO, Sixto Sánchez (org.). Derecho contractual comparado. Cizur Menor: Civitas/Thomson, 2009, 443-488, pp. 456-457; ZWEIGERT, Konrad; KÖTZ, Hein. Einführung in die Rechtsvergleichung, $3^{\text {a }}$ ed. Tübingen: Mohr Siebeck, 1996, p. 404; MOTA PINTO, Paulo. Declaração tácita e comportamento concludente no negócio jurídico. Coimbra: Almedina, 1995, pp. 201-220.

${ }^{856}$ MARINO, Francisco Paulo De C. Interpretação do Negócio Jurídico. São Paulo: Saraiva, 2011, pp. 253-261.

${ }^{857}$ MOREIRA ALVES, J. C. A parte geral do projeto de Código Civil brasileiro. Op. cit., p. 82.

${ }^{858}$ Codice civile, art. 1.363: "Interpretazione complessiva delle clausole. Le clausole del contratto si interpretano le une per mezzo delle altre, attribuendo il senso che risulta dal complesso dell'atto."

859 PECL, art. 5:105: Reference to Contract as a Whole: Terms are interpreted in the light of the whole contract in which they appear. 
reconhecido como uma espécie de 'interpretação autêntica' do contrato", ${ }^{860}$ aplicável aos contratos em geral. ${ }^{861}$

Não parece suficientemente claro, tampouco, em que medida o regime pertinente aos contratos empresariais deveria ser diverso. Tendo em vista que o CDC se aplica a todos os contratos de consumo, mesmo que envolvam empresário consumidor, ${ }^{862}$ pode-se concluir que o Código Civil somente rege às relações que não são de consumo, ou seja, na qual não se presume nenhum desequilíbrio entre as partes. A categoria dos contratos empresariais, portanto, apenas se presta a delimitar, entre os contratos que são regidos apenas pelo Código Civil, e não pelo $\mathrm{CDC}$, aqueles que seriam sujeitos a um regulamento diverso. Os diversos enunciados aprovados na $1^{\text {a }}$ Jornada de Direito Comercial do Conselho de Justiça Federal parecem pressupor, porém, aquilo que, antes, deveria ser justificado. Sem pretensão de exaustividade, pode-se analisar quatro exemplos.

Exemplo 1: o Enunciado 21 propõe que o dirigismo contratual deve ser mitigado nos contratos empresariais. Não há clareza, contudo, quanto às situações em que o Código Civil efetivamente impõe um dirigismo contratual a partes civis e que não são hipossuficientes. Pelo contrário, funda-se a ordem civil no princípio constitucional da livre iniciativa ( $\mathrm{CF}$, art. 170, caput), sem nenhuma previsão de que um contrato de compra e venda entre civis esteja sujeito a um "dirigismo contratual" de que o contrato empresarial estaria isento.

Exemplo 2: O Enunciado 25 estabelece que "a revisão do contrato por onerosidade excessiva fundada no Código Civil deve levar em conta a natureza do objeto do contrato. Nas relações empresariais, deve-se presumir a sofisticação dos contratantes e observar a alocação de riscos por eles acordada". Com tal enunciado, pretende-se uma aplicação diferenciada da onerosidade excessiva baseada em um status dos contratantes,

\footnotetext{
${ }^{860}$ AZEVEDO, Antônio Junqueira de. "Parecer: Interpretação do contrato pelo exame da vontade contratual. O comportamento das partes posterior à celebração. Interpretação e efeitos do contrato conforme o princípio da boa-fé objetiva. Impossibilidade de venire contra factum proprium e de utilização de dois pesos e duas medidas. Efeitos do contrato e do sinalagma. A assunção pelos contratantes de riscos específicos e a impossibilidade de fugir do 'programa contratual' estabelecido", in Estudos e Pareceres de Direito Privado, São Paulo, Saraiva, 2004, pp. 159-183, p. 165.

${ }^{861}$ HEINRICHS, Helmut. In: Palandt Bürgerliches Gesetzbuch, 62 ${ }^{\mathrm{a}}$ Aufl., München, Beck, 2003 , p. 116 (com indicação de jurisprudência e doutrina).

${ }^{862}$ STJ, REsp n. 1.195.642-RJ, 3 ${ }^{\text {a }}$ T., rel. Min. Nancy Andrighi, j. 13.11.2012 (defendendo a aplicação da teoria denominada "finalismo aprofundado", autorizando a aplicação do CDC quando a parte, embora não seja destinatária final do produto ou serviço, se apresenta em situação de vulnerabilidade).
} 
quando, em verdade, a condição profissional é sempre um dos elementos - mas não o único - que devem ser cotejados para determinar o que são acontecimentos “extraordinários e imprevisíveis" para as partes. Diversamente da orientação fundada na condição formal dos contratantes, porém, o Código Civil guia-se pela sua condição efetiva. Não diferencia, assim, entre empresários por exercerem atividade profissional $(\mathrm{CC}$, art. 966) ou por adotarem a forma de sociedade anônima (LSA, art. $2^{\circ}, \S 1^{\circ}$ ), de um lado, e não empresários (fundações, associações, cooperativas, agricultores), de outro, senão permite que as condições pessoais dentro de cada uma dessas classes contratantes sejam avaliadas, sem presunções apriorísticas. Permite-se, com isso, a diferenciação, por exemplo, entre uma sociedade anônima familiar erigida para administrar de forma mais racional bens imóveis, por exemplo, e grandes corporações; ou entre fundações de benemerência e fundações gestoras de previdência complementar, para determinar quando um evento seja imprevisível para aquelas partes.

Exemplo 3: quando se afirma que "em contratos empresariais, é lícito às partes contratantes estabelecer parâmetros objetivos para a interpretação dos requisitos de revisão e/ou resolução do pacto contratual" (Enunciado 23), presume-se que o mesmo não seria possível em contratos entre particulares não submetidos ao CDC. Mas não é evidente por qual razão esse pacto seria ilegal entre particulares, tendo em vista que é lícito determinar que o devedor possa responder até mesmo pelos prejuízos resultantes de caso fortuito ou força maior se expressamente houver por eles se responsabilizado (CC, art. 393). Por outro lado, se houvesse regra cogente que impedisse tal pacto, não se consegue visualizar qual seria o fundamento jurídico na ordem positiva para que uns (empresários) não estivessem sujeitos à disposição cogente, enquanto outros (não empresários) estariam.

Exemplo 4: ao se afirmar que "em razão do profissionalismo com que os empresários devem exercer sua atividade, os contratos empresariais não podem ser anulados pelo vício da lesão fundada na inexperiência" (enunciado 28), negligencia-se o fato de que a norma em questão (CC, art. 157) exige comprovação da efetiva inexperiência, que pode, ou não, ser afastada pelo exercício profissional da atividade empresarial, da mesma forma que pode, ou não, ser afastada pelo exercício de outra atividade, como a agropecuária ou liberal, como seria o caso da advocacia. Como aponta JAN PETER SCHMIDT, não há razão para considerar que um empresário não seria merecedor 
da tutela predisposta contra negócios em situação extraordinária nos casos em que efetivamente estivessem comprovados os requisitos da lesão. ${ }^{863}$

c) Inconveniência de nova distinção baseada na condição das partes

O regresso da categoria doutrinária dos contratos empresariais parece trilhar na contramão de tendência que se nota no direito europeu dos contratos de afastar categorizações apriorísticas. Entre os contratos entre empresas incluem-se situações bastante diversas, com uma crescente frequência de contratos em que um dos contratantes possui relevante restrição a seu poder negocial, como ocorre nos contratos de fornecimento, distribuição ou franquia. Atenta a essa problemática, a regulação europeia tem passado promover a tutela da parte considerada mais "fraca" nesses contratos assimétricos, razão pela qual VINCENZO ROPPO sintetiza a direção atual como "uma tendência da regulação do contrato de consumo para o contrato assimétrico". ${ }^{864}$ Percebe-se, ademais, a presença de contratos interempresariais com caráter existencial, por dizerem respeito a bens essenciais para a vida dos contratantes. ${ }^{865}$ Exemplo desse tipo de pactuação é dada pelos contratos de seguros de saúde empresariais e que são celebrados, no mais das vezes, por famílias que se organizam sob societária para buscar valores de contratação menores. A ampla categoria dos contratos empresariais, por focar na análise da condição formal dos contratantes, oferece um tratamento unitário a todos esses contratos, o que não parece o caminho mais adequado.

d) Compra e venda de participações societárias de controle não deve ser considerada compra e venda mercantil

O Projeto de Código Comercial prevê que a compra e venda de empresa, ações ou quotas representativa de capital de sociedade estaria sujeita ao regramento da compra e venda mercantil (Projeto de CCom, art. 428). Como consequência desse

\footnotetext{
${ }^{863}$ SCHMIDT, Jan Peter. Zivilrechtskodifikation in Brasilien. Op. cit., p. 203.

${ }^{864}$ ROPPO, Vincenzo. "From consumer contracts to asymmetric contracts: a trend in European contract law". In: ERCL, 2009, pp. 304-349, p. 340.

${ }^{865}$ MARTINS-COSTA, Judith. "Reflexões sobre o princípio da função social dos contratos". In: Revista Direito GV, v. 1, 2005, pp. 41-66, p. 53.
} 
enquadramento, seriam aplicáveis ao contrato, entre outras, regras como (i) possibilidade de prova do contrato "por qualquer meio, inclusive testemunhal", independentemente de “instrumento escrito ou de qualquer outra formalidade" (Projeto de CCom, art. 430); (ii) prazo de dez dias para reclamação contra a entrega de mercadorias desconformes (Projeto de CCom, art. 435, §11); (iii) impossibilidade de "revisão do contrato empresarial sob a alegação de não ter conferido as informações sobre o objeto prestadas pelo outro contratante durante as tratativas, salvo se a conferência não poderia ter sido feita em razão de segredo de empresa e for falsa a informação prestada" (Projeto de CCom, art. 425); (iv) impossibilidade de "alegar inexperiência para pleitear a anulação do negócio jurídico empresarial por lesão" (Projeto de CCom, art. 162).

A compra e venda de participações societárias, contudo, não parece dever estar enquadrada na mesma categoria contratual que viesse a ser criada para a compra e venda de mercadorias. Primeiramente, pelo fato de que, a rigor, não se trata de um contrato entre empresas, mas entre o sócio, que não é empresário. Em segundo lugar, trata-se de um contrato que pode envolver peculiar complexidade. Assiste razão a GUILHERME PereIRA quando ressalta que mesmo empresários experimentados podem celebrar um contrato desse jaez uma única vez na vida, para então tornar líquido o patrimônio que amealharam ao longo de uma vida. ${ }^{866}$ Em terceiro lugar, porque ações ou quotas não são comparáveis a mercadorias transacionadas frequentemente, sendo impróprio o prazo extremamente abreviado de 10 (dez) dias para um contrato que não é celebrado corriqueiramente. Em quarto lugar, criar-se-ia, por meio da cisão entre contratos empresariais e civis, uma divisão na aplicação do instituto da lesão que não encontraria justificativa, sobretudo quando se tem em vista a simplificação formal que cerca a transmissão de participações societárias em comparação com imóveis. Como fruto da conhecida prática de transferência de patrimônio imóvel para pessoas jurídicas como técnica de planejamento sucessório, não é incomum situações em que uma herança de patrimônio imobiliário se dá por meio do recebimento de quotas ou ações. Se alguém herda a totalidade das quotas de uma sociedade titular de um imóvel e as aliena sob premente necessidade ou por inexperiência, obrigandose a prestação manifestamente desproporcional ao valor da prestação oposta, não haveria razões para negar a aplicação da lesão a esse negócio jurídico (CC, art. 157), mas aceitá-la se o bem herdado fosse o imóvel diretamente. Sob o aspecto da necessidade de tutela da parte, não há nenhuma diferença que justifique o regime diverso.

${ }^{866}$ PEREIRA, Guilherme D. C. Alienação do Poder de Controle Acionário. Op. cit., p. 54. 


\section{E. Forma}

O contrato de compra e venda, como regra, é consensual. É válido, por conseguinte, independentemente de forma especial, inclusive a escrita (CC, art. 104, III c/c art. 107), a menos que a lei estabeleça requisito de forma relativo ao objeto, como ocorre no caso de bens imóveis, em que o contrato deve ser celebrado por escritura pública (CC, art. 108). Para determinar se a compra e venda de participações societárias de controle pode ser celebrada pelo simples consenso, independentemente de qualquer forma especial, inclusive a forma escrita, deve-se, portanto, analisar se a lei impõe a observância de solenidade como requisito para a validade do ato.

\section{Regramento vigente}

No âmbito da sociedade limitada, há previsão de que a sociedade é constituída "mediante contrato escrito, particular ou público" (CC, art. 997, caput c/c/ art. 1.054) e que a cessão da quota se dá por "instrumento". Afirma-se, com isso, que a lei exige contrato escrito "tanto para a constituição de sociedade, como para a cessão de quotas sociais". ${ }^{867} \mathrm{Na}$ Lei de Registro Público de Empresas Mercantis, ademais, determinase que "as alterações contratuais ou estatutárias poderão ser efetivadas por escritura pública ou particular, independentemente da forma adotada no ato constitutivo" (Lei n. 8.934/1994, art. 53). Na jurisprudência, considerou-se que a cessão de quotas seria "negócio jurídico solene, ou seja, de forma escrita, podendo o instrumento ser público ou privado" e que a forma escrita "é da essência do ato, é ad substantiam, de modo que sua inobservância implica a nulidade do negócio jurídico", ${ }^{868}$ ou seja, causa de invalidade,

${ }^{867}$ LUCENA, J. Waldecy. Das sociedades limitadas, 6 a ed. Rio de Janeiro: Renovar, 2005, p. 353.

${ }^{868}$ TJSP, AI n. 0229312-57.2011.8.26.0000, 6 ${ }^{\text {a }}$ Câm. Dir. Priv., rel. Francisco Loureiro, j. 08.03.2012 (grifo no original). No mesmo sentido, TJSP, Ap. n. 0107427-44.2009.8.26.0001, 1 a Câm. Res. Dir. Empr., rel. Des. Francisco Loureiro, j. 08.05.2012. 
razão pela qual se julgou "inviável a pretensão de demonstrar por prova testemunhal e outras evidências a existência de um promessa verbal de negócio de natureza solene". ${ }^{869}$

No âmbito da sociedade anônima, exige-se a lavratura de termo de cessão para transferência cambiária de ações nominativas registrais (LSA, art. 31, §1 $1^{\circ}$ ) ou ordem escrita para as ações nominativas escriturais (LSA, art. 35, $1^{\circ}$ ), sendo possível também o registro do contrato de compra e venda, desde que "à vista de documento hábil" (LSA, art. $31, \S 2^{\circ}$ ), regra que se aplica tanto à transferência de ações nominativas registrais quanto escriturais. ${ }^{870}$ Em ação proposta pelo Sr. Luiz Rodolfo Landim Machado em face do Sr. Eike Fuhrken Batista, ${ }^{871}$ discutiu-se a validade de manuscrito no qual o Sr. Batista teria proposto ao Sr. Landim o recebimento de $1 \%$ das ações da sociedade holding que criaria e $0,5 \%$ das ações da sociedade $M M X$. A despeito de a demanda ter versado sobre a eficácia da criação de uma sociedade entre as partes e não especificamente sobre compra e venda de ações, decidiu-se que seria possível "reconhecer valor jurídico em manifestações verbais ou precariamente registradas (Código Civil, art. 107), bem como buscar o real significado da manifestação de vontade das partes envolvidas" ${ }^{872}$ A demanda foi, porém, julgada improcedente por se ter considerado conflitante com os usos e costumes que um negócio de vulto fosse tido por definitivamente celebrado sem posterior formalização para determinação de seu conteúdo concreto. Avaliou-se, com isso, que não existiu proposta com todos os elementos para a contratação. ${ }^{873}$

Para a adequada compreensão da matéria, deve-se separar os requisitos de validade do negócio jurídico da compra e venda do requisito imposto ao ato material pelo qual se promove seu adimplemento. O contrato de compra e venda é consensual e a exigência de forma é excepcional. No caso de bens imóveis, o contrato de compra e venda, por visar à transferência de direitos reais sobre imóveis, deve ser celebrado por escritura pública quando diga respeito a bem de valor superior a trinta vezes o maior salário mínimo vigente no País (CC, art. 108). Nos contratos que não versam sobre direitos reais, como

\footnotetext{
${ }^{869}$ TJSP, AI n. 0229312-57.2011.8.26.0000, 6a Câm. Dir. Priv., rel. Francisco Loureiro, j. 08.03.2012. No mesmo sentido, TJSP, Ap. n. 0015139-91.2011.8.26.0006, $1^{\text {a }}$ Câm. Res. Dir. Empr., rel. Des. Francisco Loureiro, j. 26.02.2013.

${ }^{870}$ Sobre o assunto, cf. item II.B.1.b), supra.

871 Para o histórico do litígio, cf. CARVALHO, Luiz M. "A baleia branca de Rodolfo Landim". In: Revista Piauí, v. 52, 2011.

872 TJRJ, Ap. n. 0279970-14.2010.8.19.0001, 19ª Câm. Cív., rel. Des. Cláudio Brandão de Oliveira, j. 16.10.2012.

${ }^{873}$ TJRJ, Ap. n. 0279970-14.2010.8.19.0001, $19^{\text {a }}$ Câm. Cív., rel. Des. Cláudio Brandão de Oliveira, j. 16.10.2012.
} 
regra geral, admite-se a contratação verbal e, com a vigência do Código de Processo Civil de 2015, foi revogado o caput do art. 227 do Código Civil, segundo o qual, "salvo os casos expressos, a prova exclusivamente testemunhal só se admite nos negócios jurídicos cujo valor não ultrapasse o décuplo do maior salário mínimo vigente no País ao tempo em que foram celebrados”. O parágrafo único do art. 227 do Código Civil permaneceu, com isso, "acéfalo", para determinar que "qualquer que seja o valor do negócio jurídico, a prova testemunhal é admissível como subsidiária ou complementar da prova por escrito".

O contrato de compra e venda de quotas ou ações, nessa medida, pode ser celebrado validamente de forma consensual, por escrito particular ou público, ${ }^{874}$ mas também sob a forma verbal. Dessa forma, como corretamente se apontou, "para que o contrato de compra e venda de cotas sociais exista e seja válido, basta que obedeça às normas gerais do Código Civil - dentre elas previsão de preço e existência de coisa certa". 875

Questão diversa da existência e validade do contrato obrigacional de compra e venda entre as partes diz respeito ao ato pelo qual se promove a efetiva transferência das quotas ou ações. Para que a transferência das quotas seja eficaz em relação à sociedade, corretamente já se decidiu que "é necessário documento escrito por se tratar de ato solene necessário à eficácia do negócio jurídico (artigo 999 do Código Civil)" ${ }^{876}$ Sequer poderia ser diferente. Os documentos relativos à alteração do contrato social da limitada deve ser arquivados no Registro Público das Empresas Mercantis (Lei n. 8.934/1994, art. 32, II, “a”) e é por essa razão que se exige a escritura pública ou particular para que se promovam alterações contratuais ou estatutárias (Lei n. 8.934/1994, art. 53). Nada impede, porém, que o comprador que tenha celebrado contrato válido possa ingressar em juízo para exigir o cumprimento da avença pleiteando o suprimento judicial da vontade do vendedor para que lhe seja transferida a titularidade sobre a quota.

No âmbito acionário aplica-se o mesmo princípio. Sem previsão de forma legal, a compra e venda de ações é contrato consensual que se aperfeiçoa com a reunião dos elementos essenciais do negócio jurídico. Em caso de inadimplemento do vendedor,

${ }^{874}$ CAVALLI, Cássio. Sociedades limitadas: regime de circulação das quotas. Op. cit., p. 90.

${ }^{875}$ TJSP, Ap. n. 0100281-14.2007.8.26.0003, 9ª Câm. Dir. Priv., rel. Des. Piva Rodrigues, j. 14.04.2015 (a despeito da menção a somente esses elementos, no caso concreto, foi celebrado instrumento escrito).

876 TJSP, Ap. n. 0426564- 54.2009.8.26.0577, 2 ${ }^{\mathrm{a}}$ Câm. Res. Dir. Empr., rel. Des. José Reynaldo, j. 24.04.2012. 
porém, somente poderá ser exigida a transferência das ações em face da sociedade, atuando na qualidade registrária, na hipótese de ter sido celebrado contrato escrito. ${ }^{877}$ Tratando-se de contrato verbal, faz-se necessária a propositura de ação visando ao suprimento judicial da vontade para a transferência das ações.

2. Análise crítica dos requisitos de forma impostos para a transferência das participações societárias

Avaliar criticamente a liberdade de forma na compra e venda de participações societárias exige ponderar as vantagens e desvantagens ligadas à imposição de requisitos formais a qualquer negócio jurídico. Há desvantagens evidentes: a exigência de forma pública, ou mesmo a exigência de que o contrato seja celebrado por instrumento particular, impõe custos e representa intervenção estatal na esfera de autonomia das partes que são livres para negociar seus direitos disponíveis. Não é por outro motivo que, no direito brasileiro, prevalece o princípio da liberdade de forma (CC, art. 107), assim como na totalidade dos ordenamentos jurídicos europeus. ${ }^{878}$

A exigência de forma, de outra parte, é imposta pela lei em hipóteses delimitadas, e pode ser eleita pelas próprias partes (CC, art. 109). A exigência de forma serve às funções (i) assecuratória, visando a prover segurança à contratação; ${ }^{879}$ (ii) de acautelamento bilateral ou unilateral, ${ }^{880}$ tendo por objetivo chamar a atenção dos contratantes para a relevância do negócio que pretendem concluir, favorecendo a ponderação, como ocorre no caso da exigência de escritura pública para negócios jurídicos sobre bens imóveis de valor superior a trinta salários mínimos ( $\mathrm{CC}$, art. 108), ou para transferência do direito à sucessão aberta, qualquer que seja o valor envolvido (CC, art. 1.793); ou (iii) de esclarecimento, ${ }^{881}$ nos casos em que a forma especial visa a garantir ao contratante tutelado ciência de todas as estipulações que regerão a relação contratual, ou

\footnotetext{
${ }^{877}$ Sobre o assunto, cf. item II.B.1.b)(2), supra.

${ }^{878}$ ZANETTI, C. de Sousa. A conservação dos contratos nulos por defeito de forma. São Paulo: Quartier Latin, 2013, p. 190.

${ }^{879}$ ZANETTI, C. de Sousa. A conservação dos contratos nulos por defeito de forma. Op. cit., pp. 192-195.

${ }^{880}$ ZANETTI, C. de Sousa. A conservação dos contratos nulos por defeito de forma. Op. cit., pp. 195-210.

${ }^{881}$ ZANETTI, C. de Sousa. A conservação dos contratos nulos por defeito de forma. Op. cit., pp. $210-217$.
} 
parte significativa delas, como ocorre no contrato de franquia, no qual se exige a entrega por escrito de circular de oferta ao potencial franqueado, com descrição detalhada dos termos da operação econômica proposta (Lei 8.955/1994, art. $3^{\circ}$ ), acompanhada do modelo do contrato-padrão de franquia (Lei 8.955/1994, art. $3^{\circ}$, XV). A exigência de forma promove, ainda, a depender da específica configuração normativa, (i) clareza sobre a data da realização do negócio jurídico; (ii) clareza sobre o conteúdo das obrigações das partes; (iii) prova de que o negócio jurídico efetivamente foi celebrado e da data de sua celebração; (iv) possibilidade de conhecimento por terceiros; e (v) recepção pelas partes de aconselhamento profissional prestado por notário. ${ }^{882}$

A legislação, atualmente, não exige que a compra e venda de quotas ou ações de controle observe nenhuma forma especial. Trata-se de regra que oferece vantagens e se justifica pela coerência com o princípio da facilitação da mobilização de riqueza presente em matéria empresarial, mas que conduz a incongruências valorativas e a inconvenientes práticos.

a) Vantagens da liberdade de forma na compra e venda de participações societárias de controle

A facilitação da negociação de riquezas é um princípio de direito comercial que atende à necessidade de velocidade e segurança jurídica nas transações. ${ }^{883} \mathrm{O}$ Código Comercial de 1850, em consonância com as exigências do tráfego negocial, previu expressamente o princípio da liberdade de forma, determinando a obrigatoriedade dos contratos comerciais "tanto que as partes se acordam sobre o objeto da convenção, e os reduzem a escritos, nos casos em que esta prova é necessária" (CCom/1850, art. 126). ${ }^{884}$ Trata-se de tendência que não se alterou no direito vigente. A legislação societária e empresarial atuais são pautadas pela busca de desburocratização e pelo objetivo de facilitar a mobilização de riquezas, chegando a excepcionar o direito comum, como ocorre, por exemplo, nas regras que determinam que (i) o ato de incorporação de imóveis para

\footnotetext{
${ }^{882}$ HELDRICH, Karl. "Die Form des Vertrages". In: AcP, v. 147, 1941, pp. 89-129, pp. 91-93.

${ }^{883}$ CANARIS, C.-W. Handelsrecht. Op. cit., II §1, Rn. 19, p. 7.

${ }^{884}$ ZANETTI, C. de Sousa. A conservação dos contratos nulos por defeito de forma. Op. cit., p. 166.
} 
formação do capital social de sociedade anônima dispensa escritura pública, qualquer que seja o seu valor (LSA, art. 89); (ii) o empresário pode alienar imóveis que integram o patrimônio da empresa sem necessidade de outorga conjugal (CC, art. 978); e (iii) nos títulos de crédito, prevalece a posse de boa-fé sobre a titularidade real (CC, art. 896).

A reunião de bens e direitos sob o patrimônio societário passível de mobilização mostra-se consentânea com esse movimento de facilitação da circulação de recursos. Como demonstrou CALIXTO SALOMÃo FILHO, uma das principais vantagens da personalidade jurídica não é a mera limitação da responsabilidade, que poderia ser similarmente alcançada com o recurso ao patrimônio de afetação, mas à superior capacidade de circulação da empresa que a autonomização propicia. ${ }^{885}$ Para o empresário individual, é possível a realização de negócio unitário translativo do estabelecimento empresarial, mas, para a transmissão de bens imóveis ou bens sujeitos a registro como é o caso de direito de propriedade industrial, mesmo que integrantes do estabelecimento, é imprescindível, respectivamente, a lavratura de escritura pública ou a formalização de transferência junto ao INPI. ${ }^{886}$ Nas sociedades de capital, por outro lado, são transferidos apenas "os bens de segundo grau" representados pelas ações ou quotas, ${ }^{887}$ conferindo-se ao novo titular as prerrogativas e direitos a elas inerentes. Mediatamente, transfere-se de forma mais ágil e desburocratizada a participação econômica relativa aos bens.

A liberdade de forma em matéria de transferência de participações societárias, ademais, atende à circunstância de que não há somente transferências de participações societárias de controle, mas de participações individuais. A livre circulação de ações (LSA, art. 36) ou quotas, nesse sentido, protege a liquidez, ${ }^{888}$ o que repercute na capacidade de atração de investimentos da sociedade anônima. Como a mesma regra deve ser aplicada à transferência de uma ação ou quota e de ações ou quotas de controle, ${ }^{889}$ a escolha pela liberdade de forma mostra-se vantajosa.

\footnotetext{
${ }^{885}$ SALOMÃO FILHO, C. A sociedade unipessoal. Op. cit., p. 38.

${ }^{886}$ TOKARS, F. Estabelecimento empresarial. Op. cit., p. 64.

${ }^{887}$ SALOMÃO FILHO, C. A sociedade unipessoal. Op. cit., p. 39.

${ }^{888}$ WIEDEMANN, Herbert. Gesellschaftsrecht, Bd. I. Op. cit., p. 498

${ }^{889}$ Sobre o assunto, cf. item II.B, supra.
} 
b) Desvantagens da liberdade de forma

A despeito das vantagens reconhecidas, a liberdade de forma conduz, no caso da compra e venda de participações societárias de controle, a possíveis incongruências valorativas e a inconvenientes práticos.

(1) Incongruência valorativa

A legislação presume que a negociação sobre certos bens deve ser cercada de cautela, exigindo a escritura pública para negócios pertinentes, por exemplo, a bens imóveis de valor superior a trinta salário mínimos (CC, art. 108); à cessão do direito à sucessão aberta (CC, art. 1.793); ou à transação, conforme o seu objeto (CC, art. 842). Mesmo para a transferência de veículos automotores é comum a exigência de que a transferência de faça por firma do alienante reconhecida em cartório (Portaria DETRANSP n. $1.680 / 2014$, art. $\left.8^{\circ}, \S^{\circ}\right)$. A exigência de forma revela uma presunção de que certos bens representativos de riquezas tradicionais teriam superior valor social, razão pela qual o ato que conduz à sua transferência deveria ser cercado de redobrada cautela.

A exigência de forma para a transferência de bens de raiz, de um lado, e a permissividade para a transferência de bens móveis, de outro, liga-se a um descompasso entre a realidade econômica e a legislação. Como apontou HENRI BATIFFOL, ao distinguir os bens entre móveis e imóveis, o Code Civil parece ter admitido implicitamente que todos os bens seriam coisas corpóreas, ${ }^{890}$ sobre as quais o titular poderia exercer as prerrogativas típicas do domínio. Essa concepção alterou-se velozmente no curso dos séculos XIX e XX com a introdução de novos bens incorpóreos, obras do espírito, como a propriedade literária, artística e industrial; a reunião intelectual de bens móveis e imóveis, como ocorre no estabelecimento empresarial; objetos complexos criados pelo engenho jurídico que passaram a ser considerados como bens, entre os quais se incluem as ações de sociedades

${ }^{890}$ BATIFFOL, Henri. "Problèmes contemporains de la notion de biens". In: Archives de philosophie du droit, t. 24: les biens et les choses. Paris: Sirey, 1979, pp. 9-16, p. 10. 
anônimas; e mesmo direitos que deixam de ter qualquer corporeidade, como ocorre com a transferência do know how, em que o objeto do contrato é uma ideia pura. ${ }^{891}$

A legislação civil, com isso, passa a incorrer em incongruências valorativas. Em primeiro lugar, de uma forma geral, pode-se afirmar que a propriedade não corpórea passa a ter valor muitas vezes superior à propriedade corpórea, razão pela qual se torna incoerente a imposição de exigência de forma apenas para certos bens e não para outros. No caso específico das ações ou quotas, ademais, por constituírem "bens de segundo grau", surgem potenciais desníveis quando se compara a exigência imposta para a transferência de bens integrantes do patrimônio societário e para a transferência das próprias quotas ou ações. Tome-se o exemplo da exigência de escritura pública para a transferência de imóvel entre vivos e do reconhecimento de firma do alienante para a transferência de veículo automotor. No caso da alteração do contrato social, por outro lado, não se exige sequer o reconhecimento da firma dos sócios (DREI, Manual de Registro da Sociedade Limitada, item 1.2.17), mas, por meio dela, podem ser alienadas participações societárias que conferem o controle majoritário, ou mesmo totalitário, sobre sociedade que pode ser titular de uma infinidade de bens imóveis, veículos automotores, ou outros bens com valor diversas vezes superior ao de um imóvel ou veículo.

(2) Inconvenientes práticos

Para além da função de acautelamento e de promoção de ponderação, a exigência de forma solene alça à condição de elemento de validade do negócio jurídico a intervenção de um terceiro investido de fé-pública, o que diminui a possibilidade de atribuição de efeitos a atos inexistentes, praticados por terceiros fraudulentamente sem a intervenção do titular do bem. Alguém que pretenda transferir criminosamente para seu nome a propriedade sobre imóvel de outrem teria de buscar o concurso de tabelião de notas, o que não seria trivial, tendo em vista que o oficial de notas responde pelos danos a que der causa.

${ }^{891}$ BATIFFOL, Henri. "Problèmes contemporains de la notion de biens". Op. cit., pp. 10-12. 
No caso da alteração do contrato social, como se apontou, não há exigência de forma solene. Tal circunstância possivelmente esteja na base de uma presença relativamente recorrente de litígios nos tribunais ligados a transmissões fraudulentas de quotas de sociedades limitadas. Há casos em que os únicos sócios são surpreendidos por alterações ao contratos social promovidas junto ao registro de comércio por pessoas que desconhecem, ${ }^{892}$ ou em que se alega que, antes do falecimento, o de cujus teria promovido cessão das quotas a terceiro, ${ }^{893}$ privando os herdeiros legítimos de herdar as referidas quotas. E outros casos em que alguém se torna titular de quotas de sociedade endividada, sem que tenha consentido com sua inclusão no contrato social. ${ }^{894}$

Sob o viés jurídico, há quem defenda que a alteração societária em que uma das assinaturas foi falsificada seria negócio jurídico que padeceria de nulidade absoluta, ${ }^{895}$ ao passo que outros julgados defendem tratar-se de negócio jurídico inexistente, ${ }^{896}$ posicionamento que parece o mais acertado quando ausente a manifestação de vontade do cedente ou cessionário. Como consequência, deve-se anular a alteração do contrato social por ofender o princípio da verdade real que pauta os registros públicos, ${ }^{897}$ sendo equivocada a decisão ${ }^{898}$ de negar legitimidade ativa ao autor para pleitear a anulação do registro por não ter interesse jurídico na demanda, vez que se trata de matéria de ordem pública.

\footnotetext{
${ }^{892}$ TJSC, AI n. 2014.004282-9, 5a Câm. Dir. Com., rel. Des. Soraya Nunes Lins, j. 10.07.2014 (em que as únicas sócias descobriram alteração do contrato social registrada com base em assinaturas visivelmente falsificadas); TJSP, Ap. n. 0126859-57.2006.8.26.0000, $5^{\text {a }}$ Câm. Dir. Priv., rel. Des. Silvério Riberio, j. 01.06.2011; STJ, REsp n. 1.368.960-RJ, $3^{\mathrm{a}}$ T., rel. Min. Marco Aurélio Bellizze, j. 07.06.2016.

${ }^{893}$ TJSC, AR 2002.003230-1, $3^{\text {a }}$ Câm. Dir. Com., rel. Des. Marco Buzzi, j. 09.07.2009; TJSP, Ap. n. 0003961-82.2011.8.26.0318, $1^{\text {a }}$ Câm. Res. Dir. Empr., rel. Des. Francisco Loureiro, j. 12.09.2013.

${ }^{894}$ TJSP, Ap. n. 0056291-97.2012.8.26.0002, $1^{\text {a }}$ Câm. Res. Dir. Empr., rel. Des. Francisco Loureiro, j. 16.12.2015; TJSP, Ap. n. 0005112-65.2005.8.26.0586, $1^{\text {a }}$ Câm. Res. Dir. Empr., rel. Des. Fortes Barbosa, j. 13.06.2013.

${ }^{895}$ STJ, REsp n. 7.364-SP, $3^{\text {a }}$ T., rel. Min. Carlos Alberto Menezes Direito, j. 18.02.1997; STJ, REsp n. 1.368.960-RJ, $3^{\mathrm{a}}$ T., rel. Min. Marco Aurélio Bellizze, j. 07.06.2016; TJSP, Ap. Cív. c/ Rev. n. 489.125-4/200, $7^{\mathrm{a}}$ Câm. Dir. Priv., rel. Des. Luiz Antonio Costa, j. 23.05.2007.

${ }^{896}$ TJPR, Ap. 970.208-5, $5^{\text {a }}$ Câm. Cív., rel. Juiz Subst. de $2^{\circ}$ Grau Rogério Ribas, j. 18.08.2015; TJRJ, Ap. n. 0019197-68.2007.8.19.0202, $18^{\mathrm{a}}$ Câm. Cív., rel. Des. Cláudio Luiz Braga Dell Orto (decisão monocrática), j. 14.04.2015; TJSP, Ap. n. 0005112-65.2005.8.26.0586, $1^{\mathrm{a}}$ Câm. Res. Dir. Empr., rel. Des. Fortes Barbosa, j. 13.06.2013; TJSP, Ap. n. 0003961-82.2011.8.26.0318, $1^{\text {a } ~ C a ̂ m . ~ R e s . ~ D i r . ~ E m p r ., ~ r e l . ~ D e s . ~ F r a n c i s c o ~ L o u r e i r o, ~}$ j. 12.09.2013; TJSP, Ap. n. 0056291-97.2012.8.26.0002, 1 ${ }^{\text {a }}$ Câm. Res. Dir. Empr., rel. Des. Francisco Loureiro, j. 16.12.2015; TJMG, Ap. Cív. n. 1.0024.02.663387-5/002, $9^{a}$ Câm. Cív., rel. Des. Tarcisio Martins Costa, j. 09.06.2009.

${ }^{897}$ STJ, REsp n. 1.368.960-RJ, $3^{\text {a }}$ T., rel. Min. Marco Aurélio Bellizze, j. 07.06.2016.

${ }^{898}$ TJSP, Ap. n. 0003961-82.2011.8.26.0318, $1^{\text {a }}$ Câm. Res. Dir. Empr., rel. Des. Francisco Loureiro, j. 12.09.2013.
} 
Sob a ótica prática, porém, a situação pode ter consequências sérias para a vítima. De uma série de precedentes jurisprudenciais, colhem-se relatos que dão a efetiva dimensão das repercussões negativas possíveis. Sob o ponto de vista do cedente, a usurpação do controle pode ser grave, como na hipótese em que, posteriormente à transferência fraudulenta das quotas do controle, o falso cessionário inicia dissipação do patrimônio social contra a vontade dos antigos sócios. ${ }^{899}$ Da perspectiva da vítima da fraude inserida em sociedade que desconhece, por sua vez, as consequências podem ser ainda mais relevantes. Em um caso, a vítima, funcionário público, tentou ser fiador de um amigo quando foi informado, pela imobiliária, que seu nome estaria negativado por dívidas de uma sociedade limitada que desconhecia. Compareceu à Junta Comercial, onde foi informado que $95 \%$ das cotas de uma sociedade limitada teriam sido transferidas ao seu nome por meio de alteração societária, na qual constava assinatura que não era sua. Descobriu, ademais, que a empresa devia mais de $\mathrm{R} \$ 1$ milhão de reais por dívidas trabalhistas, empresariais e previdenciárias, do que decorreu o bloqueio judicial de suas contas bancárias, um período de três anos negativado e uma série de constrangimentos e custos ligados a processo para declarar a inexistência do ato, além de início de sindicância no batalhão em que servia. ${ }^{900}$ Em outro caso, a vítima da alteração contratual foi detida temporariamente pela imputação de crime falimentar, tendo permanecido preso por quase quinze dias por conta de dívidas de uma sociedade da qual nunca ouvira falar. ${ }^{901}$

No âmbito das sociedades anônimas, a transferência se dá mediante averbação no livro de Registro. ${ }^{902}$ Nas companhias com controlador, é menos comum se opere transferência fraudulenta contra a sua vontade. Tampouco há registro de litígios relativos a fraudes em que se transferiram ações contra a vontade do cessionário. A ausência de formalidade conduz, porém, a dificuldades para a prova da data em que os negócios jurídicos relativos às ações são celebrados. Basta, com efeito, que a transferência seja averbada no livro de Registro, o que pode ser feito manualmente, sem que o registro de comércio ou as autoridades fiscais tenham de ser imediatamente comunicadas. Não é impossível que alguém lance fraudulentamente a averbação antedatada. Juridicamente, não

\footnotetext{
${ }^{899}$ STJ, REsp n. 1.368.960-RJ, $3^{\text {a }}$ T., rel. Min. Marco Aurélio Bellizze, j. 07.06.2016.

900 TJRJ, Ap. Crim. N. 0133750-13.2011.8.19.0001, 1ª Câm. Crim., rel. Des. Marcus Basílio, j. 14.04.2015.

${ }^{901}$ TJMG, Ap. Cív. N. 1.0024.02.663387-5/002, 9a Câm. Cív., rel. Des. Tarcisio Martins Costa, j. 09.06.2009 (em que se comprovou que foram transferidas ao autor sem o seu consentimento, mas, não obstante isso, foi o autor detido sob a acusação de ter cometido crime falimentar);

${ }^{902}$ Sobre o assunto, cf. item II.B.1.b) supra.
} 
há dúvida de que seria hipótese de negócio jurídico simulado (CC, art. 167, §1º, III). Mas, sob o ponto de vista prático, podem surgir inconvenientes.

A certeza quanto à data em que ocorre um determinado negócio jurídico é elemento relevante para a aplicação de disciplinas protetivas dos credores. Na pendência de ação de execução que possa levar o devedor à insolvência, a alienação ou oneração do bem é considerada fraude à execução (CPC, art. 792, IV). É possível que seja proposta ação de execução e, buscando o exequente a penhora de ações de titularidade do executado, descubra que elas foram transmitidas a terceiro antes do início da demanda. Como consequência da falta de clareza quanto à data do negócio jurídico, é relativamente frequente que ocorra uma presunção de fraude, de tal forma a declarar a ineficácia do negócio jurídico de transferência ainda que se alegue que foi realizado antes da propositura da ação. ${ }^{903}$ Em outros casos, porém, prestigia-se a data da lavratura do termo de cessão. ${ }^{904}$ Tal falta de clareza sobre a data em que foi realizado o negócio jurídico gera o risco de que seja declarada a ineficácia de negócios que não deveriam ser assim considerados, em prejuízo de cedente ou cessionário; ou o risco contrário, de não ser declarada a fraude, permitindo-se, porém, um caminho fácil para a subtração de bens que deveriam satisfazer ao crédito executado.

c) Tratamento do tema no direito estrangeiro

A imposição de forma solene em contratos de venda de participações societárias é tratada no direito estrangeiro de formas diversas conforme o tipo social em questão. Nas sociedades anônimas, a transferência de ações normalmente se dá por transferência no livro de registro de ações nominativas ou por endosso, sem exigência de lavratura de escritura pública. É o que ocorre na Alemanha $(A k t G, \S 68)$ e na Itália (Codice civile, art. 2355), por exemplo.

\footnotetext{
${ }^{903}$ TST, AIRR n. 932-81.2010.5.03.0081, 2a T., rel. Min. Renato de Lacerda Paiva, j. 11.10.2011 (mantendo decisão que considerou configurada fraude pela impossibilidade de certeza de que a transferência acionária teria ocorrido antes da propositura da execução); TJSP, AI n. 990.10.020244-8, $11^{\mathrm{a}}$ Câm. Dir. Priv., rel. Mon. Renato Rangel Desinano, j. 11.11.2010.

904 TJSP, AI n. 1.160.734-2, 6 ${ }^{\mathrm{a}}$ Câm. do $1^{\text {o }}$ TAC, rel. Des. Candido Alem, j. 23.09.2003.
} 
Nas sociedades limitadas, há países em que se exige a forma notarial, como é o caso da Alemanha e da Itália. Na Alemanha, por expressa disposição legal, requer-se a lavratura de escritura pública (GmbHG, §15, Abs. 4), ${ }^{905}$ havendo certa discussão doutrinária sobre a necessidade de o próprio contrato de compra e venda observar a forma pública, ou somente o negócio jurídico dispositivo. ${ }^{906} \mathrm{Na}$ Itália, igualmente, a transferência da quota da sociedade limitada pressupõe o depósito de ato autenticado notarialmente junto ao registro de comércio (Codice civile, art. 2470, 2). ${ }^{907}$ No direito português exigia-se também a forma notarial, mas, em 2006, foi editado o Decreto-Lei n. ${ }^{\circ}$ 76-A, que tornou facultativa a adoção de escritura pública, motivado pela consideração de que seria excessiva a submissão a duplo controle, primeiro pelo registro notarial e, posteriormente, pelo registro de comércio. Atualmente, portanto, exige-se somente que a transmissão de quotas entre vivos seja reduzida a escrito (CSC, art. $\left.228^{\circ}, 1\right)$. No direito francês, por sua vez, prevalece a liberdade de forma. Requer-se apenas que a cessão de quota seja ser por escrito (Code de commerce, L. 221-14 c/c L. 223-17), regra que a Cour de cassation considera mero requisito de prova (forma ad probationem), razão pela qual o contrato vale entre as partes desde que obtido consenso sobre preço e coisa. ${ }^{908}$

d) Posicionamento

O requisito de forma ligado ao contrato de compra e venda de participações societárias e, sobretudo, com o ato dispositivo pelo qual se dá a circulação das quotas ou ações merece pontual revisão.

A previsão de escritura pública para a transferência de quotas ou ações, mesmo no caso de o patrimônio social ser integrado por bens imóveis, seria medida que conflitaria com a busca de facilitação da mobilização de riqueza que vige em matéria societária. A conclusão é de que todo aquele que escolhe adotar a forma societária para exercício de empresa, inclusive para fins de mero planejamento tributário, integralizando

\footnotetext{
905 JAGERSBERGER, Barbara. Die Haftung des Verkäufers beim Unternehmens- und Anteilskauf. $O p$. cit., pp. 94-95.

${ }^{906}$ FASTRICH, Lorenz. In: BAUMBACH, Adolf; HUECK, Alfred (org.) GmbHG, $20^{\text {a }}$ ed. München: C. H. Beck, 2013, §15, Rn. 2, p. 359; SIGLE, Walter. "Umfang des Formzwangs beim Unternehmenskauf”. In: NJW, 1984, pp. 2657-2262, p. 2661 (defendendo que seria necessária forma notarial apenas para o negócio dispositivo de transferência da quota, mas não para o contrato de compra e venda).

${ }^{907}$ TINA, Andrea. Il contratto di acquisizione di partecipazioni societarie. Op. cit., p. 26.

${ }^{908}$ COZIAN, Maurice; VIANDIER, Alain; DEBOISSY, Florence. Droit des sociétés. Op. cit., n. 1126, p. 568 .
} 
bens imóveis ao patrimônio social, deve ter presente que nessa seara os princípios regentes à forma dos negócios jurídicos dispositivos é diversa. Por um lado, obtém-se com isso a vantagem da desburocratização e diminuição de custos; de outro, inevitavelmente, perde-se parcela do efeito acautelador adstrito à forma, o que não é normalmente tão grave no caso de participações societárias minoritárias, mas pode ser relevante em matéria de participações societárias de controle.

Há, porém, alterações que parecem benéficas à segurança no tráfego negocial. Sob o ponto de vista legislativo, seria de se considerar a exigência de reconhecimento de firma dos intervenientes no negócio jurídico de cessão de quota, seja para diminuir a possibilidade de transferência fraudulenta em prejuízo do titular, seja para evitar a prática relativamente comum de serem transferidas quotas fraudulentamente para imputar responsabilidades a alguém que sequer conhece a sociedade. Sob o ponto de vista dos próprios sócios, outra medida que se afigura relevante para aqueles que desejam se acautelar é a possibilidade de preverem no próprio contrato social que as cessões de quotas da sociedade em questão deve ser realizada por instrumento público. Valendo-se da liberdade conferida pelo Código Civil (CC, art. 109), portanto, os sócios podem conferir à negociação das quotas naquela sociedade limitada caráter formal.

No âmbito das sociedades anônimas, a principal dificuldade ligada à forma é a ausência de certeza quanto à data da circulação das ações, fato que conduz à possibilidade de desconsideração da data assinalada no livro de registro no âmbito de processos de fraude à execução. De um lado, deve-se ter em mente que a falsificação de registro de sociedade anônima constitui crime $\left(\mathrm{CP}\right.$, art. $\left.197, \S 2^{\circ}\right)$, razão pela qual sua prática não poderia ser simplesmente presumida para fins civis; havendo suspeita da ocorrência de fraude, deve ser promovida notitia criminis para que se inicie investigação criminal. De outro lado, não se pode negar que, dada a circunstância de que o livro de Registro permanece sob o domínio da administração da sociedade, é fato que, em companhias com controlador, fraudes podem efetivamente ocorrer. O melhor, nesse caso, é que os acionistas, buscando acautelar-se, transcrevam o assentamento do livro de Registro junto ao Registro de Títulos e Documentos (Lei 6.015/1973, art. 127, VII), medida facultativa e, a rigor, desnecessária, mas que evita a possibilidade de posterior contestação judicial. 
Para promover maior certeza e segurança e evitar alterações fraudulentas que podem ser promovidas ao livro de Registro, uma alternativa aos sócios é prever estatutariamente que as ações somente podem ser transferidas mediante determinadas condições, como, por exemplo, o reconhecimento de firma do sócio, ou, no caso de transferência por mandatário, a exigência de que a procuração seja pública (CC, art. 109). A estipulação estatutária que exige instrumento público de mandato para a transferência de ações foi julgada contrária aos preceitos de direito empresarial, um "óbice ao rumo e informal e desburocratizado das regras mercantis", razão pela qual foi tida por inválida. ${ }^{909}$ A decisão parece adequada para companhias abertas, como era o caso, mas não para companhias fechadas, nas quais se admitem restrições à circulação das ações (LSA, art. 36). Por tal razão, considera-se que a previsão de forma específica para a transmissão de ações em companhias fechadas seria válida, podendo ser utilizada pelos acionistas como mecanismo para a melhor conformação de seus interesses.

${ }^{909}$ TJMG, Ap. Cív. n. 1.0024.01.079026-9/002, 9ª Câm. Cív. Rel. Des. Luiz Artur Hilário, j. 08.01.2013. 


\section{REGIME JURÍDICO}

As ações ou quotas de controle conferem o poder de orientar as atividades sociais. Sua negociação pode suscitar situações economicamente similares à circulação dos bens integrantes do patrimônio societário. Juridicamente, porém, não há alteração de titularidade de nenhum bem da sociedade.

No ordenamento brasileiro, a transmissão de certos bens é cercada por cuidados e cautelas especiais. Aplicam-se regras específicas para a transferência de (i) estabelecimentos empresariais; (ii) bens imóveis; ou (iii) certas posições jurídicas. Como se notará nos itens subsequentes, é relativamente frequente o questionamento quanto à possibilidade jurídica de se aplicar à compra e venda de participações societárias regras aplicáveis à alienação de algum desses elementos do patrimônio.

As situações fáticas em que tais problemáticas se colocam variam em função da distribuição do capital social e da composição do patrimônio societário. Uma sociedade pode ter um único acionista como é o caso da EIRELI ou da subsidiária integral, ou pode ter um sócio controlador cujo poder de direção é contrastado por sócios minoritários. No patrimônio societário podem estar presentes estabelecimentos empresariais, imóveis ou certas posições jurídicas, ou todos eles juntos. Para comodidade metodológica, a análise que segue toma como premissa a situação limítrofe sob ambos os aspectos: presume-se uma sociedade unipessoal com apenas o elemento analisado (estabelecimento, imóvel ou certas posições jurídicas) em seu patrimônio. Se a solução encontrada para tal hipótese for válida, supõe-se que, com maior razão, também o será para outras situações nas quais o caso concreto diferenciar-se de tal cenário.

Neste contexto, ademais, não se promoverá a análise de todas as situações que poderiam ensejar a desconsideração da personalidade jurídica ou a desconstituição sob o fundamento da prática de negócio jurídico indireto em fraude à lei. ${ }^{910}$ Pretende-se, em linha com a orientação metodológica da desconsideração atributiva pautada pela finalidade da norma, ${ }^{911}$ averiguar se, no âmbito de cada subsistema normativo haveria aspectos

\footnotetext{
${ }^{910}$ Sobre o assunto, cf. item I.B, supra.

${ }^{911}$ Sobre o assunto, cf. item I.B.4(2), supra.
} 
valorativos específicos e relevantes que conduziriam a resultados hermenêuticos divergentes da regra geral de irrelevância da alteração de controle.

\section{A. Sociedade titular de estabelecimento empresarial}

O estabelecimento empresarial é o complexo de bens organizado para exercício da empresa, por empresário, ou por sociedade empresária (CC, art. 1.142). Tratase de definição legal introduzida pelo Código Civil de 2002, mas que anteriormente já era consagrada pela doutrina e jurisprudência pátrias. ${ }^{912}$ Sua inspiração é o art. 2555 do Codice civile, do qual é tradução quase literal.

Para se referir ao estabelecimento, a legislação, por vezes, também emprega a expressão "fundo de comércio", tributária da designação francesa fonds de commerce. É o que ocorre, por exemplo, no art. 51, §2 ${ }^{\circ}$ da Lei de Locações. Em outros casos, empregava a expressão "ponto comercial", introduzida no direito brasileiro pelo Decreto n. 24.150/34, a chamada "Lei de Luvas", que se refere ao "ponto ou lugar" em que se desenvolve o comércio (Dec. n. 24.150/34, art. $8^{\circ}$, "b”). Por meio da Lei de Luvas, foi conferido direito à renovação compulsória do contrato de locação ao locatário que explorasse "commercio ou industria" pelo prazo mínimo, ininterrupto, de três anos e atendesse aos requisitos ali previstos. A matéria foi posteriormente disciplinada pela Lei de Locações, que confere ação renovatória ao locatário que, além de cumprir os demais requisitos legais, "esteja explorando seu comércio, no mesmo ramo, pelo prazo mínimo e ininterrupto de três anos" (Lei $\mathrm{n}^{\mathrm{o}}$ 8.245/91, no art. 51). A Lei de Recuperações e Falência menciona, ainda, a "unidade produtiva isolada", conceito que é associado, geralmente, ao estabelecimento empresarial. ${ }^{913}$

O emprego do termo "comércio" na legislação ordinária, desde o Código Civil de 2002, deve ser entendido como referência à empresa (CC, art. 2.037). Atualmente,

912 cf. MARCONDES, Sylvio. "Direito mercantil e atividade negocial no projeto de Código Civil". In: Questões de direito mercantil. São Paulo: Saraiva, 1977, pp. 1-29, p. 23.

${ }^{913}$ TOLEDO, Paulo F. C. S. de; POPPA, Bruno. "UPI e estabelecimento: uma visão crítica”. In: TOLEDO, Paulo F. C. S. de; SATIRO, Francisco. Direito das empresas em crise: problemas e soluções. São Paulo: Quartier Latin, 2012, pp. 267-294, p. 277; MUNHOZ, Eduardo S. “Comentários ao art. 60”. In: SOUZA Jr., Francisco S.; PITOMBO, Antônio S. A. de M. Comentários à lei de recuperação de empresas e falência, $2^{\mathrm{a}}$ ed. São Paulo: RT, 2007, p. 298. 
portanto, tanto os conceitos de estabelecimento comercial, de fundo de comércio, de ponto comercial ou de comércio e, discutivelmente, também o de unidade produtiva isolada dizem respeito a uma mesma realidade de fato, apreendida juridicamente por meio do conceito técnico de "estabelecimento empresarial".

A definição de estabelecimento empresarial pressupõe o conceito de empresa, que pode ser extraído, indiretamente, da caracterização do empresário (CC, art. 966). Empresa é a atividade econômica profissionalmente organizada para a produção ou circulação de bens. O estabelecimento, nessa medida, apresenta-se como projeção patrimonial da empresa, a organização na qual a atividade econômica empresária se concretiza por meio da coordenação dos fatores de produção. ${ }^{914} \mathrm{O}$ estabelecimento, por conseguinte, pode ser definido como o complexo ou conjunto de bens reunidos para o exercício da empresa. ${ }^{915}$ Os bens integrantes do estabelecimento, por sua vez, sendo múltiplos, mas submetidos a direção unitária, perfazem uma universalidade de fato $(\mathrm{CC}$, art. 90). ${ }^{916}$

O Código Civil reconheceu expressamente a possibilidade de o estabelecimento empresarial ser objeto unitário de direitos e de negócios jurídicos, translativos ou constitutivos, compatíveis com sua natureza (CC, art. 1.143). Convencionou-se designar pela expressão "trespasse" tal contrato que visa à alienação do estabelecimento. $^{917}$

O negócio de trespasse do estabelecimento reveste-se de relevância social e jurídica por implicar, para o empresário ou sociedade empresária, a transmissão da base material do exercício da empresa. A transferência de universalidade de fato é objeto de regras previstas (i) no Código Civil; (ii) na legislação concursal; (iii) na legislação tributária; e (iv) na legislação trabalhista. Na compra e venda de participações societárias de controle de sociedade titular de estabelecimento empresarial, pode-se questionar a possibilidade de aplicação de alguns desses conjuntos normativos.

\footnotetext{
914 CASANOVA, Mario. “Azienda” (voce).In: Digesto delle discipline privatistiche, Sezione Commerciale, v. II. Torino: UTET, 1987, pp. 75-99, p. 77.

915 MARCONDES, Sylvio. "Do objeto de direito; patrimônio". In: Problemas de direito mercantil, $2^{\text {a }}$ tir. São Paulo: Max Limonad, 1970, pp. 67-100, p. 79.

916 BARRETO FILHO, Oscar. Teoria do estabelecimento comercial. São Paulo: Max Limonad, 1969, p. 108.

${ }^{917}$ BARRETO FILHO, Oscar. Teoria do estabelecimento comercial. Op. cit., p. 208.
} 
a) Regras do Código Civil sobre trespasse de estabelecimento

O Código Civil, para além de ter introduzido um conceito legal de estabelecimento (CC, art. 1.142), previu um conjunto de regras aplicáveis aos negócios jurídicos de que ele pode ser objeto, como é o caso de regras de publicidade, de proteção aos terceiros contratantes e de vedação à concorrência.

(1) Publicidade do trespasse (CC, art. 1.144)

Alguns dos dispositivos introduzidos na legislação são claramente inaplicáveis à compra e venda de participações societárias de controle. É o caso das regras relativas à posição dos credores do estabelecimento, seus devedores e outros terceiros.

$\mathrm{Na}$ sistemática legal, o estabelecimento é transferido como conjunto de bens, direitos (CC, art. 1.149) e obrigações (CC, art. 1.146). ${ }^{918}$ Credores e devedores, por conseguinte, podem ser afetados pelo negócio de trespasse. É em virtude dessa projeção de efeitos sobre a esfera jurídica alheia que se estabelece disciplina de publicidade. Exige-se a averbação do contrato de trespasse no Registro Público de Empresas Mercantis e sua respectiva publicação para valer perante terceiros (CC, art. 1.144). Tutela-se, ademais, o devedor de boa-fé que paga ao cedente do estabelecimento, prevendo-se sua liberação da dívida (CC, art. 1.149). Visando a proteger os credores do titular do estabelecimento, ademais, determina-se a ineficácia do trespasse se não restarem bens suficientes para o alienante do estabelecimento solver o seu passivo, a menos que os credores sejam pagos ou consintam com o contrato (CC, art. 1.145).

Em todas essas hipóteses normativas, a situação fática pressuposta é o deslocamento patrimonial que se estabelece entre sujeitos diversos (alienante e adquirente do estabelecimento). Tal problema não se apresenta na compra e venda de participações societárias de controle de sociedade titular de estabelecimento, pois este permanece, antes

918 TOKARS, Fábio. Estabelecimento empresarial. Op. cit., p. 91; FÉRES, Marcelo A. Estabelecimento empresarial. São Paulo: Saraiva, 2007, pp. 108-114. 
e depois do negócio jurídico, encapsulado no patrimônio societário. Por mais que o controlador se altere, a sociedade remanesce titular do estabelecimento.

(2) Posição jurídica das contrapartes em contratos com a sociedade (CC, art. 1.148)

O trespasse implica também a sub-rogação do adquirente nos contratos estipulados para exploração do estabelecimento, ou seja, das posições contratuais a ele relacionadas, desde que (i) não haja disposição em contrário; (ii) o contrato não tenha caráter pessoal; ou (iii) se ocorrer justa causa, o terceiro não se utilizar da faculdade de rescindir o contrato em noventa dias a contar da publicação da transferência $(\mathrm{CC}$, art. 1.148). Considerando o reconhecimento legal de que os credores do titular do estabelecimento não são obrigados à manter-se vinculados aos respectivos contratos quando da ocorrência de relevante alteração subjetiva, poder-se-ia questionar se a regra seria, igualmente, aplicável à compra e venda de participações societárias de controle.

$\mathrm{Na}$ compra e venda de participações societárias de controle, não há subrogação nas posições contratuais referentes ao estabelecimento, pois elas permanecem sob a titularidade da sociedade. É certo que o contrato em questão pode contar com regra em sentido diverso, prevendo sua rescisão em caso de transferência do estabelecimento ou de troca do controle, o que, aliás, é bastante comum. Há decisões que afirmam "nula a cláusula que, em contrato de locação, equipara à sublocação ou à cessão do prédio, para o fim de sujeitá-la a prévio consentimento escrito do locador, toda alteração em contrato social de locatário pessoa jurídica". ${ }^{919}$ Ainda que tais julgados estejam corretos em reconhecer que a alteração no quadro societário da locatária não afeta o vínculo locativo, a suposta nulidade da cláusula de troca de controle não encontra fundamento legal, por não ter objeto ilícito (CC, art. 166, II). Está no campo da autonomia contratual disciplinar no contrato os efeitos do trespasse (CC, art. 1.148) ou de alterações na composição societária, sendo, portanto, válida a chamada "cláusula de troca de controle" (change of control clause). Se tal cláusula não foi prevista, por outro lado, não há alteração da contraparte

919 TJSP, Ap. n. 9076451-98.2009.8.26.0000, 28 $8^{\text {a }}$ Câm. Dir. Priv., rel. Des. Cesar Lacerda, j. 15. 05.2012; TJSP, Ap. n. 0005474-81.2012.8.26.0114, 35 Câm. Dir. Priv., rel. Des. Gilberto Leme, j. 26.01.2015. 
contratual, razão pela qual todos os contratos celebrados pela sociedade permanecem em vigor.

(3) Proibição de concorrência (CC, art. 1.147)

Questão mais complexa diz respeito à aplicabilidade da regra da impossibilidade de transferência dos contratos de caráter pessoal. A situação poderia ocorrer, sobretudo, no caso de contratos celebrados com a sociedade em virtude das características pessoais do controlador, como ocorre no caso de habilitação técnica peculiar do controlador ou sociedade controladora que atua como fundamento para a contratação pelo terceiro. Suponha-se que tenha sido celebrado contrato de empreitada com sociedade controlada por engenheiro com alta expertise técnica e reputação no mercado, que goza da confiança do contratante. A transferência das participações societárias dessa sociedade para outra pessoa sem a mesma qualificação poderia suscitar a questão da aplicabilidade regra de não sucessão (CC, art. 1.148) à compra e venda de participações societárias de controle. A orientação, contudo, deve ser rechaçada. No trespasse, há proteção aos contratantes em relação aos contratos de caráter pessoal, pois a pessoa do titular do estabelecimento com a qual o contrato foi celebrado se altera. Na compra e venda de participações societárias de controle, o mesmo não ocorre; o contrato que fora celebrado com a sociedade permanece tendo a mesma sociedade como parte contratante. Se a figura dos controladores era ou tornou-se relevante para a execução do contrato, caberia ao contratante cercar-se de cautelas para sujeitar a transferência do controle ao seu consenso. Pode-se cogitar, ademais, da ocorrência da perda da base pressuposta do negócio jurídico. Não parece possível, contudo, a aplicação direta ou analógica da previsão de não sucessão nos contratos pessoais (CC, art. 1.148). Igualmente, não cabe a rescisão do contrato por justa causa no prazo de noventa dias da compra e venda de participações societárias de controle, porque o contratante permanece sendo o mesmo.

Entre as regras relativas ao trespasse do estabelecimento inclui-se também a de que "não havendo autorização expressa, o alienante do estabelecimento não pode fazer concorrência ao adquirente, nos cinco anos subsequentes à transferência” (CC, art. 1.147). 
A possibilidade de aplicação de tal regramento à compra e venda de participações societárias de controle é objeto de controvérsias.

Na doutrina, COMPARATO, em texto originalmente publicado antes da edição do Código Civil de 2002, analisou o famoso litígio forense que envolveu a Companhia Nacional de Tecidos de Juta. ${ }^{920}$ Após a celebração de contrato, o vendedor constituiu nova empresa do ramo têxtil na cidade de São Paulo. A despeito de os advogados das partes (Rui Barbosa e J. X. Carvalho de MendonçA) e do Supremo Tribunal Federal terem tratado o caso sob a ótica da transferência de fundo de comércio, ${ }^{921}$ COMPARATO ressalta que não se tratou de mera alienação de estabelecimento (a Fábrica de Juta de Santana), mas de cessão do bloco majoritário de ações da sociedade que era sua titular (a Companhia Nacional de Tecidos de Juta). ${ }^{922}$ Para o autor, o aviamento real ou objetivo diria respeito não somente ao estabelecimento isolado, quanto à empresa em sua globalidade, razão pela qual seria “irrecusável a admissão, nos negócios de cessão de controle, da cláusula implícita de não concorrência por parte do cedente". 923

Na jurisprudência posterior ao Código Civil, já se apontou que a vedação de restabelecimento em casos de trespasse estaria pautada pela "preocupação do legislador com a proteção da concorrência eficiente diante do potencial distorcivo de condutas parasitárias que importem desvio de clientela". 924

Sobre a questão específica da aplicação do art. 1.147 do Código Civil às compras e vendas de participações societárias de controle, encontram-se decisões em sentidos diversos. Em aresto relativo à cessão da totalidade das quotas de limitada, decidiu-se pela possibilidade de "aplicação analógica do art. 1.147, do CC, ao caso, tendo em vista que a vedação de exercer o mesmo ramo de atividade decorre da cláusula geral da

\footnotetext{
${ }^{920}$ Para a posição da doutrina a respeito da vedação de concorrência no trespasse do estabelecimento antes do Código Civil de 2002, cf. GRAU, Eros R.; FORGIONI, Paula. "Cláusula de não-concorrência ou de nãorestabelecimento". In: O estado, a empresa e o contrato. São Paulo: Malheiros, 2005, pp. 273-300, pp. 274278.

921 BARBOSA, Rui. “As cessões de clientela e a interdição de concorrência nas alienações de estabelecimentos comerciais e industriais". In: Obras completas de Rui Barbosa, v. XL, T. I. Rio de Janeiro: Ministério da Educação e Saúde, 1928 (trazendo as razões de embargos apresentadas por Rui Barbosa ao Supremo Tribunal Federal bem como reprodução do acórdão proferido pelo Tribunal).

922 COMPARATO, Fábio Konder; SALOMÃO FILHO, Calixto. O poder de controle na sociedade anônima. Op. cit., n. 90, p. 256.

923 COMPARATO, Fábio Konder; SALOMÃO FILHO, Calixto. O poder de controle na sociedade anônima. Op. cit., n. 90, p. 255.

${ }_{924}$ STJ, REsp n. 1.203.109-MG, $3^{\text {a }}$ T., rel. Min. Marco Aurélio Bellizze, j. 05.05.2015 (afirmando a validade de cláusula de não concorrência prevista em contrato).
} 
boa-fé objetiva, inerente ao próprio negócio realizado entre as partes". ${ }^{925}$ Em outro julgado relativo a cessão de quotas, foi celebrado contrato com cláusula vedando o restabelecimento, mas sem previsão de prazo pelo qual deveria valer e, igualmente, considerou-se que seria aplicável por analogia o disposto no caput do art. 1.147 do Código Civil. ${ }^{926}$ Há, ainda, acórdãos em que se aplica o disposto no art. 1.147 do Código Civil sem maiores fundamentações, equiparando-se implicitamente a cessão de quotas ao trespasse. $^{927}$

Em outras decisões, por outro lado, refuta-se a aplicação da regra relativa ao trespasse à compra e venda de quotas. ${ }^{928} \mathrm{O}$ art. 1.147 do Código Civil teria em vista em vista a transferência de uma universalidade de fato, razão qual seria natural que o alienante não pudesse voltar a utilizar "a mesma lógica empregada na azienda vendida" para desviar a clientela daquele que a comprou, tutela essa que não teria lugar no âmbito da cessão de quotas. ${ }^{929}$ Em outro acórdão, no qual a cessão de quotas foi utilizada como instrumento para o desfazimento da sociedade, consignou-se que se tratava de "cessão de cotas sociais que não se confunde com trespasse de estabelecimento comercial”, afastando-se a aplicação do art. 1.147 do Código Civil. ${ }^{930}$ Assevera-se, ainda, que a regra do art. 1.147 conteria vedação que deveria ser interpretada restritivamente, não se aplicando ao negócio de cessão de quotas sociais. ${ }^{931}$

A licitude do restabelecimento do vendedor de participações societárias de controle é questão marcada por polêmica também no direito estrangeiro.

O artigo 1.147 do Código Civil inspirou-se no disposto no art. 2557 do Codice civile italiano de 1942, o qual impõe ao alienante do estabelecimento a proibição de, no prazo de cinco anos, o dever de iniciar nova empresa que, por seu objeto,

\footnotetext{
${ }^{925}$ TJSP, Ap. n. 0339888-88.2009.8.26.000, 8 a Câm. Dir. Priv., rel. Des. Pedro de Alcântara da Silva Leme Filho, j. 30.07.2014.

${ }^{926}$ TJSP, Ap. n. 0123234-93.2012.8.26.0100, $1^{\text {a }}$ Câm. Res. Dir. Empr., rel. Des. Fortes Barbosa, j. 26.09.2013.

927 TJSP, Ap. n. 1000628-26.2015.8.26.0008, 2a Câm. Res. Dir. Empr., rel. Des. Campos Mello, j. 14.03.2016; TJSP, Ap. n. 0191965-24.2010.8.26.0000, 10 $0^{\text {a }}$ Câm. Dir. Priv., rel. Des. Coelho Mendes, j. 29.03.2011.

${ }_{928}$ TJPR, AI n. 1.131.256-8, 7 Câm. Cív., rel. Des. Luiz Antonio Barry, j. 27.05.2014;

${ }^{929}$ TJSP, AI n. 2091661-41.2014.8.26.0000, $2^{\text {a }}$ Câm. Res. Dir. Empr., rel. Des. Araldo Telles, j. 15.01.2015.

${ }^{930}$ TJSP, Ap. n. 0022282-36.2012.8.26.0576, $2^{\text {a }}$ Câm. Res. Dir. Empr., rel. Des. Tasso Duarte de Melo, j. 10.12.2014. No mesmo sentido, TJSP, AI n. 0111795- 94.2012.8.26.0000, 2 ${ }^{\mathrm{a}}$ Câm. Res. Dir. Empr., rel. Des. Araldo Telles, j. 11.09.2012.

${ }^{931}$ TJSP, AI n. 2139605-68.2016.8.26.0000, $1^{\text {a }}$ Câm. Res. Dir. Empr., rel. Des. Hamid Bdine, j. 19.10.2016.
} 
localização física ou por outras circunstâncias, seja idônea a desviar a clientela do estabelecimento cedido. A aplicação da regra limitativa da concorrência também à hipótese de compra e venda de participações societárias de controle foi inicialmente rejeitada pela jurisprudência italiana, que, ainda na década de 1950, consolidou o entendimento de que a proibição de concorrência constituiria exceção à regra geral da livre-concorrência, pertinente apenas para a hipótese de trespasse do estabelecimento ou de um ramo autônomo da empresa, não podendo ser estendida por analogia à cessão de quotas sociais ou ações de controle. ${ }^{932}$

A doutrina foi contrária a essa primeira orientação. Mesmo antes da positivação promovida pelo legislador de 1942, considerava-se a proibição de concorrência norma implícita decorrente da obrigação de execução do contrato de boa-fé. ${ }^{933}$ A doutrina, posterior ao Codice civile seguiu a mesma orientação. Nesse sentido, TULLIO AsCARELLI defendeu que o início de atividade concorrente por quem houvesse transferido todas as ações ou quotas de uma sociedade como instrumento para a transmissão do estabelecimento seria inadmissível sempre que a interpretação do negócio jurídico indicasse que sua execução de boa-fé exigiria a abstenção por parte do alienante. ${ }^{934}$ Defendeu-se, assim, que (i) a norma buscaria evitar a possibilidade de exercício de concorrência qualificada e, por conta disso, particularmente perigosa ao adquirente; ${ }^{935}$ (ii) a não aplicação da regra à hipótese de compra e venda de participações societárias seria calcada em uma distinção formalista e que conduziria a resultados ilógicos; ${ }^{936}$ (iii) seria possível a aplicação analógica da regra quando a interpretação do contrato indicasse a intenção das partes de aquisição indireta do aviamento com pagamento de numerário respectivo, fazendo presumir o dever de não concorrer do alienante; ${ }^{937}$ e (iv) por conta do

\footnotetext{
${ }^{932}$ Cass. sez. I, 26.03.1956, n. 2245. In: Riv. dir. ind., II, 1957, pp. 105-126.

933 ASCARELLI, Tullio. "Divieto di concorrenza e vendita dell'azienda". In: Studi in tema di contratti. Milano: Giuffrè, 1952, pp. 487-497, p. 495 (publicado originalmente em 1930).

${ }^{934}$ ASCARELLI, Tullio. Teoria della concorrenza e dei beni immateriali. Milano: Giuffrè, 1956, p. 76.

935 MANGINI, Vito. "Cessione di quote sociale e divieto di concorrenza". In: Riv. dir. civ., 1956, II, pp. 185-196, p. 191.

${ }^{936}$ GIOIA, Vito la. “Alienazione di quota sociale e obbligo di non concorrenza". In: Riv. dir. ind., II, 1957, pp. 105-126, p. 113.

${ }^{937}$ FERRARI, Giorgio. Trasferimento di partecipazioni sociali e divieto di concorrenza". In: Riv. dir. ind., I, 1967, pp. 54-81, p. 79.
} 
seu fundamento na boa-fé, a regra do art. 2577 não seria excepcional, senão expressão de princípio geral. $^{938}$

Houve, porém, posicionamentos contrários à aplicação analógica, ressaltando-se, sobretudo, o fato de que a vedação de concorrência tutela o adquirente do estabelecimento, ao passo que, na compra e venda de participações societárias de controle, o titular do estabelecimento permanece sendo sempre a sociedade, razão pela qual não se poderia conceder um direito ao adquirente - o novo sócio - de tutelar a integridade do estabelecimento que é detido por outro sujeito de direito. ${ }^{939}$

Em 1997, a Corte di Cassazione alterou o posicionamento que manteve durante toda a segunda metade do século passado, considerando que (i) a regra do art. 2557 não seria excepcional e derrogatória do princípio da livre concorrência, mas antes determinada pelo legislador como mecanismo para disciplinar uma situação de peculiar risco diante da concorrência qualificada passível de ser praticada pelo alienante; (ii) seria possível a aplicação analógica da regra para casos similares à alienação de estabelecimento, como seria o caso da compra e venda de participações societárias que conduzisse ao mesmo resultado econômico; e (iii) o princípio da boa-fé imporia o dever de cada contratante cooperar para a realização dos interesses da contraparte. ${ }^{940}$ A decisão foi recebida com aprovação pela doutrina majoritária ${ }^{941}$ e, posteriormente, a orientação se consolidou na jurisprudência da Corte di cassazione. ${ }^{942}$

No direito francês, considera-se que, na transferência do fundo de comércio, o alienante não poderia fazer concorrência ao adquirente em virtude da garantia contra a evicção prevista no art. 1626 do Code Civil (garantie du fait personnel). ${ }^{943}$ Afirma-se que, no trespasse, a concorrência praticada pelo cedente perturbaria o uso do direito adquirido

\footnotetext{
${ }^{938}$ BOZZOLA, Gianpietro. "Divieto di concorrenza in caso di cessione d'azienda e abuso della personalità giuridica”. In: Riv. dir. ind., II, 1993, pp. 370-378, p. 375.

939 BRACCIODIETA, Angelo. “Alienazione di quota sociale e divieto di concorrenza”. In: Riv. soc., 1964, pp. 977-999, p. 998.

${ }_{940}$ Cass. sez. I, 20.06.1997, n. 549. In: I contratti, n. 3, 1997, pp. 267-269.

${ }^{941}$ CARNEVALI, Ugo. "Cessione di partecipazioni sociali e divieto di concorrenza". In: I contratti, n. 3, 1997, pp. 269-272; GUIDETTI, Barbara. "Divieto di concorrenza in caso di cessione di quote sociali". In: Riv. dir. ind., 1998, II, pp. 13-18; RORDORF, Renato. "Cessione di quote sociali e divieto di concorrenza: il velo societario si fa più trasparente". In: Foro it., 2000, pp. 3116-3119; . Contra: ALBERTINI, Lorenzo. "Cessione di quote sociali e divieto di concorrenza ex art. 2557 c.c.". In: Giustizia civile, 1997, I, pp. 12911309.

942 TINA, Andrea. Il contratto di acquisizione di partecipazioni societarie. Op. cit., pp. 186-189.

${ }^{943}$ CAFFIN-MOI, Marie. Cession de droits sociaux et droit des contrats. Op. cit., n. 346, p. 227.
} 
por potencialmente levar a um desvio da clientela, razão pela qual se reconhece que haveria uma obrigação de não-concorrência do cedente (obligation légale de nonconcurrence). ${ }^{944}$

A questão passou a ser discutida em casos nos quais se tratava da transferência de quotas ou ações de sociedade com fundo de comércio como principal ativo. $^{945}$ Em um primeiro momento, a Cour de cassation considerou que a mesma orientação deveria ser aplicada por analogia em casos envolvendo a cessão de quotas de sociedades limitadas $(S A R L) .{ }^{946}$ A doutrina dominante censurou a posição da jurisprudência, afirmando, de um lado, que o objeto do negócio jurídico seriam as quotas, de tal forma que as decisões negariam a personalidade moral. ${ }^{947}$ Como se apontou em decisão da Corte de Apelação de Paris, ademais, na compra e venda de participações societárias de controle, quem sofre a concorrência e, com ela, eventual prejuízo é a sociedade; não haveria fundamento jurídico para reconhecer legitimidade ativa ao adquirente das participações societárias para pretender obstar a concorrência praticada em face da sociedade. ${ }^{948}$

A Cour de cassation, tendo em vista essas críticas, traçou um critério mais preciso para a proibição de concorrência na compra e venda de participações societária no âmbito do chamado affaire Ducros, julgado em 1997. ${ }^{949}$ Tratava-se, na hipótese, de cessão da totalidade de participações societárias que garantiam o controle de sociedades que produziam e comercializavam ervas aromáticas. Pouco depois da celebração do contrato, o cedente criou uma nova sociedade dedicada à mesma atividade. A Cour decidiu que "tratando-se da cessão de ações de uma sociedade, a garantia legal de evicção do fato pessoal do vendedor não integra a proibição de restabelecimento, a menos que tal restabelecimento seja de tal natureza que impeça os adquirentes das ações de perseguir a atividade econômica da sociedade e de concretizar seu objeto social". ${ }^{950}$ Como se nota, a linha jurisprudencial não transpõe imediatamente a proibição de concorrência vigente no

\footnotetext{
${ }^{944}$ CAFFIN-MOI, Marie. Cession de droits sociaux et droit des contrats. Op. cit., n. 346, p. 228.

${ }^{945}$ CAFFIN-MOI, Marie. Cession de droits sociaux et droit des contrats. Op. cit., n. 347, p. 228.

${ }^{946}$ CAFFIN-MOI, Marie. Cession de droits sociaux et droit des contrats. Op. cit., n. 347, p. 228.

${ }^{947}$ CAFFIN-MOI, Marie. Cession de droits sociaux et droit des contrats. Op. cit., n. 347, p. 229.

${ }^{948}$ CAFFIN-MOI, Marie. Cession de droits sociaux et droit des contrats. Op. cit., n. 346, p. 229.

${ }^{949}$ Cass. com., 21.01.1997, Bulletin 1997 IV, n. 25, p. 22.

${ }^{950}$ Cass. com., 21.01.1997, Bulletin 1997 IV, n. 25, p. 22 (no original: "S'agissant de la cession des actions d'une société, la garantie légale d'éviction $d u$ fait personnel du vendeur n'entraîne pour celui-ci l'interdiction de se rétablir que si ce rétablissement est de nature à empêcher les acquéreurs de ces actions de poursuivre l'activité économique de la société et de réaliser l'objet social').
} 
âmbito do trespasse para a compra e venda de participações societárias. Tendo em vista que as participações societárias concedem ao comprador a possibilidade de exercer o controle para levar a sociedade a concretizar seu objeto social, passou-se a julgar que somente a concorrência praticada pelo vendedor que impossibilitasse o exercício do objeto social seria vedada, pois, nessa circunstância, os próprios títulos, e não somente a sociedade seriam afetados. $^{951}$

Mesmo tal aplicação mais restrita da proibição de restabelecimento é objeto de críticas. Para CAFFIN-MoI, para além de a jurisprudência atentar contra a autonomia da pessoa jurídica, ela geraria resultados equivocados e poderia tratar a mesma situação de forma mais adequada mediante o recurso à figura da concorrência desleal, deixando o terreno da responsabilidade contratual e passando para o âmbito da responsabilidade aquiliana. $^{952}$ A concorrência qualificada praticada pelo antigo sócio poderia ser considerada ato de desvio de clientela (détournement de clientèle) que gera danos à própria sociedade, titular do estabelecimento. ${ }^{953}$ Seguindo-se a linha jurisprudencial, no caso de uma cessão de quotas de controle com restabelecimento pelo cedente, seria reconhecida legitimidade ativa ao adquirente das participações societárias para requerer a cessação das atividades e, também, direito a indenização em caso de recusa. Ocorre que os danos são sofridos pela sociedade titular do estabelecimento, e apenas mediatamente pelo novo sócio controlador. A respectiva indenização, por conseguinte, deveria ser paga à sociedade, recompondo seu patrimônio, de forma que também os sócios minoritários dela se beneficiassem.

No direito brasileiro, a abordagem adequada da questão parece assemelharse à proposta no direito francês e à posição minoritária de BRACIODIETA ${ }^{954}$ no direito italiano, contrária à aplicação por extensão analógica ou interpretação extensiva da regra do art. 1.147 do Código Civil à compra e venda de participações societárias de controle.

A sociedade titular de estabelecimento possui direito oponível a todos, inclusive ao antigo controlador, de não sofrer concorrência desleal. Entre os atos definidos como crime de concorrência desleal incluem-se (i) o emprego de meio fraudulento para

\footnotetext{
${ }^{951}$ CAFFIN-MOI, Marie. Cession de droits sociaux et droit des contrats. Op. cit., n. 346, p. 230.

${ }_{952}$ CAFFIN-MOI, Marie. Cession de droits sociaux et droit des contrats. Op. cit., n. 602, p. 385.

${ }^{953}$ CAFFIN-MOI, Marie. Cession de droits sociaux et droit des contrats. Op. cit., n. 603, pp. 385-386.

${ }^{954}$ BRACCIODIETA, Angelo. "Alienazione di quota sociale e divieto di concorrenza". Op. cit., p. 998
} 
desvio de clientela (Lei 9.279/1996, art. 195, III); (ii) o uso ou a imitação de sinal de propaganda alheio ou sua imitação para criar confusão entre produtos ou estabelecimentos (Lei 9.279/1996, art. 195, IV); (iii) o uso indevido do nome comercial, título de estabelecimento ou insígnia alheios (Lei 9.279/1996, art. 195, V); e (iv) a divulgação, exploração ou utilização não autorizada de conhecimento, informações ou dados confidenciais a que teve acesso mediante relação contratual ou empregatícia, mesmo após o término do contrato (Lei 9.279/1996, art. 195, XI).

Se o vendedor das participações societárias de controle pratica concorrência desleal, cabe à sociedade prejudicada direito a indenização. Tal indenização revertida à sociedade beneficia indiretamente não somente o novo sócio controlador, mas todos os sócios. Se o vendedor, por outro lado, simplesmente estabelece nova atividade, não cabe a imposição por via analógica da obrigação de não-concorrência prevista para a hipótese de transferência do estabelecimento.

b) Lei de Recuperações e Falência

A Lei de Recuperações e Falência apresenta regras relativas à alienação do estabelecimento ou da unidade produtiva isolada. A pertinência desses dispositivos normativos também à compra e venda de participações societárias de controle não é clara.

(1) Compra e venda de participações societárias como ato falimentar (LRE, art. 94, III, “c") e sujeito à ineficácia (LRE, art. 129, caput, VI)

A menos que realizada nos termos de plano de recuperação judicial, a transferência de estabelecimento a terceiro, credor ou não, sem o consentimento de todos os credores e sem que remanesçam bens suficientes para solver o passivo é considerada ato falimentar (LRE, art. 94, III, “c"). A venda ou transferência do estabelecimento sem o consentimento expresso ou o pagamento de todos os credores, ademais, é ineficaz em relação à massa falida, independentemente da ciência do adquirente acerca do estado de crise econômico-financeira do devedor (LRE, art. 129, caput, VI). A legislação concursal, 
por outro lado, silencia a respeito da repercussão da transferência pelo devedor de participações societárias relativas a sociedade titular de estabelecimento.

Em um julgado em que se discutia a cessão de quotas sociais com alteração integral do quadro societário, avaliou-se que o negócio jurídico teria acarretado "por via oblíqua o trespasse do estabelecimento empresarial da falida", pois "ainda que persistindo a mesma pessoa jurídica - ocorreu autêntica alienação do controle de todo o ativo e passivo, com o automático trespasse do estabelecimento empresarial". ${ }^{955}$ Decretou-se, com isso, a ineficácia da cessão de quotas em relação à massa falida com base no disposto no art. 129, caput, VI da Lei de Recuperações e Falência. Em outro julgado, afirmou-se igualmente que a cessão de quotas representaria negócio jurídico sujeito à ineficácia em relação à massa falida. ${ }^{956}$

Em decisão posterior, adotou-se entendimento diverso. Considerando que a cessão de quotas não poderia ser equiparada à venda do estabelecimento da falida, decidiuse que "a hipótese do art. 129, caput, VI da NLF não se confunde com a cessão de quotas de sociedade de responsabilidade limitada”. Observou-se, ademais, que, no trespasse, há transferência de bens materiais e imateriais componentes do patrimônio, ao passo que, na transferência de controle, a sociedade permanece proprietária do estabelecimento. Argumentou-se, por isso, que "a venda do estabelecimento desfalca a pessoa jurídica de seu patrimônio ou parte dele, enquanto a cessão de suas quotas sociais em nada interfere no montante de seu capital social". ${ }^{957}$ Apontou-se, por fim, que não teria sido comprovado o prejuízo aos credores em decorrência da transferência das quotas sociais, razão pela qual a ineficácia não deveria ser decretada.

Não se tem notícia, por outro lado, de julgado relativo à consideração da compra e venda de participações societárias de controle como ato falimentar (LRE, art. 94, III, “c").

A compra e venda de quaisquer bens pelo devedor, como regra, não autoriza a decretação da falência ou da ineficácia do ato. O trespasse do estabelecimento, nessa medida, é uma hipótese singular no seio da legislação concursal. Quando se analisam os

\footnotetext{
955 TJSP, AI n. 556.674-4/0-00, Câm. Esp. Fal. Rec. Jud., rel. Des. Pereira Calças, j. 09.06.2009.

${ }^{956}$ TJSP, Ap. n. 9169077-78.2005.8.26.0000, 9a Câm. Dir. Priv., rel. Des. João Carlos Garcia, j. 22.02.2011.

957 TJSP, MS n. 999.09.337682-8, Câm. Res. Fal. Rec., rel. Des. Lino Machado, 14.09.2010.
} 
atos que sujeitam o devedor à decretação da falência, percebe-se que eles se ligam (i) ao inadimplemento efetivo, ou presumido pela ausência ou abandono do estabelecimento (LRE, art. 94, I; art. 94, II; art. 94, III, “f”; art. 94, III, “g”); (ii) à prática de atos de liquidação precipitada do patrimônio (LRE, art. 94, III, “a”); (iii) à prática de atos em fraude a credores (LRE, art. 94, III, “b”); ou a (iv) atos de liberalidade, como o reforço de garantia por dívida previamente existente (LRE, art. 94, III, “e”). Não há outra hipótese prevista em lei em que a celebração de um específico tipo de contrato oneroso é reputada ato falimentar pelo simples fato de não restarem bens ao devedor para saldar os passivos. A compra e venda de imóveis, ou de outros bens móveis, por exemplo, não representa ato falimentar.

Igualmente, entre os atos sujeitos à ineficácia, sobressaem os atos que quebram a igualdade entre os credores, como (i) o pagamento de dívidas não vencidas dentro do termo legal (LRE, art. 129, caput, I); (ii) o pagamento de dívidas vencidas por forma diversa da prevista no contrato (LRE, art. 129, caput, II); (iii) a constituição de direito real de garantia para dívidas contraídas anteriormente (LRE, art. 129, caput, III). Ou atos de liberalidade, como (i) a prática de atos a título gratuito (LRE, art. 129, caput, IV); ou (ii) a renúncia a herança ou legado (LRE, art. 129, caput, V). A ineficácia, com efeito, representa consequência grave; sua decretação afeta o adquirente - que perde a titularidade sobre o bem - e independe da intenção de fraudar os credores (LRE, art. 129, caput). ${ }^{958} \mathrm{O}$ trespasse de estabelecimento, nesse contexto, mostra-se como a única hipótese prevista em lei em que um negócio jurídico típico oneroso é privado de eficácia pela circunstância de não restarem bens para solver o passivo (LRE, art. 129, caput, VI). Outros atos que não configuram o trespasse, como, por exemplo, a compra e venda de conjunto de mercadorias $^{959}$ ou de imóvel ${ }^{960}$ não podem ser declarado ineficazes em relação à massa falida.

A peculiaridade da hipótese legal da transferência do estabelecimento parece ligar-se a motivos históricos, que tanto explicam a razão da existência desses dispositivos normativos, quanto indicam a falta de fundamento da sua aplicação por

\footnotetext{
958 STJ, AgInt no AREsp 901.010-SC, 4ª T., rel. Min. Luis Felipe Salomão, j. 23.08.2016 (ressaltando a desnecessidade de comprovação de consilium fraudis para decretação da ineficácia).

${ }^{959}$ STJ, REsp n. 1.079.781-RS, $3^{\text {a }}$ T., rel. Min. Nancy Andrighi, j. 14.09.2010.

${ }^{960}$ STJ, REsp n. 302.558-RJ, 4 ${ }^{\mathrm{a}}$ T., rel. Min. Aldir Passarinho Junior, j. 01.03.2007.
} 
analogia à hipótese de compra e venda de participações societárias de controle de sociedade titular de estabelecimento empresarial.

A legislação falimentar anterior contava com dispositivos de teor bastante semelhante aos aqui mencionados, prevendo que a transferência do estabelecimento a terceiros caracterizaria a falência do comerciante (Decreto-Lei n. 7.661/1945, art. $2^{\circ}, \mathrm{V}$ ) e que a venda ou transferência do estabelecimento sujeitar-se-ia à ineficácia quando praticada no termo legal (Decreto-Lei n. 7.661/1945, art. 52, VIII). O fundamento da séria consequência imposta à transferência do estabelecimento não era esclarecido pela doutrina. ${ }^{961}$ Tal orientação legislativa, porém, deve ser compreendida no contexto histórico em que o trespasse do estabelecimento privava dos credores a possibilidade de buscar a satisfação de seus créditos por meio da excussão dos bens organizados para o exercício da empresa. Isso porque, antes do Código Civil, não havia regra de direito positivo que impusesse ao adquirente responsabilidade pelos débitos contabilizados, como passou a reconhecer o Código Civil de 2002 (CC, art. 1.146).

O regramento concursal não se alterou, mas sua interpretação sob o Código Civil vigente não deve ser a mesma, ao menos no que toca à possibilidade de decretação de quebra. Como aponta FÉRES, a positivação da possibilidade de assunção das dívidas do estabelecimento pelo adquirente (CC, art. 1.146) altera o âmbito de legitimados a pedir a decretação da falência. Com a alienação do estabelecimento, adquirente e alienante tornam-se, pelo prazo de um ano, devedores solidários das dívidas contabilizadas. O titular de crédito regularmente inscrito passa, com isso, a poder pleitear o adimplemento em face do adquirente, conservando seus direitos contra o alienante. A alienação, assim, apenas reforça a possibilidade de o titular obter a satisfação de seu crédito. Tal credor, portanto, não teria interesse de agir para pleitear a decretação da falência do cedente. ${ }^{962}$

Essa correlação promovida por FÉRES entre o interesse de agir do credor e a subtração de sua garantia geral parece indicar um critério distintivo válido para a análise da sujeição da compra e venda de participações societárias aos regramentos mencionados. $\mathrm{O}$ trespasse e a compra e venda de participações societárias não se diferenciam pela circunstância de que, no trespasse do estabelecimento, haveria desfalque do patrimônio, ao

\footnotetext{
${ }^{961}$ VALVERDE, Trajano de M. Comentários à lei de falências. Op. cit., p. 87.

${ }^{962}$ FÉRES, Marcelo A. Estabelecimento empresarial. Op. cit., p. 131.
} 
passo que na, venda de quotas, não ocorreria interferência no capital social, como indevidamente se afirmou em decisão referida. ${ }^{963}$ Ambos os negócios jurídicos onerosos igualmente (i) não alteram o capital social; e (ii) não desfalcam o patrimônio do devedor, desde que celebrados em termos equitativos.

O que diferenciava o trespasse e justificava sua inclusão entre os atos falimentares e autorizadores da revogação era o fato de que, por meio dele, era possível a transferência do conjunto de bens organizados para a empresa pelo devedor, privando os credores da garantia indireta de que dispunham. Na compra e venda de quotas e ações, antes e depois do Código Civil, os credores da sociedade controladora não são afetados pelo contrato, pois não podem se valer diretamente dos bens da sociedade controlada para obter satisfação de seus créditos.

Acresce a essas considerações a circunstância de que a compra e venda de quotas ou ações é ato diverso da transferência do estabelecimento e que não está previsto na legislação concursal. Por tais razões, a aplicação dos artigos 93, III, "c" e 129, caput, VII à compra e venda de participações societárias não prospera.

(2) Possibilidade de compra e venda de participações societárias viabilizar a alienação de unidade produtiva isolada (LRE, art. 60)

Relevante inovação promovida pela Lei de Recuperações e Falência foi a previsão de que, na alienação judicial de filiais ou de unidades produtivas isoladas do devedor promovida na forma prevista no art. 142 da lei, o objeto de alienação fica livre de qualquer ônus, sem sucessão do arrematante nas obrigações do devedor, inclusive as de natureza tributária (LRE, art. 60, par. único). A regra foi complementada por alteração promovida pela Lei Complementar n. 118 de 2005 ao Código Tributário Nacional, a qual igualmente faz referência ao produto da alienação judicial "de empresa, filial ou unidade produtiva isolada" (CTN, art. $\left.133, \S 3^{\circ}\right)$, para determinar que o montante obtido fique depositado à disposição do juízo falimentar pelo prazo de um ano.

${ }^{963}$ TJSP, MS n. 999.09.337682-8, Câm. Res. Fal. Rec., rel. Des. Lino Machado, 14.09.2010. 
A expressão "unidade produtiva isolada" não era empregada previamente pela legislação, mas a doutrina considera que se teria em vista o estabelecimento empresarial. ${ }^{964}$ Tornou-se prática comum, porém, que, no âmbito de recuperações judiciais, não se promova ao trespasse do estabelecimento, mas à compra e venda de participações societárias de controle de sociedade titular de unidade produtiva isolada, nos termos de plano de recuperação judicial aprovado pela assembleia geral de credores (LRE, art. 60).

A possibilidade de a compra e venda de participações societárias servir como mecanismo para a alienação de unidade produtiva isolada, contudo, pode ser questionada. Em julgado referente à aquisição da integralidade de quotas de sociedade constituída para viabilizar a alienação de ativos (no caso, um supermercado) no curso da recuperação judicial, decidiu-se que "apesar de ser feita a menção a uma 'Unidade Produtiva Isolada', não ocorreu a alienação de um estabelecimento empresarial complexo, considerado este como universalidade constituída pela reunião de bens destinados ao exercício de uma mesma atividade empresarial, de forma conjunta e coordenada" e que a referência a uma 'UPI' no edital em questão não geraria o efeito exoneratório previsto em lei, julgando-se que o adquirente "não se colocou na posição de adquirente de um estabelecimento comercial, o que implica na falta dos pressupostos para a incidência dos referidos parágrafo único do artigo 60 e inciso II do artigo 141 da Lei 11.101 ".965

A decisão, todavia, parece equivocada, por conferir inteligência excessivamente restritiva à expressão "unidade produtiva isolada". A Lei de Recuperação e Falências entrou em vigor posteriormente ao Código Civil de 2002 que disciplinou o estabelecimento empresarial. A decisão pelo emprego de nova expressão cujo alcance é imexato certamente merece críticas pela falta de técnica. ${ }^{966}$ Buscando-se, porém, extrair significado interpretativo útil do emprego da decisão tomada pelo legislador legislador, parece adequado compreender que a intenção, no âmbito do processo de recuperação judicial, foi de buscar de forma abrangente abarcar diversas realidades econômicas produtivas que não necessariamente preencheriam os requisitos para que fossem consideradas estabelecimentos empresariais, como poderia ser o caso, por exemplo, de

\footnotetext{
${ }^{964}$ TOLEDO, Paulo F. C. S. de; POPPA, Bruno. "UPI e estabelecimento: uma visão crítica”. Op. cit., p. 277; MUNHOZ, Eduardo S. “Comentários ao art. 60”. Op. cit., p. 298.

${ }_{965}$ TJSP, AI n. 2029620-72.2013.8.26.0000, $1^{\text {a }}$ Câm. Res. Dir. Empr., rel. Des. Fortes Barbosa, j. 29.05.2014.

${ }^{966}$ MUNHOZ, Eduardo S. “Comentários ao art. 60”. Op. cit., p. 298.
} 
unidades de produção agrícola. Quotas ou ações de controle de sociedades que exercem atividade produtiva, nesse sentido, parecem passíveis de serem abarcadas pelo conceito.

A compra e venda de participações societárias de controle, nessa medida, mostra-se como mecanismo apto para a alienação de unidade produtiva isolada, de tal forma que, respeitados os requisitos legais, o adquirente deve beneficiar-se da ausência de sucessão.

c) Direito tributário: sucessão no estabelecimento (CTN, art. 133)

Em matéria tributária, reconhece-se a responsabilidade do adquirente do fundo de comércio ou estabelecimento comercial, industrial ou profissional (CTN, art. 133, caput). Na aquisição de participações societárias de controle de sociedade titular de estabelecimento, o resultado prático para o adquirente é o mesmo sob o ponto de vista econômico, pois a sociedade permanece a responsável pelos tributos relativos ao estabelecimento. Para o alienante, porém, a situação se altera. No trespasse do estabelecimento, se o alienante prosseguir na exploração ou iniciar, dentro de seis meses, nova atividade no mesmo ou em outro ramo de comércio, indústria ou profissão, ou em outro, responde subsidiariamente ao adquirente pelos tributos devidos até a data do trespasse (CTN, art. 133, caput, II). A questão que se coloca é de saber se, na compra e venda de participações societárias de controle, o vendedor poderia permanecer responsável por dívidas relativas ao fundo de comércio.

A doutrina considera que a resposta seria negativa, de tal forma que, no caso de compra e venda de participações societárias de controle de sociedade titular de estabelecimento empresarial, o alienante não permaneceria responsável por tributos relacionados ao estabelecimento, ainda que continue exercendo a mesma atividade 
empresária ou inicie nova no prazo de seis meses. ${ }^{967}$ A jurisprudência alinha-se na mesma direção. ${ }^{968}$

A orientação é acertada, pois, em matéria tributária, não cabe a desconsideração da personalidade jurídica, seja para atingir o patrimônio do antigo sócio, seja para atingir o patrimônio do sócio atual, a menos que se comprove que os diretores, gerentes ou representantes praticaram atos com excesso de poderes ou infração de lei, contrato social ou estatutos (CTN, art. 135, III).

\section{B. Sociedade proprietária de bem imóvel}

A compra e venda de bens imóveis é pautada por regras específicas que tutelam o próprio titular do bem imóvel ou terceiros que com ele se relacionam. Na compra e venda de participações societárias de controle de sociedade titular de imóvel, pode-se questionar a aplicação analógica ou extensiva de tais regras protetivas. É o que se dá no caso das regras de preferência para aquisição de imóvel e na disciplina do direito de família.

a) Direito de preferência do locatário de imóvel urbano e arrendatário de imóvel rural

O locatário tem preferência para adquirir o imóvel urbano locado em igualdade de condições com terceiros na venda, promessa de venda, cessão, promessa de cessão, ou mesmo na dação em pagamento (Lei de Locações, art. 27). O direito de preferência, por outro lado, não abarca as hipóteses de "integralização de capital, cisão, fusão e incorporação" (Lei de Locações, art. 32). Nada se menciona a respeito da alteração de controle.

\footnotetext{
${ }^{967}$ MARTINS, Ives Gandra da Silva. "Sucessão tributária e a figura desconsiderativa”. In: RTrib, v. 87, 2009, pp. 111-131; GRECO, Marco Aurélio. "Imposto sobre a renda - responsabilidade do sucessor na aquisição de estabelecimento - o art. 133 do CTN". In: RTrib, v. 29, 2001, pp. 49-85.

${ }_{968}$ STJ, AgRg no AI n. 816.318-RS, 2 ${ }^{\mathrm{a}}$ T., rel. Min. Herman Benjamin, j. 22.05 .2007 (afirmando que não restou caracterizada a sucessão empresarial, mas tão somente alteração do quadro societário da empresa e do acionista controlador).
} 
No Estatuto da Terra há previsão de que o arrendatário terá preferência para adquirir o imóvel arrendado no caso de alienação (Estatuto da Terra, art. 92, $\S 3^{\circ}$ ), sem menção às hipóteses de integralização de capital, cisão, fusão ou incorporação.

Na compra e venda de participações societárias de controle, pode-se obter efeito econômico semelhante à alienação do imóvel. É comum, ademais, que por planejamento tributário e sucessório, sejam constituídas sociedades com o propósito exclusivo de administrar patrimônio imobiliário anteriormente detido por pessoas físicas integrantes de núcleo familiar. Na transferência das quotas e ações a terceiros, é possível que o locatário ou arrendatário pretenda o exercício do direito de preferência.

(1) Direito de preferência do locatário de bem imóvel urbano

No direito estrangeiro, a posição do locatário na compra e venda de participações societárias vem sendo objeto de atenção. No direito português, o Regime do Arrendamento Urbano prevê que, para as finalidades ali previstas, "a transmissão inter vivos de posição ou posições sociais que determine a alteração da titularidade em mais de $50 \%$ face à situação existente aquando da entrada em vigor da presente lei (Lei n. ${ }^{\circ}$ 6/2006, art. 26), o que representou uma efetiva equiparação promovida por força de lei entre a compra e venda de participações societárias e a transmissão do imóvel. ${ }^{969} \mathrm{Na}$ Itália, por outro lado, a jurisprudência reconhece que nem a integralização de imóvel ao capital social, nem a eventual posterior transferência da integralidade das participações societárias autorizariam o locatário ao exercício de preferência, previsto apenas para a hipótese de alienação do próprio imóvel. ${ }^{970}$

No direito brasileiro, no âmbito da locação urbana, um possível fundamento para sustentar o direito de preferência do locatário seria o fato de que a jurisprudência e a própria Lei de Locações não respeitam em sua plenitude a distinção entre a esfera jurídica

\footnotetext{
969 MONTEIRO, António Pinto; MOTA PINTO, Paulo. "Compra e venda de empresa: a venda de participações sociais como venda de empresa (share deal)". Op. cit., p. 100.

${ }_{970}$ CALVO, Roberto. "Il trasferimento della 'proprietà' nella compravendita di titoli azionari". Op. cit., p. 1122.
} 
do sócio e da sociedade, apresentando peculiares hipóteses de desconsideração atributiva da personalidade jurídica em virtude de lei, ${ }^{971}$ tanto em benefício do locador quanto do locatário.

A desconsideração atributiva em favor do locador foi inicialmente reconhecida em uma série de julgados em que se considerou que o proprietário de imóvel poderia retomá-lo não apenas para uso próprio, mas para utilização por sociedade de que o sócio proprietário participasse. ${ }^{972}$ A matéria seria posteriormente objeto de súmula pelo STF, em que se consignou que se adimite "a retomada para sociedade da qual o locador, ou seu cônjuge, seja sócio, com participação predominante no capital social” (STF, Súmula n. 486). A Lei de Locações seguiu parcialmente essa orientação para especificar as condições de retomada do imóvel comercial, determinando que o locador não está obrigado a renovar o contrato de locação comercial se o imóvel locado vier a ser utilizado por ele próprio ou para transferência de fundo de comércio existente há mais de um ano, sendo detentor da maioria do capital o locador, seu cônjuge, ascendente ou descendente (Lei de Locações, art. 52, II).

A desconsideração atributiva da personalidade jurídica é prevista também em favor do locatário na hipótese em que o contrato de locação comercial autorizar a utilização do imóvel para atividade de sociedade da qual faça parte, pois, nessa hipótese, o locatário ou a sociedade poderão exercer o direito à renovação (Lei de Locações, art. 51, $\left.\S 2^{\circ}\right)$.

O argumento parece, contudo, equivocado. As hipóteses específicas de desconsideração previstas na legislação não autorizam afirmar que sempre que ocorresse alteração da configuração societária do locador o locatário teria direito de preferência para a aquisição do imóvel. Para além de a natureza jurídica do negócio jurídico ser distinta, não dizendo respeito à alienação de direito sobre o imóvel, o próprio preço para a aquisição das quotas sociais normalmente é calculado tendo em vista as possíveis contingências tributárias ou de outra natureza ligadas ao exercício da atividade social, o que não ocorre na aquisição de bem de raiz.

${ }^{971}$ SALOMÃO FILHO, Calixto. O novo direito societário. Op. cit., p. 234.

972 STF, AR n. 696-PR, Pleno, rel. Min. Carlos Thompson Flores, j. 15.05.1969; STF, RE, n. 61.973-SP, Pleno, rel. Min. Djaci Falcão, j. 20.03.1969; STF, RE n. 66.093-MG, $1^{\text {a }}$ T., rel. Min. Raphael de Barros Monteiro, j. 05.12.1968; STF, RE n. 58.766-SP, 3 ${ }^{\mathrm{a}}$ T., rel. Min. Gonçalves de Oliveira, j. 21.10.1966; STF, RE 61.696-SP, $1^{\text {a }}$ T., rel. Min. Victor Nunes, j. 31. 10.1966. 
Ao celebrar contrato de locação residencial em que uma sociedade consta como locadora, ademais, o locatário beneficia-se de uma restrição nas hipóteses em que ficaria sujeito à retomada do imóvel. A pessoa física locadora, com efeito, pode pedir o imóvel "para uso próprio, de seu cônjuge ou companheiro, ou para uso residencial de ascendente ou descendente que não disponha, assim como seu cônjuge ou companheiro, de imóvel residencial próprio" (Lei de Locações, art. 47, III). Não é possível, portanto, equiparar as hipóteses.

(2) Direito de preferência do arrendatário

O direito de preferência do arrendatário também é objeto de discussão na doutrina estrangeira. $\mathrm{Na}$ Itália, o arrendatário do terreno e o proprietário de terreno confinante possuem direito de preferência (prelazione) para sua aquisição, o qual, porém, não se aplica na hipótese de conferência ao capital social em virtude do caráter infungível da contraprestação recebida pelo subscritor, qual seja, a atribuição do status socii. ${ }^{973} \mathrm{E}$ consolidado, também, o entendimento de que a alienação da totalidade das participações societárias não se confunde com a alienação do próprio imóvel, razão pela qual não incide o direito de preferência em questão. ${ }^{974}$

A consequência desse entendimento foi a disseminação da prática de integralização do imóvel rural ao capital de sociedades com sócio único, seguida da transferência da integralidade das participações societárias ao adquirente. ${ }^{975}$ Para buscar lidar com tal situação social, uma proposta legislativa que se discutiu foi a de conceder ao arrendatário ou confinante direito de preferência sobre as quotas ou ações em caso de transferência a terceiros, projeto que foi objeto de acesa crítica por parte de PIERO VERRUCOLI por permitir que o agricultor participasse do capital da sociedade e, com isso, indiretamente também obtivesse resultados econômicos advindos da propriedade de outros

${ }^{973}$ CASTELLARI, Paolo. "Società unipersonale a responsabilità limitata e prelazione agraria del coltivatore insediato o proprietario di terreno confinante". In: Riv. dir. agr., 1994, pp. 504-534, p. 507.

${ }^{974}$ CALVO, Roberto. "Il trasferimento della 'proprietà' nella compravendita di titoli azionari". Op. cit., p. 1119; ZAMPERETTI, Giorgio Maria. "La cessione delle quote sociali non equivale alla vendita dei beni della società". In: Le società, 2001, pp. 1354-1358.

${ }_{975}$ CALVO, Roberto. "Il trasferimento della 'proprietà' nella compravendita di titoli azionari". Op. cit., p. 1120. 
imóveis pela sociedade. ${ }^{976}$ Em 1992, porém, foi introduzida alteração legislativa para prever o direito de preferência do agricultor também na conferência do imóvel rural ao capital social, a menos que se trate de versão do imóvel para integralização de quotas de sociedade simples constituída por cultivadores diretos ou de sociedade cooperativa agrícola (decreto legge n. 458, de 24.11.1992). ${ }^{977}$

No Brasil, não se tem notícia de litígios relacionados ao assunto, mas, a princípio, não há fundamento para estender por analogia o direito de preferência do arrendatário à hipótese de compra e venda de participações societárias de controle, por razões similares às apontadas no item anterior.

b) Direito de família

No âmbito do direito de família, é tradicional a previsão de regras limitativas do poder de disposição sobre bens imóveis. Considerando-se que quotas ou ações são bens móveis (CC, art. 83, III), na hipótese de elas terem sido emitidas por sociedade titular de bens imóveis, tem-se uma possibilidade mediata de dispor de direitos relativos a bens imóveis. A doutrina tem apontado que a separação entre a personalidade jurídica da sociedade pode ser utilizada como mecanismo para fraude às relações familiares. ${ }^{978}$ Antes de questionar a possibilidade de desconsideração, contudo, convém analisar o regramento aplicável às compras e vendas de participações societárias de controle sob o ponto de vista familiar.

$\mathrm{Na}$ vigência do casamento, o cônjuge não pode alienar ou gravar de ônus real os bens imóveis, exceto no regime da separação absoluta (CC, art. 1.647, I). A cessão de quotas sociais ou de ações qualifica-se como contrato sobre bens móveis, razão pela

\footnotetext{
${ }^{976}$ VERRUCOLI, Piero. "In tema di prelazione agraria: una legge da non fare”. In: Riv. dir. agr., 1977, pp. 441-445.

${ }_{977}$ CALVO, Roberto. "Il trasferimento della 'proprietà' nella compravendita di titoli azionari". Op. cit., p. 1120.

${ }^{978}$ MALHEIROS, Antônio Carlos. "Teoria da desconsideração inversa da personalidade jurídica aplicada às relações familiares". In: ADAMEK, Marcelo V. von. Temas de direito societário e empresarial contemporâneos. São Paulo: Malheiros, 2011, pp. 765-770.
} 
qual a outorga conjugal é desnecessária. ${ }^{979}$ A situação é diversa, por exemplo, da vigente no direito francês, em que, para a cessão de quotas não negociáveis, exige-se o consentimento conjugal (Code civil, art. 1424). ${ }^{980}$

Sob a perspectiva do consorte, a tutela para que não sejam transferidos bens imóveis que integram o patrimônio comum dá-se por meio da exigência de consentimento para a integralização de bens ao capital social ou para a livre disposição do patrimônio do casal por meio de sociedade empresária.

Para a integralização de bem imóvel ao capital social de sociedade constituída por um dos cônjuges, ou da qual somente um dos cônjuges seja sócios, seria possível argumentar que a subscrição e a integralização do bem ao patrimônio dispensaria escritura pública (LSA, art. 89; Lei 8.934/1994, art. 64) e que o próprio consentimento conjugal seria dispensável, por não se tratar de ato de alienação do bem imóvel (CC, art. 1.647, I), senão ato com natureza jurídica própria de conferência de bens. ${ }^{981}$ A orientação jurisprudencial, contudo, tem-se inclinado em sentido diverso e considerado que, sendo o imóvel integrante do patrimônio comum, seria necessário ato de disposição por parte do cônjuge que não integra a sociedade, de tal forma que se faz necessária a lavratura de escritura pública por parte do cônjuge que não será sócio. Por meio da escritura pública, o consorte que não ingressa na sociedade, de um lado, transfere a parte que lhe cabe sobre o imóvel comum e, de outro, consente com a integralização da parte do consorte ao patrimônio societário. ${ }^{982} \mathrm{O}$ risco de que o cônjuge proceda à integralização de imóveis à revelia do consorte e posteriormente proceda à alienação das participações societárias, nessa medida, é baixo.

Questão mais complexa a que se faz referência na doutrina é a possibilidade de um dos cônjuges passar a utilizar os rendimentos e a adquirir imóveis sob a titularidade

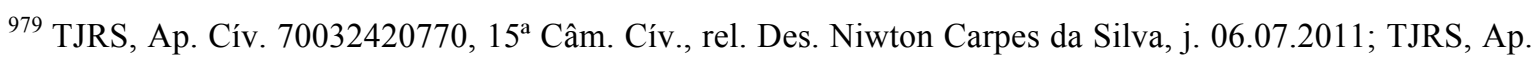
Cív. 70020129037, 8a Câm. Cív., rel. Des. Luiz Ari Azambuja Ramos, j. 09.08.2007; TJMG, Ap. Cív. 2.0000.00.479683-4/000, 9a Câm. Cív., rel. Des. Pedro Bernardes, j. 10.01.2006.

980 COZIAN, Maurice; VIANDIER, Alain; DEBOISSY, Florence. Droit des sociétés. Op. cit., n. 349, p. 195.

${ }^{981}$ GUERREIRO, J. A. T. "Sobre a conferência de bens". Op. cit., pp. 16-18.

982 TJMG, Ap. Cív. N. 1.0324.14.001030-1/001, $8^{\mathrm{a}}$ Câm. Cív., rel. Des. Teresa Cristina da Cunha Peixoto, j. 02.07.2015; TJSP, Ap. Cív. n. 626-6/9, rel. Corregedor Geral da Justiça Des. Gilberto Passos de Freitas, j. 22.02.2007 (considerando não ser suficiente que o cônjuge consinta com a integralização de imóvel no âmbito do instrumento de constituição da sociedade).
} 
de sociedade da qual é sócio único, ${ }^{983}$ o que, como se disse, se promove com frequência com vistas a minimizar impactos tributários. Esta é, talvez, a maior fonte de vulnerabilidade para o sistema de tutela do patrimônio do cônjuge, mas que pressupõe, igualmente, uma fraude caracterizada pelo desvio de bens adquiridos na constância do casamento e que integram a comunhão (CC, art. 1.660) para o patrimônio societário. ${ }^{984}$

De toda forma, mesmo que a sociedade seja titular de bens imóveis, não é possível a desconsideração atributiva para exigir o consentimento conjugal para alienação de suas participações societárias, porque a falta de consentimento importa a invalidade do ato praticado sem a outorga (CC, art. 1.650), consequência jurídica que afeta não somente o cônjuge, mas também o contratante que adquire as participações societárias. $O$ terceiro conhecedor do estado conjugal do alienante deve guiar-se pelos preceitos legais em vigor para exigir, ou não, a outorga conjugal. Tratando-se de bem móvel, o adquirente deve ter segurança de que celebrou ato válido, sem recear a possibilidade de impugnação do contrato pela falta de um consentimento não previsto em lei. Ressalvada a hipótese de negócio jurídico indireto em fraude à lei, portanto, não cabe o consentimento do cônjuge ainda que se trate de sociedade titular de bens imóveis.

Ainda no âmbito do direito de família, a alienação de participações societárias pode-se mostrar relevante no âmbito da administração dos bens dos filhos menores. Os pais no exercício do poder familiar são usufrutuários dos bens dos filhos (CC, art. 1.689, I) e administram os bens dos filhos menores sob sua autoridade (CC, art. 1.689, II). Os pais, contudo, somente podem alienar ou gravar de ônus real os imóveis dos filhos mediante prévia autorização judicial (CC, art. 1.691, caput). A alienação ou aquisição de participações societárias, nessa medida, não se inscreve entre os atos que exigem autorização judicial. Como consequência, admite-se que a cessão de quotas seja praticada por qualquer dos genitores, sem autorização judicial e sem o consentimento expresso do

\footnotetext{
${ }^{983}$ MADALENO, Rolf. Direito de família: aspectos polêmicos. Porto Alegre: Livraria do Advogado, 1998, p. 28; MALHEIROS, Antônio Carlos. "Teoria da desconsideração inversa da personalidade jurídica aplicada às relações familiares". Op. cit., p. 768.

${ }^{984}$ OLIVEIRA, J. Lamartine Corrêa de. A dupla crise da pessoa jurídica. Op. cit., p. 327 (afirmando que "muitas fraudes e injustiças seriam evitadas, aplicando-se, por exemplo, as normas sobre outorga de cônjuge [...] quando as partes, ao adquirirem quotas ou ações, tenham tido em vista, primacialmente, os bens imóveis da sociedade").
} 
outro genitor. ${ }^{985} \mathrm{O}$ mesmo vale para a negociação de ações, ${ }^{986}$ ainda que as ações ou quotas confiram o controle sobre sociedade titular de bens imóveis.

\section{Sociedade titular de posição contratual}

A sociedade pode ser titular de posições contratuais cuja cessão a terceiros seja restrita. As hipóteses mais relevantes são a posição de locatária e a posição de parte em contrato social, estatuto ou acordo de sócios que preveja direito de preferência para aquisição de ações ou quotas. A posição prevalecente na doutrina e jurisprudência a respeito de tais assuntos é assimétrica.

a) Lei de locação: necessidade de consentimento do locador para transferência de controle

A cessão da posição de locatário de bem imóvel pressupõe o consentimento do locador (Lei de Locação, art. 13). O O entendimento jurisprudencial do STJ é de que esse consentimento se faz necessário até mesmo na hipótese de o contrato de locação ser celebrado por sociedade empresária para a locação de imóvel que passa a integrar seu ponto comercial. A despeito da previsão de que o trespasse importa sub-rogação do adquirente nos contratos (CC, art. 1.148), julgou o STJ que seria "destemperado o entendimento de que o art. 13 da Lei do Inquilinato não tenha aplicação às locações comerciais, pois, prevalecendo este posicionamento, o proprietário do imóvel estaria ao alvedrio do inquilino". 987

No caso de compra e venda de participações societárias de controle, há julgado entendendo que a transferência das quotas sociais da locatária exigiria expresso consentimento do locador, sem que, porém, se fundamente tal equiparação entre a troca de

985 TJSP, Ap. n. 00311380-92.2009.8.26.0562, 1ª̂m. Res. Dir. Empr., rel. Des. Fortes Barbosa, j. 30.09.2015.

${ }^{986}$ CARVALHOSA, Modesto. Comentários à lei de sociedades anônimas. Op. cit., p. 424; REQUIÃO, Rubens. Comentários à lei das sociedades anônimas. Op. cit., p. 228; LUCENA, J. Waldecy. Das sociedades anônimas. Op. cit., p. 355.

${ }^{987}$ STJ, REsp n. 1.202.077-MS, $3^{\mathrm{a}}$ T., rel. Min. Vasco Della Giustina, j. 01.03.2011. No mesmo sentido, TJSP, Ap. n. 0179165-86.2009.8.26.0100, 29a Câm. Dir. Priv., rel. Des. Francisco Thomaz, j. 16.05.2012; TJSP, Ap. n. 992.07.019602-7, 32ª Câm. Dir. Priv., rel. Des. Walter Cesar Exner, j. 23.09.2010. 
controle e a cessão da posição contratual. ${ }^{988}$ Em outros julgados, porém, decidiu-se que a alteração de controle não importa cessão da locação, pois "ainda que ocorra modificação na razão social ou na composição da empresa em destaque, isto não acarreta alteração do vínculo locatício existente, eis que a locatária e ocupante do imóvel continuam sendo a mesma pessoa jurídica que celebrou o contrato de locação"989 e que a "alteração no quadro societário da locatária não afeta o vínculo locativo".990

O entendimento do STJ de que o consentimento do locador seria necessário para cessão da locação no âmbito do trespasse parece equivocado, por colidir com o disposto sobre o (CC, art. 1.148). É correto, por outro lado, o entendimento de que a alteração do controle não implica cessão da posição contratual, razão pela qual não se exige o consentimento do locador. Como resultado, constata-se a existência de relevante diferença entre a situação do contrato de locação no trespasse e na alienação de participações societárias de controle.

b) Direito de preferência e venda conjunta (tag along)

A posição da jurisprudência sobre a relevância da alteração de controle é diversa no caso de sociedade que é parte contrato social, estatuto ou acordo de sócios prevendo direito de preferência ou venda conjunta (tag along) de quotas ou ações. Por conveniência, será tratada neste item a hipótese da cláusula de preferência, mas o quanto aqui se afirma é aplicável também ao direito de venda conjunta (tag along).

Um julgado paradigmático sobre o assunto foi proferido no chamado Caso Schincariol, apreciado pelo Tribunal de Justiça do Estado de São Paulo. ${ }^{991}$ O controle acionário do Grupo Schincariol era exercido por meio de sociedade holding denominada Schincariol Participações e Representações S.A, cujo capital social estava dividido, fundamentalmente, entre duas sociedades limitadas denominadas Jadangil e AleadriSchinni, cada uma delas controlada por parte dos integrantes da família Schincariol. O estatuto da sociedade anônima Schincariol determinava que a negociação de ações era

\footnotetext{
988 TJSP, Ap. n. 0014809-81.2010.8.26.0248, 36 Câm. Dir. Priv., rel. Des. Jayme Queiroz Lopes, j. 31.07.2014.

${ }^{989}$ TJSP, Ap. n. 9076451-98.2009.8.26.0000, $28^{a}$ Câm. Dir. Priv., rel. Des. Cesar Lacerda, j. 15.05.2012.

${ }^{990}$ TJSP, Ap. n. 0005474-81.2012.8.26.0114, 35 Câm. Dir. Priv., rel. Des. Gilberto Leme, j. 26.01.2015.

991 TJSP, AI n. 0217635-30.2011.8.26.0000, Câm. Res. Dir. Empr., rel. Des. Enio Zuliani, j. 11.10.2011.
} 
limitada por direito de preferência, devendo-se assegurar aos demais acionistas igualdade de condições na hipótese de alienação a terceiros. Os titulares da integralidade das quotas da Aleadri-Schinni, porém, decidiram vender suas quotas naquela sociedade limitada a um grupo multinacional, sem conferir direito de preferência à sociedade Jadangil. A questão levada a juízo era de saber se a compra e venda de quotas dessa sociedade holding poderia ser equiparada à transferência das ações da sociedade anônima Schincariol.

Após analisar o caráter intuitu personae da sociedade anônima, decidiu-se que, em sede preliminar "excluir o direito de preferência pelo subterfúgio empregado nas razões, seria o mesmo que reconhecer de pronto, a legalidade de um artifício que teria sido engendrado para frustrar propósito comum e vinculativo, em nítida ofensa ao dever de conduta leal dos sócios". ${ }^{992}$ Trata-se de posicionamento que foi posteriormente adotado em sede de pleito de tutela antecipada em caso similar de cessão de controle indireto, no qual se alegava que o direito de preferência previsto no contrato social e que dizia respeito somente à compra e venda de quotas deveria ser respeitado igualmente na hipótese de compra e venda das quotas da sociedade limitada controladora. ${ }^{993}$

Na doutrina, os posicionamentos sobre a questão variam. Em parecer, LAMY FILHO analisou hipótese em que três irmãos herdaram ações de uma companhia familiar e celebraram acordo de acionistas que conferia direito de preferência aos demais sócios na alienação de ações, a menos que se tratasse de alienação das ações para outra sociedade que estivesse sob o controle de um dos sócios. Passados seis meses, dois dos irmãos aportaram as ações de que eram titulares ao capital de sociedades limitadas holding, e, posteriormente, transferiram as quotas dessas sociedades a uma empresa estrangeira. ${ }^{994}$ Para o autor, o acionista que remanesceu na companhia teria direito ao exercício da preferência na alienação a terceiro estranho ao bloco de controle, primeiramente, por tratarse de companhia com caráter pessoal (intuitus personae), ${ }^{995} \mathrm{e}$, em segundo lugar, porque a

\footnotetext{
${ }^{992}$ TJSP, AI n. 0217635-30.2011.8.26.0000, Câm. Res. Dir. Empr., rel. Des. Enio Zuliani, j. 11.10.2011.

993 TJSP, AI n. 0029218-59.2012.8.26.0000, 1 ${ }^{\mathrm{a}}$ Câm. Res. Dir. Empr., rel. Des. Francisco Loureiro, j. 27.03.2012.

${ }^{994}$ LAMY FILHO, Alfredo. “A desconsideração da personalidade jurídica em acordo de acionistas”. In: A Lei das S.A. Rio de Janeiro: Renovar, 1992, pp. 522-534, p. 523.

${ }^{995}$ LAMY FILHO, Alfredo. "A desconsideração da personalidade jurídica em acordo de acionistas". Op. cit., p. 529 .
} 
integralização das ações nos "invólucros" societários teria sido expediente ilícito e abusivo, que autorizaria a desconsideração da personalidade jurídica. ${ }^{996}$

Com argumentação diversa, mas obtendo resultado semelhante, ANTONIO JUNQUEIRA DE AZEVEDO opinou a respeito da interpretação de acordo de acionistas no qual constava direito de preferência tanto para a alienação direta das ações da companhia quanto para a alienação de participações em veículos societários intermediários que se situavam entre as sociedades signatárias e a companhia investida. ${ }^{997}$ A questão que se colocava, contudo, era de saber se a transferência das ações de controle da própria signatária do acordo estaria abrangida pela obrigação de oferta de preferência. $O$ autor sustentou que a companhia teria caráter personalíssimo ${ }^{998}$ e que a utilização da separação de personalidades jurídicas estaria sendo utilizada de forma abusiva. ${ }^{999}$ Essa trilha argumentativa não destoa da orientação de LAMY FILHO, como se viu. JUNQUEIRA DE AZEVEDO, porém, agregou à análise a avaliação de que a interpretação do contrato, pautada pela boa-fé objetiva contextual, permitia afirmar que, para a adequada aplicação daquela cláusula do acordo, o que interessava às partes era a manutenção da mesma estrutura de controle, e não a formal permanência dos títulos acionários em mãos de veículos cuja orientação e comando pudessem ser alterados. ${ }^{1000}$

\footnotetext{
${ }^{996}$ LAMY FILHO, Alfredo. "A desconsideração da personalidade jurídica em acordo de acionistas". Op. cit., pp. 533-534.

997 AZEVEDO, Antonio J. "(Parecer). Acordo de acionistas com cláusula de preferência na aquisição de ações. Contrato intuitu personae a ser interpretado em duas fases: procura da vontade comum das partes e boa-fé objetiva contratual. Teoria do abuso da personalidade jurídica. Extensão da preferência à hipótese implícita de alienação da controladora de uma das acionistas". In: Novos estudos e pareceres de direito privado. São Paulo: Saraiva, 2009, pp. 219-234, pp. 219-221.

998 AZEVEDO, Antonio J. "(Parecer). Acordo de acionistas com cláusula de preferência na aquisição de ações. Contrato intuitu personae a ser interpretado em duas fases: procura da vontade comum das partes e boa-fé objetiva contratual. Teoria do abuso da personalidade jurídica. Extensão da preferência à hipótese implícita de alienação da controladora de uma das acionistas”. Op. cit., p. 227.

${ }^{999}$ AZEVEDO, Antonio J. "(Parecer). Acordo de acionistas com cláusula de preferência na aquisição de ações. Contrato intuitu personae a ser interpretado em duas fases: procura da vontade comum das partes e boa-fé objetiva contratual. Teoria do abuso da personalidade jurídica. Extensão da preferência à hipótese implícita de alienação da controladora de uma das acionistas". Op. cit., p. 232.

${ }^{1000}$ AZEVEDO, Antonio J. "(Parecer). Acordo de acionistas com cláusula de preferência na aquisição de ações. Contrato intuitu personae a ser interpretado em duas fases: procura da vontade comum das partes e boa-fé objetiva contratual. Teoria do abuso da personalidade jurídica. Extensão da preferência à hipótese implícita de alienação da controladora de uma das acionistas". Op. cit., p. 226. Também propondo a interpretação da cláusula de preferência de acordo com a boa-fé objetiva como critério para aplicação à hipótese de alienação indireta de controle, cf. ALVARENGA, Maria I. de A. "Finalidades do direito de preferência para a aquisição de ações". In: ADAMEK, Marcelo V. von. Temas de direito societário e empresarial contemporâneos. São Paulo: Malheiros, 2011, pp. 472-491, p. 485.
} 
A visão proposta por JUNQUEIRA DE AZEVEDO, no entanto, é considerada insuficiente por CALIXTO SALOMÃo FILHO, pois a análise contratual da questão da preferência em acordo de acionistas no caso de alienação indireta de controle sempre desembocaria em "discussão da intenção das partes ao definirem a referida cláusula e dos dados objetivos que permitem presumir essa intenção. Discussões tópicas de direito privado que em muito dificultam a aplicação da cláusula". ${ }^{1001}$ A proposta do autor é de, diversamente, reconhecer o acordo de acionistas como elemento integrante da estrutura societária. ${ }^{1002} \mathrm{O}$ acordo de acionistas que contasse com cláusula de preferência revelar-seia como mecanismo para garantia do caráter personalista da sociedade. A alteração de “identidade empresarial do detentor das ações" deveria ser analisada a partir dessa perspectiva estrutural para aplicação da disciplina da preferência em alienações indiretas. $^{1003}$

Em recente monografia, IVO WAISBERG considera necessária a diferenciação entre conjunturas similares à do caso Schincariol, ou seja, alienação das participações de controle de um veículo que só tem em seu patrimônio as ações ou quotas vinculadas ao acordo de sócios, e a situação em que há alteração do controle de sociedade que é titular de ativos diversos, aí incluídas participações de controle de outras sociedades. No primeiro caso, ter-se-ia "provável negócio indireto, talvez até simulado ou fraudulento". ${ }^{1004}$ No segundo contexto, não se poderia chegar à mesma conclusão a priori. Pelo contrário, se a alteração do controle indireto representa também a mudança da orientação de outras sociedades, "a boa-fé tende para o lado do outorgante", pois não seria de se presumir a alienação de outros ativos apenas para se furtar à concessão do direito de preferência. ${ }^{1005}$ Ressalta, porém, a necessidade de interpretação funcional da cláusula. ${ }^{1006}$

Há na doutrina, porém, orientações restritivas à possibilidade de aplicação da preferência em caso de alienação indireta. É o caso de LEÃES, que, em parecer, considerou que o direito de preferência previsto em estatuto social não gozaria de eficácia

\footnotetext{
${ }^{1001}$ SALOMÃO FILHO, Calixto. O novo direito societário. Op. cit., p. 113.

1002 SALOMÃO FILHO, Calixto. O novo direito societário. Op. cit., p. 113.

${ }^{1003}$ SALOMÃO FILHO, Calixto. O novo direito societário. Op. cit., p. 113.

${ }^{1004}$ WAISBERG, Ivo. Direito de preferência para a aquisição de ações. Op. cit., p. 140.

${ }^{1005}$ WAISBERG, Ivo. Direito de preferência para a aquisição de ações. Op. cit., p. 141.

${ }^{1006}$ WAISBERG, Ivo. Direito de preferência para a aquisição de ações. Op. cit., p. 143.
} 
real, impondo apenas inalienabilidade relativa e pessoal aos acionistas. ${ }^{1007} \mathrm{O}$ direito de preferência, ademais, "não se pode ceder nem passa aos herdeiros" (CC, art. 520), dispositivo do qual o autor extrai a consequência de que a preferência teria caráter personalíssimo, ${ }^{1008}$ não se estendendo às controladoras dos acionistas, sobretudo porque a preferência, no caso concreto, teria sido celebrada em consórcio que não teria caráter personalista. ${ }^{1009}$ Rejeitou, por fim, a possibilidade de desconsideração da personalidade jurídica, porque decisão desse jaez pressuporia a comprovação de fraude, o que não teria ocorrido no caso sobre o qual opinou. ${ }^{1010}$

Para TAVARES Guerreiro, por sua vez, as hipóteses de preferência representariam limitações excepcionais ao princípio da livre-circulação das ações vigente em matéria acionária, devendo ser interpretadas restritivamente. ${ }^{1011}$ Entende, ademais, que não seria possível a aplicação por analogia da regra de oferta pública em caso de alienação indireto de controle (LSA, art. 254-A), pois o dispositivo diria respeito somente ao controle da própria companhia aberta, e não a companhias fechadas. ${ }^{1012}$

No direito estrangeiro, o tratamento do tema parece ainda incipiente. Afirma-se que, a princípio, o negócio incidente sobre as participações da sociedade sócia não deveria ter o mesmo tratamento do negócio que incide sobre ações sujeitas a restrição de livre transmissibilidade, ${ }^{1013}$ mas que a situação poderia ser analisada à luz dos institutos do abuso do direito, simulação, contrariedade à boa-fé e desconsideração de personalidade jurídica. ${ }^{1014}$ Digno de nota, contudo, é dispositivo normativo francês que autoriza o estatuto das sociedades por ações simplificadas (sociétés par actions simplifiées - SAS) a obrigar as sociedades que forem suas acionistas a notificarem qualquer alteração de seu controle. Nessa hipótese, com base nas condições previstas no estatuto, a sociedade

${ }^{1007}$ LEÃES, Luiz G. P. de B. "Pacto de preferência em estatuto social”. In: Pareceres, v. 2. São Paulo: Singular, 2004, pp. 883-891, p. 885.

${ }^{1008}$ LEÃES, Luiz G. P. de B. "Pacto de preferência em estatuto social”. Op. cit., p. 886

${ }^{1009}$ LEÃES, Luiz G. P. de B. "Pacto de preferência em estatuto social". Op. cit., p. 888.

${ }^{1010}$ LEÃES, Luiz G. P. de B. "Pacto de preferência em estatuto social”. Op. cit., p. 891.

1011 GUERREIRO, José A. T. "Interpretação de preferências na Lei de Sociedades Anônimas". In: ADAMEK, Marcelo V. von. Temas de direito societário e empresarial contemporâneos. São Paulo: Malheiros, 2011, pp. 388-408, pp. 395-396.

1012 GUERREIRO, José A. T. "Interpretação de preferências na Lei de Sociedades Anônimas". Op. cit., p. 397.

1013 MARTINS, A. Soveral. Cláusulas do contrato de sociedade que limitam a transmissibilidade das acções. Op. cit., p. 598.

1014 MARTINS, A. Soveral. Cláusulas do contrato de sociedade que limitam a transmissibilidade das acções. Op. cit., p. 599. 
participada poderia determinar a suspensão de exercício de direitos não pecuniários da acionista ou a sua exclusão do quadro social (Code de Commerce, L 227-17).

O correto enquadramento da questão não é simples. Para promover clareza analítica, convém, primeiramente, examinar os argumentos que levariam à extensão da cláusula de preferência independentemente da constatação de abuso. É o caso da interpretação contratual de JUNQUEIRA DE AZEVEDO e da interpretação estrutural de Calixto Salomão Filho. Seguindo-se qualquer dessas duas orientações, seria possível, de acordo com as circunstâncias do caso concreto, interpretar a preferência de forma ampla para abranger a transferência mediata do controle. Ainda que o estatuto, contrato social ou acordo de sócios tenha sido celebrado com uma sociedade que seja titular apenas das participações societárias vinculadas à preferência, seria possível, de um lado, afirmar que a intenção das partes obtida por inteligência do acordo em conformidade com a boa-fé objetiva seria a manutenção de um centro decisório estável (teoria contratual); ou que o estatuto, contrato social ou acordo de sócios teria a função de estabilizar o caráter personalista da sociedade (teoria estrutural).

Ambas as teorias parecem conduzir, de formas diversas, a uma ampliação inadequada das situações abrangidas pelo direito de preferência, atribuindo relevância jurídica a motivos das partes que não integram a contratação. Seguindo-se o caminho argumentativo, pode-se chegar em quase todas as situações fáticas à conclusão de que a preferência abrangeria indistintamente qualquer alteração na linha decisória. Se o elemento relevante para fins de julgamento é determinar se (i) a intenção das partes analisada segunda a boa-fé objetiva seria conferir caráter personalista à sociedade; ou (ii) a presença de acordo de caráter estrutural para a organização societária conferiria aspecto personalista ao comando, bastaria ao sócio que pleiteia a extensão da preferência comprovar que, para as partes, as características pessoais dos controladores eram relevantes. Tal comprovação não será difícil. A mera previsão de direito de preferência societário, com efeito, é considerada evidência do caráter personalista da sociedade. ${ }^{1015}$ Como resultado, tornar-seia trivial a extensão da preferência a partes não signatárias. Ambas as teorias não oferecem, ademais, um critério apto a distinguir situações nas quais a extensão da preferência parece não fazer sentido econômico, como no caso de grande grupo empresarial que tenha seu

1015 COMPARATO, Fábio K. "Restrições à circulação de ações em companhia fechada: nova et vetera". In: Novos ensaios e pareceres de direito empresarial. Rio de Janeiro: Forense, 1981, pp. 32-51, p. 34; WAISBERG, Ivo. Direito de preferência para a aquisição de ações. Op. cit., p. 119. 
controle alterado e, com isso, permita alteração não somente da orientação da sociedade vinculada ao acordo, mas de várias outras.

A teoria proposta por WAISBERG possui o mérito de avançar nessa necessária diferenciação de situações em que a sociedade possui em seu ativo apenas as participações societárias vinculadas à preferência de cenários em que a sociedade cujo controle foi alterado possui outros ativos relevantes. Como fundamento dogmático para a extensão da eficácia da cláusula de preferência no caso de transferência de controle de sociedade que não possua outros ativos além das participações societárias vinculadas ao acordo, porém, o autor vale-se de uma presunção de fraude ou simulação que não se justifica. A transmissão indireta das participações não parece poder ser avaliada como fraudulenta, por exemplo, se o acordo de acionistas foi originalmente celebrado com sociedade que não dispunha de outros ativos senão as ações ou quotas vinculadas e, ainda assim, não foi negociada cláusula restritiva da alteração do respectivo controle. A situação é diversa, porém, na hipótese examinada por LAMY FILHO, em que as ações foram aportadas em sociedades limitadas cujas quotas foram subsequentemente alienadas. A posição de WAISBERG parece impor a presunção de fraude a ambas as situações indistintamente.

Há, por fim, argumentos utilizados para a defesa da impossibilidade de a preferência abranger transferências indiretas que não parecem adequados. O artigo 520 do Código Civil, apontado por LEÃES como fundamento para afirmar que a preferência seria sempre personalíssima, efetivamente determina que a preferência não pode ser cedida a terceiros, e que não é transferida a herdeiros. Não parece possível, porém, a aplicação de tal dispositivo normativo para a preferência prevista no estatuto, contrato social no acordo de sócios. Como aponta WAISBERG, o referido dispositivo incide somente no âmbito da compra e venda, e não em matéria societária. ${ }^{1016}$ A preferência prevista em acordo de sócios, dessa forma, não desaparece com a morte do signatário beneficiado. $\mathrm{O}$ argumento de LEÃES, portanto, não oferece critério de discrímen apto a fundamentar ou a negar a extensão da preferência à alienação indireta. $\mathrm{O}$ fato de que a preferência constitui exceção ao princípio da liberdade de circulação de ações utilizado por TAVARES GUERREIRO, por sua vez, parece correto, mas, se fosse decisivo para a determinação da possibilidade de extensão da preferência à alienação indireta, geraria uma distinção entre a possibilidade de

${ }^{1016}$ WAISBERG, Ivo. Direito de preferência para a aquisição de ações. Op. cit., p. 119. 
extensão da eficácia da preferência à sociedade controladora conforme se tratasse de direito previsto no âmbito de contrato social ou acordo de quotistas, na sociedade limitada, ou de estatuto ou acordo de acionistas, na sociedade anônima. Não se trata de um resultado que parece adequado porque a repercussão para o outro sócio não se altera conforme o tipo societário escolhido para a organização da sociedade investidora.

Acredita-se que o correto equacionamento da questão deva ponderar, primeiramente, que a regra em matéria societária é a possibilidade de alteração do controle de todas as pessoas jurídicas titulares de ações ou quotas ou signatárias de contratos entre sócios. Este princípio da "livre circulação do controle", diferente do princípio da liberdade de circulação de ações, vale como regra para as sociedades limitadas ou anônimas que sejam parte do acordo de preferência. O que se mostra excepcional no ordenamento vigente é a possibilidade de extrair consequências jurídicas da alteração do controle. Tratase de previsão perfeitamente lícita, mas cuja inclusão deve ser negociada. A consequência dessa assunção é que, tratando-se de um estatuto que prevê limitação da circulação de ações em sociedade anônima que tinha sociedades limitadas como acionistas (como parece ter sido a situação no caso Schincariol), não se pode estender a preferência prevista no estatuto para a circulação das ações a um negócio celebrado entre os controladores da sociedade limitada. Não se trata, com efeito, de abuso, mas de exercício lícito de direito que não foi restringido pelo estatuto ou por acordo de acionistas.

Em segundo lugar, a preferência celebrada no âmbito da sociedade controlada não é objeto de publicidade no âmbito das sociedades controladoras, cujas participações societárias são adquiridas por terceiros. A decisão pela extensão da eficácia da cláusula de preferência terá por consequência impedir a concretização desse contrato, a despeito de não se ter observado o regramento específico registral que, como se viu, ${ }^{1017}$ é pressuposto para a oponibilidade da preferência. A decisão nesse sentido deve, portanto, ser excepcional.

As situações em que é justificada a extensão da cláusula de preferência para transferências indiretas, nesse sentido, parecem ser aquelas similares à ocorrida no litígio sobre o qual LAMY FILHO opinou. Se o estatuto é aprovado com a presença de pessoas físicas como sócias e, posteriormente, tais sócios aportam as ações em veículo societário

${ }^{1017}$ Sobre o assunto, cf. item II.B.1.d)(2), supra. 
cujo controle alienam, está-se diante de hipótese de efetivo abuso da personalidade jurídica que pode ser desconsiderada por meio da extensão da eficácia da cláusula. Nessa hipótese, pode-se presumir que o adquirente, tendo-se informado sobre o único ativo da sociedade, possuía conhecimento da preferência celebrada e atua em concerto com o vendedor para desrespeitar a preferência. 


\section{DEVER DE INFORMAR}

As formulações contratuais adotadas na prática anglo-saxônica são referência para as operações de alienação de controle praticadas no âmbito do direito continental, ao qual o direito brasileiro se filia. A transposição de modelos e minutas, porém, pode conduzir a equívocos relevantes quando não se compreende o ordenamento jurídico que rege a contratação. O dever pré-contratual de informação é um dos fatores que deve ser levado em consideração para a determinação da responsabilidade das partes. Tendo em vista que sua amplitude é diversa no direito continental e no direito anglosaxônico, percebe-se que os contratantes não adquirem a mesma posição jurídica caso celebrem contrato de mesmo teor em países diferentes. ${ }^{1018}$

No direito inglês, vige o princípio "caveat emptor", cuja origem remonta ao século $\mathrm{XVI}^{1019}$ e que foi incorporado ao direito norte-americano. Trata-se de um "desenvolvimento original único da Common Law". ${ }^{1020}$ Como regra geral, o exame das qualidades da coisa comprada é de responsabilidade exclusiva do comprador. Em contraposição aos regimes jurídicos continentais, não se reconhece nesses países um princípio geral de que as negociações contratuais devam ser conduzidas de boa-fé, nem há previsão de que o vendedor seria destinatário de um dever de informar em medida semelhante ao que se aceita nos países da Civil Law. ${ }^{1021}$ Embora o princípio tenha sido relativizado na prática no direito norte-americano, com uma crescente aceitação de deveres pontuais de informação, ${ }^{1022}$ e sofra também na Inglaterra um processo de "erosão", ${ }^{1023}$ não

${ }^{1018}$ SPERANZIN, Marco. Vendita delle partecipazione di 'controllo' e garanzie contrattuali. Op. cit., p. 22.

${ }^{1019}$ FLEISCHER, Holger. Informationsasymmetrie im Vertragsrecht. München: C. H. Beck, 2001, p. 66.

1020 TEEVEN, Kevin M. A history of the Anglo-American common law of contract. Westport: Greenwood, 1990, p. 136.(“Caveat emptor was an indigenous development unique to the common law")

${ }^{1021}$ MIRMINA, Steven A "A comparative survey of culpa in contrahendo, focusing on its origins in roman, German and French Law as well as its application in American Law". In: CJIL, vol. 8, 1993, pp. 77-108, p. 93 (indicando que a obrigação de atuação de boa-fé não se estende ao período pré- contratual); COLOMBO, Sylviane. "Present differences between the Civil Law and Common Law worlds with regard to culpa in contrahendo". In: Tilburg For. L. Rev., vol. 2, 1993, pp. 341-376.

${ }^{1022}$ KESSLER, Friedrich; FINE, Edith. "Culpa in contrahendo, bargaining in good faith, and freedom of contract”. In: Harv. L. Rev., v. 77, 1964, pp. 401-449 (apontando uma aceitação prática crescente no direito norte-americano de regras similares à responsabilidade pré-contratual no direito continental).

${ }^{1023}$ ATIYAH, P. S. The rise and fall of freedom of contract. Oxford: Clarendon, 1979, pp. 774-775. 
se deixa de reconhecer que o papel dos deveres de informação nesses países é bastante limitado. $^{1024}$

No direito continental, por outro lado, a função da boa-fé como padrão comportamental na fase pré-contratual deita raízes no direito romano, ${ }^{1025}$ e traz como desdobramentos típicos os deveres de proteção, de lealdade e de informação. Trata-se regra com plena aceitação no direito brasileiro. ${ }^{1026}$

Na compra e venda de participações societárias de controle, compete ao vendedor não somente informar o comprador a respeito dos títulos, mas sobre as condições patrimoniais da sociedade.

Um pressuposto essencial do dever de informar, porém, é a licitude da prestação de informação pelo vendedor. Ora, quando se trata de participações societárias, deve-se ter presente que a personalidade jurídica se interpõe entre o vendedor e o patrimônio social. Considerando-se que, no caso de companhias abertas, há regras de mercado de capitais e societárias que impõem o sigilo às informações confidenciais da sociedade; e que, mesmo em companhias fechadas e sociedades limitadas, o controlador não pode tratar a sociedade como propriedade sua, é necessário questionar o que pode ser informado pelo vendedor.

Por outro lado, e como contrapartida do dever de informar do vendedor, reconhece-se o ônus de se informar do comprador. Na compra e venda de participações societárias, tanto o dever de informar quanto o ônus de se informar são observados pelos contratantes mediante observância de procedimento de auditoria (due diligence), que deve ser enquadrado no contexto dinâmico de delimitação do âmbito de responsabilidade do vendedor por informa e do comprador por se informar.

\footnotetext{
${ }^{1024}$ FLEISCHER, Holger. Informationsasymmetrie im Vertragsrecht. Op. cit., p. 814 (direito inglês) e p. 882 (direito norte-americano).

${ }^{1025}$ FLEISCHER, Holger. Informationsasymmetrie im Vertragsrecht. Op. cit., p. 25.

${ }^{1026}$ COMPARATO, Fábio K. "A obrigação de informar no direito contratual". In: OLIVERA GARCÍA, Rodolfo (org.). Estudios jurídicos en memoria del Profesor Rodolfo Mezzera Alvarez. Montevideo: Fundación de Cultura Universitaria, 1999, pp. 249-256, p. 250; MARTINS-COSTA, Judith. “Os regimes do dolo civil no Direito Brasileiro: dolo antecedente, vício informativo por omissão e por comissão, dolo acidental e dever de indenizar". Op. cit.
} 
Há, por fim, possibilidade específica que se reconhece no âmbito da compra e venda de participações societárias e que consiste em uma peculiar inversão do dever de informar, que passa a incumbir ao comprador em benefício do comprador. Trata-se da situação de aquisição de controle pela administração (management buy-out), hipótese em que a disciplina de deveres societários de lealdade impostos à administração propicia conformação específica ao dever de informar do vendedor.

\section{A. Dever de informar na compra e venda de participações societárias de controle}

1. Delimitação positiva da abrangência do dever de informar

O âmbito dos deveres informativos varia conforme as circunstâncias do caso concreto, razão pela qual a exposição de motivos do BGB menciona que "subtrai-se da solução legislativa a questão decisiva para o conceito de dolo de determinar em que medida existiria um dever jurídico de um contratante informar o outro sobre circunstâncias que, pode-se supor, seriam relevantes para a sua tomada de decisão". ${ }^{1027}$

A jurisprudência alemã considera que na compra e venda há uma contraposição natural de interesses entre as partes, cabendo a cada uma delas tutelar primariamente seus próprios interesses. O contratante tem, porém, o dever de informar ao outro todas as informações (i) que sejam apenas por ele conhecidas; (ii) que sabe, ou deveria saber, que seriam de fundamental relevância para o outro contratante; e (iii) sobre as quais, de acordo com a boa-fé e os usos negociais, o contratante poderia legitimamente pretender ser informado. ${ }^{1028}$ Igualmente, no direito italiano reconhece-se que o dever de informar se impõe especialmente quando uma parte dispõe de informação que a

\footnotetext{
${ }^{1027}$ Motive zu dem Entwurfe eines Bürgerlichen Gesetzbuches für das Deutsche Reich, Bd. 1, Allg. T. (Amtliche Ausgabe). Berlin/Leipzig: Guttentag, 1888, p. 208 ("Auf die Feststellung des Betrugsbegriffes ist verzichtet. Die für die Tragweite desselben maßgebende Frage, inwieweit eine Rechtspflicht besteht, dem anderen Theile mitzutheilen, von denen vorauszusetzen ist, daß sie auf seine Entschließung von Einfluß sein würden, entzieht sich der gesetzlichen Lösung”).

${ }^{1028}$ BGH, 13.7.1983 - VIII ZR 142/82 (NJW 1983, 2493).
} 
contraparte não poderia obter com o emprego de diligência ordinária. ${ }^{1029} \mathrm{E}$, em Portugal, afirma-se que "[a] doutrina tem colocado como limites ao ónus de auto-informação as situações que, pelas suas circunstâncias, acarretam uma impossibilidade ou excessiva onerosidade de procura da informação pelo futuro declarante". ${ }^{1030}$

Para além do consenso quanto a tal formulação geral, a doutrina não oferece parâmetros claros que poderiam determinar em quais situações haveria dever de informar. As propostas sobre o assunto são variadas. Parte delas julga inviável a formulação de critérios dedutivos a partir dos quais fosse possível afirmar o direito legítimo à obtenção de informação, preferindo a lógica indutiva com base em grupos de casos. ${ }^{1031}$ Para outros, seria adequada a adoção de um sistema móvel, em linha com a proposta metodológica de WILBURG. ${ }^{1032}$ É nesse sentido, por exemplo, a formulação de BREIDENBACH, ${ }^{1033}$ que sugere a avaliação da necessidade de informação por uma parte, sua possibilidade de obter a informação e a sua qualificação técnica ou profissional. Em contribuição posterior, HOLGER FLEISCHER defende também um sistema de critérios pautados pela ponderação dos interesses dos contratantes avaliados sob uma perspectiva de eficiência alocativa. ${ }^{1034} \mathrm{De}$ forma geral, porém, são destacados os seguintes fatores de ponderação: (i) a assimetria informacional entre as partes; (ii) o cuidado tomado para com os os próprios interesses; (iii) a potencial renúncia implícita à informação; (iv) o interesse próprio do obrigado a não informar, para evitar, por exemplo, que seja obrigado a revelar por quanto estaria disposto a vender ou a pagar; (v) a intensidade e a duração do contato negocial e a confiança gerada

${ }^{1029}$ GALLO, Paolo. "Responsabilità precontrattuale e problemi di quantificazione del danno". In: Studi in onore di Cesare Massimo Bianca, Tomo IV. Milano: Giuffrè, 2006, pp. 475-566, p. 502; GRISI, Giuseppe. L'obbligo precontrattuale di informazione. Napoli: Jovene, 1990, p. 93.

${ }^{1030}$ COSTA, Mariana F. da. "O dever pré-contratual de informação". In: Revista da Faculdade de Direito da Universidade do Porto, vol. 4, 2007, pp. 367-394, p. 381.

1031 GRIGOLEIT, H. C. Vorvertragliche Informationshaftung. München: C. H. Beck, 1997, p. 11; HENSSLER, Martin. Risiko als Vertragsgegenstand. Tübingen: Mohr Siebeck, 1994, pp. 142-143.

${ }^{1032}$ WILBURG, Walter. The development of a flexible system in the area of private law: Inaugural address as Rector magnificus of the Karl-Franzens University in Graz on November 22, 1950, trad. por. Herbert Hausmanninger. Wien: Manz, 2000; CANARIS, C.-W. Systemdenken und Systembegriff in der Jurisprudenz, 2. Aufl. Berlin: Duncker \& Humblot, 1983, pp. 74-78.

${ }^{1033}$ BREIDENBACH, Stephan. Die Voraussetzungen von Informationspflichten beim Vertragsschluß. München: C. H. Beck, 1989, pp. 61-78.

${ }^{1034}$ FLEISCHER, Holger. Informationsasymmetrie im Vertragsrecht. Op. cit., pp. 277-330. Também mencionando que a avaliação do dever de informar deve ser realizada tendo em vista "factores" ou critérios "móveis", cf. MOTA PINTO, Paulo. "Falta e vícios da vontade - o Código Civil e os regimes mais recentes". In: Comemorações dos 35 anos do Código Civil e dos 25 anos da reforma de 1977, v. 2. Coimbra: Coimbra, 2006, pp. 459-500, p. 490; MARTINS-COSTA, Judith. "Os regimes do dolo civil no Direito Brasileiro: dolo antecedente, vício informativo por omissão e por comissão, dolo acidental e dever de indenizar". Op. cit., pp. 115-143. 
entre as partes; (vi) a condição pessoal e profissional dos contratantes; (vii) as razões dos possíveis riscos; e (viii) a probabilidade de materialização do risco. ${ }^{1035}$

No âmbito europeu, igualmente, adota-se uma conjugação de critérios para determinar se haveria um dever de informar. Os Princípios Europeus de Direito Contratual (PECL), nesse sentido, determinam que a configuração do dever de informar ddecorrente da boa-fé deveria considerar a conjuntura do caso concreto, cabendo ao julgador avaliar (i) se a parte possuía expertise especial; (ii) o custo para aquisição da informação; (iii) a possibilidade de a outra parte adquirir a informação por si própria; e (iv) a importância aparente da informação para a contraparte (PECL, art. 4:107, 3).

Para além do dever de informar, reconhece-se que as partes estariam sujeitas a um dever de verdade, que impõe o dever de responder corretamente as questões formuladas pela contraparte ou sobre elas se calar. ${ }^{1036}$ A obrigação de verdade, nesse caso, é aplicável ainda que o contratante não estivesse obrigado, mas, por espontânea vontade, tenha optado por emitir informações. ${ }^{1037}$

A compra e venda de participações societárias ter por objeto ações ou quotas, e não o patrimônio societário. Não há dúvida, porém, de que a boa-fé na fase negocial impõe ao vendedor o dever de informar não apenas circunstâncias relativas às próprias participações societárias, mas ao patrimônio societário, e a todas as circunstâncias a ele relativas. ${ }^{1038} \mathrm{~A}$ falha ao dever de informar, dessa forma, pode-se relacionar a aspectos fáticos, jurídicos, econômicos ou sociais pertinentes tanto aos próprios títulos quanto ao acervo de bens e direitos da sociedade. ${ }^{1039}$

1035 HENSSLER, Martin. "Haftung des Verkäufers wegen Informationspflichtverletzung beim Unternehmenskauf". In: GRUNDMANN, Stefan (org., et. al.). Festschrift für Klaus J. Hopt zum 70. Geburtstag am 24. August 2010, Bd. 1. Berlin: De Gruyter, 2010, pp. 113-139, p. 130.

1036 FLEISCHER, Holger; KÖRBER, Torsten. "Due diligence und Gewährleistung beim Unternehmenskauf". In: BB, 2001, pp. 841-849, p. 841; MOUSSERON, Pierre. "L'obligation de renseignement dans les cessions de contrôle". In: JCP, 1994, I, n. 362, pp. 261-266, p. 262; MARTINSCOSTA, Judith. "Os regimes do dolo civil no Direito Brasileiro: dolo antecedente, vício informativo por omissão e por comissão, dolo acidental e dever de indenizar”. Op. cit., pp. 115-143.

${ }^{1037}$ FABIAN, Christoph. O dever de informar no direito civil. São Paulo: RT, 2002, p. 54.

${ }^{1038}$ MOUSSERON, Pierre. "L'obligation de renseignement dans les cessions de contrôle". Op. cit., p. 262; HERNANDO CEBRIÁ, Luis. El contrato de compraventa de empresa. Op. cit., p. 426.

${ }^{1039}$ HUBER, Ulrich. "Die Praxis des Unternehmenskaufs im System des Kaufrechts". In: AcP, v. 202, 2002, pp. 179-242, p. 179. 
Diferente do que ocorre com um bem tangível como um veículo automotor, não há possibilidade de inspeção física da empresa para detecção de certos passivos financeiros ocultos, por exemplo. O comprador, com isso, torna-se dependente de documentos sintéticos como balanços, avaliações, documentos contábeis e apresentações fornecidas pelo vendedor para poder conhecer as condições patrimoniais da sociedade. ${ }^{1040}$ No direito alemão, afirma-se que, em decorrência dessa situação de déficit informacional estrutural, a compra e venda de empresas e de participações societárias seria marcada por "acentuados deveres informativos" (gesteigerte Aufklärungspflichten). ${ }^{1041}$ Como consequência dessa orientação jurisprudencial, afirma-se que o dever lateral de informar na compra e venda de empresa pode não ser satisfeito ainda que o vendedor responda todos os questionamentos formulados pelo comprador. O BGH, por conta disso, julgou que "cabe ao vendedor informar ao potencial comprador todas as circunstâncias que possam frustrar a persecução do seu objetivo contratual e que, de acordo com os usos e costumes negociais, sejam de fundamental relevância para sua tomada de decisão, ainda que não tenha sido questionado a respeito". ${ }^{1042}$

Especial manifestação do dever de informar no âmbito de alienações de participações societárias ocorre quando o vendedor, antes da conclusão do contrato, toma conhecimento de sinais concretos de que o faturamento pode sofrer impactos negativos relevantes que afetariam a decisão do comprador. ${ }^{1043} \mathrm{O} \mathrm{BGH}$, nesse sentido, julgou ter havido dolo por omissão de um alienante de participações societárias que não informou a circunstância de que um cliente responsável por mais de $40 \%$ do faturamento pretendia não mais renovar seu contrato. ${ }^{1044}$ Considerou-se que foi cometida falha ao dever de informar, igualmente, nas hipóteses em que o vendedor deixou de comunicar a resolução de contrato por cliente relevante, a existência de passivos significativos não contabilizados, ou a

1040 HENSSLER, Martin. "Haftung des Verkäufers wegen Informationspflichtverletzung beim Unternehmenskauf”. Op. cit., p. 132.

1041 HENSSLER, Martin. "Haftung des Verkäufers wegen Informationspflichtverletzung beim Unternehmenskauf". Op. cit., p. 132.

1042 NJW 2001, 483 ("bei Verhandlungen üben einen Unternehmenskauf der Verkäufer den Kaufinteressenten auch ungefragt über solche Umstände aufzuklären hat, die den Vertragszweck (des anderen) vereiteln können und daher für seinen Entschluß von wesentlicher Bedeutung sind, sofern er die Mitteilung nach der Verkehrsauffassung erwarten konnte").

1043 JAGERSBERGER, Barbara. Die Haftung des Verkäufers beim Unternehmens- und Anteilskauf. $O p$. cit., p. 422.

${ }^{1044}$ BGH NJW-RR 1996, 429 apud HUBER, Ulrich. "Die Praxis des Unternehmenskaufs im System des Kaufrechts". Op. cit., p. 184. 
circunstância de que o imóvel em que estava situada a fábrica estava contaminado por lixo tóxico. ${ }^{1045}$

No direito francês, igualmente, reconhece-se que o vendedor deve franquear ao comprador acesso aos documentos societários pertinentes aos resultados da sociedade e advertir os elementos suscetíveis de afetar não somente a sua titularidade sobre as próprias participações societárias, mas também a consistência dos ativos e a perspectiva de continuidade e perenidade da atividade econômica. ${ }^{1046}$ Admite-se que o cessionário possui também um ônus de se informar, mas teria o direito de confiar na aparência, como, por exemplo, o direito de confiar que a sociedade teria as licenças necessárias na hipótese de manter um estabelecimento em funcionamento, cabendo ao vendedor alertar o comprador caso tal assunção natural conforme os usos não corresponda à realidade. ${ }^{1047}$ Defende-se, ademais, em linha com a proposta de FABRE-MAGNAN, que a extensão do dever de informar deveria ser determinada pelo elemento material, concernente à pertinência da informação; e pelo elemento moral, consistente na circusntância de a informação relacionar-se a fato que não poderia ter sido omitido legitimamente do outro contratante. $^{1048}$ Com base nisso, sustenta-se que, na negociação de participações societárias, a existência de passivos não contabilizados ou a ausência de licenças para funcionamento regular, por exemplo, devem ser informadas pelo vendedor. ${ }^{1049}$

No Brasil, a jurisprudência em contratos de compra e venda já reconheceu a ocorrência de dolo omissivo por falha ao dever de informar quando o vendedor permite que o comprador permaneça em erro, por exemplo, quando aliena (i) carro sinistrado sem informar o comprador a respeito; ${ }^{1050}$ (ii) plantação de laranjas sem alertar para praga que assola a cultura; ${ }^{1051}$ (iii) linhas de leite, mas não noticia a edição de norma sanitária que altera de forma relevante as condições para o exercício de atividade econômica. ${ }^{1052}$

\footnotetext{
${ }^{1045}$ HUBER, Ulrich. "Die Praxis des Unternehmenskaufs im System des Kaufrechts”. Op. cit., p. 179-180.

${ }^{1046}$ CAFFIN-MOI, Marie. Cession de droits sociaux et droit des contrats. Op. cit., n. 597, p. 382.

1047 CAFFIN-MOI, Marie. Cession de droits sociaux et droit des contrats. Op. cit., n. 597, p. 382.

1048 FABRE-MAGNAN, Muriel. De l'obligation d'information dans les contrats: essai d'une théorie. Paris: LGDJ, 1992, n. 156, p. 122 ss.

${ }^{1049}$ MOUSSERON, Pierre. "L'obligation de renseignement dans les cessions de contrôle". Op. cit., p. 262.

${ }^{1050}$ TJSP, Ap. n. 0016097-63.2011.8.26.0625, 25 Cam. Dir. Priv., rel. Des. Edgard Rosa, j. 13.03.2013.

${ }^{1051}$ RT 171:165 apud RODRIGUES, Silvio. Dos vícios do consentimento, $3^{\text {a }}$ ed. São Paulo: Saraiva, 1989, n. 88, p. 169.

1052 TJSP, Ap. c/ rev. n. 933241-0/8, 33ª Câm. da Seção de Dir. Priv., rel. Des. Sá Moreira, j. 10.08.2009.
} 
No âmbito específico de alienações de controle, já se admitiu, ademais, que há dolo omissivo quando o alienante de quotas não revela ônus que pesa sobre o patrimônio, como em caso em que se considerou que agiu com dolo omissivo acidental o alienante do controle de uma revendedora de veículos que encobriu o fato de que um dos veículos da revendedora encontrava-se alienado em garantia a banco financiador. ${ }^{1053}$ Igualmente, considerou violadora da boa-fé objetiva a conduta de vendedores de quotas de sociedade proprietária de usina asfáltica que informaram potencial de produção superior àquele compatível com o maquinário instalado. ${ }^{1054}$

Há, por fim, determinação legal da forma pela qual o dever de informar deve ser observado na compra e venda de ações realizada pelo Poder Público no âmbito do Programa Nacional de Desestatização. A desestatização, com efeito, pode ser realizada mediante "alienação de participação societária, inclusive de controle acionário" (Lei n. 9.491/1997, art. $4^{\circ}$, I) e, nesse caso, deve ser publicado edital do qual devem constar diversas informações aos potenciais adquirentes (Lei n. 9.491/1997, art. 11), sendo de se destacar a exigência de divulgação (i) do "passivo das sociedade de curto e de longo prazo" (Lei n. 9.491/1997, art. 11, “c"); (ii) da "situação econômico-financeira da sociedade, especificando lucros ou prejuízos, endividamento interno e externo, nos cinco últimos exercícios" (Lei n. 9.491/1997, art. 11, “d”); (iii) do "sumário dos estudos de avaliação" (Lei n. 9.491/1997, art. 11, “f”); e (iv) do critério de fixação do valor de alienação, com base nos estudos de avaliação (Lei n. 9.491/1997, art. 11, “g”).

\section{Delimitação negativa do dever de informar}

a) Possibilidade de prestação de informação relativa à sociedade pelo vendedor

A compra e venda de participações societárias de controle representa contrato específico pela circunstância de que as informações que mais interessam às partes dizem respeito a bens que não são do vendedor. Com efeito, o que importa ao potencial adquirente é a composição patrimonial da sociedade, ou seja, a universalidade de bens,

1053 TJSP, Ap. n. 0009169-58.2008.8.26.0510, 7 Câm. Dir. Priv., rel. Des. Miguel Brandi, j. 11.09.2013.

1054 TJSP, AP. n. 0185809-45.2009.8.26.0100, 1ª Câm. Res. Dir. Empr. Rel. Des. Fortes Barbosa, j. 11.09.2014. 
direitos, ativos e passivos e informações sobre a rentabilidade futura que estão sob titularidade do ente societário, e não do vendedor. O contrato de compra e venda, espécie de negócio jurídico bilateral, no caso da compra e venda de participações societárias de controle institui uma relação que, em certa medida, se poderia denominar "triangular", por envolver a própria sociedade, titular de interesse autônomo de preservação de suas informações.

O comprador, portanto, não avalia somente as ações ou quotas, mas o próprio patrimônio societário, quando determina o preço que está disposto a ofertar. $\mathrm{O}$ cálculo do preço de participações societárias normalmente se dá com base no fluxo de caixa descontado. ${ }^{1055} \mathrm{~A}$ adequada avaliação da rentabilidade da companhia pressupõe, porém, o acesso pelo potencial adquirente a dados que são mantidos em sigilo pela sociedade. ${ }^{1056} \mathrm{O}$ vendedor, da mesma forma, deve informar o comprador não somente a respeito das participações societárias, mas sobre todas as circunstâncias relevantes pertinentes à sociedade e ao patrimônio societário de que tenha conhecimento e que geralmente não estão refletidas nas informações públicas eventualmente disponibilizadas. A questão que se impõe, nesse contexto, é da admissibilidade do fornecimento de informações sigilosas e estratégicas pela administração ao potencial adquirente das participações societárias de controle.

Tratando-se de sociedade unipessoal, não há normalmente contraposição entre o interesse do vendedor ou do comprador e o interesse autônomo da sociedade. Com ou sem fundamento jurídico - é indiferente se não há contraste por outras instâncias societárias -, o vendedor autoriza e o comprador promove auditoria sobre a sociedade.

Nas sociedades anônimas, porém, os administradores são obrigados a servir com lealdade a companhia e a manter reserva sobre seus negócios (LSA, art. 155, caput). Seria possível questionar, nesse contexto, se o administrador estaria autorizado a fornecer informações ou a dispender seu tempo - e de funcionários da companhia - em benefício de um comprador que negocia contrato apenas com o controlador. E, em caso positivo, seria ainda possível discutir a extensão do acesso passível de ser franqueado ao potencial comprador. A questão se coloca de forma semelhante na sociedade limitada (CC, art.

\footnotetext{
${ }^{1055}$ Sobre o assunto, cf. item II.C.1, supra.

${ }^{1056}$ LUTTER, Marcus. "Due diligence des Erwerbers beim Kauf einer Beteiligung”. In: ZIP, 1997, pp. 613620, p. 613.
} 
1.011). Na companhia aberta, ademais, os administradores são obrigados a manter sigilo sobre qualquer informação relevante não divulgada ao mercado (LSA, art. 155, $\S 1^{\circ}$ ), obrigação que também é imposta pela regulação ao próprio acionista controlador (Instrução CVM n. 358/2002, art. $8^{\circ}$ ). É de se questionar, nesse caso, se haveria fundamento jurídico para que os administradores da companhia transmitissem ao comprador, que não é acionista, informações recobertas pelo manto da obrigação de sigilo.

Analisando a questão sob o direito alemão, MARCUS LUTTER considera que a resposta é relativamente simples. A administração deve pautar-se pelo interesse social e somente pode transmitir informações aos sócios, aí incluído o controlador, mediante a observância de formalidades predispostas pela lei, como ocorre no caso da apresentação do relatório anual da administração, das apresentações trimestrais de companhias abertas, ou por meio de respostas a perguntas formuladas no âmbito da assembleia geral. Um direito individual de informação do controlador, sobretudo para a finalidade de alienar sua participação societária, não teria fundamento jurídico. ${ }^{1057}$ A situação seria diversa no caso de o interesse social justificar o fornecimento de dados confidenciais pela companhia a um terceiro, como ocorreria, por exemplo, na hipótese de negociação de contrato societário de incorporação ou fusão, ou mesmo de cooperação com outra sociedade. Nesse caso, por a própria sociedade ser parte do contrato, a administração poderia fornecer informações sigilosas ao terceiro com quem a própria companhia está negociando. ${ }^{1058}$

Ressalta-se, ademais, que o acionista possui direitos de informação em face da companhia, mas somente pode exercer tais direitos em respeito à finalidade para a qual foram erigidos, ${ }^{1059}$ de tal forma que as informações sigilosas eventualmente obtidas mediante a instância societária da assembleia de sócios ou mediante participação do controlador em órgãos da administração não poderiam ser utilizadas para negociação com o potencial comprador, pois a negociação contratual não representa hipótese de atuação de direção e controle societário, senão atividade em tutela de interesses patrimoniais próprios

\footnotetext{
${ }^{1057}$ LUTTER, Marcus. "Due diligence des Erwerbers beim Kauf einer Beteiligung”. Op. cit., p. 616. ${ }^{1058}$ LUTTER, Marcus. "Due diligence des Erwerbers beim Kauf einer Beteiligung”. Op. cit., p. 617. 1059 STOFFELS, Markus. "Grenzen der Informationsweitergabe durch den Vorstand einer Aktiengesellschaft im Rahmen einer 'Due Diligence”. In: ZHR, v. 165, 2001, pp. 362-382, p. 369.
} 
do controlador. ${ }^{1060} \mathrm{~A}$ administração, por sua vez, estaria vinculada à manutenção do sigilo, em atenção ao seu dever de lealdade, pautada pelo interesse social. ${ }^{1061}$

No âmbito da sociedade limitada, por sua vez, há quem defenda que o sócio somente poderia ministrar informações sigilosas ao potencial comprador mediante aprovação em assembleia de sócios. ${ }^{1062} \mathrm{Na}$ visão de GöTZE, ademais, o sócio controlador e potencial vendedor, por possuir interesse conflitante com a sociedade, estaria abrangido pela proibição de voto $\left(\mathrm{GmbHG}, \S 47\right.$, Abs. 4) e não poderia participar da deliberação. ${ }^{1063}$

O posicionamento restritivo à possibilidade de transmissão de informações ao potencial adquirente, todavia, é considerado minoritário no direito alemão. ${ }^{1064}$ Sob a perspectiva societária, avalia-se que a administração estaria autorizada a fornecer informações ao potencial comprador sempre que tal atuação fosse favorável ao interesse social, após ponderação dos riscos para a sociedade e das potenciais vantagens que poderiam a ela advir, pautada pela regra da atuação negocial (business judgment rule). ${ }^{1065}$ Afirma-se que devem ser considerados pela administração os possíveis efeitos positivos que decorreriam da aquisição do controle por terceiro, fato que normalmente conduz à constituição de um grupo societário de fato e à potencial obtenção de sinergias entre as sociedades, ou à possibilidade de ingresso em novos mercados, entre outros fatores que poderiam repercutir favoravelmente para a sociedade cujos títulos estão sendo negociados. ${ }^{1066}$ Ressalta-se, porém, que não haveria um direito do acionista à condução da

${ }^{1060}$ STOFFELS, Markus. "Grenzen der Informationsweitergabe durch den Vorstand einer Aktiengesellschaft im Rahmen einer 'Due Diligence”. Op. cit., p. 371.

${ }^{1061}$ STOFFELS, Markus. "Grenzen der Informationsweitergabe durch den Vorstand einer Aktiengesellschaft im Rahmen einer 'Due Diligence”. Op. cit., p. 372.

1062 GÖTZE, Cornelius. "Auskunftserteilung durch GmbH-Geschäftsführer im Rahmen der Due Diligence beim Beteiligungserwerb". In: ZGR, 1999, pp. 202-233, p. 227.

1063 GÖTZE, Cornelius. "Auskunftserteilung durch GmbH-Geschäftsführer im Rahmen der Due Diligence beim Beteiligungserwerb". Op. cit., p. 231.

${ }^{1064}$ HOPT, Klaus. In: HOPT, Klaus; WIEDEMANN, Herbert. AktG Großkommentar, 4. Aufl. Berlin/New York: De Gruyter, 1999, §93, Rn. 213, pp. 137-138.

${ }^{1065}$ HEMELING, Peter. "Gesellschaftsrechtliche Fragen der Due Diligence beim Unternehmenskauf". In: ZHR, v. 169, 2005, pp. 274-294, p. 276.

1066 EGGENBERGER, Jans. Gesellschaftsrechtliche Voraussetzungen und Folgen einer due-diligence Prüfung. Frankfurt a. M.: Peter Lang, 2001, pp. 101-114; ANGERSBACH, Carsten J. Due Diligence beim Unternehmenskauf. Op. cit., p. 94; STOFFELS, Markus. "Grenzen der Informationsweitergabe durch den Vorstand einer Aktiengesellschaft im Rahmen einer 'Due Diligence”. Op. cit., p. 374; HEMELING, Peter. "Gesellschaftsrechtliche Fragen der Due Diligence beim Unternehmenskauf”. Op. cit., pp. 279-280; FLEISCHER, Holger; KÖRBER, Torsten. "Due Diligence im Gesellschafts- und Kapitalmarktrecht". In: BERENS, Wolfgang (org.; et. al.). Due Diligence bei Unternehmensakquisitionen, 6. Aufl. Stuttgart: Schäffer-Poeschel, 2011, pp. 267-293, p. 278; HOPT, Klaus. In: HOPT, Klaus; WIEDEMANN, Herbert. AktG Großkommentar, 4. Aufl. Op. cit., §93, Rn. 213, pp. 137-138.; WERNER, Rüdiger. "Haftungsrisiken bei Unternehmensakquisitionen: die Pflicht des Vorstands zur Due Diligence”. In: ZIP, 2000, pp. 989-994, p. 
auditoria, cabendo à administração avaliar com autonomia e sob a perspectiva do interesse social o pedido formulado pelo acionista. ${ }^{1067}$

Sob o ponto de vista de tutela de informações sigilosas no âmbito do mercado de capitais, pondera-se que a proibição imposta aos administradores estaria pautada pela garantia do correto funcionamento do mercado, buscando evitar que certos investidores tivessem acesso a informações sigilosas antes dos demais, quebrando a igualdade de chances e de condições que deve pautar a livre negociação dos valores mobiliários. A prestação de informações ao adquirente é, nessa medida, considerada compatível com o dever de sigilo desde que haja comprometimento do comprador potencial a se abster de negociar os valores mobiliários de emissão da sociedade. ${ }^{1068}$

Em qualquer hipótese de transmissão de informações ao comprador, porém, sublinha-se que a administração, em decorrência do dever de diligência, somente poderá oferecer acesso a dados sigilosos caso o comprador celebre acordo de confidencialidade. ${ }^{1069}$ A administração, adicionalmente, poderia restringir o acesso do potencial adquirente a certas informações, atendendo, com isso, apenas de forma parcial à solicitação de auditoria. ${ }^{1070}$

No direito italiano, a matéria é abordada sob perspectiva parcialmente divergente. WEIGMANN considera que a prática da auditoria (due diligence) pelo comprador infringiria uma pluralidade de princípios e regras societárias, como o dever de tratamento igualitário entre os sócios, o controlador, o limitado direito conferido aos sócios de inspecionar os livros sociais, bem como a proibição de divulgação de segredos

991; KIETHE, Kurt. "Vorstandshaftung aufgrund fehlerhafter Due Diligence beim Unternehmenskauf". In: NZG, 1999, pp. 976-983, pp. 978-979; ROSCHMANN, Christian; FREY, Johannes. "Geheimhaltungsverpflichtungen der Vorstandsmitglieder von Aktiengesellschaften bei Unternehmenskäufen". In: AG, 1996, pp. 449-455. Na Suíça, em sentido similar: VISCHER, Markus. "Due diligence bei Unternehmenskäufen”. In: SJZ, v. 96, 2000, pp. 229-236, p. 233.

${ }^{1067}$ HEMELING, Peter. "Gesellschaftsrechtliche Fragen der Due Diligence beim Unternehmenskauf". $O p$. cit., pp. 286-287.

${ }^{1068}$ STOFFELS, Markus. "Grenzen der Informationsweitergabe durch den Vorstand einer Aktiengesellschaft im Rahmen einer 'Due Diligence". Op. cit., p. 380; HEMELING, Peter. "Gesellschaftsrechtliche Fragen der Due Diligence beim Unternehmenskauf'. Op. cit., pp. 283-284.

${ }^{1069}$ FLEISCHER, Holger; KÖRBER, Torsten. "Due Diligence im Gesellschafts- und Kapitalmarktrecht". Op. cit., p. 280.

${ }^{1070}$ HEMELING, Peter. "Gesellschaftsrechtliche Fragen der Due Diligence beim Unternehmenskauf". $O p$. cit., p. 280. 
empresariais. ${ }^{1071}$ As exceções em que se admitiria a condução de auditoria seriam representadas pelas hipóteses que envolvessem sociedade unipessoal ou sociedade na qual fosse assegurado por acordo de sócios ou por regra estatutária ou regulatória o direito de os demais sócios venderem conjuntamente suas participações societárias ou se beneficiarem de oferta pública de aquisição cuja promoção fosse imposta ao adquirente. ${ }^{1072}$

O posicionamento restritivo à legalidade de condução de auditoria sofreu a crítica de GIUSEPPE ACERBI, que defendeu que o dever de sigilo da administração somente deveria ser imposto no caso de revelação de informações a terceiros sem um motivo justificado. ${ }^{1073} \mathrm{Na}$ compra e venda de participações societárias, em sua visão, o acesso a dados privilegiados deveria ser franqueado ao potencial comprador por se tratar de elemento imprescindível e insubstituível para que o sócio pudesse transferir um conjunto de ações ou quotas que outorgam o controle. Entende ACERBI, nesse sentido, que o acionista seria titular de um direito de disposição de suas ações, que denomina jus vendendi, ${ }^{1074}$ o qual seria tutelado pelo ordenamento jurídico, caracterizando-se como um motivo justificado para autorizar a transmissão de informações confidenciais pela companhia. Assevera, inclusive, que, em sua visão, o acionista controlador teria pretensão a obter informações sigilosas da companhia para fins de alienação da participação societária, e que os administradores estariam obrigados a prestá-las. ${ }^{1075}$

Contrariando parcialmente tal posição, LUCA PICONE assimila o interesse social à perspectiva contratualista (shareholder value), associado à maximização da rentabilidade para os sócios. A venda de participações societárias representaria, nesse contexto, uma das formas de satisfação desse interesse dos sócios, razão pela qual a atuação da administração tendente a permitir a alienação da participação societária seria, a princípio, compatível com o interesse social. ${ }^{1076} \mathrm{O}$ autor discorda, porém, do posicionamento de ACERBI - que avalia que a administração estaria obrigada à prestação de

${ }^{1071}$ WEIGMANN, Roberto. "Le offerte pubbliche di acquisto". In: COLOMBO, Giovanni E.; PORTALE, Giuseppe B. (org.). Trattato delle società per azione, v. 10, t. 2. Torino: UTET, 1993, pp. 548-566, p. 559.

1072 WEIGMANN, Roberto. "Le offerte pubbliche di acquisto". Op. cit., p. 559.

1073 ACERBI, Giuseppe. "Gli amministratori di società per azioni di fronte al trasferimento del controllo: problemi e proposte di soluzione". Op. cit., p. 293.

${ }^{1074}$ ACERBI, Giuseppe. "Gli amministratori di società per azioni di fronte al trasferimento del controllo: problemi e proposte di soluzione". Op. cit., p. 303.

${ }^{1075}$ ACERBI, Giuseppe. "Gli amministratori di società per azioni di fronte al trasferimento del controllo: problemi e proposte di soluzione”. Op. cit., pp. 316-327. No mesmo sentido, SPERANZIN, Marco. Vendita delle partecipazione di 'controllo' e garanzie contrattuali. Op. cit., p. 369.

1076 PICONE, Luca. "Trattative, due diligence ed obblighi informativi delle società quotate". In: BBTC, 2004, I, pp. 234-269, pp. 256-257. 
informações -, pois, em companhias abertas, (i) a figura do sócio deveria ser indiferente; (ii) não haveria um interesse social de que o sócio promovesse um específico negócio jurídico sobre suas ações. De tal forma, caberia à administração, avaliando os demais interesses contrapostos relacionados à manutenção do sigilo, decidir-se por outorgar ou não ao comprador acesso aos dados reservados da companhia. ${ }^{1077}$

Em Portugal, igualmente, defende-se que o controlador não teria a pretensão de exigir da administração que disponibilizasse ao potencial comprador a possibilidade de realização de auditoria, cabendo à administração, pautada pelo interesse social, avaliar a conveniência e a oportunidade do processo informativo pautada pelo interesse social. ${ }^{1078}$

No direito brasileiro, a possibilidade de fornecimento de informações sigilosas da sociedade ao potencial comprador deve ser guiada por análise de circunstâncias específicas que permitem o enquadramento da compra e venda de participações societárias de controle como negócio jurídico com repercussão direta sobre a própria sociedade. A primeira delas é o fato de que o acionista controlador (e, por analogia, seria possível defender que também o sócio controlador de limitada) é destinatário de deveres especiais perante a sociedade, os demais acionistas e terceiros (LSA, art. 116, par. único), chegando-se a afirmar que teria se tornado um órgão da sociedade anônima. ${ }^{1079} \mathrm{Em}$ segundo lugar, há diversas situações previstas legislativamente em que o acionista controlador responde solidariamente por danos causados pela sociedade controlada, podendo-se destacar, por exemplo, a responsabilidade solidária da sociedade controladora por atos de corrupção da controlada (Lei n. 12.846/2013, art. $4^{\mathrm{o}}, \S 2^{\circ}$ ). No caso da companhia aberta, ademais, há previsão de que a aquisição de controle é contrato que deve ser celebrado sob a condição suspensiva ou resolutiva de que o adquirente formule oferta pública de aquisição de ações aos demais acionistas titulares de ações com direito a voto (LSA, art. 254-A). A despeito de a oferta não beneficiar os acionistas titulares de ações sem direito a voto, é evidente que, nesse caso, o negócio privado sobre o controle acionário não interessa somente vendedor e comprador, porque pauta também o valor a ser oferecido aos demais acionistas. Vale ressaltar que, na hipótese de formulação de oferta pública por

\footnotetext{
1077 PICONE, Luca. "Trattative, due diligence ed obblighi informativi delle società quotate”. Op. cit., p. 258 .. 1078 CÂMARA, Paulo; BASTOS, Miguel Brito. "O direito da aquisição de empresas: uma introdução". Op. cit., p. 28; RUSSO, Fábio C. "Due Diligence e responsabilidade". In: I Congresso DSR. Coimbra: Almedina, 2011, pp. 13-26, p. 20.

1079 COMPARATO, Fábio Konder; SALOMÃO FILHO, Calixto. O poder de controle na sociedade anônima. Op. cit., n. 32.1., p. 114.
} 
alienação de controle, o ofertante deve submeter à CVM demonstração justificada da forma de cálculo do preço devido (Instrução CVM n. 361/2002, art. 29, §6 $6^{\circ}$, I), podendo a CVM determinar a apresentação de laudo de avaliação da companhia objeto (Instrução CVM n. 361/2002, art. 29, §6 $6^{\circ}$ II). O controlador submete-se, por fim, a restritivo regime de divulgação de informações (Instrução CVM n. 358/2002).

Ainda que nenhum desses fatores seja decisivo, todos representam indícios de que a alteração do acionista controlador pode repercutir de forma direta sobre a própria sociedade e, no caso de companhia aberta, também sobre os acionistas que se beneficiam de oferta pública de aquisição, o mesmo ocorrendo na sociedade anônima ou limitada em que o estatuto, contrato social ou acordo de sócios preveja tal direito.

Contra tais fatores, porém, devem ser ponderados os eventuais interesses próprios da sociedade na manutenção de sigilo sobre informações confidenciais, por exemplo, na hipótese de o comprador potencial ser importante concorrente, que poderia se beneficiar indevidamente do acesso a informações confidenciais. ${ }^{1080} \mathrm{~A}$ administração, nesse caso, deve exercer sua discricionariedade para determinar se o potencial comprador poderá ter acesso às informações sigilosas. Deve, ademais, determinar como se processará o fluxo informacional, avaliando quais dados e documentos sigilosos podem ser apresentados ao exame do comprador e quais cautelas devem ser adotadas para garantir a manutenção de sua confidencialidade. ${ }^{1081}$

No caso de companhia aberta, ademais, como já decidiu a CVM, "a transmissão de informação relevante não divulgada a qualquer terceiro, seja analista de rating, seja consultor, somente pode ser feita (i) no interesse da companhia e (ii) sob contrato de confidencialidade, sob pena de se constituir em transmissão indevida seletiva de informação". ${ }^{1082} \mathrm{O}$ acordo de confidencialidade, ademais, deve prever o comprometimento do beneficiário de se abster de negociar com valores mobiliários da companhia.

\footnotetext{
${ }^{1080}$ HEMELING, Peter. "Gesellschaftsrechtliche Fragen der Due Diligence beim Unternehmenskauf”. $O p$. cit., p. 280.

${ }^{1081}$ HEMELING, Peter. "Gesellschaftsrechtliche Fragen der Due Diligence beim Unternehmenskauf". $O p$. cit., p. 280.

${ }_{1082}$ Declaração de voto do Pres. Dir. Marcelo Fernandez Trindade. In: CVM, PAS n. 2007/1079, rel. Dir. Eli Loria, j. 10.07.2007.
} 
Os custos relativos à prestação de informações, de toda forma, devem ser arcados pelo vendedor, que deve também ressarcir a companhia pelo dispêndio de tempo de seus funcionários. ${ }^{1083}$ A situação assemelha-se com o que ocorre no caso de oferta pública secundária, em que a regulação impõe à emissora de valores mobiliários o dever de cooperar para a elaboração de prospecto, mas sujeita ao ofertante o dever de ressarcir a emissora pelos custos incorridos (Instrução CVM n. 400/2003, art. 47, caput).

Na compra e venda de participações societárias, como decorrência do quanto se afirmou, tem-se uma delimitação negativa do dever de informar. Não cabe ao vendedor esclarecer circunstâncias que não conhece e que não pode fornecer, por dizerem respeito à sociedade, na hipótese de a administração negar-se a permitir a auditoria da companhia. $^{1084}$

b) Preservação de informações estratégicas

Uma segunda delimitação negativa proposta no direito brasileiro diz respeito a informações confidenciais da sociedade pela circunstância de que o vendedor teria um interesse em preservá-las do conhecimento do comprador. É nesse sentido o Enunciado n. 27, aprovado na $1^{\text {a }}$ Jornada de Direito Comercial do CJF, segundo o qual "não se presume violação à boa-fé objetiva se o empresário, durante as negociações do contrato empresarial, preservar segredo de empresa ou administrar a prestação de informações reservadas, confidenciais ou estratégicas, com o objetivo de não colocar em risco a competitividade de sua atividade".

Segundo FÁBIo CoElHo, proponente do enunciado, a sua aplicação teria lugar na compra e venda de participação societária, por ele considerada modalidade de

\footnotetext{
${ }^{1083}$ SPERANZIN, Marco. Vendita delle partecipazione di 'controllo' e garanzie contrattuali. Op. cit., p. 368, nota de rodapé 190. Contra: SIGLE, Axel; ZINGER, Georg. "Die Übernahme von Transaktionskosten durch die Aktiengesellschaft". In: NZG, 2003, pp. 301-306 (admitindo a assunção de custos pela companhia quando ela própria tivesse interesse econômico na alteração da figura do controlador).

${ }^{1084}$ VISCHER, Markus. "Due diligence bei Unternehmenskäufen". Op. cit., p. 233.
} 
“compra de empresa". ${ }^{1085}$ Segundo o autor, o vendedor não poderia franquear o acesso a informações internas de natureza reservada "a qualquer um, sem garantia alguma", pois entre os potenciais interessados normalmente haveria concorrentes, de tal forma que, se a aquisição se frustra, “a devassa na empresa certamente redundará em graves dificuldades de competição, por terem sido abertas aos competidores informações vitais". ${ }^{1086}$ Como exemplos de circunstâncias que poderiam deixar de ser informadas com base na reserva de sigilo, o autor defende que se o vendedor "oculta informação atinente ao atraso de suas condições tecnológicas, a saldos negativos em planilha de custos de certos produtos ou a qualquer assunto passível de comprometer a competitividade da empresa, não está necessariamente incorrendo em nenhum ilícito". ${ }^{1087}$

Há uma diferença relevante entre essa hipótese e a referida no item anterior. Na negativa da sociedade à condução de auditoria pelo comprador, o vendedor não informa porque não pode fazê-lo; na proposta do Enunciado, por outro lado, o vendedor pode informar o comprador, mas não o faz, porque privilegia a manutenção do sigilo sobre as informações estratégicas da sociedade.

O Enunciado em questão parte de uma concepção correta a respeito da composição de interesses entre o vendedor e o comprador, mas pode levar a conclusões equivocadas.

É admissível, efetivamente, que haja negociação entre as partes a respeito da amplitude do dever de informar e o vendedor pode, por exemplo, afirmar que se dispõe somente a fornecer ao comprador acesso às informações públicas disponíveis, ou aos documentos contábeis, mas não admite a condução de auditoria física, ou restringe o acesso a certas categorias de documentos. Diante de tal situação, o comprador pode desistir do negócio ou buscar cercar-se de garantias contratuais, mas não alegar uma falha ao dever de informar por parte do vendedor, pois aceitou que este dever fosse limitado. ${ }^{1088}$

\footnotetext{
${ }^{1085}$ COELHO, Fábio U. "Pequena reflexão sobre a boa-fé em arbitragens de direito societário". In: RArb, v. 38,2013 , pp. $21-23$.

${ }^{1086}$ COELHO, Fábio U. "Pequena reflexão sobre a boa-fé em arbitragens de direito societário". Op. cit., p. 22.

${ }^{1087}$ COELHO, Fábio U. "Pequena reflexão sobre a boa-fé em arbitragens de direito societário". Op. cit., p. 23.

${ }^{1088}$ WESTERMANN, Harm P. "Due Diligence beim Unternehmenskauf”. In: ZHR, v. 169, 2005, pp. 248273 , p. 255.
} 
A questão se coloca de forma diversa quando nada é determinado sobre a amplitude do dever de informar, situação para a qual, insidiosamente, poder-se-ia pretender aplicar o disposto no Enunciado. Se o vendedor não utiliza a reserva de sigilo como motivo para limitar as informações que irá prestar durante a negociação, posteriormente, não pode alegar tal circunstância como fator de legitimação de comportamento contrário à boa-fé. No exemplo fornecido por COELHO, o vendedor oculta "saldos negativos em planilha de custos de certos produtos". Pressupondo-se que, de acordo com a boa-fé, o vendedor estivesse obrigado a indicar tal fato ao comprador, e que não o faça, não parece haver fundamento válido para justificar que o vendedor pudesse, posteriormente, alegar que permitiu que o comprador incidisse em erro e celebrasse um contrato assumindo premissas equivocadas - e potencialmente pagando mais pelas participações societárias - porque a informação seria reservada e sigilosa.

Como aponta, com razão, JUDiTH MARTINS-COSTA, se o vendedor "ressalva a exclusão de determinada informação (e, para tanto, utiliza a alegação de serem “informações sensíveis à sociedade”), mas, logo após, assegura não ser a informação omitida relevante para o negócio, estará enganando". ${ }^{1089}$ Em outras palavras, o vendedor pode-se valer da exceção de sigilo, mas deve explicitar quais informações irá ou não fornecer, e não pode utilizar tal restrição para induzir o potencial comprador a contratar sob falsa percepção da realidade.

\section{B. Ônus de se informar do comprador}

O vendedor não é obrigado a informar aquilo que o comprador já conhece ou poderia conhecer com atuação diligente. Embora denominado por alguns como dever de se informar, ${ }^{1090}$ tem-se na espécie um ônus jurídico de resguardo de interesses próprios. ${ }^{1091}$ O dever de informar do vendedor e o ônus de se informar do comprador, nessa medida, apresentam-se como mutuamente excludentes. ${ }^{1092}$ Se compete ao comprador a investigação de determinada circunstância, não se pode, ao mesmo tempo, afirmar que o vendedor

\footnotetext{
${ }^{1089}$ MARTINS-COSTA, Judith. “Os regimes do dolo civil no Direito Brasileiro: dolo antecedente, vício informativo por omissão e por comissão, dolo acidental e dever de indenizar”. Op. cit.

1090 JOURDAIN, Patrice. “Le devoir de 'se' renseigner”. In: Dalloz, 1983, pp. 139-144.

1091 MARTINS-COSTA, Judith. "Os regimes do dolo civil no Direito Brasileiro: dolo antecedente, vício informativo por omissão e por comissão, dolo acidental e dever de indenizar". Op. cit., p. 133.

${ }^{1092}$ CAFFIN-MOI, Marie. Cession de droits sociaux et droit des contrats. Op. cit., n. 48, p. 43.
} 
deveria esclarecê-la. A questão mais intrincada em matéria de compra e venda de participações societária é, justamente, traçar a linha de demarcação entre essas duas esferas de responsabilidades. ${ }^{1093}$

O princípio de que o comprador não se beneficia de proteção em relação a falhas que conhecia, ou que, sendo evidentes, deveria conhecer, encontra-se implícito na exigência de que os vícios ou defeitos sejam ocultos para que haja responsabilidade edilícia (CC, art. 441). Trata-se, porém, de princípio de caráter geral, aplicável à parametrização da responsabilidade pré-contratual decorrente da boa-fé. ${ }^{1094}$ Não há, portanto, falha ao dever de informar quando o comprador contrata sob ignorância de informação que lhe cabia investigar.

A imposição de um ônus de se informar atende a um interesse de facilitação do tráfego negocial, permitindo a exclusão de responsabilidade por vícios evidentes em coisas usadas e autorizando o vendedor a legitimamente presumir que o adquirente aceitou a coisa vendida ciente dos defeitos facilmente perceptíveis. Sob o ponto de vista jurídico, tratar-se-ia de manifestação da proibição de comportamento contraditório. ${ }^{1095}$ Economicamente, ademais, a regra (i) evita a adoção de comportamento oportunista pelo comprador que já considerou o estado viciado da coisa e pretende obter nova indenização; (ii) incentiva a adoção de comportamento diligente pelo comprador, para que, conhecendo o vício perceptível, tutele seu interesse ainda na fase de negociação do contrato; e (iii) diminui a possibilidade de desfazimento de contratos validamente celebrados. ${ }^{1096}$ Impõe-se ao comprador, portanto, responsabilidade pela busca de informações que lhe importam, não se admitindo que, posteriormente, pretenda obter tutela jurídica a respeito de vícios que poderia ter percebido e considerado durante a fase de negociação do preço.

O ônus de se informar afasta a possibilidade de responsabilização do vendedor, entre outros, se (i) o comprador não adota a diligência usual que, segundo os

\footnotetext{
${ }^{1093}$ CAFFIN-MOI, Marie. Cession de droits sociaux et droit des contrats. Op. cit., n. 48, p. 44.

1094 WESTERMANN, Harm P. "Due Diligence beim Unternehmenskauf". Op. cit., p. 258; MARTINSCOSTA, Judith. "Os regimes do dolo civil no Direito Brasileiro: dolo antecedente, vício informativo por omissão e por comissão, dolo acidental e dever de indenizar”. Op. cit., p. 124 (apontando que a falha ao dever de informar pode ocasionar o erro, caracterizar o dolo antecedente, gerar responsabilidade contratual ou responsabilidade por vícios redibitórios).

${ }^{1095}$ SINGER, Reinhard. Das Verbot widersprüchlichen Verhaltens. München: C. H. Beck, 1993, p. 62.

${ }^{1096}$ FLEISCHER, Holger. Informationsasymmetrie im Vertragsrecht. Op. cit., pp. 476-478; FLEISCHER, Holger; KÖRBER, Torsten. “Due diligence und Gewährleistung beim Unternehmenskauf”. Op. cit., p. 844.
} 
usos e costumes do tráfego negocial (CC, art. 113), deveria ter empregado; (ii) o bem apresenta falhas evidentes e facilmente perceptíveis; e (iii) o comprador possui qualificação profissional ou especialização técnica, dispondo de condições privilegiadas para a verificação da informação. ${ }^{1097}$ No âmbito da compra e venda de participações societárias, diferente do que ocorre na compra de automóveis ou imóveis, porém, o comprador investiga não somente o bem que intenciona adquirir (no caso, as participações societárias), mas a constituição patrimonial da sociedade e o encadeamento de atos negociais envolvidos com sua atividade empresarial. Para tanto, é comum que se valha de procedimento de auditoria, costumeiramente denominado due diligence. ${ }^{1098}$ É por meio da auditoria que o vendedor cumpre seu dever de informar e o comprador se desincumbe do ônus de se informar. É necessário, portanto, bem compreender as funções exercidas pela auditoria na compra e venda de participações societárias de controle e seu enquadramento na interação entre dever de informar e ônus de se informar.

Na economia dos contratos relativos a participações societárias de controle, a auditoria (due diligence) desempenha papéis diversos, sendo a ela atribuída (i) função formativa, para que sejam providenciadas informações completas para a formação da vontade negocial das partes; (ii) função valorativa, para permitir a determinação do preço a ser pago; (iii) função probatória, assegurando-se a documentação dos fluxos informativos entre as partes; e (iv) função garantística, para que o comprador possa examinar o objeto negocial e assegurar-se da inexistência de vícios materiais ou ocultos. ${ }^{1099}$ É esta última a que mais diretamente interessa para o presente estudo.

A origem da expressão "due diligence" remonta ao Securities Act de 1933 e à rotina de adoção de cautelas pelo comprador na compra e venda no direito norteamericano, ligada ao princípio caveat emptor. ${ }^{1100}$ Esse contexto norte-americano em que se parte, como princípio, da assunção de que a coleta de informações relevantes compete ao

1097 FLEISCHER, Holger; KÖRBER, Torsten. "Due diligence und Gewährleistung beim Unternehmenskauf". Op. cit., pp. 844-845.

${ }^{1098}$ HERNANDO CEBRIÁ, Luis. "La incidencia de la Legal Due Diligence ("revisión legal") en la contratación mercantil contemporánea". In: Revista de derecho mercantil, n. 259, 2006, pp. 603-639, pp. 629-637; TERSILLA, Silvio. "La due diligence per l'acquisizione di un pacchetto azionario di controllo di una società non quotata in borsa: obblighi di informazione e responsabilità dei soggetti coinvolti”. In: Dir. comm. int., 2002, pp. 969-989, pp. 971-974.

1099 FLEISCHER, Holger; KÖRBER, Torsten. "Due diligence und Gewährleistung beim Unternehmenskauf”. Op. cit., p. 842; ANTUNES, José Engrácia. "A empresa como objecto de negócios ('asset deal" vs. "share deal')". Op. cit., p. 753.

${ }^{1100}$ RUSSO, Fábio C. "Due Diligence e responsabilidade". Op. cit., p. 15; MERKT, Hanno. "Rechtliche Bedeutung der 'due diligence' beim Unternehmenskauf”. In: WiB, 1996, pp. 145-192, pp. 145-146. 
comprador, pauta também a cultura formada em relação à postura esperada das partes, predominantemente reativa por parte do vendedor, e de busca ativa por parte do comprador.

A transposição da prática da auditoria (due diligence) dos países da Common Law para o âmbito do direito continental, porém, exige o enquadramento do procedimento em outro contexto jurídico, em que o comportamento esperado das partes é pautado pelo princípio da boa-fé. Inserindo-se na dinâmica de delimitação do dever de informar do vendedor e do ônus de se informar do comprador, a adoção da auditoria em países de direito continental vem suscitando questões relevantes sobre (i) a possibilidade de o comprador dispensar a realização de auditoria; (ii) os efeitos da condução falha de auditoria pelo comprador; e (iii) a postura ativa que permaneceria sendo exigida do vendedor diante da realização de auditoria pelo comprador.

1. Auditoria como costume: efeitos da ausência ou incompletude da auditoria sobre a posição jurídica do comprador

No âmbito da compra e venda de participações societárias de controle, a realização de auditoria é uma prática consolidada. Efetivamente, é raro que não seja realizada nenhuma forma de verificação ou validação das informações prestadas pelo vendedor previamente à celebração do contrato. As principais exceções a essa afirmação se dão nas hipóteses de alienação de controle de instituição financeira para fins de saneamento, em que a auditoria pode ser dispensada em função da extrema preocupação com a celeridade na conclusão do contrato para manutenção da higidez sistêmica, ou em contratos envolvendo reduzido montante financeiro.

Ainda que a condução de auditoria possa ser considerada a regra, é relativamente comum ela seja limitada, por exemplo, à análise documental, sem investigação in loco de todos os estabelecimentos, seja por conta da pressão de tempo que normalmente cerca a negociação, seja pelos custos envolvidos no desempenho dessa tarefa. Em um estudo empírico realizado na Alemanha, constatou-se que, em aquisições de participações de controle, foi realizada auditoria financeira (financial due diligence) em 
93,53\% dos casos, auditoria jurídica (legal due diligence) em 77,52\% dos casos e auditoria de mercado (market due diligence) em 76,47\%, ao passo que a chamada auditoria ambiental (environmental due diligence) foi conduzida em apenas 47,37\% das transações. ${ }^{1101}$ Em outros estudos empíricos foi constatada, igualmente, irregularidade na frequência da condução de auditoria a depender da modalidade de informação a ser analisada. $^{1102}$

Sob a perspectiva jurídica, a questão que se coloca é a de determinar se o comprador que deixa de realizar auditoria atua de forma negligente ou se, ainda assim, poderia alegar a falha do vendedor ao dever de informar. Tome-se como exemplo da problemática a hipótese em que se adquire quotas de sociedade proprietária de fábrica sem que seja realizada auditoria física, ou na qual seja realidada auditoria limitada que não abrange investigação por engenheiro civil, mas depois se descobre que o imóvel estava afetado por rachaduras perceptíveis e que, posteriormente, se revelam indicadoras de falha de construção estrutural que coloca em risco os funcionários e impossibilita o exercício da atividade fabril.

A questão pode-se apresentar também na hipótese de serem negociadas cláusulas de declarações e garantias e, posteriormente, verificar-se que a condição apresentada pelo vendedor não corresponde à realidade, como ocorreria se, no exemplo utilizado, o vendedor houvesse declarado no contrato que os imóveis encontravam-se em estado apto ao exercício da atividade empresarial.

Em matéria de vícios redibitórios, considera-se que o comprador que não adota a postura que, segundo os usos do tráfego negocial, seria considerada diligente na tutela de seus interesses não pode alegar a presença de vícios ocultos, entendimento que pode ser igualmente aplicado para a determinação da abrangência do dever de informar. ${ }^{1103}$ $\mathrm{Na}$ jurisprudência pátria, decidiu-se, por exemplo, (i) que o adquirente que celebra contrato de compra e venda no qual consta a obrigação de entrega de imóvel com garagem não pode alegar a existência de vício redibitório se o imóvel cuja propriedade foi transferida não dispuser de garagem, caso o comprador não tenha visitado o imóvel nem tenha

1101 MARTEN, Kai-Uwe; KÖHLER, Annette G. "Due Diligence in Deutschland: eine Empirische Untersuchung”. In: FB, 1999, pp. 337-348, p. 342.

${ }^{1102}$ FATEMI, Aliresa. Die Obliegenheit zur Due Diligence beim Unternehmenskauf. Baden-Baden: Nomos, 2009, pp. 149-156.

${ }^{1103}$ WESTERMANN, Harm P. “Due Diligence beim Unternehmenskauf”. Op. cit., p. 258. 
diligenciado a análise das informações registrais; ${ }^{1104}$ (ii) que o comprador de veículo usado não pode alegar a descoberta de vício oculto se não adotou o padrão de diligência usual e não submeteu o veículo a exame mecânico-automotivo previamente à celebração do contrato; ${ }^{1105}$ e (iii) que é negligente o adquirente que negocia a compra de colheitadeira tendo obtido do vendedor a informação de que ela estava apta a ser empregada na produção agrícola, mas não solicita a realização de vistoria técnica. ${ }^{1106} \mathrm{O}$ entendimento prevalece também em sede doutrinária. ${ }^{1107}$

No âmbito específico da compra e venda de participações societárias, por sua vez, rejeita-se a alegação de ocorrência de vício do consentimento se se trata de negócio jurídico celebrado "sem a adoção das normais cautelas", como a verificação da condição patrimonial da sociedade. ${ }^{1108}$ Em outra hipótese em que os compradores alegaram terem sido surpreendidos com dívida de elevado montante não informada pelo vendedor de quotas, pleiteando a anulação do contrato por erro, afirmou-se que "não se admite que os autores, empresários que ingressam na sociedade, não tenham previamente verificado as suas contas e se certificado das condições econômicas da empresa” e que seria de se esperar que os compradores adotassem "diligências necessárias para se informar acerca da situação financeira da sociedade". ${ }^{1109} \mathrm{Em}$ outro julgado no qual o adquirente da integralidade das quotas sociais igualmente alegou a descoberta de dívida não declarada no contrato e buscou a anulação por erro, decidiu-se que o comprador deveria ter adotado “cautelas que integram os usos e costumes na aquisição de empresas", buscando informarse sobre a situação financeira da sociedade. ${ }^{1110}$ Em suma, não se tutela o equívoco do

\footnotetext{
${ }^{1104}$ TJMG, Ap. Cív. n. 1.0701.08.248971-0/001, $18^{\mathrm{a}}$ Câm. Cív., rel. Des. Guilherme Luciano Baeta Nunes, j. 27.08.2013.

${ }^{1105}$ TJMG, Ap. Cív. n. 1.0701.10.035679-2/001, 9ª Câm. Cív., rel. Des. Luiz Artur Hilário, j. 25.06.2013; TJSC, Ap. Cív. n. 39.187, $1^{\text {a }}$ Câm. Cív., rel. Des. Francisco Oliveira Filho, j. 25.08.1992.

${ }_{1106}$ TJMT, Ap. n. 66754/2015, $2^{\mathrm{a}}$ Câm. Cív., rel. Des. Sebastião de Moraes Filho, j. 06.04.2016.

${ }^{1107}$ PONTES DE MIRANDA, FRANCISCO C. Tratado de direito privado, t. 38 . Op. cit., $\$ 4.235$, p. 285; MIRANDA, Custodio da P. U. Comentários ao Código Civil, v. 5. São Paulo: Saraiva, 2013, pp. 442-443; ASSIS, Araken de. Comentários ao Código Civil Brasileiro, v. 5. Rio de Janeiro: Forense, 2007, p. 318.

1108 TJSP, Ap. 9115843-55.2003.8.26.0000, 1 ${ }^{\mathrm{a}}$ Câm. Dir. Priv., rel. Des. Elliot Akel, j. 06.09.2011.

1109 TJSP, Ap. n. 0035752-36.2010.8.26.0114, $1^{\text {a }}$ Câm. Res. Dir. Empr., rel. Des. Francisco Loureiro, j. 06.05.2011.

${ }_{1110}$ TJSP, Ap. n. 0010622-35.2010.8.26.0020, $1^{\text {a }}$ Câm. Res. Dir. Empr., rel. Des. Francisco Loureiro, j. 22.06.2016.
} 
comprador decorrente de erro grosseiro, decorrente da falta de adoção de cautelas mínimas exigíveis pelos usos do tráfego negocial. ${ }^{111}$

Na compra e venda de participações societárias, diverge-se na doutrina se a condução de auditoria ter-se-ia tornado parte integrantes dos usos e costumes negociais, como aponta a última decisão mencionada, ou não. A questão é discutida doutrinariamente. Parte dos autores entende que a resposta seria positiva. É o caso, no Brasil, de CALIXTO SALOMÃo FILHO, para quem a auditoria representaria "verdadeiro costume comercial". 1112 No direito estrangeiro, igualmente, há autores que consideram que a auditoria atenderia aos requisitos para ser reputada um costume negocial, quais sejam, a observância efetiva, prolongada no tempo, mediante reconhecimento coletivo de sua obrigatoriedade, ${ }^{113}$ ao passo que outros avaliam estabelecido um costume de realização de auditoria ao menos no âmbito de aquisições de sociedades de grande porte em relação a elementos centrais, como a existência de passivos ou a titularidade de adequadas licenças de funcionamento. ${ }^{1114} \mathrm{O}$ comprador que não realizasse a auditoria ao menos desses aspectos não poderia, por consequência, alegar o descumprimento de deveres de informação pelo comprador. ${ }^{1115}$

A doutrina majoritária, porém, considera que o comprador não é negligente por deixar de realizar auditoria, pois a prática ainda não teria se consolidado como espécie dos usos do tráfego negocial. ${ }^{1116}$ Ressalta-se que, por mais que seja comum a realização de auditorias, a amplitude e a profundidade com que são conduzidas variam de forma

${ }^{1111}$ TJSP, Ap. n. 0040958-31.2010.8.26.0114, 2ª Câm. Res. Dir. Empr., rel. Des. Fabio Tabosa, j. 27.06.2016 (afirmando que averiguação de situação operacional da pessoa jurídica constitui cautela usualmente adotada em negócios relativos a compra e venda de quotas);

1112 COMPARATO, Fábio Konder; SALOMÃO FILHO, Calixto. O poder de controle na sociedade anônima. Op. cit., nota de texto n. 53, p. 239.

${ }^{1113}$ BÖTTCHER, Lars. "Due Diligence beim Unternehmenskauf als Verkehrssitte". In: ZGS, 2007, pp. 2025, pp. 22-24; FATEMI, Aliresa. Die Obliegenheit zur Due Diligence beim Unternehmenskauf. Op. cit., pp. 214-215.

${ }^{1114}$ VISCHER, Markus. "Due diligence bei Unternehmenskäufen”. Op. cit., p. 235.

1115 VISCHER, Markus. "Due diligence bei Unternehmenskäufen". Op. cit., p. 235.

1116 ANGERSBACH, Carsten J. Due Diligence beim Unternehmenskauf. Baden-Baden: Nomos, 2002, p. 141; WEITNAUER, Wolfgang. "Der Unternehmenskauf nach neuem Kaufrecht”. In: NJW, 2002, pp. 25112517, p. 2516; JAGERSBERGER, Barbara. Die Haftung des Verkäufers beim Unternehmenskauf- und Anteilskauf. Op. cit., pp. 361-364; FLEISCHER, Holger; KÖRBER, Torsten. "Due diligence und Gewährleistung beim Unternehmenskauf”. Op. cit., p. 846; MÜLLER, Klaus J. "Einfluß der due diligence auf die Gewährleistungsrechte des Käufers beim Unternehmenskauf”. In: NJW, 2004, pp. 2196-2199; PICOT, Gerhard. "Due Diligence und privatrechtliches Haftungssystem". In: BERENZ, Wolfgang (org., et. al.). Due Diligence bei Unternehmensakquisitionen, 6. Aufl. Stuttgart: Schäffer-Poeschel, 2011, pp. 295330, p. 321; HUBER, Ulrich. "Die Praxis des Unternehmenskaufs im System des Kaufrechts". Op. cit., p. 201; WESTERMANN, Harm P. "Due Diligence beim Unternehmenskauf”. Op. cit., p. 264; GAUL, Björn. “Schuldrechtsmodernisierung und Unternehmenskauf”. In: ZHR, v. 166, 2002, pp. 35-71, p. 64. Na Espanha: GIMENO RIBES, Miguel. La protección del comprador en la adquisición de empresa. Op. cit., p. 31. 
acentuada, sendo impossível a indicação de um denominador comum claramente assimilável do que integraria o comportamento diligente esperado do comprador. ${ }^{1117} \mathrm{O}$ comprador que não realiza auditoria, ou realiza apenas auditoria parcial, portanto, não é considerado negligente, não se alterando o dever de informar do vendedor. ${ }^{118}$ No direito francês, igualmente, afirma-se que integrariam as cautelas normais a serem tomadas pelo adquirente a análise dos documentos societários e contábeis, mas que não haveria negligência se o adquirente não procedesse a auditoria contábil ou submetesse os documentos financeiros à apreciação de um avaliador (commissaire aux comptes). ${ }^{119}$

Esse posicionamento parece o mais adequado. Representa transposição relativamente simplista imaginar que a não realização de auditoria, ou a delimitação de escopo específico, bastaria para a afirmação de que teria ocorrido negligência por parte do comprador.

É certo que o comprador que adquire quotas ou ações sem negociar a inserção de cláusulas de declarações e garantias não poderá alegar a ocorrência de falha ao dever de informar pelo vendedor se for surpreendido pela existência de passivos que desconhecia, e isso porque o dever de informar não é tão abrangente a exigir que todas as informações sobre a coisa vendida sejam prestadas pelo vendedor. O que se impõe ao vendedor, em decorrência da boa-fé, é uma atuação mais limitada, restrita à informação dos fatos que conhece, que o comprador ignora e que, de acordo com os usos do tráfego e com a boa-fé, constitui risco para o qual o comprador deveria ser alertado. ${ }^{1120}$ Tomando o exemplo concreto utilizado, caso o vendedor conhecesse o comprometimento estrutural do imóvel que poderia levar à impossibilidade do exercício da atividade empresarial, ter-se ia

${ }^{1117}$ JAGERSBERGER, Barbara. Die Haftung des Verkäufers beim Unternehmenskauf- und Anteilskauf. Op. cit., pp. 363; FLEISCHER, Holger; KÖRBER, Torsten. "Due diligence und Gewährleistung beim Unternehmenskauf'. Op. cit., p. 846.

1118 WESTERMANN, Harm P. "Due Diligence beim Unternehmenskauf". Op. cit., pp. 263-264; FLEISCHER, Holger; KÖRBER, Torsten. "Due diligence und Gewährleistung beim Unternehmenskauf". Op. cit., p. 846; WEITNAUER, Wolfgang. "Der Unternehmenskauf nach neuem Kaufrecht". Op. cit., p. 2516.

${ }_{1119}$ CAFFIN-MOI, Marie. Cession de droits sociaux et droit des contrats. Op. cit., n. 49, p. 45.

1120 FLEISCHER, Holger; KÖRBER, Torsten. "Due diligence und Gewährleistung beim Unternehmenskauf'. Op. cit., p. 847. 
uma condição passível de frustrar o fim econômico do contrato (Vereitelung des Vertrasgszwecks), que deveria ser informada ao comprador. ${ }^{1121}$

Em aquisições de participações societárias, ademais, pode-se adotar validamente a estratégia de evitar a realização de auditoria, ou então de realização de auditoria exaustiva - que é procedimento custoso e que envolve riscos, pois a aquisição planejada pode não se concretizar- mediante a negociação de cláusulas de "declarações e garantias". Com isso, restringe-se o escopo da auditoria, de tal forma que o comprador não dispende o mesmo esforço e não investe a mesma quantidade de recursos para avaliar as informações cuja veracidade lhe foi contratualmente assegurada. Também nessa hipótese, como aponta WESTERMANN, a omissão na realização de uma auditoria ou a decisão por condução de auditoria parcial não implica perda de direito à indenização ainda que a divergência entre a situação real do patrimônio societário e aquela que constou das declarações e garantias pudesse ser percebida mediante diligente auditoria. ${ }^{1122}$

2. Efeitos de auditoria defeituosa sobre declarações e garantias

Mesmo que o vendedor tenha assumido garantias a respeito da constituição do patrimônio da sociedade, o comprador pode ter conduzido auditoria. O comprador terá se precavido unindo a negociação contratual à sua análise independente.

Em tal circunstância, é possível (i) que o comprador tome conhecimento de que uma declaração ou garantia que negociou não corresponde efetivamente à verdade; ou (ii) que o vendedor alegue que, com a auditoria conduzida, o comprador deveria ter percebido que a declaração e garantia constante do contrato não correspondia à realidade.

A discussão sobre a primeira hipótese é particularmente relevante nos Estados Unidos, em que o conhecimento do comprador a respeito da não correspondência de uma declaração ou garantia (representations \& warranties) é conhecido como

${ }^{1121}$ LORENZ, Stephan. Der Schutz vor dem unerwünschten Vertrag. München: C. H. Beck, 1997, p. 418; FLEISCHER, Holger. Informationsasymmetrie im Vertragsrecht. Op. cit., pp. 314-316.

${ }^{1122}$ WESTERMANN, Harm P. "Due Diligence beim Unternehmenskauf". In: ZHR, v. 169, 2005, pp. 248273, pp. 265-266. 
sandbagging, expressão cuja origem estaria ligada à prática no golfe de aparentar ser um jogador pior do que realmente se é, com a intenção de obter jogadas de vantagem (handicap) de oponente. ${ }^{1123}$

No âmbito dos contratos de aquisição se tornou usual o emprego de cláusulas que protegem o comprador, garantindo que possa se valer da cláusula de garantia contratada ainda que tenha reconhecido deformidade patrimonial - as chamadas prosandbagging clauses - e também de cláusulas opostas, que afastam o direito indenizatório do comprador na mesma situação - denominadas anti-sandbagging clauses. ${ }^{1124}$

A legalidade dessas cláusulas é objeto de posicionamentos variados na jurisprudência nos Estado Unidos. ${ }^{1125}$ Um caso julgado na Corte de Nova Iorque, porém, é bastante ilustrativo da problemática de fundo. Tratava-se de contrato de aquisição que foi celebrado entre as partes com a assunção de garantia, pelo vendedor, de que a contabilidade da empresa seguia as práticas contábeis geralmente aceitas $(G A A P)$. Entre a celebração do contrato (signing) e a sua execução (closing), no entanto, o adquirente auditou a contabilidade e passou a crer que a garantia não correspondia à realidade. Ainda assim, instado pelo vendedor, promoveu a execução do contrato com transferência da titularidade sobre as ações (closing). Posteriormente, o comprador pleiteou indenização com base na garantia contratual. O julgado contou com opiniões dissidentes. Em voto vencido, o juiz BELLACOSA avaliou que a confiança do comprador sobre a autenticidade da informação seria necessária para que este obtivesse indenização e que, no caso concreto, o adquirente teria percebido a ausência de veracidade da garantia, mas, ainda assim, teria prosseguido com o contrato, o que, para o magistrado, demonstraria que o comprador "queria ter seu bolo, e também comê-lo". ${ }^{1126}$ A opinião majoritária, porém, foi em sentido diverso, considerando que, sob o ponto de vista jurídico, não importava determinar se o comprador acreditara na precisão da informação, mas sim se adquiriu a promessa do

${ }^{1123}$ WEST, Glenn; SHAH, Kim. "Debunking the myth of the sandbagging buyer: when sellers ask buyers to agree to anti-sandbagging clauses, who is sandbagging whom?”. In: The M\&A Lawyer, v. 11, 2007, pp. 19 , p. 1.

${ }^{1124}$ WHITEHEAD, Charles K. "Sandbagging: default rules and acquisition agreements". In: Del. J. of Corp. L., v. 36, 2011, pp. 1081-1115.

${ }^{1125}$ WHITEHEAD, Charles K. "Sandbagging: default rules and acquisition agreements". Op. cit., pp. 11081115 (analisando o posicionamento jurisprudencial nos diversos estados).

${ }^{1126}$ Opinião dissidente do J. BELlaCOSA. In: CBS Inc., Appellant, v. Ziff-Davis Publishing Co. et al., Respondents, 75 N.Y.2d 496 (N.Y. 1990), p. 507 ("Clearly then, CBS chose to rely on the results of its own investigation and made a business judgment to consummate the purchase rather than cancel the deal. It took the business risk of a bid deal and tried by this subsequent litigation to mitigate whatever risk, if nay, inured from that choice; in other words, CBS wanted to have its cake and eat it, too"). 
vendedor e, no caso, avaliou-se que "o comprador adquiriu a promessa do vendedor sobre a existência dos fatos assegurados". 1127

No direito continental, a solução defendida pela doutrina para a hipótese de efetivo conhecimento pelo comprador a respeito da incorreção das declarações e garantias encaminha-se em sentido diverso. Na Espanha, julgou-se demanda relacionada a contrato de compra e venda de participações societárias do qual constou a garantia de que a sociedade não teria contratos de distribuição ou agência em vigor com terceiros, fato que se considerou essencial para a determinação do preço. Posteriormente, o comprador alegou que a declaração era falsa e pretendeu a anulação do contrato por dolo. O pleito foi rechaçado pela Audiencia Provincial de Barcelona, porque se julgou que os administradores do comprador tinham conhecimento da existência dos contratos quando procederam à fixação definitiva do preço. ${ }^{1128} \mathrm{O}$ entendimento é subscrito no direito italiano por MARCO SPERANZIN, para quem o conhecimento da deformidade em relação à declaração ou garantia não somente afastaria a pretensão indenizatória, sob pena de se autorizar um comportamento contraditório do comprador. ${ }^{1129}$

Essa posição parece ser a mais adequada também para o direito brasileiro. Uma vez que se constate que o comprador conhecia a deformidade em relação ao quanto foi prometido pelo vendedor em cláusula de declaração e garantia, deve-se, a princípio, interpretar o contrato e, especificamente, a cláusula de garantia como não abrangendo uma situação conhecida pelo comprador e que poderia ser por ele utilizada para negociar eventual redução do preço.

Hipótese diversa do efetivo conhecimento pelo comprador é a situação em que é conduzida auditoria e são negociadas declarações e garantias e o vendedor alega que o comprador poderia ter tomado conhecimento de eventual deformidade com a auditoria que promoveu, ao passo que o comprador alega ter-se baseado nas declarações e garantias

${ }^{1127}$ In: CBS Inc., Appellant, v. Ziff-Davis Publishing Co. et al., Respondents, 75 N.Y.2d 496 (N.Y. 1990), p. 503.

${ }^{1128}$ SAP Barcelona 5 enero 2000 apud CARRASCO PERERA, Ángel. "Representaciones e garantías". In: ÁlVAREZ ARJONA, J. (org., et. al.). Régimen jurídico de las adquisiciones de empresas. Navarra: Arazandi, 2001, pp. 191-236, pp. 212-213. No mesmo sentido: HERNANDO CEBRIÁ, Luis. "La incidencia de la Legal Due Diligence ("revisión legal”) en la contratación mercantil contemporánea". Op. cit., pp. 629637, p. 633.

${ }^{1129}$ SPERANZIN, Marco. Vendita delle partecipazione di 'controllo' e garanzie contrattuali. Op. cit., p. 336. 
para decidir-se pela celebração do contrato, utilizando a auditoria apenas como instrumento para complemento para formação de seu quadro decisório. Em doutrina, considera-se que, em tal situação de auditoria falha, o comprador não poderia ser prejudicado. $\mathrm{O}$ argumento a fortiori empregado é de que, se o comprador não seria prejudicado por não realizar auditoria, podendo confiar nas declarações e garantias negociadas, como se apontou no item anterior, seria contraditório afirmar que seria prejudicado caso buscasse se precaver adicionalmente por meio de exame autônomo das informações prestadas. Defende-se que o “comprador realiza uma due diligence para se proteger, e não para proteger o vendedor". ${ }^{1130} \mathrm{O}$ comprador buscaria perceber os possíveis pontos negativos antes de celebrar o contrato de compra e venda. Se a iniciativa de autotutela do comprador, obtida por meio de auditoria, se dá de forma insuficientemente profissional e, assim, lacunosa, o vendedor não se eximiria se declarou algo inverídico em catálogo de garantias. ${ }^{1131}$

Trata-se de proposta doutrinária que merece ser subscrita. Uma vez que se admita que não seria negligente o comportamento do comprador que negocia declarações e garantias e deixa de realizar auditoria exaustiva, seria incoerente considerar que o comprador que decidisse inspecionar a companhia sofreria repercussão negativa em sua posição jurídica por vícios que não reconheceu, mas que poderiam ter sido percebidos com exame cuidadoso.

3. Efeitos da auditoria sobre o dever de informar

A prática das auditorias norte-americanas é influenciada pelo princípio caveat emptor, impondo ao comprador o ônus de cercar-se de todos os cuidados na investigação do bem a ser comprado. Foi nesse contexto jurídico que se consolidou a praxe de serem empregadas longas listas de solicitação de informações (as chamadas due diligence checklists). É normal, nessa situação, que o vendedor se restrinja a responder com veracidade aquilo que lhe foi perguntado, não se preocupando, por outro lado, em

\footnotetext{
${ }^{1130}$ WEITNAUER, Wolfgang. "Der Unternehmenskauf nach neuem Kaufrecht". Op. cit., p. 2515 ("Der Käufer führt die due diligence zum eigenen Schutz und nicht zum Schutz des Verkäufers durch").

${ }^{1131}$ WEITNAUER, Wolfgang. "Der Unternehmenskauf nach neuem Kaufrecht". Op. cit., p. 2515. No mesmo sentido: EGGENBERGER, Jans. Gesellschaftsrechtliche Voraussetzungen und Folgen einer duediligence Prüfung. Op. cit., p. 270; FLEISCHER, Holger; KÖRBER, Torsten. "Due diligence und Gewährleistung beim Unternehmenskauf". Op. cit., p. 848.
} 
alertar o potencial comprador acerca de outros fatores sobre os quais este não demonstrou interesse.

A transposição da prática para o direito continental, no qual a boa-fé na fase negocial impõe deveres laterais de informação, contudo, suscita questionamentos sobre a influência da auditoria na forma de exercício do dever de informar. Indaga-se, especificamente, se a iniciativa do comprador de promover auditoria reduziria o escopo do dever de informar.

Se o potencial comprador formula pedido de fornecimento de documentação e de informações mediante o envio de lista (checklist), afirma-se que, de um lado, ele circunscreve os fatores que julga relevantes para sua tomada de decisão e, de outro, autoriza ao vendedor que conclua por seu desinteresse quanto aos aspectos que não foram objeto de indagação. ${ }^{1132}$ Para alguns, seria possível extrair dessa postura uma especial eficácia sobre o dever de informar do vendedor, o qual seria acentuado em relação aos aspectos questionados, ao passo que seria atenuado ou excluído em relação àquilo por que o comprador não manifestou atenção. ${ }^{1133} \mathrm{O}$ vendedor, por conseguinte, não estaria obrigado a comunicar outras informações que não tivessem sido requisitadas na checklist. $^{1134}$

Para outra parcela da doutrina, porém, seria "manifestamente incorrecta a tese de que, ao elaborar a due diligence check list, o potencial comprador delimita os factos que considera essenciais para a sua decisão de contratar e, consequentemente, o perímetro da informação que lhe é devida". ${ }^{1135}$ Afirma-se que seria equivocado, de um lado, supor que todas informações requisitadas em uma mera lista seriam imprescindíveis para a tomada de decisão pelo comprador, quanto, por outro lado, assumir que o potencial adquirente não conferiria importância a nenhum aspecto além dos listados. ${ }^{1136}$ Defende-se, ainda, que o comprador realiza a auditoria para buscar diminuir seu déficit informacional,

\footnotetext{
${ }^{1132}$ RUSSO, Fábio C. "Due Diligence e responsabilidade”. Op. cit., p. 21.

${ }_{1133}^{113}$ RUSSO, Fábio C. "Due Diligence e responsabilidade”. Op. cit., p. 22.

1134 SPERANZIN, Marco. Vendita delle partecipazione di 'controllo' e garanzie contrattuali. Op. cit., p. 358.

1135 CÂMARA, Paulo; BASTOS, Miguel Brito. "O direito da aquisição de empresas: uma introdução". $O p$. cit., p. 27, nota de rodapé 40 .

${ }^{1136}$ CÂMARA, Paulo; BASTOS, Miguel Brito. "O direito da aquisição de empresas: uma introdução". $O p$. cit., p. 27 , nota de rodapé 40 .
} 
não para piorar sua situação jurídica. ${ }^{1137} \mathrm{~A}$ assunção de que o comprador não teria interesse por outros aspectos além dos listados, adicionalmente, seria equivocada, porque é justamente por desconhecer a informação relevante que pode faltar ao comprador elementos de conexão para conseguir direcionar seu questionamento de forma adequada. $^{1138} \mathrm{O}$ potencial alienante, por conseguinte, estaria obrigado a revelar fatos desconhecidos do adquirente de que tenha conhecimento e que possam ser de crucial relevância para a formação de vontade do adquirente, ainda que não haja solicitação específica nesse sentido. ${ }^{1139} \mathrm{O}$ dever de informar do vendedor, nessa medida, não seria alterado pela circunstância de o comprador ter formulado lista de auditoria. ${ }^{1140}$

A posição mais adequada a respeito do assunto parece ser intermediária entre o extremo que sugere que a lista de auditoria teria aptidão de reduzir ou eliminar o dever de informar e o que defende a sua neutralidade. A atuação ativa do comprador mediante a formulação de lista de auditoria e, sobretudo, o início de procedimento dinâmico em que o comprador formula novos questionamentos autoriza o vendedor a adotar postura passiva, atendendo às solicitações que lhe são formuladas, razão pela qual é possível admitir uma redução do escopo do dever de informar, que passa a ser observado pelo vendedor por meio da prestação das informações verídicas e da disponibilização ordenada de documentação pertinente. ${ }^{1141}$ Isso não obstante, o dever de informar remanesceria em relação a fatos de fundamental relevância, ainda que não questionados diretamente pelo comprador. ${ }^{1142}$

\footnotetext{
${ }_{1137}^{1137}$ PICOT, Gerhard. "Due Diligence und privatrechtliches Haftungssystem". Op. cit., p. 323.

1138 FLEISCHER, Holger; KÖRBER, Torsten. "Due diligence und Gewährleistung beim Unternehmenskauf". Op. cit., p. 848.

${ }^{1139}$ CÂMARA, Paulo; BASTOS, Miguel Brito. "O direito da aquisição de empresas: uma introdução". $O p$. cit., p. 27, nota de rodapé 40 .

${ }^{1140}$ WEITNAUER, Wolfgang. "Der Unternehmenskauf nach neuem Kaufrecht". Op. cit., p. 2516; PICOT, Gerhard. "Due Diligence und privatrechtliches Haftungssystem". Op. cit., pp. 295-330, p. 324; CÂMARA, Paulo; BASTOS, Miguel Brito. "O direito da aquisição de empresas: uma introdução". Op. cit., p. 27, nota de rodapé 40; STENGEL, Arndt; SCHOLDERER, Frank. "Aufklärungspflichten beim Beteiligungs- und Unternehmenskauf". In: NJW, 1994, pp. 158-164, p. 164; FLEISCHER, Holger; KÖRBER, Torsten. "Due diligence und Gewährleistung beim Unternehmenskauf”. Op. cit., p. 848.

1141 HENSSLER, Martin. "Haftung des Verkäufers wegen Informationspflichtverletzung beim Unternehmenskauf". Op. cit., p. 136; HUBER, Ulrich. "Die Praxis des Unternehmenskaufs im System des Kaufrechts". Op. cit., p. 218.

1142 HENSSLER, Martin. "Haftung des Verkäufers wegen Informationspflichtverletzung beim Unternehmenskauf". Op. cit., p. 136; HUBER, Ulrich. "Die Praxis des Unternehmenskaufs im System des Kaufrechts". Op. cit., p. 218.
} 


\section{Dever especial de informação do administrador na compra de participações societárias do sócio controlador}

Na compra e venda, parte-se da assunção de que, como regra, o vendedor possui melhor informação a respeito da coisa vendida. É por essa razão que a ele se impõem primordialmente deveres de informação. Na compra e venda de participações societárias, porém, há conjunturas em que o vendedor, a despeito de ser controlador da sociedade, pode não conhecer a constituição do patrimônio societário tão bem quanto o administrador. Na hipótese de o administrador pretender adquirir as participações societárias do controlador, situação normalmente designada como management buy-out, pode-se questionar se os deveres informativos não deveriam, nesse caso, ser impostos sobretudo ao administrador-comprador em benefício do sócio-vendedor.

Há bons fundamentos para defender que, na celebração de contrato com o sócio controlador, o administrador não pode-se beneficiar de informações privilegiadas de que disponha em função do exercício de sua função. $\mathrm{O}$ administrador atua como um fiduciário (agent), alguém que deve utilizar o conhecimento e a qualificação que obtém no exercício do seu cargo em benefício de outrem (principal). ${ }^{1143}$ No direito norte-americano, por consequência, considera-se que o administrador não pode-se valer da vantagem informacional que detenha como decorrência de sua função quando negocie com os sócios, devendo a eles comunicar toda informação não divulgada de que tenha ciência. ${ }^{1144}$ Nesse sentido, a Supreme Court decidiu que o administrador não poderia adquirir ações dos acionistas sem revelar que a celebração de relevante contrato com a administração pública era premente. Considerou-se que "a director upon whose action the value of the shares depends cannot avail of his knowledge of what his own action will be to acquire shares from those whom he intentionally keeps in ignorance of his expected action and the resulting value of the shares". 1145

\footnotetext{
${ }^{1143}$ CLARK, Robert C. Corporate Law. Boston/Toronto: Little, Brown and Company, 1986, §3.3.1, p. 114. 1144 ZANKEL, Norman. "Duty of corporate officers and directors who purchase stock from their shareholders". In: Syracuse L. Rev., v. 71, 1953, pp. 71-77; GIANNINI, Regina M. "Punctilio of honor' or 'disintegrating erosion'? The fiduciary duty to disclose for partners, corporate directors, and majority shareholders". In: Sw. U. L. Rev., v. 27, 1997, pp. 73-97, pp. 79-83.

${ }^{1145}$ Strong v. Repide, 213 U.S. 419 (1909).
} 
Na França a questão foi suscitada igualmente no chamado affaire Vilgrain, em caso no qual o dirigente de sociedade anônima adquiriu ações de um acionista minoritário pelo preço de 5.650 francos, sem revelar que havia confiado a um banco de investimentos a missão de negociar a venda das ações da família controladora e que já havia sido recebida proposta de compra pelo valor de 7.000 francos por ação, valor pelo qual o administrador, posteriormente, alienou as ações adquiridas do minoritário. O cedente, em vista da omissão da informação sobre a negociação, pleiteou a anulação do contrato por dolo omissivo (réticence dolosive) com base no art. 1116 do Code civil, e a Chambre commerciale julgou que seria possível afirmar a ocorrência de dolo pela falha do administrador em relação "ao dever de lealdade que se impõe ao dirigente da sociedade em relação a todos os sócios". ${ }^{1146}$ Como aponta DoMINIQUE SCHMIDT, a decisão trata de uma situação de patente conflito de interesses, pois o administrador a quem se confia a tutela do interesse de todos os sócios prefere seu próprio interesse patrimonial ao do sócio, sendo correta, portanto, a exigência da jurisprudência de que a contratação seja pautada por rígidos padrões de transparência e de lealdade. ${ }^{1147} \mathrm{O}$ julgado é relevante, ademais, pela clara intersecção que estabelece entre direito societário e civil. A afirmação do descumprimento do dever de lealdade societário, com efeito, é utilizada como fundamento para anulação do contrato fundada em dolo omissivo por falha ao dever de informar. ${ }^{1148}$

No direito inglês, há uma tradicional reserva ao reconhecimento da existência de obrigações dos administradores em relação aos sócios, afirmando-se que a beneficiária dos deveres de lealdade dos administradores seria a companhia. ${ }^{1149}$ Trata-se de princípio estabelecido no caso Percival v Wright, em que os sócios ofereceram suas ações aos administradores e as venderam, sem ciência de que estava em andamento negociação para alienação da companhia a um valor mais favorável. Considerou-se, na hipótese, que os administradores não teriam descumprido seu dever de lealdade, pois não haveria um direito dos acionistas em face dos administradores de serem informados acerca da negociação. ${ }^{1150}$ No caso Peskin v Anderson, julgado em 2001, porém, indicou-se a

\footnotetext{
${ }^{1146}$ Cass. com. 27.02.1996, Bull. civ. IV, $\mathrm{n}^{\circ}$ 65, p. 50.

1147 SCHMIDT, Dominique. Les conflits d'intérêts dans la société anonyme. Paris: Joly, 2004, n. 36, p. 49.

1148 CAFFIN-MOI, Marie. Cession de droits sociaux et droit des contrats. Op. cit., n. 88, p. 67; ROUSILLE, Myriam. "De la réticence dolosive du dirigeant en matière de cession de droits sociaux". In: JCP, 2009, n. 1631, pp. 34-39, p. 36.

1149 DAVIES, Paul L. Gower and Davies Principles of Modern Company Law, 8 a ed. London: Sweet \& Maxwell, 2008, n. 16-5, p. 481.

${ }^{1150}$ Percival $v$ Wright [1902] 2 Ch. 421 apud DAVIES, Paul L. Gower and Davies Principles of Modern Company Law. Op. cit., p. 481.
} 
possibilidade de nova orientação, considerando-se que os administradores poderiam ser destinatários de deveres fiduciários perante os acionistas quando se constatasse a existência de uma "special factual relationship between the directors and the shareholders in the particular case". 1151

No direito alemão, os administradores não são reputados destinatários de deveres perante os sócios, mas somente perante a sociedade. ${ }^{1152}$ Isso não obstante, avaliase que, na situação de aquisição de participações societárias pelos administradores, haveria um dever especial de informação sobre todas as circunstâncias relativas à sociedade que o sócio ignore e de que o administrador tenha conhecimento em função de seu cargo. $\mathrm{O}$ fundamento dogmático de tal dever é discutido. Para alguns, contrários ao entendimento doutrinário prevalecente, o dever de lealdade dos órgão societários perante os sócios poderia ser fundamentado, impondo-se aos administradores especiais deveres de informação na hipótese do chamado management buy-out. ${ }^{1153}$ Uma tese alternativa, defendida por MARTIN WEBER, é de que o dever de lealdade entre os próprios sócios poderia ser estendido para determinadas situações em que a parte ainda não é sócia. A aquisição de participações societárias pelos administradores seria uma hipótese em que seria imposta essa "relação fiduciária pré-associativa", de tal forma que caberia ao administrador informar o sócio vendedor amplamente sobre oportunidades negociais da companhia, valor das reservas ocultas, ou sobre o financiamento da companhia. ${ }^{1154} \mathrm{~A}$ fundamentação dogmática mais convincente sobre o assunto, porém, é fornecida por HOLGER FleisCher. ${ }^{1155}$ Considerando que os deveres de informação pré-contratuais são decorrentes da cláusula geral da boa-fé, a qual apresenta conteúdo relacional e moldável à situação concreta específica, FLEISCHER defende que não seria necessário buscar um fundamento para o incremento do dever de informação do administrador no direito societário ou no direito contratual, senão em ambos, admitindo-se que o dever de lealdade

${ }^{1151}$ Peskin v Anderson [2001]1 B.C.L.C. 372 apud DAVIES, Paul L. Gower and Davies Principles of Modern Company Law. Op. cit., p. 480.

${ }^{1152}$ FLEISCHER, Holger. Informationsasymmetrie im Vertragsrecht. Op. cit., p. 540.

${ }^{1153}$ RHEIN, Tilman. Der Interessenkonflikt der Manager beim Management Buy-out. München: C. H. Beck, 1996, pp. 214-217.

${ }^{1154}$ WEBER, Martin. Vormitgliedschaftliche Treuebindungen. München: C. H. Beck, 1999, pp. 284 ss.

${ }^{1155}$ FLEISCHER, Holger. Informationsasymmetrie im Vertragsrecht. Op. cit., p. 544-545. 
do administrador influenciaria a configuração concreta do dever de informar pré-contratual quando se inicia o contato negocial entre o administrador e o sócio controlador. ${ }^{1156}$

No direito brasileiro, tal entendimento parece também aplicável, cabendo ao administrador ou ao sócio minoritário que exerça função administrativa um dever amplo de levar ao conhecimento do sócio quaisquer oportunidades comerciais relativas à sociedade ou outras informações privilegiadas de que disponha em função de seu cargo, aí incluído, por exemplo, o interesse de terceiros na compra das ações ou quotas por valor superior àquele que o administrador negocia com o vendedor.

${ }^{1156}$ FLEISCHER, Holger. Informationsasymmetrie im Vertragsrecht. Op. cit., p. 544-545. 


\section{RESPONSABILIDADE CONTRATUAL}

\section{A. Vícios redibitórios}

Em contratos comutativos, a "coisa" recebida "pode ser enjeitada por vícios ou defeitos ocultos, que a tornem imprópria ao uso a que é destinada, ou lhe diminuam o valor" (CC, art. 441). Na compra e venda de participações societárias de controle, "coisas" objeto da obrigação do vendedor são as quotas ou ações. As condições patrimoniais da sociedade não integram o contrato, e permanecem, antes e depois da compra e venda, sob a titularidade da sociedade. A questão clássica que se coloca nessa matéria é de saber se o comprador que adquirisse participações societárias de controle e descobrisse, por exemplo, a existência da falha estrutural no imóvel da sociedade referida anteriormente ${ }^{1157}$ poderia considerar que a "coisa" que recebeu deveria ser enjeitada por vícios ocultos.

Para responder adequadamente a questão, vale analisar o tratamento do tema no direito comparado e proceder ao exame das manifestações da doutrina e da jurisprudência no Brasil.

1. Direito estrangeiro

No direito estrangeiro, a possibilidade de defeitos dos elementos integrantes do patrimônio serem considerados vícios redibitórios da compra e venda de participações societárias é matéria tradicionalmente discutida, mas sem uniformidade. Em alguns países, aceita-se a aplicação, desde que se trate de aquisição da totalidade ou da quase totalidade das participações societárias; em outros, nega-se. A apresentação desses posicionamentos, porém, busca ressaltar os argumentos favoráveis e contrários utilizados para a defesa de cada uma das soluções, facilitando a tomada de posição sobre o assunto no direito brasileiro.

${ }^{1157}$ Cf. item IV.B.1, supra. 
a) Alemanha

Na Alemanha, desde o início do século XX, discute-se a adequação de se aplicar o regime dos vícios redibitórios à aquisição de participações societárias. ${ }^{1158} \mathrm{O}$ tema é considerado um "clássico". ${ }^{1159}$ A devida análise da evolução da doutrina e da jurisprudência naquele país pressupõe, porém, uma prévia compreensão de certos aspectos em que o BGB apresenta regras diversas das vigentes no Brasil. Uma delas é a dualidade existente na redação original do BGB entre a compra e venda de coisas - Sachkauf (BGB a.F., §433) - e a compra e venda de pretensões ou outros direitos - Rechtskauf (BGB a.F., §437). Previam-se regimes diferentes para a responsabilidade do vendedor nesses dois tipos contratuais. Na compra e venda de coisas (Sachkauf), o vendedor respondia pela qualidade da coisa vendida, garantindo que ela estivesse livre de vícios (Fehler) que pudessem diminuir o seu valor ou a sua utilidade, ou impedir o seu uso habitual ou pressuposto contratualmente (BGB a.F., §459). Na compra e venda de pretensões ou outros direitos (Rechtskauf), por outro lado, o vendedor respondia apenas pela existência da pretensão ou do direito (BGB a.F., §437). A diferença entre os regimes de responsabilidade fica evidente na compra e venda da pretensão ao recebimento de uma coisa. Como exemplifica WIEDEMANN, se alguém vende a outrem a pretensão ao recebimento de um quadro de Cézanne, não está se obrigando a entregar o próprio quadro (algo que poderia contratar, pois nada impediria a celebração de contrato obrigacional sobre coisa que ainda não integra o patrimônio do vendedor), mas transferindo a outrem a pretensão ao recebimento de um quadro. ${ }^{1160} \mathrm{Se}$, posteriormente, se descobre que o quadro era uma falsificação, o adquirente da pretensão não pode responsabilizar o cedente se a pretensão existia, devendo voltar-se contra o responsável pela entrega do quadro de Cézanne.

\footnotetext{
1158 BERGJAN, Ralf. Die Auswirkungen der Schuldrechtsreform 2002 auf den Unternehmenskauf. Berlin: Dunker \& Humblot, 2003, p. 281.

${ }^{1159}$ WELLER, Marc-Philippe. "Sachmängelhaftung beim Unternehmenskauf”. In: GRUNEWALD, Barbara; WESTERMANN, Harm Peter (org.). Festschrift für Georg Maier-Reimer zum 70. Geburtstag. C. H. Beck, München, 2010, pp. 839-854, p. 839.

1160 WIEDEMANN, Herbert. "Die Haftung des Verkäufers von Gesellschaftsanteilen für Mängel des Unternehmens". Op. cit., p. 828.
} 
$\mathrm{Na}$ compra e venda de participações societárias de controle, a primeira questão debatida na doutrina e jurisprudência é a de saber se uma compra e venda de quotas ou ações poderia ser considerada uma compra e venda de coisas (Sachkauf) ou uma compra e venda de direitos (Rechtskauf). A discussão sobre o tema remonta ao início do século passado. Em 1904, o Tribunal do Império (Reichsgericht) considerou que a compra e venda de ações era compra de direitos, razão pela qual os vícios de uma mina explorada pela sociedade não poderiam ser considerados vícios do direito adquirido. ${ }^{1161}$ Tal orientação foi mantida mesmo em casos de aquisição da totalidade das quotas ou ações. ${ }^{1162}$ Em uma decisão de 1920, porém, o mesmo tribunal alterou sua orientação inicial. Nesse caso, julgou-se que a compra e venda da totalidade das participações societárias deveria ser vista como um contrato que teria por objeto tanto as participações como o substrato econômico da sociedade. ${ }^{1163}$ A linha argumentativa do tribunal, posteriormente, foi ainda novamente alterada para afirmar que, na aquisição da totalidade das participações societárias, dever-se-ia considerar o contrato como equiparado à compra e venda da própria empresa (Unternehmenskauf), ${ }^{164}$ ou seja, um contrato de compra e venda de coisas (Sachkauf), e não com dúplice objeto. ${ }^{1165} \mathrm{O}$ Tribunal Superior Alemão $(B G H)$, criado após a $2^{\text {a }}$ Guerra Mundial, seguiu a mesma orientação, mas ressaltou que a compra e venda somente seria de coisas (Sachkauf), e não de direitos (Rechtskauf), quando a aquisição se referisse à totalidade das ações ou quotas, ou envolvesse a permanência de uma quantidade negligenciável de participações societárias em poder dos sócios minoritários. ${ }^{166} \mathrm{~A}$ aquisição de parcela de $60 \%$ do capital social de uma sociedade por ações, por exemplo, não foi considerada como apta a justificar o tratamento da compra e venda de participações societárias como compra e venda de coisas, ${ }^{1167}$ senão como compra e venda de direitos.

$\mathrm{Na}$ doutrina, em geral, admitia-se que a compra e venda de participações societárias de controle poderia ser considerada uma compra e venda de coisas (Sachkauf), mas havia dissenso sobre o critério para que tal qualificação fosse aplicável. Havia autores

\footnotetext{
${ }^{1161}$ RGZ 59, 240.

1162 JAGERSBERGER, Barbara. Die Haftung des Verkäufers beim Unternehmenskauf- und Anteilskauf. Op. cit., p. 75.

${ }^{1163}$ RGZ 120, 283.

${ }^{1164}$ HIDDEMANN, H.-J. "Leistungsstörungen beim Unternehmenskauf aus der Sicht der Rechtsprechung”. Op. cit., p. 439.

1165 WIEDEMANN, Herbert. "Die Haftung des Verkäufers von Gesellschaftsanteilen für Mängel des Unternehmens". Op. cit., p. 817.

${ }^{1166}$ BGHZ 65, 246.

${ }^{1167}$ JAGERSBERGER, Barbara. Die Haftung des Verkäufers beim Unternehmenskauf- und Anteilskauf. Op. cit., p. 76.
} 
que se alinhavam à posição do BGH e exigiam a aquisição da totalidade ou quase totalidade das participações societárias, ${ }^{1168}$ ou uma posição de controle societário ${ }^{1169}$ (critério objetivo); outros consideravam mais relevante a interpretação da vontade das partes (critério subjetivo); ${ }^{1170}$ e uma terceira orientação exigia a presença tanto do componente objetivo, refletido na aquisição do poder de controle, quanto subjetivo, caracterizado pela intenção concreta dos contratantes de adquirir a empresa por intermédio das participações societárias. ${ }^{1171}$

Em 2002, no âmbito da reforma do direito das obrigações, o BGB foi alterado para prever no $\S 453$, Abs. 1 que as regras sobre compra e venda de coisas (Sachkauf) são subsidiariamente aplicáveis à compra e venda de direitos (Rechtskauf). A exposição de motivos menciona expressamente a compra e venda de participações societárias entre as compras e vendas de direitos passíveis de serem tratadas como compras de coisas. ${ }^{1172}$ Analisando as consequências da alteração, parte da doutrina considerou que as compras e vendas de participações societárias passariam, com isso, a ser sempre abrangidas pelo regramento aplicável às compras de coisas, e não somente pelo regramento das compras de direitos. ${ }^{1173}$ A parcela predominante da doutrina considera, porém, que, como antes da alteração do BGB, somente na aquisição de parcela de "quase $100 \%$ " das participações societárias seria possível o tratamento da compra e venda como de coisas, e não de direitos. ${ }^{1174}$

\footnotetext{
1168 WIEDEMANN, Herbert. "Die Haftung des Verkäufers von Gesellschaftsanteilen für Mängel des Unternehmens". Op. cit., p. 836; HIDDEMANN, H.-J. "Leistungsstörungen beim Unternehmenskauf aus der Sicht der Rechtsprechung". Op. cit., p. 439.

${ }^{1169}$ GRUNEWALD, Barbara. "Unerwartete Verbindlichkeiten beim Unternehmenskauf”. In: ZGR, 1981, pp. 622-642, p. 640; HOMMELHOFF, Peter. "Zur Abgrenzung von Unternehmenskauf und Anteilserwerb". In: ZGR, 1982, pp. 366-390, p. 376-384.

${ }^{1170}$ FLUME, Werner. Eigenschaftsirrtum und Kauf. Dortmund: Gebrüder Lensing, 1948, pp. 188-189; HUBER, Ulrich. "Mängelhaftung beim Kauf von Gesellschaftsanteilen". Op. cit., p. 401; LIEB, Manfred. "Gewährleistung beim Unternehmenskauf”. In: LANGE, Hermann (coord., et. al.). Festschrift für Joachim Gernhuber zum 70. Geburtstag. Tübingen: Mohr Siebeck, 1993, pp. 259-280, p. 278.

${ }^{1171}$ HOMMELHOFF, Peter. "Die Sachmängelhaftung beim Unternehmenskauf durch Anteilserwerb". In: ZHR, v. 140, 1976, pp. 271-300, p. 283.

${ }^{1172}$ DEUTSCHER BUNDESTAG. Entwurf eines Gesetzes zur Modernisierung des Schuldrechts. In: BT/Drucks. 14/6040, 2001, p. 242.

${ }^{1173}$ GRONSTEDT, Sebastian; JÖRGENS, Stefan. "Die Gewährleistungshaftung bei Unternehmensverkäufen nach dem neuen Schuldrecht". In: ZIP, 2002, pp. 52-65, p. 53; GAUL, Björn. "Schuldrechtsmodernisierung und Unternehmenskauf". Op. cit., p. 39; KNOTT, Hermann. "Unternehmenskauf nach der Schuldrechtsreform". In: NZG, 2002, pp. 249-256, p. 251; WOLF, Manfred; KAISER, Jochen. "Die Mängelhaftung beim Unternehmenskauf nach neuem Recht”. In: BB, 2002, pp. 411-420, p. 416.

${ }^{1174}$ BERGJAN, Ralf. Die Auswirkungen der Schuldrechtsreform 2002 auf den Unternehmenskauf. $O P$. cit., pp. 295-296; LORENZ, Stephan. "Der Unternehmenskauf nach der Schuldrechtsreform". In: LORENZ, Stephan (coord., et. al.). Festschrift für Andreas Heldrich zum 70. Geburtstag. München: C. H. Beck,
} 
A afirmação de que certas alienações de participações societárias não são tratadas como meras compras de direitos (Rechtskauf), sendo equiparadas à compra e venda da empresa (Unternehmenskauf), ou seja, ao que se denominaria trespasse de estabelecimento no Brasil, pode transmitir a falsa impressão de que a garantia edilícia teria proeminência no sistema alemão de tutela do adquirente de participações societárias de controle. Em verdade, as consequências extraídas dessa linha jurisprudencial são mais restritas. Mesmo que se julgue que a compra e venda de quotas ou ações deveria ser tratada como modalidade de compra e venda da própria empresa, é questionada a possibilidade de aplicação das garantias edilícias, pensadas para "coisas", a uma universalidade de fato como é a empresa.

Seja no trespasse de estabelecimento (Unternehmenskauf), seja na compra e venda de participações societárias de controle que seja a ela equiparada, há importantes diferenças entre a empresa e o conceito de "coisa", ${ }^{1175}$ que está na base das garantias edilícias no direito alemão, como no brasileiro. Essa limitação era apontada pela doutrina previamente à alteração do direito das obrigações em 2002, e são bem resumidas em um relevante trabalho de CLAUS-WILHELM CANARIS. ${ }^{1176}$

Sob o ponto de vista dos pressupostos jurídicos, a aplicação da disciplina dos vícios redibitórios seria incompatível com o contrato que tem a empresa por objeto. Primeiro, porque a empresa é um organismo social em constante mutação. Sua conformação é mais complexa do que a de um bem individual. A empresa é marcada pela atividade desenvolvida por seu titular e uma responsabilidade pela ausência de vícios nos resultados de uma atividade seria algo diverso em relação à ausência de vícios de uma coisa. ${ }^{1177} \mathrm{O}$ conceito de vícios da coisa também é de difícil aplicação para bens integrantes do inventário empresarial, pois é normal que uma empresa possa, por exemplo, contar em seu patrimônio com um caminhão que está com defeito, ou contabilizar créditos que posteriormente são considerados nulos em decorrência de demanda proposta pela

2005, pp. 305-326, p. 319; HUBER, Ulrich. "Die Praxis des Unternehmenskaufs im System des Kaufrechts". Op. cit., p. 229; GRUNEWALD, Barbara. "Rechts- und Sachmängelhaftung beim Kauf von Unternehmensanteilen". In: NZG, 2003, pp. 372-374, p. 373; EIDENMÜLLER, Horst. "Rechtskauf und Unternehmenskauf”. In: ZGS, 2002, pp. 290-296, p. 294.

1175 CANARIS, Claus-Wilhelm. "Leistungsstörungen beim Unternehmenskauf”. In: ZGR, 1982, pp. 395434, p. 398.

${ }^{1176}$ CANARIS, Claus-Wilhelm. "Leistungsstörungen beim Unternehmenskauf”. Op. cit.

${ }^{1177}$ CANARIS, Claus-Wilhelm. "Leistungsstörungen beim Unternehmenskauf”. Op. cit., p. 399. 
contraparte; é da natureza da atividade empresarial lidar com essas circunstâncias. ${ }^{1178}$ Além disso, é comum que uma empresa possua certos ativos em melhor estado, outros em estado pior; ou que a atividade dependa das qualidades do titular. Um conceito objetivo de vício, nesse sentido, seria incompatível com a empresa. ${ }^{1179}$

Da perspectiva da consequências jurídicas, o regime original do BGB referente às ações edilícias, tal qual o brasileiro, oferecia ao comprador a possibilidade de livre escolha entre a redibição e o pedido de abatimento do preço (BGB a.F., §462), solução que, na compra e venda de empresas, não geraria um regramento adequado à situação fática, pois a restituição de uma coisa singular, em geral, é menos complexa do ponto de vista fático do que a restituição de uma empresa, organização de fatores produtivos em constante mutação. ${ }^{1180}$ Em segundo lugar, o prazo de prescrição previsto para o exercício das ações edilícias, que, então, era de seis meses para coisas móveis (BGB a.F., §477), era considerado compatível com coisas passíveis de serem fisicamente analisadas, mas inadequado para a tutela do comprador com relação a informações falsas no balanço ou sobre o faturamento. Considerando que tais vícios deveriam ser reputados como relativos à coisa, o vendedor não mais responderia por eles passado o prazo prescricional. ${ }^{1181}$ Em terceiro, tem-se o fato de que a responsabilidade por vícios redibitórios no direito alemão (como no direito brasileiro) é independente de culpa e não pressupõe sequer o conhecimento do vendedor acerca da condição da coisa. Como aponta HuBER, "a garantia é objetiva; aplica-se mesmo quando o vendedor não possuía nenhuma informação além da que prestou na celebração do contrato e mesmo quando sequer poderia ter tal conhecimento da verdadeira qualidade da coisa". ${ }^{1182}$

A jurisprudência e a doutrina, nessa medida, adotavam uma interpretação propositadamente restritiva do que poderia constituir um vício da empresa (BGB a. F., §459), justamente para limitar o âmbito de aplicação da disciplina dos vícios

\footnotetext{
${ }^{1178}$ CANARIS, Claus-Wilhelm. "Leistungsstörungen beim Unternehmenskauf”. Op. cit., p. 399.

1179 CANARIS, Claus-Wilhelm. "Leistungsstörungen beim Unternehmenskauf". Op. cit., p. 399.

1180 CANARIS, Claus-Wilhelm. "Leistungsstörungen beim Unternehmenskauf". Op. cit., p. 400. Sobre as dificuldades ínsitas à pretensão de restituição da empresa, cf. BALLERSTEDT, Kurt. "Das Unternehmen als Gegenstand eines Bereicherungsanspruchs". In: FISCHER, Robert (coord., et. al.). Gesellschaftsrecht und Unternehmensrecht - Festschrift für Wolfgang Schilling zum 65. Geburtstag. Berlin/New York: De Gruyter, 1973, pp. 289-307.

1181 CANARIS, Claus-Wilhelm. "Leistungsstörungen beim Unternehmenskauf”. Op. cit., p. 401.

${ }^{1182}$ HUBER, Ulrich. "Die Praxis des Unternehmenskaufs im System des Kaufrechts". Op. cit., p. 212 ("Die Haftung ist eine objektive Haftung; sie greift auch ein, wenn der Verkäufer dem Käufer keinerlei über die reine Tatsache des Vertragsschlusses hinausgehende Information erteilt hat, und auch dann, wenn er von der wirklichen Beschaffenheit der Sache keinerlei Kenntnis haben konnte").
} 
redibitórios. ${ }^{1183}$ Em primeiro lugar, somente eram consideradas vícios as características atuais da empresa, e não características do passado que não se refletissem imediatamente no estado da empresa no momento da celebração do contrato. ${ }^{1184}$ Dados inverídicos apresentados pelo vendedor sobre o inventário empresarial, sobre a receita, sobre o lucro histórico ou sobre o passivo, ou outras informações contábeis falsas, não eram tratadas como vícios redibitórios das ações ou quotas, nessa medida, exceto se o vendedor prestasse garantia expressa sobre dados financeiros de um longo período de tempo passado, com impacto direto sobre a lucratividade atual da companhia. ${ }^{185}$ Em segundo lugar, o vício deveria ser interno e inerente à coisa, razão pela qual não se considerava que seria vício da própria empresa a sua relação econômica, social ou jurídica com o ambiente, como, por exemplo, a reputação da sociedade. Em terceiro lugar, no caso dos vícios de bens integrantes do patrimônio empresarial, somente se aceitava a existência de um vício da própria empresa se, por conta dos vícios, a capacidade produtiva da empresa como um todo fosse colocada em risco de forma definitiva, seguindo a chamada teoria da relevância geral (Gesamterheblichkeitstheorie), segundo a qual o vício de um elemento do patrimônio empresarial somente constituiria vício da empresa quando fosse tão relevante a ponto de repercutir na empresa como um todo. ${ }^{186}$

Essa interpretação restritiva do âmbito de atuação dos vícios redibitórios na compra e venda de empresa promoveu uma "marginalização" "1187 das garantias edilícias no sistema de tutela do comprador. Tal restrição, porém, teve seu significado e sua função alterados ao longo do tempo. No primeiro momento, durante a judicatura do Tribunal do Império, a interpretação restritiva representava, sob o ponto de vista prático, a negação de tutela ao comprador, que deveria se valer somente das possibilidades de anulação do negócio jurídico com base nos vícios da vontade. Na década de 1970, porém, o BGH passa a desenvolver e a aplicar a responsabilização por danos causados em função da falha ao dever de informar, fundada na boa-fé. ${ }^{188}$ Inicialmente concebida em âmbito jurisprudencial, ${ }^{189}$ a teoria que foi designada como responsabilidade pela culpa in

\footnotetext{
${ }^{1183}$ JAGERSBERGER, Barbara. Die Haftung des Verkäufers beim Unternehmenskauf- und Anteilskauf. Op. cit., p. 64.

${ }^{1184}$ LORENZ, Stephan. “Der Unternehmenskauf nach der Schuldrechtsreform”. Op. cit., p. 309.

${ }^{1185}$ GAUL, Björn. "Schuldrechtsmodernisierung und Unternehmenskauf”. Op. cit., p. 40.

${ }^{1186}$ WELLER, Marc-Philippe. "Sachmängelhaftung beim Unternehmenskauf”. Op. cit., p. 845.

${ }^{1187}$ LORENZ, Stephan. "Der Unternehmenskauf nach der Schuldrechtsreform”. Op. cit., p. 310.

${ }^{1188}$ LORENZ, Stephan. "Der Unternehmenskauf nach der Schuldrechtsreform". Op. cit., p. 310.

1189 FLEISCHER, Holger. Informationsasymmetrie im Vertragsrecht. Op. cit., pp. 416-468; NIRK, Rudolf. "Culpa in contrahendo: eine richterliche Rechtsfortbildung in der Rechtsprechung des
} 
contrahendo posteriormente foi codificada no âmbito da reforma do direito das obrigações (BGB, §311, Abs. 2, I). Diversamente da responsabilidade edilícia, ela pressupõe a culpa em sentido subjetivo e, antes da reforma do direito das obrigações, prescrevia no prazo ordinário da responsabilidade civil extracontratual, então de trinta anos. ${ }^{1190}$

Essa responsabilidade pela culpa in contrahendo mostrou-se mais apta a oferecer tutela ao comprador de participações societárias de controle, ao mesmo tempo em que compunha de forma mais ponderada os interesses contrapostos de vendedor e comprador. Como aponta STEPHAN LORENZ, a restrição do conceito de vícios da coisa na compra e venda de empresas sofreu uma mutação em sua original função de limitação da responsabilidade e passou a representar uma ampliação da possibilidade de responsabilização do vendedor, de tal forma que, quanto mais restritiva a definição de vício da coisa, mais amplo o âmbito de aplicação da culpa in contrahendo. ${ }^{1191}$ Ao mesmo tempo, representou para o vendedor uma medida mais equilibrada, por exigir a verificação concreta da culpa, aferida pelo conhecimento, ou, ao menos, pela possibilidade de conhecimento acerca do vício em questão. No caso da compra e venda de participações societárias de controle, essa exigência de que o conhecimento do ato seja imputável ao sócio controlador implica uma demonstração de que o conhecimento concentrado nas instâncias administrativas era ou deveria ser conhecido pelo controlador, algo relevante, sobretudo, nos casos de privatização promovida por meio da compra e venda de participações societárias de controle. ${ }^{1192}$

$\mathrm{Na}$ doutrina, encontram-se posicionamentos críticos à orientação jurisprudencial. ULRICH IMMENGA considerou-a como expressão de uma concepção físicoobjetiva do vício da coisa vendida, a qual deveria ser substituída por um conceito funcional

Bundesgerichtshofes". In: HEFERMEHL, Wolfgang (coord., et. al.). Festschrift für Philipp Möhring zum 65. Geburtstag. München/Berlin: C. H. Beck, 1965, pp. 385-418; LARENZ, Karl. "Bemerkungen zur Haftung für culpa in contrahendo". In: FLUME, Werner (coord., et. al.). Beiträge zum Zivil- und Wirtschaftsrecht - Festschrift für Kurt Ballerstedt zum 70. Geburtstag. Berlin: Duncker \& Humblot, 1975, pp. 397-419;

1190 WESTERMANN, Harm P. "Neuere Entwicklungen der Verkäuferhaftung beim Kauf von Unternehmensbeteiligungen". Op. cit., p. 58.

1191 LORENZ, Stephan. "Der Unternehmenskauf nach der Schuldrechtsreform". Op. cit., p. 311; WILLEMSEN, Heinz Josef. "Zum Verhältnis von Sachmängelhaftung und culpa in contrahendo beim Unternehmenskauf”. In: AcP, v. 182, 1982, pp. 515-572, pp. 553-554 (apontando que a culpa in contrahendo foi utilizado pelo BGH como um mecanismo substitutivo para a limitada proteção edilícia conferida ao comprador na compra e venda de empresas).

1192 SCHWEITZER, Heike. "Zurechnung vom Wissen beim Unternehmenskauf”. In: EGER, Thomas (coord., et. al.). Internationalisierung des Rechts und seine ökonomische Analyse - Festschrift für Hans-Bernd Schäfer zum 65. Geburtstag. Wiesbaden: Gabler, 2008, pp. 559-573, p. 564. 
e subjetivo, pautado pela avaliação concreta das partes sobre a coisa. ${ }^{1193}$ Para PETER HOMMELHOFF, passivos societários não seriam, a princípio, vícios redibitórios da empresa, mas assim deveriam ser tratados caso sua ausência fosse assegurada pelo vendedor. ${ }^{194}$ Houve quem defendesse, por fim, que sequer seria o caso de tratar informações falsas relativas ao faturamento e à rentabilidade como vícios redibitórios, sendo de se mencionar a posição de CANARIS e GERD MÜLLER no sentido de que a descoberta dos vícios deveria levar à revisão do contrato por representar alteração da base do negócio jurídico pressuposta pelas partes. ${ }^{195} \mathrm{Na}$ prática contratual, considerava-se que a sujeição da responsabilidade do vendedor à regra dos vícios redibitórios seria inadequada, por permitir a redibição à escolha do comprador; e que a solução com base na culpa in contrahendo, por outro lado, estaria vinculada a um prazo prescricional demasiadamente longo, de trinta anos, incompatível com o interesse das partes. ${ }^{1196}$ Como consequência, os contratantes recorriam frequentemente à celebração de contratos autônomos de garantia (selbständige Garantieverträge), por meio dos quais afastavam o regramento legal e moldavam o âmbito de responsabilidade do vendedor, em linha com a prática contratual anglo-saxônica. ${ }^{197}$

Com a reforma do direito das obrigações, transformações relevantes ocorreram no campo do regime de inadimplemento e dos prazos prescricionais. O conceito de vício foi alterado para incluir a falta de qualidade (Beschaffenheit) comum em coisas do mesmo gênero que o comprador poderia legitimamente esperar encontrar (BGB, §434, Abs. 1, 2). Foi abandonada a antiga possibilidade de o comprador decidir livremente pelo direito de redibir ou minorar, herdada do direito romano. ${ }^{198}$ Em caso de inadimplemento ou de entrega de coisa cominada por vícios redibitórios, o comprador deve, em primeiro lugar, assinalar prazo para que o vendedor substitua a coisa ou elimine os defeitos

${ }_{1193}$ IMMENGA, Ulrich. “Fehler oder zugesicherte Eigenschaft?”. In: AcP, v. 171, 1917, pp. 1-18.

1194 HOMMELHOFF, Peter. Die Sachmängelhaftung beim Unternehmenskauf. Köln/Berlin/Bonn/München: Carl Heymann, 1975, p. 89.

1195 CANARIS, Claus-Wilhelm. "Leistungsstörungen beim Unternehmenskauf". Op. cit.; MÜLLER, Gerd. “Umsätze und Erträge - Eigenschaften der Kaufsache?”. In: ZHR, v. 147, 1983, pp. 501-543, pp. 537-541.

${ }^{1196}$ HOMMELHOFF, Peter. "Der Unternehmenskauf als Gegenstand der Rechtsgestaltung”. In: ZHR, v. 150, 1986, pp. 254-278, p. 273-274.

${ }^{1197}$ JAGERSBERGER, Barbara. Die Haftung des Verkäufers beim Unternehmenskauf- und Anteilskauf. Op. cit., p. 79; HUBER, Ulrich. "Die Praxis des Unternehmenskaufs im System des Kaufrechts". Op. cit., p. 211.

${ }^{1198}$ CALVO, Roberto. "Vendita e rimedi nel diritto tedesco: dalla 'garanzia' all'inadempimento". In: Riv. dir. civ., 2013, pp. 297-307, p . 298 (para quem a reforma do direito das obrigações na Alemanha teria representado o "definitivo distacco dall'antico ius aedilicium"). 
encontrados (BGB, § 281, Abs. 1). ${ }^{1199}$ A resolução do contrato, ademais, não é possível se o vício não for relevante (BGB, § 281, Abs. 2). Os prazos prescricionais foram alterados para dois anos, em caso de vícios redibitórios, e para três anos, no caso de responsabilidade derivada de culpa in contrahendo. ${ }^{1200} \mathrm{Na}$ exposição de motivos da reforma legislativa, há referência expressa à compra e venda de empresas. Na opinião do legislador, os motivos práticos que levaram o BGH a adotar uma interpretação restritiva do que seriam vícios redibitórios da empresa não estariam presentes no novo regramento do direito das obrigações, entre outros, porque seria conferido ao vendedor o direito de eliminar os defeitos encontrados, não mais se permitindo que o comprador simplesmente resolvesse o contrato, além de ser dado novo tratamento, mais adequado, à questão da prescrição. ${ }^{1201}$

Na doutrina, a despeito disso, permaneceu o debate sobre a possibilidade de se considerar que informações relativas aos bens e direitos integrantes do estabelecimento empresarial poderiam ser tratados como vícios redibitórios. Parte da literatura considerou ter havido um alargamento das situações que poderiam ser enquadradas como vícios redibitórios da própria empresa, para incluir afirmações do vendedor sobre a rentabilidade da companhia, faturamento, nível de endividamento ou a ausência de passivos não contabilizados, sem a necessidade de que o vendedor prestasse garantia expressa a respeito de tais circunstâncias. ${ }^{1202}$ Tal posicionamento, contudo, é contrariado por parte da doutrina que entende que, tal qual ocorria antes da reforma do direito das obrigações, o conceito de vício redibitório na compra e venda de empresas deveria ser interpretado restritivamente. ${ }^{1203}$

${ }^{1199}$ CANARIS, Claus-Wilhelm. "O novo direito das obrigações na Alemanha". In: Revista Brasileira de Direito Comparado, 2004, pp. 3-26, p. 22.

${ }^{1200}$ GAUL, Björn. "Schuldrechtsmodernisierung und Unternehmenskauf". Op. cit., p. 44.

1201 DEUTSCHER BUNDESTAG. "Entwurf eines Gesetzes zur Modernisierung des Schuldrechts". Op. cit., p. 242.

${ }^{1202}$ CANARIS, Claus-Wilhelm. "Leistungsstörungen und Gewährleistung beim Unternehmenskauf nach der Reform des deutschen Schuldrechts". In: STATHOPOULOS, Michael (coord., et. al.). Festschrift für Apostolos Georgiades zum 70. Geburtstag. München: C. H. Beck/Sakkoulas/Stämpfli, 2006, pp. 71-94, pp. 85-86; BERGJAN, Ralf. Die Auswirkungen der Schuldrechtsreform 2002 auf den Unternehmenskauf. Op. cit., p. 154; GAUL, Björn. "Schuldrechtsmodernisierung und Unternehmenskauf”. Op. cit.; WOLF, Manfred; KAISER, Jochen. "Die Mängelhaftung beim Unternehmenskauf nach neuem Recht". Op. cit., p. 414; SCHRÖCKER, Stefan. "Unternehmenskauf und Anteilskauf nach der Schuldrechtsreform”. In: ZGR, 2005, pp. 63-100, p. 78.

1203 LORENZ, Stephan. "Der Unternehmenskauf nach der Schuldrechtsreform”. Op. cit., pp. 319-320; JAGERSBERGER, Barbara. Die Haftung des Verkäufers beim Unternehmenskauf- und Anteilskauf. Op. cit., p. 152; GRIGOLEIT, Hans Christoph; HERRESTHAL, Carsten. "Grundlagen der Sachmängelhaftung im Kaufrecht”. In: JZ, 2003, pp. 118-127, p. 125; WEITNAUER, Wolfgang. "Der 
Sintetizando, pode-se afirmar que, na Alemanha, prevalece na doutrina e na jurisprudência o entendimento favorável à possibilidade de a compra e venda de participações societárias de controle majoritário - ou seja, na qual remanesça quantidade inexpressiva de ações ou quotas sob a titularidade dos demais sócios - ser equiparada à compra e venda da própria empresa (Unternehmenskauf), deixando então de ser tratada como mera compra e venda de direitos (Rechtskauf). A efetiva aplicação da disciplina dos vícios redibitórios aplicáveis às coisas, contudo, não prospera - senão marginalmente - em matéria de compra e venda de empresas ou compra e venda participações societárias de controle (equiparada à compra de empresas), por a jurisprudência adotar um conceito restritivo do que seriam vícios da coisa. A proteção efetiva do comprador, nessa medida, baseia-se na disciplina da responsabilidade subjetiva do vendedor por falha ao dever de informar decorrente da boa-fé na fase pré-contratual, resumida na disciplina da culpa in contrahendo.

b) Itália

Na Itália, já se apontou ${ }^{1204}$ que prevalece largamente a visão de que a compra e venda de participações societárias de controle, ou mesmo da participação totalitária, não deve ser equiparada à compra e venda da empresa.

No âmbito específico da tutela do comprador, a doutrina e a jurisprudência que sustentam a distinção entre a compra e venda de participações societárias de controle e a alienação dos bens sociais ou do controle são francamente majoritárias. ${ }^{1205}$ Resumindo o

Unternehmenskauf nach neuem Kaufrecht". Op. cit., p. 2514; HUBER, Ulrich. "Die Praxis des Unternehmenskaufs im System des Kaufrechts". Op. cit., p. 224;

${ }^{1204}$ Sobre o assunto, cf. item I.A.2, supra.

${ }^{1205}$ Nesse sentido, PUGLIATTI, Salvatore. "Vendita di azioni e garanzia per evizione". Op. cit., p. 90-92; PANZARINI, Elisabetta. "Cessione di pacchetti azionari: il contenuto delle clausole di garanzia". Op. cit., p. 257-261; ROVELLI, Luigi. "Natura della vendita del pacchetto azionario". Op. cit.; CARNEVALI, Ugo. "Garanzie per vizi dei beni sociali nella cessione di azioni". Op. cit.; BONELLI, Franco. "Giurisprudenza e dottrina su acquisizioni di società e di pacchetti azionari di riferimento". Op. cit., p. 19; PETRUCCI, Anna Maria. "Cessione di pacchetti azionari e dolo del venditori". Op. cit., p. 386-387; CAMPOBASSO, Mario. "Vendita del pacchetto azionario di società in liquidazione per perdite". Op. cit., pp. 378-380; ANGELICI, Carlo. "La partecipazione azionaria come oggetto di circolazione". Op. cit., pp. 108 e 116; SCARSO, Alessandro. "La responsabilità del venditore di partecipazioni sociali nel diritto italiano e tedesco". Op. cit., p. 459-466; IUDICA, Giovanni. "Il prezzo nella compravendita di partecipazioni azionarie". Op. cit., p. 767; 
quadro vigente na Itália, BONELLI considera que "a grande maioria da doutrina entende que o sócio, vendendo ações, não transfere os bens sociais, que pertencem à sociedade e somente a ela, mas transfere algo muito diverso e inconfundível, que é precisamente a sua cota de participação na sociedade". ${ }^{1206}$ As consequências dessa orientação são de que, na ausência de pacto expresso que considere especificamente a qualidades dos bens da sociedade, o comprador não pode invocar nenhuma garantia ou tutela como a redução do preço ou o ressarcimento de danos, ou mesmo a resolução contratual, ainda que os bens sociais apresentam consistência ou características diversas daquelas consideradas pelas partes no momento da determinação do preço e da estipulação do contrato. ${ }^{1207}$

$\mathrm{Na}$ ausência de cláusula específica de garantia, portanto, o posicionamento majoritário da doutrina e da jurisprudência é no sentido de que o dispositivo que impõe ao vendedor o dever de garantir que a coisa seja isenta de vícios (Codice civile, art. 1490) não abrange o dever de o vendedor de participações societárias de controle garantir a ausência, por exemplo, de passivos ocultos ou de vícios na composição patrimonial da sociedade. ${ }^{1208}$ Sem que haja uma particular garantia, ademais, considera-se que um vício relativo a um elemento do patrimônio societário não pode representar falta de qualidade prometida em relação à coisa vendida (Codice civile, art. 1497). ${ }^{1209}$

$\mathrm{Na}$ hipótese em que o vendedor declara que o patrimônio da sociedade apresenta determinadas qualidades, em linha com a prática anglo-saxônica das representations, contudo, questiona-se se estaria configurada uma promessa de qualidade das participações sociais alienadas, ${ }^{1210}$ de tal forma que o objeto do contrato de compra e venda passaria a ser integrado pelas ações ou quotas caracterizadas pela referência a

PINTO, Maurizio. "Le garanzie 'patrimoniali' nella vendita di partecipazioni azionarie di controllo: qualificazione giuridica e termini di prescrizione". Op. cit., pp. 412-415; RUBINO-SAMMARTANO, Mauro. Garanzie nella compravendita di pacchetti azionari e di imprese. Op. cit., p. 45; SPERANZIN, Marco. Vendita delle partecipazione di 'controllo' e garanzie contrattuali. Op. cit., p. 13; TINA, Andrea. Il contratto di acquisizione di partecipazioni societarie. Op. cit., pp. 172-177.

${ }^{1206}$ BONELLI, Franco. "Giurisprudenza e dottrina su acquisizioni di società e di pacchetti azionari di riferimento". Op. cit., pp. 18-19 ("La grande maggioranza della dottrina ritiene che il socio, vendendo le azioni, non trasferisca $i$ beni sociali, che appartengono alla società e soltanto ad essa, ma trasferisca qualcosa di ben diverso ed inconfondibile, e precisamente la sua quota di partecipazione nella società.).

${ }_{1207}$ BONELLI, Franco. "Giurisprudenza e dottrina su acquisizioni di società e di pacchetti azionari di riferimento". Op. cit., pp. 19.

1208 SPERANZIN, Marco. Vendita delle partecipazione di 'controllo' e garanzie contrattuali. Op. cit., p. 12; TINA, Andrea. Il contratto di acquisizione di partecipazioni societarie. Op. cit., pp. 207-209.

${ }^{1209}$ PINTO, Maurizio. "Le garanzie 'patrimoniali' nella vendita di partecipazioni azionarie di controllo: qualificazione giuridica e termini di prescrizione". Op. cit., p. 415.

${ }^{1210}$ PINTO, Maurizio. "Le garanzie 'patrimoniali' nella vendita di partecipazioni azionarie di controllo: qualificazione giuridica e termini di prescrizione”. Op. cit., p. 421. 
determinada circunstância patrimonial da sociedade. A Corte di Cassazione, desde a década de 1960, responde positivamente a esse questionamento e admite que o comprador resolva o contrato na forma do art. 1497 do Codice civile quando o patrimônio societário referido não corresponde ao prometido. Isso não obstante o fato de que o dispositivo normativo em questão pressuponha que a falta de qualidade prometida seja da coisa vendida (cosa venduta) $)^{1211}$ e, no caso, o objeto do negócio jurídico sejam ações ou quotas. Para exercer tal direito de resolução, contudo, o comprador deve denunciar o vício no prazo de 8 (oito) dias da descoberta, sob pena de decadência (Codice civile, art. 1495). ${ }^{1212}$

A posição da jurisprudência é criticada na doutrina. Afirma-se que as partes não teriam autonomia para estender a disciplina dos vícios redibitórios especificando qualidades que não se referam diretamente à coisa vendida; ${ }^{1213}$ que a jurisprudência incorreria em contradição lógica ao considerar que os aspectos patrimoniais da sociedade não seriam objeto do contrato, mas justificariam a resolução em caso de falta de qualidade prometida; ${ }^{1214}$ e que o artigo 1497 seria aplicável somente a coisas, sendo inadequada sua extensão a participações societárias, até pelo curto prazo decadencial de oito dias previsto para denúncia do vício. ${ }^{1215}$ A orientação "quase unânime"1216 da doutrina e da jurisprudência arbitral $^{1217}$ é no sentido de que o art. 1497 não deveria ser aplicado na compra e venda de participações societárias de controle, ainda que o vendedor afirmasse a presença de determinada conformação patrimonial. ${ }^{1218}$

1211 PINTO, Maurizio. "Le garanzie 'patrimoniali' nella vendita di partecipazioni azionarie di controllo: qualificazione giuridica e termini di prescrizione". Op. cit., p. 422.

1212 PINTO, Maurizio. "Le garanzie 'patrimoniali' nella vendita di partecipazioni azionarie di controllo: qualificazione giuridica e termini di prescrizione". Op. cit., p. 424.

1213 ANGELICI, Carlo. "La partecipazione azionaria come oggetto di circolazione". Op. cit., p. 116.

1214 TINA, Andrea. Il contratto di acquisizione di partecipazioni societarie. Op. cit.; SPERANZIN, Marco. Vendita delle partecipazione di 'controllo' e garanzie contrattuali. Op. cit., p. 95.

1215 CARNEVALI, Ugo. "Compravendita di quote sociali, mancanza di qualità e aliud pro alio". In: Contratti, 2004, pp. 687-694, p. 694.

1216 TINA, Andrea. Il contratto di acquisizione di partecipazioni societarie. Op. cit., pp. 300-301.

1217 SPERANZIN, Marco. "Le clausole relative all'oggetto 'indiretto' (il patrimonio sociale); garanzie sintetiche e garanzie analitiche”. In: IRRERA, Maurizio (org.). Le acquisizioni societarie. Bologna: Zanichelli, 2011, pp. 193-210, p. 199.

${ }_{1218}$ VALSERRA, Fabrizio. "La vendita di quote o di azioni non è vendita dei beni sociali". In: Dir. fall., 1952, I, pp. 473-476, p. 475; PANZARINI, Giovanni. "La tutela dell'acquirente nella vendita dei titoli di credito". Op. cit., p. 291; BONELLI, Franco. "Giurisprudenza e dottrina su acquisizioni di società e di pacchetti azionari di riferimento". Op. cit., p. 29; IUDICA, Giovanni. "Il prezzo nella compravendita di partecipazioni azionarie". Op. cit., p. 767-769; PANZARINI, Elisabetta. "Cessione di pacchetti azionari: il contenuto delle clausole di garanzia". Op. cit., p. 330, nota 167; DE RITIS, Massimo R. "Trasferimento di pacchetti azionari di controllo: clausole contrattuali e limiti all'autonomia privata". In: Giur. comm., I, 1997, pp. 879-906, p. 886; SCARSO, Alessandro. "La responsabilità del venditore di partecipazioni sociali nel diritto italiano e tedesco". Op. cit., p. 486; MONTALENTI, Paolo. "Le acquisizioni societarie - profili 
Depreende-se do quanto se apontou que prevalece na doutrina e na jurisprudência italianas a orientação de que os vícios dos elementos integrantes do patrimônio societário não representam vícios das quotas ou ações de controle alienadas. No caso de o vendedor ter prestado declaração no sentido de que o patrimônio societário teria determinadas características que depois se revelam ausentes, a jurisprudência considera que haveria falta de qualidade prometida da coisa vendida, posição que não é compartilhada pela doutrina majoritária.

c) França

No direito francês, em um primeiro momento, houve quem rejeitasse completamente a possibilidade de se aplicar a responsabilidade do vendedor por vícios redibitórios na cessão de participações societárias. De um lado, afirmava-se que as ações edilícias tiveram origem nos edis curuis, visando à venda de animais ou escravos e que, por mais que tenham tido seu âmbito de aplicação estendido pata alcançar outros bens, pressuporiam a corporeidade e a possibilidade de exame da coisa pelo comprador e vendedor. ${ }^{1219}$ De outro, afirmava-se que a cessão de participações societárias seriam modalidade de cessão de crédito contra a sociedade, cabendo ao cedente, como regra, garantir apenas a existência do crédito, não a solvência da sociedade em relação ao cessionário. ${ }^{1220}$ Esses entendimentos hoje podem ser considerados como superados. A crescente relevância da propriedade incorpórea levou à aceitação da aplicação das garantias edilícias também para os bens que não fossem tangíveis. ${ }^{1221}$ A Cour de cassation, ademais, passou a admitir que o cedente de participações societárias não deveria responder somente pela existência de um crédito, passando a considerar que o vendedor deveria garantir a ausência de vícios ocultos na coisa vendida. ${ }^{1222}$

contrattuali”. In: Persona giuridica, gruppi di società, corporate governance. Torino: CEDAM, 1999, pp. 147-163, p. 160. Contra: PINTO, Maurizio. "Le garanzie 'patrimoniali' nella vendita di partecipazioni azionarie di controllo: qualificazione giuridica e termini di prescrizione”. Op. cit., pp. 440-447.

${ }^{1219}$ CAFFIN-MOI, Marie. Cession de droits sociaux et droit des contrats. Op. cit., n. 331, p. 218.

${ }^{1220}$ CAFFIN-MOI, Marie. Cession de droits sociaux et droit des contrats. Op. cit., n. 331, p. 219.

${ }^{1221}$ CAFFIN-MOI, Marie. Cession de droits sociaux et droit des contrats. Op. cit., n. 331, p. 218.

${ }^{1222}$ CAFFIN-MOI, Marie. Cession de droits sociaux et droit des contrats. Op. cit., n. 332, p. 220. 
As consequências dessa aceitação da aplicabilidade da disciplina dos vícios ocultos à compra e venda de participações societárias deve ser bem compreendida. Afirmar que o vendedor de ações ou quotas responde por vícios redibitórios das participações societárias não é o mesmo que afirmar que questões relativas ao patrimônio da sociedade representariam vícios das próprias ações ou quotas.

Para a aplicação do artigo 1641 do Código Civil Francês, o vício deve decorrer de um defeito da própria coisa, e não de uma diminuição das vantagens que essa coisa proporcione. No negócio jurídico de alienação de ações ou quotas, as circunstâncias do patrimônio societário não são um vício oculto da compra e venda. Em 1990, a Cour de cassation decidiu que "a revelação de passivo físcal não constitui um vício redibitório dos direitos sociais cedidos, pois a dívida não afeta as próprias partes sociais, mas somente seu valor". ${ }^{1223}$ Em 1995, enfrentou novamente a questão: o adquirente da totalidade das ações de uma sociedade que explorava um hotel foi obrigado a realizar diversos reparos no estabelecimento para que a sociedade pudesse operá-lo. Nesse caso, a Corte de Apelação (Cour d'appel) de Colmar entendera que a impossibilidade de explorar o hotel por força de uma restrição administrativa reduzira a possibilidade de o adquirente auferir dividendos por meio das ações, constituindo assim um vício redibitório das próprias ações. O julgado foi reformado pela Cour de cassation, que julgou que "a não conformidade das locações às normas de segurança não constitui vício que afeta as ações cedidas, pois a sociedade poderia ter continuado a exercer a atividade econômica que constitui seu objeto social com despesas suplementares." ${ }^{1224}$ Em 2004, a Cour de cassation julgou caso de alienação de controle acionário de sociedade com passivos ocultos, não revelados ao comprador. Quatro meses após a transferência de controle, a sociedade tornou-se insolvente e ingressou com procedimento recuperacional (redressement judiciaire). Ainda assim, adotou-se interpretação restritiva entendendo que, naquele caso, não foram somente os passivos ocultos que impediram a sociedade de perseguir seu objeto social. ${ }^{1225}$

O que se pode depreender de tais decisões é que, para a Cour de cassation, as condições patrimoniais da sociedade não constituem um vício oculto das próprias ações

\footnotetext{
${ }^{1223}$ Cass. com. 23.01.1990 apud CAFFIN-MOI, Marie. Cession de droits sociaux et droit des contrats. $O p$. cit., n. 340, p. 223.

${ }^{1224}$ Cass. com. 12.12.1995 apud CAFFIN-MOI, Marie. Cession de droits sociaux et droit des contrats. $O p$. cit., n. 341, p. 224.

${ }^{1225}$ CAFFIN-MOI, Marie. Cession de droits sociaux et droit des contrats. Op. cit., n. 356, p. 233.
} 
ou quotas; tal vício somente seria admitido na hipótese excepcional em que o adquirente se visse impedido de exercer o controle societário por meio das ações ou quotas porque a própria sociedade não poderia mais perseguir sua atividade econômica. ${ }^{1226}$ Mesmo o critério da impossibilidade de exercício da atividade, porém, é interpretado de forma rigorosa, pois, como aponta MARIE CAFFIN-MOI, a jurisprudência se recusa a considerar que haja vícios redibitórios nos títulos cedidos se a sociedade puder exercer sua atividade de qualquer maneira concebível, de tal forma que os cessionários nunca obtiveram ganho de causa fundando sua argumentação na existência de vícios ocultos. ${ }^{1227}$

O critério apresentado pela jurisprudência é criticado por parte da doutrina que o considera extremamente restritivo. ${ }^{1228}$ Para CAFFIN-MoI, contudo, mesmo essa limitada possibilidade de acionar a garantia por vícios ocultos seria equivocada. A postura jurisprudencial desrespeitaria a autonomia da personalidade jurídica, além de ser imprecisa, pois não se saberia, por exemplo, se a impossibilidade de exercício da atividade teria por referência o objeto social estatutário, ou o objeto social real, e o que seria necessário para afirmar a impossibilidade do exercício da atividade. ${ }^{1229}$

$\mathrm{Na}$ prática, a proteção dos cessionários se dá sobretudo por meio da aplicação do regime do dolo por omissão (réticence dolosive), ${ }^{1230}$ nas hipóteses em que, de acordo com o dever pré-contratual de informação, o vendedor deveria informar o comprador acerca de informações relativas às circunstâncias patrimoniais da sociedade. ${ }^{1231}$ Há, ademais, a possibilidade de tutela pela ocorrência de dolo comissivo na hipótese em que as chamadas declarações e garantias prestadas pelo vendedor se revelam falsas. ${ }^{1232}$ Agrega-se, por fim, a possibilidade de ação por adimplemento imperfeito (obligation de

\footnotetext{
${ }^{1226}$ PAILlUSSEAU, Jean (et. al.). Cession d'entreprise. $4^{\text {a }}$ ed. Paris: Dalloz, n. 1721, p. 300; COZIAN, Maurice; VIANDIER, Alain; DEBOISSY, Florence. Droit des sociétés. Op. cit., n. 783, p. 417.

${ }^{1227}$ CAFFIN-MOI, Marie. Cession de droits sociaux et droit des contrats. Op. cit., n. 375, p. 247 (o livro resulta de tese apresentada em novembro de 2007).

${ }^{1228}$ VIANDIER, Alain. "La protection du cessionnaire en cas de cession de contrôle". Op. cit., p. 325; PAILLUSSEAU, Jean. "La cession de contrôle et la situation financière de la société cédée (de la nature juridique du contrôle et de la cession de contrôle)". Op. cit., p. 198.

${ }_{1229}$ CAFFIN-MOI, Marie. Cession de droits sociaux et droit des contrats. Op. cit., n. 358, p. 235.

${ }^{1230}$ MOUSSERON, Pierre. "L'obligation de renseignement dans les cessions de contrôle". Op. cit., n. 362. Sobre o dever de informar no direito francês, cf. JUGLART, Michel. "L'obligation de renseignements dans les contrats". In: RTDeiv, 1945, pp. 1-22; FABRE-MAGNAN, Muriel. De l'obligation d'information dans les contrats: essai d'une théorie. Op. cit.

${ }^{1231}$ COZIAN, Maurice; VIANDIER, Alain; DEBOISSY, Florence. Droit des sociétés. Op. cit., n. 804, p. 428.

${ }^{1232}$ CAFFIN-MOI, Marie. Cession de droits sociaux et droit des contrats. Op. cit., n. 599, p. 383.
} 
délivrance conforme) quando são prestadas declarações e garantias que definem no caso concreto o contorno da obrigação do vendedor. ${ }^{1233}$

d) Espanha

Na Espanha, a jurisprudência do Tribunal Supremo prevalecente é no sentido de que a compra e venda de ações ou quotas não poderia ser equiparada à compra e venda de empresas para fins de aplicação das ações edilícias. Em um caso julgado em 2009, tratou-se da compra e venda de ações de uma sociedade anônima que explorava atividade hoteleira. Após a venda, descobriu-se que o imóvel em que estava situado o hotel fora afetado por aluminose, um defeito estrutural resultante da degradação do concreto, de tal forma que a segurança dos hóspedes não poderia ser garantida. O comprador pleiteou judicialmente a declaração de inadimplemento do contrato e, subsidiariamente, a minoração do preço com base na presença de vícios ocultos. O Tribunal Supremo, porém, avaliou que o objeto do contrato seriam apenas ações, e não o hotel. ${ }^{1234}$ Em outra decisão, de 2011, o mesmo Tribunal Supremo julgou hipótese de compra e venda da totalidade das ações de uma sociedade anônima. Durante a fase de auditoria, o comprador avaliou que a companhia teria alta lucratividade, mas, depois de assumir a gestão, descobriu a existência de passivos não revelados de significativa expressão, os quais levaram a sociedade a situação falimentar. O comprador ingressou com ação para obter a redibição do contrato (pretensión de saneamiento por vicios ocultos), com pedido subsidiário de anulação por dolo. O Tribunal Supremo rejeitou o pleito. Apesar de reconhecer que, economicamente, a alienação de todas as ações de uma sociedade implica a do patrimônio da mesma, considerou que "essa visão econômica não basta para tratar a venda de ações com uma norma que está prevista para solucionar anomalias surgidas no funcionamento de coisas específicas". 1235

\footnotetext{
${ }^{1233}$ CAFFIN-MOI, Marie. Cession de droits sociaux et droit des contrats. Op. cit., n. 604, pp. 386-387.

${ }^{1234}$ Tribunal Supremo, "STS de 21.12.2009" (RJ/2010|299) apud GARCÍA VICENTE, José-Ramón. "Compraventa de acciones y compraventa de empresa: defectos ocultos en el activo principal de la sociedad. Calificación e interpretación de los contratos. Causa de los contratos y móvil casualizado". Op. cit., pp. 17291746.

${ }^{1235}$ Tribunal Supremo, "STS de 30.03.2011" (RJ/2011/3133) apud GIMENO RIBES, Miguel. La protección del comprador en la adquisición de empresa. Op. cit., p. 15.
} 
A doutrina, por outro lado, posiciona-se de forma contrária a essas manifestações jurisprudenciais. Baseando-se na equiparação entre compra e venda de ações de controle e compra e venda da empresa promovida pela doutrina alemã, GIMENO RIBES critica o posicionamento jurisprudencial e defende que, nos casos julgados, deverse-ia ter superado a distinção entre o objeto formal e o objeto que considera efetivo do negócio jurídico, qual seja, a própria empresa. ${ }^{1236}$ Para outra parte da doutrina, a questão deveria ser solucionada com base na teoria da causa concreta do negócio jurídico. $\mathrm{Na}$ aquisição de ações de controle, defende-se que a causa concreta do contrato passaria a envolver a própria constituição patrimonial da sociedade, deixando o plano dos meros motivos individuais. ${ }^{1237}$

e) Portugal

No direito português, a discussão sobre a aplicação das garantias edilícias na compra e venda de participações societárias de controle era historicamente negligenciada. O posicionamento precursor sobre o a disciplina parece ${ }^{1238}$ ter sido de FERRER CORREIA quando suscitou qual deveria ser o regime aplicável à aquisição de todas as quotas por uma pessoa e posterior cessão a terceiro, defendendo que, em tal circunstância, "a venda da totalidade das aç̧ões ou das quotas terá o alcance e o significado jurídico de um verdadeiro trespasse - devendo ficar sujeita, consequentemente, a todas disposições legais concernentes a esta figura negocial". ${ }^{1239}$

${ }^{1236}$ GIMENO RIBES, Miguel. La protección del comprador en la adquisición de empresa. Op. cit., pp. 15-17. No mesmo sentido, HERNANDO CEBRIÁ, Luis. El contrato de compraventa de empresa. Op. cit., pp. 307-312; GILI SALDAÑA, Marian. "Contrato de compraventa de acciones. Incumplimiento contractual. Remedios frente al incumplimiento de las cláusulas de manifestaciones y garantías. Efectos del conocimiento del comprador en los remedios frente al incumplimiento de las manifestaciones y garantías. Comentario a la sentencia del Tribunal Supremo de 21 de diciembre de 2009”. In: CCJC, v. 86, 2011, n. 2288, pp. 10751096; SOLER PRESAS, Ana. "Tratamiento jurídico de la frustración tras la adquisición de una empresa". I Op. cit., p. 85.

1237 GARCÍA VICENTE, José-Ramón. “Compraventa de acciones y compraventa de empresa: defectos ocultos en el activo principal de la sociedad. Calificación e interpretación de los contratos. Causa de los contratos y móvil casualizado". Op. cit., pp. 1729-1746; REDONDO TRIGO, Francisco. "La causa en los contratos de compraventa de acciones. A propósito de la sentencia del Tribunal Supremo de 21 de diciembre de 2009". Op. cit., pp. 1903-1933.

1238 COUTINHO DE ABREU, Jorge Manuel. Da empresarialidade. Op. cit., p. 345 (indicando o pioneirismo de FERRER CORREIA).

${ }^{1239}$ FERRER CORREIA, António de A. Sociedades fictícias e unipessoais. Op. cit., pp. 301-302. 
Posteriormente, porém, a discussão sobre o assunto ganhou impulso por conta de um litígio de grandes proporções que envolveu a privatização da "Sociedade Financeira Portuguesa". Durante o processo de privatização de tal sociedade, foi preparado prospecto informativo, do qual não constou a concessão de duas garantias bancárias autônomas que, posteriormente, viriam a ser executadas, impondo obrigação de relevante pagamento à instituição financeira cujas ações haviam sido adquiridas. $O$ adquirente instaurou procedimento arbitral que culminou com o reconhecimento de que ocorrera falha ao dever de informar. ${ }^{1240} \mathrm{~A}$ despeito de a aplicação dos vícios redibitórios não ter sido determinante para o julgamento, a matéria foi discutida no âmbito dos diversos pareceres solicitados pelas partes para instruir o feito, incluindo-se entre os jurisconsultos que se manifestaram professores de renome como Ferrer Correia, Almeno de SÁ, Menezes Cordeiro, InOcÊnCIO Galvão Telles, Jõ̃o CALVÃo dA Silva, entre outros. O tribunal foi ainda integrado por MÁRIO JÚLIO DE ALMEIDA COSTA. ${ }^{1241}$

Nesse litígio e na doutrina que a ele se seguiu, passou-se à orientação de que a aplicação da disciplina dos vícios redibitórios ao contrato de compra e venda de participações societárias de controle dependeria da interpretação da vontade concreta das partes. $^{1242}$ Caso pudesse ser constatada que a intenção se dirige à negociação do patrimônio, valendo-se das participações societárias como mero instrumento de mobilização, a disciplina aplicável deveria ser a pertinente ao trespasse.

$\mathrm{Na}$ presença de vícios redibitórios (Código Civil Português, art. 913º), porém, a legislação determina a aplicação do regime de anulabilidade por erro ou dolo (Código Civil Português, art. 904), razão pela qual a conceituação dos defeitos dos ativos

\footnotetext{
1240 “Acórdão do Tribunal Arbitral”. In: NUNES, Arlindo Monteiro (org.). A privatização da sociedade financeira portuguesa. Lisboa: LEX, 1995, pp. 35-75, p. 51.

1241 Tanto o laudo arbitral quanto os pareceres proferidos em favor do comprador foram posteriormente reunidos em livro. Cf. NUNES, Arlindo Monteiro (org.). A privatização da sociedade financeira portuguesa. Lisboa: LEX, 1995.

1242 FERRER CORREIA, A.; SÁ, Almeno de. "Parecer". Op. cit., p. 272; MONTEIRO, António Pinto; MOTA PINTO, Paulo. "Compra e venda de empresa: a venda de participações sociais como venda de empresa (share deal)". Op. cit., p. 88; ANTUNES, José Engrácia. "A empresa como objecto de negócios ('asset deal" vs. "share deal')". Op. cit., pp. 731-732; GALVÃO, Clemente. "Conteúdo e incumprimento do contrato de compra e venda de participações sociais". Op. cit., pp. 533-573; COUTINHO DE ABREU, Jorge Manuel. Da empresarialidade. Op. cit., p. 351.

${ }^{1242}$ Tanto o laudo arbitral quanto os pareceres proferidos em favor do comprador foram posteriormente reunidos em livro. Cf. NUNES, Arlindo Monteiro (org.). A privatização da sociedade financeira portuguesa. Op. cit., 1995.
} 
como vícios redibitórios parece impor nesse ordenamento diferenças de regime jurídico menos relevantes que em outros países.

$\mathrm{Na}$ jurisprudência, dá-se notícia da existência de duas dezenas de decisões. Nesse apanhado, prevaleceriam arestos determinando a aplicação das disciplinas do erro e da responsabilidade pré-contratual por violação ao dever de informação. ${ }^{1243}$

2. Inaplicabilidade da disciplina dos vícios redibitórios em relação ao patrimônio societário

As manifestações na doutrina brasileira sobre a aplicação da disciplina dos vícios redibitórios no caso de vícios no patrimônio societário não é numerosa. De forma geral, os autores que se posicionam sobre a matéria tendem a impor ao vendedor responsabilidade pelas garantias edilícias baseando-se no argumento de que a cessão do controle societário deveria ser equiparada à compra e venda da empresa. É o que ocorre nas obras seminais de Comparato ${ }^{1244}$ e de Cunha Pereira, ${ }^{1245}$ que se manifestam de forma favorável a tal equiparação. EvandRo PONTES segue caminho semelhante de consideração do controle como objeto do negócio jurídico, mas defende que, na divergência entre as condições do patrimônio societário e aquelas apresentadas em declarações e garantias, seria aplicável a disciplina dos vícios da vontade (erro e dolo), ao passo que a aplicação da disciplina dos vícios redibitórios seria "de menor consistência jurídica". ${ }^{1246}$

Já foram apontadas as razões pelas quais se diverge do raciocínio que considera que a compra e venda de participações de controle teria como objeto real ou mediato o controle e, por consequência, a organização empresarial. ${ }^{1247}$ Não se julga adequadamente fundamentada, por conseguinte, a aplicação da disciplina dos vícios redibitórios ao patrimônio societário calcada em tal nivelamento.

1243 FONSECA, Patrícia Afonso. “A negociação de participações de controlo: a jurisprudência”. In: I Congresso DSR. Coimbra: Almedina, 2011, pp. 27-40, p. 290.

1244 COMPARATO, Fábio Konder; SALOMÃO FILHO, Calixto. O poder de controle na sociedade anônima. Op. cit., n. 89, p. 255.

1245 PEREIRA, Guilherme D. C. Alienação do poder de controle acionário. Op. cit., pp. 96-97.

${ }^{1246}$ PONTES, Evandro Fernandes de. Representations \& Warranties no Direito Brasileiro. Op. cit., p. 20.

${ }^{1247}$ Sobre o assunto, cf. item I.A.1, supra. 
A contribuição mais original sobre o tema dos vícios redibitórios na compra e venda de participações societárias, nesse sentido, parece ser a de CALIXTO SALOMÃo FILHO, que alterou seu posicionamento sobre o assunto, mas sempre se pautou por um raciocínio complexo, afastando-se da mera equiparação entre a compra e venda de participações societárias e o trespasse. Na década de 1980, o autor defendeu que “[d]esconsiderar a pessoa jurídica, permitindo a aplicação das regras da compra-e-venda diretamente aos bens e direitos componentes do ativo da empresa, implicaria admitir a consideração dos bens como coisa própria do controlador, ou seja, identificar controle a direito de propriedade, o que não é admissível". ${ }^{1248}$

$\mathrm{Na}$ atualização da obra de COMPARATO, porém, passou a defender a aplicabilidade da disciplina dos vícios redibitórios. A mudança de orientação de CALIXTO SALOMÃo FilHo liga-se, de um lado, a razões fáticas relacionadas à constatação de duas tendências contemporâneas; de outro, a uma análise dogmática e dos interesses envolvidos no contrato de compra e venda de participações societárias, que o autor desenvolve em rica nota de texto inserida na $6^{\mathrm{a}}$ edição da obra $O$ poder de controle na sociedade anônima.

Sob o ponto de vista fático, a primeira tendência que o autor aponta liga-se à formação de oligopólios e à crescente especialização técnica dos grupos societários, que passam a promover aquisições como técnica concentracionista, valendo-se de auditorias e da negociação de declarações e garantias que se referem aos bens do estabelecimento comercial, integrando na matéria contratual referência aos seus estados de funcionamento e qualidade. ${ }^{1249}$ A segunda tendência seria o fato de que o emprego de declarações e garantias ter-se-ia tornado "verdadeiro costume comercial" por influência dos padrões empresariais e jurídicos anglo-saxônicos. ${ }^{1250}$ Tomadas em conjunto, as duas tendências revelariam um reforço da imanência entre alienação de controle e transferência dos ativos e passivos, de tal maneira que "foram as próprias práticas comerciais estabelecidas em grande medida por compradores que vieram mais recentemente a fazer com que os bens componentes do estabelecimento viessem a ser vistos, por adquirente e alienantes das

\footnotetext{
${ }^{1248}$ SALOMÃO FILHO, Calixto. A sociedade unipessoal. Op. cit., p. 82.

1249 COMPARATO, Fábio Konder; SALOMÃO FILHO, Calixto. O poder de controle na sociedade anônima. Op. cit., nota de texto n. 53, p. 238.

1250 COMPARATO, Fábio Konder; SALOMÃO FILHO, Calixto. O poder de controle na sociedade anônima. Op. cit., nota de texto n. 53, p. 239.
} 
empresas ou de seu controle, diretamente como objeto de transferência". ${ }^{1251}$ É em razão dessas inovações no contexto fático que o autor reviu o posicionamento que adotara previamente, em linha com a tendência que considera identificável no direito estrangeiro alemão, italiano e francês de, progressivamente, admitir que a alienação de participação societária relevante seja considerada semelhante à venda da organização empresarial, aplicando-se "a disciplina dos vícios redibitórios mesmo aos casos de máculas não nos títulos negociados, mas nos bens da companhia cujas ações foram adquiridas". ${ }^{1252}$

Sob o ponto de vista dogmático da disciplina dos vícios redibitórios, o autor avança argumentos para justificar a sua aplicação tendo por referência os elementos integrantes do patrimônio societário. Em primeiro lugar, ressalta que toda o regramento do negócio jurídico, seja no âmbito do trespasse de estabelecimento, seja no âmbito do contrato comutativo de transferência de controle, sofre de uma "tendencial inadaptação das disciplinas negociais para a atividade empresarial" "1253 pela circunstância de que os atos empresariais praticados ao longo do tempo geram efeitos sobre terceiros e alteram a própria configuração da empresa, tornando o desfazimento do respectivo negócio impossível. Daí a razão pela qual a disciplina contratual do negócio de alienação de controle compatibilizar-se-ia especialmente com prazos exíguos, como os previstos no âmbito da disciplina dos vícios redibitórios. ${ }^{1254}$ As garantias edilícias, tendo sido concebidas para conferir estabilidade ao comércio, seriam peculiarmente aptas a disciplinar a atividade societária. Em segundo lugar, considera que o regime dos vícios redibitórios seria o único a tutelar de forma geral e abrangente o adquirente em contratos comutativos, razão pela qual, afastada a disciplina dos vícios redibitórios, não se teria norma específica a respeito da matéria, o que faria o aplicador reconhecer uma lacuna a ser colmatada por analogia, tendo de recorrer justamente à disciplina das garantias edilícias. ${ }^{1255}$

Após afirmar a aplicabilidade da disciplina dos vícios redibitórios, o autor passa a analisar as condições específicas de sua configuração no âmbito da alienação de

\footnotetext{
1251 COMPARATO, Fábio Konder; SALOMÃO FILHO, Calixto. O poder de controle na sociedade anônima. Op. cit., nota de texto n. 53, p. 239.

1252 COMPARATO, Fábio Konder; SALOMÃO FILHO, Calixto. O poder de controle na sociedade anônima. Op. cit., nota de texto n. 53, p. 241, nota de rodapé 22.

1253 COMPARATO, Fábio Konder; SALOMÃO FILHO, Calixto. O poder de controle na sociedade anônima. Op. cit., nota de texto n. 53, p. 241.

1254 COMPARATO, Fábio Konder; SALOMÃO FILHO, Calixto. O poder de controle na sociedade anônima. Op. cit., nota de texto n. 53, p. 242.

${ }^{1255}$ COMPARATO, Fábio Konder; SALOMÃO FILHO, Calixto. O poder de controle na sociedade anônima. Op. cit., nota de texto n. 53, p. 243.
} 
controle. Ressalta, em primeiro lugar, que o direito à redibição só se formaria na hipótese de defeitos ou superveniências que tornassem a coisa imprópria para o seu uso, ao passo que as demais deformidades apenas autorizariam o comprador a obter redução do preço. Para delimitar quais seriam os vícios que tornam a coisa imprópria para o uso, propugna a análise do objetivo concreto visado pelas partes, que poderia ser a negociação (i) da própria organização empresarial; ou (ii) de um bem material ou imaterial da sociedade, como seria o caso de uma concessão. ${ }^{1256}$ Os vícios que somente autorizariam o comprador a obter a redução do preço, por sua vez, seriam aqueles que implicam diminuição do valor da organização empresarial, devendo ser calculada a redução tendo em vista os mesmos parâmetros e métodos de avaliação adotados pelos contraentes. ${ }^{1257} \mathrm{Em}$ segundo lugar, defende a aplicação do prazo curto de um mês relativo às coisas móveis ( $\mathrm{CC}$, art. 445) ao negócio jurídico. Ainda que o controle seja um poder-dever, ele decorreria da titularidade de ações, que são bens móveis, ${ }^{1258}$ mas com a ressalva de que o prazo deve ser contado do momento da ciência ( $\mathrm{CC}$, art. $\left.445, \S 1^{\circ}\right)$. Na aquisição de controle, o autor entende necessário, contudo, "estabelecer um limite de prazo dentro do qual o vício deveria ser descoberto, sob pena de tornar a disciplina dos vícios redibitórios na realidade uma disciplina aberta, sem prazo decadencial". ${ }^{1259}$ Propõe, em virtude disso, que o conhecimento do comprador a respeito do vício deve ser presumido uma vez ocorrida a primeira assembleia geral ordinária de aprovação de contas. O controlador teria, em tal momento, o dever legal de verificar o estado patrimonial da sociedade e eventuais vícios de bens ou direitos que pudessem afetar o seu valor, não podendo alegar ignorância do vício. ${ }^{1260} \mathrm{O}$ terceiro aspecto que especifica é a regra de que os prazos decadenciais não correm na vigência de garantia, mas que impõe ao adquirente o dever de denunciar o vício descoberto em trinta dias (CC, art. 446). Para o autor, não bastaria a presença de cláusulas de "declarações e garantias" para a aplicação de tal dispositivo normativo, pois as tais “declarações e garantias" representariam somente qualidades prometidas do objeto, que seria a organização empresarial; o artigo 446 do Código Civil, por conseguinte, somente

\footnotetext{
1256 COMPARATO, Fábio Konder; SALOMÃO FILHO, Calixto. O poder de controle na sociedade anônima. Op. cit., nota de texto n. 53, p. 243.

1257 COMPARATO, Fábio Konder; SALOMÃO FILHO, Calixto. O poder de controle na sociedade anônima. Op. cit., nota de texto n. 53, p. 244.

1258 COMPARATO, Fábio Konder; SALOMÃO FILHO, Calixto. O poder de controle na sociedade anônima. Op. cit., nota de texto n. 53, p. 245, nota de rodapé 25.

1259 COMPARATO, Fábio Konder; SALOMÃO FILHO, Calixto. O poder de controle na sociedade anônima. Op. cit., nota de texto n. 53, p. 245, nota de rodapé 26.

1260 COMPARATO, Fábio Konder; SALOMÃO FILHO, Calixto. O poder de controle na sociedade anônima. Op. cit., nota de texto n. 53, p. 245, nota de rodapé 26.
} 
seria aplicável caso fosse previsto "prazo específico para reclamações e postulações relativas a certos bens, direitos ou obrigações da sociedade". ${ }^{1261}$

O posicionamento de CALIXTO SALOMÃO FILHO merece ser louvado pela contribuição original e profunda que ofereceu para o tratamento da aplicação dos vícios redibitórios na compra e venda de participações societárias. A despeito disso, discorda-se da posição apresentada pelo autor, seja porque se acredita que esteja calcada em pressupostos fáticos que não são decisivos para o adequado enfrentamento da questão, seja porque conduz a consequências jurídicas que se julga inadequadas.

Sob o ponto de vista fático, não se questiona que há uma tendência internacional de que as transações sobre ações ou quotas de controle convirjam para modelos e padrões contratuais, seja pela participação de investidores internacionais como adquirentes, seja pela importação cultural decorrente do contato entre advogados nacionais e estrangeiros, mas, sobretudo, pela necessidade de lidar com problemas recorrentes e comuns em todos os países e apontados por HeIKE SCHWEITZER, quais sejam (i) superar a assimetria informacional entre as partes; (ii) compatibilizar as diferentes expectativas e preferências dos contratantes, aumentando o valor para o comprador ou diminuindo o custo para o vendedor, o que cria riqueza que pode ser dividida entre eles; e (iii) diminuir o risco de comportamento oportunista (moral hazard) ou de, simplesmente, se inadimplir o que foi contratado. ${ }^{1262}$ É normal, portanto, que soluções contratuais adotadas em alguns países sejam transpostas para outros.

A consequência de tal fenômeno ligado à globalização não pode, porém, ser superestimada. Em primeiro lugar, porque, como demonstra a discussão sobre o assunto no direito alemão, em 1904, ${ }^{1263}$ ou em decisões italianas da década de $1930,{ }^{1264}$ bem antes de se imaginar a adoção de contratos com declarações e garantias, já era evidente que ninguém compraria ações ou quotas de uma sociedade empresarial porque é um “colecionador". ${ }^{1265}$ Ninguém duvida que o contrato que diz respeito a participações societárias em regra é pautado pelo patrimônio da sociedade, tenha ou não sido realizada

\footnotetext{
1261 COMPARATO, Fábio Konder; SALOMÃO FILHO, Calixto. O poder de controle na sociedade anônima. Op. cit., nota de texto n. 53, p. 245.

1262 SCHWEITZER, Heike. "Private Legal Transplants in Negotiated Deals". Op. cit., p. 82.

${ }^{1263}$ Sobre o assunto, cf. item V.A.1.a), supra.

${ }^{1264}$ Sobre o assunto, cf.. item V.A.1.b), supra.

${ }^{1265}$ VIANDIER, Alain. "La protection du cessionnaire en cas de cession de contrôle". Op. cit., p. 325.
} 
auditoria; tenham ou não sido negociadas cláusulas de declarações e garantia. Se a resposta dogmática acerca da aplicação da disciplina dos vícios redibitórios devesse ser pautada por tal consideração de ordem eminentemente econômica, a conclusão em qualquer quadrante e a qualquer tempo seria favorável à aplicação da disciplina dos vícios redibitórios.

Outra consequência da linha argumentativa que fundamentasse a aplicação da disciplina dos vícios redibitórios na presença de cláusulas de declarações e garantias ou na corriqueira condução de auditoria pelo comprador seria a de, potencialmente, conduzir a uma indevida e injustificada clivagem no tratamento da compra e venda de participações societárias. Seria necessário, por coerência, admitir que na compra e venda de participações societárias de sociedades limitadas ou anônimas de menor porte, ou em negócios de menor vulto, que representam a maioria dos contratos celebrados, e nos quais não há negociação de mesma magnitude (pense-se na compra e venda de bancas de jornal, por exemplo), a disciplina dos vícios redibitórios a princípio não poderia ser empregada por não serem adotadas as mesmas práticas indicativas da imanência entre realidade econômica e objeto jurídico. Essa dualidade de regramentos, porém, não parece adequada, tendo em vista tratar-se em todos os casos de um negócio jurídico com um mesmo objeto, qual seja, a obrigação de transferência da propriedade sobre ações ou quotas.

Quanto ao argumento de que haveria uma tendência no direito estrangeiro de se admitir que a disciplina dos vícios redibitórios poderia ser invocada pelo comprador surpreendido por vícios nos bens integrantes do estabelecimento empresarial, acredita-se que seja impossível vislumbrar tal direcionamento sobre assunto cercado de tantas polêmicas, com posicionamentos diversos que variam de país a país e mesmo dentro de um mesmo ordenamento jurídico. Trata-se, afinal, de um "problema que historicamente é objeto de vivas discussões em todos os ordenamentos continentais". ${ }^{1266}$ Atualmente, os únicos países em que se admite plenamente a equiparação entre a compra e venda de ações ou quotas e a compra e venda de empresa parecem ser Alemanha e Portugal, com a especificidade de que o efeito prático de tal equiparação é limitado (i) na Alemanha, pela interpretação extremamente restritiva do que seria um vício da empresa; e (ii) em Portugal, pelo fato de que o Código Civil português determina a aplicação da disciplina do erro às hipótese de vícios redibitórios, remetendo as partes ao mesmo tratamento dispensado em

${ }^{1266}$ SPERANZIN, Marco. Vendita delle partecipazione di 'controllo' e garanzie contrattuali. $O p$. cit., p. 98 ("il problema di quali circostanze possono costituire o meno qualità di un bene - problema che forma storicamente oggetto di vivaci discussioni in tutti gli ordinamenti continentali"). 
matéria de vícios da vontade. No direito italiano, francês e espanhol a posição que prevalece é contrária à equiparação. De toda maneira, o que importa para o presente estudo não é determinar se há ou não uma orientação que predomine sem contrastes no direito estrangeiro, mas a análise dos diversos posicionamentos favoráveis e críticos à desconsideração da personalidade jurídica, para a adequada ponderação das vantagens ou possíveis inconvenientes que decorrem de sua admissão.

Sob o ponto de vista dogmático, não parece possível afirmar que somente a disciplina dos vícios redibitórios ofereceria tutela adequada ao comprador em relação a imperfeições do patrimônio societário. Como aponta a evolução no direito alemão, italiano ou francês, a disciplina da boa-fé no âmbito pré-contratual (culpa in contrahendo) e a disciplina dos vícios do consentimento oferecem tutela mais adequada do que a desconsideração da personalidade jurídica.

A disciplina dos vícios redibitórios aplicada aos elementos do patrimônio societário, ademais, traria dificuldades relevantes. A afirmação de CALIXTO SALOMÃO FILHO no sentido de que somente vícios com certa magnitude autorizam a redibição do contrato, por exemplo, é desejável sob um ponto de vista técnico, e não somente para o contrato de compra e venda de participações societárias, como para qualquer contrato comutativo, pois a grave consequência do desfazimento não deveria ser empregada de forma trivial. Não é coincidência, portanto, que destacada alteração no direito alemão das obrigações tenha sido a introdução de dispositivo legal determinando que, quando o devedor não cumpre sua obrigação, o credor apenas pode resolver o contrato se o inadimplemento foi relevante (BGB, $\S 323$, Abs. 5, S. 2). O BGH tem considerado que o inadimplemento irrelevante, nesse sentido, é aquele caracterizado por defeitos cujos custos de superação não ultrapassem $5 \%$ do contrato. ${ }^{1267}$ No Brasil, porém, não há regra em sentido semelhante. A lei garante ao adquirente o direito de enjeitar a coisa recebida por vícios ou defeitos ocultos que a tornem imprópria ao uso a que é destinada ou que apenas "lhe diminuam o valor", tratando as duas hipóteses no mesmo dispositivo (CC, art. 441). A leitura de SALOMÃo FILHO diferenciando as situações em que a redibição seria cabível, daquelas em que somente a minoração teria lugar, seria desejável de jure condendo, mas não decorre do texto legal vigente.

${ }^{1267}$ BGHZ 201, 290. 
Um argumento relevante e adequado de SALOMÃo FILHO diz respeito à necessidade de que o desfazimento de negócios relacionados à organização empresarial estejam sujeitos a prazos curtos, sob pena de a restituição das partes ao status quo ante tornar-se inviável. A questão principal, porém, é que a disciplina dos vícios redibitórios afasta, por sua especificidade, a aplicação de outras disciplinas que poderiam tutelar o comprador, como seria o caso da responsabilidade por descumprimento ao dever de informar decorrente da boa-fé, sempre que a falha se relacionasse a uma qualidade da própria coisa objeto do negócio jurídico. ${ }^{1268}$ Tomando-se um exemplo concreto, um passivo tributário oculto de enorme relevância que, por má-fé, não foi informado pelo vendedor deveria ser descoberto pelo comprador dentro do prazo decadencial dos vícios redibitórios, sob pena de este perder qualquer direito, não somente ao desfazimento do negócio jurídico (redibição), mas também ao abatimento do preço. Após o decurso desse prazo, sequer lhe seria facultada a possibilidade de pleitear indenização por falha ao dever de informar, porque a disciplina englobante dos vícios redibitórios afastaria tal possibilidade.

O prazo decadencial a que o comprador está sujeito, ademais, é outro aspecto a respeito do qual a disciplina do Código Civil se mostra inadaptada à compra e venda de participações societárias. Segundo SALOMÃo FILHO, o prazo decadencial para a tutela dos vícios redibitórios seria de 30 (trinta) dias por tratar-se de negócio sobre ações, que são coisas móveis, mas que seria contado apenas do momento da ciência (CC, art. 445, $\S 1^{\circ}$ ), o que seria comum em organizações empresariais. O autor ressalta, porém, que tal ciência deveria ser presumida com a primeira assembleia geral ordinária, sob pena de se ter uma disciplina dos vícios redibitórios "sem prazo decadencial". ${ }^{1269}$ Ocorre que o próprio Código Civil determina, no âmbito das coisas móveis, que o prazo não corre enquanto o vício não for conhecido, até o prazo de 180 (cento e oitenta) dias (CC, art. 445, $\S 1^{\circ}$ ). Com isso, chega-se a uma possível incoerência grave, pelo fato de que o prazo para o exercício de direitos pelo comprador de bens móveis intangíveis, como são as ações ou quotas, terá de ser exercido em prazo breve, de no máximo 210 (duzentos e dez) dias, inferior, por exemplo, ao conferido ao comprador de bens imóveis. Vale notar que tais prazos não

\footnotetext{
${ }^{1268}$ SINGER, Reinhard. "Fehler beim Kauf - zum Verhältnis von Mängelgewährleistung, Irrtumsanfechtung und culpa in contrahendo". In: CANARIS, Claus Wilhelm; HELDRICH, Andreas (org.). 50 Jahre Bundesgerichtshof: Festgabe aus der Wissenschaft. München: C. H. Beck, 2000, pp. 381-405, p. 386. 1269 COMPARATO, Fábio Konder; SALOMÃO FILHO, Calixto. O poder de controle na sociedade anônima. Op. cit., nota de texto n. 53, p. 245, nota de rodapé 26.
} 
podem ser modificados por vontade das partes, pois não pode haver renúncia à decadência fixada em lei (CC, art. 209).

No caso de serem previstas cláusulas de declarações e garantias como é o comum em aquisições de maior vulto, a questão que remanesce é de determinar a incidência do disposto no art. 446 do Código Civil, segundo o qual os prazos decadenciais relativos aos vícios redibitórios não correm na constância de cláusula de garantia, mas se impõe ao adquirente o dever de denunciar o defeito nos trinta dias seguintes ao descobrimento. É certo que, admitindo-se a aplicação da disciplina dos vícios redibitórios, caminhar-se-ia para uma avaliação a respeito do enquadramento de certas garantias das partes, como, por exemplo, a garantia de ausência de passivos tributários para determinar se poderiam ou não ser consideradas cláusulas de garantias. $\mathrm{Na}$ prática empresarial é normal que os contratos de compra e venda de participações societárias contem com tais tipos de garantias, a qual normalmente é estabelecida por prazo de 5 (cinco) anos, em linha com o prazo prescricional das obrigações tributárias. Ora, há duas possibilidades de qualificação dessas avenças. A primeira seria considerá-las cláusulas de garantia para fins do art. 446, hipótese em que o efetivo prazo pelo qual o vendedor responderia não seria de 5 (cinco) anos, como negociou, mas de 5 (cinco) anos e 210 (duzentos e dez dias), pois o prazo legal apenas não correria na constância da cláusula de garantia. O comprador, ademais, estaria obrigado a denunciar o vício em um mês, ainda que nada tenha previsto sobre o assunto no contrato. A segunda possibilidade, igualmente inadequada, seria não entender a cláusula como garantia para os fins previstos no artigo 446, mas como pacto convencional para extensão do prazo decadencial fixado em lei para a tutela do comprador. Ocorre que tal convenção equivaleria a uma renúncia à decadência por parte do vendedor, à qual se comina a nulidade (CC, art. 209).

Diversamente do que defende a doutrina majoritária nacional, acredita-se que o posicionamento mais adequado seja no sentido da não aplicação da disciplina dos vícios redibitórios à compra e venda de participações societárias.

O primeiro motivo para tanto é o fato de que cada negócio jurídico por meio do qual se pode obter o resultado econômico da transferência da empresa está sujeito a regras próprias que se refletem diretamente na esfera jurídica dos contratantes. Aqueles que celebram contrato de trespasse ficam sujeitos a regramento específico a respeito de 
passivos não contabilizados, qual seja, responsabilidade integral do alienante por débitos não contabilizados, e responsabilidade do adquirente por débitos contabilizados, com responsabilidade solidária do devedor primitivo pelo prazo de um ano da publicação do trespasse no caso de créditos vencidos ou do vencimento do crédito (CC, art. 1.146). ${ }^{1270}$

Aqueles que celebram compra e venda de ações estão sujeitos a regras distintas. ${ }^{1271} \mathrm{O}$ comprador beneficia-se, por exemplo, da tutela conferida ao detentor de títulos de crédito de boa-fé. O vendedor, por sua vez, responde apenas pela integralização das ações. No caso de cessão de quotas, a posição dos contratantes se altera. Não há tutela do adquirente de boa-fé contra a reivindicação pelo proprietário. $\mathrm{O}$ cedente responde por dois anos pelas obrigações que tinha enquanto sócio. Em ambos os casos, o vendedor fica sujeito a ser responsabilizado pela desconsideração da personalidade jurídica fundada em fatos ocorridos durante o período em que controlava a sociedade. Além disso, a sociedade cujas quotas ou ações são adquiridas continua responsável não somente pelas dívidas que estejam escrituradas, mas por todas e quaisquer dívidas que lhe possam ser imputadas.

Essas diferenças não são irrelevantes. O posicionamento que propõe a aplicação da disciplina dos vícios redibitórios não somente para tutela do comprador contra vícios das próprias participações societárias, mas também a respeito da composição patrimonial da sociedade, sujeita todas as modalidades transmissivas ao mesmo regime.

Cria-se, ademais, uma responsabilidade peculiar para o vendedor, que passa a responder por vícios redibitórios ou por evicção em relação às próprias participações societárias, que pode ocorrer, por exemplo, na hipótese de não ser possível a transferência das participações societárias pelo exercício de direito de preferência por outro sócio; mas também por vícios relativos à constituição patrimonial da sociedade.

O segundo motivo que conduz à rejeição da disciplina é o fato de ela impor ao controlador uma responsabilidade pela constituição do patrimônio societário, pressupondo a entrega de coisas isentas de vícios ocultos que as tornem impróprias ao uso

1270 TJSP, Ap. n. 0000839-59.2008.8.26.0482, 6 Câm. Dir. Priv., rel. Des. Francisco Loureiro, j. 02.10.2014 (afirmando que, no contrato de trespasse, a menos que haja cláusula específica em sentido diverso, "o adquirente responde apenas pelas dívidas devidamente escrituradas"). No mesmo sentido: GONÇALVES NETO, Alfredo de A. Direito de empresa. Op. cit., p. 633 (ressalvando que poderiam ser imputados ao novo titular do estabelecimento débitos tributários e trabalhistas relativos ao estabelecimento ainda que não escriturados, com fundamento, respectivamente, no art. 133 do CTN e nos arts. 10 e 448 da CLT).

${ }^{1271}$ Sobre o assunto, cf. item II.B, supra. 
a que são destinadas ou que lhes diminuam o valor. Tal garantia seria aplicável ainda que nada fosse negociado pelas partes a respeito das qualidades do acervo patrimonial, como ocorre, por exemplo, em situações de venda de ações para execução de garantia prestada com alienação fiduciária de ações ou quotas; ou na hipótese de o controlador de instituição financeira descobrir que foi vítima de fraude por seus empregados e decidir promover venda de ações ou quotas na modalidade "porteira fechada"; ou mesmo na hipótese de privatização de empresa pública mediante compra e venda de ações (Lei n. 9.491/1997, art. $4^{\mathrm{o}}$, I). Na compra e venda de participações societárias, porém, não há uma qualidade padrão (Standardbeschaffenheit) do patrimônio societário que possa ser adequadamente tomada como referencial pelas partes e pela qual o vendedor deveria responder. ${ }^{1272}$ Como consequência, em todos esses casos, o comprador poderia alegar que os passivos que viesse a descobrir constituiriam vícios redibitórios, alterando posteriormente a economia negociada do contrato.

O terceiro motivo liga-se ao caráter objetivo da responsabilidade do vendedor pelos vícios redibitórios, que não pressupõe sequer a possibilidade de conhecimento a respeito dos defeitos ocultos (CC, art. 443). ${ }^{1273} \mathrm{Na}$ sociedade anônima, é certo que o controlador é destinatário do dever fiduciário de dirigir as atividades sociais e orientar o funcionamento dos órgãos da companhia (LSA, art. 116), respondendo em caso de omissão. ${ }^{1274}$ Há, porém, fatos que são desconhecidos por ambas as partes. Outros que sequer chegam ao conhecimento do controlador de companhia aberta, por exemplo, por dizerem respeito a informações confidenciais da administração. É comum, por conta disso, que constem de contratos de compra e venda de participações societárias que a responsabilidade do vendedor limita-se, em relação a certas matérias, ao seu melhor conhecimento dos fatos (best knowledge clauses). ${ }^{1275}$ Não é qualquer comportamento adotado pelos administradores ou por funcionários da sociedade, que pode ser de grande porte, que deverá ser imputado ao vendedor.

A responsabilidade objetiva pela constituição do patrimônio, ademais, podese revelar inadequada para a situação - rara, é certo, mas concebível e juridicamente

\footnotetext{
${ }^{1272}$ HUBER, Ulrich. "Die Praxis des Unternehmenskaufs im System des Kaufrechts”. Op. cit., p. 212.

${ }^{1273}$ STJ, REsp n. 1.520.500-SP, $3^{\mathrm{a}}$ T., rel. Min. Marco Aurélio Bellizze, j. 27.10.2015.

${ }^{1274}$ CVM, PAS n. RJ 2012/1131, rel. Dir. Luciana Dias, j. 26.05.2015.

1275 RUSSO, Fábio. "Das cláusulas de garantia nos contratos de compra e venda de participações sociais de controlo". Op. cit., p. 130; HUBER, Ulrich. "Die Praxis des Unternehmenskaufs im System des Kaufrechts". Op. cit., p. 207.
} 
fundamentada - em que a administração da sociedade se recusasse a autorizar a condução de diligência pelo comprador buscando a preservação de suas informações sigilosas. ${ }^{1276}$ Seria imposta, nessa medida, responsabilidade objetiva ao vendedor, sem que houvesse possibilidade de se esclarecer ao comprador a real constituição patrimonial da sociedade.

Em quarto lugar, a sistemática de garantia do vendedor por vícios redibitórios origina-se dos edis curuis, tendo sido concebida para a proteção do comprador de animais ou escravos a respeito de vícios ocultos. ${ }^{1277}$ O Código Civil, prosseguindo tal tradição, menciona "a coisa" recebida em virtude de contrato comutativo e é em função dessa tangibilidade pressuposta do objeto que os prazos para a averiguação da existência de vícios são curtos, ${ }^{1278}$ ligando-se ainda a uma avaliação presumida de que os eventuais vícios constantes dos bens móveis poderiam ser identificados pelo comprador em prazo mais abreviado do que os constantes dos bens imóveis. Como apontou HommelHoff, o prazo abreviado imposto ao comprador liga-se ao domínio sobre a coisa, à possibilidade de que ela seja verificada tanto por comprador quanto por vendedor, que podem reconhecer a existência de vícios ou defeitos. ${ }^{1279}$ Tal regramento não se compatibiliza com a imposição de garantia ao vendedor por todo o patrimônio societário, que pode ser composto por imóveis, posições contratuais, créditos e toda uma gama variada de equipamentos nos mais diversos estados. E o que é pior, aplica-se nesse caso o prazo decadencial curto de 30 (trinta) dias previsto para a garantia de bens móveis.

Como quinto motivo, pode-se apontar a contradição inerente e ínsita em se defender que a compra e venda de participações societárias deva ser respeitada enquanto tal para diversos efeitos jurídicos, mas não pelo comprador, justamente aquele que tem condições de negociar as condições pelas quais deseja adquirir as participações societárias. ${ }^{1280}$ Seria incongruente afirmar, por exemplo, que não incide o ITBI sobre transações relativas a ações ou quotas de controle de sociedade titular de imóvel, mas

\footnotetext{
${ }^{1276}$ Sobre o assunto, cf. item IV.A.2.a), supra.

${ }^{1277}$ FLEISCHER, Holger. Informationsasymmetrie im Vertragsrecht. Op. cit., p. 27.

${ }^{1278}$ SPERANZIN, Marco. Vendita delle partecipazione di 'controllo' e garanzie contrattuali. Op. cit., p. 99; RAAPE, Leo. "Sachmängelhaftung und Irrtum beim Kauf". In: AcP, v. 150, pp. 481-506, pp. 487-488; GRIGOLEIT, Hans Christoph; HERRESTHAL, Carsten. "Grundlagen der Sachmängelhaftung im Kaufrecht”. Op. cit., p. 127; GRUNEWALD, Barbara. Die Grenzziehung zwischen der Rechts- und Sachmängelhaftung beim Kauf. Bonn: Stollfuss, 1980, pp. 27-28. Contra: FLUME, Werner. Eigenschaftsirrtum und Kauf. Op. cit., pp. 187-190 (defendendo a aplicação analógica do regramento relativo aos vícios da coisa para participações societárias).

${ }^{1279}$ HOMMELHOFF, Peter. "Die Sachmängelhaftung beim Unternehmenskauf durch Anteilserwerb". $O p$. cit., p. 274.

${ }^{1280}$ CAFFIN-MOI, Marie. Cession de droits sociaux et droit des contrats. Op. cit., n. 522, p. 334.
} 
defender que o comprador poderia alegar a existência de vícios redibitórios se encontrasse rachaduras nas paredes. Se tal imóvel estivesse alugado, a troca de controle também não afetaria o contrato: se a sociedade fosse locadora, o locatário não teria direito de preferência para a aquisição; se fosse a locatária, o locador não poderia se opor à troca de controle alegando não ter prestado seu consentimento. ${ }^{1281}$ A autonomia da personalidade jurídica não deve ser respeitada apenas seletivamente; e, pretendendo-se a flexibilização da autonomia da personalidade jurídica, seria devido defendê-la primeiramente em benefício daquelas partes que não integram o contrato de compra e venda e que não podem tutelar seus interesses próprios. ${ }^{1282}$

Por fim, como se aponta nos itens subsequentes, há alternativas dogmáticas que parecem promover de forma mais ponderada o equilíbrio entre os interesses de comprador e vendedor, como é o caso do dolo e da responsabilidade civil por falha ao dever de informar.

\section{B. Evicção}

A responsabilidade pela evicção do vendedor abrange as situações diversas em que a transferência da propriedade não se consuma em virtude de direito de outrem sobre as participações societárias. Especialmente relevantes, nesse contexto, são os direitos de preferência e as restrições à circulação de quotas ou ações previstos em instrumento societários. ${ }^{1283} \mathrm{Em}$ tais circunstâncias, o comprador pode vir a perder o direito de titularidade sobre as participações societárias, hipótese em que haverá responsabilidade do alienante (CC, art. 447).

\section{Erro}

\footnotetext{
${ }^{1281}$ Sobre o assunto, cf. itens III.B.a)(1) e III.C.a), supra.

1282 CAFFIN-MOI, Marie. Cession de droits sociaux et droit des contrats. Op. cit., n. 522, p. 334.

1283 Sobre o assunto, cf. itens II.B.1.d) e II.B.2.c)(3), supra.
} 
O erro substancial do declarante torna o negócio jurídico anulável (CC, art. 138). Pressuposto para a anulabilidade é que o erro seja substancial e que possa ser percebido por pessoa de diligência normal, em face das circunstâncias do negócio (CC, art. 138). O erro, por sua vez, é substancial quanto ao objeto quanto "interessa à natureza do negócio, ao objeto principal da declaração, ou a alguma das qualidades a ele essenciais" (CC, art. 139, I).

O requisito da substancialidade do erro, portanto, pressupõe a divergência entre a vontade real e a declarada no que concerne ao objeto principal da declaração ou a qualidades a ele essenciais, e, nesse ponto, a discussão a respeito da aplicabilidade da disciplina dos vícios redibitórios à constituição do patrimônio societário apresenta-se em outra veste. Questiona-se, na compra e venda de participações societárias, se o objeto a respeito do qual o erro seria anulável incluiria somente os próprios títulos, ou também a constituição patrimonial da sociedade.

No direito estrangeiro, de forma geral, nos países em que se admite que os vícios relativos aos elementos patrimoniais constituiriam vícios redibitórios na compra e venda de participações societárias tende-se, igualmente e por coerência, a admitir que o erro sobre tais elementos patrimoniais constituiria erro substancial.

$\mathrm{Na}$ Alemanha, considera-se que o erro quanto às qualidades do estabelecimento somente autorizaria a anulação ${ }^{1284}$ do negócio jurídico quando a compra e venda de participações societárias envolvesse a aquisição de totalidade ou quase totalidade das quotas ou ações, sendo assimilada à compra da empresa. ${ }^{1285}$ Mesmo nessa hipótese, contudo, sublinha-se que o erro mais comumente alegado diz respeito à rentabilidade projetada pelo comprador, erro que, sendo de cálculo, e não se reportando a uma qualidade

\footnotetext{
${ }^{1284}$ EVANDRO PONTES considera que o direito brasileiro divergiria do alemão em relação à consequência do erro, pois, em sua visão, "não adotamos a nulidade de que fala o $\$ 119$ do BGB e ficamos na seara da anulabilidade" (Representations \& warranties no direito brasileiro. Op. cit., p. 126). Acredita-se que tal compreensão do dispositivo germânico não seja a mais adequada, pois nele se menciona a "Anfechtbarkeit" ou seja, possibilidade de desfazimento do negócio jurídico mediante exercício de direito formativo pelo interessado, sujeita a prazo decadencial (BGB, §121) - e não a "Nichtigkeit", prevista, por exemplo, para casos de desrespeito à forma prescrita em lei (BGB, §125). Corroborando tal conclusão, a versão em inglês do BGB disponível no site do Ministério da Justiça e Proteção do Consumidor traduz o §119 como hipótese de "voidability", ao passo que se utiliza para o §125 o termo "voidness" (https://www.gesetze-iminternet.de/englisch_bgb/). Por tal razão, a aproximação com a figura da anulabilidade nos parece justificada. ${ }^{1285}$ HUBER, Ulrich. "Die Praxis des Unternehmenskaufs im System des Kaufrechts". Op. cit., p. 222. Para os pressupostos de tal equiparação, cf. item V.A.1.a), supra.
} 
(Eigenschaft) da coisa, não autoriza a anulação do negócio jurídico. ${ }^{1286} \mathrm{O}$ âmbito de aplicação do erro, ademais, é restrito pela circunstância de que, na Alemanha, entende-se que haveria relação de especialidade entre a disciplina dos vícios redibitórios e do erro. ${ }^{1287}$ Em vista disso, se a deformidade alegada pelo comprador constituir hipótese tutelável mediante as ações edilícias, o comprador não poderia anular o negócio jurídico por erro.

Na Itália, também em consonância com o entendimento de que o patrimônio societário não é objeto da compra e venda de participações societárias, afirma-se que as circunstâncias concernentes ao patrimônio não constituiriam qualidades das participações societárias, ainda que tenham sido fundamentais e decisivas para a determinação de seu valor. Como consequência, não seria possível reconhecer a anulação, pois o erro não interessaria a natureza ou o objeto do contrato. ${ }^{1288}$

Na França, também de forma bastante semelhante ao que ocorre em matéria de vícios redibitórios, tem-se como princípio que as qualidades patrimoniais não integram o objeto do contrato. Sob a vigência da redação original do art. 1110 do Code civil, o erro somente seria anulável se dissesse respeito à própria substancia da coisa objeto da contratação. ${ }^{1289}$ A jurisprudência, interpretando tal dispositivo, considerava que o erro não seria substancial mesmo que dissesse respeito à falta de autorização para a sociedade

${ }^{1286}$ LARENZ, Karl; WOLF, Manfred. Allgemeiner Teil des Bürgerlichen Rechts, 9. Aufl. München: C. H. Beck, 2004, §36, Rn. 40, p. 662.

${ }^{1287}$ JAGERSBERGER, Barbara. Die Haftung des Verkäufers beim Unternehmenskauf- und Anteilskauf. Op. cit., pp. 442-447. Sobre a concorrência entre as ações, cf. WEILER, Frank. "Culpa in contrahendo, Anfechtung und Kaufrecht - alte Konkurrenzfragen in neuem Licht”. In: ZGS, 2002, pp. 249-256; HUBER, Peter, Irrtumsanfechtung und Sachmängelhaftung. Tübingen: Mohr Siebeck, 2001.

1288 TINA, Andrea. Il contratto di acquisizione di partecipazioni societarie. Op. cit., p. 225; GRECO, Paolo. "Le società di comodo e la vendita delle loro azioni". Op. cit., p. 137; FERRI, Giuseppe. "Incidenza delle obbligazioni sociali nei rapporti fra cedente e cessionario di quote sociali". I Op. cit., p. 719; ASCARELLI, Tullio. "In tema di vendita di azioni e responsabilità degli amministratori”. In: Foro it., 1953, pp. 1639-1644, p. 1642; IUDICA, Giovanni. "Il prezzo nella compravendita di partecipazioni azionarie". $O p$. cit., p. 768; MONTALENTI, Paolo. "Le acquisizioni societarie - profili contrattuali". Op. cit., p. 153; DE RITIS, Massimo R. "Trasferimento di pacchetti azionari di controllo: clausole contrattuali e limiti all'autonomia privata". Op. cit., pp. 881-882; ANGELICI, Carlo. "La partecipazione azionaria come oggetto di circolazione". Op. cit., p. 114; GALLETTI, Danilo. "Brevi note in tema di vendita di quota sociale ed errore sui motivi". In: BBTC, II, 1997, pp. 25-37, p. 28.

${ }^{1289}$ GuILHERME Döring CUNHA PEREIRA afirma que "[n] os sistemas que, como o francês e o suíço, não limitam a possibilidade de anulação do negócio ao erro que se poderia considerar essencial, a proteção das partes, sobretudo dos adquirentes, numa alienação do controle, com base nos vícios de consentimento, é bastante ampla" (Alienação do poder de controle acionário. Op. cit., p. 90). A informação não parece correta a respeito do direito francês, como decorria do teor literal do art. 1110 do Code civil que, em sua versão original, exigia que o erro respeitasse "la substance même de la chose", bem como do atual art. 1132 , que se refere às "qualités essentielles de la prestation". Sobre o assunto, cf. GHESTIN, Jacques. "La réticence, le dol et l'erreur sur les qualités substantielles”. In: Dalloz, 1971, 247-250, p. 250. 
exercer sua atividade, em caso de contrato que versava sobre ações. ${ }^{1290}$ Decidiu-se, igualmente, que o erro sobre o valor não justificaria a anulação do contrato, tendo-se avaliado que "a existência de um passivo social não afeta as qualidades substanciais das ações, mas somente seu valor". ${ }^{1291}$ Em julgado de $1991,{ }^{1292}$ conhecido como arrêt Quille ${ }^{1293}$ julgou-se situação em que foi celebrado contrato de venda da maioria das ações de uma sociedade em que os vendedores não informaram que alienaram a quase totalidade dos seus ativos a um terceiro, tornando impossível a continuidade da atividade. De forma similar ao que admitiu em matéria de vícios redibitórios, a jurisprudência, nesse caso, passou a considerar que a compra e venda de participações societárias poderia ser anulada por erro que dissesse respeito à impossibilidade de exercício do próprio objeto social da sociedade, pois tal erro seria pertinente à aptidão dos títulos para exercerem sua função econômica e servirem ao comprador. ${ }^{1294}$ Trata-se de decisão criticada por CAFFIN-MOI, contudo, pois a possibilidade de perseguir o objeto social não seria qualidade das ações ou quotas. $^{1295}$

É de se notar, por fim, que a Ordonnance n. 2016-131, de 10.02.2016 promoveu importantes alterações ao regime do erro, passando a adotar conceito subjetivo do que seriam qualidades essenciais da prestação (Code civil, art. 1133), razão pela qual é possível que a orientação jurisprudencial se altere também em matéria de compra e venda de participações societárias.

$\mathrm{Na}$ doutrina espanhola ${ }^{1296}$ e portuguesa ${ }^{1297}$, por sua vez, defende-se a aplicação da disciplina do erro à inadequada percepção do comprador acerca de qualidades substanciais dos bens integrantes do patrimônio societário.

Em linha com o quanto se apontou em matéria de vícios redibitórios, também não parece adequado o entendimento de que o erro sobre as condições

\footnotetext{
${ }^{1290}$ CAFFIN-MOI, Marie. Cession de droits sociaux et droit des contrats. Op. cit., n. 36, p. 35.

${ }^{1291}$ Paris, 11.07.1989 apud CAFFIN-MOI, Marie. Cession de droits sociaux et droit des contrats. Op. cit., n. 40 , p. 37.

1292 Cass. com. 01.10.1991, Bull. 1991 IV n. 277, p. 192.

1293 CAFFIN-MOI, Marie. Cession de droits sociaux et droit des contrats. Op. cit., n. 58, p. 49.

1294 CAFFIN-MOI, Marie. Cession de droits sociaux et droit des contrats. Op. cit., n. 58, pp. 49-50.

${ }^{1295}$ CAFFIN-MOI, Marie. Cession de droits sociaux et droit des contrats. Op. cit., n. 68, p. 54.

1296 GIMENO RIBES, Miguel. La protección del comprador en la adquisición de empresa. Op. cit., pp. 146-147.

${ }^{1297}$ ANTUNES, José Engrácia. "A empresa como objecto de negócios ('asset deal" vs. "share deal')". Op. cit., p. 778.
} 
patrimoniais da sociedade deveria ser considerado erro substancial autorizando a anulação do negócio jurídico. Avalia-se que o erro somente será substancial, autorizando a anulação do negócio jurídico, na hipótese em que disser respeito às próprias participações societárias, e não à composição patrimonial da sociedade. ${ }^{1298}$

\section{Dolo}

O negócio jurídico é anulável por dolo, quando este for sua causa (CC, art. 145), hipótese que se denomina dolo essencial; nas hipóteses em que ocorre dolo, mas o negócio seria realizado, embora por outro modo, o dolo é acidental e somente obriga à satisfação de perdas e danos (CC, art. 146). O dolo, em grande medida, pode ser assimilado ao erro causado pelo outro contratante, ou ao erro incorrido e reconhecido pelo outro contratante que, tendo o dever de informar, não o faz, permitindo a celebração do contrato sob equívoca percepção da realidade. ${ }^{1299}$

O dolo pode ser praticado mediante condutas ativas comissivas, ou também por omissão, pois se determina que "o silêncio intencional de uma das partes a respeito de fato ou qualidade que a outra parte haja ignorado, constitui omissão dolosa, provando-se que sem ela o negócio não se teria celebrado" (CC, art. 147). No âmbito do dolo omissivo, como aponta PAUlo Mota PINTO, deve-se atentar para a circunstância de que o dispositivo legal não menciona expressamente em sua delimitação a existência de um prévio dever de

informar. ${ }^{1300}$ A literalidade do artigo parece exigir apenas dois elementos, quais sejam, a presença de "silêncio intencional" e a prova de que, sem a omissão dolosa, "o negócio não se teria celebrado" (CC, art. 147). A norma em questão, em virtude dessa interpretação ampliativa, poderia sugerir a impressão equivocada de que bastaria que a ausência de informação influísse sobre a celebração do contrato para que estivesse configurado o dolo.

\footnotetext{
${ }^{1298}$ Em sentido contrário: PEREIRA, Guilherme D. C. Alienação do poder de controle acionário. Op. cit., pp. 90-92; PONTES, Evandro F. de. Representations \& warranties no direito brasileiro. Op. cit., p. 123. ${ }^{1299}$ GHESTIN, Jacques. "La réticence, le dol et l'erreur sur les qualités substantielles". Op. cit., p. 249.

${ }^{1300}$ MOTA PINTO, Paulo. "Falta e vícios da vontade - o Código Civil e os regimes mais recentes". Op. cit., p. 489, nota de rodapé 69.
} 
O dolo omissivo, porém, pressupõe o "silêncio intencional" e o silêncio em questão é sobre o fato a respeito do qual a boa-fé impunha um dever de informar. ${ }^{1301}$ Como JunQUeIRA DE AZEVEDo apontou ainda antes da aprovação do Código Civil de 2002, o dolo por omissão como causa de anulação do contrato pressupõe uma violação a um dever de informar a parte adversa. ${ }^{1302}$ Essa ligação entre a prévia existência de um dever de informar decorrente da boa-fé, de um lado, e a caracterização da omissão dolosa, de outro, é reconhecida por exemplo, no âmbito dos Princípios Europeus de Direito Contratual (PECL, art. 4:107) ou nos Princípios Unidroit de Contratos Comerciais Internacionais (art. 3.2.5.), sendo pacificamente admitida pela doutrina. ${ }^{1303}$

No âmbito da compra e venda de participações societárias, a tutela do comprador com base na alegação de ocorrência de dolo exerce papel proeminente. Seu domínio é mais amplo do que o do erro, porque visa à sanção de comportamento ilícito adotado por um dos contratantes. Nessa medida, o erro provocado pela contraparte não precisa ser substancial para que justifique a tutela do contratante enganado pelo emprego de má-fé. Tutela-se, com isso, o erro sobre os motivos, sobre o valor ou sobre qualidades não essenciais, o que, em matéria de participações societárias de controle, significa tutelar o comprador também a respeito das qualidades patrimoniais da sociedade. ${ }^{1304} \mathrm{Na}$ compra e venda de ações ou quotas, como apontou PAOLO GRECO ainda na década de 1930, o fato de as qualidades patrimoniais da sociedade não integrarem o objeto do contrato não impede que as partes a elas atribuam relevância, como poderia ocorrer, igualmente em uma compra imobiliária em que a negociação fosse pautada pela existência de um terreno contíguo pelo qual o comprador se interessa. Em ambos os casos, constatando-se que o vendedor maliciosamente levou o comprador ao erro sobre a qualidade não essencial (rentabilidade das ações ou perspectiva de aquisição do terreno contíguo), não se duvida da possibilidade de tutela por meio do dolo. ${ }^{1305}$ Como hipóteses de dolo na compra e venda de participações

\footnotetext{
${ }^{1301}$ MARTINS-COSTA, Judith. "Os regimes do dolo civil no Direito Brasileiro: dolo antecedente, vício informativo por omissão e por comissão, dolo acidental e dever de indenizar”. Op. cit., pp. 134-135.

1302 AZEVEDO, Antonio Junqueira de. "Rapport brésilien". Op. cit., pp. 77-84, p. 79.

${ }^{1303}$ FLEISCHER, Holger. Informationsasymmetrie im Vertragsrecht. Op. cit., p. 66; HENSSLER, Martin. "Haftung des Verkäufers wegen Informationspflichtverletzung beim Unternehmenskauf”. Op. cit., p. 117; HUBER, Ulrich. "Die Praxis des Unternehmenskaufs im System des Kaufrechts". Op. cit., pp. 183-184; MANTOVANI, Manuela. 'Vizi incompleti' del contratto e rimedio risarcitorio. Torino: Giappichelli, 1995, p. 131; MOREIRA DA SILVA, Eva Sónia. Da responsabilidade pré-contratual por violação aos deveres de informação. Coimbra: Almedina, 2003, p. 110; MOTA PINTO, Paulo. "Falta e vícios da vontade - o Código Civil e os regimes mais recentes". Op. cit., p. 489;

${ }^{1304}$ CAFFIN-MOI, Marie. Cession de droits sociaux et droit des contrats. Op. cit., n. 582, p. 370.

1305 GRECO, Paolo. "Le società di comodo e la vendita delle loro azioni". Op. cit., p. 137. No mesmo sentido: ASCARELLI, Tullio. "In tema di vendita di azioni e responsabilità degli amministratori”. Op. cit., p.
} 
societárias de controle, inserem-se a inclusão de ativos inexistentes, determinantes para a formação de vontade do adquirente, ou mesmo sobre os produtos comercializados pela sociedade, ${ }^{1306}$ ou seja, concepção errônea que não se relaciona aos títulos adquiridos, mas ao patrimônio da sociedade e à sua atividade. Tendo em vista que, para a tutela do adquirente pela via do dolo o obstáculo da personalidade jurídica não se impõe, destaca-se a adequação desse mecanismo de proteção. Por meio dele compatibiliza-se adequadamente tanto o princípio de direito societário da separação da personalidade jurídica quanto a teoria do dolo. ${ }^{1307}$

A sanção por dolo, igualmente, mostra-se mais maleável sob a perspectiva das consequências jurídicas, pois, diferente do que ocorre no erro, não se abre como alternativa ao adquirente apenas a anulação do negócio jurídico, senão também a possibilidade de pleitear a indenização por perdas e danos. ${ }^{1308}$

\section{E. Responsabilidade civil por falha ao dever de informar}

A falha ao dever de informar que causa dano ao contratante pode ser dolosa, hipótese em que o comprador obtém tutela pela via do dolo essencial ou acidental, ou culposa, caso em que também se impõe a responsabilidade civil pelo erro que poderia ser evitado. ${ }^{1309}$ É o âmbito do que se denominou convencionar responsabilidade por indução negligente ao erro (fahrlässige Irreführung) ou por culpa in contrahendo. ${ }^{1310}$

$\mathrm{Na}$ compra e venda de participações societárias de controle, a responsabilidade por falha ao dever de informar desempenha papel de grande relevância

1642; ANGELICI, Carlo. "La partecipazione azionaria come oggetto di circolazione". Op. cit., p. 114; TINA, Andrea. Il contratto di acquisizione di partecipazioni societarie. Op. cit., pp. 232-245. Concordando com a orientação no direito brasileiro, cf. COMPARATO, Fábio Konder; SALOMÃO FILHO, Calixto. O poder de controle na sociedade anônima. Op. cit., n. 89, p. 255.

${ }_{1306}$ CAFFIN-MOI, Marie. Cession de droits sociaux et droit des contrats. Op. cit., n. 582, pp. 369-370.

${ }^{1307}$ CAFFIN-MOI, Marie. Cession de droits sociaux et droit des contrats. Op. cit., n. 582 , p. 370 (" $L e$ droit des sociétés est donc sauf, autant que la théorie civiliste du dol").

${ }^{1308}$ MARTINS-COSTA, Judith. "Os regimes do dolo civil no Direito Brasileiro: dolo antecedente, vício informativo por omissão e por comissão, dolo acidental e dever de indenizar”. Op. cit., p. 122.

${ }^{1309}$ MONTEIRO, António Pinto. Erro e vinculação negocial. Op. cit., p. 23; MARTINS-COSTA, Judith. "Os regimes do dolo civil no Direito Brasileiro: dolo antecedente, vício informativo por omissão e por comissão, dolo acidental e dever de indenizar". Op. cit., pp. 126.

${ }^{1310}$ FLEISCHER, Holger. Informationsasymmetrie im Vertragsrecht. Op. cit., p. 428. 
pois o dever de informar não se reporta somente às qualidades das próprias participações societárias, abrangendo todas as características do complexo patrimonial da sociedade. ${ }^{1311}$ Diferente do que ocorre no âmbito do dolo, porém, não é necessária a comprovação da intenção de enganar ou da percepção, na hipótese omissiva, de que o contratante que negociava sob falso conhecimento da realidade contrataria de forma diversa com ciência dos fatos não revelados. ${ }^{1312}$

É em vista dessas vantagens da responsabilidade pela falha ao dever de informar que se aponta o papel desempenhado pela culpa in contrahendo na tutela do comprador surpreendido com vícios relacionados aos ativos. ${ }^{1313}$ Em comparação com a disciplina dos vícios redibitórios, porém, tem-se a diferença de que o vendedor somente é responsabilizado pelas circunstâncias patrimoniais que efetivamente conheça e que deixe de informar ao comprador, não se tratando de responsabilidade objetiva. ${ }^{1314} \mathrm{Tem}$-se, ainda, a aplicabilidade do prazo prescricional da responsabilidade civil (CC, art. 206, §3º, V).

\footnotetext{
${ }^{1311}$ Sobre o assunto, cf. item IV.A.1, supra.

1312 Sobre a distinção entre os campos de atuação das distintas figuras dogmáticas, cf. FLEISCHER, Holger. "Konkurrenzprobleme um die culpa in contrahendo: Fahrlässige Irreführung versus arglistige Täuschung". In: AcP, v. 200, 2000, pp. 91-120.

1313 LORENZ, Stephan. "Der Unternehmenskauf nach der Schuldrechtsreform". Op. cit., p. 311; WILLEMSEN, Heinz Josef. "Zum Verhältnis von Sachmängelhaftung und culpa in contrahendo beim Unternehmenskauf”. Op. cit., pp. 553-554.

${ }^{1314}$ HUBER, Ulrich. "Die Praxis des Unternehmenskaufs im System des Kaufrechts". Op. cit., p. 216.
} 


\section{CONCLUSÃO}

\section{A. Recapitulação das teses formuladas}

No presente trabalho, foram alcançadas as seguintes conclusões:

\section{Capítulo I: Objeto}

1. A compra e venda de quotas ou ações não situa nem o comprador, nem o vendedor, na mesma posição jurídica em que estariam caso tivessem celebrado contrato versando sobre bens do patrimônio da sociedade.

2. A despeito da diversidade de posições jurídicas, é fato incontroverso que a compra e venda de participações societárias de controle pode conduzir a resultado econômico similar à compra e venda dos elementos integrantes do patrimônio e ser negociada pelos contratantes tendo em vista as características do substrato patrimonial da sociedade, e não as qualidades dos próprios títulos.

3. O elemento que promove a separação entre a percepção econômica e a conformação jurídica é a interposição da personalidade da sociedade que, a despeito da alteração de controle, permanece titular do seu patrimônio.

4. A peculiaridade das participações societárias reside em seu caráter de "bens de segundo grau" (AsCARELLI), na medida em que o seu valor decorre dos direitos e deveres que outorga ao titular no âmbito da sociedade. 
5. Metodologicamente, há três possíveis posturas intelectuais para enfrentar o potencial divórcio entre realidade econômica e configuração jurídica: (i) considerar que no negócio de compra e venda de participação societária de controle há um objeto imediato ou formal, sob o qual se camufla um objeto mediato ou real, e que consiste na empresa, no poder de controle societário, ou em ambos; (ii) afirmar que o objeto do contrato de compra e venda seria constituído somente pelas próprias participações societárias; e (iii) averiguar casuisticamente quais regras pertinentes a bens integrantes do patrimônio social seriam aplicáveis a compras e vendas de participações societárias de controle, baseando-se para tanto nos institutos da analogia, da simulação, do negócio indireto em fraude à lei e da desconsideração atributiva da personalidade jurídica.

6. As duas primeiras teorias parecem equivocadas. A primeira, ao propugnar a equiparação da cessão de controle à compra e venda da empresa, defende postura que não poderia ser adotada de fomra consequente em todos os campos do direito, sob pena de conduzir ao fim da atratividade da compra e venda de participações societárias enquanto mecanismo de mobilização da riqueza.

7. A segunda teoria, por defender a impermeabilidade à realidade econômica, peca por não oferecer mecanismos de reação para o emprego da personalidade jurídica para fins ilícitos.

8. As orientações casuísticas se mostram as mais adequadas para lidar com a problemática da equiparação de regimes, postulando que, como regra, deve o contrato de compra e venda de participações societárias deve ser observado enquanto tal, mas admitindo que o negócio jurídico em fraude à lei e a desconsideração atributiva da personalidade jurídica sejam utilizadas como mecanismos corretivos; impõe-sese, porém, àquele que defende a exceção ao regime geral o ônus argumentativo de demonstrar a ocorrência dos fatos autorizadores da desconsideração. 
9. Há posicionamentos doutrinários e jurisprudenciais que afirmam que quotas ou ações escriturais não poderiam ser objeto de contrato de compra e venda por não constituírem "coisas", bens passíveis de percepção tangível. Como consequência, nega-se aplicação do artigo 496 do Código Civil à cessão de quota, ou somente se aceita tal aplicação mediante pensamento analógico.

10. Apontou-se que, efetivamente, tanto as quotas quanto as ações integram o gênero das participações societárias, apresentando natureza jurídica comum; são bens imateriais que reúnem direitos e deveres, sendo consideradas posições jurídicas contratuais.

11. A circulação da quota ou da ação, nesse contexto, representa modalidade de cessão de posição contratual.

12. O contrato de compra e venda é negócio jurídico obrigacional, passível de ser situado na base de negócios jurídicos dispositivos diversos, de que é exemplo a cessão de crédito. Não há impeditivo para que se afirme que há compra e venda com obrigação de o vendedor transferir a titularidade sobre a quota ou ação.

13. A obrigação do vendedor na compra e venda de participação societária é transmitir a titularidade sobre a participação, razão pela qual se analisou o regime de circulação das ações e das quotas.

14. O regime de circulação das ações é específico e diverso do das quotas. 
15. Ações nominativas e escriturais são títulos de crédito nominativos. $O$ titular que as adquire de boa-fé por termo de cessão (nominativas registrais) ou por ordem escrita do alienante (nominativas escriturais) é tutelado contra a reivindicação, tornando-se proprietário, ainda que o cedente não o fosse.

16. A transferência da titularidade sobre ações nominativas registrais e escriturais para cumprimento de contrato de compra e venda pode ser realizada tanto por meio de termo de cessão, hipótese em que há aquisição do título na forma cambiária; quanto por meio de registro do contrato de compra e venda no livro de Registro, hipótese em que o adquirente de boa-fé não é tutelado contra a reivindicação.

17. A inscrição do nome do cessionário no livro de Registro da companhia possui eficácia real constitutiva do direito.

18. Na sociedade anônima, o estatuto ou o acordo de acionistas podem impor limitações à circulação de ações, desde que não se sujeite o acionista ao arbítrio da maioria.

19. Pode ser prevista cláusula de preferência também no estatuto, no acordo de acionistas ou em contrato apartado, hipótese em que, para ter oponibilidade perante terceiros, mostra-se necessária a averbação no livro de Registro.

20. A negociação das ações pressupõe a integralização de $30 \%$ do preço de emissão sob pena de nulidade do ato. A nulidade, porém, não é do contrato de compra e venda, mas do registro de transferência das ações.

21. O alienante de ações de controle remanesce responsável pela sua integralização pelo prazo de dois anos, ficando sujeito à possibilidade de que seja desconsiderada a personalidade jurídica da sociedade para atingir o seu patrimônio. 
22. A cessão de quotas de limitadas rege-se por princípios diversos. Desde a vigência do Código Civil de 2002, admite-se a liberdade de cessão.

23. São admissíveis vedações convencionais à cessão da quota, aí incluídas a vedação à cessão, a exigência de unanimidade e a previsão de direito de preferência. Tais cláusulas são lícitas e não infringem nenhuma norma cogente, não havendo fundamento para a doutrina que as considera incompatíveis com a liberdade de associação.

24. O cedente da quota social responde pela integralização da quota e permanece responsável perante a sociedade pelo prazo de dois anos. O cedente fica, ademais, sujeito à desconsideração da personalidade jurídica que pode ser promovida para responsabilizá-lo por atos abusivos ocorridos no período em que foi controlador.

25. Na compra e venda, o preço pode ser determinado ou determinável. Foram analisadas as hipóteses de preço especialmente relevantes para a compra e venda de participações societárias de controle.

26. No âmbito da compra e venda com preço determinado, a negociação envolve a avaliação dos ativos da sociedade, tarefa subjetiva e complexa que deve ser bem compreendida em qualquer hipótese de posterior revisão do preço sob pena de se desnaturar a economia do contrato.

27. O preço pode ser determinável, sendo especialmente relevantes na compra e venda de participações societárias a determinação do preço por terceiro avaliador, a cláusula de ajuste de preço e a determinação contingente do preço.

28. A determinação do preço por terceiro, a despeito de ser o "campo de predileção" da compra e venda de participações societárias, sofre de 
relevante falta de certeza. A despeito de a legislação em vigor poder oferecer respostas aos problemas que mais comumente se apresentam na avaliação por arbitrador expert, parece faltar à doutrina preocupação em ancorar normativamente as afirmações que realiza e perceber os problemas relevantes que podem advir de uma concepção que não prestigie a vinculação ao contrato.

29. A cláusula de ajuste de preço deve ter seu conteúdo definido adequadamente, para que não se a confunda com cláusulas de garantia, tendo em vista a diversidade de natureza jurídica do pagamento promovido sob um ou outro fundamento.

30. As chamadas cláusulas de earn-out oferecem relevante exemplo de mecanismo contratual que se utiliza de formas societárias típicas para a obtenção de finalidades não típicas. Para além de apontar necessários pontos de regulação contratual, examinou-se a interação da cláusula com o regime das condições potestativas e da obstrução maliciosa ao implemento.

31. O mecanismo de escrow account é normalmente empregado para garantia do vendedor ou do comprador, também se verificando incompatibilidade entre a prática contratual e os mecanismos bancários previstos.

32. O contrato de compra e venda de participações societárias de controle era considerado um contrato civil sob o Código Comercial de 1850 e, sob o Código Civil vigente, não há motivo para se considerar que se trataria de contrato empresarial, até porque tal categoria dogmática de origem doutrinária e jurisprudencial não oferece critérios claros de qualificação, além de conduzir a resultados potencialmente inadequados. Constituiria retrocesso a aprovação de Código Comercial nos moldes do que atualmente tramita no Congresso Nacional, pois não há motivos para que a 
compra e venda de participações societárias fique sujeita ao regramento dos contratos comerciais.

33. O regime de forma da compra e venda de participações societárias de controle é o mesmo aplicável à compra e venda de participações minoritárias. Dessa comum sujeição ao regime geral decorre grande liberdade de forma, o que conduz a incongruências valorativas no ordenamento jurídico e a inconvenientes práticos, tendo-se sugerido medidas tópicas de aumento da segurança em matéria de transferência de quotas, qual seja, a exigência de reconhecimento de firmas. Defendeu-se, igualmente, a validade da cláusula pela qual os próprios sócios impõem a si regime formal de maior solenidade.

\section{Capítulo III: Regime Jurídico}

34. A sociedade pode ser titular de estabelecimento, de imóvel ou de posições contratuais cuja cessão é restrita e se pode questionar em quais hipóteses os regimes especiais poderiam ser aplicados à compra e venda de participações societárias de controle.

35. Nenhuma das regras do Código Civil previstas para a hipótese de trespasse do estabelecimento tem aplicação na hipótese de compra e venda de participações societárias de sociedade que seja dele titular.

36. As regras falimentares que determinam que a alienação do estabelecimento representaria ato falimentar e passível de revogação não se aplicam à compra e venda de participações societárias.

37. A alienação de unidade produtiva isolada, por não pressupor a existência de estabelecimento em sentido técnico, pode ser realizada 
por meio da compra e venda de quotas ou ações de sociedade titular de estabelecimento.

38. No âmbito tributário, reconhece-se que a compra e venda de quotas ou ações de controle não se confunde com o trespasse do estabelecimento para fins de incidência do art. 133 do CTN.

39. O regime protetivo do locatário e do arrendatário do bem imóvel não se aplica em caso de mudança de controle da sociedade locadora.

40. No âmbito do direito de família, o cônjuge pode alienar quotas ou ações de controle de sociedade proprietária de bem imóvel sem necessidade de autorização conjugal.

41. Em em matéria de usufruto dos bens dos filhos menores, os pais podem alienar ações ou quotas de sociedade titular de bem imóvel de propriedade dos filhos, sem necessidade de autorização judicial ou do outro genitor.

42. Na vigência de contrato de locação, a alteração de controle da sociedade locatária não exige consentimento do locador.

43. No caso de sociedade titular de ações ou quotas vinculadas a estatuto ou contrato social, ou acordo de sócios que preveja direito de preferência ou de venda conjunta, a extensão da eficácia de tal acordo a transferências indiretas de controle somente se justifica em hipótese de fraude à lei.

\section{Capítulo IV: Dever de Informar}


44. Na compra e venda de participações societárias de controle, o vendedor é destinatário de acentuado dever de informar, devido ao déficit informacional estrutural em que se situa o comprador, tendo em vista que, em geral, para se informar depende informações e documentos fornecidos pelo vendedor.

45. O dever de informar não abrange somente as características dos títulos, mas a constituição do patrimônio societário e todas as caraterísticas intrínsecas ou extrínsecas que possam afetar de forma ponderável a contratação.

46. $\mathrm{O}$ dever de informar na compra e venda de participações societárias de controle encontra especificidades, pois a administração da sociedade não é obrigada a fornecer ao vendedor ou ao comprador informações sobre o patrimônio societário.

47. O vendedor pode-se recusar validamente a oferecer informações sigilosas e estratégicas ao comprador.

48. Em ambas as hipóteses, contudo, não há infração ao dever de informar, desde que haja clareza das bases da contratação e a impossibilidade de informar não seja utilizada como artifício para atuação de má-fé.

49. O comprador possui o ônus de se informar, o que é realizado por meio da auditoria.

50. A realização de auditoria ainda não se consolidou como um costume jurídico e aquele que decide não promovê-la, ou, o que é mais comum, limitar a auditoria a certos aspectos empresariais, não é negligente e não perde direito de ser informado.

51. A auditoria é realizada no interesse do comprador, razão pela qual a auditoria defeituosa não retira direitos e garantias que tenham sido contratualmente assegurados ao comprador. 
52. Caso o comprador, contudo, obtenha efetivo conhecimento de não conformidade entre as declarações e garantias e a realidade no âmbito de auditoria que tenha realizado e prossiga com a contratação, deve-se interpretar o comportamento do comprador como indicativo de que aceitou a condição patrimonial da sociedade.

53. A auditoria é mecanismo pelo qual o vendedor cumpre sua obrigação de informar, bastando que, para tanto, disponibilize ao comprador as informações suficientes e necessárias para alertá-lo dos fatores relevantes para a sua tomada de decisão.

54. Na compra e venda de participações societárias de controle em que os administradores atuam como compradores impõem-se, em virtude da conjugação do dever de lealdade societário com o dever de boa-fé pré-contratual, um dever de informar todos os dados que conheça em função de seu cargo em benefício do sócio, razão pela qual, nessa específica circunstância, é o comprador-administrador obrigado a informar o vendedor-controlador.

\section{Capítulo V: Responsabilidade Contratual}

55. A garantia por vícios redibitórios na compra e venda de participações societárias de controle não abrange as condições patrimoniais da sociedade, razão pela qual o comprador não poderá exercitar as ações edilícias em caso de descoberta de defeitos entre os ativos da sociedade. Para além do argumento formal de que as ações ou quotas não são objeto do negócio jurídico, impõe-se o afastamento da disciplina pela sua inadequação à ponderada regulação dos interesses do comprador e do vendedor. 
56. Aplica-se a disciplina da evicção, sobretudo à hipótese de impossibilidade de transferência de ações ou quotas em virtude de exercício de direito de preferência ou cláusula de restrição à livre circulação de ações, ou limitativa da possibilidade de cessão da quota.

57. O erro deve se reportar a condições essenciais da coisa e, na compra e venda de participações societárias de controle, a situação patrimonial da sociedade apenas influencia o valor das ações ou quotas, não constituindo qualidade que lhes seja essencial. Em virtude disso, não se aplica a disciplina do erro em caso de falsa percepção da realidade pelo comprador.

58. O dolo comissivo e omissivo, essencial ou acidental, fundamenta a anulação do negócio jurídico ou o pleito de indenização por perdas e danos, seja na falsa percepção da realidade do comprador em relação às condições dos próprios títulos ou do acervo patrimonial. Não se impõe, no âmbito do dolo, a mesma restrição aplicável em matéria de erro.

59. Ainda que a falha ao dever de informar não seja considerada dolosa, autorizando a anulação do negócio jurídico, surge àquele que estava obrigado a informar responsabilidade civil pelas perdas e danos a que deu causa.

\section{B. Considerações Finais}

O presente trabalho buscou analisar a compra e venda de participações societárias de controle, contrato celebrado diariamente na prática empresarial, mas que, em geral, é tratado pela doutrina como mecanismo para a transferência da empresa ou do controle, ou de ambos. Acredita-se que tal orientação tenha negligenciado características peculiares desse negócio jurídico, aí incluída sua distinta aptidão para servir como 
mecanismo para a mobilização de riquezas. Mais do que meio para um fim, o contrato de compra e venda de participações societárias merece ser estudado pelo que apresenta de específico.

O tratamento da compra e venda de participações societárias, ora sob a perspectiva da empresa, ora do poder, descura do fato de que o contrato que versa sobre ações ou quotas tem como objeto - exata e redundantemente - ações ou quotas. O regime jurídico de circulação das participações societárias é acentuadamente diverso do que vige para o trespasse. Mesmo quando se compara uma cessão de quotas a uma compra e venda de ações, percebe-se que em um e em outro contrato, tanto o vendedor quanto o comprador situam-se em posições jurídicas diversas.

O cálculo do preço nos contratos pertinentes a participações societárias, ademais, pode apresentar características peculiares, por meio do entrelaçamento da dinâmica societária com mecanismos contratuais (e.g., earn out), que não estão presentes, na mesma medida, em contratos de trespasse. A natureza jurídica da compra e venda de participações societárias sempre foi discutida, porque não se trata de contrato celebrado entre empresários, ou que fosse celebrado entre comerciantes, senão entre um sócio e um adquirente versando sobre que podem alçar elevado valor, e não sobre mercadorias. E sua forma é própria e diversa da aplicável à transferência de outros bens, como imóveis, mesmo que a sociedade possua imóveis em seu patrimônio.

O regime pertinente à transmissão de estabelecimentos, imóveis e posições contratuais não é imediatamente aplicável à hipótese de uma sociedade titular de um desses bens ter as suas participações societárias de controle vendidas, em testemunho de que, como regra, admite-se no ordenamento jurídico nacional a autonomia da compra e venda de quotas ou ações como contrato com traços distintivos próprios. A despeito de a desconsideração ser possível, ela não é a regra. Incumbe a quem a pleiteia o ônus argumentativo de demonstrar que a personalidade jurídica deve ser afastada.

No âmbito do dever de informar, aludiu-se às repercussões relevantes provocadas pela interposição da personalidade jurídica entre comprador e vendedor, seja para impor deveres acentuados de informação, seja para limitar a possibilidade de condução de auditoria pelo comprador na hipótese de a administração não concordar com o 
fornecimento de informações, seja para, em certas hipóteses, até mesmo impor ao comprador que seja, concomitantemetne, administrador, um dever de informar em tudo peculiar como decorrência da conjugação entre o dever de lealdade societário e o dever de informar pré-contratual.

No âmbito da responsabilidade contratual, por sua vez, acenou-se para as relevantes discussões presentes no direito estrangeiro acerca da aplicação da disciplina dos vícios redibitórios e do erro. Adotando posição divergente da que prevalece na doutrina majoritária, a tese propôs soluções, sugerindo novo encaminhamento dogmático à disciplina.

Espera-se que o trabalho possa, com isso, contribuir para o desenvolvimento de um campo de investigação em que se acredita que a academia teria muito a colaborar com a prática empresarial e forense. 


\section{BIBLIOGRAFIA}

ABRÃO, Nelson. Sociedades limitadas, $10^{\mathrm{a}}$ ed. rev. e atual. por Carlos Henrique Abrão. São Paulo: Saraiva, 2012.

ACERBI, Giuseppe. "Gli amministratori di società per azioni di fronte al trasferimento del controllo: problemi e proposte di soluzione". In: Rivista delle società, 1997, pp. 281-367.

ADAMEK, Marcelo Vieira von. "Da Invalidade do Mecanismo de Ajuste de Preço Inserido em Contrato de Investimento, por ofensa ao Regime Jurídico da Vinculação Patrimonial (Parecer)”. In: Revista de Direito Brasileira, v. 66, 2014, pp. 245-269.

ADAMEK, Marcelo Vieira von. Abuso de minoria em direito societário. São Paulo: Malheiros, 2014.

ALBERTINI, Lorenzo. "Cessione di quote sociali e divieto di concorrenza ex art. 2557 c.c.”. In: Giustizia civile, 1997, I, pp. 1291-1309.

ALMEIDA COSTA, Mário Júlio de; MENDES, Evaristo. "Transmissão de acções tituladas nominativas". In: Estudos dedicados ao Prof. Dr. Luís Alberto Carvalho Fernandes, v. 3. Lisboa: Católica, 2011, pp. 13-61.

ALMEIDA, Carlos Ferreira de. "Interpretação do Contrato". In: Revista de direito do consumidor, v. 17, 1996, pp. 5-19.

ALVARENGA, Maria Isabel de Almeida. "Finalidades do direito de preferência para a aquisição de ações". In: ADAMEK, Marcelo V. von. Temas de direito societário e empresarial contemporâneos. São Paulo: Malheiros, 2011, pp. 472-491.

ALVIM, Agostinho. Da doação, $3^{\text {a }}$ ed. São Paulo: Saraiva, 1980.

ANDRADE, Ronaldo Alves de. In: ALVIM, Arruda; ALVIM, Thereza (coord.). Comentários ao Código Civil Brasileiro, v. 5. Rio de Janeiro: Forense, 2007. 
ANGELICI, Carlo. "La partecipazione azionaria come oggetto di circolazione". In: COLOMBO, Giovanni E.; PORTALE, Giuseppe B. (org.). Trattato delle società per azione, $2^{\circ}$ t. (Azioni e Gruppi). Torino: UTET, 1991, pp. 101-130.

ANGELICI, Carlo. "Le forme di circolazione". In: COLOMBO, Giovanni E.; PORTALE, Giuseppe B. (org.). Trattato delle società per azioni, v. 2: Azioni, Gruppi. Torino: UTET, 1991, pp. 254-297.

ANGELICI, Carlo. La società nulla. Milano: Giuffrè, 1975.

ANGERSBACH, Carsten J. Due Diligence beim Unternehmenskauf. Baden-Baden: Nomos, 2002.

ANTUNES, João Tiago M. Do contrato de depósito escrow. Coimbra: Almedina, 2007.

ANTUNES, José Engrácia. "A empresa como objecto de negócios ('asset deal" vs. "share deal')". In: Revista da Ordem dos Advogados, 2008, pp. 715-793.

ARAGÃO, Paulo Cézar. "Reflexões sobre as sentenças determinativas". In: Revista de Processo, v. 2, 1976, pp. 159-168.

ASCARELLI, Tullio. "Ancora sul concetto di titolo di credito e sulla distinzione tra tipologia della realtà e normativa". In: Banca, Borsa e Titoli di Credito, I, 1956, pp. 461480.

ASCARELLI, Tullio. "Divieto di concorrenza e vendita dell'azienda". In: Studi in tema di contratti. Milano: Giuffrè, 1952, pp. 487-497.

ASCARELLI, Tullio. "In tema di vendita di azioni e responsabilità degli amministratori". In: Foro Italiano, 1953, pp. 1639-1644.

ASCARELLI, Tullio. "In tema di vendita di pacchetti di azioni". In: Studi in tema di società. Milano: Giuffrè, 1952, pp. 63-67. 
ASCARELLI, Tullio. "O conceito de direito especial e a autonomia do direito comercial". In: Problemas das Sociedades Anônimas e Direito Comparado, $2^{\text {a }}$ ed. São Paulo: Saraiva, 1969, pp. 84-89.

ASCARELLI, Tullio. “O contrato plurilateral”. In: Problemas das sociedades anônimas e direito comparado, $2^{\text {a }}$ ed. São Paulo: Saraiva, 1969, pp. 255-312.

ASCARELLI, Tullio. "O empresário (l'imprenditore)”, trad. de F. K. Comparato. In: Revista da Faculdade de Direito da Universidade de São Paulo, v. 92, 1997, pp. 269278.

ASCARELli, Tullio. "O Negócio Indireto”. In: Problemas das Sociedades Anônimas e Direito Comparado, 2ª ed. São Paulo: Saraiva, 1969, pp. 91-163.

ASCARELLI, Tullio. "Riflessioni in tema di titoli azionari e società tra società". In: Saggi di diritto commerciale. Milano: Giuffrè, 1955, pp. 219-271.

ASCARELLI, Tullio. "Sul concetto di titolo di credito e sulla disciplina del titolo V libro IV del nostro codice". In: Banca, Borsa e Titoli di Credito, I, 1954, pp. 367-388.

ASCARELLI, Tullio. "Transferência de ações - participação na assembleia e propriedade das ações - transferência das ações e livro de presença na assembleia”. In: Ensaios e pareceres. São Paulo: Saraiva, 1952, pp. 89-98.

ASCARELLI, Tullio. Panorama do direito comercial. São Paulo: Saraiva, 1947.

ASCARELLI, Tullio. Teoria della concorrenza e dei beni immateriali. Milano: Giuffrè, 1956.

ASCARELLI, Tullio. Teoria geral dos títulos de crédito, trad. de Nicolau Nazo. São Paulo: Saraiva, 1943.

ASSIS, Araken de. Comentários ao Código Civil Brasileiro, v. 5. Rio de Janeiro: Forense, 2007. 
ATIYAH, P. S. The rise and fall of freedom of contract. Oxford: Clarendon, 1979.

AURICCHIO, Alberto. La simulazione nel negozio giuridico. Napoli: Jovena, 1957.

AZEVEDO, Antônio Junqueira de. “(Parecer) Contrato de opção de venda (put option) de ações. Conflito entre o critério de determinação do valor das ações e o piso mínimo estipulado para transferência. Interpretação do conceito de preço justo. A boa-fé e os usos, visando evitar o enriquecimento sem causa". In: Novos estudos e pareceres de direito privado. São Paulo: Saraiva, 2009, 273-286.

AZEVEDO, Antonio Junqueira de. “(Parecer). Acordo de acionistas com cláusula de preferência na aquisição de ações. Contrato intuitu personae a ser interpretado em duas fases: procura da vontade comum das partes e boa-fé objetiva contratual. Teoria do abuso da personalidade jurídica. Extensão da preferência à hipótese implícita de alienação da controladora de uma das acionistas". In: Novos estudos e pareceres de direito privado. São Paulo: Saraiva, 2009, pp. 219-234.

AZEVEDO, Antonio Junqueira de. "Parecer: Interpretação do contrato pelo exame da vontade contratual. $\mathrm{O}$ comportamento das partes posterior à celebração. Interpretação e efeitos do contrato conforme o princípio da boa-fé objetiva. Impossibilidade de venire contra factum proprium e de utilização de dois pesos e duas medidas. Efeitos do contrato e do sinalagma. A assunção pelos contratantes de riscos específicos e a impossibilidade de fugir do 'programa contratual' estabelecido", in Estudos e Pareceres de Direito Privado, São Paulo, Saraiva, 2004, pp. 159-183.

AZEVEDO, Antonio Junqueira de. "Rapport brésilien". In: La bonne foi, Travaux de l'Association Henri Capitant des amis de la culture juridique française (Journées louisianaises), t. XLIII, Paris: Litec, 1992, pp. 77-84.

AZEVEDO, Antonio Junqueira de. Negócio jurídico: existência, validade e eficácia, $4^{\mathrm{a}}$ ed. atual. São Paulo: Saraiva, 2002.

BALLERSTEDT, Kurt. "Das Unternehmen als Gegenstand eines Bereicherungsanspruchs". In: FISCHER, Robert (coord., et. al.). Gesellschaftsrecht und 
Unternehmensrecht - Festschrift für Wolfgang Schilling zum 65. Geburtstag. Berlin/New York: De Gruyter, 1973, pp. 289-307.

BAPTISTA, Luiz Olavo. Arbitragem comercial e internacional. São Paulo: Lex Editora, 2011.

BARBOSA, Rui. "As cessões de clientela e a interdição de concorrência nas alienações de estabelecimentos comerciais e industriais". In: Obras completas de Rui Barbosa, v. XL, T. I. Rio de Janeiro: Ministério da Educação e Saúde, 1928.

BARRETO FILHO, Oscar. Teoria do estabelecimento comercial. São Paulo: Max Limonad, 1969.

BATIFFOL, Henri. "Problèmes contemporains de la notion de biens". In: Archives de philosophie du droit, t. 24: les biens et les choses. Paris: Sirey, 1979, pp. 9-16.

BAUMS, Theodor. "Ergebnisabhängige Preisvereinbarungen in Unternehmenskaufverträgen”. In: Der Betrieb, 1993, pp. 1273-1276.

BERGJAN, Ralf. Die Auswirkungen der Schuldrechtsreform 2002 auf den Unternehmenskauf. Berlin: Dunker \& Humblot, 2003.

BERNINI, Giorgio. "Acquisizione di società e determinazione del prezzo". In: GALGANO, Francesco (org.). I contratti del commercio, dell'industria e del mercato finanziario, tomo primo. Torino: UTET, 1995, pp. 217-245.

BESSONE, Darcy. Da Compra e Venda. Belo Horizonte: Bernardo Álvares, 1960.

BEUTHIEN, Volker. "Zur Mitgliedschaft als Grundbegriff des Gesellschaftsrechts Subjektives Recht oder Stellung im pflichthaltigen Rechtsverhältnis?”. In: WANK, Rolf (et $a l$, org.). Festschrift für Herbert Wiedemann zum 70. Geburtstag, München: C. H. Beck, 2002, pp. 755-768.

BEVILÁQUA, Clóvis. Código Civil dos Estados Unidos do Brasil Comentado, vol. 4, São Paulo/Rio de Janeiro: Francisco Alves, 1917. 
BIONE, Massimo. "Le azioni”. In: COLOMBO, Giovanni E.; PORTALE, Giuseppe B. (org.). Trattato delle società per azioni, v. 2: Azioni, Gruppi. Torino: UTET, 1991, pp. 343.

BISIOLI, Federica. "La determinazione arbitrale del prezzo di cessione di quote di società a responsabilità limitata e sue implicazioni”. In: Il diritto fallimentare e delle società commerciali, II, 1999, pp. 140-149.

BONELLI, Franco. "Giurisprudenza e dottrina su acquisizioni di società e di pacchetti azionari di riferimento”. In: BONELLI, Franco; DE ANDRÉ, Mauro (org.). Acquisizioni di società e di pacchetti azionari di riferimento. Milano: Giuffrè, 1990, pp. 4-48.

BOTELHO DE MESQUITA, José Ignácio. "Execução específica de direito de preferência originado de acordo de acionistas". In: ADAMEK, Marcelo Vieira von. Temas de direito societário e empresarial contemporâneos. São Paulo: Malheiros, 2011, pp. 836-848.

BOTREL, Sérgio. Fusões e aquisições. São Paulo: Saraiva, 2012.

BÖTTCHER, Lars. "Due Diligence beim Unternehmenskauf als Verkehrssitte". In: Zeitschrift für das gesamte Schuldrecht, 2007, pp. 20-25.

BOZZOLA, Gianpietro. "Divieto di concorrenza in caso di cessione d'azienda e abuso della personalità giuridica". In: Rivista di diritto industriale, II, 1993, pp. 370-378.

BRACCIODIETA, Angelo. "Alienazione di quota sociale e divieto di concorrenza". In: Rivista delle società, 1964, pp. 977-999.

BRANCO, Luiz Carlos Gerson. "O regime obrigacional unificado do Código Civil Brasileiro e seus efeitos sobre a liberdade contratual. A compra e venda como modelo jurídico multifuncional”. In: Revista dos Tribunais, v. 872, 2008, pp. 11-42.

BRAUNSCHWEIG, Philipp von. "Variable Kaufpreisklauseln in Unternehmenskaufverträgen”. In: Der Betrieb, 2002, pp. 1815-1818. 
BREIDENBACH, Stephan. Die Voraussetzungen von Informationspflichten beim Vertragsschluß. München: C. H. Beck, 1989.

BULGARELLI, Waldírio. "Alguns estranhos casos de sociedades por cotas de responsabilidade limitada no direito brasileiro". In: Estudos e pareceres de direito empresarial (o direito das empresas). São Paulo: RT, 1980, pp. 185-194.

BULGARELLI, Waldirio. “Os valores mobiliários brasileiros como títulos de crédito". In: Revista de Direito Mercantil, Industrial, Econômico e Financeiro, n. 37, 1980, pp. 94112.

BUSCHINELLI, Gabriel Saad Kik. "Comentários aos arts. 19 e 20”. In: CODORNIZ, Gabriela; PATELLA, Laura (coord.). Comentários à lei do mercado de capitais. São Paulo: Quartier Latin, 2015, pp. 379-425.

BUSCHINELLI, Gabriel Saad Kik. "Condo-hotéis' e o conceito de valor mobiliário". In: Revista comercialista, v. 10, 2013, pp. 26-28.

BUTTARO, Luca. "Tullio Ascarelli e il titolo di credito". In: Banca, Borsa e Titoli di Credito, I, 1981, pp. 414-432.

BUXBAUM, Richard. "What happened to Perlman v. Feldman?". In: WANK, Rolf (et al., org.). Festschrift für Herbert Wiedemann zum 70. Geburtstag, München: C. H. Beck, 2002, pp. 769-785.

CAEMMERER, Ernst von. "The influence of the of international trade on the development and character of the commercial law in the civil law countries". In: ROTONDI, Mario. Inchieste di diritto comparato, v. 3: L'unità del diritto delle obbligazioni. Padova: CEDAM, 1974, pp. 12-29.

CAFFIN-MOI, Marie. Cession de droits sociaux et droit des contrats. Paris: Economica, 2009.

CALVO, Roberto. "Il trasferimento della 'proprietà' nella compravendita di titoli azionari”. In: Contr. impr., 1993, pp. 1063-1123. 
CALVO, Roberto. "Vendita e rimedi nel diritto tedesco: dalla 'garanzia' all'inadempimento". In: Rivista di diritto civile, 2013, pp. 297-307.

CÂMARA, Paulo; BASTOS, Miguel Brito. "O direito da aquisição de empresas: uma introdução". In: CÂMARA, Paulo; BASTOS, Miguel Brito (org.). Aquisição de empresas. Coimbra: Almedina, 2011, pp. 13-64.

CAMILO Jr., Ruy Pereira. "Contrato de cessão de quotas sociais". In: AZEVEDO, Luis André Negrelli de Moura; CASTRO, Rodrigo Rocha Monteiro de (org.). Sociedade limitada contemporânea. São Paulo: Quartier Latin, 2013, pp. 217-259.

CAMPINHO, Sérgio. O Direito de Empresa à Luz do Novo Código Civil. $3^{\mathrm{a}}$ ed. rev. e atual. Rio de Janeiro: Renovar, 2003.

CAMPOBASSO, Mario. "Vendita del pacchetto azionario di società in liquidazione per perdite”. In: Riv. dir. priv., n. 21, 1996, pp. 362-392.

CANARIS, Claus-Wilhelm; GRIGOLEIT, Hans Christoph. "Interpretation of contracts". In: HARTKAMP, Arthur (org., et.al.). Towards a European Civil Code, $4^{\mathrm{a}}$ ed. Alphen aan den Rijn: Kluwer/Ars Aequi, 2011 pp. 587-618.

CANARIS, Claus-Wilhelm. "Leistungsstörungen beim Unternehmenskauf”. In: Zeitschrift für Unternehmens- und Gesellschaftsrecht, 1982, pp. 395-434.

CANARIS, Claus-Wilhelm. "Leistungsstörungen und Gewährleistung beim Unternehmenskauf nach der Reform des deutschen Schuldrechts". In: STATHOPOULOS, Michael (coord., et. al.). Festschrift für Apostolos Georgiades zum 70. Geburtstag. München: C. H. Beck/Sakkoulas/Stämpfli, 2006, pp. 71-94.

CANARIS, Claus-Wilhelm. "O novo direito das obrigações na Alemanha". In: Revista Brasileira de Direito Comparado, 2004, pp. 3-26.

CANARIS, Claus-Wilhelm. Die Feststellung von Lücken im Gesetz, 2. Aufl. Berlin: Duncker \& Humblot, 1983. 
CANARIS, Claus-Wilhelm. Handelsrecht, 24 Aufl. München: C. H. Beck, 2006.

CANARIS, Claus-Wilhelm. Systemdenken und Systembegriff in der Jurisprudenz, 2. Aufl. Berlin: Duncker \& Humblot, 1983.

CANCELLI, Filippo. "voce Società (diritto romano)". In: AZARA, Antonio; EULA, Ernesto (org.). Novissimo digesto italiano, v. XVII, Torino: UTET, 1970, pp. 495-516.

CARMONA, Carlos Alberto. Arbitragem e processo, $3^{\text {a }}$ ed. São Paulo: Atlas, 2009.

CARNEVALI, Ugo. "Cessione di partecipazioni sociali e divieto di concorrenza". In: I contratti, n. 3, 1997, pp. 269-272.

CARNEVALI, Ugo. "Compravendita di quote sociali, mancanza di qualità e aliud pro alio". In: Contratti, 2004, pp. 687-694.

CARNEVALI, Ugo. "Garanzie per vizi dei beni sociali nella cessione di azioni”. In: Società, n. 6, 1992, pp. 822-824.

CARRASCO PERERA, Ángel. "Representaciones e garantías". In: ÁLVAREZ ARJONA, J. (org., et. al.). Régimen jurídico de las adquisiciones de empresas. Navarra: Arazandi, 2001, pp. 191-236.

CARVALHO DE MENDONÇA, José Xavier. Tratado de direito commercial brasileiro, v. 5, parte 2, $3^{\mathrm{a}}$ ed. atual. por Achilles Bevilaqua e Roberto Carvalho de Mendonça. Rio de Janeiro: Freitas Bastos, 1938.

CARVAlho SAnTOS, J. M. Código Civil Brasileiro Interpretado, $3^{\mathrm{a}}$ ed. Rio de Janeiro: Freitas Bastos, 1945.

CARVALHO, Dora Martins de. "As Sociedades Limitadas no Projeto do Código Civil". In: Revista de Direito Mercantil, Industrial, Econômico e Financeiro, v. 60, 1985, pp. 90-92. 
CARVALHO, Luiz Maklouf. “A baleia branca de Rodolfo Landim”. In: Revista Piauí, v. $52,2011$.

CARVALHO, Orlando de. "Negócio jurídico indirecto (teoria geral)". In: Boletim da Faculdade de Direito da Universidade de Coimbra, supl. 10, 1952, pp. 1-149.

CARVALHO, Orlando de. "Teixeira de Freitas e a unificação do direito privado". In: SCHIPANI, Sandro (org.). Augusto Teixeira de Freitas e il diritto latinoamericano. Padova: Cedam, 1988, pp. 101-153.

CARVALHOSA, Modesto. Comentários à lei de sociedades anônimas, v. 1, $2^{\mathrm{a}}$ ed. rev. e atual. São Paulo: Saraiva, 1997.

CARvalhosa, Modesto. Comentários ao Código Civil, v. 13, $2^{\text {a }}$ ed. São Paulo: Saraiva, 2005.

CASANOVA, Mario. "Azienda" (voce). In: Digesto delle discipline privatistiche, Sezione Commerciale, v. II. Torino: UTET, 1987, pp. 75-99.

CASQUET, Andréia Cristina Bezerra. Alienação de Controle de Companhias Fechadas. São Paulo: Quartier Latin, 2015.

CASTANHEIRA NEVES, António. Questão-de-facto - questão-de-direito ou o problema metodológico da juridicidade. Coimbra: Almedina, 1967.

CASTELLARI, Paolo. "Società unipersonale a responsabilità limitata e prelazione agraria del coltivatore insediato o proprietario di terreno confinante". In: Rivista di diritto agrario, 1994, pp. 504-534.

CAVALLI, Cássio. Sociedades limitadas: regime de circulação das quotas. São Paulo: Revista dos Tribunais, 2011.

CHAMPAUD, Claude. "Présentation de la cession de contrôle". In: Nouvelles techniques de concentration. Paris: LITEC, 1972, pp. 140-141. 
CHAVES, Antônio. "Cessão de posição contratual e cessão de situação acionária. Apossamento posterior, pelo cedente, de bens do acervo transmitido. Frustração da finalidade contratual. Responsabilidade civil, criminal e administrativa". In: Revista dos Tribunais, v. 427, 1971, pp. 35-56.

CHAZAL, Jean-Pascal.; VICENTE, Serge. "Le transfert de propriété par l'effet des obligations dans le Code Civil”. In: Revue trimestrielle de droit civil, n. 3, 2000, pp. 477 506.

CLARK, Robert Charles. Corporate Law. Boston/Toronto: Little, Brown and Company, 1986.

COELHO, Fábio Ulhoa. “As obrigações empresariais”. In: COELHO, Fábio Ulhoa (Coord.). Tratado de direito comercial, v. 5. São Paulo: Saraiva, 2015, 13-20.

COELHO, Fábio Ulhoa. “Compra e venda mercantil”. In: COELHO, Fábio Ulhoa (coord.). Tratado de direito comercial, v. 5. São Paulo: Saraiva, 2015, pp. 235-269.

COELHO, Fábio Ulhoa. "Os contratos empresariais no projeto de Código Comercial”. In: Revista da Faculdade de Direito da Universidade do Porto, v. XI, 2014, pp. 387-395.

COELHO, Fábio Ulhoa. "Pequena reflexão sobre a boa-fé em arbitragens de direito societário". In: Revista de Arbitragem e Mediação, v. 38, 2013, pp. 21-23.

COELHO, Fábio Ulhoa. Curso de direito comercial, 17ª ed. São Paulo: Saraiva, 2013.

COLOMBO, Sylviane. "Present differences between the Civil Law and Common Law worlds with regard to culpa in contrahendo". In: Tilburg Law Review, vol. 2, 1993, pp. 341-376.

COMPARATO, Fábio Konder; SALOMÃO FILHO, Calixto. O poder de controle na sociedade anônima, $6^{\mathrm{a}}$ ed. rev. e atual. Rio de Janeiro: Forense, 2014. 
COMPARATO, Fábio Konder. “A cessão de controle acionário é negócio mercantil?”. In: Novos ensaios e pareceres de direito empresarial. Rio de Janeiro: Forense, 1981, pp. 245-260.

COMPARATO, Fábio Konder. "A obrigação de informar no direito contratual”. In: OLIVERA GARCÍA, Rodolfo (org.). Estudios jurídicos en memoria del Profesor Rodolfo Mezzera Alvarez. Montevideo: Fundación de Cultura Universitaria, 1999, pp. 249-256.

COMPARATO, Fabio Konder. "As ações de sociedade anônima como valores mobiliários - natureza e efeitos do registro acionário". In: Novos ensaios e pareceres de direito empresarial. Rio de Janeiro: Forense, 1981, pp. 16-31.

COMPARATO, Fábio Konder. "Da imprescritibilidade da ação direta de nulidade estatutária”. In: Novos ensaios e pareceres de direito empresarial. Rio de Janeiro: Forense, 1981, pp. 215-225.

COMPARATO, Fábio Konder. "Eficácia dos acordos de acionistas". In: Novos ensaios e pareceres de direito empresarial. Rio de Janeiro: Forense, 1981, pp. 74-87

COMPARATO, Fábio Konder. "Exclusão de sócio, independentemente de específica previsão legal ou contratual". In: Ensaios e pareceres de direito empresarial. Rio de Janeiro: Forense, 1978, pp. 131-149.

COMPARATO, Fábio Konder. "Parecer sobre o Projeto de Lei n. 634/75, do Executivo". In: Revista de Direito Mercantil, Industrial, Econômico e Financeiro, n. 17, 1975, pp. 173-187.

COMPARATO, Fábio Konder. "Poder de controle na sociedade anônima". In: Revista de Direito Mercantil, Industrial, Econômico e Financeiro, n. 9, 1973, pp. 67-75.

COMPARATO, Fábio Konder. "Responsabilidades na transferência de ações escriturais". In: Direito empresarial: estudos e pareceres. São Paulo: Saraiva, 1990, pp. 354-361. 
COMPARATO, Fábio Konder. "Restrições à circulação de ações em companhia fechada: nova et vetera". In: Novos ensaios e pareceres de direito empresarial. Rio de Janeiro: Forense, 1981, pp. 32-51.

COMPARATO, Fábio Konder. "Validade e eficácia de acordo de acionistas. Execução específica de suas estipulações”. In: Novos ensaios e pareceres de direito empresarial. Rio de Janeiro: Forense, 1981, pp. 52-73.

CORTEZ, Jorge Simões. "As formalidades da transmissão de quotas e acções no Direito Português: dos princípios à prática”. In: COELHO, Fábio Ulhoa; RIBEIRO, Maria de Fátima (org.). Questões de direito comercial em Portugal e no Brasil. Coimbra: Almedina, 2012, pp. 313-343.

CORVO, Erick. "Acordos de sócios de sociedades limitadas à luz do Código Civil de 2002”. In: ADAMEK, Marcelo Vieira von. Temas de direito societário e empresarial contemporâneos. São Paulo: Malheiros, 2011, pp. 84-114.

COSTA, Mariana Fontes da. "O dever pré-contratual de informação". In: Revista da Faculdade de Direito da Universidade do Porto, vol. 4, 2007, pp. 367-394.

COSTA, Philomeno Joaquim da. “Comentário ao acórdão n. 26.147, do TJSP”. In: Revista de Direito Mercantil, Industrial, Econômico e Financeiro, v. 50, 1983, pp. 106-109.

COSTA, Philomeno Joaquim da. Anotações às companhias. São Paulo: RT, 1980.

COSTA, Philomeno Joaquim da. Autonomia do direito comercial. São Paulo: RT, 1956.

COTTINO, Gastone. Diritto societario, 2a ed. Padova: CEDAM, 2011.

COUTINHO DE ABREU, Jorge Manuel. Da empresarialidade. Coimbra: Almedina, 1999.

COUTO E SILVA, Clóvis Veríssimo do. "Cessão de crédito (parecer)". In: Revista dos Tribunais, v. 638, 1988, pp. 10-14. 
COUTO E SILVA, Clóvis Veríssimo do. "Miguel Reale, civilista". In: LAFER, Celso; FERRAZ Jr., Tércio Sampaio (org.). Direito, política, filosofia, poesia: estudos em homenagem ao Professor Miguel Reale no seu octogésimo aniversário. São Paulo: Saraiva, 1992, pp. 413-425.

COUTO E SILVA, Clóvis Veríssimo do. "Negócios jurídicos e negócios jurídicos de disposição". In: FRADERA, Véra (org.). O direito privado brasileiro na visão de Clóvis do Couto e Silva. Porto Alegre: Livraria do Advogado, 1997, pp. 73-87.

COUTO E SILVA, Clóvis Veríssimo do. A Obrigação como Processo, reimpressão. Rio de Janeiro: Editora FGV, 2007.

COZIAN, Maurice; VIANDIER, Alain; DEBOISSY, Florence. Droit des sociétés, $26^{\mathrm{a}}$ ed. Paris: LexisNexis, 2012.

CRAVEIRO, Mariana Conti. Contratos entre sócios. São Paulo: Quartier Latin, 2013.

CRISTIANO, Romano. Sociedades limitadas. São Paulo: Malheiros, 2008.

CROSIO, Stefano; GREGORI, Claudia. "Acquisizione di società ad elevato contenuto tecnologico: clausole di earn-out e dichiarazioni e garanzie del venditore". In: Contratto e impresa, 2000, pp. 1109-1123.

CUNHA PEIXOTO, C. F. A sociedade por cotas de responsabilidade limitada, v. 1, $2^{\text {a }}$ ed. Rio de Janeiro: Forense, 1958.

CUNHA PEIXOTO, Carlos F. Sociedades por ações, v. 1. São Paulo: Saraiva, 1972.

D'ALESSANDRO, Carlo. "Vendita di partecipazioni sociali e promessa di qualità". In: Giustizia civile, 2005, pp. 1071-1078.

DANET, Didier. “Cession de droits sociaux: information préalable ou garantie des vices?”. In: Revue trimestrielle de droit commercial, 1992, pp. 315-349.

DAVIES, Paul L. Gower and Davies Principles of Modern Company Law, $8^{\text {a }}$ ed. London: Sweet \& Maxwell, 2008. 
DE ANDRÉ, Mauro. "Le clausole relative al prezzo". In: BONELLI, Franco; DE ANDRÉ, Mauro. (org.). Acquisizioni di società e di pacchetti azionari di riferimento. Milano: Giuffrè, 1990, pp. 4-48.

DE RITIS, Massimo Rubino. "Trasferimento di pacchetti azionari di controllo: clausole contrattuali e limiti all'autonomia privata”. In: Giurisprudenza commerciale, I, 1997, pp. 879-906.

DEUTSCHER BUNDESTAG. "Entwurf eines Gesetzes zur Modernisierung des Schuldrechts”. In: BT/Drucks. 14/6040, 2001.

DRAETTA, Ugo. "Alcune clausole di adeguamento del prezzo a seguito di verifica contabile nei contratti di acquisto di partecipazioni azionarie". In: Diritto del commercio internazionale, 1991, pp. 143-150.

DUBOUT, Hubert. "La distinction des clauses d'ajustement de prix et des clauses de garantie dans les contrats d'acquisition d'entreprises". In: Bull Joly, 2004, pp. 891-899.

DYCK, Alexander; ZINGALES, Luigi. "Private benefits of control: an international comparison”. In: Journal of Finance, v. 59, 2004, pp. 537-600.

EGGENBERGER, Jans. Gesellschaftsrechtliche Voraussetzungen und Folgen einer due-diligence Prüfung. Frankfurt a. M.: Peter Lang, 2001.

EIDENMÜLLER, Horst. "Rechtskauf und Unternehmenskauf”. In: Zeitschrift für das gesamte Schuldrecht, 2002, pp. 290-296.

EIZAGUIRRE, José María. "Bases para una reelaboración de la teoría general de los títulos-valores”. In: Revista de derecho mercantil, 1982, pp. 7-112.

EIZIRIK, Nelson. A Lei das S/A Comentada, v. 1, São Paulo: Quartier Latin, 2011.

EIZIRIK, Nelson. A lei das S/A comentada, v. 1, 2 a ed. São Paulo: Quartier Latin, 2015.

FABIAN, Christoph. O dever de informar no direito civil. São Paulo: RT, 2002. 
FABRE-MAGNAN, Muriel. De l'obligation d'information dans les contrats: essai d'une théorie. Paris: LGDJ, 1992.

FASTRICH, Lorenz. In: BAUMBACH, Adolf; HUECK, Alfred (org.) GmbHG, 20a ed., München: C. H. Beck, 2013.

FATEMI, Aliresa. Die Obliegenheit zur Due Diligence beim Unternehmenskauf. Baden-Baden: Nomos, 2009.

FAZZIO Jr., Waldo. Sociedades limitadas. São Paulo, Atlas, 2003.

FÉRES, Marcelo A. Estabelecimento empresarial. São Paulo: Saraiva, 2007.

FERRARI, Giorgio. Trasferimento di partecipazioni sociali e divieto di concorrenza”. In: Rivista di diritto industriale, I, 1967, pp. 54-81.

FERRAZ Jr., Tércio Sampaio. "Simulação e negócio jurídico indireto. No Direito Tributário e à luz do novo Código Civil”. In: Revista Fórum de Direito Tributário, n. 48, 2010, pp. 9-25.

FERREIRA, Mariana Martins-Costa. "Reflexões sobre o regime jurídico do acordo de acionistas e seus mecanismos de cumprimento forçado". In: YARSHELL, Flávio Luiz; PEREIRA, Guilherme Setogutti Júlio. Processo societário II. São Paulo: Quartier Latin, 2015, pp. 509-551.

FERREIRA, Waldemar. Tratado de direito comercial, v. 10. São Paulo: Saraiva, 1963.

FERREIRA, Waldemar. Tratado de sociedades mercantis, v. 3, 5 ed. Rio de Janeiro: Editora Nacional.

FERRER CORREIA, António de Arruda; SÁ, Almeno de. "Parecer". In: NUNES, Arlindo Monteiro (org.). A privatização da sociedade financeira portuguesa. Lisboa: Lex, 1995, pp. 257-302. 
FERRER CORREIA, António de Arruda. Sociedades fictícias e unipessoais. Coimbra: Atlântica, 1948.

FERRI, Giuseppe. "Incidenza delle obbligazioni sociali nei rapporti fra cedente e cessionario di quote sociali”. In: Foro italiano, I, 1936, 712-720.

FERRI, Giuseppe. "La teoria 'realista' dei titoli di credito". In: Estudios jurídicos en homenaje a Joaquín Garrigues, II. Madrid: Tecnos, 1971, pp. 313-324, pp. 321-322.

FERRI, Giuseppe. "Sul concetto di titolo di credito". In: Banca, Borsa e Titoli di Credito, I, 1956, pp. 322-336.

FERRI, Giuseppe. Causa e tipo nella teoria del negozio giuridico. Milano, Giuffrè, 1966.

FERRI, Giuseppe. Le società. Torino: UTET, 1971.

FINKENAUER, Thomas. "Ergänzende Auslegung bei Individualabreden". In: Archiv für die civilistische Praxis, v. 213, 2013, pp. 619-651, p. 630-642.

FISCHER, Markus. "Due diligence bei Unternehmenskäufen". In: Schweizerische Juristenzeitung, v. 96, 2000, pp. 229-236.

FLEISCHER, Holger; JAEGER, Felix. "Gesellschaftsrechtliche Anteilsbewertung in Frankreich gemäß Art. 1843-4 Code civil - Eine Vorstudie zur Komparatistik im Recht der Unternehmensbewertung”. In: RabelsZ, v. 77, 2013, pp. 693-722.

FLEISCHER, Holger; KÖRBER, Torsten. "Due Diligence im Gesellschafts- und Kapitalmarktrecht". In: BERENS, Wolfgang (org.; et. al.). Due Diligence bei Unternehmensakquisitionen, 6. Aufl. Stuttgart: Schäffer-Poeschel, 2011, pp. 267-293.

FLEISCHER, Holger; KÖRBER, Torsten. "Due diligence und Gewährleistung beim Unternehmenskauf'. In: Betriebs-Berater, 2001, pp. 841-849. 
FLEISCHER, Holger. "Konkurrenzprobleme um die culpa in contrahendo: Fahrlässige Irreführung versus arglistige Täuschung”. In: Archiv für die civilistische Praxis, v. 200, 2000, pp. 91-120.

FLEISCHER, Holger. "Unternehmensbewertung und Bewertungsabschläge beim Ausscheiden aus einer geschlossenen Kapitalgesellschaft”. In: KALSS, Susanne; FLEISCHER, Holger; VOGT, Hans-Ueli. (org.). Gesellschafts- und Kapitalmarktrecht in Deutschland, Österreich und der Schweiz 2013. Tübingen: Mohr Siebeck, 2014, pp. 137-161.

FLEISCHER, Holger. Informationsasymmetrie im Vertragsrecht. München: C. H. Beck, 2001.

FLUME, Werner. Eigenschaftsirrtum und Kauf. Dortmund: Gebrüder Lensing, 1948. FONSECA, Patrícia Afonso. "A negociação de participações de controlo: a jurisprudência”. In: I Congresso DSR. Coimbra: Almedina, 2011.

FORGIONI, Paula Andrea. "A interpretação dos negócios empresariais no novo Código Civil”. In: Revista de Direito Mercantil, Industrial, Econômico e Financeiro, n. 130, 2003, pp. 7-38.

FORGIONI, Paula Andrea. “A unicidade do regramento jurídico das sociedades limitadas e o art. 1.053 do Código Civil. Usos e costumes e regência supletiva". In: ADAMEK, Marcelo Vieira von. Temas de direito societário e empresarial contemporâneos. São Paulo: Malheiros, 2011, pp. 216-223.

FORGIONI, Paula Andrea. Teoria geral dos contratos empresariais, $2^{\mathrm{a}}$ ed. São Paulo: RT, 2010.

FRANÇA, Erasmo Valladão Azevedo e Novaes; ADAMEK, Marcelo Vieira von. "Empresa individual de responsabilidade limitada (Lei no 12.441/2011): anotações". In: AZEVEDO, Luis André Negrelli de Moura; CASTRO, Rodrigo Rocha Monteiro de (org.). Sociedade limitada contemporânea. São Paulo: Quartier Latin, 2013, pp. 39-77.

FRANÇA, Erasmo Valladão Azevedo e Novaes; ADAMEK, Marcelo Vieira von. “Aproveitamento de oportunidades comerciais da companhia pelo acionista controlador 
(corporate opportunity doctrine)". In: FRANÇA, Erasmo Valladão Azevedo e Novaes; ADAMEK, Marcelo Vieira von. (coord). Temas de direito empresarial e outros estudos em homenagem ao Prof. Luiz Gastão Paes de Barros Leães. São Paulo: Malheiros, 2014, pp. 88-110.

FRANÇA, Erasmo Valladão Azevedo e Novaes. "Dever de lealdade do acionista controlador por ocasião da alienação do controle - dever de maximização do valor das ações dos acionistas não controladores - interpretação de estatuto de companhia aberta possibilidade de cumulação de OPAs”. In: Revista de Direito Mercantil, Industrial, Econômico e Financeiro, v. 158, 2011.

GALGANO, Francesco. "Cessione di partecipazione sociali e superamento della alterità soggettiva fra socio e società”. In: Contratto e impresa, 2004, pp. 537-544.

GALLETTI, Danilo. "Brevi note in tema di vendita di quota sociale ed errore sui motivi". In: Banca, Borsa e Titoli di Credito, II, 1997, pp. 25-37.

GALLO, Paolo. "Responsabilità precontrattuale e problemi di quantificazione del danno". In: Studi in onore di Cesare Massimo Bianca, Tomo IV. Milano: Giuffrè, 2006, pp. 475566.

GALVÃO, Clemente. "Conteúdo e incumprimento do contrato de compra e venda de participações sociais”. In: Revista da Ordem dos Advogados, v. 70, n. 3-4, 2009, pp. 533-573.

GARCÍA VICENTE, José-Ramón. “Compraventa de acciones y compraventa de empresa: defectos ocultos en el activo principal de la sociedad. Calificación e interpretación de los contratos. Causa de los contratos y móvil casualizado". In: Cuadernos Cívitas de jurisprudencia civil, v. 84, 2010, pp. 1729-1746.

GARÇON, Jean-Pierre. "Fixation d'un prix de cession de titres et référence aux éléments comptables". In: La semaine juridique - Entreprise et affaires, 2000, pp. 496-498.

GATTI, Serafino. L’iscrizione nel libro dei soci. Milano: Giuffrè, 1969. 
GAUL, Björn. "Schuldrechtsmodernisierung und Unternehmenskauf”. In: Zeitschrift für das gesamte Handelsrecht und Wirtschaftsrecht, v. 166, 2002, pp. 35-71, p. 64.

GHESTIN, Jacques. "La réticence, le dol et l'erreur sur les qualités substantielles". In: Dalloz, 1971, 247-250.

GHESTIN, Jacques. La formation du contrat, $3^{\text {a }}$ ed. Paris: LGDJ, 1993.

GIANNINI, Regina M. 'Punctilio of honor' or 'disintegrating erosion'? The fiduciary duty to disclose for partners, corporate directors, and majority shareholders". In: South Western University Law Review, v. 27, 1997, pp. 73-97.

GILI SALDAÑA, Marian. "Contrato de compraventa de acciones. Incumplimiento contractual. Remedios frente al incumplimiento de las cláusulas de manifestaciones y garantías. Efectos del conocimiento del comprador en los remedios frente al incumplimiento de las manifestaciones y garantías. Comentario a la sentencia del Tribunal Supremo de 21 de diciembre de 2009”. In: Cuadernos Cívitas de jurisprudencia civil, v. 86, 2011, n. 2288, pp. 1075-1096.

GILSON, Ronald; BLACK, Bernard. The law and finance of corporate acquisitions, $2^{\mathrm{a}}$ ed. Westbury: Foundation Press, 1995.

GIMENO RIBES, Miguel. La protección del comprador en la adquisición de empresa. Granada: Comares, 2013.

GIOIA, Vito la. "Alienazione di quota sociale e obbligo di non concorrenza". In: Rivista di diritto industriale, II, 1957, pp. 105-126.

GOMES, Orlando. "Cessão de crédito; caracterização". In: Novíssimas questões de direito civil. São Paulo: Saraiva, 1984, pp. 79-94.

GOMES, Orlando. "Em tema de sociedade anônima”. In: Revista dos Tribunais, v. 429, 1971, pp. 13-20.

GOMES, Orlando. Contratos, $22^{\mathrm{a}}$ ed. atual. por Humberto Theodoro Jr., Rio de Janeiro: Forense, 2000. 
GOMES, Orlando. Contratos, 26 ${ }^{\mathrm{a}}$ ed. atual. por Antônio Junqueira de Azevedo e Francisco Paulo de Crescenzo Marino. Rio de Janeiro: Forense, 2007.

GOMES, Orlando. Pareceres inéditos. Belo Horizonte: Nova Alvorada, 1999, pp. 209217.

GONÇALVES NETO, Alfredo de Assis. Direito de empresa, 4a ed. São Paulo: RT, 2012.

GONÇALVES NETO, Alfredo de Assis. In: CARVALHOSA, Modesto. (coord.). Tratado de direito empresarial, v. 2. São Paulo: RT, 2016.

GONÇAlVES, Luiz da Cunha. Da Compra e Venda no Direito Comercial Brasileiro. São Paulo: Max Limonad, 1950.

GÖTZE, Cornelius. “Auskunftserteilung durch GmbH-Geschäftsführer im Rahmen der Due Diligence beim Beteiligungserwerb”. In: Zeitschrift für Unternehmens- und Gesellschaftsrecht, 1999, pp. 202-233.

GRAU, Eros Roberto; FORGIONI, Paula Andrea. "Cláusula de não-concorrência ou de não-restabelecimento". In: O estado, a empresa e o contrato. São Paulo: Malheiros, 2005, pp. 273-300.

GRECO, Marco Aurélio. "Imposto sobre a renda - responsabilidade do sucessor na aquisição de estabelecimento - o art. 133 do CTN". In: Revista Tributária e de Finanças Públicas, v. 29, 2001, pp. 49-85

GRECO, Paolo. "Le società di comodo e la vendita delle loro azioni". In: Rivista del diritto commerciale e del diritto generale delle obbligazioni, v. 33, II, 1935, pp. 123-141.

GRIGOLEIT, Hans Christoph; HERRESTHAL, Carsten. "Grundlagen der Sachmängelhaftung im Kaufrecht”. In: Juristenzeitung, 2003, pp. 118-127.

GRIGOLEIT, Hans Christoph. “Abstraktion und Willensmängel - Die Anfechtbarkeit des Verfügungsgeschäfts”. In: Archiv für die civilistische Praxis, v. 199, 1999, pp. 379-420. 
GRIGOLEIT, Hans Christoph. Vorvertragliche Informationshaftung. München: C. H. Beck, 1997.

GRISI, Giuseppe. L’obbligo precontrattuale di informazione. Napoli: Jovene, 1990.

GRONSTEDT, Sebastian; JÖRGENS, Stefan. "Die Gewährleistungshaftung bei Unternehmensverkäufen nach dem neuen Schuldrecht”. In: Zeitschrift für Wirtschaftsrecht, 2002, pp. 52-65.

GRUNDMANN, Stefan. "Verbraucherrecht, Unternehmensrecht, Privatrecht - warum sind sich UN-Kaufrecht und EU-Kaufrechtsrichtlinie so ähnlich?. In: Archiv für die civilistische Praxis, v. 202, 2002, pp. 40-71.

GRUNEWALD, Barbara. "Rechts- und Sachmängelhaftung beim Kauf von Unternehmensanteilen”. In: Neue Zeitschrift für Gesellschaftsrecht, 2003, pp. 372-374.

GRUNEWALD, Barbara. “Unerwartete Verbindlichkeiten beim Unternehmenskauf”. In: Zeitschrift für Unternehmens- und Gesellschaftsrecht, 1981, pp. 622-642.

GRUNEWALD, Barbara. Die Grenzziehung zwischen der Rechts- und Sachmängelhaftung beim Kauf. Bonn: Stollfuss, 1980.

GUERREIRO, José Alexandre Tavares. "A função registrária das sociedades anônimas". In; WALD, Arnoldo. (coord.). O direito na década de 80: estudos jurídicos em homenagem a Hely Lopes Meirelles. São Paulo: RT, 1985, pp. 143-149, p. 145.

GUERREIRO, José Alexandre Tavares. "Interpretação de preferências na Lei de Sociedades Anônimas". In: ADAMEK, Marcelo Vieira von. Temas de direito societário e empresarial contemporâneos. São Paulo: Malheiros, 2011, pp. 388-408.

GUERREIRO, José Alexandre Tavares. "O usufruto de ações ao portador e a posição da companhia emissora". In: Revista de Direito Mercantil, Industrial, Econômico e Financeiro, n. 39, 1980, pp. 84-90. 
GUERREIRO, José Alexandre Tavares. "Sobre a conferência de bens". In: Revista de Direito Mercantil, Industrial, Econômico e Financeiro, n. 48, 1982, pp. 16-24.

GUIDETTI, Barbara. "Divieto di concorrenza in caso di cessione di quote sociali". In: Rivista di diritto industriale, 1998, II, pp. 13-18.

GUIMARÃES, Ruy Carneiro. Sociedades por ações, v. 2. Rio de Janeiro: Forense, 1960.

HABERSACK, Mathias. Die Mitgliedschaft - subjektives und 'sonstiges' Recht. Tübingen: Paul Siebeck, 1996.

HAICAL, Gustavo. Cessão de crédito. São Paulo: Saraiva, 2013.

HALEMBECK, Luiz Fernando Amaral. "Compra e venda de sociedades fechadas". In: ROVAI, Armando Luiz; MURRAY NETO, Alberto (coord.). As sociedades por ações na visão prática do advogado. Rio de Janeiro: Elsevier, 2010, pp. 147-168.

HARPUM, Charles; JONES, David Lloyd. "Certainty at one fell swoop”. In: Cambridge Law Journal, v. 41, 1982, pp. 233-236,

HECK, Phillip von. "Weshalb besteht ein von dem bürgerlichen Rechte gesondertes Handelsprivatrecht?”. In: Archiv für die civilistische Praxis, 1902, pp. 438-466.

HEINRICHS, Helmut. In: Palandt Bürgerliches Gesetzbuch, 62ª Aufl., München, Beck, 2003.

HELDRICH, Karl. "Die Form des Vertrages”. In: Archiv für die civilistische Praxis, v. 147,1941, pp. 89-129.

HEMELING, Peter. "Gesellschaftsrechtliche Fragen der Due Diligence beim Unternehmenskauf'. In: Zeitschrift für das gesamte Handelsrecht und Wirtschaftsrecht, v. 169, 2005, pp. 274-294.

HENCKEL, Wolfram. "Die ergänzende Vertragsauslegung”. In: Archiv für die civilistische Praxis, v. 160, 1960, pp. 107-126. 
HENSSLER, Martin. "Haftung des Verkäufers wegen Informationspflichtverletzung beim Unternehmenskauf”. In: GRUNDMANN, Stefan (org., et. al.). Festschrift für Klaus J. Hopt zum 70. Geburtstag am 24. August 2010, Bd. 1. Berlin: De Gruyter, 2010, pp. 113139.

HENSSLER, Martin. Risiko als Vertragsgegenstand. Tübingen: Mohr Siebeck, 1994.

HERNANDO CEBRIÁ, Luis. "La incidencia de la Legal Due Diligence ("revisión legal”) en la contratación mercantil contemporánea”. In: Revista de derecho mercantil, n. 259, 2006, pp. 603-639.

HERNANDO CEBRIÁ, Luis. El contrato de compraventa de empresa. Valencia: Blanch, 2005.

HIDDEMANN, Hans-Joachim. "Leistungsstörungen beim Unternehmenskauf aus der Sicht der Rechtsprechung”. In: Zeitschrift für Unternehmens- und Gesellschaftsrecht, 1982, pp. 435-451.

HILGARD, Mark. “Earn-out Klauseln beim Unternehmenskauf”. In: BB, 2010, pp. 29122919.

HOMMELHOFF, Peter. "Der Unternehmenskauf als Gegenstand der Rechtsgestaltung". In: Zeitschrift für das gesamte Handelsrecht und Wirtschaftsrecht, v. 150, 1986, pp. 254-278.

HOMMELHOFF, Peter. "Die Sachmängelhaftung beim Unternehmenskauf durch Anteilserwerb". In: Zeitschrift für das gesamte Handelsrecht und Wirtschaftsrecht, v. 140, 1976, pp. 271-300.

HOMMELHOFF, Peter. "Zur Abgrenzung von Unternehmenskauf und Anteilserwerb”. In: Zeitschrift für Unternehmens- und Gesellschaftsrecht, 1982, pp. 366-390.

HOMMELHOFF, Peter. Die Sachmängelhaftung beim Unternehmenskauf. Köln/Berlin/Bonn/München: Carl Heymann, 1975. 
HOPT, Klaus. In: HOPT, Klaus; WIEDEMANN, Herbert. AktG Großkommentar, 4. Aufl. Berlin/New York: De Gruyter, 1999, §93, Rn. 213, pp. 137-138.

HUBER, Peter. Irrtumsanfechtung und Sachmängelhaftung. Tübingen: Mohr Siebeck, 2001.

HUBER, Ulrich. "Die Praxis des Unternehmenskaufs im System des Kaufrechts". In: Archiv für die civilistische Praxis, v. 202, 2002, pp. 179-242.

HUBER, Ulrich. "Mängelhaftung beim Kauf von Gesellschaftsanteilen”. In: Zeitschrift für Unternehmens- und Gesellschaftsrecht, 1972, pp. pp. 395-420.

HÜBNER, Ulrich. "Der gerechte Preis". In: BAUR, Jürgen F. (org., et. al.). In: Festschrift für Ernst Steindorff zum 70. Geburtstag. Berlin/New York: De Gruyter, 1990, pp. 589610.

HÜBNER, Ulrich. "Mängelhaftung beim Kauf von Gesellschaftsanteilen”. In: Zeitschrift für Unternehmens- und Gesellschaftsrecht, 1972, pp. 395-420.

IMBID IRUJO, José Miguel. "Prefacio". In: GIMENO RIBES, Miguel. La protección del comprador en la adquisición de empresa. Granada: Comares, 2013, p. XVII-XX.

IMMENGA, Ulrich. "Fehler oder zugesicherte Eigenschaft?". In: Archiv für die civilistische Praxis, v. 171, 1917, pp. 1-18.

IUDICA, Giovanni. "Il prezzo nella compravendita di partecipazioni azionarie". In: Rivista delle società, 1991, pp. 750-771.

JAGERSBERGER, Barbara. Die Haftung des Verkäufers beim Unternehmenskaufund Anteilskauf. Baden-Baden: Nomos, 2006.

JOURDAIN, Patrice. “Le devoir de ‘se’ renseigner”. In: Dalloz, 1983, pp. 139-144.

JUGLART, Michel. "L'obligation de renseignements dans les contrats". In: Revue trimestrielle de droit civil, 1945, pp. 1-22. 
KESSLER, Friedrich; FINE, Edith. "Culpa in contrahendo, bargaining in good faith, and freedom of contract”. In: Harvard Law Review, v. 77, 1964, pp. 401-449.

KIETHE, Kurt. "Vorstandshaftung aufgrund fehlerhafter Due Diligence beim Unternehmenskauf”. In: Neue Zeitschrift für Gesellschaftsrecht, 1999, pp. 976-983.

KLEINSCHMIDT, Jens. "Die Bestimmung durch einen Dritten im Europäischen Vertragsrecht”. In: RabelsZ, v. 76, 2012, pp. 785-818,

KLEINSCHMIDT, Jens. Delegation von Privatautonomie auf Dritte. Tübingen: Mohr Siebeck, 2014.

KNOTT, Hermann. "Unternehmenskauf nach der Schuldrechtsreform". In: Neue Zeitschrift für Gesellschaftsrecht, 2002, pp. 249-256.

KUGLER, Herbert Morgenstern. Os acordos de sócios nas sociedades limitadas. São Paulo: Quartier Latin, 2014.

LA LUMIA, Isidoro. "Appunti sulla natura giuridica dei titoli di credito". In: Rivista del diritto commerciale e del diritto generale delle obbligazioni, I, 1940, pp. 120.

LA ROSA, António Pavone. “Azioni 'dematerializzate' e legittimazione all'esercizio dei diritti sociali”. In: Rivista delle società, 2002, pp. 1209-1222.

LA SALA, Gian Paolo. "L'acquisto a non domino di strumenti finanziari dematerializzati”. In: Banca, Borsa e Titoli di Credito, I, 2004, pp. 467-525.

LAMY FILHO, Alfredo. “A desconsideração da personalidade jurídica em acordo de acionistas". In: A Lei das S.A. Rio de Janeiro: Renovar, 1992, pp. 522-534.

LAMY FILHO, Alfredo. "Ações nominativas e ações escriturais - natureza - usucapião". In: Temas de S.A. Rio de Janeiro/São Paulo/Recife: Renovar, 2007, pp. 415-429. 
LAMY FILHO, Alfredo. "Doação de ações nominativas sem a assinatura do termo no livro próprio". In: A lei das S.A., v. II: Pareceres, $2^{\mathrm{a}}$ ed. Rio de Janeiro: Renovar, 1997, pp. 37 45.

LANCIANI, Andrea. "Il prezzo (modalità, aggiustamenti, garanzie del pagamento dilazionato)". In: IRRERA, Maurizio (org.). Le acquisizione societarie. Bologna: Zanichelli, 2011, pp. 319-335.

LARENZ, Karl; WOLF, Manfred. Allgemeiner Teil des Bürgerlichen Rechts, 9. Aufl. München: C. H. Beck, 2004.

LARENZ, Karl. "Bemerkungen zur Haftung für culpa in contrahendo". In: FLUME, Werner (coord., et. al.). Beiträge zum Zivil- und Wirtschaftsrecht - Festschrift für Kurt Ballerstedt zum 70. Geburtstag. Berlin: Duncker \& Humblot, 1975.

LARENZ, Karl. Methodenlehre der Rechtswissenschaft, $6^{\mathrm{a}}$ ed. Berlin (et. al.): Springer, 1991.

LEÃES, Luiz Gastão Paes de Barros. "Pacto de preferência em estatuto social”. In: Pareceres, v. 2. São Paulo: Singular, 2004, pp. 883-891.

LEÃES, Luiz Gastão Paes de Barros. “Ações escriturais”. In: Estudos e pareceres sobre sociedades anônimas. São Paulo: RT, 1989, pp. 53-70.

LEÃES, Luiz Gastão Paes de Barros. "Doação e regime de transferência da propriedade acionária”. In: Pareceres, v. 1. São Paulo: Singular, 2004, pp. 221-231.

LEAL, Murilo Zanetti. “Transmissão de participações sociais”. In: COELHO, Fábio Ulhoa; RIBEIRO, Maria de Fátima (coord.). Questões de direito societário em Portugal e no Brasil. Coimbra: Almedina, 2012, pp. 279-312.

LEONARDO, Rodrigo Xavier. "A cessão de créditos à luz da tese da separação relativa". In: MARTINS-COSTA, Judith; FRADERA, Véra Jacob de. Estudos de direito privado e processual civil em homenagem a Clóvis do Couto e Silva. São Paulo: RT, 2014, pp. 255-277. 
LEVY, Daniel de A. “Acionista controlador - abuso do poder de controle - diminuição do valor das ações - exercício do call pelo controlador - alegação da própria torpeza incorporação de contingências". In: YARSHELL, Flávio Luiz; PEREIRA, Guilherme Setogutti Júlio. Processo societário II. São Paulo: Quartier Latin, 2015, pp. 117-136.

LIBCHABER, Rémi. "Pour un renouvellement de l'analyse des droits sociaux". In: Aspects actuels du droit des affaires: Mélanges en l'honneur de Yves Guyon. Paris: Dalloz, 2003, pp. 717-736.

LIEB, Manfred. "Gewährleistung beim Unternehmenskauf”. In: LANGE, Hermann (coord., et. al.). Festschrift für Joachim Gernhuber zum 70. Geburtstag. Tübingen: Mohr Siebeck, 1993, pp. 259-280.

LIMA, Alcides de Mendonça. "Contrato de compra e venda de ações de banco. Fixação do preço por terceiro em desacordo com o contrato”. In: Revista de Processo, v. 14, 1979, pp. 271-294.

LIMA, Alvino. A fraude no direito civil. Saraiva: São Paulo, 1965.

LOBO, Carlos Augusto da Silveira. "Acordo de acionista". In: PEDREIRA, José Luiz Bulhões; LAMY FILHO, Alfredo. (org.). Direito das companhias, v. 1. Rio de Janeiro: Forense, 2009, pp. 441-499, pp. 474-475.

LOBO, Jorge. Sociedades limitadas, v. I. Rio de Janeiro: Forense, 2004.

LÔBO, Paulo Luiz Netto. Comentários ao Código Civil, v. 6. São Paulo: Saraiva, 2003.

LÓPEZ FRIAS, Ana. Los contratos conexos. Barcelona: Bosch, 1994.

LORENZ, Stephan. "Der Unternehmenskauf nach der Schuldrechtsreform”. In: LORENZ, Stephan (coord., et. al.). Festschrift für Andreas Heldrich zum 70. Geburtstag. München: C. H. Beck, 2005, pp. 305-326.

LORENZ, Stephan. Der Schutz vor dem unerwünschten Vertrag. München: C. H. Beck, 1997. 
LORENZO, Sixto Sánchez. "La interpretación del contrato". In: LORENZO, Sixto Sánchez (org.). Derecho contractual comparado. Cizur Menor: Civitas/Thomson, 2009, 443-488.

LUCCA, Newton De. Aspectos da teoria geral dos títulos de crédito. São Paulo: Pioneira, 1979.

LUCCA, Newton de. Comentários ao Novo Código Civil, v. 12. Rio de Janeiro: Forense, 2003 .

LUCENA, José Waldecy. Das sociedades anônimas, v. 1. Rio de Janeiro: Renovar, 2009.

LUCENA, José Waldecy. Das sociedades limitadas, 6ª ed. Rio de Janeiro: Renovar, 2005.

LUNARDI FILHO, Ferdinando César. A remuneração dos administradores das sociedades anônimas. Dissertação de mestrado, São Paulo: Faculdade de Direito - USP, 2013.

LUTTER, Marcus. "Due diligence des Erwerbers beim Kauf einer Beteiligung". In: Zeitschrift für Wirtschaftsrecht, 1997, pp. 613-620.

LUTTER, Marcus. "Theorie der Mitgliedschaft". In: Archiv für die civilistische Praxis, v. 180,1980 , pp. 84-159.

LYON-CAEN, Charles; RENAULT, Louis. Traité de droit commercial, t. II, première partie, $4^{\mathrm{a}}$ ed. Paris: LGDJ, 1908.

MACEDO, Ricardo Ferreira de. Controle não Societário. São Paulo/Rio de Janeiro/Recife: Renovar, 2004.

MACHADO FILHO, Caio. O sistema de destinação de resultado e da distribuição de dividendos na Lei n. 6.404/76. Dissertação de mestrado (FDUSP), São Paulo, 2016.

MAGALHÃES, José Carlos de. "Perspectivas da arbitragem comercial no Brasil". In: Revista de Direito Mercantil, Industrial, Econômico e Financeiro, v. 69, 1988. 
MALHEIROS, Antônio Carlos de. "Teoria da desconsideração inversa da personalidade jurídica aplicada às relações familiares”. In: ADAMEK, Marcelo Vieira von. Temas de direito societário e empresarial contemporâneos. São Paulo: Malheiros, 2011, pp. 765770 .

MANGINI, Vito. "Cessione di quote sociale e divieto di concorrenza". In: Rivista di diritto civile, 1956, II, pp. 185-196.

MANTOVANI, Manuela. 'Vizi incompleti' del contratto e rimedio risarcitorio. Torino: Giappichelli, 1995.

MARANI, Giovanni. "In tema di arbitrato, arbitraggio, perizia contrattuale". In: Rivista trimestrale di diritto e procedura civile, 1983, pp. 610 ss.

MARASÀ, Giorgio. "Comunione di mero godimento in forma di società per azioni, simulazione e nullità". In: Rivista del diritto commerciale e del diritto generale delle obbligazioni, II, 1989.

MARCONDES, Sylvio. "Direito mercantil e atividade negocial no projeto de Código Civil”. In: Questões de direito mercantil. São Paulo: Saraiva, 1977, pp. 1-29.

MARCONDES, Sylvio. "Do objeto de direito; patrimônio". In: Problemas de direito mercantil, $2^{\mathrm{a}}$ tir. São Paulo: Max Limonad, 1970, pp. 67-100.

MARINO, Francisco P. de Crescenzo. Contratos coligados no direito brasileiro. São Paulo: Saraiva, 2009.

MARINO, Francisco Paulo De C. Interpretação do Negócio Jurídico. São Paulo: Saraiva, 2011.

MARTEN, Kai-Uwe; KÖHLER, Annette G. "Due Diligence in Deutschland: eine Empirische Untersuchung”. In: Finanz-Betrieb, 1999, pp. 337-348.

MARTINS-COSTA, Judith. "Contrato de cessão e transferência de quotas. Acordo de sócios. Pactuação de parcela variável do preço contratual denominada earn out. 
Caraterísticas e função ('causa objetiva') do earn out”. In: Revista de Arbitragem e Mediação, v. 42, 2014, pp. 153-188.

MARTINS-COSTA, Judith. "Os regimes do dolo civil no Direito Brasileiro: dolo antecedente, vício informativo por omissão e por comissão, dolo acidental e dever de indenizar". In: Revista dos Tribunais, v. 923, 2012, pp. 115-143.

MARTINS-COSTA, Judith. "Reflexões sobre o princípio da função social dos contratos". In: Revista Direito GV, v. 1, 2005, pp. 41-66.

MARTINS-COSTA, Judith. A Boa-fé no Direito Privado. São Paulo: RT, 1999.

MARTINS-COSTA, Judith. Comentários ao novo Código Civil, v. 5, t. 1. Rio de Janeiro: Forense, 2003.

MARTINS, Alexandre Soveral. Cessão de quotas. Coimbra: Almedina, 2007.

MARTINS, Alexandre Soveral. Cláusulas do contrato de sociedade que limitam a transmissibilidade das acções. Coimbra: Almedina, 2006, p. 520.

MARTINS, Fran. Comentários à lei das sociedades anônimas, v. 1, $2^{\mathrm{a}}$ ed. Rio de Janeiro: Forense, 1982.

MARTINS, Fran. Títulos de crédito, $15^{\mathrm{a}}$ ed. atual. por Joaquim Penalva Santos e Paulo Penalva Santos. Rio de Janeiro: Forense, 2010.

MARTINS, Ives Gandra da Silva. "Sucessão tributária e a figura desconsiderativa". In: Revista Tributária e de Finanças Públicas, v. 87, 2009, pp. 111-131.

MATTOS FILHO, Ary Oswaldo (et.al.). "Radiografia das Sociedades Limitadas" (Relatório de pesquisa). Fundação Getúlio Vargas, 2014.

MATTOS FILHO, Ary Oswaldo. Direito dos valores mobiliários, v. 1, t. 1. FGV: Rio de Janeiro, 2015. 
MENEZES CORDEIRO, António Manuel da Rocha e. Da boa-fé no direito civil. Coimbra: Almedina, 1983.

MENEZES CORDEIRO, António Manuel da Rocha e. Manual de direito das sociedades, II, $2^{\mathrm{a}}$ ed. Coimbra: Almedina, 2007.

MENGONI, Luigi. Gli acquisti ‘a non domino’, 2a ed. Milano: Giuffrè, 1968.

MERKT, Hanno. 'Rechtliche Bedeutung der 'due diligence' beim Unternehmenskauf”. In: Wirtschaftliche Betrachtung, 1996, pp. 145-192.

MIRANDA, Custódio da Piedade Ubaldino. "Negócio jurídico indireto e negócios fiduciários”. In: Revista de Direito Civil, v. 29, n. 81, 1984.

MIRANDA, Custódio da Piedade Ubaldino. Comentários ao Código Civil, v. 5. São Paulo: Saraiva, 2013.

MIRMINA, Steven A "A comparative survey of culpa in contrahendo, focusing on its origins in roman, German and French Law as well as its application in American Law”. In: Chicago Journal of International Law, vol. 8, 1993, pp. 77-108.

MONIZ DE ARAGÃO, Egas Dirceu. "Participação do Poder Judiciário no arbitramento de preço cuja fixação foi deixada a terceiro". In: Revista de Processo, v. 13, 1979, pp. 177187.

MONTALENTI, Paolo. "Le acquisizioni societarie - profili contrattuali”. In: Persona giuridica, gruppi di società, corporate governance. Torino: CEDAM, 1999, pp. 147163.

MONTEIRO, António Pinto; MOTA PINTO, Paulo. "Compra e venda de empresa: a venda de participações sociais como venda de empresa (share deal)". In: Revista de Legislação e Jurisprudência, n. 3947, 2007, pp. 76-102.

MONTEIRO, António Pinto. Erro e vinculação negocial. Coimbra: Almedina, 2002. 
MOREIRA ALVES, J. C. "Panorama do Direito Civil Brasileiro: das origens aos dias atuais". In: Revista da Faculdade de Direito da Universidade de São Paulo, v. 88, 1993, pp. $185-238$.

MOREIRA AlVES, J. C. A parte geral do projeto de Código Civil brasileiro, $2^{\mathrm{a}}$ ed. São Paulo: Saraiva, 2003.

MOREIRA DA SILVA, Eva Sónia. Da responsabilidade pré-contratual por violação aos deveres de informação. Coimbra: Almedina, 2003.

MOTA PINTO, Carlos Alberto. Cessão de contrato. São Paulo: Saraiva, 1985.

MOTA PINTO, Paulo. "Falta e vícios da vontade - o Código Civil e os regimes mais recentes". In: Comemorações dos 35 anos do Código Civil e dos 25 anos da reforma de 1977, v. 2. Coimbra: Coimbra, 2006, pp. 459-500.

MOTA PINTO, Paulo. Declaração tácita e comportamento concludente no negócio jurídico. Coimbra: Almedina, 1995.

MOUSSERON, Pierre. "L'obligation de renseignement dans les cessions de contrôle". In: La semaine juridique - Édition générale, 1994, I, n. 362, pp. 261-266.

MÜLLER-FREIENFELS, Wolfram. “Zur 'Selbständigkeit' des Handelsrechts”. In: FICKER, Hans Claudiu (org., et. al.). Festschrift für Ernst von Caemmerer zum 70. Geburtstag. Tübingen: Mohr Siebeck, 1978, pp. 583-622.

MÜLLER-FREIENFELS, Wolfram. “Zur Lehre vom sogenannten ,Durchgriff” bei juristischen Personen im Privatrecht”. In: Archiv für die civilistische Praxis, 1957, pp. $522-543$.

MÜLLER, Gerd. “Umsätze und Erträge - Eigenschaften der Kaufsache?”. In: Zeitschrift für das gesamte Handelsrecht und Wirtschaftsrecht, v. 147, 1983, pp. 501-543.

MÜLLER, Klaus J. "Einfluß der due diligence auf die Gewährleistungsrechte des Käufers beim Unternehmenskauf”. In: Neue Juristische Wochenschrift, 2004, pp. 2196-2199. 
MUNHOZ, Eduardo S. "Comentários ao art. 60”. In: SOUZA Jr., Francisco S.; PITOMBO, Antônio $\mathrm{S}$. A. de $\mathrm{M}$. Comentários à lei de recuperação de empresas e falência, $2^{\mathrm{a}}$ ed. São Paulo: RT, 2007.

MUNHOZ, Eduardo Secchi. Aquisição de Controle na Sociedade Anônima. São Paulo: Saraiva, 2013.

NABASQUE, Hervé Le. "Le développement du devoir de loyauté en droit des sociétés". In: Revue trimestrielle de droit commercial, v. 52 (2), 1999, pp. 273-290.

NABASQUE, Hervé Le. "Les actions sont des droits de créance négociables”. In: Aspects actuels du droit des affaires: Mélanges en l'honneur de Yves Guyon. Paris: Dalloz, 2003, pp. 671-694.

NACATA Jr., Edson Kiyoshi. "Tradição romanista e soluções de continuidade no direito obrigacional brasileiro: a eficácia translativa do contrato no projecto de Joaquim Felício dos Santos”. In: Revista de Direito Civil Contemporâneo, v. 5, 2015, pp. 35-68.

NIRK, Rudolf. "Culpa in contrahendo: eine richterliche Rechtsfortbildung in der Rechtsprechung des Bundesgerichtshofes”. In: HEFERMEHL, Wolfgang (coord., et. al.). Festschrift für Philipp Möhring zum 65. Geburtstag. München/Berlin: C. H. Beck, 1965, pp. 385-418.

NUNES, Arlindo Monteiro (org.). A privatização da sociedade financeira portuguesa. Lisboa: LEX, 1995.

OLIVEIRA, Ana Perestrelo de. Grupos de Sociedades e Deveres de Lealdade. Coimbra: Almedina, 2012, pp. 276-291.

OliveIRA, José Lamartine Corrêa de. A Dupla Crise da Pessoa Jurídica. São Paulo: Saraiva, 1979.

OPPETIT, Bruno. "Les cessions de droits sociaux emportant le transfert du contrôle d'une société: essai de synthèse”. In: Revue des Sociétés, 1978, pp. 631-654. 
OPPETIT, Bruno. "Sur le concept d'arbitrage". In: FOUCHARD, P. (org., et. al.). Droit des relations économiques internationales - Études offertes a Berthold Goldman. Paris: Litec, 1982, pp. 229-239.

PAILlUSSEAU, Jean (et. al.). Cession d'entreprise. 4a ed. Paris: Dalloz, n. 1721.

PAILLUSSEAU, Jean; CONTIN, Raphaël. "La cession de contrôle d'une société (à propos d'un important arrêt de la Cour d'appel de Rennes)". In: La semaine juridique - Édition générale, II, 1969, n. 2287.

PAILLUSSEAU, Jean. "La cession de contrôle et la situation financière de la société cédée (de la nature juridique du contrôle et de la cession de contrôle)". In: La semaine juridique - Édition générale, I, 1992, n. 3587, pp. 185-199.

PANZARINI, Elisabetta. "Cessione di pacchetti azionari: il contenuto delle clausole di garanzia”. In: GALGANO, Francesco (org.). I contratti del commercio, dell'industria e del mercato finanziario, t. I. Torino: UTET, 1995, pp. 247-347.

PANZARINI, Giovanni. "La tutela dell'acquirente nella vendita dei titoli di credito". In: Rivista del diritto commerciale e del diritto generale delle obbligazioni, I, 1959, pp. 252-294.

PARGENDLER, Mariana. “O direito societário em ação: análise empírica e proposições de reforma". In: Revista de Direito Brasileira, v. 59, 2013, pp. 215-256.

PARO, Giácomo; DINIZ, Rodrigo de Madureira Pará. "As implicações das cláusulas de ajustes de preço e das contas escrow na tributação pelo imposto de renda". In: Revista Tributária e de Finanças Públicas, v. 121, 2015, pp. 141-159.

PEDREIRA, José Luiz Bulhões; LAMY FILHO, Alfredo. “Ação como participação societária”. In: PEDREIRA, José Luiz Bulhões; LAMY FILHO, Alfredo. (org.). Direito das companhias, v. 1. Rio de Janeiro: Forense, 2009, pp. 215-274. 
PEDREIRA, José Luiz Bulhões; LAMY FILHO, Alfredo. "Valores mobiliários". In: PEDREIRA, Jose Luiz Bulhões; LAMY FILHO, Alfredo (org.). Direito das companhias, v. 1. Rio de Janeiro: Forense, 2009, pp. 503-542.

PEDREIRA, José Luiz Bulhões. "Alienação de Controle de Companhia Aberta (Parecer)". In: PEDREIRA, José Luiz Bulhões; LAMY FILHO, Alfredo. A Lei das S.A. Rio de Janeiro: Renovar, 1992, pp. 691-717.

PEDREIRA, José Luiz Bulhões. "Natureza de título de crédito da ação escritural”. In: A lei das S.A., v. II: Pareceres, $2^{\text {a }}$ ed. Rio de Janeiro: Renovar, 1997, pp. 45-71.

PEIXOTO, Carlos Fulgêncio da Cunha. Sociedades por ações, v. 2. São Paulo: Saraiva, 1972.

PÉLLE, Sebastien. La notion d'interdépendance contractuelle: contribution à l'étude des ensembles de contrats. Paris: Dalloz, 2007.

PELLIZZI, Giovanni. "Panorama dei titoli di credito". In: Banca, Borsa e Titoli di Credito, I, 1984, pp. 1-13.

PENTEADO, Luciano de C. "Que coisa é uma coisa? Reflexões em torno a um pequeno ensaio de Carnelutti”. In: Revista de Direito Privado, v. 39, 2009, pp. 249-258.

PEREIRA, Caio Mário da Silva. Instituições de direito civil, v. 3, 19a ed. rev. Rio de Janeiro: GEN/Forense, 2015.

PEREIRA, Guilherme Döring Cunha. Alienação do Poder de Controle Societário. São Paulo: Saraiva, 1995.

PEREIRA, Lafayette Rodrigues. "Sociedade de facto: sua natureza; liquidação; direitos dos credores (Parecer n. 69)". In: Pareceres, v. 2. Rio de Janeiro: Candido de Oliveira, 1921.

PETITPIERRE-SAUVAIN, Anne. La cession de contrôle, mode de cession de l'entreprise. Genève: Georg, 1977. 
PETRUCCI, Anna Maria. "Cessione di pacchetti azionari e dolo del venditori". In: Rivista del diritto commerciale e del diritto generale delle obbligazioni, II, 1994, pp. 384-393.

PICONE, Luca. "Trattative, due diligence ed obblighi informativi delle società quotate". In: Banca, Borsa e Titoli di Credito, 2004, I, pp. 234-269.

PICOT, Gerhard. "Due Diligence und privatrechtliches Haftungssystem". In: BERENZ, Wolfgang (org., et. al.). In: Due Diligence bei Unternehmensakquisitionen, 6. Aufl. Stuttgart: Schäffer-Poeschel, 2011, pp. 295-330.

PINTO, Maurizio. 'Le garanzie 'patrimoniali' nella vendita di partecipazioni azionarie di controllo: qualificazione giuridica e termini di prescrizione”. In: Rivista delle società, 2004, pp. 411-468.

POITRINAL, François-Denis. "Cession d'entreprise: les conventions de earn out”. In: La semaine juridique - Entreprise et affaires, 1999, pp. 18-28.

PONTES DE MIRANDA, Francisco Cavalcanti. "Parecer n. 201. Sobre compra-e-venda de ações de banco e responsabilidade contratualmente assumida, em termos explícitos e restritos, pelo vendedor e atos ilícitos de outrem". In: Dez anos de pareceres, v. 8. Rio de Janeiro: Francisco Alves, 1976, pp. 34-47.

PONTES DE MIRANDA, Francisco Cavalcanti. Tratado de direito privado. Rio de Janeiro: Borsoi, 1962.

PONTES, Evandro Fernandes de. Representations \& warranties no direito brasileiro. São Paulo: Almedina, 2014.

POTHIER, Robert-Joseph. Traité du contrat de vente, 1 t. Paris/Orléans: s/e, 1772

PUGLIATTI, Salvatore. "Vendita di azioni e garanzia per evizione". In: Banca, Borsa e Titoli di Credito, II, 1937, pp. 86-100. 
QUACK, Karlheinz. "Der Unternehmenskauf und seine Probleme”. In: Zeitschrift für Unternehmens- und Gesellschaftsrecht, 1982, pp. 350-365.

RAISER, Thomas; VEIL, Rüdiger. Das Recht der Kapitalgesellschaften. München: Franz Vahlen, 2010, §11, Rn. 15.

REALE, Miguel. História do novo Código Civil. São Paulo: RT, 2005.

REDONDO TRIGO, Francisco. "La causa en los contratos de compraventa de acciones. A propósito de la sentencia del Tribunal Supremo de 21 de diciembre de 2009”. In: Revista Critica de Derecho Imobiliario, v. 720, 2010, pp. 1903-1933.

REDONDO TRIGO, Francisco. "La impugnación de la determinación del precio por un tercero en los contratos de compraventa de acciones y la sentencia del tribunal supremo de 1 de septiembre de 2006”. In: Revista Critica de Derecho Imobiliario, n. 704, 2007, pp. 2766-2782.

REED, Stanley Foster; LAJOUX, Alexandra Reed. The art of M\&A, $2^{\mathrm{a}}$ ed. New York: Irwin, 2011.

REQUIÃO, Rubens. "O Controle e a Proteção dos Acionistas". In: Revista de Direito Mercantil, Industrial, Econômico e Financeiro, v. 15/16, 1974, pp. 23-36.

REQUIÃO, Rubens. "Parecer sobre o Projeto de Lei n. 634/75, do Executivo". In: Revista de Direito Mercantil, Industrial, Econômico e Financeiro, n. 17, 1975, pp. 133-173.

REQUIÃO, Rubens. Comentários à lei das sociedades anônimas. São Paulo: Saraiva, 1980.

RHEIN, Tilman. Der Interessenkonflikt der Manager beim Management Buy-out. München: C. H. Beck, 1996.

RICHTER JR., Mario Stella. "Trasferimento del controllo" e rapporti tra soci. Milano: Giuffrè, 1996. 
RIPERT, Georges. Aspects juridiques du capitalisme moderne, $2^{\mathrm{a}}$ ed. Paris: LGDI, 1951.

RIZZARDO, Arnaldo. Direito de empresa, $4^{\mathrm{a}}$ ed. atual. Rio de Janeiro: Forense, 2012.

RODRIGUES, Silvio. Direito civil, v. 3, 30ª ed. atual. São Paulo: Saraiva, 2004.

RODRIGUES, Silvio. Dos vícios do consentimento, $3^{\text {a }}$ ed. São Paulo: Saraiva, 1989.

ROPPO, Vincenzo. "From consumer contracts to asymmetric contracts: a trend in European contract law”. In: European Review of Contract Law, 2009, pp. 304-349.

RORDORF, Renato. "Cessione di quote sociali e divieto di concorrenza: il velo societario si fa più trasparente”. In: Foro italiano, 2000, pp. 3116-3119.

ROSA Jr., Luiz Emygdio da. Títulos de crédito, $3^{\mathrm{a}}$ ed. Rio de Janeiro/São Paulo/Recife: Renovar, 2004.

ROSCHMANN, Christian; FREY, Johannes. "Geheimhaltungsverpflichtungen der Vorstandsmitglieder von Aktiengesellschaften bei Unternehmenskäufen”. In: Die Aktiengesellschaft, 1996, pp. 449-455.

ROSENVALD, Nelson. “Comentário ao art. 485”. In: PELUSO, Cezar. (coord.). Código Civil comentado, $9^{\mathrm{a}}$ ed. atual. São Paulo: Manole, 2015.

ROTONDI, Mario. "Entstehung und Niedergang des autonomen Handelsrechts in Italien”. In: Archiv für die civilistische Praxis, 1967, pp. 29-63.

ROTONDI, Mario. “The proposed franco-italian code of obligations". In: American Journal of Comparative Law, v. 3, 1954, pp. 345-359.

ROUSILLE, Myriam. "De la réticence dolosive du dirigeant en matière de cession de droits sociaux”. In: La semaine juridique - Édition générale, 2009, n. 1631, pp. 34-39.

ROUX, Daniel. "La spécificité des cessions de contrôle”. In: Revue des Sociétés, 1980, pp. 49-71. 
ROVELLI, Luigi. "Natura della vendita del pacchetto azionario". In: Società, n. 11, 1988, pp. 1164-1167.

RUBINO-SAMMARTANO, Mauro. Garanzie nella compravendita di pacchetti azionari e di imprese. Milano: Giuffrè, 2006.

RÜFNER, Thomas. $\S \S$ 90-103. In: SCHMOECKEL, Mathias; RÜCKERT, Joachin; ZIMMERMANN, Reinhard (org.). Historisch-kritischer Kommentar zum BGB, Bd. 1: Allg. Teil (§§ 1-230). Tübingen: Mohr Siebeck, 2003.

RUSSO, Fábio C. "Due Diligence e responsabilidade". In: I Congresso Direito das Sociedades em Revista. Coimbra: Almedina, 2011, pp. 13-26.

RUSSO, Fábio. "Das cláusulas de garantia nos contratos de compra e venda de participações sociais de controlo”. In: Direito das Sociedades em Revista, v. 4, 2010, pp. 115-136.

SÁ, Fernando Oliveira e. "A determinação contingente do preço de aquisição de uma empresa através de cláusulas de earn-out". In: CÂMARA, Paulo; BASTOS, Miguel (org.). Aquisição de empresas. Coimbra: Almedina, 2011, pp. 401-415.

SACHS, Klaus. "Die rechtliche Abgrenzung des Schiedsgutachtens vom Schiedsverfahren am Beispiel des Unternehmenskaufvertrages”. In: BACHMANN, Birgit (org., et. al.). Grenzüberschreitungen - Festschrift für Peter Schlosser zum 70. Geburtstag. Tübingen: Mohr Siebeck, 2005, pp. 805-820.

SALAMA, Bruno Meyerhof. O fim da responsabilidade limitada no Brasil. São Paulo: Malheiros, 2014.

SALOMÃO FILHO, Calixto. A Sociedade Unipessoal. São Paulo: Malheiros, 1995.

SALOMÃO FILHO, Calixto. O novo direito societário. Malheiros: São Paulo, 1998.

SALOMÃO NETO, Eduardo. Direito bancário, 2a ed. São Paulo: Atlas, 2014. 
SALOMÃO NETO, Eduardo. O trust e o direito brasileiro. São Paulo: Trevisan, 2016.

SANTA MARIA, Luigi. "Società e simulazione, società e comunione di godimento". In: Rivista trimestrale di diritto e procedura civile, 1995.

SANTOS, Teófilo de Azeredo Santos. "Natureza jurídicas das ações das sociedades". In: Revista Forense, v. 169, 1957, pp. 484-498.

SCALZILLI, João Pedro; SPINELLI, Luís Felipe. "Reflexões sobre a sociedade em conta de participação no direito brasileiro”. In: Revista Jurídica Empresarial, v. 12, 2010, pp. 17-115.

SCARSO, Alessandro. "La responsabilità del venditore di partecipazioni sociali nel diritto italiano e tedesco". In: Rivista delle società, 1999, pp. 455-486.

SCHMIDT, Dominique. "Les définitions du contrôle d'une société". In: Revue de jurisprudence commerciale, n. 1, 1998, pp. 9-14, p. 10.

SCHMIDT, Dominique. Les conflits d'intérêts dans la société anonyme. Paris: Joly, 2004 .

SCHMIDT, Jan Peter. Zivilrechtskodifikation in Brasilien. Tübingen: Mohr Siebeck, 2009.

SCHMIDT, Karsten. Gesellschaftsrecht. Köln/Berlin/Bonn/München: Carl Haymann, 1986.

SCHÖN, Wolfgang. „Gibt es das partiarische Darlehen?”. In: Zeitschrift für Unternehmens- und Gesellschaftsrecht, 1993, pp. 210-244.

SCHREIER, W. Terrance; JOY, O. Maurice. "Judicial valuation of 'close' corporation stock: Alice in Wonderland revisited". In: Oklahoma Law Review, v. 31, 1978, pp. 853885 . 
SCHRÖCKER, Stefan. "Unternehmenskauf und Anteilskauf nach der Schuldrechtsreform”. In: Zeitschrift für Unternehmens- und Gesellschaftsrecht, 2005, pp. 63-100.

SCHWEITZER, Heike. "Private legal transplants in negotiated deals". In: European Company and Financial Law Review, 2007, pp. 79-125.

SCHWEITZER, Heike. "Zurechnung vom Wissen beim Unternehmenskauf”. In: EGER, Thomas (coord., et. al.). Internationalisierung des Rechts und seine ökonomische Analyse - Festschrift für Hans-Bernd Schäfer zum 65. Geburtstag. Wiesbaden: Gabler, 2008, pp. 559-573.

SERICK, Rolf. Rechtsform und Realität juristischer Personen. Berlin/Tübingen: De Gruyter/Mohr, 1955.

SERPA LOPES, Miguel Maria de. Curso de direito civil, v. III, $2^{\text {a }}$ ed. Rio de Janeiro/São Paulo: Freitas Bastos, 1957.

SIGLE, Axel; ZINGER, Georg. "Die Übernahme von Transaktionskosten durch die Aktiengesellschaft”. In: Neue Zeitschrift für Gesellschaftsrecht, 2003, pp. 301-306.

SIGLE, Walter. "Umfang des Formzwangs beim Unternehmenskauf”. In: Neue Juristische Wochenschrift, 1984, pp. 2657-2262.

SILVA, Jorge Cesa Ferreira da. Inadimplemento das obrigações. São Paulo: RT, 2007.

SINGER, Reinhard. "Fehler beim Kauf - zum Verhältnis von Mängelgewährleistung, Irrtumsanfechtung und culpa in contrahendo". In: CANARIS, Claus Wilhelm; HELDRICH, Andreas (org.). 50 Jahre Bundesgerichtshof: Festgabe aus der Wissenschaft. München: C. H. Beck, 2000, pp. 381-405.

SINGER, Reinhard. Das Verbot widersprüchlichen Verhaltens. München: C. H. Beck, 1993. 
SOLER PRESAS, Ana. "Tratamiento jurídico de la frustración tras la adquisición de una empresa". In: Anuário de Derecho Civil, 2014, pp. 81-111.

SPADA, Paolo. "La circolazione della 'ricchezza assente' alla fine del millennio". In: Banca, Borsa e Titoli di Credito, I, 1999, pp. 407-425..

SPERANZIN, Marco. “Le clausole relative all'oggetto 'indiretto' (il patrimonio sociale); garanzie sintetiche e garanzie analitiche”. In: IRRERA, Maurizio (org.). Le acquisizioni societarie. Bologna: Zanichelli, 2011, pp. 193-210.

SPERANZIN, Marco. Vendita delle partecipazione di 'controllo' e garanzie contrattuali. Milano: Giuffrè, 2006.

SPINELLI, Luis Felipe. Exclusão de sócio por falta grave na sociedade limitada. São Paulo: Quartier Latin, 2015.

STENGEL, Arndt; SCHOLDERER, Frank. “Aufklärungspflichten beim Beteiligungs- und Unternehmenskauf”. In: Neue Juristische Wochenschrift, 1994, pp. 158-164.

STOFFELS, Markus. "Grenzen der Informationsweitergabe durch den Vorstand einer Aktiengesellschaft im Rahmen einer 'Due Diligence". In: Zeitschrift für das gesamte Handelsrecht und Wirtschaftsrecht, v. 165, 2001, pp. 362-382.

STOLFI, Giuseppe. "Rilievi in tema di società fittizie". In: Rivista del diritto commerciale e del diritto generale delle obbligazioni, I, 1976.

TEEVEN, Kevin M. A history of the Anglo-American common law of contract. Westport: Greenwood, 1990.

TEIXEIRA DE FREITAS, Augusto. Consolidação das leis civis, ed. fac-símile. Brasília: Senado Federal, 2003.

TEIXEIRA, Egberto Lacerda; GUERREIRO, José Alexandre Tavares. Das sociedades anônimas no direito brasileiro, v. I. São Paulo: Bushatsky, 1979. 
TEIXEIRA, Egberto Lacerda. Das sociedades por quotas de responsabilidade limitada, $2^{\mathrm{a}}$ ed. atual. por Syllas Tozzini e Renato Berger. São Paulo: Quartier Latin, 2007.

TEIXEIRA, Tarcísio. "Estabelecimento empresarial virtual: regime jurídico". In: Revista de Direito Mercantil, Industrial, Econômico e Financeiro, v. 157, 2011.

TEPEDINO, Gustavo; BARBOZA, Heloísa Helena; MORAES, Maria Celina Bodin de. Código civil interpretado, v. 2, 2ª ed. Rio de Janeiro: Renovar, 2012.

TERSILLA, Silvio. "La due diligence per l'acquisizione di un pacchetto azionario di controllo di una società non quotata in borsa: obblighi di informazione e responsabilità dei soggetti coinvolti”. In: Diritto del commercio internazionale, 2002, pp. 969-989.

THALLER, Edmond-Eugène. Traité élémentaire de droit commercial, $3^{\mathrm{a}}$ ed. Paris: Rousseau, 1904.

TINA, Andrea. Il contratto di acquisizione di partecipazioni societarie. Milano: Giuffrè, 2007.

TOKARS, Fábio. Sociedades limitadas. São Paulo: LTr, 2007.

TOLEDO, Paulo Fernando Campos Salles de; POPPA, Bruno. "UPI e estabelecimento: uma visão crítica”. In: TOLEDO, Paulo Fernando Campos Salles de; SATIRO, Francisco. Direito das empresas em crise; problemas e soluções. São Paulo: Quartier Latin, 2012, pp. 267-294.

TOMAZETTE, Marlon. Curso de direito empresarial, v. 1, 4 ed. São Paulo: Atlas, 2012.

TROPLONG, Raymond-Théodore. Le droit civil expliqué - Du contrat de société civile et commerciale. Paris: Charles Hingray, 1843.

VALSERRA, Fabrizio. "La vendita di quote o di azioni non è vendita dei beni sociali”. In: Il diritto fallimentare e delle società commerciali, 1952, I, pp. 473-476. 
VALVERDE, Trajano de Miranda. Fôrça probante dos livros mercantis. Forense: Rio de Janeiro, 1960.

VALVERDE, Trajano de Miranda. Sociedades por ações, v. 1, $2^{\mathrm{a}}$ ed. Rio de Janeiro: Forense, 1953.

VANZELLA, Rafael Domingos Faiardo. Os contratos e os direitos reais. São Paulo: RT, 2012 .

VENTURA, Raúl. Sociedade por quotas, v. I, 2ª ed. Coimbra: Almedina, 1989.

VERÇOSA, Haroldo Malheiros Duclerc. Direito Comercial, v. 2, $3^{\text {a }}$ ed. atual. São Paulo: Revista dos Tribunais, 2014.

VERRUCOLI, Piero. "In tema di prelazione agraria: una legge da non fare". In: Rivista di diritto agrario, 1977, pp. 441-445.

VIANDIER, Alain. "La protection du cessionnaire en cas de cession de contrôle". In: La semaine juridique - Édition générale, v. II, 1997, n. 22875, pp. 323-325.

VIDIGAL, Geraldo apud PEDREIRA, José Luiz Bulhões. "Natureza de título de crédito da ação escritural". In: A lei das S.A., v. II: Pareceres, $2^{\mathrm{a}}$ ed. Rio de Janeiro: Renovar, 1997, pp. 45-71.

VIEIRA, Iacyr de Aguilar. "A compra e venda e a transferência de propriedade: modelos causais e abstratos”. In: Revista dos Tribunais, v. 765, 1999, pp. 59-77.

VILLELA, João Baptista. Controle Acionário: corpus et anima. São Paulo: Malheiros, 2011

VIO, Daniel de Ávila. A exclusão de sócios na sociedade limitada de acordo com o Código Civil de 2002. Dissertação de Mestrado- FDUSP, São Paulo, 2008.

VISCHER, Markus. "Due diligence bei Unternehmenskäufen”. In: Schweizerische Juristenzeitung, v. 96, 2000, pp. 229-236. 
VISCHER, Markus. "Earn out-Klauseln in Unternehmenskaufverträgen”. In: Schweizerische Juristenzeitung, v. 98, 2002.

VIVANTE, Cesare. Trattato di diritto commerciale, v. 3, $5^{\text {a }}$ ed. Milano: Francesco Villardi, 1929.

VIVANTE, Cesare. Trattato di diritto commerciale, v. III, $4^{\text {a }}$ ed. Milano: Francesco Vallardi, 1914.

VOGENAUER, Stefan. "Interpretation of contracts: concluding comparative observations". In: BURROWS, Andrew; PEEL, Edwin. Contract terms. Oxford: Oxford, 2007, pp. 123-150.

WAISBERG, Ivo. Direito de preferência para a aquisição de ações. São Paulo: Quartier Latin, 2016.

WALD, Arnoldo. Comentários ao novo Código Civil, v. 14, $2^{\mathrm{a}}$ ed. Rio de Janeiro: Forense.

WEBER, Martin. Vormitgliedschaftliche Treuebindungen. München: C. H. Beck, 1999.

WEIGMANN, Roberto. "Le offerte pubbliche di acquisto". In: COLOMBO, Giovanni E.; PORTALE, Giuseppe B. (org.). Trattato delle società per azione, v. 10, t. 2. Torino: UTET, 1993, pp. 548-566.

WEILER, Frank. "Culpa in contrahendo, Anfechtung und Kaufrecht - alte Konkurrenzfragen in neuem Licht”. In: Zeitschrift für das gesamte Schuldrecht, 2002, pp. 249-256.

WEITNAUER, Wolfgang. "Der Unternehmenskauf nach neuem Kaufrecht". In: Neue Juristische Wochenschrift, 2002, pp. 2511-2517.

WELLER, Marc-Philippe. "Sachmängelhaftung beim Unternehmenskauf”. In: GRUNEWALD, Barbara; WESTERMANN, Harm Peter (org.). Festschrift für Georg Maier-Reimer zum 70. Geburtstag. C. H. Beck, München, 2010, pp. 839-854. 
WERNER, Rüdiger. "Earn-Out-Klauseln - Kaufpreisanpassung beim Unternehmenskauf”. In: Deutsches Steuerrecht, 2012, pp. 1662-1667.

WERNER, Rüdiger. "Haftungsrisiken bei Unternehmensakquisitionen: die Pflicht des Vorstands zur Due Diligence”. In: Zeitschrift für Wirtschaftsrecht, 2000, pp. 989-994.

WERTENSCHLAG, Bruno. "Prix déterminable et cession de droits sociaux". In: La semaine juridique - Entreprises et affaires, I, 1999, n. 99, pp. 503-508.

WEST, Glenn; SHAH, Kim. "Debunking the myth of the sandbagging buyer: when sellers ask buyers to agree to anti-sandbagging clauses, who is sandbagging whom?”. In: The M\&A Lawyer, v. 11, 2007, pp. 1-9.

WESTERMANN, Harm Peter. "Due Diligence beim Unternehmenskauf”. In: Zeitschrift für das gesamte Handelsrecht und Wirtschaftsrecht, v. 169, 2005, pp. 248-273.

WESTERMANN, Harm Peter. "Neuere Entwicklungen der Verkäuferhaftung beim Kauf von Unternehmensbeteiligungen". In: Zeitschrift für Unternehmens- und Gesellschaftsrecht, 1982, pp. 45-62.

WHITEHEAD, Charles K. "Sandbagging: default rules and acquisition agreements". In: Delaware Journal of Corporate Law, v. 36, 2011, pp. 1081-1115.

WIEDEMANN, Herbert. "Die Haftung des Verkäufers von Gesellschaftsanteilen für Mängel des Unternehmens”. In: DIETZ, Rolf (et. al., org.). Festschrift für Hans Carl Nipperdey zum 70. Geburtstag, Bd. 1. München/Berlin, Beck, 1965, pp. 815-836.

WIEDEMANN, Herbert. Die Übertragung und Vererbung von Mitgliedschaftsrechten bei Handelsgesellschaften. München/Berlin: C. H. Beck, 1965.

WIEDEMANN, Herbert. Gesellschaftsrecht, Bd. I: Grundlagen, München: C. H. Beck, 1980.

WIEDEMANN, Herbert. Minderheitenschutz und Aktienhandel. Stuttgart: Ferdinand Enke, 1968. 
WILBURG, Walter. The development of a flexible system in the area of private law: Inaugural address as Rector magnificus of the Karl-Franzens University in Graz on November 22, 1950, trad. por. Herbert Hausmanninger. Wien: Manz, 2000.

WILLEMSEN, Heinz Josef. "Zum Verhältnis von Sachmängelhaftung und culpa in contrahendo beim Unternehmenskauf'. In: Archiv für die civilistische Praxis, v. 182, 1982, pp. 515-572.

WOLF, Manfred; KAISER, Jochen. "Die Mängelhaftung beim Unternehmenskauf nach neuem Recht”. In: Betriebs-Berater, 2002, pp. 411-420.

ZACCARIA, Alessio. In: CIAN, Giorgio (coord). Commentario breve al codice civile, 11 ed. Padova: CEDAM, 2011.

ZAMPERETTI, Giorgio Maria. "La cessione delle quote sociali non equivale alla vendita dei beni della società". In: Le società, 2001, pp. 1354-1358.

ZANETTI LEAL, Murilo. A transferência involuntária de quotas nas sociedades limitadas. São Paulo: Revista dos Tribunais, 2002.

ZANETTI, Cristiano de Sousa. A conservação dos contratos nulos por defeito de forma. São Paulo: Quartier Latin, 2013.

ZANKEL, Norman. "Duty of corporate officers and directors who purchase stock from their shareholders”. In: Syracuse Law Review, v. 71, 1953, pp. 71-77.

ZIMMERMANN, Reinhard. The law of obligations: roman foundations of the civilian tradition. Oxford: Oxford, 1996.

ZÖLLNER, Wolfgang. "Die Zurückdrängung des Verkörperungselements bei den Wertpapieren". In: BAUR, Fritz (et. al., org.). Funktionswandel der Rechtsinstitutionen - Festschrift für Ludwig Raiser zum 70. Geburtstag. Tübingen: Mohr Siebeck, 1974, pp. $249-285$. 
ZWEIGERT, Konrad; KÖTZ, Hein. Einführung in die Rechtsvergleichung, $3^{\mathrm{a}}$ ed. Tübingen: Mohr Siebeck, 1996. 


\section{Resumo}

BUSCHINELli, Gabriel Saad Kik. Compra e Venda de Participações Societárias de Controle. 403 páginas. Doutorado - Faculdade de Direito da Universidade de São Paulo, São Paulo, 2017.

A compra e venda de participações societárias de controle é contrato de inegável relevância prática. Juridicamente, a sociedade permanece titular de seus bens. Economicamente, a transferência das participações societárias possui efeito similar à circulação dos ativos. É natural e intuitiva, portanto, a equiparação entre a alienação de quotas e de ações, de um lado, e a negociação da empresa, de outro. O estudo, porém, investiga os fundamentos e os limites das teorias que definem o regime do negócio jurídico com base na realidade econômica, defendendo sua inadequação. A tese sustenta que o contrato de compra e venda de participações societárias (i) é dotado de autonomia categorial; (ii) suscita problemas específicos, que devem ser assim analisados; e (iii) somente deve ser equiparado com outras formas de transmissão de bens integrantes do patrimônio de maneira excepcional e justificada. O trabalho é composto por cinco capítulos. No primeiro, questiona-se quais seriam os pressupostos metodológicos para o afastamento da personalidade jurídica societária. Assentadas as bases teóricas, passa-se, no segundo, à compreensão dos traços específicos que caracterizam o contrato. A partir de perspectiva funcional, o terceiro capítulo indaga a possibilidade de serem aplicados regimes jurídicos previstos para o trespasse de estabelecimento, para a transferência de imóveis ou para a cessão de posição contratual quando ocorre negociação de participações de controle de sociedade que seja titular desses bens. No quarto capítulo, são analisados o dever de informar e o ônus de se informar na fase pré-contratual. Ao final, é apresentado o regime de responsabilidade do vendedor e os mecanismos de tutela de que o comprador pode-se valer caso constate deformidades dos títulos ou dos elementos do patrimônio societário.

Palavras-chave: Compra e venda - ações - quotas - participações societárias estabelecimento - dever de informar - responsabilidade contratual. 


\section{Summary}

BUSCHINELLI, Gabriel Saad Kik. Purchase of controlling shares. 403 pages. Doctorate - Faculty of Law, University of São Paulo, São Paulo, 2017.

The purchase and sale of controlling shares is a contract of undeniable practical relevance. Legally, the company remains the holder of its assets. Economically, the transfer of shares has an effect similar to the movement of assets. It is natural and intuitive, therefore, to equate the sale of shares, on the one hand, and the sale of the company, on the other. The study, however, investigates the foundations and limits of theories that define the legal business regime based on economic reality, considering them inadequate. The thesis holds that the agreement for the purchase and sale of shareholdings (i) is endowed with categorical autonomy; (ii) raises specific problems; and (iii) should only be assimilated with other forms of transmission of assets in an exceptional and justified manner. The work consists of five chapters. In the first, it questions what are the methodological assumptions for the disregarding of the legal entity. Once the theoretical bases have been established, the second chapter focus on analyzing the specific features that characterize the contract. From a functional perspective, the third chapter examines the possibility of applying legal regimes for the transfer of a business establishment, for the transfer of real estate or for the assignment of contractual rights when there is a negotiation of controlling shares of a company that owns such properties. In the fourth chapter, the duty to inform and the burden of being informed in the pre-contractual phase are analyzed. At the end, the seller's liability regime and the protection mechanisms that the buyer can avail himself if he finds deformities of the securities or of the elements of corporate assets are presented.

Key terms: Purchase and sale - shares - equity investments - business establishment duty to inform - contractual liability. 


\section{Zusammenfassung}

BUSCHINELLI, Gabriel Saad Kik. Kauf von Mehrheitsanteilen. 403 Seiten. Doktor der Rechte - Juristische Fakultät, Universität São Paulo, São Paulo, 2017.

Der Kauf von Mehrheitsanteilen ist ein besonders wichtiger Vertrag. Aus juristischer Sicht, bleibt die Gesellschaft Inhaber ihres Vermögens. Wirtschaftlich betrachtet, die Übertragung von Aktien und Anteilen ähnelt sich der Bewegung von Vermögenswerten. Es ist daher natürlich und intuitiv, den Kauf von Mehrheitsanteilen und den Unternehmenskauf gleichzusetzen. Die Studie untersucht jedoch die Voraussetzungen und Grenzen von den Theorien, die das Rechtsgeschäft auf der Grundlage der wirtschaftlichen Betrachtung $\mathrm{zu}$ definieren versuchen und verteidigt, daß diese Lehrmeinung von Unzulänglichkeit geprägt ist. Die These vertritt die Ansicht, daß der Kauf von Mehrheitsanteilen (i) mit kategorischer Autonomie ausgestattet ist; (ii) spezifische Probleme aufwirft, die auch spezifisch untersucht werden sollten; und (iii) sollte mit anderen Formen der Übertragung von Vermögenswerten nur ausnahmsweise assimiliert werden. Die Arbeit besteht aus fünf Kapiteln. In dem ersten stellt sich die Frage, was die methodischen Anhaltspunkte für den Durchgriff der juristische Person sein könnten. Mit untermauerten theoretischen Grundlagen, konzentriert sich das zweite Kapitel auf die Analyse der spezifischen Merkmale, die den Vertrag charakterisieren. Aus funktionaler Sicht untersucht das dritte Kapitel die Möglichkeit der Anwendung juristischer Normen betreffend die Übertragung des Unternehmens, die Disposition von Grundeigentum oder die Abtretung von vertraglichen Rechten, wenn eine Verhandlung über Mehrheitsbeteiligung einer Gesellschaft stattfindet, der diese Güter gehört. Im vierten Kapitel werden die vorvertraglichen Aufklärungspflichten und die Untersuchungsobliegenheit des Käufers analysiert. Am Ende werden die Haftungsregeln des Vertrages vorgestellt.

Schlüsselwörter: Kauf - Aktien - Anteilen - Unternehmen - Aufklärungspflichten Untersuchungsobliegenheit. 